\section{2) Wiadomości \\ (3). Lekarskie \\ Czasopismo Polskiego Towarzystwa Lekarskiego}



Rok założenia 1928 
Wiadomości Lekarskie is abstracted and indexed in: PubMed/Medline, EBSCO, SCOPUS, Index Copernicus, Polish Medical Library (GBL), Polish Ministry of Science and Higher Education.

Copyright: $\odot$ ALUNA Publishing.

Articles published on-line and available in open access are published under Creative Common Attribution-Non Commercial-No Derivatives 4.0 International (CC BY-NC-ND 4.0) allowing to download articles and share them with others as long as they credit the authors and the publisher, but without permission to change them in any way or use them commercially.

\section{Zasady prenumeraty miesięcznika Wiadomości Lekarskie na rok 2019}

Zamówienia na prenumeratę przyjmuje Wydawnictwo Aluna:

- e-mailem: prenumerata@wydawnictwo-aluna.pl

- listownie na adres:

Wydawnictwo Aluna

ul. Z.M. Przesmyckiego 29, 05-510 Konstancin-Jeziorna

Prosimy o dokonywanie wpłat na numer rachunku Wydawnictwa: Credit Agricole Bank Polska S. A.: 82194010763010740700000000

Cena prenumeraty dwunastu kolejnych numerów: 240 zł/rok (w tym 5\% VAT)

Cena prenumeraty zagranicznej: 120 euro/rok.

Cena pojedynczego numeru - $30 \mathrm{zl}$ (w tym 5\% VAT) + koszt przesyłki.

Przed dokonaniem wpłaty prosimy o złożenie zamówienia. 


\section{2) Wiadomości Lekarskie}

\section{Editor in-Chief:}

Prof. Władysław Pierzchała

\section{Deputy Editor in-Chief:}

Prof. Aleksander Sieroń

\section{Statistical Editor:}

Dr Lesia Rudenko
Polskie Towarzystwo Lekarskie:

Prof. Waldemar Kostewicz - President PTL

Prof. Jerzy Woy-Wojciechowski - Honorary President PTL

Prof. Tadeusz Petelenz

\section{International Editorial Board - in-Chief:}

Marek Rudnicki

Chicago, USA

\section{International Editorial Board - Members:}

Kris Bankiewicz

Christopher Bara

Krzysztof Bielecki

Zana Bumbuliene

Ryszarda Chazan

Stanislav Czudek

Jacek Dubiel

Zbigniew Gasior

Andrzej Gładysz

Nataliya Gutorova

Marek Hartleb

Roman Jaeschke

Andrzej Jakubowiak

Oleksandr Katrushov

Peter Konturek

Jerzy Korewicki

Jan Kotarski
San Francisco, USA

Hannover, Germany

Warsaw, Poland

Vilnius, Lithuania

Warsaw, Poland

Ostrava, Czech Republic

Cracow, Poland

Katowice, Poland

Wroclaw, Poland

Kharkiv, Ukraine

Katowice, Poland

Hamilton, Canada

Chicago, USA

Poltava, Ukraine

Saalfeld, Germany

Warsaw, Poland

Lublin, Poland
George Krol

Krzysztof Łabuzek

Henryk Majchrzak

Ewa Małecka-Tendera

Stella Nowicki

Alfred Patyk

Palmira Petrova

Krystyna Pierzchała

Tadeusz Płusa

Waldemar Priebe

Maria Siemionow

Vladyslav Smiianov

Tomasz Szczepański

Andrzej Witek

Zbigniew Wszolek

Vyacheslav Zhdan

Jan Zejda
New York, USA

Katowice, Poland

Katowice, Poland

Katowice, Poland

Memphis, USA

Gottingen, Germany

Yakutsk, Russia

Katowice, Poland

Warsaw, Poland

Houston, USA

Chicago, USA

Sumy, Ukraine

Katowice, Poland

Katowice, Poland

Jacksonville, USA

Poltava, Ukraine

Katowice, Poland

\section{Managing Editor:}

Agnieszka Rosa

International Editor:

Lesia Rudenko

I.rudenko@wydawnictwo-aluna.pl

Distribution and Subscriptions:

Bartosz Guterman prenumerata@wydawnictwo-aluna.pl

\section{Graphic design / production:}

Grzegorz Sztank

www.red-studio.eu

\section{Publisher:}

ALUNA Publishing

ul. Przesmyckiego 29, 05-510 Konstancin - Jeziorna www.aluna.waw.pl www.wiadomoscilekarskie.pl www.medlist.org 


\section{REGULAMIN PRZYJMOWANIA I OGŁASZANIA PRAC W WIADOMOŚCIACH LEKARSKICH}

1. Miesięcznik Wiadomości Lekarskie jest czasopismem Polskiego Towarzystwa Lekarskiego, ma charakter naukowo-edukacyjny. Zamieszczane są w nim prace oryginalne, kliniczne i doświadczalne oraz poglądowe w języku polskim lub angielskim oraz innych językach (za zgodą redakcji).

2. Publikacja pracy w Wiadomościach Lekarskich jest płatna. Od stycznia 2017 roku koszt opublikowania artykułu wynosi 1000 zł plus 23\%VAT. Jeżeli pierwszym autorem pracy jest członek Rady Naukowej czasopisma lub zespołu recenzentów - za druk nie pracy nie pobieramy opłaty, jeśli zaś jest kolejnym współautorem - opłata wynosi 500 zł plus 23\%VAT. Wydawca wystawia faktury. Opłatę należy uiścić po otrzymaniu pozytywnej recenzji, przed opublikowaniem pracy. Z opłaty za publikację zwolnieni są członkowie Polskiego Towarzystwa Lekarskiego z udokumentowaną opłatą za składki członkowskie za ostatnie 3 lata.

3. Prace zapisane w formacie DOC ( $z$ wyłączeniem rycin, które powinny stanowić osobne pliki) należy przesłać pocztą elektroniczną na adres redakcji: Agnieszka Rosa-amarosa@wp.pl.

4. Objętość prac oryginalnych - łącznie z rycinami i piśmiennictwem - nie może przekraczać 21600 znaków (12 stron maszynopisu), prac poglądowych - do 36000 znaków (20 stron).

5. Strona tytułowa powinna zawierać:

- tytuł w języku angielskim i polskim,

- pełne imiona i nazwiska autorów,

- afiliację autorów,

6. Praca oryginalna powinna mieć następującą strukturę: wstęp, cel pracy, materiał i metody, wyniki, dyskusja i wnioski, które nie mogą być streszczeniem pracy. Przy zastosowaniu skrótów konieczne jest podanie pełnego brzmienia terminu przy pierwszym użyciu. W pracach doświadczalnych, w których wykonano badania na ludziach lub zwierzętach, a także w badaniach klinicznych, należy umieścić informację o uzyskaniu zgody komisji etyki badań naukowych.

7. Streszczenia zarówno w języku polskim, jak i angielskim powinny zawierać 200250 słów. Streszczenia prac oryginalnych, klinicznych i doświadczalnych powinny posiadać następującą strukturę: cel, materiał i metody, wyniki wnioski. Nie należy używać skrótów w tytule ani w streszczeniu.

8. Słowa kluczowe (3-6) należy podawać w języku angielskim i polskim, zgodnie z katalogami MeSH (Medical Subject Headings Index Medicus http://www.nim. nih.gov.mesh/MBrower.html). Słowa kluczowe nie mogą być powtórzeniem tytułu pracy.

9. Materiał ilustracyjny - ryciny, wykresy, rysunki, fotografie, slajdy - powinien być opisany cyframi arabskimi i zapisany jako pliki JPG, TIFF lub EPS o rozdzielczości $300 \mathrm{DPI}$ (nie w plikach tekstowych). Ich opisy należy przesłać w osobnym pliku. W tekście muszą znajdować się odniesienia do wszystkich rycin (w nawisach okrągłych).

10. Tabele - ich tytuły (nad tabelą) i treść - powinny być zapisane w programie Microsoft Word, ponumerowane cyframi rzymskimi. Wszystkie stopki dotyczące tabeli powinny znajdować się poniżej tekstu tabeli. W tekście pracy należy umieścić odniesienia do wszystkich tabel (w nawiasach okrągłych).

11. W wykazie piśmiennictwa ułożonym według kolejności cytowania należy uwzględnić wyłącznie te prace, na które autor powołuje się w tekście. W pracach oryginalnych nie powinno być więcej niż 30 pozycji, a w poglądowych nie więcej niż 40 pozycji. Każda pozycja powinna zawierać: nazwiska wszystkich autorów, pierwsze litery imion, tytuł pracy, skrót tytułu czasopisma (wg Index Medicus), rok, numer, stronę początkową i końcową. Przy pozycjach książkowych należy podać: nazwisko autora (autorów), pierwszą literę imienia, tytuł rozdziału, tytuł książki, wydawnictwo, miejsce i rok wydania. Dopuszcza się cytowanie stron internetowych z podaniem adresu URL i daty użycia artykułu oraz o ile to możliwe nazwisk autorów. Każda pozycja piśmiennictwa powinna mieć odwo- łanie w tekście pracy umieszczone w nawiasie kwadratowym, np. [1], [3-6]. Pozycje zapisuje się w sposób zaprezentowany w Załączniku nr 1 do niniejszego regulaminu.

12. Po piśmiennictwie należy podać adres do korespondencji, nazwisko i imię pierwszego autora, adres, numer telefonu oraz adres e-mail.

13. Do pracy należy dołączyć oświadczenie podpisane przez wszystkich autorów określające udział poszczególnych autorów w przygotowaniu pracy (np. koncepcja i projekt pracy, zbieranie danych i ich analiza, odpowiedzialność za analizę statystyczną, napisanie artykułu, krytyczna recenzja itd.), a także oświadczenie, że biorą oni odpowiedzialność za treść. Ponadto należy zaznaczyć, że praca nie była publikowana ani zgłaszana do druku w innym czasopiśmie.

14. Jednocześnie autorzy powinni podać do wiadomości wszelkie inne informacje mogące wskazywać na istnienie konfliktu interesów, takie jak:

- zależności finansowe (zatrudnienie, płatna ekspertyza, doradztwo, posiadanie akcji, honoraria),

- zależności osobiste,

- współzawodnictwo akademickie i inne mogące mieć wpływ na stronę merytoryczną pracy,

- sponsorowanie całości lub części badań na etapie projektowania, zbierania, analizy i interpretacji danych lub pisanie raportu.

Konflikt interesów ma miejsce wtedy, gdy przynajmniej jeden z autorów ma powiązania lub zależności finansowe z przemysłem bezpośrednie lub za pośrednictwem najbliższej rodziny. Jeśli praca dotyczy badań nad produktami częściowo lub całkowicie sponsorowanymi przez firmy, autorzy mają obowiązek ujawnić ten fakt w załączonym oświadczeniu.

15. Każda praca podlega weryfikacji w systemie antyplagiatowym (zapora ghostwriting).

16. Redakcja przestrzega zasad zawartych w Deklaracji Helsińskiej, a także w Interdisciplinary and Guidlines for the Use of Animals In Research, Testing and Education, wydanych przez New York Academy nof Sciencees' Adhoc Resarch. Wszystkie prace odnoszące się do zwierząt lub ludzi muszą być zgodne z zasadami etyki określanymi przez Komisję Etyczną.

17. Czasopismo recenzowane jest $w$ trybie podwójnej, ślepej recenzji. Nadesłane prace są oceniane przez dwóch niezależnych recenzentów, a następnie kwalifikowane do druku przez Redaktora Naczelnego. Recenzje mają charakter anonimowy. Krytyczne recenzje autorzy otrzymują wraz z prośbą o poprawienie pracy lub z decyzją o niezakwalifikowaniu jej do druku. Procedura recenzowania artykułów jest zgodna z zaleceniami Ministerstwa Nauki i Szkolnictwa Wyższego zawartymi w opracowaniu "Dobre praktyki w procedurach recenzyjnych w nauce" (Warszawa 2011) i szczegółowo została opisana na stronie http://www.nauka. gov.pl/g2/oryginal/2014_02/307f933b1a75d6705a4406d5452d6dbf.pdf

18. Redakcja zastrzega sobie prawo redagowania nadesłanych tekstów (dokonywania skrótów i poprawek). Prace są wysyłane do akceptacji autorów. Poprawki autorskie należy przesłać w terminie 3 dni od daty wysłania wiadomości e-mail (pocztą elektroniczną). Brak odpowiedzi w podanym terminie jest równoznaczny z akceptacją przez autora nadesłanego materiału.

19. Przyjęcie pracy do druku oznacza przejęcie praw autorskich przez Redakcję Wiadomości Lekarskich.

20. Autorzy otrzymują nieodpłatnie plik PDF wydania, w którym znajduje się ich praca, a na życzenie - egzemplarz drukowany. Plik elektroniczny przeznaczony jest do indywidualnego użytku autora, bez prawa do rozpowszechniania bez zgody redakcji.

21. Prace przygotowane niezgodnie z regulaminem zostaną zwrócone autorom do poprawienia.

22. Redakcja nie odpowiada za treść zamieszczanych reklam. 


\section{SPIS TREŚCI}

PRACE ORYGINALNE/ ORIGINAL ARTICLES

Volodymyr H. Hryn, Yuriy P. Kostylenko, Valentyna P. Bilash, Olena B. Ryabushko

MICROSCOPIC STRUCTURE OF ALBINO RATS'SMALL INTESTINE

Oleksandr Yu. loffe, Mykola S. Kryvopustov, Yuri A. Dibrova, Yuri P. Tsiura

TYPE 2 DIABETES MELLITUS REMISSION AND ITS PREDICTION AFTER TWO-STAGE SURGICAL TREATMENT OF PATIENTS WITH MORBID OBESITY

Alisa V. Pachevska, Yurii V. Filimonov, Valerij Yu. Filimonov, Olena P. Dudik, Olena I. Popova, Nadiia V. Drachuk, Dmytro M. Kasianenko, Alina V. Biloshitska, Valerij M. Istoshyn CLINICAL AND LABORATORY ASSESSMENT THE LEVELS OF ORAL HYGIENE, TOTAL PROTEIN, HYDROGEN SULFIDE AND NITROGEN METABOLITES IN ORAL FLUID IN THE DEVELOPMENT OF INFLAMMATORY COMPLICATIONS DURING ORTHODONTIC TREATMENT OF CHILDREN

Dmytro Y. Nikolenko, Dmytro M. Boiko, Olexandr A. Shkurupii, Oksana V. Ovcharenko

MORPHOMETRIC AND HISTOCHEMICAL CHARACTERISTICS OF THE CRIBRIFORM TYPE OF INTRADUCTAL CARCINOMA OF THE MAMMARY GLAND

Oksana S. Khukhlina, Viktoriia Yu. Drozd, Alona A. Antoniv, Tamara H. Kopchuk, Zoriana la. Kotsiubiichuk

PATHOGENETIC ROLE OF NITROGEN MONOXIDE EFFICIENCY OF PHARMACOTHERAPY IN PATIENTS WITH GASTROESOPHAGEAL REFLUX DISEASE AND STABLE ANGINA OF TENSION

Natalia V. Medvedovska, Valerii I. Bugro, Ivan I. Kasianenko

PARENTERAL VIRAL HEPATITIS INFECTION RISK ASSESSMENT BY TEENAGERS

Aidyn G. Salmanov, Olena A. Dyndar, Yuriy P.Vdovychenko, Tetiana R. Nykoniuk, Igor V. Maidannyk, Olena 0. Chorna, Iryna A. Holovanova

SURGICAL SITE INFECTIONS AND ANTIMICROBIAL RESISTANCE IN KYIV CITY HOSPITALS, UKRAINE

LyubovV. Smahliuk, Dmytro V. Sheshukov

PECULIARITIES OF TEETH SIZE IN ADOLESCENTS WHO ARE DIAGNOSED TO HAVE ANGLE'S CLASS I MALOCCLUSION AND DISPLAY DIFFERENT SOMATOTYPES

Yevhen Ya. Kostenko, Volodymyr S. Melnyk, Liudmyla F. Horzov

SOCIO-PSYCHOLOGICAL ASPECTS IN THE PREVENTION OF DENTAL DISEASES

Iryna V. Markovskaya

THE EFFECT OF LOW FREQUENCY ELECTROMAGNETIC RADIATION ON THE MORPHOLOGY OF DENTAL AND PERIODONTAL TISSUES (EXPERIMENTAL INVESTIGATION)

Victor A. Ognev, Anna A. Podpriadova, Anna V. Lisova

IDENTIFICATION AND ASSESSMENT OF RISK FACTORS ROLE IN MYOCARDIAL INFARCTION DEVELOPMENT

Tetyana A. Andrushchenko, Sergiy V. Goncharov, Victor E. Dosenko, Konstantin E. Ishhejkin

ALLELIC POLYMORPHISMS OF DNA REPAIR GENES AND THEIR INFLUENCE ON THE FORMATION OF RESISTANCE TO THE DEVELOPMENT OF BRONCHOPULMONARY PATHOLOGY UNDERTHE ACTION OF INDUSTRIAL AEROSOLS

Oleg Y. Kanikovskyi, Yaroslav V. Karyi, Yura V. Babiichuk, Yevhen V. Shaprynskyi

IMPROVING THE RESULTS OF THE LAPAROSCOPIC CHOLECYSTECTOMY IN PATIENTS WITH COMPLICATED COURSE OF THE CALCULOUS CHOLECYSTITIS

Tetiana L. Protsiuk, Olga S. Yablon, Liudmyla 0. Protsiuk, Olga A. Bykovska, Olena V. Herasymova, Tetiana V. Kapitan

FEATURES OF CLINICAL MANIFESTATIONS OF DISEASE AND PSYCHOLOGICAL STATUS OF ADOLESCENTS WITH BRONCHIAL ASTHMA OF VARIOUS LEVELS OF CONTROL

AND THE INFLUENCE OF RISK FACTORS

Kyrylo V. Makolinets, Vasyl I. Makolinets, Dmytro V. Morozenko, Kateryna V. Gliebova, Svitlana I. Danylchenko

DYNAMICS OF BIOCHEMICAL MARKERS OF CONNECTIVE TISSUE METABOLISM IN PATIENTS WITH KNEE OSTEOARTHRITIS DURING CONSERVATIVE TREATMENT WITH LASER THERAPY

Olga Ostash, Oksana Shvager, Liudmyla Grygorenko, Svetlana Stepanchuk, Nina Balenko, Igor Chernychenko

ON THE ISSUE OF ACCELERATED HYGIENIC ASSESSMENT OF ENVIRONMENTAL GENOTOXIC CARCINOGENS

Oksana V. Oriekhova, Oleksandr I. Pavlenko

PREDICTION OF RISK IN DEPENDENCE FROM DISEASE AND WORKING CONDITIONS OF EMPLOYEESWHICH EMPLOYED IN EXTRACTION OF IRON ORE

Olena 0. Oshyvalova, Oleg L. Ziukov, Vitaliy G. Gurianov

PROGNOSTIC MODEL OF SKIN CANCER RISK ASSESSMENT

Olga V. Garmash

ORAL HEALTH ABNORMALITIES IN CHILDREN BORN WITH MACROSOMIA ESTABLISHED DURING MIXED DENTITION PERIOD

Lyubov Y. Vlasyk, Natalia 0. Ryngach, Leonid I. Vlasyk, Hanna Y. Stupnytska

STUDY OF THE LIFESTYLE OF ECONOMICALLY ACTIVE POPULATION OF THE CHERNIVTSI REGION: THE PREVALENCE OF RISK FACTORS AMONG BUSINESS ENTITIES IN THE MARKET 
Tetiana Maksymets, Maria Sorochka, Olha Bondarenko, Natalia Karpyshyn, Olesia Bochar, Yevhen Sklyarov COMPARISON OF METABOLIC PROFILE OF OBESE NON-DIABETIC PATIENTS WITH CORONARY ARTERY DISEASE DEPENDING ON ATORVASTATIN DOSE

Viktoriya K. Zezekalo, Konstantin F. Pochernyaev, Vasyl M. Voloshchuk, Liudmyla V. Zasukha, Natalia S. Shcherbakova, Serhii M. Kulynych MULTIPLEX PCR ASSAY FOR CHLAMYDIA-LIKE BACTERIA DETECTION

Nataliya Gutorova, Oleksandr Zhytnyi, Oleksii Soloviov

FALSIFICATION OF MEDICAL PRODUCTS: CRIMINAL LAW MECHANISM COMBATING THREATS TO PUBLIC HEALTH

Igor I. Mytrofanov, Igor V. Lysenko, Mykola M. Ryabushko

MENTAL ILLNESS AS A CONSEQUENCE OF CRIMINAL OFFENCE AGAINST THE PERSON

PRACE POGLADDOWE / REVIEW ARTICLES

Jaroslaw L. Grshybowskyj, Vladyslav A. Smiianov, Ivan M. Myronyuk, Oleh V. Lyubinets

TEN INDICATORS WHICH CHARACTERIZE MEDICAL-DEMOGRAPHIC PROCESSES IN ADJACENT REGIONS OF UKRAINE AND POLAND

Alesia Gornostay, Alona Ivantsova, Tetiana Mykhailichenko

MEDICAL ERROR AND LIABILITY FOR IT IN SOME POST-SOVIET COUNTRIES (BELARUS, KAZAKHSTAN, MOLDOVA, UKRAINE)

Nina Perederii, Andrey Zaytsev

EVOLUTIONARY GENETIC APPROACHES TO STUDY THE PROBLEM OF DENTAL CARIES

Serhii V. Knysh, Sergiy M. Gusarov, Nikolay L. Shelukhin, Ivan F. Kharaberiush, Viktoriia R. Bila MODERNIZATION OF STATE ADMINISTRATION SYSTEM IN THE HEALTH CARE SPHERE OF UKRAINE

Olha A. Poda, Tetyana 0. Kryuchko, Inna N. Nesina, Olha Ya. Tkachenko, Nataliia V. Kuzmenko

MODERN APPROACHES TO TREATMENT OF PSEUDOMONAS AERUGINOSA VENTILATOR-ASSOCIATED PNEUMONIA (LITERATURE REVIEW)

Nadia S. Vasilevskaya, Olena V. Bailo

MEDICAL INSURANCE AS A DIRECTION OF REFORMING THE HEALTH SYSTEM IN UKRAINE

Tetiana V. Stepanova, Olga P. Nedospasova, Mykhailo V. Golubchykov

ANALYSIS OF TUBERCULOSIS/HIV CO-INFECTION TRENDS IN UKRAINE IN 2008-2017

Olha M. Bereziuk, Julia V. Mazur, Galyna K. Berko, Larysa S. Perebetiuk, Maryna M. Velychkovych, Olena V. Temna, Halyna 0. Movchan PRIMARY AND SECONDARY THROMBOPHILIA: PATHOGENESIS, CLINICAL PRESENTATION, APPROACHES TO THROMBOTIC COMPLICATIONS PREVENTION AND TREATMENT

Serhii M. Hermanchuk, Volodymyr I. Struk, Vitaliy I. Bida, AlexanderV. Bida ANALYSIS OF INDICATORS OF THE ORTHOPEDIC CAREPROVISION TO THE ADULT POPULATION OF UKRAINE DURING 2012-2017

Lyubov V. Smaglyuk, Hanna V. Voronkova, Anna Y. Karasiunok, Anastasiia V. Liakhovska, Kseniia 0. Solovei

INTERDISCIPLINARY APPROACH TO DIAGNOSTICS OF MALOCCLUSIONS (REVIEW)

Roman I. Trutiak

EARLY CAROTID ENDARTERECTOMY IN SYMPTOMATIC PATIENTS

Nataliia 0. Iakovenko, Maksim Y. Zak, Mykola 0. Klymenko, Svetlana V. Zhuk, Olena K. Nuzhna

METHODS OF TRANSMISSION AND FEATURES OF THE COURSE OF HEPATITIS CVIRUS INFECTION IN CHILDREN: MEDICAL AND SOCIAL ASPECTS

Alona 0. Milevska, Alexander A. Lyubchik, Alina N. Chorna, Olha M. Khimich, Roman M. Opatskyi

INTERNATIONAL EXPERIENCE OF LEGAL REGULATION OF THE PROCEDURE OF TATTOOING SERVICES'PROVISION AND ITS IMPLEMENTATION IN UKRAINE

Olexander Ye. Kononov, Liliana V. Klymenko, Ganna V. Batsiura, Larysa F. Matiukha, Olha V. Protsiuk, OleksandrV. Klymenko, Marina A. Trishinska, Oksana I. Pogorila RETROSPECTIVE ANALYSIS OF THE MEDICAL DOCUMENTATION OF PATIENTS WHO APPLIED TO THE AMBULATORY OF GENERAL PRACTICE - FAMILY MEDICINE

\section{OPISY PRZYPADKÓW / CASE REPORTS}

Vyacheslav M. Zhdan, Yevdokiia M. Kitura, Maryna Yu. Babanina, Oksana Ye. Kitura, Maksym V. Tkachenko

FAMILIAL HETEROZYGOUS HYPERCHOLESTEROLEMIA: A CASE REPORT

Anatoly A. Avramenko

THE CASE OF FORMATION OF «KISSING» ULCERS OF DUODENAL BULB OF THE PATIENT WITH CHRONIC NONATROPHIC GASTRITIS ON THE BACKGROUND OF THE EATING OF AVEGETABLESALAD AND PHYSICAL EXERTION

Pavlo I. Tkachenko, Ivan I. Starchenko, Serhii 0. Bilokon, Oleksii K. Prylutskyi, Nataliia M. Lokhmatova, Olha B. Dolenko, Nataliia M. Korotych, Andrii V. Vakhnenko, Andrii M. Gogol, Kateryna Yu. Rezvina INSECT BITES AS THE CAUSE OF INFECTIOUS AND ALLERGIC INFLAMMATORY PROCESSES OF THE MAXILLOFACIAL AREA IN CHILDREN 


\title{
MICROSCOPIC STRUCTURE OF ALBINO RATS' SMALL INTESTINE
}

\author{
Volodymyr H. Hryn, Yuriy P. Kostylenko, Valentyna P. Bilash, Olena B. Ryabushko \\ UKRAINIAN MEDICAL STOMATOLOGICAL ACADEMY, POLTAVA, UKRAINE
}

\begin{abstract}
Introduction: The small intestine of albino rats is a transitive canal between the stomach and the cecum that is closely located from each other, reaches a length of one meter, which in comparison ratio to body weight significantly exceeds the corresponding segment in humans.

The aim: The paper is aimed at thorough histological study of the wall and structure of albino rats'small intestine mucosa.

Materials and methods: 30 mature albino male rats were involved into the study. The specimens of albino rats'small intestine, fixed in $10 \%$ neutral buffered formalin solution, have been studied. The study was carried out using conventional histological methods for obtaining serial paraffin sections stained with hematoxylin-eosin. Epoxy plastination of individual tissue samples of the small intestine was performed. Subsequently, polished thin sections were made, stained with $1 \%$ methylene blue and $1 \%$ borax solution. The obtained specimens were studied on the "Konus" light microscope equipped with Sigeta DCM-900 9.0MP digital microphoto attachment with the Biorex 3 software adapted for studies of such type.

Results and conclusions: For the first time in the practice of histological study of the epithelial covering of the mucous membrane of the small intestine, attention is drawn to the specific pattern of its organization on the intestinal villi. It has been found that epithelial covering consists of alternating cluster epithelial aggregations separated by fissured depressions. Since no mentioning about them has been found in the publication, these cluster aggregations of enterocytes can be called epithelial buds of the intestinal villi. Consequently, it can be concluded that with the exception of some specific morphological features, the small intestine of albino rats is homologous to human one by its histological structure, which means that it can be used as a model for various experimental studies.
\end{abstract}

KEY WORDS: small intestine, epithelial buds, enterocytes, albino rats

Wiad Lek 2019, 72, 5 cz. I, 733-738

\section{INTRODUCTION}

The small intestine of albino rats is a transitive canal between the stomach and the cecum that are closely located from each other, reaches a length of one meter, which in comparison ratio to body weight significantly exceeds the corresponding part in human $[1,2,3,4,5,6,7]$. However, publications report that they are considered to be completely homologous by the histological structure of their wall, which proves the validity of the experimental modeling of the pathological processes of the small intestine on albino rats $[8,9,10]$. And yet, with a more demanding approach to the data available in the literature, a number of questions arise that cannot be neglected when trying to increase the reliability of the findings of experimental studies and, thus, verify the extrapolation of their validity to human one.

\section{THE AIM}

The paper is aimed at thorough histological study of the wall and structure of albino rats' small intestine mucosa.

\section{MATERIALS AND METHODS}

30 mature albino male rats weighted $200,0 \pm 20,0 \mathrm{~g}$ were involved into the study. The specimens of albino rats' small intestine, fixed in $10 \%$ neutral buffered formalin solution, have been studied. Euthanasia of rats was made under thiopentone anesthesia overdose $(75 \mathrm{mg} / \mathrm{kg}$ animal body weight intramuscularly in the upper third of the hip of the hind paw) $[8,11]$.

Before the experiment, all animals were kept in standard conditions of the experimental biological clinic (vivarium) at the Ukrainian Medical Stomatological Academy in compliance to the regulations on keeping experimental animals adopted by the European Parliament and Council Directive (2010/63 / EU), the Order of the Ministry of Education and Science, Youth and Sports of Ukraine as of 01.03.2012, No. 249 "On approval of the procedure for conducting tests, experiments on animals by research institutions" and "General ethical principles of experiments on animals", adopted by the V National Congress on Bioethics (Kiev, 2013), (Minutes No. 155 as of 26.04.2017 of meeting the Commission on Biomedical Ethics at Ukrainian Medical Stomatological Academy) $[12,13,14]$.

The study was carried out using conventional histological methods for obtaining serial paraffin sections of $4 \mu \mathrm{m}$ thick (Microm HM 325), stained with hematoxylin-eosin. Additionally, methods of epoxy plastination of individual tissue samples of the small intestine were used. Subsequently, polished thin sections were made, stained with $1 \%$ methylene blue and $1 \%$ borax solution $[15,16,17]$. The obtained specimens were studied on the "Konus" light 
microscope equipped with Sigeta DCM-900 9.0MP digital microphoto attachment with the Biorex 3 (serial number 5604) software adapted for these studies. Morphometric studies were performed using the system for visual analysis of histological specimens.

\section{RESULTS}

Considering the great length of above region of the gastrointestinal tract of albino rats, it is possible to restrict studying of the autopsy material to only three of its selected portions, namely, 1) the duodenum; 2) small intestine between the Peyer's patches and 3) in the zone of Peyer's patches localization.

The findings of the study has established that the wall of the albino rats' duodenum consists (if not considering the finest outer covering in the form of adventitia or serous membrane) of only two membranes, namely, mucous and muscular. In this regard, the first one is about three times thicker than the second one (Fig. 1). If the muscular layer is a simple uniform layer (about 10 layers) of the fusiform smooth myocytes, then the mucous membrane is rich in content of various structures, but among them entirely muscle plate is located. Consequently, its lamina propria is directly associated with the muscular layer, i.e., in the wall of the duodenum of albino rats the submucosa does not exist at all, in contrast to human one. Therefore, all the glandular structures of the mucous membrane, such as the crypts of Lieberkühn and the Brunner's glands, are entirely localized in its lamina propria. It has long been known that the first of them are tubular invaginations of the epithelium, originating between the intestinal villi and extend down into the lamina propria (in albino rats this corresponds to the border with the muscular layer). These formations are notable for the Paneth cells contained in their walls, which produce the anti-microbial enzyme lysozyme (muramidase), which is commonly assigned to the humoral factors of the innate (nonspecific) immunity. Interestingly, scarce intraepithelial lymphocytes reside among the Paneth cells at the basal portion (Fig. 2). Notably, in the duodenum of albino rats, crypts of Lieberkühn also serve as the excretory ducts for the mucous Brunner's glands, entering them, the acini of which are in the form of compact glomeruli between the basal portions of the crypts and the muscular layer.

In contrast to the proliferated (invaginated) crypts, the mucous membrane of the duodenum forms numerous villous projections, which, among other similar formations of the small intestine, are characterized by a variety of shapes and large sizes. Figure 3 shows that such formations are bushy-branched, so that a common base and a number of short branches can be identified in each villus. They are based on connective tissue papillae, which are derivatives of the lamina propria of the mucous membrane, covered with simple columnar epithelium. Compacted bundle of collagen fibers is located in their axial position, surrounded by a fine-fiber network of reticular fibers, containing predominantly lengthwise amorphous substance, within which blood microvessels of the capillary type are found. Publications report that no lymph vessels of the appropriate caliber are found in the duodenal villi. Noteworthy, this interstitial space, occupying the place between the axial connective tissue induration, and the covering epithelium is abundantly infiltrated by the lymphocytic elements.

It is known that the epithelial covering of the mucous membrane of the small intestine is monostratal. However, its description, available from the publications, does not entirely coincide with the observed pattern during the study of histological specimens, on which the covering epithelium of the intestinal villi is not uniformly organized. Magnified microimages clearly show that it has an uneven, tuberous relief on its external surface, due to the fact that the components of its epitheliocytes are distributed in separate cluster aggregations, which are separated by fissured depressions (Fig. 4). Since no mentioning about them has been found in the publication, these cluster aggregations of enterocytes can be called epithelial buds. Each epithelial cluster consists of a certain number of high (columnar) cells, located very close to each other, the borders between which, even in higher magnifications of the light microscope, can hardly be identified. They are better identified by their nuclei, which, being in a row, form a kind of twisted chain that repeats the form of convex surfaces of epithelial buds and depressions between them. Due to the fact that the intestinal epitheliocytes are closely interconnected, their brush borders form a continuous common coating on the convex surfaces of the epithelial buds, interrupting only in the zones of fissured depressions between them. It is well known that the brush borders of enterocytes are formed by numerous microvilli in the form of finest projections of the apical plasmolemma. Such type of increasing the area of the plasma membrane is characteristic of cells carrying out transmembrane transport of substances. This suggests that in the duodenum, the process of absorbing the products of hydrolysis of high molecular nutrients is performed in the zone of free surfaces of epithelial buds, whereas in the zones of fissured depressions such process cannot occur because of the absence, according to the findings of the research, of brush borders. Therefore, the question arises about the role of these depressions in the digestive process of the duodenum. However, it is not known whether such a structural organization of the intestinal villi epithelium is peculiar in other laboratory animals, and, moreover, that it is particularly significant in humans. To date, no solution to such issues has been found.

Essential formations of the mucous membrane of the mesenteric part of the small intestine of albino rats are represented by innumerable intestinal crypts, residing in the lamina propria and bordering its basal portions with the muscular layer. Their shape and cytological composition are similar to the aboveglands of Lieberkühn, which, as in the duodenum, open with narrow orifices between the villi. In contrast to latter, the mucous (Brunner's) glands are not found in the rest of mesenteric portion of the small intestine. Apparently, their absence is compensated by the diffuse distribution of mucous cells among the epithelial 


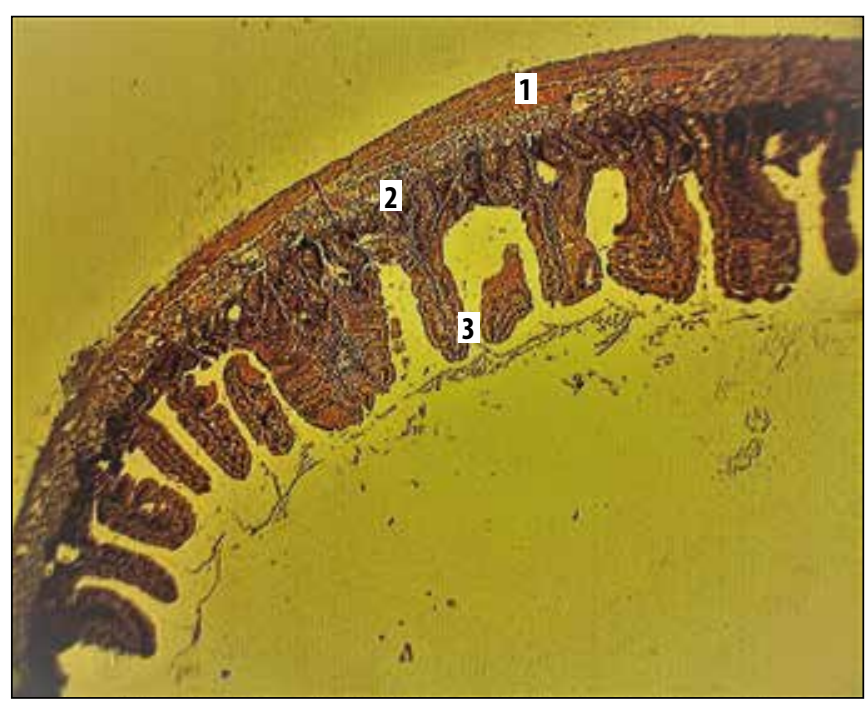

Figure 1. The wall of duodenum of albino rat. Paraffin section; H\&E stain; $4 \times$ magnification.

1 - muscular layer; 2 - mucous membrane; 3 - intestinal villi.

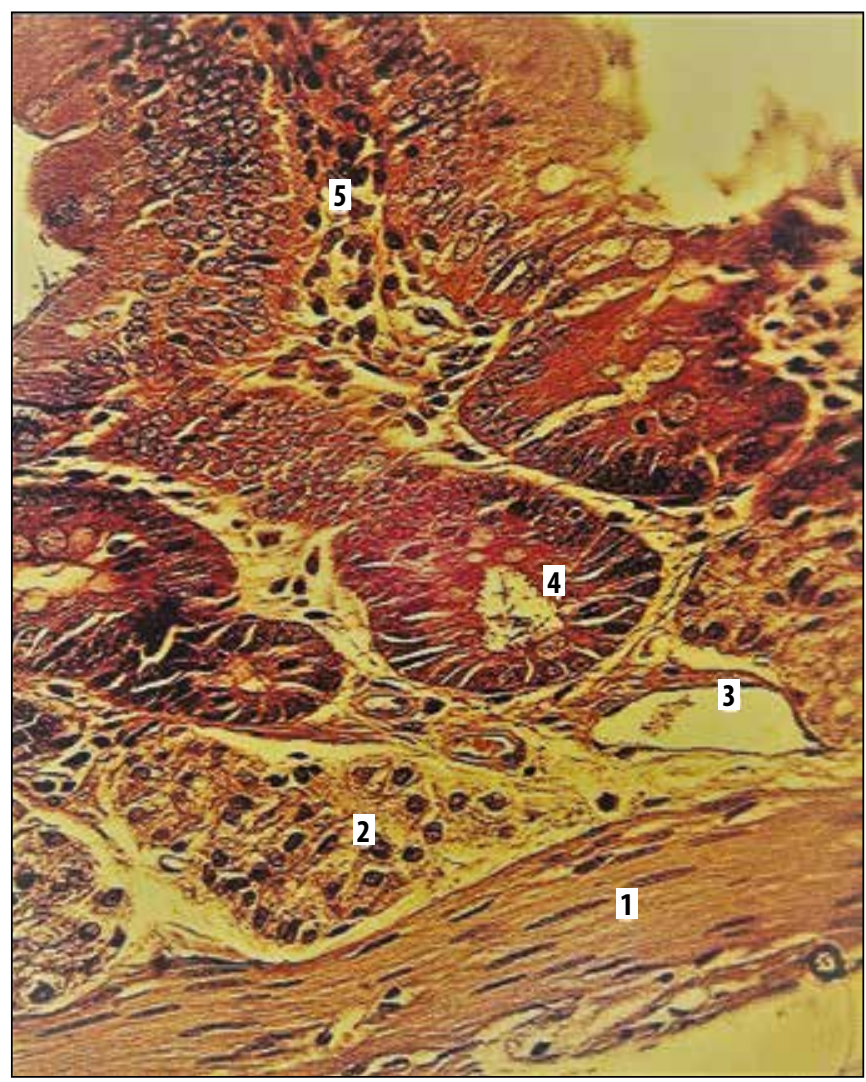

Figure 2. Microscopic structure of the wall of albino rat's duodenum. Paraffin section; H\&E stain; $40 \times$ magnification.

1 - muscular layer; 2 - acini of the mucous (Brunner's) glands; 3 - blood microvessels; 4 - basal portions of the crypts of Lieberkühn; 5 -lymphocytic infiltration of the connective tissue.

cells of the intestinal villi, which are variable in shape, but of the same type in their internal structure. It should be noted that they differ from similar formations of the duodenum by the presence of centric lymphatic microvessel in their

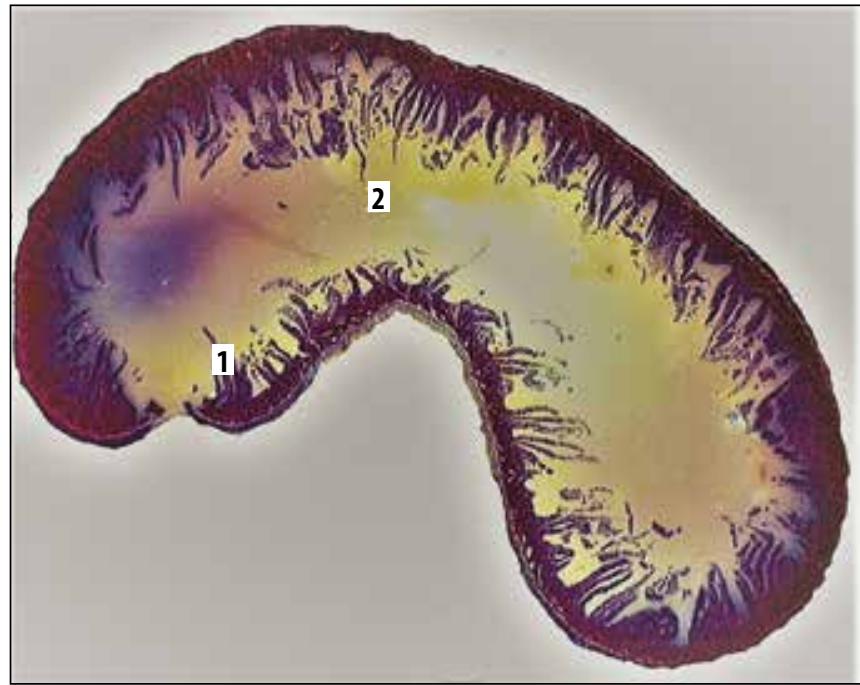

Figure 3. Villous projections of the albino rat's duodenal mucosa. Epoxy slice in tangential section; methylene blue stain; $2 \times$ magnification. 1 - villi of the mucosa; 2 - inner lumen.

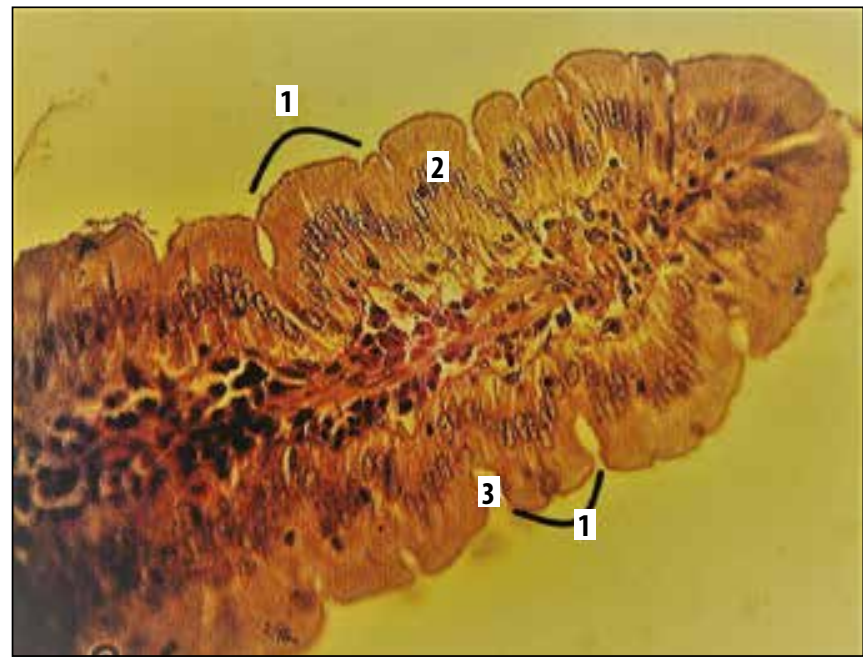

Figure 4. The structure of the villus of the duodenal mucosa. Paraffin section; H\&E stain; $40 \times$ magnification.

1 - epithelial buds; 2 - nuclei of prismatic, columnar epithelial cells; 3 fissured depressions between epithelial buds.

connective tissue, around which connective tissue is diffusely infiltrated by the cells of the lymphocyte series, from the mass of which migration of individual lymphocytes to the covering epithelium is noted (Fig. 5). Moreover, among these cells, sporadic transverse and oblique profiles of blood microvessels are found. Furthermore, the intestinal villus of the covering epithelium is organized in the form of cluster aggregations that can be called epithelial buds, similar to duodenum ones, though sporadic mucous cells are found among their prismatic columnar epithelium (in contrast to the duodenum).

In addition, solitary lymphoid nodules are found in the intermediate zone of the small intestine between the Peyer's patches in an irregular order. Noteworthy, these lymphoepithelial formations, occupying the entire thick- 




Figure 5. The villus of albino rat's small intestine. Paraffin section; H\&E stain; $40 \times$ magnification.

1 - muscular layer; 2 - the basal portions of the intestinal crypts; 3 epithelial buds; 4 - mucous cells; 5 - lymphocytic infiltration of the connective tissue base of intestinal villus; 6 - lymphatic vessel.

ness of the mucous membrane, are surrounded by typical intestinal villi, being circumferentially connected with the basal portions of crypts. At the same time, the bases of these nodules are directly adjacent to the muscular layer, whereas their apical surface is covered with similar columnar epithelium, forming the small villi, which are not mentioned in the publications. Since the objective of our prospective investigations is the experimental study of the nature of structural changes in the lymphoid aggregations of the mucous membrane of the albino rats' gastrointestinal tract in the effect of antibiotics to its microflora, a more detailed description of their single and grouped nodules in its small intestine will be presented in the subsequent publications.

\section{DISCUSSION}

The small intestine is the longest part of the digestive tract, intended to perform the major functions in the process of the consumption of nutrients by the body, which are mainly products of enzymatic hydrolysis of proteins, fats and polysaccharides. The final phase of this process is the absorption of these nutrients into the internal environment of the body. The conveyor nature of digestion in the small intestine is generally expressed in the well-known anatomical distinguishing of such parts as the duodenum, jejunum and ileum, the length of which in a human is approximately (separately) is $30 \mathrm{~cm}-2 \mathrm{~m}-3 \mathrm{~m}$, respectively. Evidently, the length of the rat small intestine is much smaller. However, the data reported in the literature are questionable. Thus, according to them, the length of the rat duodenum is comparable to that of a human one, and the rest of its small intestine is approximately equal to 1 meter. Consequently, the entire rat small intestine is only by $4-5$ times shorter than that of a human one. Obviously, in a limited volume of the rat abdomen of such a length, the digestive tube can fit if it is sufficiently thin $[18,19]$. Unfortunately, no data on its thickness have been found in the literature to date. It is known, the transverse size of the human small intestine varies in length from 2 to $3 \mathrm{~cm}[2,4]$.

The mucous membrane of the human small intestine, preserving its general principle of the structure, has not only its own distinctive features, but also differs in certain morphological features in its various parts. A common anatomical feature for it is the presence of numerous transverse-ring folds throughout it, due to the loose submucosa and smooth muscle tone. But their number and degree of manifestation gradually decreases towards the distal part of the ileum. In the duodenum, the folding of the mucous membrane is somewhat different in that from the side of the medial wall of its descending part where a permanent longitudinal fold is located, which inferiorly becomes higher and ends with a large papilla. It opens with one common hole of the bile duct and pancreatic duct. A little superiorly, the second papilla of a smaller size is located, on which the accessory pancreatic duct opens.

The mucous membrane of the small intestine, in the straightened state, is distinguished by a dull, velvety appearance, due to the numerous tiny (about $1 \mathrm{~mm}$ long) finger- or foliate processes called the intestinal villi [20, $21,22]$. The mucous membrane of the small intestine has a greatly developed local representation of the immune system in the form of intestinal lymphoepithelial clusters called lymphoid nodules. Mostly they are in the form of single nodules and their group clusters $[9,10,23]$.

\section{CONCLUSIONS}

1. The wall of the small intestine of albino rats, in its entire length (about one meter) from the pyloric part of the stomach to the place of the entering to the cecum, consists of two, most pronounced, coaxial membranes, namely, mucous and muscular, which are not separated by a well-marked submucosa. 
2. The essential basic structures of the entire intestinal tract of albino rats are simple tubular (Lieberkühn) glands, i.e. intestinal crypts, which in the duodenum, along with their particular secretory properties, serve as excretory ducts for the acini of the mucous (Lieberkühn) glands located between the muscular layer and the lamina propria of the mucosa.

3. The orifices of intestinal crypts are distributed regularly along the mucous membrane surface, being hidden in depth between the intestinal villi, the size of which steadily decreases in the caudal direction while maintaining, as is known from the publications, the typical principle of structural organization.

4. For the first time in the practice of histological study of the epithelial covering of the mucous membrane of the small intestine, attention is drawn to the specific pattern of its organization on the intestinal villi. It has been found that epithelial covering consists of alternating cluster epithelial aggregations separated by fissured depressions. Since no mentioning about them has been found in the publication, these cluster aggregations of enterocytes can be called epithelial buds of the intestinal villi.

Consequently, it can be concluded that with the exception of some specific morphological features, the small intestine of albino rats is homologous to human one by its histological structure, which means that it can be used as a model for various experimental studies.

\section{REFERENCES}

1. Tatarenko D. Pishchevaritel'naya sistema belykh krys: anatomofunktsional'nyye osobennosti i eksperimental'nyye raboty: monografiya [The digestive system of white rats: anatomical and functional features and experimental work: monograph]. Moskva: RUSAYNS;2016, 90p. (Ru).

2. Makarova M, Ryibakova A, Guschin Ya i dr. Anatomo-fiziologicheskaya harakteristika pischevaritelnogo trakta u cheloveka i laboratornyih zhivotnyih [Anatomical and physiological characteristics of the digestive tract in humans and laboratory animals]. Mezhdunarodnyiy vestnik veterenarii. 2016;1:82-104. (Ru).

3. Hryn V, Kostylenko Yu, Brovarnik Ya. Nekotoryye osobennosti anatomicheskogo stroyeniya tolstoy kishki belykh krys [Some features of the anatomical structure of the colon of white rats]. Vísnik problem bíologí" ímeditsini. 2018;4,2(147):265-270. (Ru). doi:10.29254/20774214-2018-4-2-147-265-270.

4. Nozdrachev A, Polyakov E. Anatomiya kryisyi (Laboratornyie zhivotnyie) [Rat Anatomy (Laboratory animals)]. Pod red. akademika A.D. Nozdracheva. SPb.: Iz-vo «Lan»; 2001, 464 p. (Ru).

5. Herasimyuk I, Miz A. Vikova morfolohichna kharakterystyka stinky tonkoyi kyshky u shchuriv. [Age morphological characteristics of the wall of the small intestine in rats]. Klinichna anatomiya ta operatyvna khirurhiya. 2013;12(1):12-16. (Ua).

6. Hnatyuk M, Harhula T, Slabyy 0 i dr. Morfometrychna kharakterystyka dvanadtsyatypaloyi kyshky u eksperymental'nykh tvaryn [Morphometric characteristics of the duodenum in experimental animals]. Visn. L'viv. un-tu. 2012;59:271-276. (Ua).

7. Hryn V. Zahal'na anatomichna kharakterystyka tonkoyi kyshky bilykh shchuriv [General anatomical characteristics of small intestine in white rats]. Aktual'ni problemy suchasnoyi medytsyny: Visnyk Ukrayins'koyi medychnoyi stomatolohichnoyi akademiyi. 2018;4(64)18:88-93. (Ua) doi:10.31718/2077-1096.18.4.88.
8. Bagry M, Dibrova V, Popadinets 0 i dr. Metodyky morfolohichnykh doslidzhen': Monohrafiya [Methods of morphological research: Monograph]. Vinnytsya: Nova knyha. 2016, 328 p. (Ua).

9. HrynV, Kostylenko Yu, Yushchenko Yu etal.Comparativehistological structure of the gastrointestinal mucosa in human and white rat: a bibliographic analysis. Wiadomości Lekarskie. 2018; tom LXXI, nr 7:1398-1403.

10. Hryn V. Planimetric correlations between Peyer's patches and the area of small intestine of white rats. Reports of morphology. 2018;2(24):66-72. doi: 10.31393/morphology-journal-2018-24(2)-10.

11. Vasyutina M,Smirnova S. Sravnitel'nyy analiz preparatov, ispol'zuyemykh dlya obshchey anestezii u krys [Comparative analysis of drugs used for general anesthesia in rats]. Vestnik novgorodskogo gosudarstvennogo universiteta 2015;86(1):41-43. (Ru).

12. Direktiva 2010/63/EUYevropeyskogo parlamenta iSoveta ot 22 sentyabrya $2010 \mathrm{~g}$. po zashchite zhivotnykh, ispol'zuyemykh dlya nauchnykh tseley [Directive 2010/63/ElA of the European Parliament and of the Council of 22 September 2010 on the protection of animals used for scientific purposes]. Official Journal L. 20.10.2010;276:0033-0079. (Ru).

13. Nakaz Ministerstva osvity i nauky, molodi ta sportu Ukrayiny № 249 vid 01.03.2012 r. [Order of the Ministry of Education and Science, Youth and Sports of Ukraine No. 249 dated 01.03.2012]. Ofitsiynyy visnyk Ukrayiny. 06.04.2012;24:82. (Ua).

14. Rybakova A, Makarova, M. Sanitarnyy kontrol'eksperimental'nykh klinik (vivariyev) v sootvetstvii lokal'nymi i mezhdunarodnymi trebovaniyami [Sanitary control of experimental clinics (vivariums) in accordance with local and international requirements]. Mezhdunarodnyy vestnik veterinarii. 2015;4;81-89. (Ru).

15. Belokon $S$, Vitko Yu, Tkachenko P i dr. Optimizatsiya issledovaniya strukturnyih elementov biologicheskih tkaney na gistotopograficheskih shlifah [Optimization of the study of the structural elements of biological tissues on histotopographic thin sections]. Kazan: Molodoy uchyonyiy. 2014;l, 15(74):134-137. (Ru).

16. Kostilenko Yu, Boyko I, Starchenko I i dr. Metod izgotovleniya gistologicheskih preparatov, ravnotsennyih polutonkim srezam bolshoy obzornoy poverhnosti, dlya mnogotselevyih morfologicheskih issledovaniy [Method for making histological preparations equivalent to semi-thin slices of a large viewing surface for multi-purpose morphological studies]. Morfologiya. 2007;132(6):77-82. (Ru).

17. Mal'kov P, Frank G, Moskvina Li dr. Osnovy obespecheniya kachestva v gistologicheskoy laboratornoy tekhnike: Rukovodstvo [Fundamentals of quality assurance in the histological laboratory equipment: Guide]. Moskva: GEOTAR-Media. 2011. - 108 p. (Ru).

18. Hryn V, Kostylenko Yu, Yushchenko Yu et al. General comparative anatomy of human and white rat digestive systems: a bibliographic analysis. Wiadomości Lekarskie. 2018; tom LXXI, nr 8:1599-1602.

19. Nagwa E. Effect of High Fat Diet on the Structure of the lleum of Adult Female Albino Rat and The Role of Concomitant L-arginine Treatment. Light and Scanning Electron Microscopic Study. Egyptian Journal of Anatomy. 2016;39(2):1-17.

20. Gusejnova S, Gusejnov T. Anatomija struktur slizistoj obolochki tonkoj kishki belyh krys [Anatomy of the structures of the mucous membrane of the small intestine of whiterats]. Souremennye naukoemkietehnologii. 2010;8:140.(Ru).

21. Yuldashev A, Kakhkharov Z, Nishanova A. Osobennosti strukturnofunktsional'nogo stanovleniya dvenadtsatiperstnoy kishki i brunnerovykh zhelez krys v ranniy postnatal'nyy period zhizni [Features of the structural and functional formation of the duodenum and brunner glands of rats in the early postnatal period of life]. Sovremennyye problemy nauki i obrazovaniya. 2009;3:77-80. (Ru). 
22. Ermund $A$, Schütte $A$, Johansson $M$ et al. Studies of mucus in mouse stomach, small intestine, and colon. I. Gastrointestinal mucus layers have different properties depending on location as well as over the Peyer's patches. American journal of physiology. Gastrointestinal and liver physiology. 2013;305(5):341-347. doi: 10.1152/ajpgi.00046.2013.

23. Umoren E, Osim E. Morphology of the Small Intestine of Albino Wistar Rats Following Long Term Administration of Nevirapine. Biochem Pharmacol. 2014;3:132-137. doi:10.4172/2167-0501.1000132.
The paper has been written within the research scientific work, carried out at the Department of Human Anatomy of the Ukrainian Medical Stomatological Academy, entitled "Age-related aspects of the structural organization of the organs of the human immune system, glands of gastrointestinal and urogenital system in normal condition and pathology"; State registration number $0116 U 004192$.

\section{Authors' contributions:}

According to the order of the Authorship.

\section{Conflict of interest:}

The Authors declare no conflict of interest.

\author{
CORRESPONDING AUTHOR \\ Volodymyr H. Hryn \\ Department of Human Anatomy \\ Ukrainian Medical Stomatological Academy \\ Shevchenko 23 str., 36011 Poltava, Ukraine \\ tel: +380668126497 \\ e-mail:vogrin034@gmail.com
}

Received: 11.03.2019

Accepted: 26.04.2019 
PRACA ORYGINALNA

ORIGINAL ARTICLE

\title{
TYPE 2 DIABETES MELLITUS REMISSION AND ITS PREDICTION AFTER TWO-STAGE SURGICAL TREATMENT OF PATIENTS WITH MORBID OBESITY
}

\author{
Oleksandr Yu. Ioffe, Mykola S. Kryvopustov, Yuri A. Dibrova, Yuri P. Tsiura \\ 0. 0. BOGOMOLETS NATIONAL MEDICAL UNIVERSITY, KYIV, UKRAINE
}

\begin{abstract}
Introduction: Morbid obesity (MO) has a significant impact on mortality, health and quality of life of patients. Type 2 diabetes mellitus (T2DM) is a common comorbidity in patients with MO.

The aim is to study T2DM remission and to develop a prediction model for T2DM remission after two-stage surgical treatment of patients with M0.

Materials and methods: The study included 97 patients with M0. The mean BMI was 68.08 (95\% Cl: $66.45-69.71) \mathrm{kg} / \mathrm{m} 2.70(72,2 \%)$ patients with M0 were diagnosed with T2DM. The first stage of treatment for the main group $(n=60)$ included the IGB placement, for the control group $(n=37)$ - conservative therapy. In the second stage of treatment the patients underwent bariatric surgery. The study addresses such indicators as BMI, percentage of weight loss, percentage of excess weight loss, ASA physical status class, fasting glucose level, HbA1c, C-peptide.

Results: Two-stage treatment of morbidly obese patients with T2DM promotes complete T2DM remission in $68.1 \%$ of patients. The risk prediction model for failure to achieve complete T2DM remission 12 months after LRYGB based on a baseline C-peptide level has a high predictive value, $A U C=0.84$ (95\% Cl:0.69-0.93), 0R =0.23 (95\% Cl: $0.08-0.67$ ). Conclusions: Two-stage treatment of patients with M0 promotes improvement of carbohydrate metabolism indicators. With a C-peptide level $>3.7 \mathrm{ng} / \mathrm{ml}$, prediction of complete T2DM remission 12 months after Laparoscopic Roux-en-Y Gastric Bypass is favorable.
\end{abstract}

KEY WORDS: Morbid Obesity, Bariatric Surgery, Type 2 Diabetes Mellitus

Wiad Lek 2019, 72, 5 cz. I, 739-743

\section{INTRODUCTION}

About $13 \%$ of adult population in the world suffer from obesity [1]. Being aware of the risks that the patients face, doctors pay special attention to the problem of morbid obesity (MO) in patients with a body mass index (BMI) $\geq 40$ $\mathrm{kg} / \mathrm{m} 2$ [2]. MO has a significant impact on mortality, health status and quality of life of these patients, which determines the relevance of this problem [3]. In particular, the presence of excess body weight leads to a substantial increase in the incidence of type 2 diabetes mellitus (T2DM) [4].

Since the causes of obesity are multifactorial, the solution to this problem should be multidisciplinary [5]. At the same time proper consideration should be given to lifestyle and dietary modifications, changes in physical activity, behavioral counseling, and pharmacotherapy [3]. However, the patients, who do not respond to the indicated conservative treatment, require bariatric surgery [6].

The $2^{\text {nd }}$ Diabetes Surgery Summit (DSS-II) adopted a series of recommendations for bariatric surgery in patients with T2DM based on evidence-based medicine. Thus, metabolic surgery is recommended for patients with T2DM and BMI $\geq 40 \mathrm{~kg} / \mathrm{m} 2$ and for individuals with BMI $35.0-39.9 \mathrm{~kg} / \mathrm{m} 2$ when hyperglycemia can't be adequately controlled by lifestyle and relevant medical therapy [7]. However, patients with MO that is strongly associated with T2DM have a high surgical and anesthetic risk $[8,9]$.
In order to reduce it and make bariatric surgery appropriate and beneficial, two-stage treatment of these patients is used: the first stage - the placement of an intragastric balloon (IGB) before surgery, the second stage - bariatric surgery itself [10].

\section{THE AIM}

The aim of the research is to study the onset of T2DM remission and to develop a prediction model for T2DM remission after two-stage surgical treatment of patients with MO.

\section{MATERIALS AND METHODS}

The study included 97 patients with MO - 45 (46.4\%) men and $52(53.6 \%)$ women. The mean weight of 97 patients was 191.63 (95\% CI: 186.75 - 196.51) kg, BMI 68.08 (95\% CI: 66.45 - 69.71) kg/m2. The surgical and anesthetic risk on the ASA PS scale was 3.27 (95\% CI: 3.18-3.36). 70 $(72,2 \%)$ patients with $\mathrm{MO}$ were diagnosed with T2DM. This diagnosis was supported by the reference to the criteria recommended by the American Diabetes Association (2018) [11]. T2DM was diagnosed in 46 (76.7\%) patients assigned to the main group and in $24(64.9 \%)$ patients assigned to the control group. 
The treatment was carried out in 2 stages. The first stage of treatment for the main group $(n=60)$ included the IGB placement, for the control group $(n=37)$ - conservative therapy. There was no statistically significant difference $(p>0.05)$ in the gender, age and clinical parameters for both groups of patients. In the second stage of treatment the patients of both groups underwent surgical procedure for the MO management. The duration of the study included 6 months of the follow-up period for all patients after the first stage of treatment and 12 months - after the second stage. $61(62.9 \%)$ patients completed the two-stage treatment, including the preparatory stage and bariatric surgery.

Clinical and laboratory methods of investigation were used to monitor fasting glucose levels, glycosylated hemoglobin $\mathrm{HbAlc}$, and C-peptide throughout the study. BMI, weight loss (\%WL) and excess weight loss (\%EWL) were calculated. The surgical and anesthetic risk was assessed on the scale presented by the American Society of Anesthesiologists as ASA Physical Status Classification System 2014 (ASA PS) [12].

The conservative treatment of obese patients incorporated a complex of measures aimed at lifestyle modifications, including dietary changes, physical activity and behavioral therapy. Pharmacotherapy of co-morbidities was administered individually in each case. The endoluminal treatment of patients in the main group was conducted by the placement of IGB, namely the ORBERA ${ }^{\text {Tx }}$ Intragastric Balloon System produced by Apollo Endosurgery, Inc. The surgical procedure, which was used in the presence of T2DM, included the Laparoscopic Roux-en-Y Gastric Bypass (LRYGB) according to the Fobi-Capella technique. In the absence of T2DM and positive outcomes of the treatment with IGB, restrictive bariatric surgery was performed - Laparoscopic Adjustable Gastric Banding (LAGB) (until 2013) and Laparoscopic Sleeve Gastrectomy (LSG) [10].

Statistical analysis was conducted using IBM SPSS Statistics Base (version 22). A value of $\mathrm{p}<0.05$ was considered statistically significant. Quantitative data are expressed as mean and with 95\% confidence interval (CI). To analyze the relationship between the risk of failure to achieve complete remission of T2DM and a set of factors, single-factor logistic regression models were constructed and analyzed. The strength of the relationship between each factor and the risk of failure to achieve complete remission of T2DM was estimated by the odds ratio (OR) with $95 \%$ CI calculated. In order to compare the quality of prediction of the risk of failure to achieve complete remission of T2DM based on the selected significant factors, Receiver Operating Characteristic (ROC) curve construction and analysis were used. Optimization of the decision threshold was realized with the help of the Youden Index test.

The research was carried out in compliance with the modern principles of bioethics. The design of this study was approved by the commission on bioethical expertise and ethics of scientific research at the National Medical University named after O.O. Bogomolets, the research does not present an increased risk for the subjects of the study and was implemented in view of existing bioethical norms and scientific standards for conducting clinical trials involving patients. All patients signed a written informed consent form.

\section{RESULTS}

After the first stage of treatment the patients of the main group had the mean \%WL 14.86 (95\% CI: 13.87 - 15.85)\%, \%EWL - 22.46 (95\% CI: 20.93 - 24.0) \%. The patients of the control group had the mean \%WL 1.39 (95\% CI: -0.52 - 3.30)\%, \%EWL - 1.87 (95\% CI: - 1.22 - 4.96)\%. In the main group, after the first stage of treatment, partial remission of T2DM, which was defined based on the ADA criteria (2009), was seen in 3 patients. In the control group, none of the patients achieved either partial or complete remission of T2DM.

61 patients with MO, who completed the first stage of treatment with a decrease in the initial level of surgical and anesthetic risk for ASA PS and/or clinical improvement of co-morbidities, and, therefore, had no contraindications for bariatric surgery, and gave informed written consent, underwent bariatric surgery: $51(83.6 \%)$ patients underwent LRYGB, 9 (14.8\%) - LAGB, 1 (1.6\%) - LSG.

12 months after surgery, the mean BMI decreased from 58.02 (95\% CI: 56.16 - 59.88) $\mathrm{kg} / \mathrm{m} 2$ to 38.53 (95\% CI: 37.39 - 39.67) $\mathrm{kg} / \mathrm{m} 2$ ( $\mathrm{p}<0.001$ ). The mean \%EWL was 55.27 (95\% CI: 53.32 $57.23) \%$, with 47 (77.0\%) patients having $\% E W L \geq 50 \%$. Before surgery, the level of glycosylated hemoglobin ( $\mathrm{HbAlc}$ ) was 6.70 (95\% CI: 6.44 - 6.96)\%, 12 months after surgery - 5.49 (95\% CI: 5.26 - 5.71$) \%(\mathrm{p}<0.001)$. Before surgery, the mean C-peptide level was 3.77 (95\% CI: 3.30-4.23) ng/ml, after surgery it reduced to 2.47 (95\% CI: $2.18-2.75) \mathrm{ng} / \mathrm{ml}(\mathrm{p}<0.001)$.

$44(72.1 \%)$ patients were diagnosed with T2DM. Before surgery, the mean level of fasting glucose was 8.64 (95\% CI: 8.30 - 8.97) $\mathrm{mmol} / \mathrm{L}$, glycosylated hemoglobin (HbA1c) 7.18 (95\% CI: 6.97 - 7.39)\%. 12 months after surgery, the mean levels of fasting glucose and glycosylated hemoglobin (HbAlc) decreased to 6.23 (95\% CI: 5.79 - 6.68) mmol/L and 5.67 (95\% CI: 5, 38 - 5.95)\% respectively, in both cases $\mathrm{p}<0.001$. Before surgery, a C-peptide level in morbidly obese patients with T2DM was 4.16 (95\% CI: 3.70 - 4.63) $\mathrm{ng} / \mathrm{ml}$, and after surgery, it statistically significantly decreased to 2.64 (95\% CI: 2.27 - 3.01) ng/ml ( $<<0.001)$.

Complete remission of T2DM, which was defined based on the ADA criteria (2009), was observed in 29 (65.9\%) patients 12 months after the second stage of treatment that included LRYGB. The study investigated the effect bariatric surgery had on the onset of complete remission of T2DM in patients with MO 12 months after LRYGB, which was defined based on the ADA criteria (2009) [13].

To analyze the relationship between the risk of failure to achieve complete remission of T2DM and a set of factors, single-factor logistic regression models were constructed and analyzed. A set of factors included 10 variables that were observed: gender, age, height, body weight, BMI, excess body weight, C-peptide level, glycosylated hemoglobin level (HbAlc), fasting glucose level, assessment on the DiaRem scale before surgery. The primary endpoint was a prediction of the probability of complete remission of 
Table I. Analysis of single-factor logistic regression models for predicting the risk of failure to achieve complete remission of T2DM in patients with MO 12 months after surgery.

\begin{tabular}{cccc}
\hline Factor & $\begin{array}{c}\text { Area under the ROC curve } \\
\text { model, } \\
\text { AUC }(\mathbf{9 5 \%} \mathbf{C I})\end{array}$ & $\begin{array}{c}\text { Odds Ratio, } \\
\text { OR (95\% CI) }\end{array}$ & $\begin{array}{c}\text { Level of significance } \\
\text { of difference } \\
\text { between OR and 0, } \mathbf{p}\end{array}$ \\
\hline Gender & $0.58(0.42-0.72)$ & $0.54(0.15-1.96)$ & 0.35 \\
\hline Age & $0.51(0.35-0.66)$ & $1.01(0.94-1.09)$ & 0.79 \\
\hline Height & $0.53(0.37-0.68)$ & $0.97(0.91-1.04)$ & 0.42 \\
\hline Body weight & $0.60(0.44-0.75)$ & $1.00(0.97-1.03)$ & 0.89 \\
\hline BMI & $0.58(0.42-0.72)$ & $1.04(0.95-1.13)$ & 0.45 \\
\hline Excess body weight & $0.52(0.37-0.68)$ & $1.00(0.97-1.04)$ & 0.84 \\
\hline C-peptide level & $0.84(0.69-0.93)$ & $0.23(0.08-0.67)$ & 0.007 \\
\hline HbA1c level & $0.74(0.59-0.86)$ & $3.97(1.34-11.8)$ & 0.01 \\
\hline Fasting glucose level & $0.73(0.58-0.85)$ & $2.32(1.17-4.60)$ & 0.02 \\
\hline $\begin{array}{c}\text { Assessment on } \\
\text { the DiaRem scale }\end{array}$ & $0.71(0.55-0.84)$ & $1.27(1.04-1.55)$ & 0.02 \\
\hline
\end{tabular}

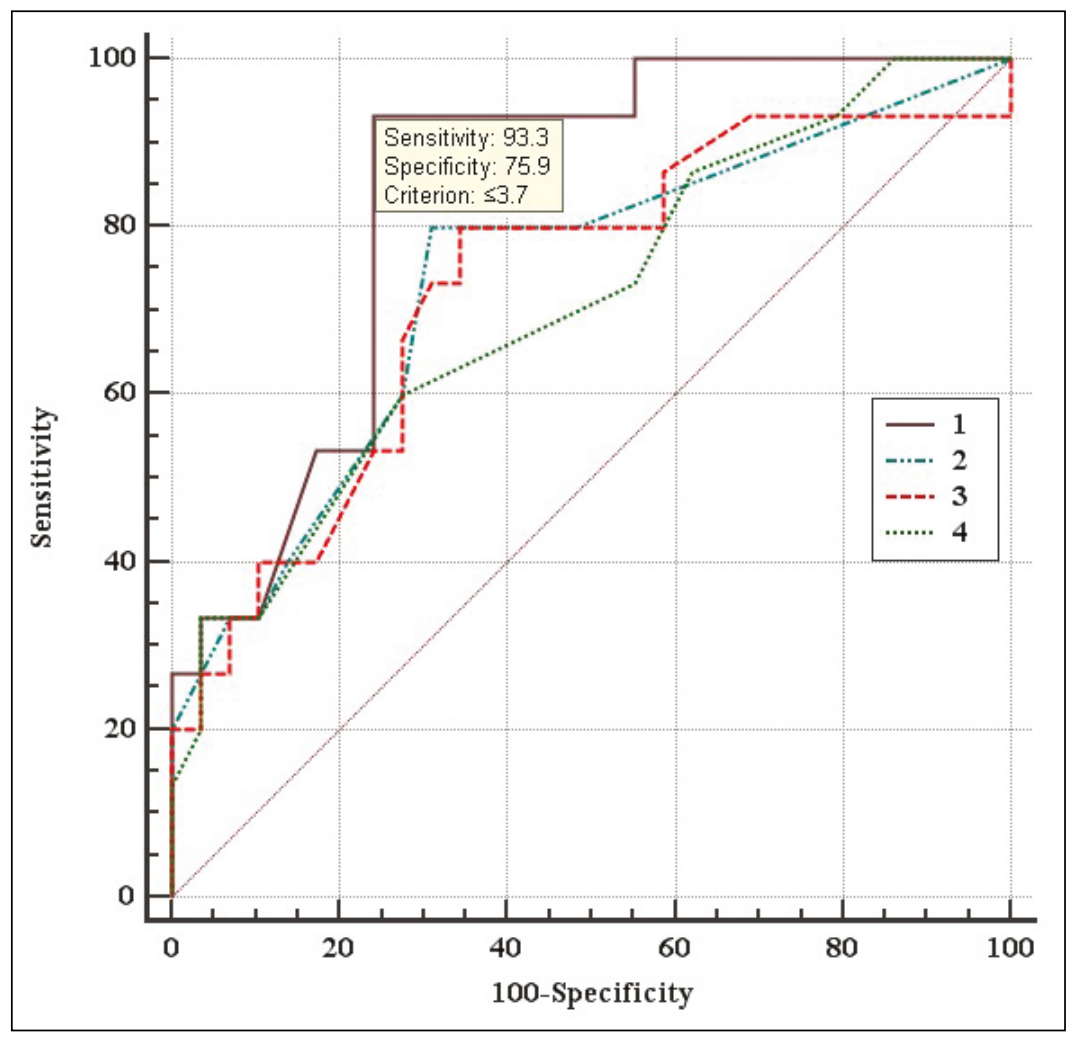

Figure 1. Receiver Operating Characteristic (ROC) curves for the risk prediction tests for failure to achieve remission 12 months after surgery: 1 - C-peptide level, 2 - glycosylated hemoglobin HbA1clevel, 3 -fasting glucose level, 4 - assessment on the DiaRem scale.
T2DM 12 months after surgery, $\mathrm{Y}=0$ in case of remission and $\mathrm{Y}=1$ in case of failure to achieve remission. The analysis was carried out based on the findings of the follow-up period that included 44 patients with $\mathrm{MO}$, who underwent LRYGB, with 29 (65.9\%) achieving complete remission of T2DM 12 months after surgery and 15 (34.1\%) patients failing to achieve the same result within the indicated period. Table I shows the results of single-factor analysis.

The conclusion can be made about the presence of a link $(p<0,05)$ between the risk of failure to achieve complete remission of T2DM 12 months after surgery and the value of the C-peptide index (risk reduction with an increase in the index, OR $<1$ at $p=0.007)$, the value of glycosylated hemoglobin $\mathrm{HbAlc}$ level (increased risk with an increase in the index, OR $>1$ at $p=0.01$ ), the value of fasting glucose level (increased risk with an increase in the index, OR $>1$ at $p=0.02)$, the value of the assessment on the DiaRem scale (increased risk with an increase in the indicator, $\mathrm{OR}>$ 1 at $\mathrm{p}=0.02)$.

No link was found between gender, age, height, body weight, BMI, excess body weight and the risk of failure to achieve complete remission of T2DM 12 months after 
surgery (the area under the ROC curve does not differ from 0.5 and the OR score does not differ from 1 at $\mathrm{p}>0.05$ ). In order to compare the quality of prediction of the risk of failure to achieve complete remission of T2DM based on the selected significant factors, Receiver Operating Characteristic (ROC) curve analysis was used for these four tests (Figure 1).

The analysis shows a high predictive value of the risk prediction test for failure to achieve complete remission of T2DM 12 months after surgery for a C-peptide level, AUC $=0.84$ (95\% CI: 0.69-0.93), which indicates a "very good" quality of the model). When the level of C-peptide increases to $1 \mathrm{ng} / \mathrm{ml}$, the chances of failure to achieve remission decrease $(\mathrm{p}=0.007)$ by 4 times, $\mathrm{OR}=0.23(95 \%$ CI: 0.08-0.67). For the other three significant factors, the predictive characteristics are worse.

A selection of the optimal threshold for the risk prediction test for failure to achieve complete remission of T2DM 12 months after surgery was based on the initial level of C-peptide and carried out with the help of the Youden Index test optimization, the critical threshold for C-peptide $=3.7 \mathrm{ng} / \mathrm{ml}$. With a C-peptide level $\leq 3.7 \mathrm{ng} / \mathrm{ml}$, a high probability of failure to achieve complete remission of T2DM is expected after 12 months following surgery, with a C-peptide level $>3.7 \mathrm{ng} / \mathrm{ml}$ prediction is favourable.

When selecting the optimal test threshold, its sensitivity is 93.3 (95\% CI:68.1 - 99.8)\%, specificity - 75.9 (95\% CI: 56.5 - 89.7)\%, positive predictive value $\mathrm{PPV}=66.7$ (95\% CI: $50.8-79.5) \%$, negative predictive value NPV $=95.7(95 \%$ CI: 76.6 - 99.3)\%. Thus, if the C-peptide level is $>3.7 \mathrm{ng} / \mathrm{ml}$, then it is possible to predict the achievement of complete remission of T2DM and in $95.7 \%$ of cases this remission will actually be achieved 12 months after bariatric surgery.

In the analysis of $\mathrm{C}$-peptide, it was noted that 12 months after surgical treatment of $\mathrm{MO}$ in the subgroup of patients with a C-peptide value $>3.7 \mathrm{ng} / \mathrm{ml}$, complete remission of T2DM was observed in $22(75.9 \%)$ patients, with a Cpeptide value $\leq 3.7 \mathrm{ng} / \mathrm{ml}$ - in $7(24.1 \%)$ patients.

\section{DISCUSSION}

The patients with the mean BMI of 68.08 (95\% CI: 66.45 $69.71) \mathrm{kg} / \mathrm{m} 2$ were characterized not only as morbidly obese, but also as extremely overweight (BMI $\geq 50 \mathrm{~kg} / \mathrm{m} 2)$. In this case, the presence of co-morbidities, first of all, T2DM is an essential clinical problem. These patients have a high surgical and anesthetic risk, which makes bariatric surgery significantly complicated or even impossible. The two-stage treatment used in this study is consistent with the current views of the American Society of Metabolic and Bariatric Surgery (ASMBS, 2017) on the treatment of patients with $\mathrm{MO}$ and high surgical and anesthetic risks [6]. The two-stage treatment of patients with $\mathrm{MO}$, which included the IGB placement during the first stage, showed its efficacy both in terms of anthropometry and analysis of T2DM as comorbidity.

An overview of the first stage of treatment suggests that IGB is effective in improving carbohydrate metabolism in patients with MO. It impacts the relevant indicators of carbohydrate metabolism, probably due to the reduction in adipose tissue. The dynamics of the C-peptide level did not become statistically significant in both groups of patients, since the use of IGB does not have any action on the incretin effect. In general, the first stage of treatment in patients with $\mathrm{MO}$ is not enough to solve the clinical problem of T2DM. At the same time, the improvement of important indicators of carbohydrate metabolism is one of the essential factors in reducing surgical and anesthetic risks.

In the second stage of treatment, morbidly obese patients with T2DM underwent LRYGB, a surgical procedure that was more preferable than restrictive interventions such as gastric volume reduction and bypass, during which a significant part of the small intestine is excluded from the digestion, as well as combined interventions including both procedures. Gastric bypass combines mechanisms of restriction and malabsorption and, in addition, it has a direct effect on the achievement of T2DM remission by reducing the production of anti-incretins and accelerating the passage of food in the distal part of the small intestine that stimulates the release of glucagon-like polypeptide-1. Consequently, the type of bariatric surgery in patients with MO should be selected taking into account T2DM that is a commonly present co-morbidity. The dynamics of the laboratory indicators that were investigated showed positive outcomes of LRYGB in terms of the key indicators of carbohydrate metabolism.

The aforementioned dynamics of carbohydrate metabolism and C-peptide in patients after LRYGB give evidence of equal importance of adipokinin and other mechanisms related to secretory activity of the duodenum [14]. It is widely known that due to the exclusion of the duodenum and the proximal part of the small intestine from digestion, the production of anti-incretin factors in the duodenum decreases and the production of glucagon-like peptide GLP-1 and glucose-dependent insulinotropic peptide GIP in the small intestine increases, which contributes to the normalization of insulin levels $[15,16,17]$.

\section{CONCLUSIONS}

$\mathrm{T} 2 \mathrm{DM}$ is a common co-morbidity in patients with $\mathrm{MO}$, which emphasizes the medical and social significance of the problem.

Two-stage treatment of morbidly obese patients with T2DM promotes complete remission of T2DM in $68.1 \%$ of patients. The first stage of treatment should include the use of IGB for 6 months, and the second stage of treatment should be realized through bariatric surgery.

The risk prediction model for failure to achieve complete remission of T2DM 12 months after LRYGB that is based on the preoperative level of $\mathrm{C}$-peptide has a high predictive value, $\mathrm{AUC}=0.84$ (95\% CI: $0.69-0.93), \mathrm{OR}=0.23$ (95\% CI: $0.08-0.67$ ). With a C-peptide level $\leq 3.7 \mathrm{ng} / \mathrm{ml}$, a high probability of failure to achieve complete remission of T2DM is expected after 12 months after surgery, with a C-peptide level $>3.7 \mathrm{ng} / \mathrm{ml}$ prediction is favourable. The sensitivity of the test is $93.3 \%$ (95\% CI: $68.1-99.8$ ), specificity - 75.9\% (95\% CI: $56.5-89.7), \mathrm{PPV}=66.7 \%(95 \%$ CI: $50,8-79.5) \%$, NPV $=95.7 \%$ (95\% CI: $76.6-99.3) \%$. 


\section{REFERENCES}

1. WHO. Obesity and overweight. [Internet] 2018 Feb 16. [cited 2018 June 12] Available from: http://www.who.int/news-room/fact-sheets/ detail/obesity-and-overweight

2. Yoshizawa T, Ishikawa K, Nagasawa H, Takeuchi I, Jitsuiki K, Omori K, et al. A fatal case of super-super obesity $(\mathrm{BMI}>80)$ in a patient with a necrotic soft tissue infection. Intern Med. 2018 May 15;57(10):1479-81.

3. Kryvopustov MS. Morbid obesity as medical and social problem and ways of its solutions. Bulletin of Problems Biology and Medicine. 2018;(1 Pt 1):34-9.

4. Caro JF, Dohm LG, Pories WJ, Sinha MK. Cellular alterations in liver, skeletal muscle, and adipose tissue responsible for insulin resistance in obesity and type Il diabetes. Diabetes Metab Rev. 1989 Dec;5(8):665-89.

5. Stroh C, Birk D, Flade-Kuthe R, Frenken M, Herbig B, Hohne S, et al.. [Quality assurance in bariatric surgery in Germany--results of the German multicentre trial 2005 and 2006] Zentralbl Chir. 2008 Sep;133(5):473-8. German.

6. American Society for Metabolic and Bariatric Surgery Clinical Issues Committee. American Society for Metabolic and Bariatric Surgery updated position statement on sleeve gastrectomy as a bariatric procedure. Surgery for Obesity and Related Diseases. 2017 Oct 1;13(10):1652-7.

7. IFSO. Surgical treatment for type 2 diabetes: summary of recommendations and guidelines from the 2nd Diabetes Surgery Summit (DSS-II). [Internet]. [cited 2018 June 16] Available from: http:// www.ifso.com/wp-content/themes/ypo-theme/pdfs/intl-guidelinesendorsed-ifso.pdf

8. Ioffe OYu, Tsiura YuP, Stetsenko OP, et al. Mozhlyvosti dooperatsiinoi pidhotovky khvorykh na morbidne ozhyrinnia do vykonannia radykalnykh operatyvnykh vtruchan [Preoperative preparation opportunities for radical surgery in patients with morbid obesity]. Khirurhiia Ukrainy. 2014;2:38-42. [Ukrainian].

9. Zerrweck C, Maunoury V, Caiazzo R, Branche J, Dezfoulian G, Bulois P, et al. Preoperative weight loss with intragastric balloon decreases the risk of significant adverse outcomes of laparoscopic gastric bypass in super-super obese patients. Obes Surg. 2012 May;22(5):777-82.
10. loffe OY, Kryvopustov MS, Tsiura YP. Substantiation of expediency of a two-staged surgical treatment of morbid obesity. Klinicheskaia khirurgiia. 2018 Aug;85(8):49-2.

11. Introduction: Standards of Medical Care in Diabeotes-2018. Diabetes Care. 2018 Jan;41(Suppl 1):S1-2.

12. ASA. ASA Physical Status Classification System. [Internet] $20140 \mathrm{ct} 15$. [cited 2018 May 1] Available from: https://www.asahq.org/resources/ clinical-information/asa-physical-status-classification-system

13. Weykamp C. HbA1c: a review of analytical and clinical aspects. Ann Lab Med. 2013 Nov;33(6):393-400.

14. Litvinova L, Vasilenko M, Zatolokin P, Aksenova N, Fattakhov N, Vaysbeyn I et al. Adipokines in metabolic processes regulating during obesity treatment. Diabetes mellitus. 2014;17(3):51.

15. Laferrere $B$. Effect of gastric bypass surgery on the incretins. Diabetes Metab. 2009 Dec;35(6 Pt 2):513-7.

16. Chaudhry S, Bernardes M, Harris PE, Maffei A. Gastrointestinal dopamine as an anti-incretin and its possible role in bypass surgery as therapy for type 2 diabetes with associated obesity. Minerva Endocrinol. 2016 Mar;41(1):43-56.

17. Meek CL, Lewis HB, Reimann F, Gribble FM, Park AJ. The effect of bariatric surgery on gastrointestinal and pancreatic peptide hormones. Peptides. 2016 Mar;77:28-37.

The work is a fragment of the planned research work of the Department of General Surgery №2 of the O. O. Bogomolets National Medical University "Implementation of minimally invasive surgical techniques in the treatment of pathologies of the abdominal cavity, anterior abdominal wall, morbid obesity by fast track technique" (state registration No. 0118U000147).

\section{Authors' contributions:}

According to the order of the Authorship.

\section{Conflict of interest:}

The Authors declare no conflict of interest.

\section{CORRESPONDING AUTHOR Mykola S. Kryvopustov \\ Department of General Surgery 2 \\ 0. 0. Bogomolets National Medical University Taras Shevchenko Boulevard, 13, 01601 Kyiv, Ukraine tel: +38(066) 3916946 \\ e-mail: mykola.kryvopustov@gmail.com}

Received: 10.03 .2018

Accepted: 25.04.2019 


\title{
CLINICAL AND LABORATORY ASSESSMENT THE LEVELS OF ORAL HYGIENE, TOTAL PROTEIN, HYDROGEN SULFIDE AND NITROGEN METABOLITES IN ORAL FLUID IN THE DEVELOPMENT OF INFLAMMATORY COMPLICATIONS DURING ORTHODONTIC TREATMENT OF CHILDREN
}

\author{
Alisa V. Pachevska, Yurii V. Filimonov, Valerij Yu. Filimonov, Olena P. Dudik, Olena I. Popova, Nadiia V. Drachuk, \\ Dmytro M. Kasianenko, Alina V. Biloshitska, Valerij M. Istoshyn \\ NATIONAL PIROGOV MEMORIAL MEDICAL UNIVERSITY, VINNYTSYA, UKRAINE
}

\begin{abstract}
Introduction: Orthodontic treatment often causes inflammatory diseases in the oral cavity.

The aim: To increase the effectiveness of prevention of inflammatory complications in the provision of orthodontic care to children with dentomaxillary anomalies using nonremovable orthodontic devices on the basis of study of clinical and biochemical parameters.

Materials and methods: The study was conducted among 100 patients divided into two groups: control and experimental group 2 (50 patients in each). The control group included healthy children without dento-maxillary anomalies. The second group were children aged 9-15 years with dento-maxillary anomalies which used non-removable (bracket systems) orthodontic devices. The oral fluid was collected at the beginning of the medical application of orthodontic devices (at the first day of treatment in the clinic) and after 3 and 6 months of treatment.

The study included the definition of the oral hygiene degree by using the Green-Vermillion index (OHI-S), the modified Fedorov-Volodkin's and Siness-Loe index, the determination of hydrogen sulfide and total protein levels, the content of nitrogen metabolites in the oral liquid.

Results: The use of non-removable orthodontic devices led to signs of inflammation in the oral cavity. This was accompanied by a deterioration of the oral hygiene, increase the total protein, hydrogen sulfide and nitrogen metabolites levels in the oral fluid.

Conclusions: Complex accounting is required of keeping oral hygiene in good condition, level determination of total protein, hydrogen sulfide and nitrogen metabolites for the prevention of the development of inflammatory diseases in the provision of orthodontic care.
\end{abstract}

KEY WORDS: dento-maxillary anomalies, oral hygiene, total protein, hydrogen sulfide and nitrogen metabolites

Wiad Lek 2019, 72, 5 cz. I, 744-747

\section{INTRODUCTION}

The whole world system of health care in general and dentistry in particular pay more attention to the fight against dental diseases, including dental anomalies [1]. As the study showed [2] morphological deviations in the dento-jaw system are often accompanied by significant functional disorders that lead to periodontal tissue diseases and early teeth loss. This pathology progresses rapidly with age and is accompanied by a deformation of the tooth-skeletal system, as well as aesthetic disorders. In addition to postures and functional disorders in the small circle of blood circulation, delayed psychosomatic development, there are neuroses and neurosis-like conditions associated with dissatisfaction with their own appearance.

Orthodontics is a relatively modern and rapidly progressive section of stomatology that studies the etiology and pathogenesis of dento-maxillary anomalies, the development of methods for their diagnosis, the development of methods for the prevention and treatment of anomalies of the position of the teeth, forms of dental arches, occlusion, jaw growth, normalization of the function of the dento-jaw system, elimination of aesthetic disorders, the influence on the development of adjacent organs and the organism as a whole [3]. The second half of the 20th century and the first decade of the 21st century are characterized by the rapid development of orthodontics, both in Ukraine and in other countries. It is known significant achievements of [4] which are obtained in the development of new methods of differential diagnosis of functional and mechanical methods for treatment of bite anomalies, which are used by more dental practitioners. It has been established that the inflammatory complications often accompany orthodontic treatment of children [5]. Sometimes inflammatory diseases (gingivitis, periodontitis) hinder the continuation of orthodontic treatment [6]. Therefore, effective prevention of inflammatory diseases is a key to successful orthodontic treatment. 


\section{THE AIM}

To increase the effectiveness of prevention of possible complications in the provision of orthodontic care to children with dento-maxillary anomalies using non-removable orthodontic devices on the basis of study of clinical and biochemical parameters.

\section{MATERIALS AND METHODS}

The study was conducted among 100 patients divided into two groups: control and experimental group 2 (50 patients in each). The control group included healthy children without dentomaxillary anomalies, signs of inflammation in the oral cavity and diseases of the gastrointestinal tract. Children aged 9-15 years with dentomaxillary anomalies of the first class by Engle with moving 2-3 teeth which were used non-removable (bracket systems) orthodontic devices were the second group.

The oral fluid was collected at the beginning of the medical application of orthodontic devices (on the first day of treatment at the clinic) and after 3 and 6 months of treatment. The material used for the study was oral fluid (unstimulated mixed saliva), which was collected from patients always on an empty stomach at the same time. The freshly collected samples of oral fluid, which were collected in tubes with a sealed lid, were analyzed, centrifuged and the supernatant was transferred to Eppendorf tubes. Samples of saliva (oral liquid) were kept at $-20^{\circ} \mathrm{C}$ to direct determination of biochemical parameters.

Clinical examination included questioning, review, palpation, percussion, auscultation. The mother of the child determined her state of health during pregnancy, heredity, the course of birth, how much they were, with what weight at birth, how fed and by what time. Revealed the transmitted diseases and their course, the time of teething, the causes of their premature loss, the time of change in teeth, as well as the age when the child began to walk and talk. After that, the patient's oral cavity was examined: the mucous membrane and the degree of development of the upper and lower lip bridle, tongue, the shape and size of the tongue, the tongue swelling, the depth of the solid palate, the state of the development of the alveolar jaws and the apical basis compared to the dental and alveolar arcs. They studied the shape, size and number of teeth, their condition and location in the tooth ranks, the shape of dental arches, the ratio of jaws and dentitions, and the type of bite.

Comprehensive consideration of clinical examination methods allowed us to form groups with non-removable devices for the treatment of dento-maxillary anomalies, namely, we involved in the study group children of 9-15 years old with the first class of dento-maxillary anomalies by Engl and with moving no more than 2-3 teeth, then we selected the appropriate fixed orthodontic devices. We used bracket systems.

The study determined the degree of oral hygiene by using the Green-Vermillion index (OHI-S), the modified Fedorov-Volodkin's and Siness-Loe index according to the generally accepted method [7]. Patients with poor oral hygiene were excluded from the study at the beginning of treatment.
The oral fluid of the patients to determine the hydrogen sulfide content was collected in a test tube containing 0.5 $\mathrm{ml}$ of $1 \%$ zinc acetate solution. The content of hydrogen sulfide was determined by the reaction of the formation of thionine using $\mathrm{n}$-phenylenediamine [8].

The study of the level of total protein was carried out according to the generally accepted method [9].

Determination of the content of nitrites in the oral liquid was carried out by measuring the optical density of the colored azo compound formed by the interaction of nitrites with alpha-naphthylamine and sulfanilic Griss in acidic medium, as described previously [10].

The Bioethics Committee of the National Pirogov Memorial Medical University, Vinnytsya found that the research materials did not deny the basic bioethical norms of the Helsinki Declaration, the Council of Europe Convention on Human Rights and Biomedicine (1977), the relevant provisions of the WHO and the laws of Ukraine.

\section{RESULTS AND DISCUSSION}

Clinical examination of the oral cavity of healthy children, children with non-removable orthodontic treatment was performed at the beginning of the study, after 3 and 6 months. It was found that in healthy children at the beginning of the observation, after 3 and 6 months, the mucous membrane of the oral cavity was pale pink, shiny, without pathological changes. In a group of children who used non-removable orthodontic devices for 3 months of observation, the mucous membrane was characterized by slight edema and small events of mild degree of localized catarrhal gingivitis. After 6 months of observation in 75\% of children, who used non-removable orthodontic devices, the mucous membrane of the oral cavity was characterized by catarrhal gingivitis.

The level of oral hygiene was determined using the Green-Vermillion Index (OHI-S), the modified Fedorov-Volodkin Index and the Silness-Loe Index. During the study period, oral hygiene in the group of healthy children was almost unchanged. The study of the Green-Vermillion index showed that in the group with treatment with non-removable devices in 3 months of treatment the oral hygiene condition deteriorated 1.7 times. After 6 months the state of hygiene of the oral cavity deteriorated 1.8 times.

The study of the modified Fedorov-Volodkin's index showed that if 3 months of treatment the state of oral hygiene in the group with non-removable devices was 1.5 times worse, then after 6 months the deterioration of the oral hygiene status during the treatment of non-removable devices was 2 times, than at the beginning of treatment.

The study of the oral hygiene status by the Silness-Loe index were correlated with previous studies: at 3rd month of treatment the oral hygiene status was worse 1.66 times, and at the 6th month of observation this index was also worse 1.7 times compared with the beginning of treatment.

Clinical examination of patients, examination of the oral hygiene state were accompanied by oral fluid biochemical study. 
Table I. The results of biochemical research

\begin{tabular}{|c|c|c|c|c|c|c|}
\hline & \multicolumn{3}{|c|}{ Healthy children } & \multicolumn{3}{|c|}{ Treatment patients } \\
\hline & Start of treatment & $3 \mathrm{~m}$ & $6 \mathrm{~m}$ & Start of treatment & $3 \mathrm{~m}$ & $6 \mathrm{~m}$ \\
\hline $\begin{array}{c}\mathrm{H}_{2} \mathrm{~S} \\
\mathrm{mkm} / \mathrm{l}\end{array}$ & $38,05 \pm 1,28$ & $39,21 \pm 1,38$ & $41,61 \pm 1,51$ & $41,13 \pm 0,71$ & $63,22 \pm 1,66^{*}$ & $88,10 \pm 2,33^{*}$ \\
\hline $\begin{array}{c}\mathrm{NO} \\
\mathrm{mkg} / \mathrm{ml}\end{array}$ & $0,426 \pm 0,04$ & $0,475 \pm 0,04$ & $0,591 \pm 0,09$ & $0,751 \pm 0,66$ & $1,530 \pm 0,05^{*}$ & $3,048 \pm 0,60^{*}$ \\
\hline Total protein, g/l & $5,25 \pm 0,14$ & $5,68 \pm 0,11$ & $6,01 \pm 0,14$ & $5,94 \pm 0,11$ & $7,26 \pm 0,20^{*}$ & $8,27 \pm 0,32^{*}$ \\
\hline
\end{tabular}

* the difference was statistically significant $(p \leq 0,05)$.

At the initial stage of the carious process, as with gingivitis, researchers observed growth in the content of total protein [6]. As is known, the most important elements of the secretory activity of the salivary glands are substances of proteins, which can be conventionally divided by functional properties into three groups: those who takes part in the processes of digestion, proteins which are associated with local immunity and proteins that perform regulatory functions.

The study showed that in the control group of children the level of total saliva protein varied, namely: after 3 months it was higher by $8 \%$ from the initial one, and in samples taken after 6 months, the total protein level was higher by $6 \%$ compared with the 3- month of study and $14 \%$ compared to the start of the study.

In patients of the experimental group which were used non-removable equipment during the treatment an increase in the total salivary protein level was 1.2 times at the $3 \mathrm{rd}$ month of treatment and 1.5 times at the sixth month of treatment (table I).

Increasing the level of total protein can be explained by the fact that the aggressive effect of orthodontic devices causes the formation of a local focus of infection in the oral cavity, sensitization of the mucosa, an increase of autoimmune disorders and aggravation of the course of the underlying disease.

Hydrogen sulfide reduces production of pro-inflammatory substances of protein-like nature, a well-known toxic gas with an unpleasant smell, which is formed mainly during the decay of proteins of animal and vegetable origin. For a long time its role in living organisms was considered only from the perspective of exo- and endotoxicants. Since the late $90 \mathrm{~s}$ of the XX century, interest in hydrogen sulfide has increased considerably in connection with the establishment of its involvement in the regulation of physiological functions in animals and humans. The results of the studies of K. Abe and H. Kimura (1996), which described the peculiarities of the formation of this metabolite in the rat brain and identified the first molecular target, $\mathrm{N}$-methyl $\mathrm{D}$-aspartate receptors (NMDA receptors), were the impetus for a more in-depth study of the biological role of hydrogen sulfide.

The conducted study showed that the level of hydrogen sulfide in healthy children changed slightly, namely: after 3 months it was higher only by $3 \%$ of the initial, and in samples taken after 6 months, the hydrogen sulfide level was higher by $6 \%$ compared with 3 month of study and $9 \%$ compared with the start of the study (table I).

At 3 months after starting treatment patients of the experimental group who used non-removable devices were experienced an increase in hydrogen sulfide level in 1.5 times compared to the start of treatment and at the 6 month of treatment the level of hydrogen sulfide increased in 2 times compared with the the beginning of treatment (table I).

Scientists believe that in supra-physiological concentrations, hydrogen sulfide induces hyperalgesia, causes tissue inflammation and cell apoptosis [8], which we noted in a clinical examination of patients on the 3rd and 6th months of treatment.

Recent studies have shown that nitrogen metabolites play an important role in regulating the local immune response: together with hydrogen sulfide they are signaling molecules for the regulation of vascular tone and inflammation. Reduction of nitrogen metabolites production leads to increased perception of infection. The nitrogen metabolites synthesized refers to the antimicrobial protection factors, as it destroys bacteria, viruses, fungi. Therefore, the growth of the level of nitrogen metabolites is considered as an important factor of non-specific immunity, necessary for regulatory of cytoprotective processes.

Indeed, in our study, we found that in healthy children, the level of nitrogen metabolites varied, namely: after 3 months it was higher by $12 \%$ of the original, and in samples taken after 6 months, nitrogen metabolites level was higher by $27 \%$ than the 3 - month of study and by $39 \%$ compared to the start of the study.

In patients of the experimental group with non-removable orthodontic devices during treatment, there was a significant increase of nitrites (nitrogen metabolites) in the oral liquid: 3 months after starting treatment in 2 times and after 6 months of the beginning of treatment in 4 times. The obtained data may indicate that the multiple increase in nitrogen metabolites level during the use of non-removable orthodontic devices leads to greater activation of the immunological reactivity of the oral cavity.

\section{CONCLUSIONS}

We have followed a cascade of interconnected clinical and biochemical changes that occur during the treatment of non-removable orthodontic devices. The presence of met- 
al-plastic structures in the oral cavity complicates care and causes a deterioration of the index of oral hygiene. Remains of food, undigested carbohydrates cause disturbances in the oxidative-reducing processes, violation of the buffer properties of the oral fluid. The greater activation of the immunological reactivity of the oral cavity manifest in pathologically high levels of total protein, hydrogen sulfide and nitrogen metabolites.

Therefore, we consider it necessary in the provision of orthodontic care timely complex accounting of keeping oral hygiene in good condition, level determination of total protein, hydrogen sulfide and nitrogen metabolites for the prevention of the development of inflammatory diseases.

\section{REFERENCES}

1. Savichuk $N$, Klitynska 0 . Analiz prohram profilaktyky osnovnykh stomatolohichnykh zakhvoriuvan u rozvynenykh krainakh [The prevention programs analysis of the basic dental diseases in development countries]. Sovremennaya stomatologiya. 2014;(Ш4):64-6. ( UA)

2. Paliychuk I. Vyznachennia skhylnosti do vynyknennia proteznoho stomatytu na osnovi pokaznykiv mistsevoho imunitetu, mikrobiotsenozu rotovoi porozhnyny ta stanu imunnoi systemy v patsiientiv z chastkovymy defektamy zubnykh riadiv do protezuvannia za dopomohoiu znimnykh konstruktsii zubnykh proteziv [Determination of susceptibility to the emergence of prosthetic stomatitis based on indicators of local immunity, oral cavity microbiocenosis and the state of immune system in patients with partial dentition defects before making removable prosthetic dentures]. Sovremennaya stomatologiya. 2015;1:72. (UA)

3. Golovko NV, Babenko AD. Pidvyshchennia efektyvnosti likuvannia khronichnoho hipertrofichnoho hinhivitu v ortodontychnykh patsiientiv [Increasing the effectiveness of treatment of chronic hypertrophic gingivitis in orthodontic patients]. Ukrayinskiy stomatologichniy almanah. 2013;(5):60-2. (UA)

4. Kovach IV, Lavrenyuk YV. Stan mikrobiotsenozu porozhnyny rota u ditei z neznimnoiu ortodontychnoiu tekhnikoiu [State of microbiocenosis of oral cavity in children with nonremovable orthodontic appliances]. Innovatsiyi v stomatologiyi. 2016;(1):15-9. ( UA)
5. Voronkova GV. Suchasne uiavlennia pro stan tkanyn parodonta v patsiientivizzuboshchelepnymy anomaliiamy pid chas ortodontychnoho likuvannia neznimnoiu tekhnikoiu. [Contemporary presentation of the state of periodontal tissues in patients with dentoscheleal anomalies during orthodontic treatment with non-removable equipment]. Ukrayinskiy stomatologichniy almanah. 2012;1 (2):94-104. ( UA)

6. Petrushanko TA, Kirilenko MA. Analiz faktorov riska bolezney parodonta pri ispolzovanii breket-sistem [Analysis of the risk factors of periodontal diseases when using bracket systems]. Ukrayinskiy stomatologichniy almanah. 2013;(5): 35-8. (Ru)

7. Smaglyuk LV, Luchko EV, Davyidenko SV. Primenenie shemyi individualnoy profilakticheskoy programmyi pri lechenii breket-tehnikoy [The use of the scheme of individual preventive programs in the treatment of bracket]. Ukrayinskiy stomatologschniy almanah. 2013;(3):65-7. (Ru)

8. Zaichko NV, Melnik AV, Yoltuhovsky NM et al. Hydrohensulfyd: metabolyzm, byolohycheskoe y medytsynskoe znachenye [Hydrogen sulfide: metabolism, biological and medical significance]. Ukr Biochem J. 2014; 86 (5): 5-25. (Ru)

9. Korobeinykova $Э \mathrm{~N}$, Ylynykh EY. Kolychestvennoe opredelenye belka i mutsyna (hlykoproteinov) v sliune [Quantitative determination of protein and mucin (glycoproteins) in saliva]. Klynycheskaia laboratornaia dyahnostyka. 2001;8:34-5. (Ru)

10. Kurnosov MN. Opredelenie nitritov v sliune [Determination of nitrites in saliva]. Laboratornoye delo. 1991; 3: 34-7. (Ru)

The research was carried out in accordance with the research plan of the Department of Pediatric Dentistry of the Vinnitsa National Medical University named after MI Pirogov "Clinical and experimental basis of the application of new methods of prevention, diagnosis, treatment of children and adolescents with anomalies of the dento-jaw system and complications of caries" (№0115U007010).

\section{Authors' contributions:}

According to the order of the Authorship.

\section{Conflict of interest:}

The Authors declare no conflict of interest.

\section{CORRESPONDING AUTHOR Alisa V. Pachevska \\ National Pirogov Memorial Medical University \\ 56 Pirigova St., Vinnytsya, Ukraine \\ e-mail:alisa.paczewska@gmail.com}

Received: 15.03 .2019

Accepted: 24.04 .2019 


\title{
MORPHOMETRIC AND HISTOCHEMICAL CHARACTERISTICS OF THE CRIBRIFORM TYPE OF INTRADUCTAL CARCINOMA OF THE MAMMARY GLAND
}

\author{
Dmytro Y. Nikolenko, Dmytro M. Boiko, Olexandr A. Shkurupii, Oksana V. Ovcharenko \\ UKRAINIAN MEDICAL STOMATOLOGICAL ACADEMY, POLTAVA, UKRAINE
}

\begin{abstract}
Introduction: Due to the increasing morbidity and mortality rates from breast cancer, the problem of early, especially morphological diagnosis, continues to be important. The aim of this study to investigate the karyometric and histochemical features of cribriform pattern of parenchyma of intraductal carcinoma of the mammary gland. Materials and methods: Operational and biopsy material was studied in form of serial sections of micropreparations of cribriform type intraductal carcinoma of the mammary gland. Fixation with 10\% neutral formalin, paraffin sections are stained with hematoxylin and eosin, complex Bergman + Periodic Acid - Schiff (PAS) reaction + alcyan blue. Cariometry was performed on 100 parenchymal tumor cell, tenth logarithms of the nucleus volume ( $\mathrm{LgV}$ ) were determined, kariocavirogram was constructed.

Results: The atypical cellular polymorphism of the tumor, cribriform structures with cancerous cells in the state of apoptosis was revealed. The modal nuclear classes are defined in the interval $\operatorname{LgV} 0,75 ; 0,9 ; 1,2 ; 1,45$, and do not comply with the law of rhythmic growth of nuclei in normal and confirm the cellular atypism of a cancerous tumor. Results are deprived of subjectivity through mathematical analysis of data in percentages (\%). Histochemically, in the cytoplasm of cancer cells, precursors of lipids were detected in the form of a Schiff (PAS) positive reaction; alcyan-positive basal membrane of the duct; Bergman-positive protein structures in the nuclei.

Conclusions: Cariometry and histochemical analysis of intraductal carcinoma of the mammary gland is an objective and accessible complex method for the analysis of atypical cells, reveals the degree of differentiation, apoptosis of cells and non-invasive stage of cancer.
\end{abstract}

KEY WORDS: morphometry, histochemistry, cribriform type, duct cancer, mammary gland

Wiad Lek 2019, 72, 5 cz. I, 748-752

\section{INTRODUCTION}

Over the past decade, breast cancer incidence and mortality rates have been observed among women in Ukraine and in most developed countries, indicating the acute relevance of this problem. According to the data of the National Cancer Registry of Ukraine, in the past two years, more than 14,000 new cases of the illness have been detected, accounting for $63.7 \%$ out of 100,000 female population, in Poltava region it reaches up to almost $61.0 \%$, as in the world this standardized indicator is $43.9 \%$. At the same time, mortality in Ukraine from breast cancer has reached $24.4 \%$, but the incidence among women in the world is $15.6 \%[1,2]$. That is why, despite some successes in clinical diagnosis and treatment of breast cancer, the problem of early, especially morphological diagnosis of malignant tumors of the mammary gland (MG), continues to be important.

It should be noted that morphologically the mammary glands have certain features. They respond to rhythmic changes in the hormonal state of the ovaries. As a result, there is a periodic stimulus to the proliferation of parenchyma of the germinal zones of the MG: in the intercalated part of the terminal ducts, the epithelium of which has a morphological identity to the cuticular epithelium, and in the strained zone of the pathway of milk, with a pseudo-layered epithelium structure similar to the embryonic milkpoints in embryogenesis [3, 4,5,6,7].
That is why the proximity of the structure of the germinal zones of the MG ducts to the embryonic analogues makes them too sensitive to adverse factors, in particular carcinogens, which influence the proliferative process and lead to oncogenesis in the mature period of the woman's life $[8,9,10]$.

It is known that the nucleus contains the genetic material of the cell, organized as multiple long linear DNA molecules that coil around to form chromosomes. These compact structures are stained with hematoxylin (chromatin). It binds to basophilic substances. In this case, the dynamics of the cell cycle of the chromosome may be in a state of complete decondensation (euchromatin). At the same time, the maximum condensation of chromatin (heterochromatin) occurs in mitosis of cells. The nucleus (one or two) is also associated with the activity of cells, forming ribosomal RNA [11,12]. Normally, the matrix of the cytoplasm stained with eosin shows cytoplasm blue. The cytoplasm contains membranous and non-membranous organelles that produce various substances with the accumulation of glycogen stores, fat drops and other substances $[11,13]$.

However, specialists of pathomorphology are wellknown in the difficulties associated with differential and histogenetic diagnosis of MG cancer ducts. It is due to the 
fact that the usual histological methods have certain limits and are used to establish a formal diagnosis of malignant neoplasia. At that time, as it is known, a qualitative morphological diagnosis of a malignant tumor needs to take into account a complex of features: morphometric and morpho-functional characteristics, tissue and cell atypism, which allows to determine the degree of differentiation of the tumor. The above have a direct impact on the prognosis of the disease and the choice of cancer treatment methods $[9,14,15,16]$.

According to the new classification of tumors WHO (2012), most carcinomas of MG develop from the terminal lumen-flow structural unit (TDLU, terminal duct lobular unit). An in situ carcinoma (DCIS) code 8500/2 has features in the form of proliferation of atypical epithelial cells of nonspecific type with clear boundaries and absence of polarity; degree of malignancy (low, moderate, high) depending on nuclear atypia; various type of structure, among which there is a cribriform type $[17,18,19,20]$.

In this case, the karyometric and histochemical characteristics of the cribriform type of non-invasive stage of development in the elaborated scientific-practical medical literature are not sufficiently highlighted.

\section{THE AIM}

The aim of the study is to investigate the karyometric and histochemical features of the parenchyma of the cribriform type of non-invasive intraductal carcinoma of the mammary gland.

\section{MATERIALS AND METHODS}

The research was carried out within the framework of the Agreement on scientific and practical cooperation between the Dnipropetrovsk State Medical Academy and the Ukrainian Medical Stomatological Academy (Poltava), the state registration number $0101 \mathrm{U} 4001002$ and is a fragment of the topic "Individualization of the treatment of malignant tumors, taking into account the biological indices of the activity of the tumor process and markers of chemo hormone-resistance". The material was collected from both the archives database and the current histological study at the Poltava Regional Pathological Bureau, taking into account the "Law of Ukraine on burial and funeral affairs with changes introduced in accordance with the Law № 2246-IV February 16, 2004; BBP, 2005, № 4, Art. 105 “, and the Agreement on Scientific and Practical Cooperation between the Ukrainian Medical Stomatological Academy and the PRPB.

Serial sections of histological preparations of 24 cases of operative and biopsy material with intraductal carcinoma of the mammary gland in women aged 30-70 years with a formally verified cribriform type of cancer stained with hematoxylin and eosin were subject to the study. Fixation of the material in a $10 \%$ solution of neutral formalin, paraffin histological sections of the tumor tissue was repeatedly stained with hematoxylin and eosin, as well as the combined histochemical Bergman + Periodic Acid - Schiff (PAS) reaction + alcyan blue. The reason for conducting Periodic Acid - Schiff (PAS) reaction with additional treatment with amylase was that neutral polysaccharides react during cell proliferation to reorganize the energy metabolism [21]. In the presence of crimson coloration of cells, this is considered a Periodic Acid - Schiff (PAS)-positive reaction. The clarification of the presence of acidic glycosaminoglycans in the histostructure of the tumor occurred alcian blue by Steedmen, blue-green color was considered alcian-positive [22]. The coloring of micropreparations by the Bergman method reveals the neurosecretory granules in the cytoplasm and the clear outlines of the brown nucleus, which was important for caryometry. In the microscopy of the tumor tissue, the degree of basophilia of the nucleus of the cells was considered, which is related to fine, medium, and large-splintered chromatin.

Cariometry, as the most informative among morphometric methods [23, 24], was carried out on microfoto imprints in a size of $18 \times 24 \mathrm{~cm}$ with enlarged study objects in 1000 times in 100 atypical cells. The size of the nuclei was determined $(\mathrm{V})$ by the formula:

$$
\mathrm{V}=\frac{\pi}{6} k^{3} d
$$

where $d$ is the small diameter of the nucleus, $\mathrm{D}$ - the large diameter of the nucleus, $\mathrm{k}$ - coefficient of increase of an object $(1,545) ; \pi(3.14)$. The error did not exaggerate $0.03 \%$, which corresponds to the requirements for medical biology research $(\mathrm{P}<0.005)$. All values of the volume of the nuclei were logarithmized $(\operatorname{lgV})$ by the formula for the rotary ovoid:

$$
\operatorname{LgV}=\operatorname{Lg} \frac{p \times \pi}{6} d^{2},
$$

where $p$ is the multiplicity of increase $(1,545) ; \pi \pi-3.14$; $\mathrm{d}$ - small diameter of the nucleus, $\mathrm{D}$ is the large diameter of the nucleus, followed by computer processing $[25,26,27]$. The quantity of all nuclear classes acquire the values in percent (\%) of the maximum nuclear class taken for $100 \%$. The combination of these results was karyocovariogram. Study of stained micropreparations was carried out using the light microscope of the company "Olympus BX41" with lenses $x 10, x 20, x 40, x 100$. The statistical processing of the karyometric data was performed on an IBMPC compatible computer using the «Microsoft office Excel, 2007» licensing program for Windows XP. The work was followed by legal norms and requirements for scientific morphological studies [28].

\section{RESULTS AND DISCUSSION}

An overview optical-optical microscopy of hematoxylin-colored and eosin-colored histopathologic preparations of intraductal carcinoma of the mammary gland revealed the duct with canceromatosis, the lumen of which is completely filled with polymorphic cellular elements (Fig. 1a). They have a mostly chaotic orientation with the loss of 




1a

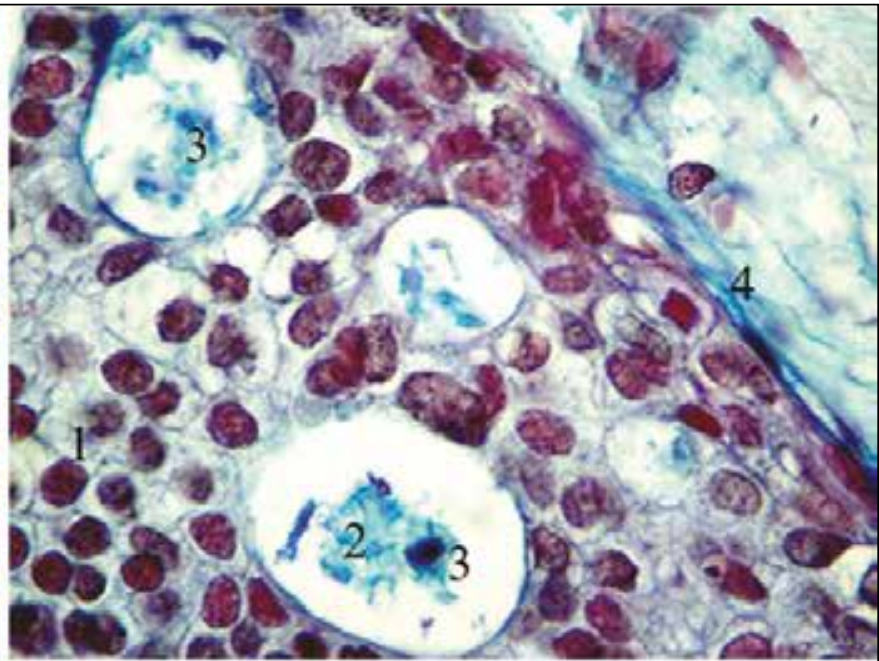

$1 b$

Fig. 1. Cribriform type of intraductal carcinoma of the mammary gland.

a) Hematoxylin \& Eosin staining (x400 magnification): 1 - Atypical cells in the lumen of the duct; 2- "cribriform structures" in the cancer population; 3-moderate lymphoid infiltration.

b) Bergman + Periodic Acid - Schiff (PAS) reaction + alcyan blue staining (x1000 magnification): 1- Schiff-positive coloration of the cell cytoplasm; 2-Alcyan-positive secret in the secondary luminaries; 3 - apoptotic nucleus; 4-Alcyan-positive staining of the basal membrane of the cancerous duct.

stratification and their polarity. At the same time, attention is drawn to the orderly arrangement of some tumor cells with radial orientation around randomly located round cavities - cribriform (lattice) structures, among some isolated solid layers of tumor tissue from the periphery. Most of the cellular elements of the tumor are not in contact with the basal membrane of the cancerous duct, which is a sign of the entropy of the atypical proliferation. An analysis of the cancer cell complex found in most cells in the center a large nucleus with a convoluted nuclear membrane. There is a change in the ratio of the nucleus and cytoplasm of tumor cells, which correlates with the change of their nuclear chromatin. Cell elements with a broad rim of cytoplasm containing basophilic inclusions have an intranuclear content of preferably light-basophilic chromatin and one or two nucleoli. In this case, the chromatin is in the dusty state and occasionally coarse-shaped. This character of chromatin characterizes, according to literature [13], the decondensation of chromosomal material (euchromatin) in the synthetic process of transcription and reduplication of genetic material in the interphase of the cell cycle, which is a sign of the functional activity of atypical cells. This cell corresponds to a modal nuclear class with $\mathrm{LgV}$ 0.9 and is the maximum, the most numerous, taken for $100 \%$. Among the atypical cellular population of the MG ducts, there are also such cells that have a narrow rim of a pale pink cytoplasm surrounding the large hyperchromic nucleus. It contains predominantly mass chromatin, which is highly condensed in mitosis of atypical cells. These cellular elements are tumors of different ploidy, have no signs of functional activity and constitute, in our opinion, a population that provides tumor growth. In this case, the $\mathrm{LgV}$ nuclei of these cells is 0.75 , which is $35 \%$ of the maximum nuclear class.

Atypical cells of the duct cancer that form the environment of cribriform structures in the neoplasia and the one pole in contact with the fluid (the secret) are not located on the basal membrane. These cells contain a rounded hyperchromic nucleus, in some of them it is pressed to the membrane of the cytoplasm with colorless vacuoles. This sign sometimes reveals the developed atypical secretory activity, which is characteristic of malignant tumors at the expense of partial differentiation $[16,29]$. The presence of two more modal nuclear classes among the aforementioned cell population was detected by kariometry. They are located within $\mathrm{LgV} 1.2$ and 1.45 (representing 75\% and $68 \%$ respectively of the maximum nuclear class). The difference is $\mathrm{LgV}$ of the nucleus in 0.2 , according to the Beningoff's law [25], corresponds to an increase in the volume of the nucleus under functional load, and confirms the established signs of secretion founded in cribriform structures. Combined histochemical coloring of microsamples of the tumor (Bergman + Periodic Acid - Schiff (PAS) reaction + alcyan blue) revealed, first of all, the presence of the Periodic Acid - Schiff (PAS) reaction-positive substances in the cytoplasm of pale-raspberry color around the nuclei of atypical cells (Fig.1b). Obviously, these are precursors of lipids - acetal lipids, which, according to literature review [22], contain aldehyde groups and with a Schiff reagent form lipid peroxides; and secondly: alcian-positive substance both in the cytoplasm of atypical cells, and in its outer membrane, as well as in the lumen of cribriform structures. It should be noted that the blue color of alcian-positive content in the structure of the 
tumor, has a different degree of saturation. It is especially expressed in the lumen of the cavities in the tumor, has a deep structure and resembles fragments of cell nuclei in a state of apoptosis. Along with this, alcian-positive coloration also acquired the basal membrane of the MG ducts, which is affected by the tumor, as well as the submembrane structures of the surrounding connective tissue. It should be noted that the varying degree of saturation of the alcian-positive color of the basal membrane of the cancerous duct of the gland demonstrates both continuity and fluctuations in its organic structure, and hence the threat of the development of invasive growth of the intraductal carcinoma of the mammary gland.

\section{CONCLUSIONS}

1. It has been determined that the cell population of the cribriform type of the non-invasive form of intraductal carcinoma of the mammary gland is varied by morphological features and functional activity.

2. It has been established that the atypical cell proliferate in the affected duct of the mammary gland is polymorphic-cellular, characterized by four growing modal nuclear classes with $\operatorname{LgV} 0.75 ; 0.9 ; 1.2 ; 1.45 \mathrm{i}$ confirms neoplastic nuclear polymorphism, while:

a) the smallest nucleus ( $\mathrm{LgV} 0.75$ and 0.9 ) have an oval or rounded shape, a dark basophilic color, and are surrounded by a narrow rim of weak eosinophilic cytoplasm, indicating a population of atypical epithelial cells capable of mitosis.

b) the largest by volume nuclei ( $\operatorname{LgV} 1.2$ and 1.45) with a difference of 0.2 have a rounded shape, a light basophilic color, the nuclei are shifted by optically empty vacuoles of the cytoplasm, apparently, due to the secretion of acetyl lipids, as a result of moderate differentiation of atypical cells.

3. It was found out that the atypical epithelium of cribriform structures with a combined histochemical color (Bergman + Periodic Acid - Schiff (PAS) reaction + alcyan blue) has:

a) Schiff-positive cytoplasm and alcyan-positive secret in cribriform structures, together with apoptotic fragments of cell nuclei;

b) continuous alcyan-positive basal membrane indicates on absence of invasive growth of the duct carcinoma.

4. To determine the prediction of the cribriform type of intraductal carcinoma of the mammary gland it is expedient to carry out the histochemical coloration of Bergman + Periodic Acid - Schiff (PAS) reaction + alcyan blue with the detection of Schiff- and alcyan-positive secretion, which determine the degree of differentiation of atypical cells, and the continuity of the alcyan-positive basal membrane indicates a non-invasive form of growth cancer.

Prospects for Further Research: In the future, it is planned to improve the technique of morphological research, to improve the tactics of anticancer therapy in patients with intraductal carcinoma of the mammary gland.

\section{REFERENCES}

1. Biuleten Natsionalnoho kantser-reiestru Ukrainy № 10 « Rak v Ukraini, 2007-2008:zakhvoriuvanist, smertnist, pokaznyky diialnosti onkolohichnoi sluzhbi» [Cancer in Ukraine, 2007-2008: morbidity, mortality, indicators of the oncology service activity]. Pid red.: I.B.Shchepotina. 10-te vydannia. Kyiv: Natsionalnyi instytut raku; 2009, 103 s. (UA)

2. Biuleten Natsionalnoho kantser-reiestru Ukrainy № 9. «Rak v Ukraini, 2016-2017: zakhvoriuvanist, smertnist, pokaznyky diialnosti onkolohichnoi sluzhbi»[Cancer in Ukraine, 2016-2017: morbidity, mortality, indicators of the oncology service activity]. Kyiv: Natsionalnyi instytut raku; 2018, S. 39-40.(UA)

3. Volkova 0 . V. Embriohenezi vozrastnaia histolohiia vnutrennikh orhanov cheloveka[Embryogenesis and age histology of human internal organs]. Moskva: Meditsina; 1976, 410s.(RU)

4. Afanasev Yi.Y. Histolohiia[Histology]: uchebnik. 5-e izd., pererab. idop. Moskva: Meditsina; 2002, 743 s.(RU)

5. Kokolina V. F. Razvitie molochnoi zhelezy v protsesse reproduktivnoi sistemy[Breast development in the process of reproductive system]. Ros. Vestnik akushera-hinekoloha. 2006;6(3):26-32.(RU)

6. Nikolenko D. Y. Morfolohiia molochnoi zaloz y zhinky reproduktyvnoho viku [Morphology of the mammary gland of a woman of reproductive age]. Aktualni problem suchasnoi medytsyny. 2007;4(24):275-278.(UA)

7. Nikolenko D. Y.Zarodok molochnoi zalozy yak prototypyiiherminatyvnoi zony u zhinky reproduktyvnoho viku [Breast gland as a prototype of it germinal zone in a woman of reproductive age]. Svitmedytsyny ta biolohii. 2008;2(2):78-82.(UA)

8. Hilakivi-Clarce L, Shayahan A, Yu B, de Assis S. Differentiation of Mammary Glandsas a Mechanism to Reduse Breast cancer Risk. J Nutr. 2006;136:2697S-26995.

9. Kantserohenez[Carcinogenesis]. Pod. red. D.H.Zaridze. Moskva: Meditsina; 2004, 576s.(RU)

10. Celia-Terrassa T. Mammary Stem Cells and Breast Cancer Stem Cells: Molecular Connections and Clinical Implications. Biomedicines. 2018;6(2):E50. doi: 10.3390/biomedicines6020050.

11. Khiem A, Kormak D. Histolohyia[Histology]: Per. s anhl. Moskva: Mir; 1983, S. 5-25.(RU)

12. Crum CP, Lester SC, Cotran RS. The Female Genital System and Breast. In: KumarV, Cotran RS, Robbins SL. Robbins Basic Pathology. Philadelphia, London, Toronto, Montreal, Sydney, Tokyo:Saunders; 2003, p. 679-718.

13. Afanasev Yu. Y., Yurina N. A., Kotovskii E. F.i dr. Histolohiia[Histology]: Uchebnik. 5-e izd., pererab. idop. Moskva: Meditsina; 1999, S. 73.(RU)

14. Honcharova S.V. Kriterii klinichnoii morfolohichnoi diahnostiki preinvazivnii (in situ) ta invaziinoho raku molochnoizalozy [Criteria for clinical and morphological diagnosis of preinvasive (in situ) and invasive breast cancer]. Vestnik neotlozhnoi y vosstanovyt. meditsiny. 2006;7(1):126-130.(UA)

15. Farid MoinfarEssentialis of Diagnostic Breast Pathology. A Practical Approach. Springer-Verlag Berlin Heidelberg; 2007, p. 496.

16. Viale $G$. Specifics of breast cancer diagnosis in every day practice. Arhivpatoloh. 2013;75(4):54-61.

17. Frank H. A., Danilova N. V., Andreeva Yu. Yu., et al. Klassifikatsiia opukholei molochnoi zhelezy VOZ 2012 hoda [WHO classification of breast cancer 2012]. Arkhivpatolohii. 2013;75(2):53-62.(RU)

18. Holovin D. I. Oshibki i trudnosti histolohicheskoi diahnostiki opukholei[Errors and difficulties of histological diagnosis of tumors]: rukovodstvo dlia vrachei. Leninhrad: Meditsina;1982, S. 182-200.(RU)

19. Tumor of the Breast and female genital organs. Word Health Organization Classification of Tumors. Edit. by F.A.Tavassoli, P.Devilee. Lyon: JARC Press; 2003, P. 432. 
20. $A B C$ of breast diseases. Edit. by J.Michael Dixon. 3rd ed. Blackwell Publishing; 2006, P. 112.

21. Lilli R. Patohistolohicheskaiatekhnikaiprakticheskaiahistokhimiia [Pathogistological technique and practical histochemistry]. Moskva: Izdatelstvo «Mir»; 1969, S. 645.(RU)

22. Pirs M. Histokhimiia [Histochemistry]. Moskva: izd. inostr. liter.; 1962, 962 s.(RU)

23. Avtandilov H. H. Osnovy kolichestvennoi patolohicheskoi anatomii [Fundamentals of quantitative pathological anatomy]. Moskva: Meditsina; 2002, 240 s.(RU)

24. Tsyhanova V. I., Melnikova N. P., Mohileva H. L., et. al. Morfotipy yade rzhelezistoho epiteliia pri dobrokachestvennykh i zlokachestvennykh zabolevaniiakh molochnykh zhelez [Morphotypes of nuclei of ferruginous epithelium in benign and malignant diseases of the mammary glands]. Klin Lab d-ka. 2004;1:43-45.(RU)

25. KhesinYa. E. Razmery yader i funktsionalnoe sostoianie kletki[The size of the nucleus and the functional state of the cell]. Moskva: Meditsina; 1967, S. 10-12.(RU)
26. JacobiW. UberdasrtythischesWaschstumderCellendurch Verduppelungihres Volumens. Arch Entwicklungsmech. 1935;10:S.124-126.

27. Tashke E. K. Vvedenie v kolichestvennuiut sito-histolohycheskuiu morfolohiiu [Introduction to quantitative cytological and histological morphology.]. Rumynia: Iz-voAkademiia; 1980, S.7-25.(RU)

28. Mishalov V. D, Chaikovskyi Yu. B., Tverdokhlib I. V. Pro pravovi zakonodavchi ta etychninormyi vymohy pry vykonani naukovykh morfolohichnykh doslidzhen[0n legal and ethical norms and requirements when performing scientific morphological research]. Morfolohiia. 2007;1(2):1-5.(UA)

29. Russo I, Mailo D, Hu YF, et. al. Breast differentiation and its implication in cancer prevention. Clin Cancer Res. 2005;11:931s - 6s.

\section{Authors' contributions:}

According to the order of the Authorship.

\section{Conflict of interest:}

The Authors declare no conflict of interest.

\section{CORRESPONDING AUTHOR Dmytro M. Boiko \\ Ukrainian Medical Stomatological Academy Shevchenko 23 str., 36011 Poltava, Ukraine e-mail:dim.xata@gmail.com}

Received: 01.03.2019

Accepted: 24.04.2019 


\title{
PATHOGENETIC ROLE OF NITROGEN MONOXIDE EFFICIENCY OF PHARMACOTHERAPY IN PATIENTS WITH GASTROESOPHAGEAL REFLUX DISEASE AND STABLE ANGINA OF TENSION
}

\author{
Oksana S. Khukhlina, Viktoriia Yu. Drozd, Alona A. Antoniv, Tamara H. Kopchuk, Zoriana la. Kotsiubiichuk \\ HIGHER STATE EDUCATIONAL INSTITUTION OF UKRAINE "BUKOVINIAN STATE MEDICAL UNIVERSITY", CHERNIVTSI, UKRAINE
}

\begin{abstract}
Introduction: The search for new mechanisms of their interconnection and effective pharmacological correction of gastroesophageal reflux disease (GERD) for comorbidity with stable angina of tension (SAT).

The aim: To establish the role of nitrogen monoxide (NO) in the pathogenesis of GERD in patients with SAT and to study the effectiveness of the correction of the basic therapy of SAT in order to eliminate the clinical manifestations of GERD and prevent its development.

Materials and methods: 88 patients with SAT with a comorbid GERD were examined. We determined clinical symptoms, the level of stable NO metabolites, calculated the number of nitroglycerin tablets taken one week. All patients (2 groups) received baseline therapy for GERD and SAT. In this case, the patients of the $2^{\text {nd }}$ group ( 45 persons) received therapy with the exception of long-acting nitrates and, in addition, meldonium for 30 days.

Results: With the exception of the use of nitro-containing drugs and adding to the basic therapy of SAT the drug meldonium we faster $(p<0,05)$ achieved a regression of clinical symptoms of GERD and decrease in the level of metabolites NO molecule in patients with SAT.

Conclusion: In the case of the exclusion of the intake of long-acting nitrates with the adding of meldonium to the basal therapy of the SAT and the GERD the content of metabolites of nitrogen monoxide in the blood is more normalized, which correlates with a decrease in the frequency of GERD symptoms in patients with SAT and GERD.
\end{abstract}

KEY WORDS: gastroesophageal reflux disease, stable angina of tension, nitrogen monoxide, meldonium

Wiad Lek 2019, 72, 5 cz. I, 753-756

\section{INTRODUCTION}

Ischemic heart disease (IHD) is headed by a pedestal of major causes of mortality and disability. One of the most common comorbid diseases of stable angina of tension is gastroesophageal reflux disease (GERD). About $40 \%$ of patients with coronary artery disease have lesions in the gastroesophageal area, and in $62.7 \%$ of gastroenterologic patients, concomitant diseases of the cardiovascular system occur. Scientists constantly search for new pathogenetic causes of this comorbidity, its progression and mutual burden. And, accordingly, effective pharmacological correction in patients with comorbidity of IHD and GERD.

The main causes of the occurrence of pathological gastroesophageal reflux (GER) are the primary reduction in the tone and the increase in the time of transient relaxation of the lower esophageal sphincter (LES) [1] due to many reasons, the use of organic nitrates - nitrogen monoxide dopants (NO) $[2,3,4,5,6]$. Relaxation of the muscles of the esophagus and the LES is due to nonadrenergic noncholinergic innervation, in which the main mediator is $\mathrm{NO}$ $[1,7]$, which is released from nonadrenergic noncholinergic (NANC) neurons of the intermucosal plexus [1]. In addition to the relaxation of LES against the background of hyperproduction of $\mathrm{NO}$ also a possible intensification of nitrosatitistic stress, which not only plays an important role in the emergence of pathological GERD, damage to the esophagus mucosa with the development of erosive reflux esophagitis, but can contribute to carcinogenesis of the esophagus [6]. In recent years, numerous data have appeared on the harmful role of high NO production, which normally occurs in small quantities, in particular in endothelial cells and platelets, and under physiological conditions, is a vasodilator. But under the conditions of inflammation a high amount of NO is produced, which, when in contact with free radicals of oxygen (superoxide anion), forms an even more powerful cytotoxic radical - peroxynitrite (ONOO-) [4]. Under conditions of insufficiency of coronary circulation, which is accompanied by a deficit of oxygen supply to the myocardium in IHD, against the background of deficiency of $\mathrm{NO}$ products, organic nitrates are used, which are NO dopants and perform relaxation of smooth muscle of coronary vessels. However, their metabolites are also able to react with superoxide anion with the subsequent formation of peroxynitrite, which leads to a disruption of the functioning of cardiomyocytes, reduces the ability of the myocardium to contract [3]. Dysregulation of synthesis and vasodilating function of the NO molecule is the cause of endothelial dysfunction, which leads to a decrease in the resistance of the esophageal tissues due to a decrease in regional esophageal perfusion and LES dysfunction [2]. It is described that when using nitro-containing drugs, high concentrations of NO are already formed in the 
esophagus cavity, with the interaction of saliva, hydrochloric acid in the esophagus, and nitrate [6,3]. During reflux of the acid, nitrosative stress occurs already inside the esophagus and can contribute to carcinogenesis of the esophagus. It has been demonstrated that external flow or local synthesis of a significant amount of NO induces the development of a representative marker of the Barrett esophagus, which causes and stimulates the progression of metastasis and neoplasia of the esophagus [1]. Consequently, NO plays an important role in the development and regulation of physiological and pathological processes of the cardiovascular system, but the use of nitrates in patients with coronary heart disease promotes relaxation of LES or an increase in GERD symptoms and may lead to the onset of Barrett's esophagus. Therefore, we searched for an effective treatment regimen for patients with SAT and GERD with the exception of NO dopants. Our attention has attracted meldonium (Vazonat) $[10,11]$, because it provides inhibition of oxidation of long chain fatty acids and stimulates glucose oxidation, thus protecting the cell from death in conditions of oxygen fasting, while short-chain fatty acids can penetrate freely in the mitochondria and oxidize there, that allows organs to function effectively in conditions of chronic hypoxia. As a result of inhibition of gamma-buutrobethene-hydroxylase, which converts gamma-butyrobatein (GBB) into carnitine, gradually decreasing the concentration of carnitine and the accumulation of GBB, which leads to optimization of energy production in ischemic cells. It is known that GBB has an acetylcholine-like effect that stimulates endogenous NO synthesis physiologically, which results in moderate vasodilation and improved microcirculation [11].

\section{THE AIM}

To establish the role of nitrogen monoxide (NO) in the pathogenesis of GERD in patients with SAT and to study the effectiveness of the correction of the basic therapy of SAT in order to eliminate the clinical manifestations of GERD and prevent its development.

\section{MATERIALS AND METHODS}

88 patients with stable angina of tension of I-II functional class (FC) with a comorbid endoscopically positive GERD (A, B, C) were examined. Age of patients varied from 48 to 82 years. Diagnosis was established in accordance with the orders of the Ministry of Health of Ukraine No. 152 from 02.03.2016 and No. 943 of October 31, 2013. Patients with comorbidity included in the study were using for the control of angina attack, intramuscular drugs (mainly nitroglycerin). All patients included in the study had an ECG, count of the number of painful myocardial ischemia episodes, the number of nitroglycerin tablets taken, and the levels of stable metabolites of nitrogen monoxide (NO) (nitrites, nitrates) by L.C. Green et al. [12] one week before correction of treatment, on the 10th and 30th day of therapy. The obtained result was compared with the result of practically healthy person (PHP, $n=30$ ). Detection of clinical symptoms of
GERD (heartburn, acid bloating, dysphagia, odynophagia, pain in the esophagus area), long-term monitoring of the $\mathrm{pH}$ of the stomach, endoscopy of the esophagus before and after treatment. After conducting surveys, instrumental studies and determination of NO level, the patients were divided into 2 representative groups. Patients in both groups received baseline treatment for GERD (PPP (rabeprazole), antacids) and SAT. In this case, patients of the 1st group (43 persons) took basal therapy of SAT, which included long-acting nitrates and nitroglycerin for the elimination of angina attacks), $\beta$-adrenoblocker (bisoprolol), statin (rosuvastatin), antiaggregant (clopidogrel)), and the $2^{\text {nd }}$ group (45 persons) received baseline therapy for SAT, with the exception of nitrates, in addition to the drug meldonium (Vasonate) $500 \mathrm{mg} 2$ times a day for 30 days. All drugs were prescribed in medium therapeutic doses.

\section{RESULTS AND DISCUSSION}

The average value of the level of metabolites of the NO molecule in the sample prior to treatment was $(42.83 \pm 1.58)$ $\mu \mathrm{mol} / \mathrm{L}$ (PHP (20.88 \pm 1.16$)$ ), which exceeded the index of PHP group by 2.09 times. The average number of tablets taken nitroglycerin per week in the monitoring group was $3.9 \pm 0.15$ tablets. After an in-depth analysis of the results, we found a strong direct linear correlation $(\mathrm{r}=0.84)$ between the level of end-metabolites of $\mathrm{NO}$ and the number of nitroglycerin tablets taken (Fig.1). At the same time, the significance level of the correlation was $\alpha=0.01$, which indicates its significant importance. Patients in both groups had almost identical clinical symptoms prior to treatment. Yes, all patients complained of frequent episodes of heartburn, with an intensity of an average of $4.1 \pm 0.8$ points. The frequency of complaints on acid bursts was $88.6 \%$ ( 78 people), the intensity of which was on average $4.0 \pm 0.5$ points. $61.3 \%$ of patients (51 persons) complained about odynophagia, the intensity was $3.1 \pm 0.6$ points. With a lower frequency of patients disturbed dysphagia, but its symptoms were present. According to esophagogastroduodenofibroscopy, erosive form of GERD was detected in $89.7 \%(n=79)$ of the sample. The rest of the patients $(n=9,10.3 \%)$ were diagnosed with a non-erosive form of GERD. Analyzing the data of the many-hour $\mathrm{pH}$-meter, it can be concluded that in patients with SAT and GERD who were included in the study, the average daily monitoring of the $\mathrm{pH}$ of the esophagus is characterized by the presence of an average severity of GERD [11].

Analysis of the treatment outcomes on the 10th day, of patients in group 2 shows a visible regression of the frequency of detected clinical symptoms of GERD, compared with patients in group 1 . Thus, $91 \%(n=41)$ of group 2 patients confirmed the absence of GERD symptoms, which can not be said about patients in group 1, in which on the 10 th day of therapy only $39.5 \%(n=17)$ of the symptoms of GERD diSAT peared or significantly decreased, and the result of the 2 nd group was obtained only on the 20th day of therapy. With the abolition of nitrates against the background of effective drugs therapy of SAT on the 10th day of therapy, the level of NO metabolites decreased in 


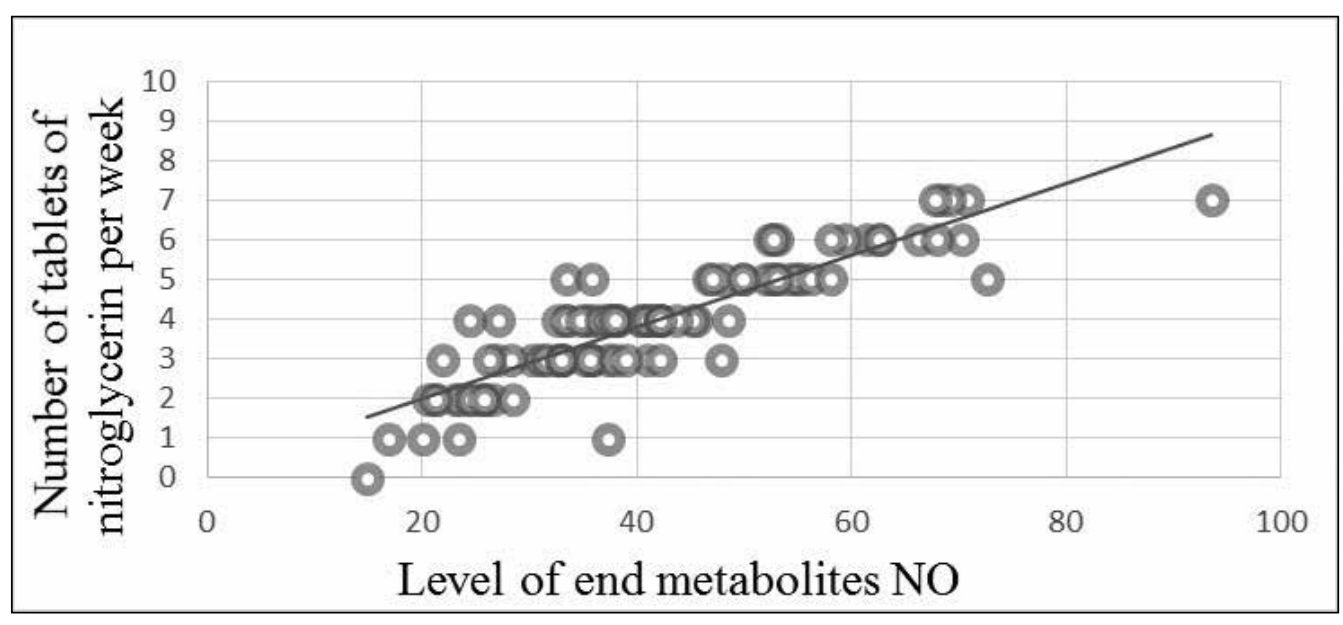

Fig.1. Direct linear correlation $(r=0.884)$ between the level of end metabolites of nitrogen monoxide and the number of tablets taken nitroglycerin per week. the $2^{\text {nd }}$ group by $35.3 \%$ (from $(43.54 \pm 2.25) \mu \mathrm{mol} / \mathrm{L}$ to $(28.17 \pm 1.86) \mu \mathrm{mol} / \mathrm{L}, \mathrm{p}<0.05)$. Comparing this indicator with the results of patients in group 1, its level decreased by only $11.8 \%$ under the same conditions, with a statistically significant difference between the groups $(\mathrm{p}<0.05)$. The reduction in this indicator in groups we connect with the abandonment of nitrates (group 2) or decrease in the frequency of taking nitroglycerin against the background of basic therapy (group 1). The mean value of the number of metabolites of NO reached the value in PHP in the 1st group on the 10th day of treatment only in $55.8 \%(n=24)$, when in the comparison group (group 2) in $97.7 \%$ ( 44 of 45 people). In addition, a strong linear correlation relationship was established (Pearson correlation coefficient ( $r$ ) is 0.81 ) between the level of end metabolites $\mathrm{NO}$ and the frequency of clinically expressed episodes of heartburn, as well as acidic rites $(r=0.79 ; r=0.76)$. On the 30 th day of therapy in group 2, the average value of NO metabolites reached the PHP value, GERD symptoms were not disturbed by any patient, which cannot be said about group 1 , in which the level of metabolites NO did not reach normal values, patients continued to receive nitrates, and the symptoms of GERD remained present in $12(27.9 \%)$ patients, although they began to appear less on the background of GERD therapy. According to the data of esophagogastroduodenophibroscopy, the result of the $2^{\text {nd }}$ group was the complete healing of erosive esophagitis in $100 \%$ of patients, which exceeded the rate of the 1 st group by 2.7 times, since in the first group on the 30th day of the study, $37 \%(n=16)$ patients the presence of erosive esophagitis was detected. According to the results of 24-hour $\mathrm{pH}$ monitoring of the esophagus, a decrease in the total time with a $\mathrm{pH}<4$ by $32 \%(\mathrm{p}<0.05)$, a decrease in the number of refluxes with a $\mathrm{pH}<4$ was $28 \%$ on average $(\mathrm{p}<0.05)$, reducing the number of refluxes that lasted more than 5 minutes. in 2.8 times, compared to the patients in group 1 after treatment $(\mathrm{p}<0.05)$ and a decrease in the mean of the maximum duration of reflux by 1.5 times, comparing with the same indicator of patients in group 1 who continued to receive organic nitrates [11]. Clinically visible result was also found on the effective therapy support of SAT in the $2^{\text {nd }}$ group: decreased frequency of angina attacks, increased tolerance to physical activity, improved well-being, sleep, mood, already on the 10th day with the preservation of the same trend. In our opinion, the detection of high levels of $\mathrm{NO}$ end-metabolites in patients with SAT and GERD due to the constant intake of organic nitrates for the purpose of the lowering of relapsing pain, which may not have been of coronary origin. Thus, in patients with SAT and GERD in the conditions of receiving NO dopants, the level of end metabolites of the NO molecule increases, as evidenced by the correlation established by us. Against the background of an increase in the level of $\mathrm{NO}$ and its metabolites, GERD symptoms are exacerbated by the fact that $\mathrm{NO}$ regulates the activity of the cardiac sphincter, causing its relaxation. Therapy of the SAT with the exclusion of highspeed nitrates and an additional drug to the basal therapy, meldonium in a dose of $500 \mathrm{mg} 2$ times daily and against the background of the basic therapy of GERD, leads to a rapid decrease in blood metabolites of nitrogen monoxide and the achievement of the index of PHP, which correlates with the decrease symptoms of GERD in patients with SAT and GERD, compared with the results of group 1 and was more effective in eliminating clinical manifestations of SAT.

\section{REFERENCES}

1. Koturek J.W, Thor P., Lukashyk A. [et al.]. Endogenous nitric oxide in the control of esophageal motility in humans. J. Physiol. Pharmacol. 1997;48: 201-9.

2. Moriya A., Grant J., Mowat C. [et al.].In vitro studies indicate that acid catalysed generation of $\mathrm{N}$-nitrosocompounds from dietary nitrate will be maximal at the gastrooesophageal function and cardia. Scand. J. Gastroenterol.2002;37(3):253 $\neg 61$.

3. Winter JW, Paterson S, Scobie G, Wirz A. N-nitrosamine generation from ingested nitrate via nitric oxide in subjects with and without gastroesophageal reflux. Gastroenterology.2007Jul;133(1):164-74.D0I: 10.1053/j.gastro.2007.04.047

4. Stelzner F. Stretch sphincter of the esophagus: Paradoxical sphincter with angiomyoelastic architecture.Chirurg.2015 Aug; 86(8):752-60. doi: 10.1007/s00104-014-2777-z.

5. Stelzner F. Paradoxical sphincters in the abdomen. Chirurg. 2015 Aug;86(8):761-70. doi: 10.1007/s00104-015-0029-5. 
6. lijima K, Shimosegawa T. Involvement of luminal nitric oxide in the pathogenesis of the gastroesophageal reflux disease spectrum. J Gastroenterol Hepatol.2014 May;29(5):898-905. doi: 10.1111/jgh.12548.

7. Valdovinos MA, Zavala-Solares MR, Coss-Adame E Esophageal hypomotility and spastic motor disorders: current diagnosis and treatment. Curr Gastroenterol Rep. 2014 Nov;16(11):421. doi: 10.1007/ s11894-014-0421-1.

8. Oparin A., Vnukova A. The Role of Endothelial Dysfunction in the Mechanism of Gastroesophageal Reflux Disease Development in Patients with Ischemic Heart Disease. Acta Clin Croat. 2017 Dec;56(4):635-9. doi: 10.20471/acc.2017.56.04.08.

9. Kusaka G, Uno K, lijima K, Shimosegawa T. Role of nitric oxide in the pathogenesis of Barrett's-associated carcinogenesis. World J Gastrointest Pathophysiol. 2016 Feb 15;7(1): 131-137. doi: 10.4291/wjgp.v7.i1.131
10. Khukhlina 0.S., Drozd V.Yu. Optymizatsiia likuvannia nealkoholnoho steatohepatytu u khvorykh na ozhyrinnia ta ishemichnu khvorobu sertsia [Optimization of treatment of nonalcoholic steatohepatitis in patients with obesity and coronary artery disease]. Liky Ukrainy. 2016; 9(205): 46-52. (Ua)

11. Khukhlina 0.S., Drozd V.Yu. Dosvid zastosuvannia meldoniiu u kompleksnii terapii khvorykh na stabilnu stenokardiiu napruhy ta hastroezofahealnu refliuksnu khvorobu [Experience of meldonium in combined therapy of stable angina and gastroesophageal reflux disease]. Zdobutky klinichnoi ta eksperymentalnoi medytsyny. 2017; 2(30): 84-88 D0l:10.11603/1811-2471.2017.v0.i2.7732. (Ua)

12. Green LC, Wagner DA, Glogowski J, Skipper PL, Wishnok JS, Tannenbaum SR. Analysis of nitrate, nitrite, and [15N] nitrate in biologica fluids. Anal Biochem. 1982 0ct; 126(1):131-8.

This work is a fragment of the research work "Peculiarities of the comorbid course of the diseases of internal organs: risk factors, mechanisms of progression, pharmacotherapy", registration number $0114 U 002475$ (2014-2018).

\section{Authors' contributions:}

According to the order of the Authorship.

\section{Conflict of interest:}

The Authors declare no conflict of interest.

\section{CORRESPONDING AUTHOR}

\section{Alona A. Antoniv}

Department of Internal Medicine,

Clinical Pharmacology and Occupational Diseases,

Higher Educational Establishment of Ukraine

"Bukovinian State Medical University", Chernivtsi, Ukraine

tel: +380992321861

e-mail: antonivalona@ukr.net

Received: 11.03 .2019

Accepted: 25.04 .2019 


\title{
PARENTERAL VIRAL HEPATITIS INFECTION RISK ASSESSMENT BY TEENAGERS
}

\author{
Natalia V. Medvedovska' ${ }^{1}$ Valerii I. Bugro' ${ }^{1}$ Ivan I. Kasianenko² \\ 'NATIONAL MEDICAL ACADEMY OF POSTGRADUATE EDUCATION, KYIV, UKRAINE \\ 2GOVERNMENT AGENCY "UKRAINIAN INSTITUTE OF STRATEGIC RESEARCH, MINISTRY OF HEALTH OF UKRAINE", KYIV, UKRAINE
}

\begin{abstract}
Introduction: Developing strategy of parenteral viral hepatitis prevention among adolescents and youth is becoming an urgent issue.

The aim of the research was to study the available data on the risk factors and ways of parenteral viral hepatitis transmission among adolescents and youth, as well as their attitude toward the problem of infection process spread by parenteral way and awareness of the personal risk of contamination.

Materials and methods: Primary source of research became the data of anonymous sociologic studies (questionnaire) among teenagers in the Kirovograd Region. The following methods were used to reach the set goals: systemic approach, medico-statistical, sociological (questionnaire).

Results: The sociologic research showed a low level of awareness of the threat of personal infection with parenteral viral hepatitis in a teenage environment. It actualizes the need for development of systemic measures to prevent the infection of adolescents by parenteral way, since informing only is insufficient.

Conclusions: Alertness to the spread of parenteral viral hepatitis and the risk of personal infection remains immature among teenagers and adolescents. The obtained results prove the expediency of the scientific substantiation of the cross-sectoral complex approach to solving the problem of preventing the spread of parenteral viral hepatitis among adolescents at the regional level.
\end{abstract}

KEY WORDS: child population of adolescence, parenteral viral hepatitis, risk of infection

Wiad Lek 2019, 72, 5 cz. I, 757-759

\section{INTRODUCTION}

Every year, on the initiative of the International Hepatitis Alliance (WHA), on July, 28 the World Hepatitis Day is observed, it confirms recognition of the global scale of the problem.

According to WHO data, $3.5 \%$ of the world population (95\% uncertainty range: $2.7-5.0 \%$ ) or 257 million people (199-368 million) have a chronic stage of HBV infection (with positive serum HBsAg for at least 6 months, approximately 686.000 people die each year from HBV infection[1-5]. The spread of the epidemic process of parenteral viral hepatitis is promoted by the ignorance of patients due to asymptomatic onset of the disease with the tendency to develop chronic state.

Of particular relevance is the problem of the spread of parenteral viral hepatitis among adolescent environment, which is characterized by a low level of knowledge about ways of transmission and risk factors for parenteral viral hepatitis, risk behavior and bad habits (especially the use of narcotic substances).

\section{THE AIM}

Study of the availability of data on risk factors and ways of transmission of parenteral viral hepatitis among adolescents, their attitude to the problem of spreading the infectious process by parenteral way and awareness of the personal risk of infection.

\section{MATERIALS AND METHODS}

The primary material for the study was the data of anonymous sociological research (questionnaire) among adolescents after their prior consent, including their parents' consent for their participation.

410 adolescents from the Kirovograd region at the age of 10-17 years were interviewed, who, with the consent of their parents, participated in the research as respondents.

As a result of the analysis of the primary materials of the sociological study, 8 questionnaires were rejected, which was $1.95 \%$ of 410 , so that 402 questionnaires were subject to analysis. To achieve the goal, the following methods were used: systematic approach, medical-statistical, sociological (questionnaire survey). The analysis of the received primary material was done by creating Microsoft Excel based databases, where the material was grouped according to the contingent of study (sex, age, place of residence). During the research, the confidentiality of respondents' information was fully ensured.

\section{RESULT}

Among the respondents, $51.74 \pm 2.49 \%$ were boys and 48.26 $\pm 2.49 \%$ were girls living mostly in the city $(92.79 \pm 1.29 \%)$, the average age of the respondents was $14.2 \pm 0.97$ years.

Half of respondents argued that parenteral viral hepatitis causes a small threat $(45.27 \pm 2.48 \%)$ or does not at all threaten $(6.22 \pm 1.20 \%)$ in the city in which they live, yet 
$18.41 \pm 1.93 \%$ did not know how to answer the question. Only a third $(30.10 \pm 2.29 \%)$ showed that the spread of parenteral viral hepatitis poses a serious threat to the city. Less than one third $(25,62 \pm 2,18 \%)$ are aware that the spread of parenteral viral hepatitis is endangering children and their family members, and a large proportion believes that the threat is low $(39.80 \pm 2.44 \%)$ or absent $(17,41 \pm$ $1.89 \%$ ), yet $17.16 \pm 1.88 \%$ did not know how to answer the question. The above shows the low alertness of adolescents and their families regarding the threat of personal infection with parenteral viral hepatitis.

Among the respondents, adolescents who believed they should be informed about peers diagnosed with parenteral viral hepatitis were prevailing $(61.44 \pm 2.43 \%)$. Only half of respondents reported that parenteral viral hepatitis was not transmitted through hand shaking, hugs (58.71 $\pm 2.46 \%)$, shared use of school supplies (56.72 $\pm 2.47 \%)$, the other half of the respondents did not know how to answer (27.86 $\pm 2.24 \%$ and $28.36 \pm 2.25 \%$ respectively) or were confident that parenteral viral hepatitis $(13.43 \pm 1.70 \%$ and $14.93 \pm$ $1.78 \%$ respectively) are transmitted through this way. More than $40.0 \%$ of the interviewed believe that parenteral viral hepatitis is transmitted through shared use of a toilet, bath, towel, soap (41.04 $\pm 2.45 \%)$, dishes ( $43.78 \pm 2.47 \%)$, while communicating during conversations $(35,07 \pm 2,38 \%)$ with a high percentage (almost one third) of respondents who could not answer the question $(28,61 \pm 2,25 \%, 28,11$ $\pm 2,24 \%$ and $29,85 \pm 2.28 \%$, respectively). The obtained results testify to the low level of knowledge about the ways of transmission (infection) of parenteral viral hepatitis.

The majority of respondents were aware of the risk of contracting parenteral viral hepatitis in: conducting medical manipulations $(73.13 \pm 2.21 \%)$; visiting a dentist $(60,70 \pm 2,44 \%)$; medical interventions, injections, blood transfusions (80.35 $\pm 1.98 \%)$; non-compliance with the rules of sterilization of tools at tattooing, manicure, pedicure $(75,62 \pm 2,14 \%)$; the close relationship between men and women with sexual contacts without using a condom $(64.18 \pm 2.39 \%)$, similar to men with men $(57.46 \pm 2.47 \%)$. Almost a third of the respondents did not know how to answer $(27.86 \pm 2.24 \%$ and $34.83 \pm 2.38 \%$ respectively), which actualizes the work with adolescents regarding risk factors and ways of transmission of parenteral viral hepatitis in order to prevent their distribution in adolescent environment.

One third $(34.83 \pm 2.38 \%)$ of respondents believe that if a classmate was diagnosed with parenteral viral hepatitis, he should stop attending an educational institution, another third $(29.35 \pm 2.27 \%)$ did not know how to answer this question, it may explain why in the majority $(64,93 \pm$ $2,38 \%$ ) the attitude to a familiar person, after finding out about his/her infection, would not change.

The risk of infection with hepatitis while making tattoos is not understood to $51.24 \pm 2.49 \%$ of adolescents, one third $(29.35 \pm 2.27 \%)$ does not have any warning about possible infection among people with early sexual relations.

The majority of respondents indicated that they were aware of the appropriateness of observing the principles of a healthy lifestyle from childhood $(84.33 \pm 1.81 \%)$ and the threat of early unprotected sexual contacts to the health $(82.84 \pm 1.88 \%)$.

Most of the respondents $(78,61 \pm 2,05 \%)$ would like to be able to undergo a prophylactic examination for the presence of parenteral viral hepatitis once a year, although one in five $(21,39 \pm 2,05 \%)$ would refrain from such surveys.

Most children in adolescence indicated that they had no sexual relations $(87.06 \pm 1.67 \%)$, although $28.11 \pm 2.24 \%$ indicated that they used condoms during intercourse while answering a corresponding question, $11.44 \pm 1.59$ - do not use, yet $6.97 \pm 1.27$ - do not always use, and only $53.48 \pm$ $2.59 \%$ have indicated in comments that they did not have such experience.

It confirms that in applying a direct question the percentage of adolescents with a sexual relationship exceeds the detected percentage $(12.94 \pm 1.67 \%)$ and suggests that almost every second teenager has such experience and should therefore be informed about the risks of parenteral infection.

\section{DISCUSSION}

In modern complex socio-economic conditions of Ukraine, early interventions among adolescence aimed at preventing the spread of parenteral viral hepatitis do not lose their relevance. The majority $(80.35 \pm 1.98 \%)$ are aware that there is a risk of infection with parenteral viral hepatitis during medical interventions, injections, blood transfusions, due to non-compliance with sterilization rules during tattoo applying, manicure, pedicure $(75.62 \pm 2, .14 \%)$, with close relationships between men and women with sexual contacts without using a condom (64.18 $\pm 2.39 \%)$, similar to men with men (57.46 $\pm 2.47 \%)$, although about one third did not know what to answer to the last question about sexual relations $(27.86 \pm 2.24 \%$ and $34.83 \pm 2.38 \%$ respectively).

One third of adolescents $(29.35 \pm 2.27 \%)$ do not have any warning about possible infection with parenteral viral hepatitis in people with early sexual relations, a small percentage uses protective equipment (condom) in sexual relations. There is a paradox: in practice, the acquired knowledge (in particular, about healthy lifestyle) is not used by adolescents, which leads us to the need to develop tools and measures, possibly of complex interbranch effects, the implementation of which would contribute to preventing the spread of parenteral viral hepatitis among adolescents.

The future interaction should be based on the identified regional peculiarities of the population health with the implementation of early preventive interventions starting from childhood and adolescence.

\section{CONCLUSIONS}

With a high level of awareness among adolescents about the principles of healthy lifestyles and healthy behavior, their caution regarding the spread of parenteral viral hepatitis and the risk of personal infection remains immature. There is a low level of knowledge about the ways in which infections with parenteral viral hepatitis among adolescents can occur. 
The obtained results prove the expediency of the scientific substantiation of the cross-sectoral complex approach to solving the problem of preventing the spread of parenteral viral hepatitis among adolescents at the regional level.

\section{REFERENCES}

1. Gural A. L., Marievskiy V. F., Sergeeva T. A. i dr. Harakteristika i tendentsii razvitiya epidemicheskogo protsessa gepatita S v Ukraine [Characteristics and trends of the epidemic process of hepatitis $C$ in Ukraine]. Profilaktychna medytsyna. 2011; 1 (13): 9- 18.

2. Barut H. S., Günal Ö., Göral A., Etikan I. Prevalence of hepatitis B virus infection in children of HBsAg positive parents. Mikrobiyol. Bul. 2011; 45 (2): $359-365$.
3. Sheikh S.M. Hepatitis $B$ and $C$ value of universal antenatal screening. J. Coll. Physicians. Surg. Pak. 2009; 19: 179-182.

4. World Health Organization. WHO country office in Pakistan. Blood Safety (2009). Access mode: http:// www.Embo.who.int/pakistan/ programmeareas_bloodsafety.htm.

5. World Health Organization: Hepatitis B. 2008: http://www.who.int/ mediacentre / factsheets/fs204/en/.

\section{Authors' contributions:}

According to the order of the Authorship.

\section{Conflict of interest:}

The Authors declare no conflict of interest.

\section{CORRESPONDING AUTHOR}

Valerii I. Bugro

N. Vasylenko Str. 8-B, 6, Kyiv, 03124, Ukraine

tel: +380508500070

e-mail: valeriybugro@ukr.net

Received: 14.03 .2019

Accepted: 26.04 .2019 


\title{
SURGICAL SITE INFECTIONS AND ANTIMICROBIAL RESISTANCE IN KYIV CITY HOSPITALS, UKRAINE
}

\author{
Aidyn G. Salmanov', Olena A. Dyndar², Yuriy P. Vdovychenko', Tetiana R. Nykoniuk², Igor V. Maidannyk², \\ Olena 0. Chorna'2, Iryna A. Holovanova ${ }^{3}$ \\ 'SHUPYK NATIONAL MEDICAL ACADEMY OF POSTGRADUATE EDUCATION, KYIV, UKRAINE \\ 2BOGOMOLETS NATIONAL MEDICAL UNIVERSITY, KYIV, UKRAINE \\ 3UKRAINIAN MEDICAL STOMATOLOGICAL ACADEMY, POLTAVA, UKRAINE
}

\begin{abstract}
Introduction: Surgical site infections (SSIs) are associated with increased morbidity and mortality. Scant information is available on the SSI in Ukrainian hospitals. The aim: to determine the incidence of SSIs and estimates antimicrobial resistance of the major responsible pathogens in Kyiv city hospitals.

Materials and methods: This study was conducted from January 2011 to December 2013 in 3 hospitals. Definitions of SSIs were adapted from the CDC/NHSN. The identification and antimicrobial susceptibility of cultures were determined, using automated microbiology analyzer. Some antimicrobial susceptibility test used Kirby - Bauer antibiotic testing. Results: Among 9,162 patients, 1,912 (20.9\%) SSIs were observed. The high SSI case in appendectomy (29.8\%), gastric, small and large bowel surgeries (28.4\%), cholelithiasis (25.7\%), and orthopedic procedures (22.9\%). Low infection rate in excision of dermoid cysts, lipoma (5.3\%) and lower segment caesarean structure (6.5\%). Staphylococcus aureus were most commonly reported, accounting for $27,8 \%$ of all organisms, followed by Escherichia coli (18.4\%), Pseudomonas aeruginosa (11.9\%) and Enterococcus faecalis (11.6\%). The antimicrobial resistance in the isolates associated with SSIs showed, among the Gram-positive bacteria, that $43.8 \%$ and $4.7 \%$ of CoNS isolates were $\beta$-lactam (oxacillin) - and glycopeptide (teicoplanin) - resistant, respectively. Meticillin resistance was reported in $35.7 \%$ of $S$. aureus isolates

Conclusions: SSIs and antimicrobial resistance of the responsible pathogens is an actually problem. One essential step in the prevention of SSIs is to implement a national system for their surveillance.
\end{abstract}

KEY WORDS: Surgical site infection, antimicrobial resistance, surveillance

Wiad Lek 2019, 72, 5 cz. I, 760-764

\section{INTRODUCTION}

Despite major advances in infection control interventions, healthcare-associated infections (HAI) remain a major public health problem and patient safety threat worldwide [1]. Surgical site infections (SSI) are the most common type of HAI among patients [2-5]. These infections are one of the most frequently reported types of HAI, constituting up to $19.6 \%$ of all HAIs in Europe in 2011-2012 [2].

SSI associated with longer post-operative hospital stays, additional surgical procedures, treatment in intensive care units and higher mortality [6]. Furthermore, development of an SSI causes a substantial increase in the clinical and economic burden of surgery [7]. The financial burden of surgery is increased due to the direct costs incurred by prolonged hospitalization of the patient, diagnostic tests, and treatment. Certain patients may also require reoperation after the contraction of an SSI, which is associated with considerable additional costs [8].

In the literature, variable proportions of HAIs, considered to be preventable by intensive hygiene and control programs, have been reported $[9,10]$. Among the infection prevention initiatives, surveillance of HAIs is the cornerstone to decrease infection rates in hospitalized patients, and it is considered to be the best way to assure patient safety [11]. Continuous monitoring of HAI rates can be used to assess effectiveness of interventions and provides information which may be used for benchmarking comparison [12]. Due to high morbidity and mortality caused by these infections, early diagnosis and treatment of these infections with appropriate antibiotics is essential.

Knowledge on the antimicrobial susceptibility status of circulating pathogens in hospitals is important for better management of infectious pathogens particularly where routine culture and sensitivity testing is not practiced $[13,14]$.

To identify HAI prevention targets and reduce thus disparities between countries, ongoing surveillance is necessary. However, resources are severely limited in Ukraine, creating difficulties implementing surveillance and establishing effective measures for infection control and HAI prevention. In Ukraine, efforts to improve infection control training and begin HAI surveillance have been underway. However, previous reports of SSIs in Ukraine were limited and did not address all types SSI and antimicrobial resistance their pathogens. 


\section{THE AIM}

The objective of the current study was to determine the incidence of SSIs and estimates antimicrobial resistance of the major responsible pathogens in Kyiv city hospitals.

\section{MATERIALS AND METHODS}

\section{STUDY DESIGN AND SETTING}

This retrospective study was based on surveillance data for SSIs of 9,162 patients in Kyiv city hospitals (2 general and 1 women's hospitals), Ukraine. The sample was all patients hospitalized in 3-year (from January 1, 2011 to December $31,2013)$. We have included hospitals that are similar in terms of medical equipment, personnel, and laboratory facilities. The hospitals had 1150 beds. All participating hospitals were required to have at least one full-time infection-control professional, a clinical microbiology laboratory with the capacity to process cultures. The exclusion criteria were patients with a community acquired infection. The follow-up of each patient was continued until discharge.

\section{ETHICS}

The data was collected as a part of the hospital's infection prevalence survey. According to the Health Research Act of Ukraine, quality assurance projects, surveys and evaluations that are intended to ensure that diagnosis and treatment actually produce the intended results do not need ethical committee approval and patient consent is not required.

\section{DEFINITIONS AND DATA COLLECTION}

Surveillance data on all SSIs, both in patients, and their causative pathogens were collected retrospective on a specifically designed form by the investigators using medical records comprising charts, daily flow sheets, laboratory (microbiology) results. The collected data included demographics; date of infection onset; clinical signs; and isolated pathogens with antibiogram results. Healthcare workers in hospitals screened patients for signs and symptoms of SSI during clinical rounds. SSIs were identified according to a simplified version of the definitions developed and recommended by the CDC/NHSN [15].

\section{MICROBIOLOGICAL SAMPLING}

The identification and antimicrobial susceptibility of the cultures were determined, using automated microbiology system (Vitek-2 $2^{\text {in }}$; bioMérieux, France). Some antimicrobial susceptibility test used Kirby - Bauer antibiotic testing. Interpretative criteria were those suggested by the Clinical and Laboratory Standards Institute (USA).

\section{STATISTICAL ANALYSIS}

We analyzed by all types of SSIs. The analysis of statistical data was performed using Microsoft Excel for Windows. Comparisons were carried out using the Student's t-test, $\chi 2$. Values of $\mathrm{p}<0.05$ were considered statistically significant.

\section{RESULTS}

\section{PATIENT CHARACTERISTICS AND INCIDENCE OF SSI}

During the study period 9,162 patients were included, $1,912(20.9 \%)$ patients had SSIs. The incidence of the most frequently recorded types of SSI was for Appendectomy $29.8 \%$ [95\% CI 27.6 - 32.0], Gastric and small bowel 28.4\% [95\% CI 25.9 - 30.9], Cholelithiasis 25.7\% [95\% CI 22.6 - 28.8], and Orthopedic procedures $22.9 \%$ [95\% CI 20.1 - 25.7]. A minority of SSIs were Excision of Dermoid cysts, lipoma $5.3 \%$ [95\% CI 3.9 - 6.7] and Lower segment caesarean structure (LSCS) $6.5 \%$ [95\% CI 4.3 - 8.7] (Table I).

Fifty-two percent of the patients were females. The overall incidence of SSI was higher in males than in females (12.7 $\%$ vs. $10 \%$ ) and increased with age. For the oldest patients

Table I. Incidence of SSI after surgical procedures in Kyiv hospitals, Ukraine, 2011-2013 ( $p<0.05)$

\begin{tabular}{cccc}
\hline Surgical procedure & $\begin{array}{c}\text { Number } \\
\text { of patients }\end{array}$ & $\begin{array}{c}\text { Number } \\
\text { of cases infected }\end{array}$ & $\%(\mathbf{9 5} \mathbf{C l})$ \\
\hline Orthopedic procedures & 841 & 193 & $22.9(20.1-25.7)$ \\
\hline Gastric and small bowel & 1269 & 361 & $28.4(25.9-30.9)$ \\
\hline Appendectomy & 1651 & 492 & $29.8(27.6-32.0)$ \\
\hline Cholelithiasis (hepatobiliary) & 767 & 197 & $25.7(22.6-28.8)$ \\
\hline Excision of Dermoid cysts, lipomas & 989 & 52 & $5.3(3.9-6.7)$ \\
\hline Hernia & 2384 & 459 & $19.3(17.7-20.9)$ \\
\hline Lower segment caesarean structure & 475 & 31 & $6.5(4.3-8.7)$ \\
\hline Uterus and adnexa & 284 & 34 & $12.0(8.2-15.8)$ \\
\hline Urinary tract and genitalia & 502 & 93 & $18.5(15.1-21.9)$ \\
\hline Total & 9162 & 1912 & $20.9(20.1-21.7)$ \\
\hline
\end{tabular}


Table II. Microorganisms isolated from SSI in Kyiv city hospitals, Ukraine, 2011-2013 ( $\mathrm{n}=2179)$

\begin{tabular}{ccc}
\hline Microorganisms & Number of strains & Proportion, $\%$ \\
\hline Gram-positive coccus & & 27,8 \\
\hline Staphylococcus aureus & 601 & 6,2 \\
\hline Coagulase-negative staphylococci & 135 & 11,6 \\
\hline Enterococcus faecalis & 253 & 4,1 \\
\hline Enterococcus faecium & 89 & 1,3 \\
\hline Streptococcus spp. & 28 & 18,4 \\
\hline Gram-negative bacilli & & 6,4 \\
\hline Escherichia coli & 408 & 5,3 \\
\hline Enterobacter spp. & 139 & 2,4 \\
\hline Klebsiella spp. & 116 & 11,9 \\
\hline Proteus spp. & 53 & 2,2 \\
\hline Pseudomonas aeruginosa & 259 & 0,8 \\
\hline Acinetobacter spp. & 48 & 1,5 \\
\hline Other* & 18 & 33 \\
\hline Candida spp. & 39 & \\
\hline
\end{tabular}

Note: *0ther" includes 11 different organisms.

(>74 years old), we found incidence of $79.4 \%$ vs. $20.6 \%$ for the youngest patients (18-25 years). Acute admission patients had a higher incidence of SSI than those with elective admission, $62.1 \%$ and $37.9 \%$, respectively.

\section{MICROORGANISMS CAUSING SSIS}

Among all 9,162 SSIs, a total of 2,179 organisms were identified. Considering all SSI types together, Staphylococcus aureus, were most commonly reported, accounting for $27,8 \%$ of all organisms, followed by Escherichia coli (18,4\% of organisms), Pseudomonas aeruginosa (11,9\% of organisms), and Enterococcus faecalis (11,6\% of organisms). The etiological role was lower for Streptococcaceae (1.3\%) and Acinetobacter spp.(2.2\%). (Table II).

Patients with SSIs Staphylococcus had the highest proportion of conditionally pathogenic microorganisms (CPM) (34.0\%) followed by Enterobacteriaceae (32.8 $\%)$. Gram-negative organisms were mostly isolated from surgeries on bowel, urinary tract and appendix. S. aureus is the predominant organism infecting LSCS. No other organism is particularly associated with specific surgery.

\section{ANTIMICROBIAL RESISTANCE}

Prevailing causal agents of SSIs were resistant to many antimicrobials used in the hospitals. The antimicrobial-resistance in the isolates associated with SSIs showed, among the Gram-positive bacteria, that $43.8 \%$ and $4.7 \%$ of Coagulase-negative staphylococci isolates were $\beta$-lactam (oxacillin) - and glycopeptide (teicoplanin) - resistant, respectively. Vancomycin resistance was reported in $12.6 \%$ of isolated enterococci (VRE). Among the Gram-negative bacteria third-generation cephalosporins (cefotaxime or ceftazidime) resistance was found in $52.2 \%$ of Klebsiella spp. and $33.9 \%$ of E.coli isolates. Carbapenem resistance was reported in $8.1 \%$ of all included Enterobacteriaceae, also highest in Klebsiella spp., and in $47.4 \%$ of $P$. aeruginosa isolates and $63.7 \%$ of Acinetobacter spp. isolates.

Antibiotic susceptibility testing showed that all the strains of $S$. aureus resistant to penicillin. The most active antibiotics found in the study were linezolid and tigecycline, showing growth inhibition of $100 \%$ strains tested. Susceptibility to the other antimicrobials was also on a high level: $99 \%$ of strains were found susceptible to nitrofurantoin, $98.7 \%$ to trimethoprim/sulphamethoxazole, $98 \%$ - to fusidic acid, $97.1 \%$ to mupirocin, $95.9 \%$ - to teicoplanin, $95.0 \%$ - to fosfomycin, $91.2 \%$ - to gentamycin, $90.7 \%$ - to vancomycin, $90.2 \%$ - to tobramycin, $90,6 \%$ - to vancomycin, and $88.1 \%$ - to levofloxacin. Meticillin resistance was reported in $35.7 \%$ of $S$. aureus (MRSA) isolates (Table III).

\section{DISCUSSION}

Our study demonstrated that $20.9 \%$ patients developed postoperative SSI in Kyiv hospitals. The most frequently recorded of SSI was for Appendectomy $29.8 \%$, Gastric and small bowel $28.4 \%$, Cholelithiasis $25.7 \%$, and Orthopedic procedures $22.9 \%$. According to the literature reports, SSIs are the most frequent post-surgical complications in Ukraine with incidences from $13.3 \%$ to $35 \%$ [4, 13, $14,16]$. However, only $0.07 \%$ cases of SSIs are officially registered per year $[4,14]$. Results of our investigation revealed a much higher SSIs incidence rate that reported in the official statistical data. The proportion of SSI European 
Table III. Antimicrobial susceptibility of S. aureus in Kyiv city hospitals, 2011-2013 $(\mathrm{n}=601)$

\begin{tabular}{|c|c|c|c|}
\hline \multirow{2}{*}{ Antibiotic } & \multicolumn{3}{|c|}{ Division by susceptibility, \% } \\
\hline & Susceptible & Intermediate & Resistant \\
\hline Cefoxitin & 71.4 & 0 & 28.6 \\
\hline Benzylpenicillin & 0 & 0 & 100.0 \\
\hline Oxacyllin & 64.3 & 0 & 35.7 \\
\hline Gentamycin & 91.2 & 0 & 8.8 \\
\hline Tobramycin & 90.2 & 0 & 9.8 \\
\hline Levofloxacin & 88.1 & 2.0 & 9.9 \\
\hline Moxifloxacin & 84.1 & 1.0 & 14.9 \\
\hline Erythromycin & 73.4 & 0 & 26.6 \\
\hline Clindamycin & 70.8 & 0 & 29.2 \\
\hline Linezolid & 100.0 & 0 & 0 \\
\hline Teicoplanin & 95.9 & 0 & 4.1 \\
\hline Vancomycin & 90.6 & 0 & 9.4 \\
\hline Tetracycline & 76.6 & 0 & 23.4 \\
\hline Tigecycline & 100.0 & 0 & 0 \\
\hline Fosfomycin & 95.0 & 0 & 5.0 \\
\hline Nitrofurantoin & 99.0 & 0 & 1.0 \\
\hline Fusidic acid & 98.0 & 1.0 & 1.0 \\
\hline Mupirocin & 97.1 & 0 & 2.9 \\
\hline Rifampicin & 76.1 & 3.0 & 20.9 \\
\hline Trimethoprim/sulphamethoxazole & 98.7 & 0 & 1.3 \\
\hline
\end{tabular}

Union region varied between $8.8 \%$ in Luxembourg and $29.0 \%$ in Spain [2].

Results our study showed that 2,179 strains bacteria were isolated from patients during the 2011-2013, the Gram-negative bacilli was $49.2 \%$, Gram-positive cocci was $50.8 \%$. Considering all SSI types together, S. aureus, were most commonly reported, accounting for $27,8 \%$ of all organisms, followed by E.coli (18,4\%), P. aeruginosa (11,9\%), and E.faecalis $(11,6 \%)$. The etiological role was lower for Streptococcaceae (1.3\%) and Acinetobacter spp.(2.2\%). Our results correspond to data of other investigators on prevailing species of CPM that cause SSIs in the hospitals. The distribution of various groups of microorganisms varies considerably $[2,4,5,13,14,16-22]$. This proves the necessity of carrying out microbiological monitoring in every hospital.

In the present study, the high level of resistance to multiple antibiotics is of great concern. Prevailing causal agents of SSIs were resistant to many antimicrobials used in the Kyiv city hospitals. The antimicrobial-resistance in the isolates associated with SSIs showed, among the Gram-positive bacteria, that $43.8 \%$ and $4.7 \%$ of Coagulase-negative staphylococci isolates were $\beta$-lactam (oxacillin) - and glycopeptide (teicoplanin) - resistant, respectively. Vancomycin resistance was reported in $12.6 \%$ of isolated enterococci (VRE). Among the Gram-negative bacteria third-generation cephalosporins (cefotaxime or ceftazidime) resistance was found in $52.2 \%$ of Klebsiella spp. and $33.9 \%$ of E.coli isolates. Carbapenem resistance was reported in $8.1 \%$ of all included Enterobacteriaceae, also highest in Klebsiella spp., and in $47.4 \%$ of $P$. aeruginosa isolates and $63.7 \%$ of Acinetobacter spp. isolates. Meticillin resistance was reported in $35.7 \%$ of $S$. aureus (MRSA) isolates. The resistance to antimicrobials distribution of various groups of microorganisms varies considerably $[2,4,5,14,18-24]$.

Results of this investigation indicate that official statistical data fail to report the actual scale of HAI transmission in Ukrainian hospitals due to the lack of reliable SSIs registration. To estimate the epidemiological situation correctly, it is necessary to assess SSIs incidence rates based on diagnostic information determined by medical officers (passive method) and epidemiological data (active method) using commonly applied standard criteria of case definition $[4,17]$.

\section{CONSULSION}

SSIs and antimicrobial resistance of the responsible pathogens is an actually problem. One essential step in the prevention of SSIs is to implement a national system for their surveillance, as such a system provides an overview of the specific national situation and allows healthcare authorities to identify priorities and implement effective prevention measures. Antibiotics application tactics should be determined in accordance with the local data of resistance to them. 


\section{REFERENCES}

1. World Health Organization. Report on the burden of endemic health care-associated infection worldwide. WHO Document Production Services, Geneva[Switzerland]; 2011. Available from: http://apps.who. int/iris/bitstream/10665/80135/1/9789241501507_eng.pdf.

2. European Centre for Disease Prevention and Control. Point prevalence survey of healthcare-associated infections and antimicrobial use in European acute care hospitals. Stockholm: ECDC; 2013. Available from: https://ecdc.europa.eu/sites/portal/files/media/en/publications/ Publications/healthcare-associated-infections-antimicrobial-use-PPS. pdf. (Accessed January 11, 2018).

3. Magill SS, Hellinger W, Cohen J, Kay R, Bailey C, Boland B, et al. Prevalence of healthcare-associated infections in acute care hospitals in Jacksonville, Florida. Infection Control Hospital Epidemiology, 2012 Mar; 33 (3):283-91. doi:10.1086/664048.

4. Salmanov AG. Antimicrobial resistance and healthcare-associated infections in Ukraine. Epidemiological report of the multicenter study (2010-2014). Kyiv: AgrarMediaGroup, 2015:452 p. [In Ukrainian].

5. Yunzhou Fan, Zhaoxia Wei, Weiwei Wang, Li Tan, Hongbo Jiang, Lihong Tian, et al. The Incidence and Distribution of Surgical Site Infection in Mainland China: A Meta-Analysis of 84 Prospective Observational Studies. Sci Rep. 2014;4:6783. doi: 10.1038/srep06783.

6 . Awad SS. Adherence to surgical care improvement project measures and post-operative surgical site infections. Surg Infect (Larchmt). 2012 Aug;13(4):234-7. doi: 10.1089/sur.2012.131.

7. Badia JM, Casey AL, Petrosillo N, Hudson PM, Mitchell SA, Crosby C. Impact of surgical site infection on healthcare costs and patient outcomes: a systematic review in six European countries. J Hosp Infect. 2017 May;96(1):1-15. doi: 10.1016/j.jhin.2017.03.004.

8. O'Keeffe, A.B., Lawrence, T., and Bojanic, S. Oxford craniotomy infections database: a cost analysis of craniotomy infection. Br J Neurosurg. 2012 Apr;26(2):265-9. doi: 10.3109/02688697.2011.626878.

9. Brown J, Doloresco FIII, Mylotte JM. "Never events": not every hospitalacquired infection is preventable. Clin Infect Dis. 2009; 49:743-6. doi: $10.1086 / 604719$.

10. Harbarth S, Sax H, Gastmeier P. The preventable proportion of nosocomial infections: an overview of published reports. J Hosp Infect. 2003;54:258-266. doi: 10.1016/S0195-6701(03)00150-6.

11. Van Bunnik BA, Ciccolini M, Gibbons CL, Edwards G, Fitzgerald R, McAdam $P R$, et al. Efficient national surveillance for health-care-associated infections. BMC Public Health. 2015;15:832. doi: 10.1186/s12889-0152172-9.

12. Mitchell BG, Russo PL. Preventing healthcare-associated infections: the role of surveillance. Nurs Stand. 2015 Feb 10;29(23):52-8. doi: 10.7748/ ns.29.23.52.e9609.

13. Salmanov A., Vozianov S., Kryzhevsky V., Litus 0., Drozdova A., et al. Prevalence of healthcare-associated infections and antimicrobial resistance in Kyiv acute care hospitals, Ukraine. J Hosp Infect. 2019 Mar 22. pii: S0195-6701(19)30112-4. https://doi:10.1016/j. jhin.2019.03.008

14. Salmanov AG, Shkorbotun V0, Shkorbotun YV. Antimicrobial resistance of Staphylococcus aureus causing of surgical site infections in ear, nose and throat surgery. Wiad Lek. 2019;72(2):154-158. Available from: https://www.ncbi.nlm.nih.gov/pubmed/30903764

15. Horan TC, Andrus M, Dudeck MA.CDC/ NHSN surveillance definition of health care-associated infection and criteria for specific types of infections in the acute care setting. Am J Infect Control. 2008 Jun; 36(5):309-32. doi: 10.1016/j.ajic.2008.03.002.
16. Salmanov AG, Usenko AYu. Intraabdominal infections and resistance of their causative agents towards antibiotics in surgical stationaries in the City of Kyiv. Klinichna khirurhiia. 2018 Sept;85(9):42-49. doi: 10.26779/2522-1396.2018.09.42.[In Russian]

17. Salmanov AG. Occurrence of surgical site infections detected by standard criteria of diseases. Ukrainian Journal of Extreme Medicine named after G.0. Mozhaeva. 2007;8(4):49-51. [In Ukrainian].

18. Maehara Y, Shirabe K, Kohnoe S, Emi Y, Oki E, Kakeji Y. et al. Impact of intra-abdominal absorbable sutures on surgical site infection in gastrointestinal and hepato-biliarypancreatic surgery: results of a multicenter, randomized, prospective, phase II clinical trial. Surg Today.2017 Sep;47(9):1060-71. doi: 10.1007/s00595-017-1480-3.

19. Aga E, Keinan-Boker L, Eithan A, Mais T, Rabinovich A, Nassar F. Surgical site infections after abdominal surgery: incidence and risk factors. A prospective cohort study. Infect Dis (Lond). 2015;47(11):761-7. doi: 10.3109/23744235.2015.1055587.

20. Owens CD, Stoessel K. Surgical site infections: epidemiology, microbiology and prevention. J Hosp Infect. 2008 Nov;70 Suppl 2:3-10. doi: 10.1016/S0195-6701(08)60017-1.

21. Baker AW, Dicks KV, Durkin MJ, Weber DJ, Lewis SS, Moehring RW et al. Epidemiology of Surgical Site Infection in a Community Hospital Network. Infect Control Hosp Epidemiol. 2016 May;37(5):519-26. doi: 10.1017/ice.2016.13.

22. Qiyun Fu, Shaotong Zheng. The analyses of distribution and antimicrobial resistance of pathogens isolated from neurosurgery ward for three years. Life Sci J. 2013;10(4):1620-3.

23. Salmanov A.G., Marievsky V.F. Antibiotic resistance of nosocomial strains of Staphylococcus aureus in the Ukraine: the results of multicenter study. Novosti Khirurgii. 2013;21 (4):78-83 [In Russian].

24. Sanchez G, Master R, Clark R, Fyyaz M, Duvvuri P, et al. Klebsiella pneumoniae antimicrobial drug resistance, United States, 1998-2010. Emerg Infect Dis. 2013;9(1):33-136.doi: 10.3201/eid1901.120310.

Acknowledgment: The authors wish to express their grateful acknowledgement to all the microbiologists, physicians and nurses who contributed to this study.

Authors' contributions:

According to the order of the Authorship

Conflict of interest:

The Authors declare no conflict of interest

\section{CORRESPONDING AUTHOR \\ Aidyn Salmanov}

Shupyk National Medical Academy of Postgraduate Education,

St. Dorohozhytska 9, 04112 Kyiv, Ukraine

tel: +380667997631

e-mail:mozsago@gmail.com

Received: 15.03 .2019

Accepted: 23.04.2019 


\title{
PECULIARITIES OF TEETH SIZE IN ADOLESCENTS WHO ARE DIAGNOSED TO HAVE ANGLE'S CLASS I MALOCCLUSION AND DISPLAY DIFFERENT SOMATOTYPES
}

\author{
Lyubov V. Smahliuk, Dmytro V. Sheshukov \\ UKRAINIAN MEDICAL STOMATOLOGICAL ACADEMY, POLTAVA, UKRAINE
}

\begin{abstract}
Introduction: The issues on identifying criteria for teeth aesthetic and teeth size evaluation regarding body constitutional characteristics are still remaining undeveloped. The aim of this study was to specify the peculiarities of teeth size in adolescents who were diagnosed with Angle's Class I malocclusion and display different somatotypes. Materials and methods: The study included 63 male and 66 female subjects diagnosed with Class I malocclusion by E. Angle classification (1906).

Results: It has been determined that the $33^{\text {rd }}$ tooth in hypersthenic female individuals is of a greater mesiodistal size than in normosthenic and asthenic body types ( $p<0.05$ ). Left maxillary incisor in hypersthenic individuals is of a larger size than in asthenic and normosthenic $(p<0,05)$. The normosthenic male individuals have been found out to have significantly larger size of all canines than that in the females $(p<0,05)$. The asthenic male adolescents compared with females of the same somatotype there has been revealed the difference in the size of the left mandibular canine $(p<0.05)$. The hypersthenic male adolescents demonstrate an increase in the size of the lateral maxillary incisors and the first right premolar $(p<0,05)$ compared with those in female individuals of the same somatotype.

Conclusions: Some peculiarities of mesiodistal size typical for adolescents with Angle's Class I malocclusion and their somatotypes should be taken into account in treatment planning and maintaining the stability of orthodontic treatment results.
\end{abstract}

KEY WORDS: teeth, mesiodistal size, Angle's Class I malocclusion, somatotype

Wiad Lek 2019, 72, 5 cz. I, 765-768

\section{INTRODUCTION}

Investigating constitutional characteristics of anatomical components of the body as well as their somatometric characteristics provides more specific and detailed information on the morphological risk factors, which might be typical for a particular somatotype, and hereditary predisposition to certain pathology [1,2]. It has been reported that Angle's Class I malocclusion described as a normal mesiodistal relationship between upper and lower teeth but front teeth occlusion is impaired ranks the leading position among the dentofacial abnormalities [3,4]. I Class anomalies have been diagnosed in $72.3 \%$ of adolescents who were determined based the presence of the "key of occlusion" by E. Angle to have 7 different types of abnormally positioned individual teeth, and namely, supraposition, infraposition, medial and distal position, vestibular and oral position of teeth [ 5]. Correspondence, or balance between the teeth size of the upper and lower dental arches is considered a key criterion for developing optimal functional occlusion as the main purpose of orthodontic treatment [6]. Different sizes of teeth are known as one of the etiological factors contributing to malocclusions. In our previous reports we have determined the characteristics of mesiodistal teeth size in adolescents in connection with their constitutional typology [7]. However, the issues on identifying criteria for teeth size in adolescents with Angle's Class I malocclusion regarding their body constitutional characteristics are still undeveloped.

\section{THE AIM}

The aim of this study was to specify the peculiarities of teeth size in adolescents who were diagnosed as having Angle's Class I malocclusion depending on their somatotype.

\section{MATERIALS AND METHODS}

The study included 63 male subjects (mean age $23.30 \pm 0.29$ years) and 66 female subjects (mean age $23.24 \pm 0.16$ years) diagnosed with Class I malocclusion according to E. Angle classification (1906). Each patient underwent the procedure of taking impressions to manufacture models for control and diagnostic. To identify occlusal problems, the irregularities in the teeth positioning and dentoalveolar arch abnormalities, we carried out the three-dimensional biometric assessment of plaster casts of the jaws (in three mutually transverse planes). To assess diagnostic models, we measured mesiodistal dimensions of 12 teeth of the upper and lower jaws. We used electronic calipers for measuring the models.

Clinical dental examination was carried out according to the elaborated algorithm with following fixation in the form №043-1 /o with addendum on evaluating individual typological parameters. The individuals included into the study were fully informed about the course of the research and then signed informed voluntary consents on their participation in the research. 
Table I. Parameters of mesiodistal teeth size in female adolescents of different somatotypes

\begin{tabular}{|c|c|c|c|c|}
\hline \multirow{3}{*}{ Dental formula } & \multicolumn{4}{|c|}{ Tooth size, $M \pm m$} \\
\hline & \multicolumn{3}{|c|}{ Somatotype } & \multirow{2}{*}{ Mean size } \\
\hline & Asthenic group & Normosthenic group & Hypersthenic group & \\
\hline 16 & $9,88 \pm 0,11$ & $9,76 \pm 0,08$ & $9,87 \pm 0,17$ & $9,79 \pm 0,07$ \\
\hline 15 & $6,16 \pm 0,11$ & $6,13 \pm 0,07$ & $6,3 \pm 0,19$ & $6,15 \pm 0,05$ \\
\hline 14 & $6,19 \pm 0,49$ & $6,26 \pm 0,2$ & $6,4 \pm 0,11$ & $6,26 \pm 0,18$ \\
\hline 13 & $7,48 \pm 0,11$ & $7,37 \pm 0,08$ & $7,62 \pm 0,15$ & $7,41 \pm 0,06$ \\
\hline 12 & $6,45 \pm 0,17$ & $6,49 \pm 0,09$ & $6,15 \pm 0,17$ & $6,46 \pm 0,07$ \\
\hline 11 & $8,16 \pm 0,14$ & $8,23 \pm 0,09$ & $8,4 \pm 0,18$ & $8,22 \pm 0,07$ \\
\hline 21 & $8,24 \pm 0,14$ & $8,26 \pm 0,09$ & $8,25 \pm 0,19$ & $8,25 \pm 0,07$ \\
\hline 22 & $6,46 \pm 0,13$ & $6,53 \pm 0,08$ & $6,20 \pm 0,18$ & $6,49 \pm 0,06$ \\
\hline 23 & $7,46 \pm 0,12$ & $7,39 \pm 0,06$ & $7,57 \pm 0 \pm, 13$ & $7,42 \pm 0,05$ \\
\hline 24 & $6,72 \pm 0,09$ & $6,67 \pm 0,07$ & $6,57 \pm 0,15$ & $6,67 \pm 0,06$ \\
\hline 25 & $6,25 \pm 0,11$ & $6,05 \pm 0,14$ & $6,25 \pm 0,22$ & $6,1 \pm 0,11$ \\
\hline 26 & $9,79 \pm 0,15$ & $9,6 \pm 0,14$ & $9,62 \pm 0,23$ & $9,64 \pm 0,11$ \\
\hline 36 & $9,87 \pm 0,79$ & $10,16 \pm 0,24$ & $10,55 \pm 0,21$ & $10,12 \pm 0,24$ \\
\hline 35 & $6,72 \pm 0,17$ & $6,68 \pm 0,09$ & $6,75 \pm 0,08$ & $6,69 \pm 0,07$ \\
\hline 34 & $6,55 \pm 0,14$ & $6,73 \pm 0,06$ & $6,65 \pm 0,12$ & $6,68 \pm 0,05$ \\
\hline 33 & $6,25 \pm 0,09$ & $6,25 \pm 0,05$ & $6,72 \pm 0,23^{*, * *}$ & $6,28 \pm 0,05$ \\
\hline 32 & $5,67 \pm 0,07$ & $5,58 \pm 0,07$ & $5,62 \pm 0,06$ & $5,6 \pm 0,05$ \\
\hline 31 & $5,21 \pm 0,09$ & $5,09 \pm 0,07$ & $5,07 \pm 0,02$ & $5,12 \pm 0,06$ \\
\hline 41 & $5,12 \pm 0,09$ & $5,06 \pm 0,08$ & $4,9 \pm 0,11$ & $5,06 \pm 0,06$ \\
\hline 42 & $5,67 \pm 0,11$ & $5,56 \pm 0,08$ & $5,52 \pm 0,14$ & $5,58 \pm 0,06$ \\
\hline 43 & $6,32 \pm 0,08$ & $6,29 \pm 0,07$ & $6,47 \pm 0,15$ & $6,31 \pm 0,05$ \\
\hline 44 & $6,79 \pm 0,13$ & $6,74 \pm 0,07$ & $6,50 \pm 0,08$ & $6,74 \pm 0,06$ \\
\hline 45 & $6,58 \pm 0,17$ & $6,49 \pm 0,16$ & $6,65 \pm 0,17$ & $6,52 \pm 0,12$ \\
\hline 46 & $9,87 \pm 0,78$ & $10,07 \pm 0,23$ & $10,55 \pm 0,17$ & $10,06 \pm 0,23$ \\
\hline
\end{tabular}

Note:

* - difference is probable when comparing between asthenics and hypersthenics, $p<0,05$

** - difference is probable when comparing between normosthenics and hypersthenics, $p<0,05$

The constitutional type of male and female individuals was assessed by the W. L. Rees and H. J. Eysenck index, 1945 , including the following anthropometric characteristics as height, weight, transverse chest diameter, etc.). The index was calculated by the formula: body length $\mathrm{x} 100$ / transverse chest diameter $x 6$. Based on the index values obtained and to sex, all subjects were divided into three somatotypes: hypersthenic group (index value was less than 96), normosthenic (index value ranged from 96 to 106 ) and asthenic (index was over 106) groups.

The quantitative indices obtained during the examination of patients were analyzed by applying the methods of mathematical statistics and calculating sample average $(M)$, dispersion $(\sigma)$, and errors of mean values $(m)$. The probability of differences in the findings obtained for different groups was calculated by Student's t-test. To assess the relationships between semi-quantitative and qualitative indicators, we calculated non-parametric Spearman correlation coeffi- cient. Correlation coefficients were considered statistically significant when error probability was $\mathrm{p}<0,05$.

The statistical analyses were performed by computerized software of Microsoft Excel 2007, NCSS 2004 and SPSS for Windows. Release 13.0.

\section{RESULTS AND DISCUSSION}

The examination of the adolescents with Angle's Class I malocclusion revealed that the normosthenic body type was found to be predominant and seen in 48 female (72.73\%) and 31 male (49.21\%) individuals. Nearly the equal number of the individuals, 14 females (21.2\%) and 15 males (23.8\%) were of asthenic body type. The hypersthenic body type was more often common in male individuals (17 patients) that made up 26,98\%, vs. 4 female individuals $(6,06 \%)(p<0,05)$.

The measurements of mesiodistal teeth sizes in female individuals according to their somatotypes, is presented in Table I. 
Table II. Parameters of mesiodistal teeth sizes in male adolescents of different somatotypes

\begin{tabular}{|c|c|c|c|c|}
\hline \multirow{3}{*}{ Dental formula } & \multicolumn{4}{|c|}{ Tooth size, $M \pm m$} \\
\hline & \multicolumn{3}{|c|}{ Somatotype } & \multirow{2}{*}{ Mean size } \\
\hline & Asthenic group & Normosthenic group & Hypersthenic group & \\
\hline 16 & $9,91 \pm 0,12$ & $10,03 \pm 0,11$ & $9,88 \pm 0,16$ & $9,96 \pm 0,07$ \\
\hline 15 & $6,48 \pm 0,15$ & $6,22 \pm 0,22$ & $6,38 \pm 0,11$ & $6,32 \pm 0,12$ \\
\hline 14 & $6,73 \pm 0,09$ & $6,82 \pm 0,06^{* * *}$ & $6,75 \pm 0,1^{* * *}$ & $6,78 \pm 0,05$ \\
\hline 13 & $7,57 \pm 0,11$ & $7,73 \pm 0,08^{* * *}$ & $7,96 \pm 0,15^{*}$ & $7,76 \pm 0,06$ \\
\hline 12 & $6,47 \pm 0,15$ & $6,51 \pm 0,11$ & $6,68 \pm 0,14^{* * *}$ & $6,55 \pm 0,07$ \\
\hline 11 & $8,45 \pm 0,13$ & $8,54 \pm 0,09 * * *$ & $8,55 \pm 0,22$ & $8,52 \pm 0,08$ \\
\hline 21 & $8,33 \pm 0,13$ & $8,56 \pm 0,11^{* * *}$ & $8,55 \pm 0,18$ & $8,5 \pm 0,08$ \\
\hline 22 & $6,43 \pm 0,15$ & $6,52 \pm 0,1$ & $6,90 \pm 0,15^{*, * * * * * *}$ & $6,6 \pm 0,08$ \\
\hline 23 & $7,51 \pm 0,13$ & $7,74 \underline{ \pm 0,09 * * *}$ & $7,99 \pm 0,14^{*}$ & $7,75 \pm 0,07$ \\
\hline 24 & $6,7 \pm 0,09$ & $6,86 \pm 0,07$ & $6,85 \pm 0,11$ & $6,82 \pm 0,05$ \\
\hline 25 & $6,41 \pm 0,07$ & $6,21 \pm 0,23$ & $6,26 \pm 0,13$ & $6,27 \pm 0,12$ \\
\hline 26 & $9,83 \pm 0,16$ & $9,59 \pm 0,34$ & $9,69 \pm 0,2$ & $9,68 \pm 0,18$ \\
\hline 36 & $9,97 \pm 0,73$ & $10,76 \pm 0,14^{* * *}$ & $10,15 \pm 0,65$ & $10,41 \pm 0,25$ \\
\hline 35 & $7,05 \pm 0,14$ & $6,44 \pm 0,33$ & $6,88 \pm 0,13$ & $6,71 \pm 0,17$ \\
\hline 34 & $6,85 \pm 0,14$ & $7,02 \pm 0,07^{* * * *}$ & $6,85 \pm 0,14$ & $6,94 \pm 0,06$ \\
\hline 33 & $6,57 \pm 0,11^{* * *}$ & $6,53 \pm 0,1^{* * *}$ & $6,82 \pm 0,17$ & $6,62 \pm 0,07$ \\
\hline 32 & $5,54 \pm 0,12$ & $5,62 \pm 0,08$ & $5,73 \pm 0,12$ & $5,63 \pm 0,06$ \\
\hline 31 & $5,16 \pm 0,11$ & $5,21 \pm 0,09$ & $5,1 \pm 0,11$ & $5,17 \pm 0,06$ \\
\hline 41 & $5,14 \pm 0,12$ & $5,23 \pm 0,08$ & $5,14 \pm 0,11$ & $5,18 \pm 0,06$ \\
\hline 42 & $5,68 \pm 0,12$ & $5,72 \pm 0,1$ & $5,69 \pm 0,11$ & $5,7 \pm 0,06$ \\
\hline 43 & $6,63 \pm 0,15$ & $6,68 \pm 0,09 * * *$ & $6,8 \pm 0,16$ & $6,7 \pm 0,07$ \\
\hline 44 & $6,86 \pm 0,06$ & $6,93 \pm 0,07$ & $6,93 \pm 0,15^{* * *}$ & $6,91 \pm 0,05$ \\
\hline 45 & $6,96 \pm 0,1$ & $6,83 \pm 0,27$ & $6,79 \pm 0,16$ & $6,58 \pm 0,14$ \\
\hline 46 & $9,98 \pm 0,73$ & $10,47 \pm 0,33$ & $10,2 \pm 0,65$ & $10,28 \pm 0,29$ \\
\hline
\end{tabular}

Note:

* - difference is probable when comparing between asthenics and hypersthenics, $p<0,05$

** - difference is probable when comparing between normosthenics and hypersthenics, $p<0,05$

*** - difference is probable when comparing between male and female subjects within the same somatotype, $p<0,05$

The comparative analysis of the teeth size in the adolescents of different somatotypes has enabled to find out the following peculiarities. The $33^{\text {rd }}$ tooth of hypersthenic females is of a greater mesiodistal dimension than that in the normosthenic $(\mathrm{p}<0.05)$ and asthenic females $(\mathrm{p}<0.001)$.

When comparing the mesiodistal teeth size of male subjects who had Angle's Class I malocclusion, we revealed the probable difference between the maxillary canines: they were of less size in asthenics than in hypersthenics (Table II). The upper left incisor in hypersthenic male subjects was larger than that of the asthenics and normosthenics $(\mathrm{p}<0.05)$

By comparing the mesiodistal dimensions of the teeth of the upper and lower jaws in female and male subjects diagnosed with Angle's Class I malocclusion within the same constitutional body type, we have established that the most significant difference in parameters is observed normosthenic individuals. The dimensions of all canines in normosthenic males are probably larger than those in female subjects $(\mathrm{p}<0,05)$. The larger sizes have been found out as typical for the lower first right and left premolar, upper incisors and lower left molar $(\mathrm{p}<0,05)$.

The male adolescents of asthenic somatotype, in comparison with the females of the relevant somatotype show a difference in the size of the lower left canine $(p<0.05)$. The hypersthenic male individuals when comparing with the females, demonstrate the large size of upper lateral incisors and the first right premolar $(\mathrm{p}<0,05)$.

\section{CONCLUSIONS}

Some peculiarities of mesiodistal size typical for adolescents with Angle's Class I malocclusion and their somatotypes should be taken into account in treatment planning and maintaining the stability of orthodontic treatment results. 


\section{REFERENCES}

1. Zhavoronkova I. Somatotipologicheskiye i dermatoglificheskiye priznaki konstitutsii kak marker sistemnoy organizatsii fizicheskogo razvitiya. [Dental and dermatoglyphic characteristics of the body constitution as a marker of the systemic peculiarities of physical development]:Vestnik sovremennoy klinicheskoy meditsiny. 2012; 5(1):54-56.

2. Andreenko $E$, Mladenova $S$. Changes in somatotype characteristics in the middle-aged Bulgarian men: Nutr Hosp. 2015;32(6):2910-2915.

3. Smaglyuk L., Smaglyuk V. Stan prykusu v doroslykh patsiyentiv [Characteristics of occlusion in adults.] :Ukrayins'kyy stomatolohichnyy al'manakh. 2012;3:45-47.

4. Mansur YU. Ortodonticheskaya patologiya kak aspekt kachestva zhizni vzroslykh lits. [Orthodontic pathology as an aspect of life quality in adults.] : Vestnik VolgGMU. 2015; 3(55): 34-36.

5. Kuroyedova V, Makarova A. Rasprostranennost' zubochelyustnykh anomaliy u vzroslykh i dolya asimmetrichnykh form sredi nikh [Prevalence of dentofacial anomalies and the share of asymmetric types among them]: Svít meditsini ta bíologíi". 2012; 4:31-35.
6. Khera AK, Singh GK, Sharma VP, Sing A. Relationship between Dental Arch Dimensions and Vertical Facial Morphology in Class I Subject: J.Ind. Ortod. Soc. 2012; 46 (4): 316-324.

7. SmahlyukL, Sheshukov D. Deyaki vidminnosti u rozmirakh zubiv molodykh lyudey riznykh somatotypiv. [Some differences in teeth size of adolescents of different somatotypes]: Svit biolohiyi ta medytsyny. 2018; 2(64): 78-80.

This study is a part of the research project "Substantiation of treatment and prevention approaches for patients having dentofacial abnormalities based on their constitutional body type and physical development", Orthodontics Department, State Registration: № 0113 U003715.

\section{Authors' contributions:}

According to the order of the Authorship.

\section{Conflict of interest:}

The Authors declare no conflict of interest.

\section{CORRESPONDING AUTHOR Dmytro V. Sheshukov \\ Ukrainian Medical Stomatological Academy Shevchenko 23 str., 36011 Poltava, Ukraine tel: +38095171145 \\ e-mail: dimsheshukov@gmail.com}

Received: 09.03.2019

Accepted: 20.04 .2019 


\title{
SOCIO-PSYCHOLOGICAL ASPECTS IN THE PREVENTION OF DENTAL DISEASES
}

\author{
Yevhen Ya. Kostenko, Volodymyr S. Melnyk, Liudmyla F. Horzov \\ UZHHOROD NATIONAL UNIVERSITY, UZHHOROD, UKRAINE
}

\begin{abstract}
Introduction: Measures to prevent dental diseases are included in the list of medical care provided by dentists. Modern socio-economic transformations, including in health care, have contributed to the gradual evolution of the patient from the recipient of medical care to the consumer of services.

The aim: To study the position of patients regarding the need and effectiveness of preventive dental care.

Materials and methods: Study was conducted among 310 patients who were admitted in various municipal and state medical institutions, dental clinics and private dental offices in Uzhhorod. The average age of respondents is 26 years. The survey was conducted using questionnaires.

Results: $90 \%$ of respondents are willing to pay for dental treatment based on the use of innovative technologies; $64 \%$ of people refer to paid services aesthetic therapeutic treatment; $87 \%$ of patients agree to pay for orthopedic treatment and $48 \%$ - for surgical intervention. Only $16 \%$ of respondents consider additional professional hygiene services and ready to pay for it themselves. Survey data show that $43.2 \%$ of patients give a doctor the main role in the treatment process. $42.8 \%$ of respondents need medical help in the form of advice or counseling for a decision on treatment. $14 \%$ of patients prefer to choose their own medical care and control the treatment.

Conclusions: Dental prophylactic measures that are implemented in the practice of regulating social and labor relations, the presence of relationships between the physician and the patient develop by socio-psychological laws.
\end{abstract}

KEY WORDS: patient, the social aspect, dental diseases, prevention, treatment

Wiad Lek 2019, 72, 5 cz. I, 769-772

\section{INTRODUCTION}

Measures to prevent dental diseases provided by dentists are included in the list of medical care. Modern socio-economic transformations, including in health care, have contributed to the gradual evolution of the patient from the recipient of medical care to the consumer of services. Increasingly, the patient becomes a participant in the decision on the method of treatment, has the right to choose a doctor, medical treatment [1].

Providing medical dental care is becoming one of the varieties of market services. This imprints on professional ethics in the field of medicine. For dentistry, this problem arose earlier, since it is one of the first medical practices that provide commercial and additional services on a paid basis.

Market relations, in general, have a beneficial effect on the work of state dental institutions. At the expense of attracting money from the population ("paid services"), it is possible not only to buy new equipment and materials but also to carry out repairs of premises, all this certainly affects the attitude of patients to the dental service. The growth of prices for dental services, which has taken place in recent years, was mainly due to external macroeconomic factors. It led to the transition of the market to a higher price level while maintaining demand at the same level [2].

Such changes lead to the emergence of new modelsof relations a "doctor-patient", because consumer firstly, always produces higher requirements to the producer ofservices, and secondly, participates in thedrawing up a plan of measures. The population`s awareness level about the necessity of prophylaxis measures ofdifferent stomatological diseases is high enough. In thiscontext, the social constituent of the profession of doctor goes outinto first place, in particular, that, as far as a doctor is able toconvince a patient to accept correct decisions [3].

All-around competence means not only an experienced clinicianthat owns luggage of medical and biological knowledge but alsothe man, prepared to effective communications. Mutual relationsbetween a doctor and patient, their positions, behavioral options and real actions of these subjects of social relations, in an eventual result, determine quality and result of therendered stomatological service, in our case areprophylaxes of stomatological diseases. A situationbecomes complicated that a patient does not see atransparent necessity for prophylactic measures, and is the consumer of stomatological services, he can be charged with an unnecessary treatment at his expense [4].

\section{THE AIM}

The aim of the research to study the position of patients regarding the need and effectiveness of preventive dental care. 


\section{MATERIALS AND METHODS}

Analyzed 310 responses of patients who were admitted in various municipal and state medical institutions, dental clinics and private dental offices in Uzhhorod. The average age of respondents is 26 years. The survey was conducted using questionnaires. All calculations were performed on a PC using a licensed software for operating system Windows and standard software package STATISTICA 6.1. Statistical data processing was carried out using Student's probability t-test. This study was approved by the local ethical committee [5].

\section{RESULTS}

The status of the patient in the dental profile acts as a consumer of medical care and stomatological services. However, if it comes to the prevention of dental diseases, then the patient, in general, may not fully understand its necessity. In this regard, we were curious to find out how much the patient is prepared for preventive measures, how to assess the dentist's service to date, and what quality criteria it operates.

In the course of the survey, we found that almost half of the patients choose dental care in communal and public health care institutions - 46\%,15\% of patients are willing to pay extra for additional medical services, 39\% of patients use services in private dental offices.Despite the fact that public medicine covers only the minimum amount of dental care, for most social groups this is the only way to maintain a satisfactory oral cavity. $47 \%$ of respondents who participated in our survey can be attributed to a socially vulnerable low-income group. It should be noted that preventive measures are often carried out only in the presence of hygienists in polyclinics and offices, which is still far from every medical institution. In this case, there is a problem not only of the socio-economic but also of the moral and ethical plan. On the one hand, every person has the right to medical care, including services related to the prevention of dental diseases, on the other hand, when buying a service, medical care becomes inaccessible to those patients who need it. In this case, even if the patient is aware of its importance and the need for preventive measures, it simply cannot afford it.

However, the development of modern society involves fundamental changes in the structure of the population, affected by the polarization of its strata, social groups, which excludes the possibility of a monotonous approach to the organization of medical care. The aesthetic requirements of patients, which include additional expenses for treatment, have grown. There was an awareness of the need for preventive measures.

According to our research, patients who were willing to pay for preventive measures included people with an average age of 26 years, mainly those patients who had higher or secondary special education and who had the income of more than 6,000 hryvnias per month.

The results of the questionnaire allowed to reveal a list of dental services, which patients agree to pay extra. As respondents were able to select several responses, we received the following data: $90 \%$ of respondents are willing to pay for dental treatment based on the use of innovative technologies; $64 \%$ of people refer to paid services aesthetic therapeutic treatment; $87 \%$ of patients agree to pay for orthopedic treatment and $48 \%$ - for surgical intervention. Only $16 \%$ of respondents consider additional professional hygiene services and are ready to pay for it themselves. Basically, the patient as an active consumer is focused on the paid nature of dental care, but the innovation of technology is considered a priority choice for them, considering them both health-preserving and aesthetically justifiable. And there is almost no understanding that health precautionary measures are precisely preventive measures.

The quality of dental care (services) is determined not only by the volume and level of professionalism of the doctor but also by the degree of its availability, the effectiveness of interaction between the physician and the patient, entering into relations in the public sphere providing dental care to the population.

What model of relationship do patients choose for a dental practice? What position do they adhere to as a consumer of dental care? Survey data show that $43.2 \%$ of patients give a doctor the main role in the treatment process. The paternalistic (authoritarian, traditional) model of a doctor-patient relationship is that the doctor takes a decision in the treatment, informs the patient to the extent that he considers fit, and the patient is passive, fully subordinates to the doctor. to a greater extent inherent in patients whose behavior is formed on the basis of a low level of competence in medicine. However, medical paternalism can be justified in terms of the concept of medical humanism: the attitude to the patient from the position of mercy, especially when the patient personifies suffering, helplessness. $42.8 \%$ of respondents need medical help in the form of advice or counseling (interpretative model) for a decision on treatment, while the autonomy of the patient lies not only in the freedom of choice but also in understanding the arguments in favor of the right choice. $14 \%$ of patients prefer to choose their own medical care and control the treatment. In this case, the information model of the relationship between the physician and the patient is realized. The obtained data testify to the high trust of the patients of the dentist and confidence in his professional competence, despite the fact that the patient himself is increasingly positioned himself as an active consumer of dental services. And despite this, a number of patients noted that dentist rarely mentioned the existence of any prevention program. Unfortunately, not only the average patient is not ready for preventive measures, the doctors themselves are under-conscious of the importance of this issue.

The therapeutic alliance in dentistry is due to a rather specific interaction between a physician and a patient, therefore, the psychological characteristics of each of them determine the success of treatment. In our opinion, even now, when dental care is transformed into one of the varieties of market services, the patient positions himself primarily as a person in need of specific treatment, and 
then as a consumer of medical services. In this case, we can talk about the usual understanding of the activities of the doctor as an artist of a certain professional role. The results of the survey showed that the most valuable qualities of a doctor for a patient are traditionally his professional knowledge and skills. This fact was noted by all respondents. In the second place, according to patients, the quality of a doctor is the ability to empathize with the condition of the patient $-77.5 \%$ of respondents. Important qualities characteristic of a doctor is "responsibility" - 73\% of the respondents, "moral and ethical" - $44.7 \%$ of patients. None of the patients left out of the attention as a doctor's positive quality of his desire and ability to send dental care in the prophylactic direction.

Satisfaction of the patient with dental help is formed in the process of communication in the interaction of "doctor-patient". An important role in this interaction belongs to the personal characteristics of the dentist himself. $83 \%$ of the patients who participated in the survey are of the opinion that $12 \%$ of the respondents do not have a doctor's personal qualities, the remaining $5 \%$ could not determine the answer.

\section{DISCUSSION}

The transition of health care to market relations requires the dentistry and dental managers the profound theoretical knowledge in the field of marketing. There is practically no systematized fundamental knowledge in the field of marketing of the dental service for this problem in the literature. Marketing is a complex system of organization of production and sales of products, focused on satisfying the needs of specific consumers and making profits on the basis of research and market forecasting, developing strategies and tactics of market behavior.

The marketing of dental services means achieving goals based on the orientation of the entire organization's activities to meet the needs of patients in various types of preventive, diagnostic, therapeutic and rehabilitation services. Dental marketing is defined as the process by which the market of dental care or dental services is managed and implemented. Marketing is required for all dental institutions, both private and public, as the amount of paid dental care increases annually. The population that serves as a consumer of dental care can choose any dental office, and if you pay for dental care at your own expense, you can dictate their conditions. The basic principle of marketing is the orientation of the results of treatment to real requirements and wishes of consumers. In this situation, the doctor should be the connecting link that combines all the possibilities of dental prophylaxis and the patient's aspiration. Information should be communicated in such a way that the patient first thought about preventive measures, and moreover, considered this way the only true [6].

In the middle of the twentieth century, the paternalistic model of the relationship between patient and patient faced with serious difficulties, the main of which was the growing self-awareness of man as a citizen and as a patient; increase of the status of health, life as the highest value of a person, put at risk by modern medical technologies. The time has come for new models of relations "doctor-patient", including models of "informed consent" $[7,8,9]$.

The analysis of the results allowed to determine the position of the patient in the dental profile regarding the personal characteristics of the dentist, who form the patient's installation of satisfaction with the quality of the service provided. The opinion that the doctor should be diplomatically shared by $74 \%$ of the respondents, organized - $82 \%$ of respondents, have knowledge and skills of communication with the patient - $97 \%$ of respondents, initiative - $68 \%$ and intellectually flexible - $65 \%$ of patients. $97 \%$ of the polled responded respectfully to doctors who seek to prevent dental disease, but less than half were not prepared for such actions by the doctor and were not sure that they would agree to take preventive measures for dental diseases.

\section{CONCLUSIONS}

Thus, dental prophylactic measures that are implemented in the practice of regulating social and labor relations, the presence of relationships between the physician and the patient develop by socio-psychological laws. The high trust of patients in the work of a dentist and confidence in his professional competence should be properly used by physicians to focus not only on modern methods of treatment but especially on prevention. The development of prevention of dental diseases is primarily due to the development of a culture of both patients and doctors, the relationship between the doctor and the patient, which includes not only economic problems but also social and ethical issues.

\section{REFERENCES}

1. Savychuk N.0., Klitynska 0.V. Analiz prohram profilaktykyosnovnykh stomatolohichnykh zakhvoriuvanu rozvynenykh krainakh[Analysis of prevention programs for main dental diseases in developed countries]. Sovremennaia stomatolohyia.2014; 4: 64-66. (UA)

2. Mihalchenko D. V. Ethics of consumption of medical services. Bioetika. 2010; 2(6): 48-49.

3. Canadian Centre for Policy Alternatives. Putting our money where our mouth is: the future of dental care in Canada. Ottawa, ON: CCPA; 2011. Available from: http://www.policyalternatives.ca/sites/default/files/ uploads/.

4. Isaieva N. S., Yakubova I. I. Psykholohichni osoblyvosti nadannia stomatolohichnoi dopomohy patsiientam dytiachoho viku[Psychological features of providing dental care to children of childhood]. Novynystomatolohii. 2013; 2 (75): 16-20. (UA)

5. Suplyk-Didenko D.M. Sotsialno-psykholohichni osoblyvosti roboty likaria-stomatoloha shchodo zberezhennia psykhichnoho zdorovia patsiientiv [Socio-psychological peculiarities of the work of the dentist concerning the preservation of mental health of patients] Visnyk Natsionalnoi akademii Derzhavnoi prykordonnoi sluzhby Ukrainy. 2016; 1. (UA)

6. Aristidis Arhakis, Eirini Athanasiadou, Christina Vlachou.Social and psychological aspects of dental trauma, behavior management of young patients who have suffered dental trauma. Open Dent J. 2017; 11: 41-47. 
7. Kobiyasova I. V. Psihologiya v stomatologii: vazhneyshie aspektyi gramotnogo obscheniya s patsientom [Psychology in dentistry: the most important aspects of competent communication with the patient] // Saratovskiy nauchno-meditsinskiy zhurnal. 2011; 1: 297-300. (Ru)

8. World Health Organization. Oral Health Surveys: Basic Methods. 4th. Geneva, Switzerland: World Health Organization; 1997.

9. Earl Clarkson, Sanjeev Bhatia. Management and Marketing for the General Practice Dental Office. Dental Clinics of North America. 2008; $52(3)$ : 495-505.
This work is a fragment of the research work of pediatric dentistry department Uzhhorod National University "Prevention, diagnosis, treatment of basic dental diseases in children of Transcarpathia", state registration number $0116 U 003555$.

\section{Authors' contributions:}

According to the order of the Authorship.

\section{Conflict of interest:}

The Authors declare no conflict of interest.

\section{CORRESPONDING AUTHOR}

Liudmyla F. Horzov

Dovzhenka Str., 18/3, 88000, Uzhhorod, Ukraine

tel: +380507626129

e-mail: liudmyla.horzov@uzhnu.edu.ua

Received: 12.03 .2019

Accepted: 24.04.2019 
PRACA ORYGINALNA

ORIGINAL ARTICLE

\title{
THE EFFECT OF LOW FREQUENCY ELECTROMAGNETIC RADIATION ON THE MORPHOLOGY OF DENTAL AND PERIODONTAL TISSUES (EXPERIMENTAL INVESTIGATION)
}

\author{
Iryna V. Markovskaya \\ KHARKIV NATIONAL MEDICAL UNIVERSITY, KHARKIV, UKRAINE
}

\begin{abstract}
Introduction: Low intensity electromagnetic effects possess a high biological activity, reduce the adaptive reserves of the body, impair immunity, adversely affect the functional state of the organs and body systems.

The aim of the study was to identify in the experiment the effect of low-frequency electromagnetic radiation on the morphological state of the dental and periodontal tissue. Materials and methods: The experiment was conducted on WAG rats weighing $180-200 \mathrm{~g}$, during which two groups were formed: group 1 (control group) included 12 WAG rats, which were not performed any manipulations; the rats of group 2 (investigation group) ( $n=12$ ) for 30 days were exposed to a $70 \mathrm{kHz}$ low-frequency alternating electric field (5th frequency range) daily from 9.00 to 12.00 . To simulate a low-frequency $70 \mathrm{kHz}$ alternating electric field, certified experimental equipment was used. The study material was the upper jaw tissue. Histological and histochemical staining methods were used. Morphometric study was conducted.

Results: Complex morphological study on the experimental material allowed identifying the damaging effect of low-frequency electromagnetic radiation on the structural components of tooth and periodontal tissues.

Conclusions: Our findings suggest that the workers who are exposed to occupational low-frequency electromagnetic radiation should be included in the risk group for developing diseases of the dentomandibular system in order to carry out timely therapeutic and preventive measures.
\end{abstract}

KEY WORDS: morphology, dental and periodontal tissues, low frequency electromagnetic radiation, experiment

Wiad Lek 2019, 72, 5 cz. I, 773-778

\section{INTRODUCTION}

The evolutionary development of science and technology has allowed creation and use of the latest developments in order to obtain the products necessary for life and meet the growing needs of the mankind. This increased the comfort of living in a technocratic society, but at the same time gave rise to many factors affecting the health, one of which is electromagnetic radiation [1]. At present, electromagnetic radiation is being actively introduced into various spheres of human activity: industry, medicine, agriculture, etc. [2].

The interaction of electromagnetic radiation with the human body depends on the intensity of electromagnetic radiation, the time of exposure, the frequency, the greatest point of application. Electromagnetic waves are known to be low frequency (from 3 to $300 \mathrm{kHz}$ ), medium frequency (from $300 \mathrm{kHz}$ to $3 \mathrm{MHz}$ ) and high frequency (from 3 to $30 \mathrm{MHz}$ ) [3], with electromagnetic waves of low frequencies having the greatest negative impact on human health.

Low intensity electromagnetic effects possess a high biological activity, reduce the adaptive reserves of the body, impair immunity, adversely affect the functional state of the organs and body systems [4], with the most sensitive being the nervous, immune, endocrine, cardiovascular and reproductive systems.

The literature analysis revealed isolated clinical studies showing the negative effect of low-frequency electro- magnetic radiation on the dentomandibular system, the results of which in most cases are inconsistent; complex morphological studies on the effect of the above factor on tooth and periodontal tissue have not been revealed, which is relevant, given the high prevalence and incidence of dentomandibular diseases in the population [5].

\section{THE AIM}

The aim of the study was to identify in the experiment the effect of low-frequency electromagnetic radiation on the morphological state of the dental and periodontal tissue.

\section{MATERIALS AND METHODS}

The experiment was conducted on WAG rats weighing 180 $200 \mathrm{~g}$, during which two groups were formed: group 1 (control group) included 12 WAG rats, which were not performed any manipulations; the rats of group 2 (investigation group) $(n=12)$ for 30 days were exposed to a $70 \mathrm{kHz}$ low-frequency alternating electric field ( $5^{\text {th }}$ frequency range) daily from 9.00 to 12.00 . To simulate a low-frequency $70 \mathrm{kHz}$ alternating electric field, certified experimental equipment was used.

When the animals were removed from the experiment, it was the upper jaw that was dissected, given that in humans 
this jaw is more susceptible to the damage compared to the lower jaw due to the peculiarities of the blood supply and worse cleaning from the food debris. The material was fixed in $10 \%$ neutral formalin, decalcified, and then the pieces of hard and soft tissues of the upper jaw about $0.4-0.6 \mathrm{~cm}$ thick were dissected longitudinally through the center of the upper central incisor, which were dehydrated using standard alcohol treatment and embedded in paraffin. 5-6 micron thick slices were made. The specimens stained with hematoxylin and eosin were used for general assessment of the state of hard and soft tissues of the upper jaw. Van Gieson staining with picrofuchsin was used to identify and assess the degree of development of collagen fibers in the studied tissues. To assess the content of nucleic acids in the nuclei of cells, Einarson staining with gallocyanin-chromic alum for total nucleic acids was used. MacManus-Hotchkiss PAS reaction (control with amylase) was used to revealed neutral glycosaminoglycans. The microscopic specimens were studied using Olympus BX-41 microscope (Japan).

Morphometry was carried out on Olympus BX-41 microscope (Japan) using Olympus DP-soft version 3.1 software, during which the thickness of enamel, dentin, predentin, ameloblast and odontoblast density were determined. To identify the density of odontoblasts in each specimen, the area occupied by these cells $\left(\right.$ in $\mathrm{mm}^{2}$ ) was determined, the number of cells on it was counted, and the ratio of the number of ameloblasts and odontoblasts to the corresponding area was calculated. On the specimens stained with gallocyanin-chromic alum for total nucleic acids, optical density of nuclei of the basal gum epithelial cells, ameloblasts and odontoblasts was determined.

Statistical processing of the data was performed using non-parametric (Mann-Whitney) methods. The results were considered significant at $\mathrm{p}<0.05$. Statistical processing of the results obtained was performed using Excel and Statistic Soft 6.0.

\section{RESULTS AND DISCUSSION}

Microscopically, in group 2, the periodontal tissue of the maxillary incisor was represented by the gum, periodontium, bone tissue of the dental alveolus, and cementum. The gum was covered with a multi-layered flat keratinizing epithelium, which contained 16-18 rows of cells differentiated into basal, spinous, granular and horny layers. The basal layer cells were rounded with a weakly eosinophilic cytoplasm and a moderately basophilic nucleus, the mitosis figures were few. Compared with group 1, the spinous layer cells were enlarged and contained a large rounded basophilic nucleus. Pyknotic or weakly basophilic nuclei surrounded by a narrow rim of cytoplasm were found in individual cells and their small groups in the basal and spinous layers. In some cells or their groups, the nuclei were defined as "shadows", the intercellular connections between them were broken (fig. 1). The horny layer was loose, voluminous, with foci of thickening and loci of horny scales with rod-shaped basophilic nuclei (foci of parakeratosis). The optical density of the basal cell nuclei was $0.162 \pm 0.014$ relative units of optical density, which was significantly $(\mathrm{p}<0.05)$ less compared to the indicator of group 1 ( $0.235 \pm 0.017$ relative units of optical density). The basement membrane of the epithelium contained the areas of thickening and thinning, was not visualized focally. The intensity of the PAS reaction was greatest in the areas of parakeratosis.

The papillary layer of the lamina propria was somewhat thickened due to elongation of the papillae, widening of the optically empty spaces between the collagen fibers. The collagen fibers were weakly fuchsinophilic. There were foci of swelling and dissociation of yellow connective tissue fibers. The capillaries were lined with endotheliocytes with a swollen nucleus lying on a moderately PAS-positive membrane. Some of the capillaries had signs of stasis, some were in a collapsed state and had a slit-like lumen. Perivascular spaces were somewhat enlarged, containing small focal accumulations of macrophages and lymphocytes.

The bundles of collagen fibers of the reticular layer at van Gieson staining, were moderately fuchsinophilic with loci of homogenization, dissociation and reduction of fuchsinophilia. A moderate number of fibroblastic differon cells with weakly basophilic cytoplasm and a rounded bright nucleus was visualized between the fibers; their content was somewhat reduced compared with group 1 . The arterioles showed signs of irregular spasm, endothelial cells desquamation and proliferation loci. The venules of the reticular layer were unevenly expanded, plethoric, and the endotheliocytes lining them were flattened and contained an elongated basophilic nucleus. At PAS reaction, the vascular basement membrane was irregularly thickened, sometimes dissociated. The enlarged perivascular spaces demonstrated a few small focal lymphohistiocytic infiltrates (fig. 2).

In the slit-like periodontal space, collagen fibers of dense periodontal connective tissue were visualized. The direction of the bundles varied from radial in the zone of cemento-enamel attachment, to tangential in the zone of the lateral surfaces of cementum and vertical in the zone of the apical foramen. The bundles of collagen fibers were thick, moderately fuchsinophilic, with foci of swelling, dissociation and reduced fuchsinophilia. Periodontal arteries with uneven lumens, the endothelium lining them focally had signs of karyopyknosis and desquamation, proliferation loci. The venous vessels were lined with flattened endothelium with a moderately basophilic extended nucleus and a weakly basophilic cytoplasm; their lumens were unevenly widened, overfilled with blood. PAS reaction demonstrated that the vascular basement membrane had areas of thickening and thinning, in some places with cleavage loci (fig. 3). Fibroblasts with a rounded or oval, moderately basophilic nucleus and spindle-shaped fibroblasts prevailed among the cellular elements of the periodontium, there were macrophages, lymphocytes, plasma cells and tissue basophiles. In some specimens they formed small perivascular clusters.

In the area of the anatomical neck of the tooth, the epithelium of the gum attachment was replaced by a layer of differentiated active ameloblasts, which towards the root of 


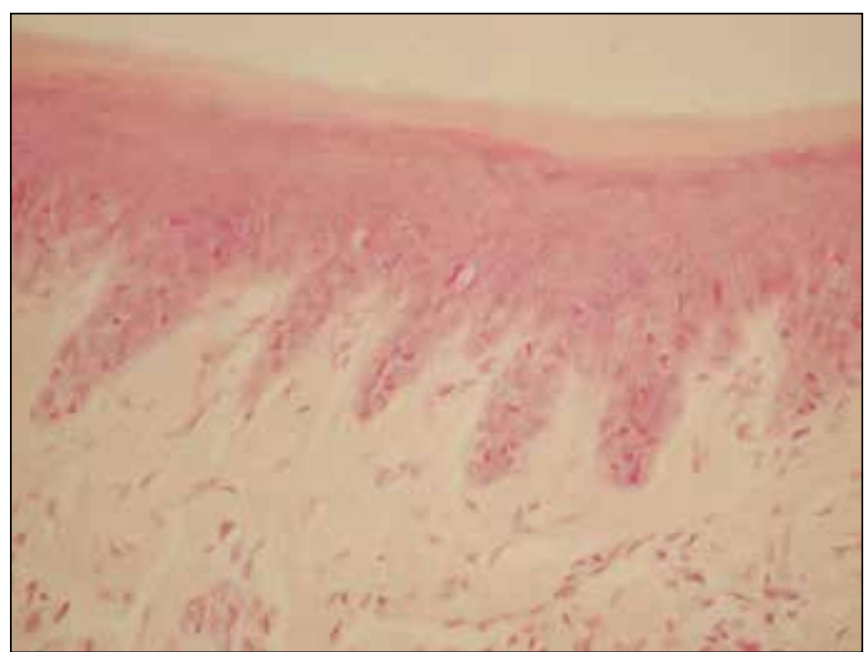

Fig. 1. Gum epithelium. Karyopyknosis in the cells of the basal and spinous layers. "Shadow" cells in the basal layer. Group 2. Stained with hematoxylin and eosin, $\times 400$

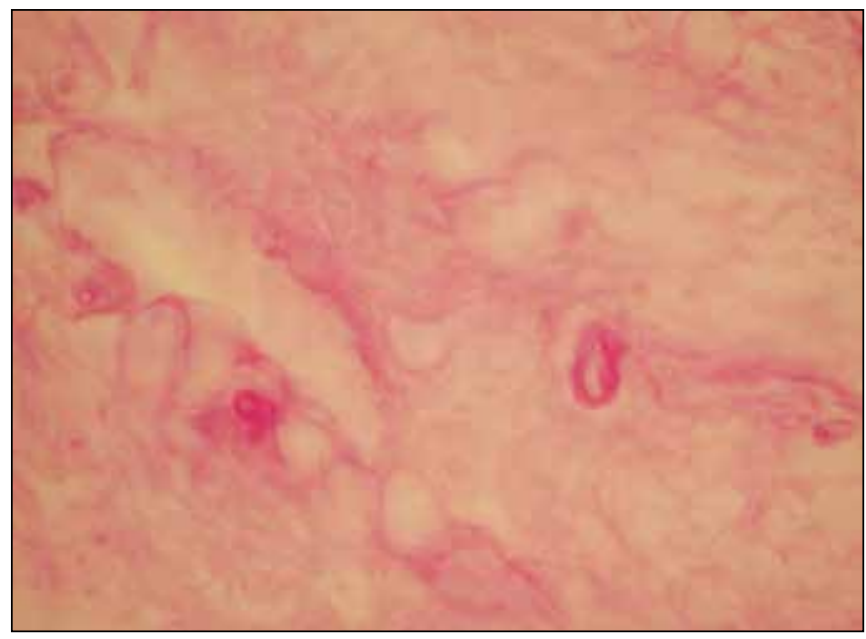

Fig. 3. Thickening and dissociation of the basement membrane of the periodontal vessels. Group 2. PAS-reaction with saliva amylase control, $\times 400$

the tooth acquired a more elongated shape. The ameloblasts were located parallel to each other, their cytoplasm was slightly eosinophilic, the nucleus was elongated, moderately took the basic dyes. In comparison with group 1 , in this group numerous cells or their groups were in a state of hydropic or balloon degeneration. The boundaries between such groups of ameloblasts were blurred, the cytoplasm contained vacuoles or was completely filled with a clear liquid, the nuclei showed the signs of karyopychnosis and karyolysis (fig. 4). The optical density of the nuclei of ameloblasts was $0.118 \pm 0.011$ relative units of optical density, which was significantly $(\mathrm{p}<0.05)$ less as compared to the same indicator of group $1(0.164 \pm 0.016$ relative units of optical density). In the groups of cementoblasts visualized on the border with the cementum, cytoplasmic eosinophilia decreased, in some cells dystrophic and necrobiotic changes were determined. PAS-positive basement membrane of ameloblasts and cementoblasts was uneven.

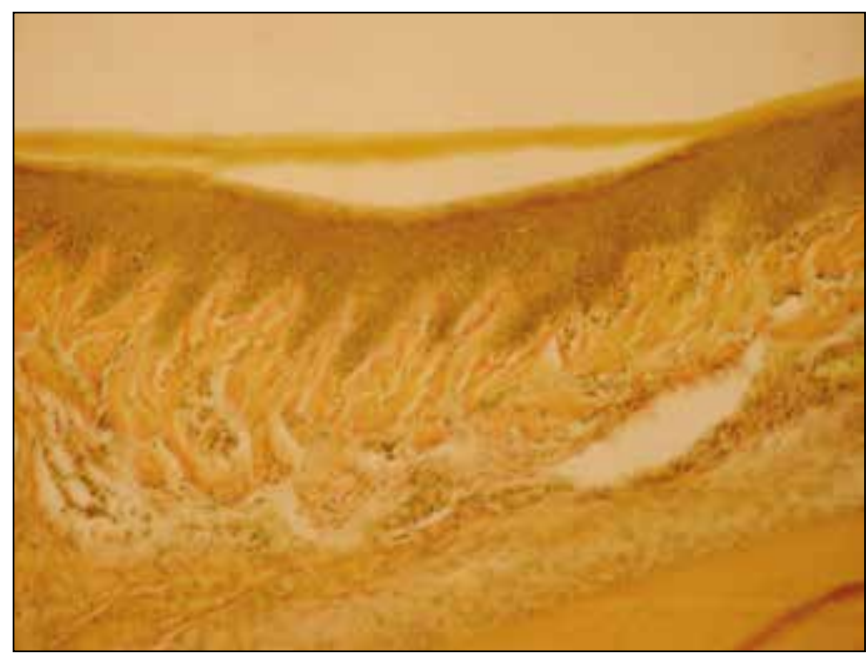

Fig. 2. Swelling of the gingival lamina propria, weakly and moderately fuchsinophilic collagen fibers of the gum. Plethora of venous vessels, small-focus perivascular lymphohistiocytic infiltrates. Group 2. Van Gieson staining with picrofuchsin, $\times 400$

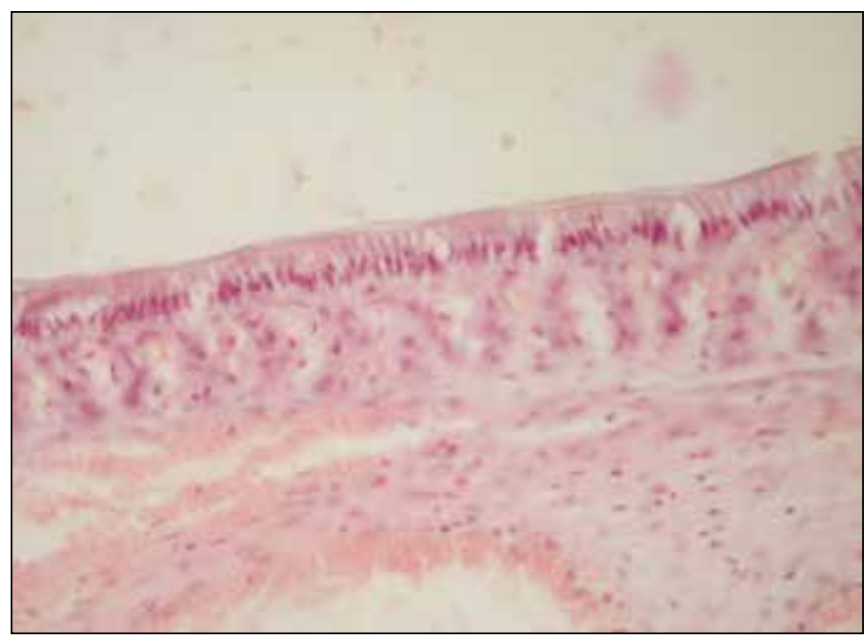

Fig. 4. Dystrophic and necrobiotic changes of ameloblasts. Group 2. Stained with hematoxylin and eosin, $\times 400$

The bone plate of the dental alveoli wall, surrounding the tooth root, consisted, as in group 1, of the system of osteons; however, in this group, pyknotic wrinkling of the nuclei was observed in individual cells with an increase in their basophilia. Thin connective tissue fibers of the bone plate, penetrating from the periodontium, contained loci of fuchsinophilia reduction at van Gieson staining. In the bone trabeculae of the spongy bone of the dental alveoli, the nuclei of osteocytes were smaller and hyperchromic compared with group 1 . At van Gieson staining, the collagen fibers of the organic bone beam base were unevenly fuchsinophilic, and in the areas where their fuchsinophilia decreased, the fibers looked slightly swollen. The cells between the bone trabeculae contained bone marrow and blood vessels. Compared with group 1, the number of hematopoietic cells decreased in the bone marrow, and the fatty tissue content increased (fig. 5).

The decrease in the number of hematopoietic cells testified to the inhibitory effect of electromagnetic radiation 


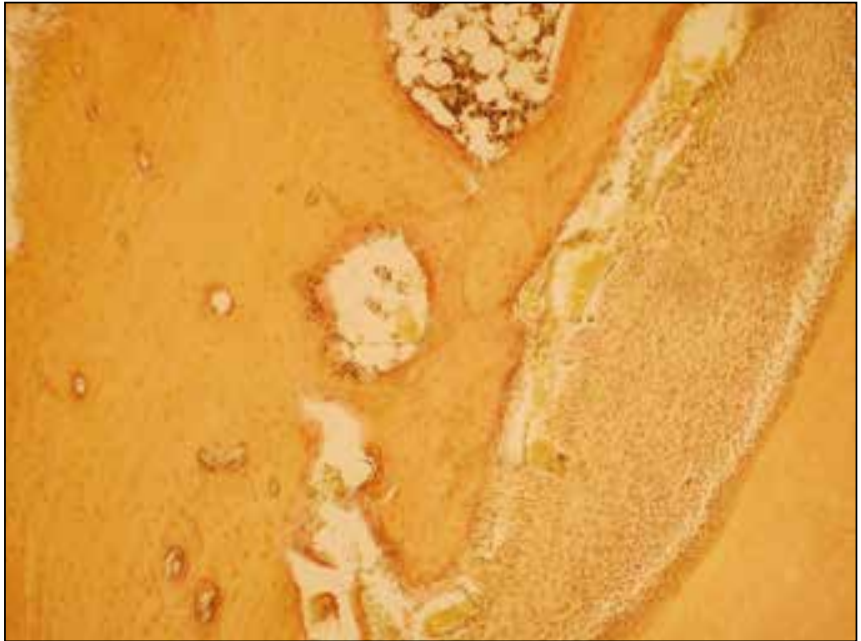

Fig. 5. Unevenly pronounced fuchsinophilia of periodontal collagen fibers and bone trabeculae. Bone marrow hypoplasia. Group 2. Van Gieson staining with picrofuchsin, $\times 100$.



Fig. 7. Dystrophic and necrobiotic changes in odontoblasts. Group 2. Stained with hematoxylin and eosin, $\times 400$

on hematopoietic processes, which has been noted in other investigations [6].

The described necrotic changes in periodontal tissues are possibly due to the fact that radiation leads to ionization of the molecules and atoms, formation of free radicals and peroxide compounds, which in turn violate the biochemical processes, cell functions and contribute to necrosis development [7].

The hard tooth tissues were represented by cementum, enamel, dentin and predentin. Van Gieson staining demonstrated that, the collagen fibers of the main substance of the cementum were moderately fuchsinophilic; there were foci of mucoid swelling with fuchsinophilia reduction, swelling and dissociation of collagen fibers, expansion of the spaces between them. Demineralization sites were uneven.

A weakly eosinophilic layer of enamel began to be visualized under a layer of narrowing cementum in the area of the cementoenamel border and covered the vestibular surface of the incisor crown. Enamel hypomineralization



Fig.6. Uneven arrangement of small demineralization foci in dentin. Group2. Stained with hematoxylin and eosin, $\times 400$.

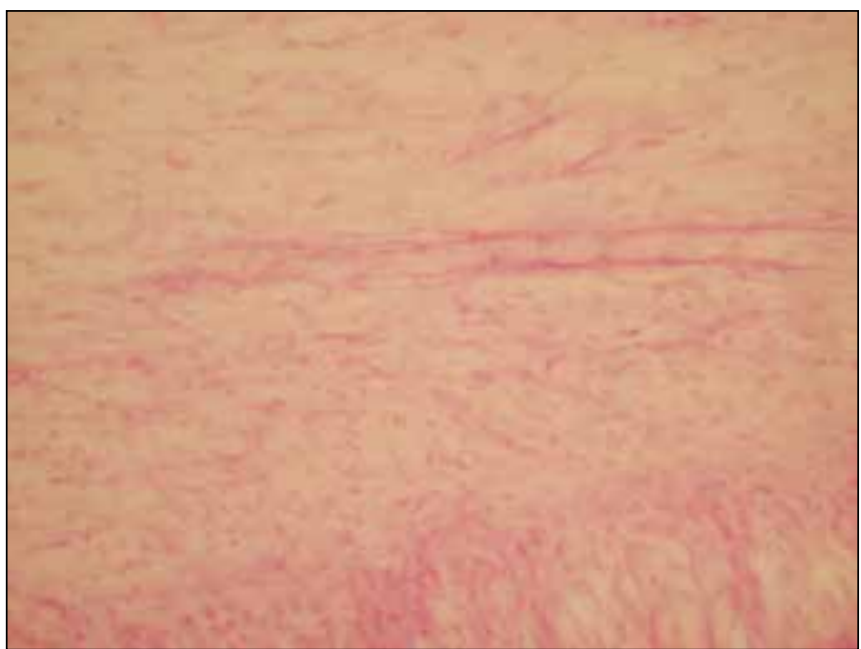

Fig. 8. Irregular vascular basement membrane with dissociation sites in the dental pulp. Group 2. PAS-reaction with saliva amylase control, $\times 400$.

sites were unevenly located, Gunter-Schreger lines in them were weakened, Retzius lines were widened. In the area of the anatomical neck of the tooth, the average value of the enamel thickness in this group was $8.57 \pm 0.25 \mu \mathrm{m}$, which was significantly less $(\mathrm{p}<0.05)$ compared with the indicator of group $1(10.59 \pm 0.12 \mu \mathrm{m})$.

Dentinoenamel border was focally blurred. The layers the dentine and predentin were somewhat narrowed. Morphometrically, the average thickness of the dentin in the group was $166.67 \pm 0.72 \mu \mathrm{m}$, which was significantly $(\mathrm{p}<0.05)$ lower compared with the indicator of group 1 $(173.67 \pm 0.77 \mu \mathrm{m})$. The thickness of the predentin layer in group $2(28.19 \pm 0.42 \mu \mathrm{m})$ was significantly $(\mathrm{p}<0.05)$ lower compared with group $1(33.68 \pm 0.35 \mu \mathrm{m})$. Dentin and predentin had areas of uneven location of dentinal tubules, expanded spaces between them. Van Gieson staining shoed the main substance with the signs of mucoid swelling in these areas, the collagen fibers were swollen, fibrous, weakly fuchsinophilic. The boundary between dentin and preden- 
tin was defined as a corrugated line and was somewhat blurred in the areas of the mucoid swelling of the main substance. Predominantly small demineralization foci were visualized in the dentin, which were poorly stained by the main dyes or were not stained, were located unevenly (fig. 6). The area of demineralized foci averaged $136.71 \pm 6.67$ $\mu \mathrm{m}^{2}$, which was significantly $(\mathrm{p}<0.05)$ lower compared with the indicator of group $1\left(251.45 \pm 14.97 \mu \mathrm{m}^{2}\right)$.

It has been noted that electromagnetic radiation leads to necrosis of hard tooth tissues due to direct influence of this factor on protein structures of enamel and dentin. Besides, electromagnetic radiation violates the function of the salivary glands, up to xerostomia, which in turn can lead to violation of remineralization [7]. Moreover, not only decrease in the production of saliva, but also a change in its structural and mineralizing properties was revealed [8].

Pronounced carious changes in workers who were subjected to electromagnetic radiation while performing their duties have been described [8].

In the pulp of the incisor, the odontoblast layer was narrowed; its average thickness in the group was $47.53 \pm 1.29$ $\mu \mathrm{m}$, which was significantly $(\mathrm{p}<0.05)$ less than in group $1(61.71 \pm 0.86 \mu \mathrm{m})$. The cytoplasm of odontoblasts was poorly basophilic, the nucleus was moderately or poorly demonstrated by the basic dyes. In groups of cells, the protoplasm contained vacuoles with cytoplasmic fluid, the nucleus was in the state of karyopyknosis or karyolysis and shifted towards the dentinal processes (fig. 7). The optical density of odontoblast nuclei in the average was $0.159 \pm 0.014$ relative. Units of optical density, which was significantly $(\mathrm{p}<0.05)$ less in comparison with the indicator of group 1 ( $0.201 \pm 0.004$ relative units of optical density). The intercellular spaces of the odontoblast layer were enlarged, optically empty. Some capillaries had signs of stasis, were lined with endothelium with a swollen nucleus. Some capillaries were collapsed, their lumens were slitlike. The vascular basement membrane was uneven at PAS reaction. Morphometrically, the density of odontoblasts was $6167.41 \pm 316.48 \mathrm{pcs} / \mathrm{mm}^{2}$, which was significantly $(\mathrm{p}<0.05)$ less than the corresponding indicator of group 1 $\left(7261.93 \pm 272.36 \mathrm{pcs} / \mathrm{mm}^{2}\right)$.

In the intermediate layer of the pulp, there was an uneven narrowing of the outer zone, decreased content of cellular elements in the inner zone. Increased content of fibroblasts and unevenly fuchsinophilic collagen fibers was observed in the stroma of the pulp nucleus. Collagen fibers were focally swollen, slightly fibrous and slightly fuchsinophilic. The spaces between the fibers were somewhat expanded due to accumulation of edematous fluid. The vessels were unevenly filled with blood. PAS reaction demonstrated that the vascular basement membrane had areas of thickening and splitting; it was not visualized focally (fig. 8). In the endothelial lining, there were loci of cells with a pyknotic nucleus and signs of desquamation, as well as groups of proliferating cells with a swollen basophilic nucleus. Some capillaries had signs of stasis, some were collapsed with a slit-like lumen. Small focal hemorrhages were perivascularly visualized.
Thus, a complex morphological study on the experimental material allowed identifying the damaging effect of low-frequency electromagnetic radiation on the structural components of tooth and periodontal tissues.

\section{CONCLUSIONS}

1. In the multilayered flat epithelium of the gingival mucosa, pronounced necrobiotic changes in the epitheliocytes of the basal and spinous layers developed, proliferative activity in the basal epithelium was inhibited, cell differentiation with focal parakeratosis was disturbed; these changes were accompanied by reduction in the optical density of the basal cell nuclei. Moderate hemodynamic disturbances, focal dystrophic changes of the connective tissue and mild cellular perivascular lymphohistiocytosis infiltration appeared in the gingival lamina propria mucosa and periodontium.

2. In the bone component of the periodontal, signs of focal alterative changes in osteocytes and reduction in collagenization of the bone trabeculae organic matrix were found. In ameloblasts, widespread dystrophic and necrobiotic changes developed, which was accompanied by reduction in the optical density of their nuclei. The revealed alterative changes of ameloblasts caused development of hypoplasia and impaired mineralization of the enamel, which was confirmed by reduction in its thickness.

3. In the pulp of the tooth, dyscirculatory changes were detected, which were accompanied by focal mucoid swelling of the stromal pulp nucleus, appearance of fibroblast hyperplasia loci with focal enhancement of stromal collagenization. In odontoblasts, signs of hydropic degeneration and necrobiosis appeared, inhibition of their proliferative activity was noted, which was confirmed by reduction in the thickness of the odontoblast layer and their density, decrease in the optical density of the cell nucleus.

4. The identified pathological changes in the structural components of the pulp caused development of focal dystrophic changes in dentin and predentin, disrupting the process of their mineralization, which was confirmed by narrowing of the predentin and dentin zones, reduction in the area of dentin demineralization and their uneven location.

5. Our findings suggest that the workers who are exposed to occupational low-frequency electromagnetic radiation should be included in the risk group for developing diseases of the dentomandibular system in order to carry out timely therapeutic and preventive measures.

\section{REFERENCES}

1. Cherny A.P., Nikiforov V.V., Rodkin D.I. et al. Sovremennoe sostojanie issledovanij vlijanija jelektromagnitnyh izluchenij na organizm cheloveka [The current state of research on the influence of electromagnetic radiation on the human body]. Engineering and Educational Technologies. 2013; 2:112-124. (Ru)

2. Smirnov A.I. Vlijanie jelektromagnitnyh polej nizkoj chastoty na rost sejancev sosny obyknovennoj [Influence of low frequency electromagnetic fields on the growth of pine seedlings]. Forestry Bulletin. 2014; 4:52-56. (Ru) 
3. OdinayevF.I.,OdinayevSh.F.,Shafiev Sh.I.etal.Jelektromagnitnyeizluchenija i zdorove cheloveka [Electromagnetic radiation and human health]. Tomsk State University Journal Vestnik. 2015; 20(6):1714-1717. (Ru)

4. Schepina T.P., Nekrasova D.A., Egorkina S.B. Vlijanie vrashhajushhego jelektricheskogo polja nizkoj chastoty na reproduktivnyj potencial jeksperimentalnyh zhivotnyh [Influence of a rotating low-frequency electric field on the reproductive potential of experimental animals]. Population health and life environment. 2014; 8(257): 53-55. (Ru)

5. Bugorkova I.A. Rasprostranennost stomatologicheskih zabolevanij u narkozavisimyh bolnyh dlja razrabotki programmy po snizheniju riskov [The prevalence of dental diseases in drug-addicted patients for developing a risk reduction program]. Ukraine. Health of the nation. 2015; 2(34): 28-31. (Ru)
6. SolovyovV.S.,ZhevnovskayaA.N.,GashevS.N.etal.Vlijaniejelektromagnitnogo izluchenija promyshlennoj chastoty na gematologicheskie pokazateli perifericheskoj krovi gryzunov [The influence of electromagnetic radiation of industrial frequency on the hematological parameters of the peripheral blood in rodents]. Principles of the ecology. 2016; 2: 84-90. (Ru)

7. Hadzhibragimov M.S. Vlijanie jelektromagnitnogo izluchenija kompjuterov na tverdye tkani zuba [The effect of electromagnetic radiation of computers on tooth hard tissues]. Bulletin of medical internet conferences. 2018; 8: 4: 144-145. (Ru)

8. Leontyeva E.Yu., Bykovskaya T.Yu., Ivanov A.S.Vlijanie neionizirujushhego izluchenija na sostojanie tkanej polosti rta: obzor literatury [Influence of non-ionizing radiation on the state of the tissues of the oral cavity: a review of the literature]. Chief doctor. 2018; 64: 6-9. (Ru)

\section{Conflict of interest:}

The Author declare no conflict of interest.

\section{CORRESPONDING AUTHOR}

\section{Iryna V. Markovskaya}

Kharkiv National Medical University

Pobedy Avenue 78a, apartment 77, 61204 Kharkiv, Ukraine

tel: +380501699763

e-mail: msmyroshnychenko@ukr.net

Received: 15.03 .2019

Accepted: 26.04.2019 


\title{
IDENTIFICATION AND ASSESSMENT OF RISK FACTORS ROLE IN MYOCARDIAL INFARCTION DEVELOPMENT
}

\author{
Victor A. Ognev, Anna A. Podpriadova, Anna V. Lisova \\ KHARKIV NATIONAL MEDICAL UNIVERSITY, KHARKIV, UKRAINE
}

\begin{abstract}
Introduction:The high level of morbidity and mortality from cardiovascular disease is largely due toinsufficient influence on the main risk factors that contribute to the development of myocardial infarction.Therefore, a detailed study and assessment of risk factors is among the most important problems of medical and social importance.

The aim: To study and evaluate the impact of biological, social and hygienic, social and economic, psychological, natural and climatic risk factors on the development of myocardial infarction.

Materials and methods: A sociological survey was conducted in 500 people aged 34 to 85 . They were divided into two groups. The main group consisted of 310 patients with myocardial infarction. The control group consisted of 190 practically healthy people, identical by age, gender and other parameters, without diseases of the cardiovascular system. Results: It was defined that 30 factors have a significant impact on the development of myocardial infarction. Data analysis revealed that the leading risk factors for myocardial infarction were biological and socio-hygienic. The main biological factors were: hypertension and hypercholesterolemia. The man socio-hygienic factor was smoking. Conclusions: Identification of risk factors provides new opportunities for the development of more effective approaches for the prevention and treatment of myocardial infarction.
\end{abstract}

KEY WORDS: myocardial infarction, risk factors

Wiad Lek 2019, 72, 5 cz. I, 779-783

\section{INTRODUCTION}

Diseases of the cardiovascular system, in particular myocardial infarction, rank high among the causes of morbidity, disability and adult mortality throughout the world. As follows from 2016 data, 15.2 million out of 56.9 million of deaths worldwide were attributed to ischemicheart disease and stroke [1]. According to the American Association of Cardiologists, by 2030 the death rate from cardiovascular system diseases will reach 23.6 million people [2]. A high morbidity and mortality rate is largely due to insufficient influence on the main risk factors that contribute to myocardial infarction development, namely: hypertension, hypercholesterolemia, smoking, unhealthy diet, stress, physical inactivity, heredity, alcohol consumption, obesity $[3,4,5,6]$. A detailed study and assessment of risk factors for myocardial infarction development is among the most important issues of medical and social importance.

\section{THE AIM}

The purpose of the survey was to study and assess the impact of biological, socio-hygienic, socioeconomic, psychological and climatic factors on myocardial infarction development.

\section{MATERIALS AND METHODS}

A survey of patients with myocardial infarction was performed in order to conduct a sociological study. The study included 500 people, aged 34 to 85 years. The main group included 310 patients with myocardial infarction (195 (63 $\pm 2.7 \%)$ men and $115(37 \pm 2.7 \%)$ women), whose average age was $58.7 \pm 0.5$ years and who were treated in cardiology department for patients with myocardial infarction of Kharkivmunicipal hospital No. 28 and Clinical health resort "Roshcha". The control group consisted of 190 practically healthy individuals (110 $(58 \pm 3.6 \%)$ men and $80(42 \pm 3.6 \%)$ women), whose average age was 59.6 \pm 0.9 years, identical in age, sex, and other indicators, having no cardiovascular disease in past medical history. A copy of control cards data from the of the follow-up clinic (form No. 30/y) and inpatient medical records (form No. 003/y) was also performed in order to clarify the information in the course of the study. The main risk factors of myocardial infarction were studied with the help of variance analysis. Statistical processing of the data was performed using the programs Statistica 9.0 and Microsoft Office Excel. The following indicators were calculated: the strength of factors impact $(\eta-\%)$, odds ratio (OR), level of significance $(\mathrm{p})$.

\section{RESULTS AND DISCUSSION}

The study found that 30 factors have a significant impact on myocardial infarction development. All factors were divided into 5 groups: biological, socioeconomic, socio-hygienic, psychological, and natural and climatic. Data analysis showed that biological factors had the greatest 
influence on myocardial infarction occurrence. Thus, the frequency of hypertension occurrence in the main group of $51.6 \pm 2.8 \%$ was significantly higher than in the control group of $18.4 \pm 2.8 \%(\mathrm{OR}=4.8 ; \mathrm{p}<0.001 ; \eta-11 \%)$. The presence of hypercholesterolemia was detected in $45.2 \pm 2.8 \%$ of the main group patients and $15.8 \pm 2.6 \%$ of the control group $(\mathrm{OR}=4.5 ; \mathrm{p}<0.001 ; \eta 9 \%)$. Heredity remarkable for cardiovascular diseases was observed in $32.3 \pm 2.7 \%$ of the main group patients and in $10.5 \pm 2.3 \%$ of the control group $(\mathrm{OR}=4.1, \mathrm{p}<0.001 ; \eta-6 \%)$. It should be noted that the occurrence frequency of chronic diseases in the main group was significantly higher than in the control group, respectively $-32.3 \pm 2.7 \%$ and $15.8 \pm 2.7 \%(\mathrm{OR}=2.5$; $\mathrm{p}<$ $0.001 ; \eta-3 \%)$. Using anthropometric data, the body mass index was calculated and it was found that $25.8 \pm 2.5 \%$ of the main group patients were overweight, while only $10.5 \pm 2.3 \%$ of the control group had this risk factor (OR = $2.9 ; \mathrm{p}<0.001 ; \eta-3 \%)$. High blood glucose was remarkable in $22.6 \pm 2.4 \%$ of the main group patients and in $10.5 \pm 2.3 \%$ of the control group $(\mathrm{OR}=2.3 ; \mathrm{p}<0.001 ; \eta-2 \%)$. The results are shown in the Table I.

Based on the study, it was determined that all socio-hygienic factors had a significant effect on myocardial infarction development. The study examined such factors as: smoking, excessive consumption of fatty foods, alcohol abuse, failure to comply with dietary pattern, physical inactivity, excessive consumption of food, coffee, fast foods, ready-to-cook foods, and the presence of occupational hazards in past medical history. Smoking is known to be one of the significant risk factors for myocardial infarction worldwide. In our study, it was revealed that smoking had the greatest influence on this pathology development among the socio-hygienic factors. Smoking was significantly more common in the main group $35.5 \pm 2.7 \%$, than in the control group $10.4 \pm 2.3 \%(\mathrm{OR}=4.7 ; \mathrm{p}<0.001 ; \eta-7 \%)$. Diet nature was also of great importance. Excessive consumption of fatty foods was observed in $26.5 \pm 2.5 \%$ of the main group patients and in $8.4 \pm 1.9 \%$ of the control group $(\mathrm{OR}=$ $3.9 ; \mathrm{p}<0.01 ; \eta-5 \%)$. When assessing the dietary pattern, it was found that $33.9 \pm 2.7 \%$ of the main group patients and $17.9 \pm 2.8 \%$ of the control group did not comply with the $\operatorname{diet}(\mathrm{OR}=2.4 ; \mathrm{p}<0.01 ; \eta-3 \%)$; excessive food consumption was observed in $21.9 \pm 2.4 \%$ of the main group patients and in $11.1 \pm 2.3 \%$ of the control group $(\mathrm{OR}=2.3 ; \mathrm{p}<0.001$; $\eta-2 \%)$. A certain effect of excessive alcohol consumption on myocardial infarction development has also been proven. In our study, it was revealed that among the patients of the main group and the control group, excessive alcohol consumption was $32.3 \pm 2.6 \%$ and $13.2 \pm 2.4 \%$, respectively $(\mathrm{OR}=2.9 ; \mathrm{p}<0.001 ; \eta-4 \%)$. Factors such as fast foods and ready-to-cook foods consumption also had a definite influence on myocardial infarction development. We found that $10.6 \pm 1.8 \%$ of the main group patients and $3.2 \pm 1.2 \%$ of the control groupoften consumed fast foods $(\mathrm{OR}=3.7 ; \mathrm{p}$ $<0.001 ; \eta-1 \%)$ and $16.5 \pm 2.1 \%$ of the main group patients and $7.9 \pm 1.9 \%$ of the control group patients consumed ready-to-cook foods $(\mathrm{OR}=2.3 ; \mathrm{p}<0.05 ; \eta-1 \%)$. According to the World Health Organization, physical activity of $60 \%$ of the world population does not reach the level necessary to maintain and preserve health, causing 1.9 million deaths in the world every year. Thus, physical inactivity is one of the causes of death and is considered as one of the risk factors for the cardiovascular pathology development, in particular myocardial infarction $[7,8]$. Therefore, the study found that the frequency ofphysical inactivity occurrence in patients of the main and control groups was $29.0 \pm 2.6 \%$ and $14.7 \pm 2.6 \%$, respectively $(\mathrm{OR}=2.4 ; \mathrm{p}<0.001$; $\eta-3 \%)$. It is believed that coffee, whose active substance is caffeine, is one of the products affecting cardiovascular disease development, in particular myocardial infarction. Under the influence of caffeine, myocardial contractions are enhanced, and the heart rate increases. In our study, it was found that $15.2 \pm 2.0 \%$ of the main group patients and $6.8 \pm 1.9 \%$ of the control group regularly consumed coffee $(\mathrm{OR}=2.4 ; \mathrm{p}<0.01 ; \eta-1 \%)$. Various scientific researchers have also studied the role of occupational hazards and their relationship with myocardial infarction development. When assessing the impact of occupational hazards on this pathology development, we found that $9.4 \pm 1.6 \%$ of the main group patients and $2.6 \pm 1.2 \%$ of the control group were exposed to occupational hazards $(\mathrm{OR}=3.8 ; \mathrm{p}<0.05$; $\eta-1 \%)$. The results are shown in the Table II.

The study found that socioeconomic as well as psychological factors also had a significant impact on myocardial infarction development. We attributed the following to the group of psychological factors: the type of personality temperament and the presence of stress at work and at home. Socioeconomic factors included: marital status, education level, professional status, financial security level. It should be noted that such factors as stressful situations at work and stress in the family were of the greatest influence among all the factors of these groups. It was established that $26.5 \pm 2.5 \%$ of the main group patients and $8.4 \pm 1.9 \%$ of the control group were exposed to stress at workplace $(\mathrm{OR}=3.9 ; \mathrm{p}<0.01 ; \eta-5 \%) ; 40.0 \pm 2.8 \%$ of the main group patients and $21.1 \pm 2.9 \%$ of the control group indicated stressful situations in the family $(\mathrm{OR}=2.5 ; \mathrm{p}<0.001$; $\eta$ - $4 \%)$. The type of personality temperament also plays a specific role in myocardial infarction development. Thus, the personal and behavioral characteristics of people with such as "choleric" temperament type are considered to be an expressive factor in cardiovascular diseases development, in particular myocardial infarction [9]. Based on our scientific research, it was found that $24.5 \pm 2.4 \%$ of the main group patients and $13.2 \pm 3.1 \%$ of the control group had this type of temperament $(\mathrm{OR}=2.1 ; \mathrm{p}<0.001 ; \eta-2 \%)$. It was also found that professional status and education level in a certain way affect this pathology development. Thus, $12.3 \pm 1.9 \%$ of the main group patients and $4.7 \pm 1.6 \%$ of the control group did not have a higher education $(\mathrm{OR}=2.8$; $\mathrm{p}<0.01 ; \eta-1 \%)$. The executive positions at work among patients of the main and control groups was $16.1 \pm 2.1 \%$ and $5.3 \pm 1.6$, respectively $(\mathrm{OR}=3.5 ; \mathrm{p}<0.01 ; \eta-2 \%)$. When analyzing the level of financial security, it was found that $20.0 \pm 2.3 \%$ of the main group patients and $10.5 \pm 2.3 \%$ of the control group had a low level of financial security 
Table I. Biological risk factors for myocardial infarction in adults

\begin{tabular}{|c|c|c|c|c|c|c|}
\hline & Risk factors & $\begin{array}{l}\text { The main } \\
\text { group } \\
\mathrm{P} \pm \mathrm{m}(\%)\end{array}$ & $\begin{array}{c}\text { The control } \\
\text { group } \\
\mathrm{P} \pm \mathrm{m}(\%)\end{array}$ & $\begin{array}{c}\text { Odds } \\
\text { Ratio } \\
\text { (OR) }\end{array}$ & $\begin{array}{c}\text { Power } \\
\text { of influence } \\
\eta(\%)\end{array}$ & $\mathbf{P}$ \\
\hline 1. & Hypertension & $51,6 \pm 2,8$ & $18,4 \pm 2,8$ & 4,8 & 11 & $<0,001$ \\
\hline 2. & Hypercholesterolemia & $45,2 \pm 2,8$ & $15,8 \pm 2,6$ & 4,5 & 9 & $<0,001$ \\
\hline 3. & Heredity & $32,2 \pm 2,7$ & $10,5 \pm 2,3$ & 4,1 & 6 & $<0,001$ \\
\hline 4. & Chronic diseases & $32,3 \pm 2,7$ & $15,8 \pm 2,7$ & 2,5 & 3 & $<0,001$ \\
\hline 5. & Overweight & $25,8 \pm 2,5$ & $10,5 \pm 2,3$ & 2,9 & 3 & $<0,001$ \\
\hline 6. & High blood glucose & $22,6 \pm 2,4$ & $10,5 \pm 2,3$ & 2,3 & 2 & $<0,001$ \\
\hline
\end{tabular}

Table II. Socio-hygienic risk factors for myocardial infarction in adults

\begin{tabular}{|c|c|c|c|c|c|c|}
\hline & Risk factors & $\begin{array}{c}\text { The main } \\
\text { group } \\
\mathrm{P} \pm \mathrm{m}(\%)\end{array}$ & $\begin{array}{c}\text { The control } \\
\text { group } \\
\mathrm{P} \pm \mathrm{m}(\%)\end{array}$ & $\begin{array}{c}\text { Odds } \\
\text { Ratio } \\
\text { (OR) }\end{array}$ & $\begin{array}{c}\text { Power of } \\
\text { influence } \\
n(\%)\end{array}$ & $\mathbf{P}$ \\
\hline 1. & Smoking & $35,5 \pm 2,7$ & $10,4 \pm 2,3$ & 4,7 & 7 & $<0,001$ \\
\hline 2. & Excessive consumption of fatty foods & $26,5 \pm 2,5$ & $8,4 \pm 1,9$ & 3,9 & 5 & $<0,01$ \\
\hline 3. & Alcohol abuse & $32,3 \pm 2,6$ & $13,2 \pm 2,4$ & 2,9 & 4 & $<0,001$ \\
\hline 4. & Failure to comply with dietary pattern & $33,9 \pm 2,7$ & $17,9 \pm 2,8$ & 2,3 & 3 & $<0,01$ \\
\hline 5. & Physical inactivity & $29,0 \pm 2,6$ & $14,7 \pm 2,6$ & 2,4 & 3 & $<0,001$ \\
\hline 6. & Excessive consumption of food & $21,9 \pm 2,4$ & $11,1 \pm 2,3$ & 2,2 & 2 & $<0,001$ \\
\hline 7. & Drinking coffee & $15,2 \pm 2,0$ & $6,8 \pm 1.9$ & 2,4 & 1 & $<0,01$ \\
\hline 8. & Eating fast foods & $10,6 \pm 1,8$ & $3,2 \pm 1,2$ & 3,5 & 1 & $<0,001$ \\
\hline 9. & Eating of ready-to-cook foods & $16,5 \pm 2,1$ & $7,9 \pm 1,9$ & 2,3 & 1 & $<0,05$ \\
\hline 10. & Occupational hazards & $9,4 \pm 1,6$ & $2,6 \pm 1,2$ & 3,8 & 1 & $<0,05$ \\
\hline
\end{tabular}

$(\mathrm{OR}=2.1, \mathrm{p}<0.01 ; \eta-1 \%) .15 .2 \pm 2.0 \%$ of the main group patients and $6.8 \pm 1.9 \%$ of the control group indicated their marital status as divorced, single and widowed $(\mathrm{OR}=2.4$; $\mathrm{p}<0.01 ; \eta-1 \%)$. The results are shown in the Table III.

According to the results of the study, it can be asserted that natural and climatic factors also had a significant impact on myocardial infarction development. According to literary sources, it is known that $80 \%$ of patients with various diseases respond to unstable weather conditions. It was also established that the frequency of myocardial infarction cases depends in a certain way on natural factors. Thus, when assessing the influence of meteorological factors, we found that $33.9 \pm 2.7 \%$ of the main group patients and $15.8 \pm 2.4 \%$ of the control group felt their health deteriorated as a result of changing weather conditions $(\mathrm{OR}=3.1 ; \mathrm{p}<0.001 ; \eta-4 \%)$. Arterial pressure drops were reported in $18.1 \pm 2.8 \%$ of the main group patients and $6.3 \pm 2.4 \%$ of the control group $(\mathrm{OR}=3.3 ; \mathrm{p}<0.001 ; \eta-3 \%)$. It was found that chest pain in case of changing weather conditions was present in $19.7 \pm 2.3 \%$ of the main group patients and $6.8 \pm 1.9 \%$ of the control group $(\mathrm{OR}=3.3 ; \mathrm{p}$ $<0.001 ; \eta-3 \%)$; headaches were present in $25.8 \pm 2.3 \%$ of the main group patients and $13.2 \pm 3.1 \%$ of the control group
$(\mathrm{OR}=2.3 ; \mathrm{p}<0.001 ; \eta-2 \%)$. It is known that the human body is covered with a circadian rhythm, all organs work cyclically. The effect of circadian rhythms on the function of various biological systems was investigated and changes were observed depending on the time of day. It was found that fibrinolysis suppression in the morning coincides with the peak of thrombotic complications. The peak of cardiovascular complications incidence occurs at 4-5 in the morning. We found that $20.9 \pm 2.3 \%$ of the main group patients and $8.9 \pm 2.1 \%$ of the control group showed deterioration in their health conditions in the morning $(\mathrm{OR}=$ $2.7 ; \mathrm{p}<0.01 ; \eta-2 \%)$. Intense changes in the weather play a significant role in the complex effects of climate on the human body. Significant changes occur especially in the transitional seasons of the year - autumn-spring. During our study, it was found out that $31.9 \pm 2.7 \%$ of the main group patients and $17.9 \pm 2.7 \%$ of the control group showed a dependence of their health status on the season $(\mathrm{OR}=$ $2.2 ; \mathrm{p}<0.001 ; \eta-2 \%)$. The level of oxygen consumption by the body has been studied for many years. Scientists have concluded that insufficient oxygen consumption also leads to cardiovascular diseases development. In the study, $14.8 \pm 2.8 \%$ of the main group patients and $6.3 \pm 2.4 \%$ of the 
Table III. Socio-economic and psychological risk factors for myocardial infarction in adults

\begin{tabular}{|c|c|c|c|c|c|c|}
\hline & Risk factors & $\begin{array}{l}\text { The main } \\
\text { group } \\
\mathrm{P} \pm \mathrm{m}(\%)\end{array}$ & $\begin{array}{c}\text { The control } \\
\text { group } \\
\mathrm{P} \pm \mathbf{m}(\%)\end{array}$ & $\begin{array}{c}\text { Odds } \\
\text { Ratio } \\
\text { (OR) } \\
\end{array}$ & $\begin{array}{c}\text { Power of } \\
\text { influence } \\
\eta(\%)\end{array}$ & $\mathbf{P}$ \\
\hline 1. & Stress at work & $26,5 \pm 2,5$ & $8,4 \pm 1,9$ & 3,9 & 5 & $<0,01$ \\
\hline 2. & Stress at home & $40,0 \pm 2,8$ & $21,1 \pm 2,9$ & 2,5 & 4 & $<0,001$ \\
\hline 3. & The type of personality temperament "choleric" & $24,5 \pm 2,4$ & $13,2 \pm 3,1$ & 2,1 & 2 & $<0,001$ \\
\hline 4. & Executive position at work & $16,1 \pm 2,1$ & $5,3 \pm 1,6$ & 3,5 & 2 & $<0,01$ \\
\hline 5. & Lack of higher education & $12,3 \pm 1,9$ & $4,7 \pm 1,6$ & 2,8 & 1 & $<0,01$ \\
\hline 6. & Low material support & $20,0 \pm 2,3$ & $10,5 \pm 2,3$ & 2,1 & 1 & $<0,01$ \\
\hline 7. & $\begin{array}{l}\text { Marital status: married, } \\
\text { divorced, widows }\end{array}$ & $15,2 \pm 2,0$ & $6,8 \pm 1,9$ & 2,4 & 1 & $<0,01$ \\
\hline
\end{tabular}

Table IV. Natural and climatic risk factors for myocardial infarction in adults

\begin{tabular}{|c|c|c|c|c|c|c|}
\hline & Risk factors & $\begin{array}{l}\text { The main } \\
\text { group } \\
\mathrm{P} \pm \mathrm{m}(\%)\end{array}$ & $\begin{array}{c}\text { The control } \\
\text { group } \\
\mathrm{P} \pm \mathrm{m}(\%)\end{array}$ & $\begin{array}{c}\text { Odds } \\
\text { Ratio } \\
\text { (OR) }\end{array}$ & $\begin{array}{c}\text { Power of } \\
\text { influence } \\
n(\%)\end{array}$ & $\mathbf{P}$ \\
\hline 1. & $\begin{array}{l}\text { Felt health deteriorated as a result of } \\
\text { changing weather conditions }\end{array}$ & $33,9 \pm 2,7$ & $15,8 \pm 2,4$ & 2,7 & 4 & $<0,001$ \\
\hline 2. & Drop in blood pressure & $18,1 \pm 2,8$ & $6,3 \pm 2,4$ & 3,3 & 3 & $<0,001$ \\
\hline 3. & Chest pain & $19,7 \pm 2,3$ & $6,8 \pm 1,9$ & 3,3 & 3 & $<0,001$ \\
\hline 4. & Headaches at change of weather & $25,8 \pm 2,3$ & $13,2 \pm 3,1$ & 2,3 & 2 & $<0,001$ \\
\hline 5. & $\begin{array}{l}\text { Deterioration of health depending on the } \\
\text { time of day }\end{array}$ & $20,9 \pm 2,3$ & $8,9 \pm 2,1$ & 2,7 & 2 & $<0,01$ \\
\hline 6. & $\begin{array}{l}\text { Deterioration of health depending on the } \\
\text { season }\end{array}$ & $31,9 \pm 2,7$ & $17,9 \pm 2,7$ & 2,2 & 2 & $<0,001$ \\
\hline 7. & $\begin{array}{l}\text { The dependence of health on the amount } \\
\text { of time spent on the fresh air }\end{array}$ & $14,8 \pm 2,8$ & $6,3 \pm 2,4$ & 2,6 & 1 & $<0,001$ \\
\hline
\end{tabular}

control group indicated that they had not spent enough time in the out-of-doors (OR $=2.6 ; \mathrm{p}<0.001 ; \eta-1 \%)$. The results are shown in the Table IV.

\section{CONCLUSIONS}

1. The main risk factors for myocardial infarction among the adult population were identified; they were classified as biological and socio-hygienic.

2. It was determined that the most significant biological factors are hypertension and hypercholesterolemia $(\mathrm{OR}=$ $4.8 ; \mathrm{p}<0.001 ; \eta-11 \%$ and $\mathrm{OR}=4.5 ; \mathrm{p}<0.001 ; \eta 9 \%$, respectively). At the same time, heredity, the presence of chronic diseases, overweight and high blood glucose levels also had a significant effect on myocardial infarction development.

3. It was determined that such socio-hygienic factors as smoking and excessive consumption of fatty foods have a great influence on myocardial infarction development $(\mathrm{OR}=4.7 ; \mathrm{p}<0.001 ; \eta-7 \%$ and $\mathrm{OR}=3.9 ; \mathrm{p}<0,001 ; \eta-5 \%$, respectively). It was also proved that physical inactivity, failure to comply with dietary pattern, excessive consumption of food, alcohol, fast foods, ready-to-cook foods, as well as the presence of occupational hazards, have a certain impact on this pathology development.
4. The study results indicate that such psychological factors as stress at work and stress at home have a significant influence on myocardial infarction development $(\mathrm{OR}=$ $3.9 ; \mathrm{p}<0.01 ; \eta-5 \%$ and $\mathrm{OR}=2.5 ; \mathrm{p}<0.001 ; \eta-4 \%$,respectively). Such natural and climatic factors as felt health deteriorated as a result of changing weather conditions and drop in blood pressure $(\mathrm{OR}=3,1 ; \mathrm{p}<0,001 ; \eta 4 \%$ and $\mathrm{OR}=3,3 ; \mathrm{p}<0,001 ; \eta-3 \%$, respectively)also influence myocardial infarction development in a certain way.

5. Identification of the main risk factors for myocardial infarction is important for the effective primary and secondary measures to prevent this pathology occurrence.

\section{REFERENCES}

1. Terenda N. Vchennya pro infarct miokarda $v$ istorychnomu aspekti [The doctrine of myocardial infarction in historical aspect]. Visnyksotsial'noyimedytsyny ta organizatsiyiohoronyzdorov'yaUkrainy. 2013;1:56-61 (Ua).

2. Lawrence J, Laslett M, Alagona P. The Worldwide Environment of Cardiovascular Disease: Prevalence, Diagnosis, Therapy, and Policy Issues. Journal American College of Cardiology. 2012:1-49.

3. Libbi P, Oganov R, Bonou R et al. Bolezni serdtsa po Braunval'du. Rukovodstvo po serdechno-sosudistoy sisteme [Heart disease according to Braunwald. Guide to Cardiovascular Medicine]. 2013; 3:158-176 (Ru). 
4. KianiF, Hesabi N, Arbabisarjou A. Assessment of Risk Factors in PatientsWith Myocardial Infarction. Global Journal of Health Science. 2016;8(1):255-262.

5. Pedersen L, Frestada D, Michelsen M etal. Risk factors for myocardial infarction in women and men: a review of the current literature. Current Pharmaceutical Design. 2016:3835-3852.

6. Salehi R, Motemavele M, Goldust M. Risk factors of coronary disease in women. Pac J Biol Sci. 2013:195-197.

7. Roberts R. Genetics of Coronary Artery Disease. Circ. Res. 2014;114 (12):1890-1903.
8. Roever L. Risk Factors for Cardiovascular Disease: Evidence from Studies Journal of Cardiovascular Diseases and Diagnosis. 2015;3 (2):23-25.

9. Bondarevich S. Teoreticheskiye predposylki razrabotki modeli zdorovya v usloviyah postneoklassiki v ramkah sinergeticheskogo podhoda. Modeli metafizicheskogo zdorovya [Theoretical prerequisites for the development of a model of health in post-non-classical conditions within the framework of a synergistic approach. Model of metaphysical health]. Visnyk ONY imeni I.I. Mechnikova. Psihologiya. 2012;17:466$478(\mathrm{Ru})$.

Authors' contributions:

According to the order of the Authorship.

Conflict of interest:

The Authors declare no conflict of interest.

\section{CORRESPONDING AUTHOR}

Anna A. Podpriadova

Kharkiv National Medical University

4 Nauky Avenue, 61022 Kharkiv, Ukraine

tel: +380637622394

e-mail:anna.podpryadova@gmail.com

Received: 14.03 .2019

Accepted: 26.04 .2019 


\title{
ALLELIC POLYMORPHISMS OF DNA REPAIR GENES AND THEIR INFLUENCE ON THE FORMATION OF RESISTANCE TO THE DEVELOPMENT OF BRONCHOPULMONARY PATHOLOGY UNDER THE ACTION OF INDUSTRIAL AEROSOLS
}

\author{
Tetyana A. Andrushchenko ${ }^{1}$, Sergiy V. Goncharov ${ }^{2}$, Victor E. Dosenko ${ }^{2}$, Konstantin E. Ishhejkin ${ }^{3}$ \\ 'STATE INSTITUTION «KUNDIIEV INSTITUTE OF OCCUPATIONAL HEALTH OF THE NATIONAL ACADEMY OF MEDICAL SCIENCES OF UKRAINE ", KYIV, UKRAINE \\ 2DEPARTMENT OF GENERAL AND MOLECULAR PATHOPHYSIOLOGY OF THE BOGOMOLETZ INSTITUTE OF PHYSIOLOGY OF THE NATIONAL ACADEMY \\ OF SCIENCES OF UKRAINE, KYIV, UKRAINE \\ 3UKRAINIAN MEDICAL STOMATOLOGICAL ACADEMY, POLTAVA, UKRAINE
}

\begin{abstract}
Introduction: The frequency of alleles and genotypes of DNA repair genes in people working due to the influence of industrial aerosols (miners and workers of asbestos-cement plants $(\mathrm{n}=215))$ was studied.

The aim of the work was to identify allelic polymorphisms affecting the formation of resistance or leading to an increased risk of developing bronchopulmonary pathology. Materials and methods: In 90 patients with bronchopulmonary pathology and 125 persons working under the same conditions but without respiratory system diseases, the polymerase chain reaction in real time was determined by the polymorphisms of DNA repair genes: XPD (rs13181, rs799793), ERCC1 (rs11615), XRCC1 (rs25487) and XRCC3 (rs861539), ATM (rs664677), XRCC7 (rs7003908) and MLH1 (rs1799977).

Results: In the course of this study the alleles and genotypes contributing to resistance to the development of respiratory system pathologies were determined: $X R C(1 \cdot G / A$ (rs25487) $\left(0 \mathrm{R}=0.57 ; 95 \% \mathrm{Cl}: 0.32-1.02 ; \mathrm{P} \leq 0.040 ; X^{2}=4.14\right) ; M L H 1 \cdot A(\mathrm{rs} 1799977)\left(\mathrm{OR}=0.62 ; 95 \% \mathrm{Cl}: 0.40-0.96 ; \mathrm{P} \leq 0.020 ; X^{2}=5.06\right) ; M L H 1 \cdot A / A(\mathrm{rs} 1799977)(0 \mathrm{R}=0.43 ; 95 \% \mathrm{Cl}:$ $\left.0.24-0.79 ; \mathrm{P} \leq 0.003 ; X^{2}=8.73\right)$. Also, we established the alleles and genotypes associated with the risk of developing bronchopulmonary pathology: $X P D \cdot C / C(\mathrm{rs} 13181)(0 \mathrm{R}=2.20$, 95\% Cl: $\left.1.02-4.77 ; \mathrm{P} \leq 0.020 ; X^{2}=4.85\right) ; X R C C 1 \cdot A / A$ (rs25487) (OR=3.37; $95 \%$ Cl: $\left.1.22-9.63 ; \mathrm{P} \leq 0.008 ; X^{2}=6.94\right) ; A T M \cdot T / T$ ( $\left.r 5664677\right)(0 \mathrm{R}=2.48 ; 95 \%$ Cl: $1.16-5.31 ; \mathrm{P} \leq 0.010$; $\left.X^{2}=6.61\right) ; M L H 1 \cdot G(\mathrm{rs} 1799977)\left(O R=1.61 ; 95 \% \mathrm{Cl}: 1.04-2.49 ; \mathrm{P} \leq 0.020 ; X^{2}=5.06\right) ; M L H 1 \cdot A / G(\mathrm{rs} 1799977)\left(0 \mathrm{R}=2.32 ; 95 \% \mathrm{Cl}: 1.29-4.21 ; \mathrm{P} \leq 0.002 ; X^{2}=9.01\right)$.

Conclusions: The results indicate the influence of allelic polymorphisms of DNA repair genes on the formation of resistance to the development of bronchopulmonary pathology under the action of industrial aerosols and open up prospects for the development of modern preventive measures.
\end{abstract}

KEY WORDS: SNP; DNA repair; bronchopulmonary pathology

Wiad Lek 2019, 72, 5 cz. I, 784-789

\section{INTRODUCTION}

In Ukraine, annually, 6-8 thousand occupational diseases are registered, $70 \%$ of those are bronchopulmonary pathologies (BPP) [1]. The nature, clinical course and complications of BPP depend on the composition of the industrial aerosols, their aggressiveness and genetic predispositions and immunological characteristics of the individual [2]. In living organisms, there are various systems that protect from exogenous damaging agents, such as DNA repair [3-7]. There are 4 basic DNA repair systems: base-excision repair (BER); nucleotide excision repair (NER); double-strand break repair (DSBR), which is divided into homologous recombination (HR) and non-homologous end joining (NHEJ); mismatch repair (MMR).

Most of the damages to DNA (up to 70\%) are removed by BER [8]. The genes encoding for BER are characterized by a high level of polymorphism, which, due to changes in the activity of reparative enzymes, can affect individual sensitivity to the ac- tions of various genotoxic agents, including tobacco smoke and industrial aerosols. The XRCC1 gene (X-ray-repair cross-complementing group 1) is localized on the 19-th chromosome (19q13.2). A protein that it encodes, regulates the regeneration ofDNA molecules that have been damaged by ionizing radiation and alkylating agents $[3,8-9]$. The XRCC3 gene (X-ray-repair cross-complementing group 3) is involved in recombinant DNA repair and double-stranded DNA breaks [10].

The protein products of the NER genesare involved in the removal of the damaged nucleotides with the subsequent restoration of the structure of the DNA molecule, through the recognition and correction of basal cross-linking [11]. The XPD protein (xeroderma pigmentosum group D) functions at the beginning of the synthesis of all proteins as a subunit of the complex protein TFIIH, a complementary factor of RNA polymerase II $[5,6]$. The main function of the ERCC1 gene (Excision repair cross complementing 1) is nucleotide recovery [11]. 
Table I. General characteristics of study groups

\begin{tabular}{ccc}
\hline Indication & $\begin{array}{c}\text { Control } \\
(\mathbf{n = 1 2 5 )}\end{array}$ & $\begin{array}{c}\text { Study } \\
(\mathbf{n = 9 0 )}\end{array}$ \\
\hline Age & $45.0 \pm 7.2$ & $50.5 \pm 7.3$ \\
\hline Harmful experience & $16.9 \pm 5.4$ & $21.0 \pm 6.1$ \\
\hline Age at the beginning of the influence of harmful factors & $26.4 \pm 6.7$ & $28.7 \pm 6.8$ \\
\hline Smoking & $68 \pm 4,2$ & $50 \pm 5,3$ \\
\hline
\end{tabular}

Variants of DSBR errors lead to different types of mutations and chromosome rearrangements that induce a genome instability and carcinogenesis $[3,6]$. The gene XRCC7 (X-ray-repair cross-complementing group 7) is located on the 8 th chromosome (8q11), encodes a protein which is a large catalytic subunit of the DNA-PC complex (DNA-PKc), which forms an active protein kinase with $\mathrm{Ku}$ and initiates recovery by NHEJ $[8,13,14]$. The ataxia-telangiectasia mutation (ATM) gene is localized on the 11th chromosome (11q22-23), encoding the DNA-dependent proteincanase, localized mainly in the nucleus. The carriers of mutant alleles are characterized by sensitivity to radiation, multiple defects in development, predisposition to oncology [15]. A special place among the DNA repair systems belongs to the MMR, thanks to which it is possible to preserve genetic information even when there is a high number of mutations. The MLH1 gene (mutL (E. coli) homolog 1) is located on chromosome 3 , encoding a protein that regulates the replacement of improperly coupled DNA bases and is inactivated by methylation [16].

Consequently, there is a lot of data on DNA repair of SNPs associated with high risk factors for lung carcinogenesis due to tobacco smoke, therefore we decided to study these molecular markers in people working in an environment in which industrial aerosols have an impact on them.

\section{THE AIM}

The aim of the work was to identify allelic polymorphisms affecting the formation of resistance or an increased risk of developing bronchopulmonary pathology.

\section{MATERIALS AND METHODS}

The materials used in the study do not violate the principles of bioethics and can be published (excerpt from the protocol №2 of the meeting of the Bioethics Commission of the State Institution « Institute of Occupational Health of the National Academy of Medical Sciences of Ukraine ", February 29,2016). All patients participating in the study gave their consent and signed an informational agreement.

The study included people working with industrial aerosols $(n=215)$, these are workers of asbestos-cement plants (ACP, $n=95)$, and coal miners $(n=120)$. For a comparative analysis, two groups were formed: the experimental group included people with BPP (chronic bronchitis, chronic obstructive pulmonary disease, pneumoconiosis). The diagno- sis was established or confirmed in the Clinic of Occupational Diseases of the Kundiiev Institute of Occupational Health of the National Academy of Medical Sciences of Ukraine. The diagnosis was established by $\mathrm{X}$-ray examination of the chest organs, respiratory function and diffusion capacity of the lungs for carbon monoxide (DLCO). The control group consisted of the ACP and the miners, who did not have BPP in their medical history, but their experience and working conditions coincided with the data of the respondents of the experimental group, table I.

DNA was isolated from peripheral blood leukocytes using NeoPrep100DNA and NEOGENE (Ukraine) kits. The genotypes of the genes were determined by the polymerase chain reaction method in real time: $X P D$ (rs13181, rs799793), ERCC1 (rs11615), XRCC3 (rs861539), XRCC1 (rs25487), ATM (rs664677), XRCC7 (rs7003908) and MLH1 (rs1799977) using the amplifier 7500 Fast Real-Time PCR System (Applied Biosystems, USA) and TaqMan Assays.

The obtained results were statistically analyzed using Orion 7.0, Statistica 10 and Excel 2010 programs. The probability of differences was determined by $\chi 2$-criterion, values $\mathrm{P}<0.05$ were considered significant.

\section{RESULTS AND DISCUSSION}

The frequency distribution of alleles and genotypes of DNA repair systems of the participants from the experimental and control groups were studied. The frequencies of the alleles of NER gene: XPD (rs13181, rs799793), ERCC1 (rs11615); BER gene: XRCC3 (rs861539), XRCC1 (rs25487); DBSR gene: ATM (rs664677), XRCC7 (rs7003908) - were not characterized by significant differences between the experimental and control groups $(\mathrm{P}>0.05)$. It was found that the frequency of carriers the dominant allele $M L H 1 \bullet A$ (rs1799977) was significantly higher in the control group compared to the experimental group, and vice versa, the minor allele $M L H 1 \bullet G$ (rs1799977) was significantly more often represented in the group with BPP $\left(\chi^{2}=5.06\right.$; $\mathrm{P}$ $<0.020$ ), (Table II, III).

It should be noted that the obtained frequencies of genotypes of DNA repair genes in our study closely matched the population frequencies of European race, Table IV.

In the study of genotypes of NER genes (XPD (rs13181, rs799793) and ERCC1 (rs11615)), it was found that there were no significant differences in the frequencies of dominant homozygotes and heterozygotes between the experimental 
Table II. The distribution frequency of DNA repair gene alleles in the study group

\begin{tabular}{|c|c|c|c|c|c|}
\hline \multirow{3}{*}{ Gene polymorphisms } & \multicolumn{4}{|c|}{ Alleles } & \multirow{3}{*}{$\mathbf{P}$} \\
\hline & \multicolumn{2}{|c|}{ A } & \multicolumn{2}{|c|}{$\mathbf{a}$} & \\
\hline & Control & Study & Control & Study & \\
\hline$X P D($ rs13181) & 61.6 & 56.1 & 38.4 & 43.9 & 0.200 \\
\hline XPD (rs799793) & 67.6 & 63.9 & 32.4 & 36.1 & 0.400 \\
\hline$E R C C 1(\mathrm{rs} 11615)$ & 61.6 & 62.2 & 38.4 & 37.8 & 0.900 \\
\hline XRCC3 (rs861539) & 65.2 & 64.4 & 34.8 & 35.6 & 0.900 \\
\hline$X R C C 1(\mathrm{rs} 25487)$ & 66.8 & 62.8 & 33.2 & 37.2 & 0.300 \\
\hline ATM (rs664677) & 61.2 & 52.2 & 38.8 & 47.8 & 0.060 \\
\hline XRCC7 (rs7003908) & 65.2 & 67.8 & 34.8 & 32.2 & 0.500 \\
\hline$M L H_{1}(\mathrm{rs} 1799977)$ & 74.0 & 63.9 & 26.0 & 36.1 & 0.020 \\
\hline
\end{tabular}

Table III. Analysis of associations of alleles of DNA repair genes in the study group

\begin{tabular}{|c|c|c|}
\hline Gene polymorphisms & Alleles & OR, $95 \% \mathrm{Cl}$ \\
\hline \multirow{2}{*}{$X P D($ rs13181) } & A & $0.80(0.53-1.20)$ \\
\hline & $\mathrm{C}$ & $1.25(0.83-1.89)$ \\
\hline \multirow{2}{*}{ XPD (rs799793) } & Asp & $0.85(0.56-1.30)$ \\
\hline & Asn & $1.18(0.77-1.80)$ \\
\hline \multirow{2}{*}{$E R C C 1(\mathrm{rs} 11615)$} & $T$ & $1.03(0.68-1.55)$ \\
\hline & $\mathrm{C}$ & $0.97(0.64-1.47)$ \\
\hline \multirow{2}{*}{$X R C C 3(\mathrm{rs} 861539)$} & $C$ & $0.97(0.64-1.47)$ \\
\hline & $\mathrm{T}$ & $1.03(0.68-1.57)$ \\
\hline \multirow{2}{*}{$X R C C 1(\mathrm{rs} 25487)$} & $G$ & $0.84(0.55-1.28)$ \\
\hline & $A$ & $1.19(0.78-1.82)$ \\
\hline \multirow{2}{*}{ ATM (rs664677) } & $A$ & $0.69(0.46-1.04)$ \\
\hline & $\mathrm{T}$ & $1.44(0.96-2.17)$ \\
\hline \multirow{2}{*}{ XRCC7 (rs7003908) } & C & $1.12(0.73-1.72)$ \\
\hline & $\mathrm{T}$ & $0.89(0.58-1.37)$ \\
\hline \multirow{2}{*}{$M L H_{1}(\operatorname{rs} 1799977)$} & A & $0.62(0.40-0.96)$ \\
\hline & G & $1.61(1.04-2.49)$ \\
\hline
\end{tabular}

and control groups $(\mathrm{P}>0.05)$. In addition to the heterozygote frequencies of the XPD gene (rs13181), a trend towards a statistically significant difference between the $X P D \bullet A / C$ in the examined experimental and control groups was found $\left(\chi^{2}=3.18 ; \mathrm{P}<0.070\right)$. The XPD (rs13181) minor genotype was found to be significantly more common in the experimental group with the $X P D \cdot C / C$ rate of $24.4 \%$ than in the control group - 12.8\% $\left(\chi^{2}=4.85 ; \mathrm{P}<0.020\right)$, (Table 5,6$)$. Analysis of the frequency distribution of the genotypes of BER genes, did not establish an association between the polymorphism of XRCC3 (rs861539) and an increase in the risk of developing $\mathrm{BPP}(\mathrm{P}>0.05)$. In the analysis of the frequency of genotypes of the gene XRCC1 (rs25487), statistically significant differences were found between the heterozygotes $G / A\left(\chi^{2}=4.14\right.$; $\mathrm{P}$ $<0.040)$ and the minor homozygotes $A / A\left(\chi^{2}=6.94 ; \mathrm{P}<0.008\right)$ (Table 5,6$)$. The distribution of frequencies DSBR of genes ATM (rs664677) and XRCC7 (rs7003908) showed a link of polymorphism rs664677 with the risk of BPP development in occupational groups of miners and ACP workers. Therefore, the frequency of minor homozygotes in the ATM $\cdot T / T$ in the experimental group was $26.7 \%$ and in the control group $12.8 \%$, indicating a correlation with the risk of respiratory system pathology $\left(\chi^{2}=6.61 ; \mathrm{P}<0.010\right)$ (Table 5). Upon analyzing the frequencies of the genotypes of the gene XRCC7 (rs7003908), no statistically significant differences were detected $(\mathrm{P}>0.05)$.

In the study of frequency distribution of genotypes of polymorphism MLH1 (rs1799977) MMR, it was found that dominant $A / A$ homozygotes were reported more often in $56.6 \%$ of respondents in the control group as compared to a corresponding frequency in the study group, which was $35.6 \%\left(\chi^{2}=8.73 ; \mathrm{P}<0.003\right)$. It was also found that $A / G$ heterozygotes were significantly more common in the experimental group - $56.7 \%$ as compared to the control group - 36.0\% ( $\left.\chi^{2}=9.01 ; \mathrm{P}<0.002\right)$, which indicates an association with the risk of developing BPP among workers of harmful and hazardous professions (Table V, VI). 
Table IV. Frequency distribution of genotypes of DNA repair genes in European race

\begin{tabular}{|c|c|c|c|c|}
\hline Polymorphisms & AA, \% & $\mathrm{Aa}, \%$ & aa, \% & Notes \\
\hline $\begin{array}{c}X P D \\
\text { (rs13181) }\end{array}$ & $A / A-35.4$ & $A / C-52.4$ & $C / C-12.2$ & 12 \\
\hline $\begin{array}{c}X P D \\
\text { (rs799793) }\end{array}$ & Asp/Asp - do 43 & Asp/Asn 50-53 & Asn/Asn - 17 & 17 \\
\hline $\begin{array}{c}\text { ERCC1 } \\
\text { (rs11615) }\end{array}$ & С/C-до 50 & $C / T-30$ & $\mathrm{~T} / T-17$ & 9 \\
\hline $\begin{array}{c}X R C C 3 \\
\text { (rs861539) } \\
\end{array}$ & $C / C-53.1$ & $C / T-30.1$ & $T / T-16.8$ & 10 \\
\hline $\begin{array}{c}X R C C 1 \\
(\mathrm{rs} 25487) \\
\end{array}$ & $G / G-33$ & $G / A-50$ & $A / A-17$ & 11 \\
\hline $\begin{array}{c}\text { ATM } \\
\text { (rs664677) } \\
\end{array}$ & $A / A-30-35$ & $A / T-50$ & $T / T-13$ & 15 \\
\hline $\begin{array}{c}\text { XRCC7 } \\
\text { (rs7003908) } \\
\end{array}$ & C/C - 33 & $C / T-50$ & $\mathrm{~T} / \mathrm{T}-17$ & 18 \\
\hline $\begin{array}{c}M L H_{1} \\
\text { (rs1799977) }\end{array}$ & $A / A-25-45$ & $A / G-35-45$ & G/G - до 10 & 16 \\
\hline
\end{tabular}

Table V. Frequency of distribution of genotypes of DNA repair genes in the study group

\begin{tabular}{|c|c|c|c|c|c|c|c|}
\hline \multirow{3}{*}{ Gene polymorphisms } & \multicolumn{6}{|c|}{ Genotypes } & \multirow{3}{*}{$\mathbf{P}$} \\
\hline & \multicolumn{2}{|c|}{ AA } & \multicolumn{2}{|c|}{$\mathbf{A a}$} & \multicolumn{2}{|c|}{ aa } & \\
\hline & Control & Study & Control & Study & Control & Study & \\
\hline$X P D($ rs13181) & 36.0 & 36.7 & 51.2 & 38.9 & 12.8 & 24.4 & 0.050 \\
\hline XPD (rs799793) & 44.0 & 38.9 & 47.2 & 50.0 & 8.8 & 11.1 & 0.700 \\
\hline$E R C C 1(\mathrm{rs} 11615)$ & 42.4 & 41.1 & 38.4 & 42.2 & 19.2 & 16.7 & 0.800 \\
\hline$X R C C 3$ (rs861539) & 41.6 & 41.1 & 47.2 & 46.7 & 11.2 & 12.2 & 0.900 \\
\hline$X R C C 1(\mathrm{rs} 25487)$ & 39.2 & 42.2 & 55.2 & 41.1 & 5.6 & 16.7 & 0.010 \\
\hline ATM (rs664677) & 35.2 & 31.1 & 52.0 & 42.2 & 12.8 & 26.7 & 0.030 \\
\hline XRCC7 (rs7003908) & 44.8 & 46.7 & 40.8 & 42.2 & 14.4 & 11.1 & 0.700 \\
\hline$M L H_{1}(\mathrm{rs} 1799977)$ & 56.0 & 35.6 & 36.0 & 56.7 & 8.0 & 7.7 & 0.008 \\
\hline
\end{tabular}

As a result of the study, the alleles and genotypes that have a protective effect on the development of BPP in workers of hazardous and harmful industries were defined as: $X R C$ $C 1 \bullet G / A(\mathrm{rs} 25487)(\mathrm{OR}=0.57 ; 95 \% \mathrm{CI}: 0.32-1.02 ; \mathrm{P} \leq 0.040$; $\left.\chi^{2}=4.14\right) ; M L H 1 \bullet A(\operatorname{rs} 1799977)(\mathrm{OR}=0.62 ; 95 \% \mathrm{CI}: 0.40$ - 0.96; $\left.\mathrm{P} \leq 0.020 ; \chi^{2}=5.06\right) ; M L H 1 \bullet A / A(\mathrm{rs} 1799977)(\mathrm{OR}=$ 0.43; 95\% CI: $\left.0.24-0.79 ; \mathrm{P} \leq 0.003 ; \chi^{2}=8.73\right)$. Also, the alleles and genotypes associated with the risk of BPP development in miners and ACP workers were determined by the OR method for genotypes of DNA repair: $X P D \bullet C / C$ (rs13181) $(\mathrm{OR}=2.20$; 95\%CI: $\left.1.02-4.77 ; \mathrm{P} \leq 0.020 ; \chi^{2}=4.85\right) ; X R C C 1 \bullet \mathrm{A} / \mathrm{A}(\mathrm{rs} 25487)$ $\left(\mathrm{OR}=3.37 ; 95 \% \mathrm{CI}: 1.22-9.63 ; \mathrm{P} \leq 0.008 ; \chi^{2}=6.94\right) ; A T M \bullet T / T$ (rs664677) (OR=2.48; 95\%CI: $\left.1.16-5.31 ; \mathrm{P} \leq 0.010 ; \chi^{2}=6.61\right)$; $\mathrm{MLH}_{1} \bullet \mathrm{G}(\mathrm{rs} 1799977)(\mathrm{OR}=1.61 ; 95 \% \mathrm{CI}: 1.04-2.49 ; \mathrm{P} \leq 0.020$; $\left.\chi^{2}=5.06\right) ; \mathrm{MLH}_{1} \bullet A / G(\mathrm{rs} 1799977)(\mathrm{OR}=2.32 ; 95 \% \mathrm{CI}: 1.29-$ 4.21; $\left.\mathrm{P} \leq 0.002 ; \chi^{2}=9.01\right)$.

These polymorphisms were previously considered by researchers as markers of the incidence of cancer of various types and localizations, including lung cancer, and as mark- ers of radiosensitivity to the effects of ionizing radiation. However, our results indicate the existence of associations between certain alleles of DNA repair genes and the risk of respiratory system pathology due to industrial aerosols.

\section{CONCLUSION}

For the first time results indicating the significance of polymorphisms of DNA repair genes in the formation of predisposition or resistance to the development of bronchopulmonary pathology among workers of hazardous and harmful industries of Ukraine were obtained. The established alleles and genotypes that promote resistance to respiratory system diseases: $X R C C 1 \bullet G / A(\mathrm{rs} 25487)$ $\left(\mathrm{OR}=0.57 ; 95 \% \mathrm{CI}: 0.32-1.02 ; \mathrm{P} \leq 0.040 ; \chi^{2}=4.14\right) ; M L-$ $H 1 \bullet A / A(\mathrm{rs} 1799977)(\mathrm{OR}=0.43 ; 95 \% \mathrm{CI}: 0.24-0.79 ; \mathrm{P} \leq$ $0.003 ; \chi 2=8.73)$. Also, alleles and genotypes associated with the risk of developing bronchopulmonary disease were identified: $X P D \cdot C / C$ (rs13181) $(\mathrm{OR}=2.20$; 95\% CI: 1.02 - 
Tetyana A. Andrushchenko et al.

Table VI. Analysis of associations of genotypes of DNA repair genes in the study group

\begin{tabular}{|c|c|c|}
\hline Gene polymorphisms & Genotypes & $\mathrm{OR}, 95 \% \mathrm{Cl} ; \mathrm{P}, \mathrm{X}^{2}$ \\
\hline \multirow{3}{*}{$X P D(\mathrm{rs} 13181)$} & $\mathrm{A} / \mathrm{A}$ & $1.03(0.56-1.88) ; P \leq 0.900$ \\
\hline & $A / C$ & $0.61(0.34-1.09) ; P \leq 0.070$ \\
\hline & $\mathrm{C} / \mathrm{C}$ & $2.20(1.02-4.77) ; P \leq 0.020 ; x^{2}=4.85$ \\
\hline \multirow{3}{*}{$X P D($ rs799793) } & Asp/Asp & $0.81(0.45-1.46) ; P \leq 0.400$ \\
\hline & Asp/Asn & $1.10(0.62-1.97) ; P \leq 0.700$ \\
\hline & Asn/Asn & $1.28(0.48-3.44) ; P \leq 0.500$ \\
\hline \multirow{3}{*}{$E R C C 1(\mathrm{rs} 11615)$} & $T / T$ & $0.95(0.53-1.71) ; P \leq 0.800$ \\
\hline & $\mathrm{T} / \mathrm{C}$ & $1.16(0.64-2.09) ; P \leq 0.600$ \\
\hline & $\mathrm{C} / \mathrm{C}$ & $0.83(0.39-1.79) ; P \leq 0.600$ \\
\hline \multirow{3}{*}{$X R C C 3(\mathrm{rs} 861539)$} & $C / C$ & $0.98(0.54-1.76) ; P \leq 0.900$ \\
\hline & $\mathrm{C} / \mathrm{T}$ & 0.98 (0.55-1.75); $P \leq 0.900$ \\
\hline & $T / T$ & $1.10(0.44-2.75) ; P \leq 0.800$ \\
\hline \multirow{3}{*}{$X R C C 1(\mathrm{rs} 25487)$} & $G / G$ & $1.13(0.63-2.04) ; P \leq 0.600$ \\
\hline & $G / A$ & $0.57(0.32-1.02) ; P \leq 0.040 ; X^{2}=4.14$ \\
\hline & $A / A$ & $3.37(1.22-9.63) ; P \leq 0.008 ; x^{2}=6.94$ \\
\hline \multirow{3}{*}{ ATM (rs664677) } & $A / A$ & $0.83(0.45-1.54) ; P \leq 0.500$ \\
\hline & $A / T$ & $0.67(0.38-1.21) ; P \leq 0.100$ \\
\hline & $T / T$ & $2.48(1.16-5.31) ; P \leq 0.010 ; x^{2}=6.61$ \\
\hline \multirow{3}{*}{$X R C C 7$ (rs7003908) } & $C / C$ & $1.08(0.60-1.93) ; P \leq 0.700$ \\
\hline & $\mathrm{C} / \mathrm{T}$ & $1.06(0.59-1.91) ; P \leq 0.800$ \\
\hline & $T / T$ & $0.74(0.30-1.81) ; P \leq 0.400$ \\
\hline \multirow{3}{*}{$M L H_{1}(\mathrm{rs} 1799977)$} & $A / A$ & $0.43(0.24-0.79) ; P \leq 0.003 ; x^{2}=8.73$ \\
\hline & $A / G$ & $2.32(1.29-4.21) ; P \leq 0.002 ; X^{2}=9.01$ \\
\hline & $\mathrm{G} / \mathrm{G}$ & 0.97 (0.32-2.91); $P \leq 0.900$ \\
\hline
\end{tabular}

4.77; $\left.\mathrm{P} \leq 0.020 ; \chi^{2}=4.85\right) ; X R C C 1 \bullet A / A(\mathrm{rs} 25487)(\mathrm{OR}=3.37$; 95\% CI: $\left.1.22-9.63 ; \mathrm{P} \leq .008 ; \chi^{2}=6.94\right) ; A T M \bullet T / T(\mathrm{rs664677})$ $\left(\mathrm{OR}=2.48 ; 95 \%\right.$ CI: $\left.1.16-5.31 ; \mathrm{P} \leq 0.010 ; \chi^{2}=6.61\right) ; M L-$ $H 1 \bullet A / G(\mathrm{rs} 1799977)(\mathrm{OR}=2.32 ; 95 \% \mathrm{CI}: 1.29-4.21 ; \mathrm{P} \leq .002$; $\left.\chi^{2}=9.01\right)$.

\section{REFERENCES}

1. Kundiyv YI., Nagorna AM. Professional morbidity in Ukraine in the dynamics of long-term observation. Ukrainian Journal of the problems of Occupational Medicine. 2005; 1: 3-11(in Ukrainian).

2. Izmerov NF, Chuchalin AG. Occupational diseases of the respiratory system (National leadership). Moscow. Publish in group "GEOTARMedia". 2015; 785: 119-48 [in Russian].

3. Andrushchenko TA., Basanets AV. Violations of the system of DNA repair, induced by the action of professional factors of miners. Ukrainian Journal of the problems of Occupational Medicine. 2015; 4(45): 69-78.

4. Kuschel B, Auranen A, McBride $S$ et al. Variants in double-strand break repair genes and breast cancer susceptibility. Hum Mol Genet 2002; 11: 1399-440.

5. Urzhumov PV, Pogodina AV, Akleev AV. Polymorphisms of NBS1 and PARP1 genes and the efficiency of DNA repair: Bull Chelyabinsk State Univer. 2013; 7 (298): 107-8. [ in Russian].
6. Kiffmeyer WR., Langer E., Davies S.M. Genetic Polymorphisms in the Hum Popul. Cancer. 2004; 100(2): 411-7.

7. Pavanello S, Clonfero E. Individual susceptibility to occupational carcinogens: the evidence from biomonitiring and molecular epidemiology studies. G Ital Med Lav Ergon. 2004; 26(4): 311- 21.

8. Hao B, Miao X, Li Y, Zhang X et al. A novel T-77C polymorphism in DNA repair gene XRCC1 contributes to diminished promoter activity and increased risk of non-small cell lung cancer. Oncogene. 2006; 25 : 3613-20.

9. Wang $\mathrm{Y}$, Yang $\mathrm{H}$, Li H et al. Association between $\mathrm{X}$-ray repair cross complementing group 1 codon 399 and 194 polymorphisms and lung cancer risk: a meta-analysis. Cancer. 2009; 285: 134-40.

10. Rodriguez S, Gaunt TR, Day NM. Hardy-Weinberg Equilibrium Testing of Ascertainment for Mendelian Randomization Studies. American J Biol Epidemiol. 2009; 10: 1093-359.

11. Andrushchenko TA, Goncharov SV, Dosenko VE Genetic predisposition to bronchopulmonary pathology in workers of harmful and hazardous industries: analysis of five polymorphisms of DNA gene repair. Fiziol Zh. 2018; 64 (4): 12-9. [in Ukrainian].

12. Shin A, Lee KM, Ahn B et al. Genotype-phenotype relationship between DNA repair gene genetic polymorphisms and DNA repair capacity. Asian Pac J Cancer Prev 2008; 9:501-5. 
13. Hsieh YH., Chang WS., Tsai CW. et al. DNA double-strand break repair gene XRCC7 genotypes were associated with hepatocellular carcinoma risk in Taiwanese males and alcohol drinkers, Tumour Biol. 2015; 36(6): 4101-6.

14. Xiao M., Shen Y., Chen L. et al. The rs7003908 ( $T>G)$ polymprphism in the XRCC7 gene and the risk of cancers, Mol. Biol. Rep. 2014; 41(6): 3577-82.

15. Tretyak B., Makukh H., Kitsera N. et al. The molecular genetic analysis of common ATM gene mutations among patients with Ataxiatelagiectasiasuspection, Factors of experimental evolution of organisms. 2015; vol. 16: 251-5.
16. Lanza G, Gafa R, Maestri l et al. Immunohistochemical pattern of MLH1/ MSH2 expression is related to clinical and pathological features in colorectal adenocarcinomas with microsatellite instability, Mol Pathol. 2002;15(7): 741-9.

17. Bukowski K, Wozniak K. Polymorphism of genes encoding proteins of DNA repair vs. occupational and environmental exposure to lead, arsenic and pesticides. Med. Pr. 2017; 12: 758-79.

18. Wang C., Huang X-Y., Yao J-G. et al. XRCC7 rs7003908 polymorphism and Helicobacter pylori Infection - Related Gastric Antrum Adenocarcinoma, Int. J. Genomics 2013: 1246-52.

\section{Authors' contributions:}

According to the order of the Authorship.

\section{Conflict of interest:}

The Authors declare no conflict of interest.

\section{CORRESPONDING AUTHOR \\ Tetyana A. Andrushchenko}

State Institution «Kundiiev Institute of Occupational Health of the National Academy of Medical Sciences of Ukraine « 75 Saksagansky str, 01033 Kijów, Ukraina

tel: +380503124814

e-mail:imp-cys@ukr.net

Received: 21.02 .2019

Accepted: 19.04 .2019 


\title{
IMPROVING THE RESULTS OF THE LAPAROSCOPIC CHOLECYSTECTOMY IN PATIENTS WITH COMPLICATED COURSE OF THE CALCULOUS CHOLECYSTITIS
}

\author{
Oleg Y. Kanikovskyi, Yaroslav V. Karyi, Yura V. Babiichuk, Yevhen V. Shaprynskyi \\ NATIONAL PIROGOV MEMORIAL MEDICAL UNIVERSITY, VINNYTSYA, UKRAINE
}

\begin{abstract}
Introduction: The laparoscopic cholecystectomy (LCE) has become "gold standard" in treatment of the gallstone disease (GSD). However, introduction of LCE is accompanied by increase in the frequency of the bile duct injuries by 2-5 times, and transfer to the conversion offsets main advantages of the laparoscopic access.

The aim: To improve the results of treatment of the patients with complicated course of the calculous cholecystitis by developing new methods of the laparoscopic cholecystectomy. Materials and methods: The results of surgical treatment of 420 patients with complicated course of the calculous cholecystitis were analyzed. The patients were divided intwo groups: group I $(n=210)$ where the standard four-trocar LCE was used and the group II $(n=210)$ where the developed methods of LCE were used. The average age made up $62 \pm 6.0$ years. Duration of disease made up from 1 month to 35 years.

Results: The patients in group I LCE with complicated course of the acute cholecystitis was performed in 108 (25.7\%) cases, chronic - in 102 (24.3\%) cases. The patients in group II surgical intervention with complicated course of the acute cholecystitis was performed in $112(26.7 \%)$ cases, chronic - in $98(23.3 \%)$ cases. The patients of group l intraoperative injuries were observed in $12(5.7 \%)$ cases and patients of group II - in $4(1.9 \%)$ cases. The conversion was applied in $13(6.2 \%)$ and in $4(1.9 \%)$ cases, respectively. $2(0.9 \%)$ patients died. Conclusions: Introduction of the developed methods of LCE with complicated course of the calculous cholecystitis allows to reduce the frequency of intraoperative injuries by $3,8 \%$ and conversion rate - by $4,3 \%(p<0,001)$.
\end{abstract}

KEY WORDS: complicated course of the acute and chronic calculous cholecystitis, laparoscopic cholecystectomy, intraoperative injuries

Wiad Lek 2019, 72, 5 cz. I, 790-794

\section{INTRODUCTION}

The incidence of GSD disease in the last decades has a tendency to increasing, especially its complicated forms $[1,2]$. Among the population of Europe, the incidence of GSD disease makes up $17-25 \%$, over the age of $60-35-55 \%[3,4]$. Among the patients with complicated GSD $65-70 \%$ are persons of elderly and old age [5]. LCE has become "gold standard" in treatment of GSD. The advantages of LCE over the open method are determined by the less trauma of abdominal wall, decrease in the level of complications and decrease in the duration of stay of the patient in the hospital $[6,7]$. However, introduction of LCE is accompanied by increase in the frequency of the bile duct injuries by $2-5$ times compared with the open method of surgery, and transfer to the conversion negates main advantages of the laparoscopic access $[8,9,10]$.

\section{THE AIM}

To improve the results of treatment of the patients with complicated course of the calculous cholecystitis by developing new methods of the laparoscopic cholecystectomy.

\section{MATERIALS AND METHODS}

In the period from 2002 to 2018 at the surgical clinic of the medical faculty No. 2 of National Pirogov Memorial Medical
University, Vinnytsya there were 420 patients with complicated course of the calculous cholecystitis treated. There were 133 men (31.7\%), and 287 (68.3\%) women. Average age was $62 \pm 6.0$ years. Duration of disease made up from 1 month to 35 years.

The complicated course of the acute calculous cholecystitis was observed in $220(52.4 \%)$ patients, including empyema of gallbladder - in $74(17.6 \%)$, perivesical infiltrate - in $83(19.8 \%)$, perivesical abscess - in $22(5.2 \%)$, biliary peritonitis - in $6(1.4 \%)$, choledocholithiasis - in $35(8.4 \%)$ cases. The complicated course of the chronic calculous cholecystitis was registered in $200(47.6 \%)$ patients, including sclerotic gallbladder - in 49 (11.6\%), gallbladder hydrops - in 37 (8.8\%), widespread adhesion process - in $66(15.7 \%)$, Mirizzi's syndrome - in $10(2.4 \%)$, choledocholithiasis - in 15 (3.6\%), biliodigetive fistula - in 5 (1.2\%), stenosing papillitis - in 18 (4.3\%) cases.

The screening method for diagnostics of gallbladder and bile duct pathology included transabdominal ultrasonography, which was performed for all patients. Echography study was performed on the diagnostic apparatus Lodgiq-500 PRO Series GE. In the patients with obstruction of the common bile duct (CBD), fibrogastroduodenoscopy was performed using fibrogastroduodenoscope Pentax-290V. The endoscopic retrograde pancreatic cholan- 


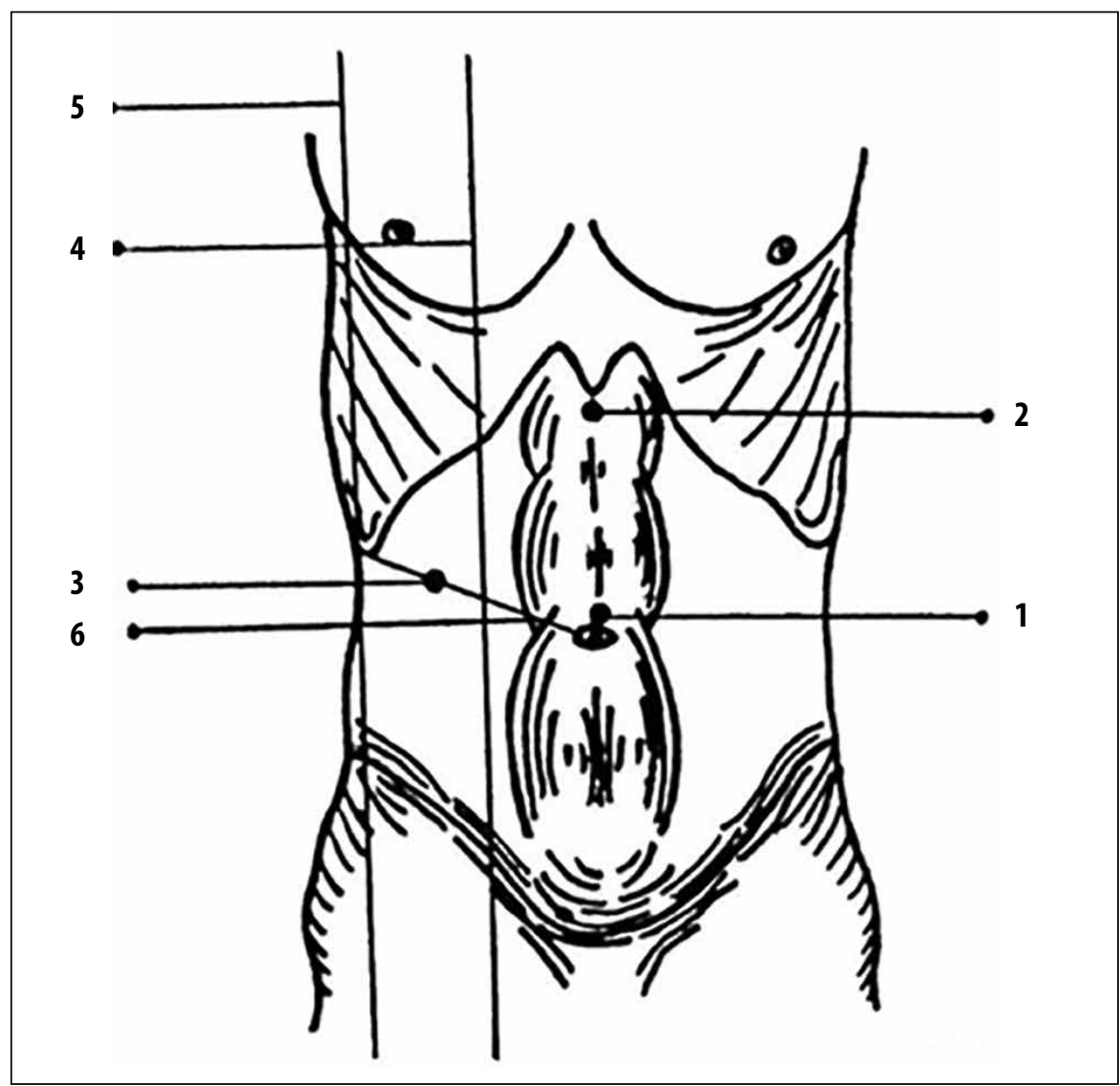

Figure 1. The method of three-trocar laparoscopic cholecystectomy in the widespread adhesion process in the hepatoduodenal area

\author{
first port -1 \\ second port -2 \\ third port -3 \\ medioclavicular line -4 \\ front axillary line -5 \\ oblique line -6
}

giography was used for direct contrasting of the bile ducts using $30 \%$ of contrast in volume of $10-20 \mathrm{ml}$ and 3-5 $\mathrm{ml}$ for contrasting of the main duct of pancreas. For contrasting of the bile ducts during operation, the intraoperative cholangiography was performed by administering 10-20 $\mathrm{ml}$ of $30 \%$ contrast through the cystic duct or by biliary puncture. By the impossibility of cannulation of the major duodenal papilla the endoscopic ultrasonography was performed using the diagnostic apparatus Olympus Exera EU M 60 and magnetic resonance imaging on the computer tomography Somatom-CR.

\section{RESULTS AND DISCUSSION}

During the study the patients were divided into two groups: group I, where the standard four-trocar LCE was performed and described by Reddick-Olsen, included 210 persons and group II - 210 patients, where the developed methods of LCE were used: "The method of the laparoscopic cholecystectomy in the complicated course of the acute and chronic calculous cholecystitis" (patent of Ukraine No. 77985) and "The method of three-trocar laparoscopic cholecystectomy in the widespread adhesion process in the hepatoduodenal area" (patent of Ukraine No. 111662).

For prevention of intraoperative injuries of the hepatoduodenal area the patients of both groups were thoroughly examined before operation, and the timely scheduled surgical treatment of the patients with GSD was carried out in the "cold" period. By the acute cholecystitis, LCE was conducted in period of up to 72 hours from the onset of the disease, with a lower probability of perivesical complications. With duration of the chronic cholecystitis over 5 years, there was marked sclerosis of gallbladder wall, that's why the planned surgical intervention was attempted at the shortest duration of GSD.

LCE under the intubation anesthesia was performed in $298(69.3 \%)$ patients. In $132(30.7 \%)$ patients with the severe cardiovascular and pulmonary diseases, LCE was performed under the epidural anesthesia. For the purpose of anesthesia, catheterization of the epidural space was continued in early postoperative period. Pneumoperitoneum was created and maintained at the average pressure level of $12-14 \mathrm{~mm} \mathrm{Hg}$. The maximum intra-abdominal pressure was $15 \mathrm{~mm} \mathrm{Hg}$. The pressure in the abdominal cavity of patients older than 60 years in presence of cardiovascular and pulmonary pathology was not more than $10 \mathrm{~mm} \mathrm{Hg}$. By the long surgical intervention, after 20-30 minutes, the pressure was reduced to $4-6 \mathrm{~mm} \mathrm{Hg}$ for up to 10 minutes.

LCE in the patients of group I $(n=210)$ was performed according to the standard four-trocar method. LCE by complicated course of the acute calculous cholecystitis was performed in $108(25.7 \%)$ patients, chronic - in 102 (24.3\%) patients.

Four-trocar LCE (Reddick-Olsen) was performed as follows: 4 trocars were introduced into the abdominal cavity (the first one, of $10 \mathrm{~mm}$, to the paraumbilical area, the second, of $10 \mathrm{~mm}$, - to the epigastric area, the third and fourth, of $5 \mathrm{~mm}$, - in the right hypohondrica area). After 
insertion of instruments into the abdominal cavity, the main traction was performed for the gallbladder bottom and lateral traction - for Hartmann's pocket. Mobilization of the gallbladder was carried out by the L-shaped electrode from medial surface to lateral in projection of the gallbladder neck. After discharge of the cystic duct, one clip was applied proximally and two clips - on its distal department. The cystic duct was crossed between clips. The cystic artery was clipped in proximal department or coagulated with bipolar clamp and crossed. After intersection of tubular structures of the Calot triangle gallbladder was removed from the liver bed. The gallbladder was removed from the abdominal cavity through the under-ensiform access or through the umbilical ring in presence of the umbilical hernia.

The developed methods of LCE were used for the patients of group II $(n=210)$. The operative interference by the complicated course of the acute calculous cholecystitis was performed in $112(26.7 \%)$ patients, chronic - in 98 $(23.3 \%)$ patients.

The method of the laparoscopic cholecystectomy in the complicated course of the acute and chronic calculous cholecystitis (patent of Ukraine No. 77985) was applied in $150(35.7 \%)$ cases. 4 trocars were also introduced in the abdominal cavity. All ports, except for the first one, were introduced under control of laparoscope. For the more secure introduction of the first trocar, aponeurosis was previously dissected by the scalpel for 3-4 $\mathrm{mm}$. The direction of the trocars introduction was oblique in projection of the gallbladder. Then revision of organs of the abdominal cavity was performed. Due to presence of the tense gallbladder in $44(10.4 \%)$ patients there was difficulty in grasping it with a clamp, that's why the operation was started with puncture of the gallbladder and evacuation of its contents. When the acute process lasted for more than 72 hours, the infiltrate became dense, which created danger of intraoperative injuries. In $68(16.2 \%)$ patients due to presence of the dense perivesical infiltrate, which spread to the hepatoduodenal ligament, it was impossible to seize the Hartmann's pocket and to perform the lateral traction. In such cases, the gallbladder was mobilized from the lateral (free wall) to the medial wall in the projection of the gallbladder neck, which made it possible to avoid intraoperative injuries. After mobilization of the gallbladder neck with a clamp, the lateral traction for the Hartmann's pocket was performed. Dissection of the cystic duct and arteries was carried out with opening of the Calot triangle at the sufficient distance from the major bile ducts and blood vessels. The cystic duct was dissection to distance sufficient for its clipping and crossing. First, the proximal clip was laid as close as possible to the gallbladder neck, and then - two clips to distal section of the cystic duct. It was crossed between the clips. With diameter of the cystic duct over $5 \mathrm{~mm}$ it was clipped by the cascade technique. For this purpose, the clip was placed on $2 / 3$ of diameter of the duct and crossed it over the clip. After that, the second clip was placed and the duct was completely crossed. The cystic artery was clipped in the proximal department with one clip or coagulated with the bipolar clamp, leaving a long residual limb. Crossing of the cystic artery was performed by the L-shaped electrode or scissors near the gallbladder wall. In the pronounced infiltrative changes the full mobilization of main trunk of the cystic artery was not the aim. In such cases, the vessels were clipped which clearly passed on the wall of the gallbladder (arteries of II, III order). After intersection of the cystic duct and arteries, the gallbladder was isolated from the bed in the connective tissue layer between the wall of the gallbladder and the liver parenchyma. For the clear detection of the connective tissue layer, traction of the gallbladder was performed for the bottom in opposite direction to the mobilization area. In the postoperative period, for control of bile leakage and hemorrhage, the subhepatic space was drained by the tubular drainage, which was removed on 1-2 day of the postoperative period.

In the presence of the sclerotic gallbladder in 30 (7.1\%) patients LCE had technical difficulties due to induration and rigidity of its walls, filling of the lumen of the gallbladder with stones, shortening and shrinking of the tubular structures of the Calot triangle. Due to induration and shrinking of the gallbladder walls, lateral traction for the Hartmann's pocket was more difficult, and there was high placement of the cystic duct and artery observed. In such cases, the gallbladder was mobilized from the lateral wall to the medial one in projection of the Hartmann's pocket. High mobilization of the gallbladder made it possible to avoid intraoperative injuries. In $8(1.9 \%)$ patients with the severe sclerotic changes removal of the gallbladder from the bed created danger of significant damage to the liver. In such cases, the anteriolateral wall of the gallbladder was cut off by the scissors or the L-shaped hook. After that the mucoclase of the back wall was carried out by the bipolar clamp. The cut part of the gallbladder together with its contents was placed in the container and removed from the abdominal cavity.

By the excessive peritoneal adhesion in the hepatoduodenal area there is a risk of the intraoperative bile duct injuries by introducing of the first and third trocars. In such cases, in $60(14.3 \%)$ patients, the method of three-trocar laparoscopic cholecystectomy in the widespread adhesion process in the hepatoduodenal area was used (patent of Ukraine No. 111662). Prior to the surgery, the transabdominal ultrasonography of the paraumbilical area was performed to prevent intraoperative injuries by introducing of the first trocar. The first port 1 , of $10 \mathrm{~mm}$ in diameter, was introduced into the paraumbilical area. Under laparoscopic control, the second port 2, of $10 \mathrm{~mm}$ in diameter, was introduced to the epigastric area. After revision of the abdominal cavity, the third port 3 , of 5 $\mathrm{mm}$ in diameter, was introduced in the middle of distance between the medioclavicular line 4 and the front axillary line 5 at the intersection with the oblique line 6 , which connects the right arc of the ribs with the navel (figure I). In the presence of the widespread peritoneal adhesion process in the subhepatic space, the low input of the third port made it possible to prevent injuries to the tubular 
structures of the hepatoduodenal area. With the help of a grasper, introduced into the abdominal cavity through the third trocar, main traction was performed for the bottom of the gallbladder. The dissection of the adhesions was carried out by the L-shaped electrode at distance necessary to mobilize the gallbladder neck. After that, the lateral traction was performed on the gallbladder neck with the grasper from the third port. Due to the fact that the third trocar was located in the middle of distance between the medioclavicular line and the front axillary line, traction for the bottom and neck of the gallbladder was carried out without any technical difficulties and did not complicate the course of the surgical intervention.

In the patients of both groups, 75 (17.9\%) minimally invasive interventions were performed on the bile ducts. By the complicated course of the acute calculous cholecystitis in 30 (7.1\%) cases the two-stage tactics was used (LCE with the endoscopic transpapillary interventions in early postoperative period). At the first stage endoscopic hydrostatic balloon dilation of the major duodenal papilla was performed in $3(0.7 \%)$ patients in the presence of single stones with the diameter of up to $5 \mathrm{~mm}$ located in the distal parts of the CBD. In 27 (6.4\%) patients endoscopic papillosphincterotomy (EPS) was performed. Spontaneous passage of stones of up to $10 \mathrm{~mm}$ in diameter occurred in $11(2.6 \%)$ of the cases. Lithoextraction by means of the Dormia basket (Olympus FG-22Q, Boston scientific trapezoid RX) was performed in $10(2.4 \%)$ patients. Mechanical lithotripsy was performed using Olympus BML-201Q lithotripter in $6(1.4 \%)$ patients with diameter stones of $10-20 \mathrm{~mm}$, after what the fragmentated stones were removed with the Dormia basket. The single-stage interventions (LCE with the lithoextraction through the cystic duct) were performed in the presence of the not dense perivesical infiltrate in $5(1.2 \%)$ patients, when CBD was defined without technical difficulties.

In the presence of complicated course of the chronic calculous cholecystitis, the two-stage tactics (EPS followed by LCE) was used in $10(2.4 \%)$ patients with choledocholithiasis and 18 (4.3\%) - with the stenosing papillitis, which were diagnosed before surgery. The time interval between EPS and LCE was minimal (2-3 days), which reduced the risk of migration of the stones in CBD. In the absence of the sclerotic gallbladder and excessive peritoneal adhesion, the one-stage intervention was performed: LCE with the cysticolithotomy - in $5(1.2 \%)$ patients with choledocholithiasis, LCE with the external drainage of the CBD through the cystic duct - in 7 (1.7\%) patients with Mirizzi's syndrome of the I type.

Conversion in the patients of group I was applied in 13 (6.2\%) cases due to impossibility of verifying the tubular structures of the Calot triangle during 30 minutes. The transrectal minilaparotomy was performed in $6(2.8 \%)$ patients, including because of the dense perivesical infiltrates - in $2(0.9 \%)$, sclerotic gallbladder - in $2(0.9 \%)$, excessive peritoneal adhesion in the hepatoduodenal area - in $2(0.9 \%)$ cases. The supramedian laparotomy was performed in $7(3.3 \%)$ patients: $1(0.5 \%)$ because to inju- ry of the right hepatic artery, $2(0.9 \%)$ - complete injury of the CBD, Mirizzi's syndrome of type II - in $1(0.5 \%)$, biliodigestive fistula - in $3(1.4 \%)$ cases. In the patients of group II conversion on the supramedian laparotomy was performed in $4(1.9 \%)$ cases. The reason for this was: Mirrizzi's syndrome of type II - in 2 (0.9\%), biliodigestive fistula - in $2(0.9 \%)$ cases.

The intraoperative injuries of the patients of group I were observed in $12(5.7 \%)$ patients: complete injury of the CBD - in $2(0.9 \%)$, marginal injury of the CBD - in 1 $(0.5 \%)$, clapping of the common hepatic duct - in $1(0.5 \%)$, cystic duct stump inefficiency - in 3 (1.4\%), bile leakage from the gallbladder bed - in $2(0,9 \%)$, bleeding from the right hepatic artery - in $1(0.5 \%)$, bleeding from the bed of the gallbladder - in $2(0.9 \%)$ cases. $2(0.9 \%)$ patients died due to the extensive myocardial infarction and massive thromboembolism of the pulmonary artery. The patients of group II intraoperative injuries arose in $4(1.9 \%)$ patients: cystic duct stump inefficiency - in $2(0.9 \%)$, bile leakage from the gallbladder bed - in $2(0,9 \%)$ cases. There were no fatalities.

The statistical data analysis showed a statistically significant difference of the frequency of the intraoperative injuries after the standard four-trocar LCE and developed methods of LCE $(p<0.001)$ and conversions in patients of groups I and II $(\mathrm{p}<0.001)$. The evaluation of long-term results based on the questionnaire SF-36 (Short Form-36) showed no real difference in the studied groups of patients.

\section{CONCLUSIONS}

1. Introduction of the developed methods of LCE with complicated course of the calculous cholecystitis allows to reduce the frequency of intraoperative injuries by $3,8 \%$ and conversion rate - by $4,3 \%(\mathrm{p}<0,001)$.

2. When combine the calculous cholecystitis with the choledolithiasis, it is expedient to use the two-stage surgical intervention: LCE with the endoscopic transpapillary interventions in early postoperative period with the acute course of the calculous cholecystitis and EPS followed by LCE for the chronic course of the cholecystitis.

3. The single-stage operations (LCE with the subsequent intervention on the bile ducts) it is expedient to use in patients with the acute cholecystitis, complicated by the not dense perivesical infiltrate, and in absence of the sclerotic gallbladder and excessive peritoneal adhesion in the chronic cholecystitis.

\section{REFERENCES}

1. Becker B.A., Chin E., Mervis E. Emergency biliary sonography: utility of common bile duct measurement in the diagnosis of cholecystitis and choledocholithiasis. Engl. J. Med. 2014; 46(1): 54-60.

2. Anand A., Pathania B.S., Singh G. Conversion in laparoscopic cholecystectomy: An Evaluation study. J. Med. Educat. \& Resear. 2007; 9(4): 171-174.

3. Dan D., Harnanan D., Maharaj R. Laparoscopic cholecystectomy: analysis of 619 consecutive cases in a Caribbean setting.J. Natl. Med. Assoc. 2009; 101(4): 355-360. 
4. Topal B., Vromman K., Aerts R. Hospital cost categories of one-stage versus two-stage management of common bile duct stones. Surg. Endoscop. 2010; 24: 413-416.

5. Costi R., Mazzeo A., Tartamella F. Cholecystocholedocholithiasis: a case-control study comparing the short- and long-term outcomes for a "laparoscopy-first" attitude with the outcome for sequential treatment (systematic endoscopic sphincterotomy followed by laparoscopic cholecystectomy). Surg. Endoscop. 2010; 24: 51-62.

6. Litwin D.E., Cahan M.A. Laparoscopic cholecystectomy. Surg. Clin. North Am. 2008; 88(6): 1295-1313.

7. Wolf A.S., Nijsse B.A., Sokal S.M. Surgical outcomes of open cholecystectomy in the laparoscopic era. Am. J. Surg. 2009; 197(6): 781-874.
8. Mercado M.A., ChanC.,OrozcoH.Prognosticimplications of preserved bileduct confluence after iatrogenic injury. Hepatogastroenterol. 2005; 52(61): 40-44.

9. Le V.H., Smith D.E., Johnson B.L. Conversion of laparoscopic to open cholecystectomy in the current era of laparoscopic surgery. Am. Surg. 2012; 78(12): 1392-1395.

10. Zhang W.J., Li J.M., Wu G.Z. Risk factors affecting conversion in patients undergoing laparoscopic cholecystectomy. ANZJ.Surg. 2008;78(11):973-976.

\section{Authors' contributions:}

According to the order of the Authorship.

\section{Conflict of interest:}

The Authors declare no conflict of interest.

\section{CORRESPONDING AUTHOR Yaroslav V. Karyi}

National Pirogov Memorial Medical University, Vinnytsya

Surgery Department of the Medical Faculty No. 2

56 Pirogov Str., Vinnytsya, Ukraine, 21018

tel: +380677429457

e-mail:yaroslavkaryi@gmail.com

Received: 11.01 .2019

Accepted: 10.04 .2019 
PRACA ORYGINALNA

ORIGINAL ARTICLE

\title{
FEATURES OF CLINICAL MANIFESTATIONS OF DISEASE AND PSYCHOLOGICAL STATUS OF ADOLESCENTS WITH BRONCHIAL ASTHMA OF VARIOUS LEVELS OF CONTROL AND THE INFLUENCE OF RISK FACTORS
}

\author{
Tetiana L. Protsiuk, Olga S. Yablon, Liudmyla 0. Protsiuk, Olga A. Bykovska, Olena V. Herasymova, Tetiana V. Kapitan \\ NATIONAL PIROGOV MEMORIAL MEDICAL UNIVERSITY, VINNYTSYA, UKRAINE
}

\begin{abstract}
Introduction: The problem of psycho-emotional state of patients with asthma is of great importance from a mental and social point of view.

The aim: To find out the factors which influence mental state of adolescents, to determine features of clinical manifestations and of mental status in patients with bronchial asthma, depending on degree of its control.

Materials and methods: 108 adolescents aged 11-17, ill with BA, of various levels of control. Luscher color test was used to determine the child's mental status. Anxiety score was assessed by Spielberger-Hanin State-Trait Anxiety Inventory. Depressive status and depression severity were evaluated by HDRS.

Results: The patients with UC BA reported unsatisfactory living conditions significantly more often compared to those with $C B A$ and the children with $P C B A$ compared to those with C BA ( $p<0.01)$. Patients with PC BA and UC BA were found to have significantly increased proneness to conflict, marked emotional tension and lability, mood swings, increased anxiety, vulnerability and sensitivity, as compared to those with C BA. Significantly lower state anxiety was revealed in the patients with ( BA as compared to those with $P C B A(p=0.004)$ and $U C B A(p=0.0001)$. Significantly lower mean values of depression values were detected in the patients with $C B A$ compared to those with UC $B A(p=0.011)$ and $\mathrm{PC} B A(\mathrm{p}=0.0015)$.

Conclusions: The major factors influencing the psychological status of adolescents were: unsatisfactory living conditions, psychic and physical punishment, stress, heavy workload etc. The patients with BA developed psychological disorders under the influence of those factors.
\end{abstract}

KEY WORDS: adolescents, bronchial asthma, psychosocial factors, psycho-emotional disorders, psychosomatic pathology

Wiad Lek 2019, 72, 5 cz. I, 795-801

\section{INTRODUCTION}

Psychosomatic pathology develops and persists due to a special mechanism of relationship between the state of mind and body - this is the so-called mechanism of vicious circle: somatic disorders which develop first result in psychic changes, and the latter, in their turn, cause further somatic disorders. Bronchial asthma (BA) is a disease in which psychic and somatic disorders are closely interconnected and influence each other, but none of the numerous theories could give comprehensive explanation of etiology and pathogenesis of psychosomatic disorders. Study of psychosomatic pathology development in children, particularly in adolescents, takes a special place in modern medical science. Adolescence is one of the critical phases in a person's life - the period of hormonal changes and sexual maturation, myelinization of conductive pathways of the nervous system, personality development and formation of social attitudes [1]. Age of adolescence is characterized by strong emotional sufferings, difficult relations with adults $[2,3]$. All these factors can increase the incidence and severity of BA course in adolescents. Psycho-emotional problems are most evident in the children with severe asthma [4].
Significantly high score of anxiety among BA children as compared to healthy children have been found by a number of researchers [5].

Modern conceptions of BA pathogenesis include, except chronic inflammation, the mechanisms of neurogenic inflammation, which involve neuropeptides and imbalanced chains of autonomous nervous system. Continuous effect of stress inevitably results in exhaustion of psychological adaptive reserves, leading to the increased risk of somatic disorders [6].

Thus, BA belongs to classic psychosomatic disorders, but some authors do not exclude the direct effect of psychological factors on bronchomotor tone. According to recent data, about $25-30 \%$ of BA exacerbations in children and adolescents are associated with the periods of emotional exertion [7]. Changes in emotional and psychic status lead to more severe BA course as well as to the worsening of quality of life [8]. There have been numerous studies of psychosomatic disorders in BA, but few of them deal with psycho-emotional status of adolescents ill with BA as well as the role of environmental factors in this status. The problem of psycho-emotional state in this period of life is 
of great significance from psychic and social point of view, and study of BA on the basis of integrated psychosomatic approach is thought to be the most pressing today.

\section{THE AIM}

To find out the factors which influence mental state of adolescents, to determine features of clinical manifestations and of mental status in patients with bronchial asthma, depending on degree of its control.

\section{MATERIALS AND METHODS}

According to the purpose of the study, 108 adolescents (45 females and 63 males) aged 11-17, ill with BA, were examined. The children were divided into three groups according to BA control level. Group 1 consisted of 36 patients (33.3\%) with controlled course of the disease. Group 2 included 38 adolescents (35.2\%) with partially controlled BA course, and group 3 - 34 patients (31.48\%) with uncontrolled BA. 54 healthy adolescents - 22 males and 32 females - served as controls. Along with the complaints and history details, the most essential psychological factors, inducing predisposition to BA development and influencing the control over the disease in adolescents were studied. All the children underwent general clinical laboratory tests, allergic skin tests, determination of specific IG E level, and pulmonary function test. Anxiety score was assessed by Spielberger-Hanin State-Trait Anxiety Inventory [9]. Depressive status and depression severity were evaluated by Hamilton Depression Rating Scale (HDRS) [10]. Luscher color test was used to determine the child's mental status. The study was carried out in compliance with the provisions of World Medical association Declaration of Helsinki (1989), and was approved by Ethics Committee at Vinnytsia National Pirogov Memorial Medical University. All patients gave an informed consent to participate in the study.

Statistical data processing was done with Statistical package for Windows v. 8.0 (№AXXR910A374605FA). The normal distribution was evaluated according to Shapiro-Wilk test. Digital information of all clinical investigations was processed by variance statistical method calculating the mean value $(M)$ and its error $(\mathrm{m})$. For all specific data, the median (Me), lower and upper quartiles [LQ25-UQ75] were established. The comparison of quality indicators was performed using the $\chi^{2}$ criterion. The significance of difference between two means was calculated by Student's t-test $(t)$, between two relative values by Fisher angular transformation method $\left(\varphi^{*}\right)$. Comparison of quantitative values in some clinical groups was done using non-parametric analogue of ANOVA (analysis of variance) Kruskal-Wallis $\mathrm{H}$-test, $\mathrm{p}<0.05$ was considered significant difference. In case of significant differences between the groups, their pair-wise comparison was performed using Mann-Whitney U-test with regard to Bonferroni correction for multiple testing. The difference between the groups according to Bonferroni adjustment was considered statistically significant in $\mathrm{p}<0.017$.

\section{RESULTS}

The major studied factors, influencing adolescents' mental state, were found to be fatigue, anxiety, restlessness, sleep disorders, psychic tension and lability. Fatigue was reported by $76.8 \%$ of patients, anxiety and emotional lability - by $48.2 \%$ and $37.9 \%$ of patients, respectively, while sleep disorders were found in $92.8 \%$ of patients. $37.7 \%$ of patients had several signs of anxiety and depressive disorders (ADD).The questionnaire survey demonstrated that fatigue occurred in $10.1 \%$ of children with controlled BA (C BA) and in $73.7 \%$ of those with uncontrolled course of disease (UC BA), the percentage being significantly higher $\left(\chi^{2}\right.$ $=8,3 ; \mathrm{p}<0.01$ ). Apart from high probability of relationship between fatigue rate and asthma attacks in patients with UC BA, relatively high degree of relationship was found $(\varphi=0.53, p<0.001)$. Psychic tension and anxiety was observed significantly more often in adolescents with UC BA and partially controlled BA (PC BA) than in those with C $\mathrm{BA}-28.7 \%$ and $24.9 \%$ versus $2.6 \%(\chi=5.61 ; \mathrm{p}=0.029$; and $\chi=10.8 ; \mathrm{p}=0.001$, respectively). Sleep disorders occurred in $8.2 \%$ of cases among those with C BA, while they were found in $98.7 \%$ of cases among children with UC BA and $\operatorname{PCBA}\left(\chi^{2}=8.20 ; \mathrm{p}<0.001\right)$ and $92.6 \%\left(\chi^{2}=10.28 ; \mathrm{p}<0.001\right)$, respectively. ). Apart from high probability of relationship between sleep disorder rate and asthma attacks in patients with UC BA and PC BA, high degree of relationship was found ( $\varphi=0.71 ; \varphi=0.68, p<0.001$, respectively). Mothers of the children with UC BA were unemployed four times as often as those with C BA - $19.0 \%$ versus $5.6 \%\left(\chi^{2}=8.32\right.$, $\mathrm{p}<0.01)$. Among fathers of the children with UC BA and PC BA there were much less persons of trade jobs than among fathers of those with C BA $(20.3 \%$ versus $41.1 \%$; $\chi^{2}=10.17, \mathrm{p}<0.01 ; 20.3 \%$ versus $55.6 \%, \chi^{2}=8.06, \mathrm{p}<0.01$, respectively). The results of the study showed that most of families with UC BA and PC BA children had strained relations between the parents, different outlook on bringing up children and attitude towards the disease, as well as other negative factors, in contrast to the families who had children with C BA.

According to the results of the study, formation and development of BA are greatly influenced by unsatisfactory living conditions. The patients with UC BA reported unsatisfactory living conditions significantly more often compared to those with C BA ( $49.4 \%$ versus $12.2 \%, \chi^{2}=8.57, p<0.01$ ), and the children with PC BA compared to those with $\mathrm{C}$ BA ( $46.6 \%$ versus $\left.12.2 \%, \chi^{2}=4.16, p<0.01\right)$. The families of C BA children had better living conditions as opposed to those with UC BA and PC BA adolescents. 78.9\% of children with C BA had a separate room in the family's private house or apartment compared to $56.3 \%\left(\chi^{2}=6.86, p<0.01\right)$ and $49.7 \%,\left(\chi^{2}=9.22, p<0.01\right)$ of those with PC BA and UC BA, respectively. The children as well as their parents reported the presence of a private house or apartment with a separate child's room to be a positive factor in maintaining family well-being.

Physical and psychological punishment was found to be used significantly more frequently by the parents of children with UC BA and PC BA compared to those with C BA. For example, punishment of various types, as the main form of education, was used significantly more often by the parents of UC BA children compared to those with PC BA (40.7\% 
versus $25.2 \%, \mathrm{p}<0.01)$ and $\mathrm{CBA}(25.2 \%$ versus $5.3 \%, \mathrm{p}<0.01)$, while the parents of children with C BA used occasional punishment significantly more often as compared to those with UC BA ( $65.7 \%$ versus $42.1 \%$, $\mathrm{p}<0.01)$. No significant difference in this parameter was found between the children with PC BA and CBA (65.7\% versus $49.5 \%, \mathrm{p}>0.05)$, PC BA and UC BA ( $42.1 \%$ versus $49.5 \%, \mathrm{p}>0.05)$.

The study demonstrated that the first signs of bronchial asthma in the examined adolescents were caused by the following factors: psycho-emotional stress - $18.3 \%$, stressful situations at school or family (changing school in particular) $-4.9 \%$, divorce of the parents $-8.5 \%$, loss of the beloved person $-4.9 \%$.

The adolescents with UC BA and PC BA were found to have incomplete families as opposed to those with $\mathrm{C} \mathrm{BA}$ $\left(13.6 \%\right.$ and $15.9 \%$ versus $6.1 \%, \chi^{2}=3.72 ; \mathrm{p}<0.05$, and $\chi^{2}$ $=4.22 ; \mathrm{p}<0.05$, respectively), and $51.2 \%$ of patients with UC BA and PC BA lived in the families with low financial status. The frequency of stress situations among the adolescents was found to be similar: $52.3 \%$ - in the patients with UC BA, $50.8 \%$ - with PC BA and $44.5 \%$ - with C BA, with no significant difference between the groups, $p>0.05$, respectively. $48.7 \%$ of adolescents with UC BA, $33.5 \%$ with C BA and $42.9 \%$ of children with PC BA studied at lyceums and gymnasiums. $28.9 \%$ of adolescents with UC BA and $19.8 \%$ with PC BA spent their study-free time at the computer (2-6 hours a day on an average), the boys preferring computer games and the girls - internet, as compared to the adolescents with $\mathrm{C} \mathrm{BA}$, who were engaged in sport activities significantly more often than being at computer ( $40.7 \%$ versus $9.4 \%, \mathrm{p}=0.0001$ ). The study demonstrated that the adolescents with UC BA required communication with both parents significantly more often compared to those with C BA $-2.96 \pm 0.58$ versus $2.18 \pm 0.50, \mathrm{p}<0.05$, while no significant difference between the groups of the patients with UC BA and PC BA was detected $(2.96 \pm 0.58$ versus $2.77 \pm 0.42, \mathrm{p}>0.05)$. Need in communication with mother was observed significantly more often in the adolescents with UC BA compared to those with PC BA ( $2.58 \pm 0.45$ versus $2.02 \pm 0.69 \mathrm{p}=0.003)$, while there was no significant difference between the groups of patients with UC BA and C BA, PC BA and C BA $(2.58 \pm 0.45$ versus $2.47 \pm 0.70, p=0.09$ and $2.02 \pm 0.69$ versus $2.47 \pm 0.70, p=0.25$, respectively). Evaluation of emotional affinity with the child showed the following results: $94.9 \%$ of mothers of C BA children reported mutual understanding and warm relations, $5.1 \%$ - distancing of the child, while $31.0 \%$ of adolescents with UCBA marked the absence of confidential relations with the parents.

Adolescents with UC BA needed warm relations with father significantly more often compared to those with PC BA and C BA ( $2.09 \pm 0.65$ versus $1.59 \pm 0.84, \mathrm{p}=0.0005$; and $2.09 \pm 0.65$ versus $1.80 \pm 0.95, p=0.02$, respectively). Adolescents with $\mathrm{C} B A$ reported the wish to communicate with mother, indicating the lack of contacts which would meet their emotional need.

Luscher color test was used to determine mental status of study adolescents.
Analysis of the data obtained found no significant differences in emotional status of adolescents with C BA as compared to the group of healthy adolescents (by the following parameters: ostentation $(\mathrm{p}=0,83)$, asociality $(\mathrm{p}=0,96)$, environment dependence $(p=0,67)$, frankness $(p=0,31)$, optimism $(p=0,20)$, need for understanding $(p=0,83)$, need for communication $(\mathrm{p}=0,80)$, need for quietness $(\mathrm{p}=0,47)$, rationality $(\mathrm{p}=0,49)$, sensitivity $(\mathrm{p}=0,11)$, psychic lability $(\mathrm{p}=0,61)$, craving for dominance $(\mathrm{p}=0,48)$, anxiety $(\mathrm{p}=0,62)$, difficulty in adaptation $(\mathrm{p}=0,21)$, proneness to conflict $(\mathrm{p}=0,79)$, persistence $(\mathrm{p}=0,37)$, fatigue $(\mathrm{p}=0,46)$, feeling of desolation $(\mathrm{p}=0,24)$, emotional tension $(\mathrm{p}=0,22)$, emotional immaturity $(\mathrm{p}=0,62)$, emotional vulnerability $(\mathrm{p}=0,49))$ (Fig. 1).

Patients with PC BA and UC BA were found to have significantly increased proneness to conflict $(p=0,004 ; p=0,002$, respectively), marked emotional tension $(\mathrm{p}=0,03 ; \mathrm{p}=0,02$, respectively) and lability $(\mathrm{p}=0,016 ; \mathrm{p}=0,003$, respectively), mood swings $(\mathrm{p}=0,001 ; \mathrm{p}=0,007$, respectively), increased anxiety $(\mathrm{p}=0,028$ and $\mathrm{p}=0,047)$, vulnerability $(\mathrm{p}=0,0059$ and $\mathrm{p}=0,008)$, and sensitivity $(\mathrm{p}=0,006$ and $\mathrm{p}=0,007$, respectively), as compared to those with C BA (Fig. 2).

The desire to free from restrictions and craving for freedom and self-affirmation proved to be significantly stronger among wide range of problems in patients with UC BA and PC BA. Yellow and red colors were first to be chosen significantly more often both by patients with UC $\mathrm{BA}$ and those with PC BA as compared to those with by patients C BA $(27.3 \%$ and $23.3 \%$, versus $10.9 \%, p<0.05$, respectively).

The first position of yellow color implied the desire to free from conflict, hope for freedom. Red and yellow (23.3\% and $29.8 \%$, versus $8.7 \%, \mathrm{p}<0.001$, respectively) colors took the second position, while dark blue and violet $(24.8 \%$ and $20.7 \%$, versus $5.4 \%, \mathrm{p}<0.001$, respectively) colors appeared on the third position. Besides, $22.2 \%$ of adolescents with UC BA, $18.6 \%$ of adolescents with PC BA and $1,2 \%$ of adolescents with $\mathrm{C} B A$ gave the first position to additional colors - black, grey and brown, being indicative of need for escaping the reality, unrealistic requirements to life, subjectivism, emotional immaturity, non-participation, detachment, the desire to protect oneself against any external influence.

Besides, black color on the first positions suggested some additional source of anxiety in children, the protest against current circumstances, predisposition to depression. In children with $\mathrm{C}$ BA and in the control group red, dark blue and green colors took the third place significantly more often, as compared to those with by patients UC BA and PC BA (33.8\% and $32.2 \%$, versus $9.3 \%$ and $11,4 \%$, $\mathrm{p}<0.001$, respectively).

The average values of both trait and state anxiety by Spielberger-Hanin State-Trait Anxiety Inventory appeared to be significantly higher than anxiety scores in healthy individuals - 44.0 [35.0; 49.0] scores and 41.0 [34.0; 48.0] scores, respectively, versus 24.0 [22.0; 28.0] and 28.0 [26.0; $32.0]$ scores, respectively $(\mathrm{p}<0.05)$. Adolescents ill with BA had significantly higher level of trait and state anxiety 


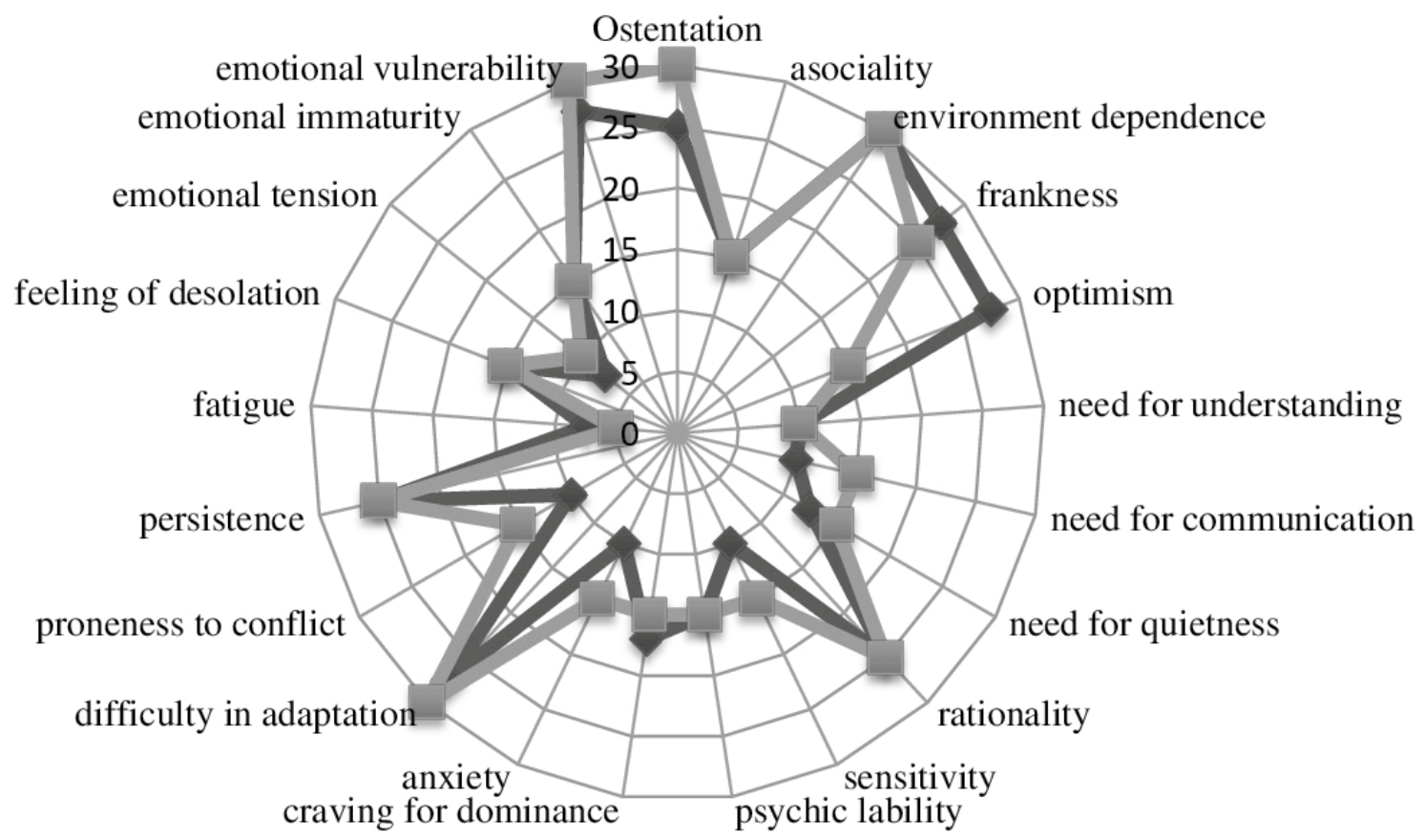

$\hookrightarrow$ adolescents with C BA healthy adolescents

Fig. 1. Indicators of the emotional status of adolescents with C BA and healthy adolescents by Lusher's test

(TA and SA) by Spielberger-Hanin scale compared to their healthy counterparts $\left(48.1 \%\right.$ versus $8.5 \% \varphi^{*} \mathrm{emp}=4.732>$ $1.64=\varphi_{\text {cr, }} \rho_{\varphi}<0.001$ and $42.6 \%$ versus $6.7 \%, \varphi^{\star} \mathrm{emp}=4.262$ $>1.64=\varphi_{\text {cr, }} \rho_{\varphi}<0.001$, respectively). Low SA level was found significantly more often in the group of adolescents with $\mathrm{C}$ BA $(83.3 \%)$ compared to those with PC BA (25.9\%), at $\varphi_{*}$ $=2.819>1.64=\varphi_{\mathrm{cr}} \rho_{\varphi}<0.01$ and UC BA $(16.7 \%)$, at $\varphi_{\star_{\mathrm{emp}}}$ $=3.606>1.64=\varphi$ cr $\rho_{\varphi}<0.01$, respectively.

Evaluation of TA and SA in the patients with various degrees of BA control demonstrated significant difference in SA between the studied groups (K-W H $(2)=21.47$, $\mathrm{p}=0.000<0.05)$, while no significant difference in TA was found $(\mathrm{K}-\mathrm{W} \mathrm{H}(2)=2.75, \mathrm{p}=0.25>0.05)$. SA level in the patients with $\mathrm{C} B \mathrm{BA}$ was revealed to be significantly lower as compared to those with $\mathrm{PC} \mathrm{BA}(\mathrm{M}-\mathrm{W} \mathrm{U}=415, \mathrm{Z}=-2.90$, $\mathrm{p}=0.004<0.017=0.05 / 3)$ and UC BA $(\mathrm{M}-\mathrm{W} \mathrm{U}=242$, $\mathrm{Z}=-4.37, \mathrm{p}=0.000<0.017=0.05 / 3)$, while there was no significant difference in this index between the groups of patients with UC BA and PC BA (M-W U=445.5, $\mathrm{Z}=2.26$, $\mathrm{p}=0.02>0.017$ ), (Fig. 3).

Mean values of depression (DD) in adolescents ill with BA proved to be $13.1 \pm 5.1$ scores by HDRS scale, being significantly higher than those in the control group - 3.3 \pm 1.9 scores $(\mathrm{p}<0.001)$.
The analysis of DD values in the patients with various control levels found significant difference between the groups according to HDRS (K-W test: $\mathrm{H}(2)=9.85$, $\mathrm{p}=0.007<0.05)$. Significantly lower DD values were detected in the patients with $\mathrm{C} \mathrm{BA}$ compared to those with UC BA (M-W U=397.0, $\mathrm{Z}=-2.5, \mathrm{p}=0.011<0.017=0.05 / 3)$ and PC BA (M-W U=390.0, Z=-3.17, p=0.0015<0.017 = $0.05 / 3)$. No significant difference in DD values between the groups of patients with $\mathrm{UC} \mathrm{BA}$ and PC BA were found $(\mathrm{M}-\mathrm{W} \mathrm{U}=624.0, \mathrm{Z}=-0.24, \mathrm{p}=0.080>0.017=0.05 / 3)$ (Fig. 4).

Thus, bronchial asthma changes the lifestyle of sick children and negatively influences

their psychological status. BA is known to change the emotional state of the patients, leading to pathologic anxiety, - the factor contributing to emotional hyperfunction.

The data obtained were confirmed by the clinical study data. In adolescents with UC BA and PC BA, accompanied by $\mathrm{ADD}$, asthma attacks rate significantly increased unlike those with UC BA and PC BA with no signs of ADD (5.2 \pm 0.8 and $4.7 \pm 0.5$ versus $2.2 \pm 0.4$ and $1.8 \pm 0.2, \mathrm{p}<0.05$, respectively). Patients with $\mathrm{UC} \mathrm{BA}$ and $\mathrm{PC} \mathrm{BA}$ were found to require medicines for emergency care significantly more often as compared to those with no ADD signs ( $8.7 \pm 0.5$ and $7.6 \pm 0.3$ versus $2.3 \pm 0.4$ and $1.2 \pm 0.2, \mathrm{p}<0.05$, respectively), 


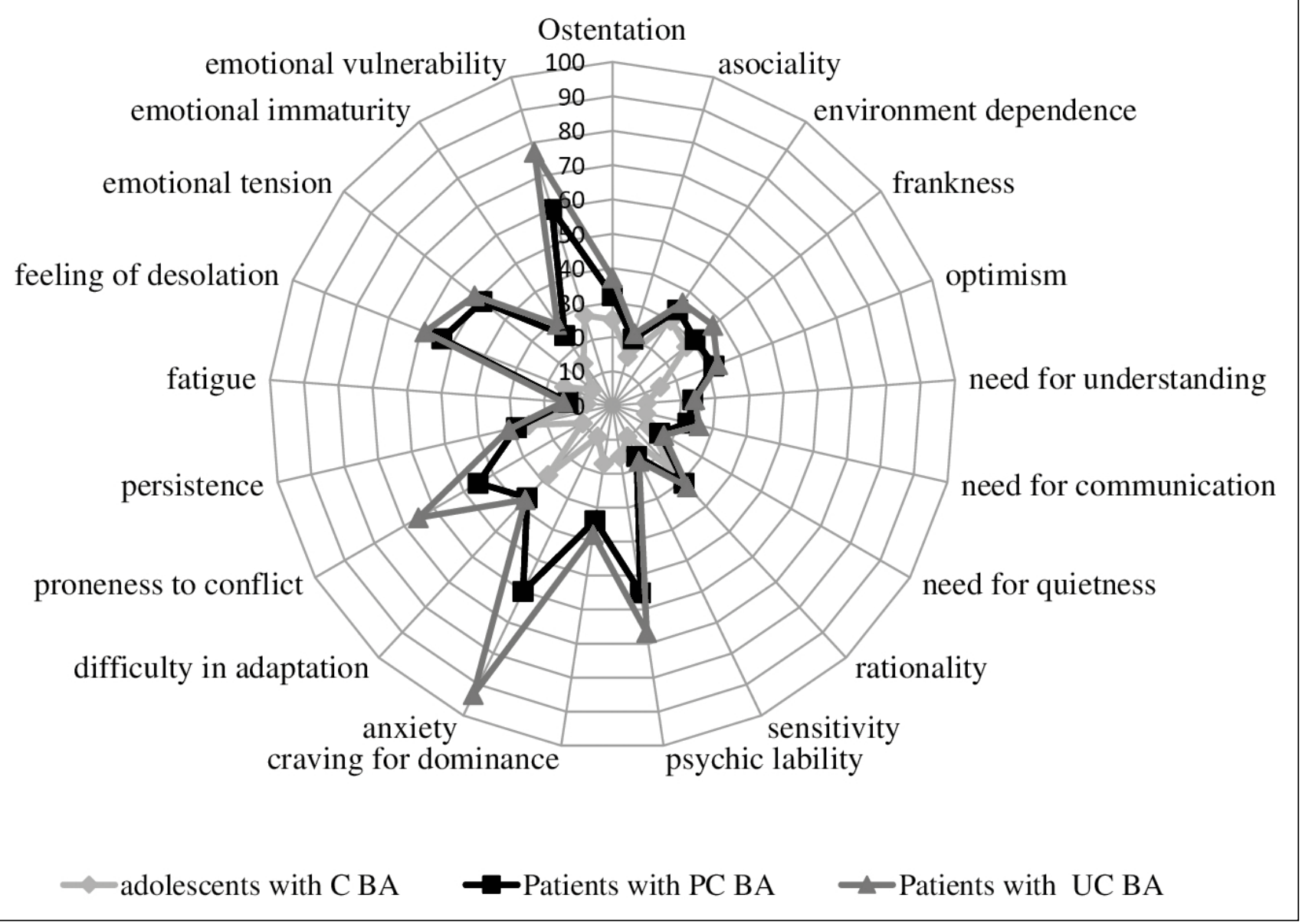

Fig. 2. Indicators of the emotional status of adolescents with $C B A, U C B A$ and $P C B A$ by Lusher's test.

their hospital stay was $23 \pm 2.4$ days, being significantly longer than in patients with no ADD, $11.3 \pm 0.9$ days, $\mathrm{p}<0.05$, respectively.

\section{DISCUSSION}

Asthma is one of the most common chronic diseases of childhood. Those particularly affected are young, poor, children. Paediatric bronchial asthma causes respiratory related mortality and morbidity globally and elevates the risk of psychological and social problems (psychosocial problems); which may result in poorer asthma control $[4,8,13,14]$. Some studies which identify anxiety disorders as very common among children with asthma. Despite the ample published research on asthma prevalence and asthma management interventions, there is little research available on barriers to asthma care among $[1,7,11,15]$. The data received in the study are consistent with those obtained by Bellin M. H., et al., [7] children with a reduced socioeconomic status have low levels of control and effects of symptoms. Low socioeconomic status of mothers can lead to social deterioration or deficits in many areas such as finance, self-management and home management, knowledge of the disease, as well as the ability to understand asthma education.
Tunde-Ayinmode M. F., [8] found that psychological morbidity was present in $25 \%$ of the children. Psychological morbidity was significantly associated with lower maternal education $(\mathrm{p}=0.020)$ and occupation $(\mathrm{p}=0.038)$, polygamy $(\mathrm{p}=0.012)$, fathers having more than 5 children $(\mathrm{p}=0.027)$ and mothers having inadequate spousal support $(\mathrm{p}=0.012)$, which is consistent with our data

Özkaya E., et al., [11] report that depressive disorders are also very common or even more prevalent among these patients, while usually there are cases of anxiety and depression. The data received in the study are consistent with those obtained by S.L. Letitre et al., [12] indicating that children with well controlled bronchial asthma have no increased risk of anxiety, depression and low self-assessment.

Family factors have always received attention in literature as being able to influence onset and course of asthma and as risk factor of psychological morbidity in both child and family members. Sadof M et al., [13] indicate that family emotional characteristics, asthma management behaviors, and physiological factors account for key influences on pediatric asthma onset and outcomes. Behavioral and physiological mechanisms may act independently or may interact to affect asthma manifestations. Families with specific emotional characteristics may be at an elevated 


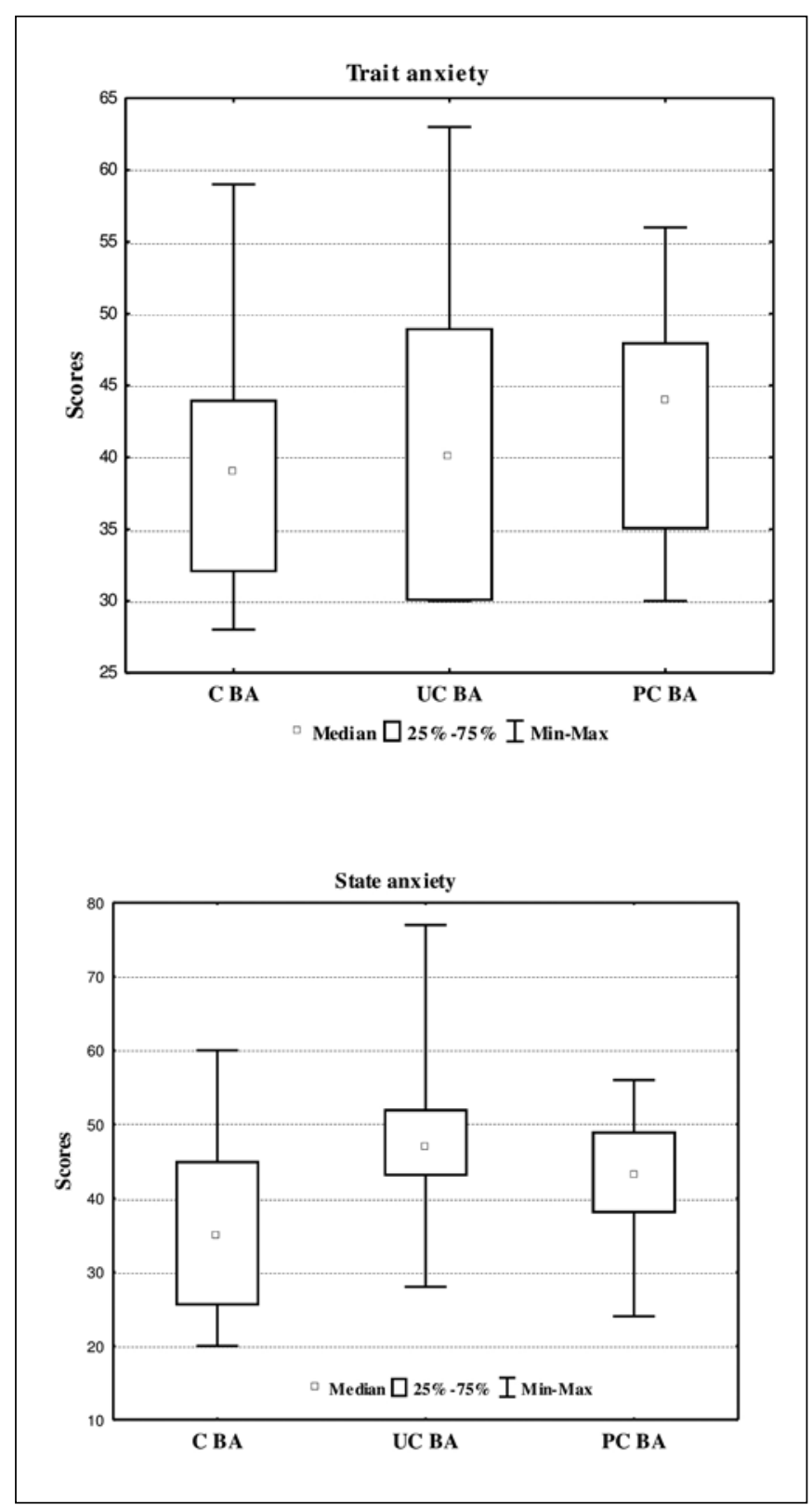

Fig.3. Levels of TA and SA by Spielberger-Hanin scale in adolescents ill with $B A$ of various control levels (scores).

risk for poorer asthma outcomes. Different types of parental stress/coping behaviors and parenting styles may differently predict their children's asthmatic status, and such associations may change as children grow, which is consistent with our data.

Goodwin R. D., et al., [14] found that more severe and persistent asthma at age 5 was associated with significantly increased odds of affective, anxiety, somatic, oppositional defiant and conduct problems at ages 5-17. Mild asthma and remitted asthma were not associated with heightened vulnerability to mental disorders. Results suggest that youth with symptomatic asthma are more likely to suffer from a wide range of mental health problems, and that the likelihood of mental health problems appears to increase as a function of asthma severity. Youth with poorly con-

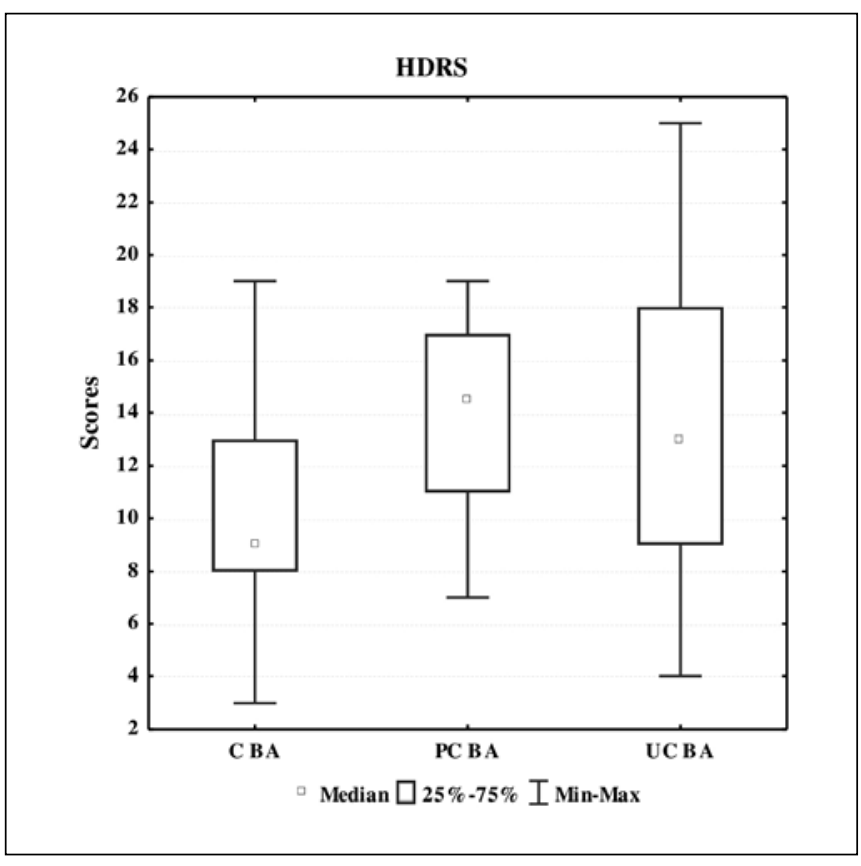

Fig. 4. Values of HDRS scale in adolescents with BA and various types of disease control (scores).

trolled and/or more severe and persistent asthma may be considered a vulnerable group who might benefit from mental health screening in clinical, school and community settings. According to our data, patients with UC BA had the signs of depression and anxiety significantly more often, while mental state of adolescents with C BA was characterized by low anxiety score and depression. The data received in the study are consistent with those obtained by Brady A.M., Deighton J. et al., [15] found a strong relationship between asthma in adolescence and an increase in the prevalence of anxiety and depressive disorders. The psychological characteristics of asthmatic patients and the presence of mental problems, have been shown to be linked to both asthma severity and level of disease control.

According to Yatham L.N., et al., [6] anxiety produces constant tension, similar to chronic uncontrolled stress with consequent disturbances in neuromediator system which influence the immune system and lead to persistent BA. Psychological trauma (even the minimal one), in its turn, enhances the anxiety, leading to the development of clinical symptoms of the disease due to neuropeptide overproduction, as well as the activation of sympathetic or parasympathetic nervous system. Increased anxiety, combined with atopic mechanisms of BA formation, result in more severe clinical manifestations of the disease and contribute to its progression.

Difficulties in achieving the objectives of asthma therapy suggested by current guidelines may depend also on psychological factors. Despite numerous data support this association, a causal relationship between asthma and mental health is not clear. Independently of the nature of this association, when a psychological problem or 
difficulty is present, it interferes with an optimal disease management, especially in patients with severe asthma and poor control. At the same time, the psychological characteristics of asthmatic patients have an influence on symptoms' recognitions, daily management and disease outcomes.

A screening of mental symptoms and psychological aspects that are known as associated to asthma, could lead to plan appropriate intervention to better control asthma and to improve the patient's well-being.

\section{CONCLUSIONS}

The main factors influencing mental status of adolescents were: psychic and physical punishment, absence of trusting relationships with parents, stress, heavy workload, emotional lability and tension. The results obtained were indicative of emotional disorders in adolescents ill with BA, their severity depending on the level of disease control. Under the influence of those factors, patients with BA developed the following psychological disorders: anxiety, psychic and emotional tension, restlessness. Patients with UC BA most often had the signs of depression and anxiety, while mental status of adolescents with C BA was characterized by low anxiety score and depression.

\section{REFERENCES}

1. Rebrov A.P, Karoli N.A. Psychological status peculiarities in bronchial asthma patients. Allergologiya. 2012 (2); 34-38.

2. Yonas M. A., Lange N. E., Celedón J. C. Psychosocial stress and asthma morbidity. Curr Opin Allergy Clin Immunol. 2012(12); 48-52.

3. Beasley R., Mitchell E. A., Semprini A. Risk factors for asthma: Is prevention possible? The Lancet. 2015; 386(9998);1075-85.

4. Oland A. A., Booster G. D., Bender B. G. Psychological and lifestyle risk factors for asthma exacerbations and morbidity in children. World Allergy Organization Journal. 2017 (22); 10-15.

5. Pachi A., Giotakis K., Tselebis A., et al. Psychosocial variables and the role of family support in patients with bronchial asthma. Encephalos. 2013 (50); 43-49.
6. Yatham L.N., Kennedy S.H., O'Donovan C. Canadian Network for Mood and Anxiety Treatments guidelines for the management of patient with bipolar disorder. Bipolar Disord. 2016 (8); 721-39.

7. Tunde-Ayinmode M. F. Children with bronchial asthma assessed for psychosocial problems in a teaching hospital in Nigeria. Afr Health Sci. 2015; 15(2): 690-700.

8. Bellin M.H., Osteen P., Kub J., et al. Stress and Quality of Life in Urban Caregivers of Children With Poorly Controlled Asthma: A Longitudinal Analysis. J Pediatr Health Care. 2015; 29(6):536-46.

9. Hamilton M. A. Rating scale for depression. Journal of Neurology, Neurosurgery and Psychiatry. 1960; (23); 56-62.

10. Spielberge, Ch.D. Theory and research on anxiety. Anxiety and Behavior. Acad. Press, New York 1966; $150 \mathrm{p}$.

11. Özkaya E., Çetin M., Uğurad Z., et al. Evaluation of family functioning and anxiety- depression parameters in mothers of children with asthma. Allergol Immunopathol (Madr.,) 2010; 38:25-30.

12. Letitre S.L., de Groot E.P., Draaisma E., et al. Anxiety, depression and self esteem in children with well controlled asthma: case control study. Arch. Dis. Child. 2014; 99 (8); 744-748.

13. Sadof M., Kaslovsky R. Adolescent asthma: a developmental approach. Current Opinion in Paediatrics. 2011; 23:373-378.

14. Goodwin R.D., Robinson M., Sly P.D. et al. Severity and persistence of asthma and mental health: a birth cohort study. Psychol Med. 2013; 43(6):1313-22.

15. Brady A.M., Deighton J., Stansfeld S. Psychiatric outcomes associated with chronic illness in adolescence: A systematic review. J. Adolesc. 2017; 32 (4); 112-123.

The work is a fragment of the scientific work of the Department of Pediatrics № 1 of the National Pirogov Memorial Medical University "Investigation of the role of genetic and environmental factors in the development of bronchial asthma in children" (№ 0107U009976).

\section{Authors' contributions:}

According to the order of the Authorship.

\section{Conflict of interest:}

The Authors declare no conflict of interest.

\author{
CORRESPONDING AUTHOR \\ Tetiana L. Protsiuk \\ National Pirogov Memorial Medical University \\ 56 Pirigova St., Vinnytsya, Ukraine \\ e-mail: rossata@ukr.net
}

Received: 18.03 .2019

Accepted: 24.04 .2019 


\title{
DYNAMICS OF BIOCHEMICAL MARKERS OF CONNECTIVE TISSUE METABOLISM IN PATIENTS WITH KNEE OSTEOARTHRITIS DURING CONSERVATIVE TREATMENT WITH LASER THERAPY
}

\author{
Kyrylo V. Makolinets', Vasyl I. Makolinets' ${ }^{2}$, Dmytro V. Morozenko ${ }^{1,2}$, Kateryna V. Gliebova ${ }^{2}$, Svitlana I. Danylchenko ${ }^{3}$ \\ 'SYTENKO INSTITUTE SPINE AND JOINT PATHOLOGY, KHARKIV, UKRAINE \\ 2NATIONAL UNIVERSITY OF PHARMACY, KHARKIV, UKRAINE \\ 3PETRO MOHYLA BLACK SEA NATIONAL UNIVERSITY, MYKOLAIV, UKRAINE
}

\begin{abstract}
Introduction: The biochemical markers of the connective tissue metabolism in blood serum may characterize the disturbances in inflammatory, destructive processes, and also serve the criteria for diagnostic evaluation of the state of cartilage and bone tissue of the joints in knee osteoarthritis to control the effectiveness of conservative treatment. The aim: determination of biochemical markers of connective tissue metabolism in the blood of patients with the $1^{\text {st }}$ and $2^{\text {nd }}$ stages of knee osteoarthritis in order to prove the effectiveness of the complex conservative treatment of patients with the use of low-intensity infrared laser radiation.

Materials and methods: During the study we examined 80 patients with the $1^{\text {st }}$ and $2^{\text {nd }}$ stages of knee osteoarthritis according to the Kellgren and Lawrence classification. Some patients were prescribed diclofenac sodium and glucosamine hydrochloride, others were prescribed an additional course of laser therapy.

Results: At the end of the treatment the group of patients with knee osteoarthritis who were treated with the use of laser therapy, diclofenac sodium and glucosamine hydrochloride, showed a decrease in the content of the following blood serum components: glycoproteins (by $28.9 \%$ ), sialic acids (by $28.8 \%$ ), chondroitinsulfates (by $91.3 \%$ ) due to chondroitin-6-sulfate, activity of alkaline phosphatase (by $36.1 \%$ ) compared with the indicators before treatment.

Conclusions: a more significant decrease in the inflammation and destruction of the cartilage tissue of the affected joints was observed during knee osteoarthritis treatment with the use of laser therapy than without it.
\end{abstract}

KEY WORDS: knee osteoarthritis, patients, laser therapy, glucosamine hydrochloride, sodium diclofenac

Wiad Lek 2019, 72, 5 cz. I, 802-806

\section{INTRODUCTION}

Modern views to connective tissue in the human body do not characterize it as a component of organs and systems, but present it as an integrative buffer environment. At present, it is impossible to consider connective tissue elements of joints as separate components of any pathological process, especially at knee osteoarthritis [1]. All cellular and fibrous elements of the matrix connective tissue are surrounded by gelatinous substance, which, on the one hand, participates in their integration; on the other hand, it prevents their convergence and aggregation. This substance provides metabolic processes between the blood and cells that are located outside the vascular bed. In this regard, the substance is defined as the integrative buffer metabolic environment of the connective tissue, which is known in the literature as the main substance. The degree of tissue concentration and density depends on its localization. Thus, this substance has a liquid jelly-like consistency in the intercellular space of loose unformed connective tissue, and in the hyaline cartilage tissue, it determines the elastic properties of the cartilage, which enable it to function as a shock reducer. The main substance is a multicomponent system. Its main component is glycoconjugates (glycopro- teins and proteoglycans), as well as water $[2,3]$. Proteoglycans create the structural basis of the gel, and water is a solvent for substances that are present in it, and is involved in depreciation. This water contains inorganic ions, blood proteins and urea, products of metabolism of parenchymal, myeloid and connective tissue cells, as well as products of their synthesis: soluble forms of fibrous proteins, proteoglycans, glycoproteins and complexes formed by them $[4,5]$. It is obvious that the biochemical markers determining any components of glycoconjugates in biological fluids (blood, urine) can indirectly characterize metabolic disorders in inflammatory and destructive processes. They can also become the criteria for diagnostic evaluation of the state of connective tissue elements of the body, in particular, cartilage and bone tissue joints in knee osteoarthritis both for evaluating the course of the disease and determination of the leading parts of its pathogenesis, and for monitoring the effectiveness of conservative treatment [6].

\section{THE AIM}

The aim of the study was to determine the biochemical markers of connective tissue metabolism in the blood of 
patients with the $1^{\text {st }}$ and $2^{\text {nd }}$ stages of knee osteoarthritis in order to prove the effectiveness of complex conservative treatment of patients with the use of low-intensity infrared laser radiation.

\section{MATERIALS AND METHODS}

The research was carried out on the basis of the consultative-polyclinic department, departments of conservative treatment and rehabilitation, laboratory diagnostics and immunology of the Sytenko Institute of Spine and Joint Pathology, National Academy of Medical Sciences of Ukraine. The clinical study was based on the observation of 80 patients with knee osteoarthritis of the $1^{\text {st }}$ and $2^{\text {nd }}$ stages according to the classification of Kellgren and Lawrence [7]. The duration of the disease varied from 2 weeks to 10 years. Additionally, we involved 30 volunteers, they made up a control group of practically healthy people, aged from 25 to 63 (mean age $38.6 \pm 1.8$ years).

According to anamnestic data, 14 patients (17.5\%) indicated the knee injury as a possible trigger factor in the development of knee osteoarthritis, 28 patients (35\%) reported chronic overload of the lower extremities, although 38 patients $(47.5 \%)$ failed to identify the causative factor for the development of knee osteoarthritis. Taking into account the nascence of the first symptoms of the disease, the patients were distributed as follows: 15 (18.8\%) of them suffered from knee osteoarthritis up to 1 month, 31 (38.8\%) patient had it from 1 to 12 months, 28 (35\%) patients suffered from knee osteoarthritis from 1 to 5 years, and $5(6.6 \%)$ patients had it from 5 to 10 years.

In the process of treatment all patients were divided into 2 groups. The first group consisted of 40 patients, 16 men and 24 women. The age of the patients was from 18 to 67 , and the average age was $38.2 \pm 15.7$. This group of patients was treated with the use of diclofenac sodium and glucosamine hydrochloride. The second group also included 40 patients, among whom there were 15 men and 25 women. The age of patients was from 19 to 63 , and the average age was 40.7 \pm 16.2 years. Besides diclofenac sodium and glucosamine hydrochloride this group patients were prescribed a course of laser therapy. These patients took medications twice a day. The control test was administered to patients after 30 days from the treatment beginning. Laser therapy was performed using the CM-3 (Nizhyn Laboratories of Scanning Devices) device, which generates infrared laser radiation with a wavelength of 0.8-0.9 microns, with an output of $1.5 \mathrm{~mW}$. At irradiation of knee joints, we used the scanning beam in the form of a grid $60 \mathrm{~cm}^{2}$ in size with 3-4 fields. The time of one procedure did not exceed 25-30 minutes, and the dose was $0.3 \mathrm{~J}$. The course of treatment consisted of 10 procedures. At the end of treatment, we performed the control clinical examination and determined the content of biochemical markers in blood serum. The research plan was approved by the Bioethics Committee of "Sytenko Institute of Spine and Joint Pathology", Protocols № 81 of December 20, 2010.

The activity of alkaline phosphatase in the patients' blood serum was determined by the kinetic method, glycopro- teins were assessed by Steinberg-Dotsenko method, sialic acids were measured by Hess method, chondroitin sulfates were assessed by Nemeth-Csoka method in L. I. Slutskii modification, fraction of glycosaminoglycans (GAG) were determined using M. R. Stern et al method $[8,9]$. The statistical analysis of the data was carried out using software packages Microsoft Excel XP and Statsoft Statistica 10.0. Comparison of patient groups was performed according to Student's parametric criterion and Wilcoxon's non-parametric criterion [10].

\section{RESULTS AND DISCUSSION}

The collapse of collagen and proteoglycans in the cartilage of the knee joints in knee osteoarthrosis is reflected in such biochemical markers as glycoproteins, chondroitin sulfates, and glycosaminoglycans fractions. This fact was confirmed during the experimental study on rats [11]. According to the results of biochemical study of blood in patients with the $1^{\text {st }}$ and $2^{\text {nd }}$ stages of knee osteoarthrosis, the content of glycoproteins was increased by $55 \%$, sialic acids was increased by $54.7 \%$ compared with these indicators in clinically healthy subjects. Increasing their concentration in blood indicates the presence of inflammatory process in the body, apparently due to inflammatory-destructive disorders in the joints during knee osteoarthritis. Glycoproteins of cartilage tissue perform the following functions: maintain the connection of chondrocytes with the matrix and stabilize its structure, facilitate the attachment of chondrocytes to the matrix, bind calcium, participate in the formation of joints and enhondral ossification, bind to collagen of the $2^{\text {nd }}$ type and proteoglycans, strengthen connections between agrekan and hyaluronic acid. Cartilage glycoproteins also participate in the differentiation and stabilization of the chondrocytes phenotype, bind to proteoglycans, and can be expressed in osteoarthrosis getting into the bloodstream. The content of chondroitin sulfates in patients with early stages of knee osteoarthritis was increased by 3.3 times due to the glycosaminoglycans fraction increase (chondroitin-6-sulfate) compared with clinically healthy people. The activity of alkaline phosphatase increased by $94.5 \%$ compared with clinically healthy people, which can be obviously explained by increased activity of bone tissue osteoblasts. All of the above-mentioned changes are due to inflammation and catabolism of proteoglycans of joints cartilage tissue in knee osteoarthritis (Table I).

In the study of glycoprotein content in blood serum of patients with knee osteoarthritis who were treated without laser therapy, we observed a decrease of this indicator by only $17.4 \%$ compared with the same indicator before treatment. The content of sialic acids in serum decreased by $18.6 \%$, chondroitin sulfates lessened by $25.3 \%$, and alkaline phosphatase activity dropped by $21.6 \%$ compared with the pre-treatment rates. Such a dynamics of biochemical markers data indicates a decrease in the intensity of the inflammatory process in joints during knee osteoarthritis. But it should be noted that the content of glycoproteins and 
Table I. Biochemical markers will be connective tissue in serum of blood and urine in patients with early stages of knee osteoarthritis ( $\pm \pm m)$

\begin{tabular}{ccc} 
Biochemical markers & $\begin{array}{c}\text { Control group, } \\
\mathbf{n = 3 0}\end{array}$ & $\begin{array}{c}\text { Patients with osteoarthritis, } \\
\mathbf{n = 8 0}\end{array}$ \\
\hline Glycoproteins, g/l & $0.60 \pm 0.06$ & $0.93 \pm 0.06^{* * *}$ \\
\hline Sialic acids, $\mathrm{mmol} / \mathrm{I}$ & $1.92 \pm 0.15$ & $2.97 \pm 0.07^{* * *}$ \\
\hline Chondroitin sulfates, g/l & $0.078 \pm 0.003$ & $0.256 \pm 0.015^{* * *}$ \\
\hline Total GAG, g/l & $0.123 \pm 0.009$ & $0.120 \pm 0.003$ \\
\hline I fraction GAG, g/l & $0.060 \pm 0.003$ & $0.084 \pm 0.002^{* * *}$ \\
\hline II fraction GAG, g/l & $0.036 \pm 0.004$ & $0.022 \pm 0.002^{* * *}$ \\
\hline III fraction GAG, g/l & $0.027 \pm 0.003$ & $0.014 \pm 0.002^{* *}$ \\
\hline Alkaline phosphatase, U/L & $4.00 \pm 0.04$ & $7.78 \pm 0.17^{* * *}$ \\
\hline
\end{tabular}

Notes: ${ }^{* *}-p<0.01 ;^{* * *}-p<0.001$ compared with the control group

Table II. Dynamics of biochemical markers of connective tissue in patients with knee osteoarthritis during treatment without the use of laser therapy (Me, 25\%-75\%)

\begin{tabular}{|c|c|c|c|}
\hline \multirow{2}{*}{ Biochemical markers } & \multirow{2}{*}{ Control group, $n=30$} & \multicolumn{2}{|c|}{ During the treatment, $n=40$} \\
\hline & & Before treatment & After treatment \\
\hline \multirow{2}{*}{ Glycoproteins, g/l } & 0.60 & 0.92 & $0.76 * * *$ \\
\hline & $0.48-0.72$ & $0.88-0.93$ & $0.73-0.78$ \\
\hline \multirow{2}{*}{ Sialic acids, mmol/l } & 1.92 & 2.90 & $2.36 * * *$ \\
\hline & $1.61-2.23$ & $2.80-3.00$ & $2.28-2.45$ \\
\hline \multirow{2}{*}{ Chondroitin sulfates, g/l } & 0.078 & 0.245 & $0.183 * * *$ \\
\hline & $0.072-0.084$ & $0.231-0.265$ & $0.174-0.204$ \\
\hline \multirow{2}{*}{ Total GAG, g/l } & 0.123 & 0.129 & 0.120 \\
\hline & $0.105-0.141$ & $0.121-0.140$ & $0.113-0.130$ \\
\hline \multirow{2}{*}{ I fraction GAG, $\mathrm{g} / \mathrm{l}$} & 0.060 & 0.078 & $0.069 *$ \\
\hline & $0.054-0.066$ & $0.074-0.085$ & $0.064-0.074$ \\
\hline \multirow{2}{*}{ II fraction GAG, g/l } & 0.036 & 0.029 & $0.026 *$ \\
\hline & $0.028-0.044$ & $0.028-0.032$ & $0.024-0.028$ \\
\hline \multirow{2}{*}{ III fraction GAG, g/l } & 0.027 & 0.021 & 0.024 \\
\hline & $0.021-0.033$ & $0.019-0.024$ & $0.023-0.026$ \\
\hline \multirow{2}{*}{ Alkaline phosphatase, U/L } & 4.00 & 7.60 & $5.96 *$ \\
\hline & $3.92-4.08$ & $7.00-8.25$ & $5.49-6.47$ \\
\hline
\end{tabular}

Notes: ${ }^{*}-p<0.05{ }^{* * *}-p<0.001$ compared to before treatment by Wilcoxon

sialic acids in the blood serum of this group of patients did not reach the level of clinically healthy persons. The redistribution of the fractional glycosaminoglycans composition in the group of patients who did not use laser therapy was as follows: the $1^{\text {st }}$ fraction increased by $11.5 \%$, the $2^{\text {nd }}$ fraction decreased by $10.3 \%$, the $3^{\text {rd }}$ fraction did not change compared with the indicators before treatment (Table II).

Having analyzed the results of biochemical markers we observed a significant decrease in blood levels of glycoproteins, sialic acids and chondroitin sulfates in the group of patients treated with low-intensity infrared laser radiation and drug medications. After therapy, the content of glycoproteins decreased in blood serum by $28.9 \%$ and sialic acids lessened by $28.8 \%$, which can be explained by a significant decrease in the activity of the joints inflammatory process during knee osteoarthritis. It should be noted that these rates did not differ from the values of clinically healthy subjects after the course of treatment, which indicates a higher efficiency of the treat- ment regimen with the use of laser therapy than without it. It is obvious that the activity of the inflammatory process in the connective tissue of the joints under the influence of infrared laser radiation, diclofenac and glucosamine hydrochloride decreases faster and more significantly than in patients treated without laser therapy. Decrease in the activity of degenerative processes in cartilage tissue of joints of patients in the early stages of knee osteoarthritis was confirmed by the decrease in serum chondroitin sulfate serum concentrations by $91.3 \%$ compared with the indicator before treatment, mainly due to chondroitin-6-sulfate. The alkaline phosphatase activity was decreased by $36.1 \%$ after therapy. This fact confirms the decrease in the activity of osteoblasts of the connective tissue of the affected joints. This suggests that the activity of osteoblasts of bone tissue begins to increase at the very beginning of the disease development. This means that without an appropriate early treatment using a complex of medical and physiotherapeutic measures, the pathological process in the 
Table III. Dynamics of biochemical markers of connective tissue in patients with knee osteoarthritis during treatment with the use of laser therapy (Me, 25\%-75\%)

\begin{tabular}{|c|c|c|c|}
\hline \multirow{2}{*}{ Biochemical markers } & \multirow{2}{*}{$\begin{array}{c}\text { Control group, } \\
n=30\end{array}$} & \multicolumn{2}{|c|}{ During the treatment, $n=40$} \\
\hline & & Before treatment & After treatment \\
\hline \multirow{2}{*}{ Glycoproteins, g/l } & 0.60 & 0.90 & $0.64^{* * *}$ \\
\hline & $0.48-0.72$ & $0.87-0.92$ & $0.62-0.66$ \\
\hline \multirow{2}{*}{ Sialic acids, mmol/l } & 1.92 & 2.92 & $2.08 * * *$ \\
\hline & $1.61-2.23$ & $2.08-3.05$ & $1.99-2.17$ \\
\hline \multirow{2}{*}{ Chondroitin sulfates, $\mathrm{g} / \mathrm{l}$} & 0.078 & 0.243 & $0.127^{* * *}$ \\
\hline & $0.072-0.084$ & $0.227-0.270$ & $0.118-0.140$ \\
\hline \multirow{2}{*}{ Total GAG, g/l } & 0.123 & 0.131 & 0.124 \\
\hline & $0.105-0.141$ & $0.124-0.135$ & $0.118-0.127$ \\
\hline \multirow{2}{*}{ I fraction GAG, g/l } & 0.060 & 0.082 & $0.060 * * *$ \\
\hline & $0.054-0.066$ & $0.078-0.084$ & $0.057-0.062$ \\
\hline \multirow{2}{*}{ II fraction GAG, g/l } & 0.036 & 0.030 & 0.036 \\
\hline & $0.028-0.044$ & $0.028-0.031$ & $0.035-0.037$ \\
\hline \multirow{2}{*}{ III fraction GAG, g/l } & 0.027 & 0.019 & $0.026 *$ \\
\hline & $0.021-0.033$ & $0.018-0.020$ & $0.020-0.028$ \\
\hline \multirow{2}{*}{ Alkaline phosphatase, $U$} & 4.00 & 7.85 & $5.02 * * *$ \\
\hline & $3.92-4.08$ & $6.90-8.45$ & $4.42-5.41$ \\
\hline
\end{tabular}

Notes: ${ }^{*}-p<0.05 ;{ }^{* *}-p<0.001$ compared to before treatment by Wilcoxon

joints can lead to severe metabolic disorders from the side of the cartilage, and from the bone tissue. Thus, in assessing the degree of metabolic disorders in the body of patients at early stages of knee osteoarthritis, the decline in the activity of the enzyme alkaline phosphatase has not only a diagnostic but also an important prognostic value (Table III).

Thus, having compared two groups of patients with knee osteoarthritis treated with different regimens, it can be noted that the treatment scheme with low-intensity infrared laser radiation, sodium diclofenac and glucosamine hydrochloride was more effective compared to drug therapy. Therefore, the effectiveness of the complex treatment regimen using laser radiation and medication was confirmed by a more significant decrease in the biochemical markers of inflammatory-distractive changes in the connective tissue of the affected joints in patients with knee osteoarthritis.

\section{CONCLUSION}

The obtained results showed an increase in the content of glycoproteins by $55 \%$, sialic acids growth by $54.7 \%$, chondroitin sulfates increase by 3.3 times due to chondroitin- 6 -sulfate, and alkaline phosphatase growth by $94.5 \%$ compared with those in clinically healthy individuals, indicating the inflammatory and destructive changes in knee joints in the early stages of the disease, and requiring the appointment of integrated therapy. The patients treated only with diclofenac sodium and glucosamine hydrochloride showed the content of glycoproteins in blood serum decreased by $17.4 \%$, sialic acids lessened by $18.6 \%$, chondroitin sulfates decreased by $25.3 \%$, and alkaline phosphatase activity slowed down by $21.6 \%$ after treatment compared with the indicators before treatment. The group of patients with knee osteoarthritis treated with the use of laser therapy, diclofenac sodium and glucosamine hydrochloride showed the decrease in the content of glycoproteins by $28.9 \%$, sialic acids - by $28.8 \%$, chondroitin sulfates - by $91.3 \%$ due to chondroitin-6-sulfate, and alkaline phosphatase activity slowed down by $36.1 \%$ after treatment in comparison with the indicators before treatment. The above mentioned results showed a more significant decrease in the inflammation and destruction of the cartilage tissue of the affected joints in the treatment of knee osteoarthritis after application of laser therapy than without it.

\section{REFERENCES}

1. Klement'yeva VI, Chernyshova TV, Sarycheva YuA. Otsinka stanu khryashcha i subkhondral'noyi kistkovoyi tkanyny u khvorykh na rannikh stadiyakh honartroza [Evaluation of the condition of cartilage and subchondral bone tissue in patients at the early stages of gonarthrosis]. Suchasni problemy nauky ta osvity. 2016; 4. Available from: http:// www.science-education.ru/ru/article/view?id=24907 (Russian)

2. Omel'yanenko NP, Sluts'kyy LI Spoluchna tkanyna (histofiziolohiya i biokhimiya). [Connective tissue (histophysiology and biochemistry)]. T. 1. M: Yzvestyya; 2009. 380 s. (Russian)

3. Omel'yanenko NP, Sluts'kyy LI. Spoluchna tkanyna (histofiziolohiya i biokhimiya) [Connective tissue (histophysiology and biochemistry)]. T. 2. M: Yzvestyya; 2010.600 s. (Russian)

4. Kovalenko VM, Bortkevych OP. Osteoartroz. Praktychna nastanova [Osteoarthritis Practical guidance]. K: Morion; 2010.608 s. (Ukrainian)

5. Hons'kyy Yal, Maksymchuk TP, Kalyns'kyy MI. Biokhimiya lyudyny [Human biochemistry]. Ternopil': Ukrmedknyha; 2002. $744 \mathrm{s.}$ (Ukrainian)

6. Tan'kut VA, Makolinets KV. Konservatyvne likuvannya honartrozu na rannikh stadiyakh (ohlyad literatury) [Conservative treatment of gonarthrosis in the early stages (literature review)]. Ortopediya, travmatolohiya i protezuvannya. 2013; 4: 122-7. (Russian) 
7. Kohn MD, Sassoon AA, Fernando ND. Classifications in Brief: KellgrenLawrence Classification of Osteoarthritis. Clin Orthop Relat Res. 2016 Aug; 474(8): 1886-93. Doi: 10.1007/s11999-016-4732-4.

8. Morozenko DV, Leont'yeva FS. Metody doslidzhennya markeriv metabolizmu spoluchnoyi tkanyny u klinichniy ta eksperimental'niy medytsyny [Methods of studying the markers of connective tissue metabolism in clinical and experimental medicine]. Molodyy vchenyy. 2016; 2(29); 168-72. (Ukrainian)

9. Goryachkovskiy AM. Klinicheskaya biokhimiya v laboratornoy diagnostika [Clinical biochemistry in laboratory diagnostics]. Odessa: Ekologiya; 2005.616 s. (Russian)

10. Glants S. Mediko-biologicheskaya statistika [Biomedical statistics]: Per. s angl. M: Praktika; 1998.459 s. (Russian)
11. Makolinets KV, Makolinets VI, Morozenko DV, Gliebova KV, Danylchenko SI. Biochemical markers of connective tissue metabolism in rats' blood serum with experimental knee osteoarthritis and their dynamics during conservative treatment. Wiadomości Lekarskie. 2019; LXXII(2): 193-7.

The research is a fragment of the scientific work of the Sytenko Institute of Spine and Joint Pathology for 2008-2010 "To study the influence of the complex application of low-intensity infrared laser radiation and medical preparations on the course of osteoarthritis" (State registration number 0108U000391).

\section{Authors' contributions:}

According to the order of the Authorship.

\section{Conflict of interest:}

The Authors declare no conflict of interest.

\section{CORRESPONDING AUTHOR}

\section{Dmytro V. Morozenko}

Sytenko Institute of Spine and Joint Pathology

80 Pushkinskaya Street, Kharkov, Ukraine

tel: +380677225748

e-mail:d.moroz.vet@gmail.com

Received: 10.03 .2019

Accepted: 25.04 .2019 


\title{
ON THE ISSUE OF ACCELERATED HYGIENIC ASSESSMENT OF ENVIRONMENTAL GENOTOXIC CARCINOGENS
}

\author{
Olga Ostash ${ }^{1}$, Oksana Shvager ${ }^{2}$, Liudmyla Grygorenko ${ }^{1}$, Svetlana Stepanchuk ${ }^{1}$, Nina Balenko ${ }^{1}$, Igor Chernychenko ${ }^{1}$ \\ 'STATE INSTITUTION “O.M. MARZEYEV INSTITUTE FOR PUBLIC HEALTH OF THE NATIONAL ACADEMY OF MEDICAL SCIENCES OF UKRAINE", KYIV, UKRAINE \\ 2BOGOMOLETS NATIONAL MEDICAL UNIVERSITY, KYIV, UKRAINE
}

\begin{abstract}
The aim of the work was assessment of the criterial significance of the complex of early immunological reactions of the organism, pathomorphological and genotoxic changes in the organs for the acceleration of testing and hygienic assessment of carcinogenic danger of chemical substances.

Materials and methods: Investigations were carried out in the chronic experiment on white random-bred male mice and included 2 series of the investigations: 1 - application of benz(a)pyrene on skin in different doses $(10.5 \mu \mathrm{g} ; 2.1 \mu \mathrm{g} ; 0.21 \mu \mathrm{g})$; 2 - peroral administration of benz(a)pyrene and phenol (single dose - $0.1 \mathrm{mg}$ ). Genotoxic changes in skin and forestomach were assessed with the help of micronuclear test.

Results: Under carcinogen exposure, regardless of routes of administration we determined an increase frequency of the cells with micronuclei and suppression of T-link of immune system during the first month which were characterized by a parallelism of development, unidirectional relative to carcinogenesis and presence of reliable reverse correlative connection between them. In the period between the $1 \mathrm{t}$ and the $3 \mathrm{~d}$ months we observed a stabilization of the number of cells with micronuclei and deepening of immunosuppression at the expense of the suppression of humoral chain of the immunity.

Conclusions: The obtained data became a basis for the development of methodic scheme of accelerated testing of the chemical substances under investigations for carcinogenicity and hygienic setting of genotoxic carcinogens.
\end{abstract}

KEY WORDS: micronuclear test, immunosuppression, benz(a)pyrene, phenol, acetone.

Wiad Lek 2019, 72, 5 cz. I, 807-812

\section{INTRODUCTION}

A primary prophylaxis of ecodependent forms of the malignant tumors among population is known to imply the timely revealing of carcinogenic factors and development of the measures for man's protection from their adverse effect.

According to the USA National Toxicological Program a total number of chemical substances in a man's life, industrial medium and environment exceeds 100 thousand [1]. 5-10\% of them are supposed to be the carcinogens [2].

Special urgency of this problem is illustrated by the fact that only nearly 3000 chemical compounds were studied from the whole number of chemical substances. Carcinogenicity was demonstrated in the experiments on the animals and in the epidemiological investigations for almost 1000 of them. At present time 113 agents which contain chemical substances, including medicinal, and also biological, household, and physical factors, industrial processes are considered by the experts of the International Agency for Cancer Research as the human carcinogenic agents and 66 are probably carcinogenic [3]. At the same time their control and assessment become complicated because of the absence of correspondent hygienic standards in the Ukrainian base. By present time hygienic standards have been adopted only for 17 compounds and only for 5 taking into account the carcinogenic criteria of damage [4].
Mentioned circumstances tell about permanent necessity of the intensification of this process. In this connection we propose one of possible approaches which must promote a solution of the issue of the accelerated hygienic setting. For the determination of such an approach we performed experimental investigations, including a study of the complex of joint immunological reactions of the organism, pathomorphological and genotoxic changes in the organs of the experimental animals at different ways of entry (skin application and peroral administration) of carcinogenic and toxic substance.

\section{THE AIM}

The aim of the work was assessment of the criterial significance of the complex of early immunological reactions of the organism, pathomorphological and genotoxic changes in the organs for the acceleration of testing and hygienic assessment of carcinogenic danger of chemical substances.

\section{MATERIALS AND METHODS}

Experiment was carried out on the white random-bred male mice with a body weight of 15-20 $\mathrm{g}$ at the beginning of the experiment., purchased in the nursery "Phoenix" (Kiev) and included 2 series of research: the $1^{\text {st }}$ - application of benz(a)pyrene on the skin; the $2^{\text {nd }}$ - peroral administration 
of benz(a)pyrene (BP) and phenol. For administration we used the substances (BP, phenol, acetone) produced by SIGMA-ALDRICH, Germany.

For application we took 160 mice divided into 5 groups. Application of BP in the form of acetone solution (in the volume of $0.1 \mathrm{ml}$ ) was carried out with the help of pippet-doser on the areas of the skin on interscapular part of previously sheared back. Single doses of BP made up 0.21 $\mu \mathrm{g} . ; 2.1 \mu \mathrm{g} ; 10.4 \mu \mathrm{g}$. Two groups of mice were the control ones: mice of the first group were put on the applications of the solutions (acetone) in the same volume, the second group was an intact control. Substances were applied 5 times a week during 11 months.

The second series of the experiment was performed on 195 mice divided into 4 groups which contained intact control, control of the solvent - triethylene glycol (TEG) and 2 groups of animals taking BP or phenol isolatedly in the equal single doses of $0.1 \mathrm{mg}$. Substances in the volume of $0.2 \mathrm{ml}$ were administrated intragastrically on an empty stomach by the probe once a week up to the end of the experiment lasted for 14 months.

Periodically in a day after last exposure of the substance, on the $8^{\text {th }}, 22^{\text {nd }}, 90^{\text {th }}$ days and after 6,11 months from the beginning of the experiment at the skin applications, $9^{\text {th }}$, $31^{\text {st }}, 95^{\text {th }}$, days and $6,11,14$ months at peroral administration, 6 animals from each group were killed by means of dislocation of the vertebrae of the cervical part of the spinal column and took the material for study. The work with the animals was performed in accordance with the rules of local Committee for Bioethics [5].

Mutagenic effect was determined with the help of micronuclear $(\mathrm{MN})$ test $[6,7]$ taking into account literary data about its advantages [8]. Method is a useful and informative enough short-term test (STT) for the identification of genotoxicity, it is relatively simple, available, economically profitable, it allows to explore a large number of chemical substances for a short period of time. Taking into account a coincidence of organospecificity of MN test with the localization of carcinogenic effect [9], on the one hand, and an advantage of local character of the BP exposure, on the other hand, mice's skin and forestomach were taken for the study of the mutagenic effect and the morphological changes.

ZEISS and BIOLAM light-optical microscopes at the magnifications $\times 1000$ and $\times 900$, respectively, were used for the analysis of the number of the cells with MN. Identification of $\mathrm{MN}$ was performed by the criteria presented in literature [10].

Immunological disorders were determined simultaneously with the determination of genotoxic effect by means of the determination of the content of leucocytes in the peripheral blood and their cell composition; amount of $\mathrm{T}$ - and B - lymphocytes, natural cells-killers, and the reactions as well: degranulation of basophils (after Shelly), inhibition of the spreading of macrophages, phagocytosis, precipitation of the circulating immune complexes by the solution of polyethylene glycol.

Pathomorphological investigations of skin and forestomach were performed with the use of pathohistological technique of the production of histologic preparations by means of the paraffin embedding of the organs after their fixation in the $10 \%$ stabilized neutral formalin. Histological sections were stained with hematoxylin-eosine.

Statistical analysis of the obtained data was performed using Student's $t$-test. Values are reported as mean \pm standard error. Significance level was set at $\mathrm{P} \leq 0.05$. Existence of the connections between the parameters of the frequency of the cells with $\mathrm{MN}$ and immunosupression was determined after Pirson correlative analysis.

\section{RESULTS AND DISCUSSION}

By the results of the analysis of all organism's reactions we revealed the most informative indices, their character and level under exposure of the carcinogen (BP) and toxic compounds (phenol, acetone) in the generalized form are presented in the Table I.

At both ways of BP administration we identified the following general regularities.

Thus genotoxic effect (existence of the cells with $\mathrm{MN}$ ) in the experimental animals of all groups, received the applications of the substances, is registered in the first days of the experiments (the 8th day); number of the cells with $\mathrm{MN}$ depends upon a single dose of carcinogen and is increased during the first month of exposure; maximum effect is observed at the application of the largest does of BP (10.5 $\mu \mathrm{g})$, while minimum dose $(0.21 \mu \mathrm{g})$ didn't have any effect: frequency of the cells with MN didn't significantly differ from the level in the animals of intact control. Genotoxic effect wasn't revealed also in the mice receiving acetone applications. Frequency of the cells with MN didn't differ from the observed one in the intact mice. It agrees with the literary data that acetone is not a mutagen [11].

Henceforth, in the period between the first and the third months we revealed a stabilization of the number of the cells with $\mathrm{MN}$ even just at the lower levels in comparison with the previous period. This may be connected with the existence of a definite critical value of cytogenetic effect for each dose.

A similar dynamics of the exhibition of the mutagenic effect depending on the total dose and time of exposure took place also at peroral administration of BP.

Dose dependence of genotoxic effect, established by us, correlates with the results of other authors, obtained at the study of carcinogenic compounds of different chemical classes [11-13], and it is a reflection of the general regularity of the effect of mutagenic agents [14-15]. Similar peculiarity of the dynamics of genotoxic effect - increase of the number of the cells with $\mathrm{MN}$ and further stabilization of the indices after reaching a definite level was observed in the cells of thyroid gland (TG) and polychromatophil erythrocytes (PCE) of the rat's bone marrow after repeated administrations of N-nitro-N-methyl urea [16]. A level of the frequency of the cells with MN was different in the cells TG and PCE at the moment of stabilization. Definite reasons of this phenomenon are unknown. However, taking into account the fact that levels of stabilization of the cells with 
Table I. Comparative characteristics of appearing of the genotoxic and immunological changes in random-bred white male mice after benzo(a)pyrene and toxic compounds (acetone, phenol) administration

\begin{tabular}{|c|c|c|c|c|c|c|c|c|}
\hline \multirow{3}{*}{$\begin{array}{c}\text { Rout of } \\
\text { administration }\end{array}$} & \multirow{3}{*}{ Substances } & \multirow{3}{*}{$\begin{array}{l}\text { Single } \\
\text { dose }\end{array}$} & \multicolumn{6}{|c|}{ Effects } \\
\hline & & & \multicolumn{3}{|c|}{ Number of micronucleated cells, \%o } & \multicolumn{3}{|c|}{ T-cells, \% } \\
\hline & & & Day 8; 9 & Day 22; 31 & Day 90; 95 & Day 8; 9 & Day 22; 31 & Day 90; 95 \\
\hline \multirow{5}{*}{ Dermal } & Benzo(a)pyrene & $0.21 \mu \mathrm{g}$ & $0.50 \pm 0.29$ & $0.50 \pm 0.34$ & $0.60 \pm 0.40$ & $32.16 \pm 2.32$ & $25.83 \pm 0.60 *$ & $24.67 \pm 0.33^{*}$ \\
\hline & Benzo(a)pyrene & $2.1 \mu \mathrm{g}$ & $1.50 \pm 0.29 *$ & $3.00 \pm 0.26^{*}$ & $2.67 \pm 0.21^{*}$ & $32.83 \pm 2.12$ & $26.83 \pm 0.87^{*}$ & $24.50 \pm 0.48^{*}$ \\
\hline & Benzo(a)pyrene & $10.5 \mu \mathrm{g}$ & $2.5 \pm 0.29 *$ & $5.83 \pm 0.31^{*}$ & $3.20 \pm 0.58^{*}$ & $32.78 \pm 2.16$ & $26.33 \pm 0.61^{*}$ & $22.60 \pm 1.50^{*}$ \\
\hline & Acetone & $0.2 \mathrm{ml}$ & $0.25 \pm 0.25$ & $0.40 \pm 0.24$ & $0.50 \pm 0.22$ & $32.67 \pm 2.15$ & $22.17 \pm 0.91^{*}$ & $27.17 \pm 0.60$ \\
\hline & Intact control & & $0.25 \pm 0.25$ & $0.40 \pm 0.24$ & $0.50 \pm 0.22$ & $32.33 \pm 2.20$ & $30.50 \pm 0.99$ & $29.33 \pm 0.49$ \\
\hline \multirow{4}{*}{ Peroral } & Benzo(a)pyrene & $0.1 \mathrm{mg}$ & $1.33 \pm 0.21^{*}$ & $2.83 \pm 0.31^{*}$ & $2.33 \pm 0.33^{*}$ & $31.16 \pm 2.32$ & $17.83 \pm 0.70^{*}$ & $18.67 \pm 0.76^{*}$ \\
\hline & Phenol & $0.1 \mathrm{mg}$ & $0.33 \pm 0.21$ & $0.50 \pm 0.22$ & $0.33 \pm 0.21$ & $30.17 \pm 3.31$ & $19.67 \pm 1.05^{*}$ & $19.33 \pm 0.84$ \\
\hline & Triethyleneglycol & $0.2 \mathrm{ml}$ & $0.50 \pm 0.022$ & $0.50 \pm 0.022$ & $0.67 \pm 0.21$ & $31.00 \pm 0.55$ & $27.50 \pm 0.89$ & $14.67 \pm 0.56^{*}$ \\
\hline & Intact control & & $0.33 \pm 0.21$ & $0.33 \pm 0.21$ & $0.50 \pm 0.22$ & $29.83 \pm 5.78$ & $30.00 \pm 0.55$ & $21.83 \pm 0.91$ \\
\hline
\end{tabular}

Notes: ${ }^{*}$ - significant change of indexes of compared to the control $(p<0.05)$.

$\mathrm{MN}$ are unequal depending on the size of mutagen dose and also examined tissues, we can assume that it is connected both with a different degree of caused injures

and functional state of the protection mechanisms of the organism and organ-tissue-specific peculiarities of these processes.

At the analysis of immunologic reactions we revealed that in the early period of the exposure of carcinogen (end of the first month) T-cell chain of the immunity was the most sensitive early parameter, it revealed by its suppression (a decrease of the relative number of T-lymphocytes). With an increase of the time of BP exposure up to three months we noted an increase of immunosupression at the expense of the addition of the suppression of humoral chain of the immunity (a decrease of the relative number of B-lymphocytes). Immunotoxicity by the type of immunosupression is inherent in the majority of chemical carcinogens [17-18].

According to the retrospective studies, the compounds - immunotoxicants for the rodents, are concurrently carcinogenic for them. At the same time the issues what particularly immunotoxic parameters are connected with the potential carcinogenicity is unsettled in full [19].

Literary data on the BP immunotoxicity concerning its exhibition have not a uniform character and are concerned both with cell and with humoral chains of immunity and the factors of unspecific resistance as well $[17,20]$. It may be connected with the different conditions of the performance of the experiments and with a use of different doses and time of carcinogen exposure in particular, and also methods and indices characterizing a state of immune system.

According to the modern points of view, there are two main mechanisms in the basis of immunosuppression induced with the polycyclic aromatic hydrocarbons (PAH) including BP. One of them is realized by means of the activation of aryl hydricarbon receptor (AhR), another one is connected with an capacity of the carcinogens to increase the intracellular calcium concentration in the immune cells, possibly due to protein - tyrosine - kinase activation by PAH. In any case, antigen and mitogen recep- tor signaling pathways are altered leading to proliferation and/or apoptosis of immune cells [17, 21-23].

At the comparison of the revealed indices one can see ( $\mathrm{Ta}-$ ble I) that increase of mutagenic effect (number of the cells with $\mathrm{MN}$ ) was accompanied by the parallel development of immunosupression during the first month. That is, these two phenomena, typical for the effect of chemical carcinogens, are intercommunicated between each other and have a unidirected character relative to carcinogenesis. This is proved by the results of performed correlative analysis after the Pirson method they indicate the reliable reverse correlative connection between them. Coefficients of correlation between parameters of mutagenic effect and immunosupression made up : for BP -10.5 $\mu \mathrm{g}$ $\mathrm{r}=(-0.87), \mathrm{p}<0.01 ; 2.1 \mu \mathrm{g} \mathrm{r}=(-0.89), \mathrm{p}<0.01$ (skin application); for $0 / 1 \mathrm{mg} \mathrm{r}=(-0.80), \mathrm{p}<0.05$ (peroral administration).

According to the present formed point of view there are mechanisms in the organism, controlling integrity of genome at different levels - from molecular up to organism, reparative processes and immune supervision, in particular, fall into them [11].

According to the modern point of view on the immunobiology of the tumor there are three phases of interconnection of the tumor and the immune system (phase of immunological supervision, phase of equilibrium and phase of slipping off), each of them correlates with a definite stage of disease [24]. The early period of the exposure of carcinogens falls in the first phase, it is the beginning of single mutant and tumor cells which are revealed and eliminated from the organism with the help of the components of congenital and adaptive immunity. T- and B-lymphocytes fall into the last one as well. From the point of view of anti-tumor protection a cell link is assessed as the most significant one in this phase.

Obviously that violation of reparation and suppression of the function of immune system as one of the key factors of genetic instability may lead to the accumulation of genetically injured cells, including mutated ones which contain $\mathrm{MN}$, in the tissues of organism, that is observed at tumor growth [11].

It is known that carcinogenic PAH even in the early terms of the exposure cause injuries of the cells, accompanied with 
a suppression of reparative processes, and as a result of this the injured cells are preserved in the tissues for a long time.

The pathomorphologic research, performed by us in the early period, point to this possibility, they indicate changes in the organs of mainly dystrophycal and atrophic character with the separate small foci of epithelium proliferation.

Taking into account mentioned literary data and results of our pathmorphological and immunological investigations we consider that an increase of the number of cells with MN during the first month is connected with a violation of the processes of reparation and suppression of T-cell chain of the immunity.

It should be mentioned that there are no many investigations devoted to the simultaneous study of joint changes of genotoxic effect by the indices of MN-test, in particular, and immunological reactions of the organism and their interconnection both in the experiment and on a man.

Thus it is informed about interconnection between frequency of the cells with $\mathrm{MN}$ and immunosuppression among population: the persons with a stable high level of the number of the cells with $\mathrm{MN}$ in the erythrocytes of peripheral blood had simultaneously an immunosupression $[11,25]$. Correlation between individual levels of the number of the cells with $\mathrm{MN}$ and specific immunological indices was revealed also in the workers of rubber industry contacting with many carcinogenic compounds [26].

In comparison of the results of genotoxic and pathomorphologic research were carried out an increase of the number of the cells with $\mathrm{MN}$ in the late period of the experiment (the sixth month) after application of BP in the animals with pathomorphological diagnostics of the development of proliferative-hyperplastic changes and skin tumors.

A similar character of the changes of genotoxic effect was determined also at the peroral administration of $\mathrm{BP}$ in the period of the beginning of pretumor changes and tumors in the mice's forestomach in eleven and fourteen months from the beginning of the experiment. That is, at this time a growth of the indices of genotoxicity was connected not with a dose but with the morphological pretumor changes and tumors, that was connected with a growth of the unbalance between processes of proliferation and apoptosis, violation of differentiation of the cells and high level of instability of genome in the process of carcinogenesis $[27,28]$.

It is important to mention that increase of the frequency of the cells with $\mathrm{MN}$ in exfoliative epithelium in connection with proliferative-hyperplastic changes in mucous membrane of oral cavity (hyperplasia, metaplasia, dysplasia), considered as the pretumor states, were determined in the people as well [29].

As for hematologic and immunologic indices, they didn't differ from the indices revealed in the mice of intact control in the late period.

Unlike carcinogen, under exposure of toxic substances (phenol and acetone) the mutagenic and carcinogenic effects were not observed, and suppression of T-and B-chains of the immunity and factors of unspecific resistance, noted in the early period, had a transient character and didn't appear at the end of the $3^{\mathrm{d}}$ month.
Thus we consider that the obtained results - parallelism of development and unidirection relative to carcinogenesis of the changes of the indices of mutagenic effect and immunologic reactions and also a presence of the reliable correlative link between them in early period (during 1 month) only under exposure of BP doses which induced the tumors of skin and forestomach is an evidence of a possibility of the use of the complex of these indices as an early criteria of the carcinogenicity of genotoxic chemical compounds. It is expediently to perform the experiment during 3 months. It ensures, on the one hand, a determination of the typical features of chemical carcinogenesis - mutagenic effects and immunosupression, and, on the other hand, differentiation with toxic substances.

Materials of the performed research became a basis for the development of the methodic scheme of accelerated testing of the chemical substances for carcinogenicity, studied for the first time, and regulation of chemical genotoxic carcinogens at the presence of the data on carcinogenic potential (Figure 1). As we can see, a developed scheme includes a performance of the experiment for the revealing of dose-effect dependences of the manifestation of the complex of early changes of immune system by the type of suppression and mutagenic effect by polyorgan micronuclear method with a further assessment of carcinogenic properties of the substances and their doses.

Unlike other systems for prediction of the carcinogenicity of chemical substances by genotoxic indices proposed by other authors and also with a use of the latter in the complex with the medium-term tests [30] our scheme includes an additional early attributive index (immunological) encouraging more exact identification of carcinogenic effect.

We consider a use of the foregoing complex allows to move to a new level of the quality of the data of the experimental research both from the point of view of acceleration and increase of the reliability of testing and screening of carcinogenic chemical compounds with genotoxic mechanisms of effect and from the accelerated assessment of carcinogenic activity of their doses for hygienic setting.

\section{CONCLUSIONS}

In the experiments on mice at different ways of administration (application on skin, peroral administration) of benzopyrene and toxic compounds (acetone, phenol) we revealed definite regularities of the changes of genotoxic and immunologic indices which manifestations depended upon dose, duration of exposure and character of affecting substances.

Under effect of carcinogen, we determined an increase of mutagenic effect (frequency of the cells with micronuclei) and suppression of T-link of immune system during the first month which were characterized by a parallelism of development, unidirection relative to carcinogenesis and presence of reliable reverse correlative connection between them. In the period between the $1 \mathrm{t}$ and the $3 \mathrm{~d}$ months we observed a stabilization of the number of cells with micronuclei and deepening of immunosuppression at the expense of the suppression of humoral chain of the immunity. 


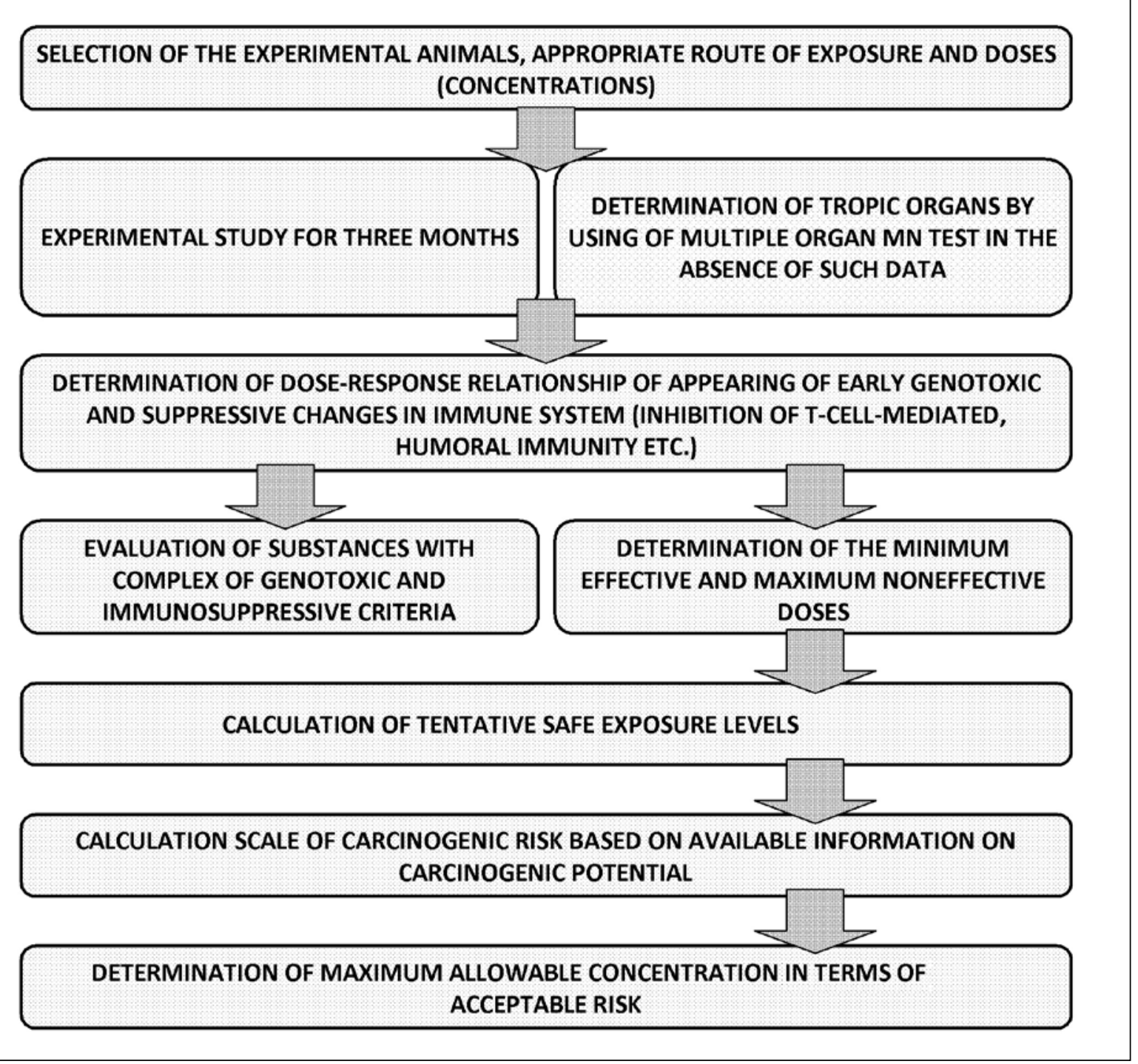

Figure 1. The main stages of rapid testing and hygienic regulation of genotoxic carcinogens

Dynamics of the revealed changes under effect of toxic compounds (acetone, phenol) has another regularities of manifestations of genotoxicity and immunologic reactions. There was no genotoxic effect and a number of the cells with micronuclei didn't differ significantly from the quantities of a spontaneous level in the intact animals, and indices of suppression of T-chain and unspecific resistance of the organism, observed during the first month, had a transitory character and regenerated up to the levels noticed in the intact animals for 3 months.

Revealed differences in the effect of carcinogen and toxic substances allow to consider a complex of the indices of genotoxicity and immunosuppression as possible early criteria of carcinogenicity of chemical substances. Use of this complex ensures a possibility of the determination of carcinogenic properties of chemical compounds, their differentiation from toxic compounds in the experiment during 3 months.

The obtained data became a basis for the development of methodic scheme of accelerated testing of the chemical substances under investigations for carcinogenicity and hygienic setting of genotoxic carcinogens.

\section{REFERENCES}

1. National Toxicology Program (NTP). Technical Report Series 1-567, 1976-2011. doi: http: // nttp.niehs.nih.gov.

2. Sychova LP. Otsenka mutagennyih effektov faktorov okrujayuschey sredyi poliorgannyim mikroyadernyim testom [Evaluation of the mutagenic effects of environmental factors using polyorgan micronucleus test]. Vestnik Rossiyskoy AMN. 2006; 7: 27-32 . $(\mathrm{Ru})$.

3. Review of Human Carcinogens: Chemical Agents and Related Occupations, IARC Monographs, Vol. 100 (F).

4. Perelik rechovin, produktiv, virobnichih protsesiv, pobutovih ta prirodnih faktoriv, kantserogennih dlya lyudini [Hygienic standard 1.1.2.123. List of substances, products, production processes, household and environmental factors, carcinogenic to humans]. Kyiv: Hygienic standard Publ., 2006. 16 p. (UA)

5. Kozhem'yakin Yu, Hromov OS, Filonenko MA etal. Naukovopraktichni rekomendatsiï $z$ utrimannya laboratornih tvarin ta robit iz nimi [Scientific and practical advice on the maintenance of laboratory animals and work with them]. Kiev: Avitsena.; 2002. 152p. (UA) 
6. Otsenka mutagennoy aktivnosti faktorov okrujayuschey sredyi v kletkah raznyih organov mlekopitayuschih mikroyadernyim metodom: metodicheskie rekomendatsii [Evaluation of mutagenic activity of environmental factors in the cells of various organs of mammals with micronucleus method: the guidelines. methodological recommendations]. Interdepartmental Scientific Council for Human Ecology and Environmental Health of the Russian Federation. Moscow: 2001. 22 p. (Ru)

7. Chernichenko IA, Balenko NV, Ostash OM etal. Sposib otrimannya izolovanih klitin z mikroyadrami iz epiteliyu shkiri [Method of getting isolated cells with micronucleus of the skin's epithelium]. Patent, 54040 Ukraine, IPC G01N 1/28. Number 20, 2010. (UA)

8. Zhurkov VS, Sycheva LP, Ingel'Fl etal. Harmonization with international approaches to guidance documents on methods of assessment of the mutagenic properties of chemical environmental factors. Gig Sanit. 2013 Nov-Dec;(6):49-52.

9. Sycheva LP, Zhurkov VS, Rakhmanin YuA. Novyiy podhod k diagnostike mutagennyih i kantserogennyih svoystv okrujayuschey sredyi [A new approach to diagnosing the mutagenic and carcinogenic properties of environmental factors]. Hygiene and Sanitation. 2003: 6: 87-91. (Ru)

10. Otsenka tsitologicheskogo i tsitogeneticheskogo statusa slizistyih obolochek polosti nosa i rta u cheloveka: metodicheskie rekomendatsii [Evaluation of cytological and cytogenetic status of the nasal and oral of mucous in humans: methodological recommendations]. Scientific Council of Medical Sciences and the Ministry of Health and Social Development in related to Human Ecology and Environmental Hygiene in Russian. The Russian Federation. Moscow: 2005. (Ru)

11. Ilyinskikh NN. Mikroyadernyiy test i tsitogeneticheskaya nestabilnost [Micronucleus test and cytogenetic instability]. Tomsk: 1992.340 p. (Ru)

12. Sycheva LP, Kovalenko MA Sheremetyeva SM, et al. Izuchenie mutagennogo deystviya dioksidina poliorgannyim mikroyadernyim testom [Study of mutagenic action of dioksidine by polyorganic micronucleus test]. Bulletin of Experimental Biology and Medicine.2004; 8: $188-190(\mathrm{Ru})$

13. Kirsch-Volders M , Bonassi S, Knasmueller S etal. Commentary: Critical questions, misconceptions and a road map for improving the use of the lymphocyte cytokinesis-block micronucleus assay for in vivo biomonitoring of human exposure to genotoxic chemicals-A HUMN project perspective, Mutation Research. 2014;759:49-58.

14. Bochkov NP, Durnev AD. Ochevidnoe i neveroyatnoe v predstavleniyah o mutatsionnom protsesse u cheloveka [Obvious and incredible visions of mutation process in humans]. Hygiene and Sanitation. 2011; 5: 9-10 (Ru)

15. Sucheva LP, Mikhailova RI, Beliaeva NN etal. Study of cytogenetic and cytotoxic effect of non-contact electrochemically-activated waters in the five organs of rats, Gig Sanit. 2014 Nov-Dec;93(6):46-51.

16. Pavlov AV, Gansbursky MA Gansbursky AN, et al. Ispolzovanie mikroyadernogo testa dlya vyiyavleniya genotoksicheskih povrejdeniy schitovidnoy jelezyi [Using the micronucleus test to detect genotoxic damage the thyroid gland]. Bulletin of ecology, biology and medicine. 2006; 1: 99-102 (Ru).

17. Opinion of the Scientific Committee on Food on the risks to human health of Polycyclic Aromatic Hydrocarbons in food/Scientific Committee on Food. Brussels-Belgium.,2002.84 p.

18. Wen H, Yuan L, Wei C etal. Effects of combined exposure to formaldehyde and benzene on immune cells in the blood and spleen in Balb/c mice. Environ Toxicol Pharmacol. 2016; 45:265-73.
19. Luster MI, Portier C, Pait G, et al. Risk Assessment in Immunotoxicology. Fundam. and Appl. Toxicol. 1992; 18: 2-200.

20. Raw WN. Environmental and occupational megicine. Philadelfia-New York:1998.1437p

21. Burchiel SW, Luster MI. Signaling by environmental polycyclic aromatic hydrocarbons in human lymphocytes. Clin. Immunol., 2001; 1: 2-10.

22. Near R, Matulka KK, Schneider A, et al. Regulation of pre-B cell apoptosis by AhR/transcription factor expressing stromal/adheren T-cell. Proc. Soc. Exp. Biol. Med., 1999; 221: 242-252.

23. Davila DR, Davis DP, Campbell K, et al. Role of alterations in $\mathrm{Ca}++$ associated signaling pathways in the immunotoxicity of benzo[a]pyrene in subacute toxicity study after oral exposure in rats. Toxicol. Sci., 1995; 45: 101-126.

24. Granov AM, Molchanov OE. Kantserogenez i immunologiya opuholi. Fundamentalnyie i klinicheskie aspektyi [Carcinogenesis and tumor immunology. Basic and clinical aspects]. Problems of Oncology. 2008; 4: 401-409 (Ru)

25. Ilyinskikh NN, Kudryavtsev DP, Perepechaev LYa, etal. Svyaz kolichestva eritrotsitov s mikroyadrami s immunologicheskim statusom u cheloveka [Connection of micronucleated red blood cell count with immunological status in humans]. Cytology and Genetics. 1990; 6: 20-24 (Ru)

26. Somorovska M, Szabova E, Vodicka P, et al. Biomonitoring of genotoxic risk in workers in a rubber factory: comparison of the Comet assay with cytogenetic methods and immunology. Mutat. Res. 1999; 2: 181-192.

27. Agapova LS, Kopnin BP. Progress v izuchenii molekulyarnyih osnov onkogeneza i novyie sposobyi kontrolya opuholevogo rosta [Progress in understanding moleculr mechanism of oncogenesis and novel methods of tumor growth control]. Bulletin of the Russian Academy of Medical Sciences. 2007; 11: 3-9 (Ru).

28. Galitsky VA. Kantserogenez i mehanizmyi vnutrikletochnoy peredachi signalov [Carcinogenesis and intracellular signaling mechanisms]. Problems of Oncology. 2003; 3: 278-293 (Ru).

29. Rosin MP. The use of the micronucleus test on exfoliated cells to identify anti-clastogenic action in humans: a biological marker for the efficacy of chemopreventive agents. Mutat. Res., 1992; 267(2): 265-276.

30. Sycheva LP ZhurkovVS, Rahmanin Yu.A., etal. Novyiy podhod k diagnostike mutagennyih i kantserogennyih svoystv okrujayuschey sredyi [A new approach to the diagnosis of mutagenic and carcinogenic properties of the environment]. Hygiene and Sanitation. 2003; 6: 87-91(Ru).

\section{Authors' contributions:}

According to the order of the Authorship.

\section{Conflict of interest:}

The Authors declare no conflict of interest.

\section{CORRESPONDING AUTHOR Olga 0stash}

State Institution "0.M. Marzeyev Institute

for Public Health of the National Academy of

Medical Sciences of Ukraine", Kyiv, Ukraine

tel: +380683012702

Received: 14.03 .2019

Accepted: 26.04 .2019 


\title{
PREDICTION OF RISK IN DEPENDENCE FROM DISEASE AND WORKING CONDITIONS OF EMPLOYEES WHICH EMPLOYED IN EXTRACTION OF IRON ORE
}

\author{
Oksana V. Oriekhova, Oleksandr I. Pavlenko \\ SI «UKRAINIAN SCIENTIFIC RESEARCH INSTITUTE OF INDUSTRIAL MEDICINE», KRYVYI RIH, UKRAINE
}

\begin{abstract}
Introduction: The assessment and management of occupational risks has the purpose conducting of analysis and assessing the health of workers by timely, complete and adequate passing of the previous and periodic medical examination, registration and analysis of morbidity and establishment of cause-and-effect relationship with working conditions. The aim:Prediction of occupational risk based on study of diseases with temporary disability was conducted in the analysis of disability sheets and the report on causes of temporary disability in workers extraction of iron ore.

Materials and methods: Hygienic, epidemiological and statistical methods of research were used to solve this purpose.

Results: In the workers involved in the extraction and processing of iron ore the level of morbidity with temporary disability is from $81,87 \pm 3,64$ to $98,06 \pm 2,49$ cases ( $p<0,05$ ), from $806,53 \pm 40,51$ to $1217,67 \pm 63,50$ days of disability $(p<0,05)$, the average duration of one case was from $10,00 \pm 1,42$ to $12,39 \pm 0,24$, and according to the scale of assessment of the indicators of morbidity rates by L. E. Notkin characterized in days as average; in cases as high. The calculation of morbidity rates (L and OR) makes it possible to predict what degree and class of harmful production factors can lead to the corresponding levels of morbidity. The proposed forecasting method makes it possible to predict the categories of occupational risk in depending on the class of working conditions and the relative risk of morbidity with temporary disability.

Conclusions: Studying the morbidity and condition of working conditions is the basis for predicting occupational risk for effective management decisions.
\end{abstract}

KEY WORDS: labor conditions, morbidity, extraction and processing of iron ore, mining and metallurgical complex

Wiad Lek 2019, 72, 5 cz. I, 813-816

\section{INTRODUCTION}

The health of an employee should be considered as an indispensable condition that directly affects the production process and the quality of the manufactured product: «a sick worker cannot produce qualitative goods", and ensuring the health of such an employee is the most important function of not only the state but also the employer, it is the basis of social policy, which in practice is realized by creating safe working conditions and healthy living conditions [1].

Creation and development of a system of occupational medicine at an industrial enterprise contributes to strengthening and maintaining the highest degree of physical, mental and social well-being of workers in all spheres, prevention of working deviations in health condition, which caused by working conditions, protection of workers from risks, caused by harmful production factors, placement and preservation of workers in the production environment, what adapted to their physiological and psychological abilities, adaptation of work to the workers and everyone working to his or her work (BOO3 i MOП, 1995) $[1,2]$.

The assessment and management of occupational risks has the purpose conducting of analysis and assessing the health of workers by timely, complete and adequate pass- ing of the previous and periodic medical examination, registration and analysis of morbidity and establishment of cause-and-effect relationship with working conditions, informing about the risk of the subject of labor law, and the management of occupational risks by improving working conditions, reducing exposure, dose rates, and also "time protection" $[3-4,6]$. When assessing risk, great attention is given to the quantitative assessment of losses from risk for select the most effective management measures, that is prevention, what in last years, is a priority of research and development in occupational medicine $[7,8]$.

An important prerequisite for the development and implementation of prophylactic measures which are aimed to improving the health of workers and increasing of labor productivity is the establishment of an objective connection between the morbidity of workers and sanitary and hygienic working conditions, which is based on an understanding of the causes which influencing the morbidity, and on reliable evidence of the impact on the morbidity not only of biological, family and domestic, medical and preventive factors, but also of industrial and professional [9].

The frequency of cases of temporary disability in diseases is of paramount importance, due to the fact that the change in the frequency of cases is evidence of the impact of working conditions on the health of workers [9]. 
Reducing morbidity with temporary disability has not only social but also economic value, as it promotes the preservation of a significant number of workers in the production sector.

At present, this problem is incredibly relevant, which is related to the demographic situation in the country, as a result of which the restoration of labor resources is decreasing. However, to adequately address the issues of health of workers and the development of health measures, which aimed at reducing morbidity, it is necessary to understand the reasons, that support its high level, and reliable evidence of the impact on it of certain factors, first of all production -professional, neutralizing or mitigating the action of which is most realistic [9].

Thus, the results that can be obtained during the analysis of the morbidity with temporary disability of workers of the abovementioned professions can be considered as the initial data and will allow to set up dynamic monitoring, monitoring of the health status of each particular worker in order to timely identify the initial manifestations of occupational disease and obligatory conduct of restorative treatment in order to maintain the worker's ability to work in his profession.

\section{THE AIM}

Prediction of occupational risk based on study of diseases with temporary disability was conducted in the analysis of disability sheets and the report on causes of temporary disability in workers extraction of iron ore.

\section{MATERIALS AND METHODS}

Hygienic, epidemiological and statistical methods of research were used to solve this purpose. The study of morbidity with temporary disability was carried out in the analysis of disability sheets and a report about the causes of temporary disability. To obtain more reliable data, temporary disability was studied over the last 5 years (2010-2014) in «year-round» workers (28970 people) of underground, open mining of iron ore, and in workers of the control group (2090 people). The analysis of indicators of morbidity with temporary disability is conducted taking into account cases and days of disability for 100 employees on average over the last 5 years, as well as for nosological forms according to the «International statistical classification of diseases, injuries and causes of death of X revision». The level of morbidity with temporary disability was estimated in accordance with the scale of assessment of morbidity rates by L. E. Notkin. Professional risk of disease development was determined according to the methodology for assessing occupational risk for worker's health.

Material handling was performed using the standard Microsoft Office Excel program package. The obtained data had a normal law of probability distribution, and, for their analysis, mainly, parametric criteria of Student and Fisher were used. The number of observations was sufficient to obtain unmatched estimates of the first two points: the arithmetic mean (M) and the mean square deviation (d). In order to compare the mean values of the quantitative indices, in the normal distribution of the sign used t-criterion of Student. The significance level was considered reliable $\mathrm{p}<0,05$ with reliability of $95 \%$.

All the research methods used were considered at the Ethics Commission of the Institute and allowed for use during the organization and conduct of research.

\section{RESULTS AND DISCUSSION}

During the analysis of morbidity with temporary disability for workers of the mining it was established that the number of workers occupied by underground mining of iron ore the level of morbidity with temporary disability is $81,87 \pm 3,64$ cases $(p<0,05), 806,53 \pm 40,51$ days of disability $(p<0,05)$, the average duration of one case is $10,00 \pm 1,42$, which is in 1,39 times higher than in cases and in 1,29 times than in days of disability than in workers of the control group and according to the scale of assessment of morbidity rates by L. E. Notkin characterized in days as average; in cases as high (table I).

For employees engaged in open mining of iron ore the level of morbidity with temporary disability is $98,06 \pm 2,49$ cases $(p<0,05), 1217,67 \pm 63,50$ days of disability $(p<0,05)$, the average duration of one case is $12,39 \pm 0,24$, which is in 1,64 times higher than in cases and in 1,95 times than in days of disability than in workers of the control group and according to the scale of assessment of morbidity rates by $\mathrm{L}$. E. Notkin characterized in days as average; in cases as high.

According to the results of their own researches, it was found that the risk of developing general diseases is higher than that of the control group for underground mining of iron ore $(R 1=0,127)$, for open ore mining $(R 1=0,173)$, the average duration of periods between diseases is 59,1 for open mining and 68,3 days for underground mining of iron ore, and the odds ratio of illness to occupational disease (OR) is $0,0516,0,041$, respectively (Table II).

According to the calculated indicators, they correspond to 3 Class 2 degree of the hazard for underground and open mining of iron ore. Depending on the level of $\mathrm{L}$ and OR, it is possible to predict which degree and class of harmful production factors can lead to the corresponding levels of morbidity. (Table III).

For effective professional risk management in workers of industrial enterprises a prerequisite is to establish an objective connection between risk factors and the severity of the consequences, what they are doing at workers and categorization of occupational risk. On the basis of the results we have received of hygienic and epidemiological researches, we propose a method for predicting occupational risk that takes into account the coefficients of estimation of the probability of harmful influence of working conditions and the probability of the consequences in the form of relative risk of morbidity in order to prove the direct connection of working conditions with the disease with temporary disability and, consequently, a clear risk categorization for making managerial decisions. 
Table I. The level of morbidity with temporary disability in the workers of the mining and metallurgical complex for 100 employees $(p<0,05)$.

\begin{tabular}{cccc}
\hline Production & Cases & Days & Average case duration \\
\hline Underground mining of iron ore & $81,87 \pm 3,64^{*}$ & $806,53 \pm 40,51^{*}$ & $10,00 \pm 1,42$ \\
\hline Open mining iron ore & $98,06 \pm 2,49^{*}$ & $1217,67 \pm 63,50^{*}$ & $12,39 \pm 0,24$ \\
\hline Control group & $59,84 \pm 1,48$ & $624,23 \pm 17,43$ & $10,40 \pm 1,06$ \\
\hline
\end{tabular}

Note. ${ }^{*}$ - the difference is significant with the control group.

Table II. Disease rates of temporary disability in workers of the mining complex $(p \leq 0,05)$

\begin{tabular}{ccc}
\hline \multirow{2}{*}{ Disease rates } & \multicolumn{2}{c}{ Production } \\
\cline { 2 - 3 } Risk ratio (RR) & Underground mining of iron ore & Open ore mining \\
\hline Average duration of periods between illnesses, (L) (days) & 0,127 & 0,173 \\
\hline The ratio of chances to get sick an occupation disease, (OR) & 68,3 & 59,1 \\
\hline Class of working conditions, according to normative documents. & 0,0516 & 0,041 \\
\hline
\end{tabular}

Table III. Dependence of indicators of morbidity on the class of working conditions.

\begin{tabular}{ccc}
\hline $\begin{array}{c}\text { Duration of the disease with temporary disability } \\
\text { before transition to occupational disease. (L, days) }\end{array}$ & $\begin{array}{c}\text { The odds ratio } \\
\left(\mathbf{O R} \boldsymbol{*}^{\mathbf{1}} \mathbf{- 5}\right)\end{array}$ & $\begin{array}{c}\text { Class of working conditions according to the } \\
\text { "Hygienic Classification of Labor ..." }\end{array}$ \\
\hline $109,00 \pm 8,00$ & 13 & 2 Class \\
\hline $85,00 \pm 3,00$ & 43 & 3 Class 1 degree \\
\hline $67,00 \pm 4,00$ & 110 & 3 Class 2 degree \\
\hline $55,00 \pm 3,00$ & 230 & 3 Class 3 degree \\
\hline $45,00 \pm 3,00$ & 440 & 3 Class 4 degree \\
\hline $37,00 \pm 3,00$ & 4 Class \\
\hline
\end{tabular}

Table IV. Determination of the magnitude of the risk of a disease with a temporary disability, caused by working conditions

\begin{tabular}{|c|c|c|c|c|c|c|c|}
\hline \multirow{3}{*}{$\begin{array}{l}\text { Class of working } \\
\text { conditions }\end{array}$} & \multirow{3}{*}{$\begin{array}{l}\text { Points } \\
\text { (P) }\end{array}$} & \multicolumn{6}{|c|}{ Risk ratio of a disease with a temporary disability /points, (S) } \\
\hline & & $0<R R \leq 1,0$ & $1,0<R R \leq 1,5$ & $1,5<R R \leq 2,0$ & $2,0<R R \leq 3,2$ & $3,2<R R \leq 5,0$ & RR $>5,0$ \\
\hline & & 1 & 2 & 3 & 4 & 5 & 6 \\
\hline 2 & 1 & 1 & 2 & 3 & 4 & 5 & 6 \\
\hline 3.1 & 2 & 2 & 4 & 6 & 8 & 10 & 12 \\
\hline 3.2 & 3 & 3 & 6 & 9 & 12 & 15 & 18 \\
\hline 3.3 & 4 & 4 & 8 & 12 & 16 & 20 & 24 \\
\hline 3.4 & 5 & 5 & 10 & 15 & 20 & 25 & 30 \\
\hline 4 & 6 & 6 & 12 & 18 & 24 & 30 & 36 \\
\hline
\end{tabular}

In the method proposed by us, the risk assessment (R) (or risk rating) is evaluated as a product of the severity (S) of consequences and probability $(\mathrm{P})$, which is expressed as follows:

$\mathrm{R}=\mathrm{P} \cdot \mathrm{S}$

where $\mathrm{P}$ - point according to the class of working conditions is estimated in accordance with the «hygienic classification of labor»;

$\mathrm{S}$ - the point, according to the risk ratio of the disease with temporary disability, is calculated according to the international methodology for this professional group.

Category of occupational risk depending on the class of working conditions and risk ratio of a disease with tem- porary disability (table IV):

1 - risk is absent;

2 - insignificant risk;

3-4 - low risk;

5-9 - average risk;

10-16 - high risk;

18-25 - very high risk;

30-36 - unacceptable risk;

Example: the class of working conditions by the hygienic classification of labor is -3.2 , the magnitude of the risk ratio of a disease with temporary disability is $\mathrm{RR}=1,8$.

We determine the points for the matrix for $\mathrm{P}=3$ points, for $S=3$ points. Risk assessment $R=P \bullet S=3 \times 3=9$ points, or 
at the intersection of the column $1,5<\mathrm{RR} \leq 2,0$ and line 3.2 , we find the answer 9 points.

Conclusion: the risk is average - necessary measures to reduce the risk in the prescribed time.

The results, that can be obtained during the analysis of the morbidity with temporary disability for workers of the mentioned professional groups can be considered as initial data for calculate occupational risks, which will allow to establish dynamic supervision and monitoring of the health status in order to maintain the worker's ability to work in his profession. In the future, the results are planned to be used for determining as group as individual safe working terms, criteria for early diagnosis of initial manifestations of diseases, and the definition of the list of production- associated diseases in these professional groups.

\section{CONCLUSIONS}

1. An in-depth analysis of the disease with temporary disability is conducted for establish a credibly proven cause-and-effect relationship between the state of health of workers and production and professional conditions for the purpose of development, implementation and control of the effectiveness of preventive measures aimed at reducing the disease and management of occupational risk.

2. In the workers involved in the extraction and processing of iron ore the level of morbidity with temporary disability is from $81,87 \pm 3,64$ to $98,06 \pm 2,49$ cases ( $p<0,05$ ), from $806,53 \pm 40,51$ to $1217,67 \pm 63,50$ days of disability $(p<0,05)$, the average duration of one case was from $10,00 \pm 1,42$ to $12,39 \pm 0,24$, and according to the scale of assessment of the indicators of morbidity rates by L. E. Notkin characterized in days as average; in cases as high.

3. Calculation of indicators of the disease with temporary disability (L ra OR) provides an opportunity to predict which degree and class of harmful production factors can lead to the corresponding levels of morbidity. The proposed method makes it possible to predict the category of occupational risk, depending on the class of working conditions and the relative risk of morbidity with temporary disability.

4. The conducted studies confirms the necessity of establishing dynamic supervision, monitoring of the health of workers in order to timely identify the initial manifestations of occupational diseases and the obligatory introduction of preventive measures in order to maintain the worker's ability to work in his profession and predict the category of occupational risk.

\section{REFERENCES}

1. Oriekhova 0. V. Optymizatsiya strakhovykh vneskiv zalezhno vid klasiv profesiynoho ryzyku [Optimization of insurance premiums according to the classes of professional risk]. Dosiahnennia biolohii ta medytsyny. 2016; (28):38-42. (UA)

2. Pavlenko 0. I. Ryzyk rozvytku profesiynoyi pylovoyi patolohiyi lehen' u pratsivnykiv osnovnykh profesiy suchasnoho metalurhiynoho vyrobnytstva [The risk of developing professional dust pathology of lungs in the workers of the main occupations of modern metallurgical production]. Ukrainskyi zhurnal z problem medytsyny pratsi. 2014;1(38):3-10. (UA)
3. Izmerov N. F. Otsenka professional'nogo riska i upravleniye im - osnova profilaktiki v meditsine truda [The assessment and management of occupational risk is the basis of prevention in labor medicine]. Gigiena i sanitaria. 2006;5: 14-16. (Ru)

4. Izmerov N. F., Denisov E. I. Professionalnyi risk dlya zdorovya rabotnikov: Rukovodstvo [0ccupational risk to workers' health: a Guide]. Moskva: Trovant; 2003, 448. (Ru)

5. Kundiiev Y. I., Nahorna A. M. Profesiine zdorovya v Ukraini. Epidemiologichnyi analiz [0ccupational health in Ukraine. Epidemiological analysis]. Kyiv: Avitsena; 2006, 316. (UA)

6. Sevalnev A. I., Saravara L. P. Systema otsinky ta upravlinnya ryzykom profesiynykh zakhvoryuvan' sered metalurhiynykh pidpryyemstv povnoho tsyklu [The system of assessment and management of occupational disease risk among full-cycle metallurgical enterprises]. Visnyk problem biolohii i medytsyny, 2016;2(127): 57-61. (UA)

7. Oriekhova 0.V., Pavlenko 0 .I. Profesiyni ryzyky zdorov'yu pratsyuyuchykh yak suchasna kontseptsiya medytsyny pratsi [Occupational risks workers ' health, as the modern concept of occupational medicine]. Ukrainskyi zhurnal z problem medytsyny pratsi, 2017;3(52):77-87. (UA)

8. Sevalnev A. I., Saravara L. P. Otsinka profesiynoho ryzyku zdorov'yu pratsivnykiv providnoho metalurhiynoho pidpryyemstva [Assessment of occupational risk of health workers in the leading metallurgical enterprise]. Ukrainskyi zhurnal z problem medytsyny pratsi, 2015;4(45):62-68. (UA)

9. Dohle N. V., Yurkevych A. F. Zabolevaemost s vremennoi utratoi trudosposobnosty (metody izucheniia) [Incidence with temporary disability (study methods)]. Moskva: Medicine; 1984, 176. (Ru)

The work was carried out within the frames of the budget research work "Managing the risk of developing the most common occupational diseases among workers in the mining and metallurgical industry» (state registration numbers 0117U002310, 0118U001146).

\section{Authors' contributions:}

According to the order of the Authorship.

\section{Conflict of interest:}

The Authors declare no conflict of interest.

\section{CORRESPONDING AUTHOR \\ Oksana V. Oriekhova}

Ukrainian Institute of Scientific

Research in Industrial Medicine

Vinogradova str., 40, 50096, Kryvyi Rih, Ukraine

tel: +380671605307

e-mail: orehovaoksana@ukr.net

Received: 01.03 .2019

Accepted: 20.04.2019 


\title{
PROGNOSTIC MODEL OF SKIN CANCER RISK ASSESSMENT
}

\author{
Olena 0. Oshyvalova ${ }^{1,2}$, Oleg L. Ziukov' ${ }^{1}$, Vitaliy G. Gurianov ${ }^{3}$ \\ "STATE INSTITUTION OF SCIENCE"RESEARCH AND PRACTICAL CENTRE OF PREVENTIVE AND CLINICAL MEDICINE"STATEADMINISTRATIVE DEPARTMENT, KYIV, UKRAINE \\ 2SHUPYK NATIONAL MEDICAL ACADEMY OF POSTGRADUATE EDUCATION, KYIV, UKRAINE \\ 3BOGOMOLETS NATIONAL MEDICAL UNIVERSITY, KYIV, UKRAINE
}

\begin{abstract}
Introduction: Early detection of people at risk of skin cancer will reduce the incidence of disease, lower the cost of health technologies and decrease anxiety level in patients. The aim of the work is to create a prognostic model for identifying people at increased risk of skin cancer development.

Material and methods: We used the results of our previous research on identifying risk factors in patients with actinic keratosis (AK), squamous cell carcinoma in situ (SCCis) and cutaneous squamous cell carcinoma ( $\mathrm{CSCC}$, who were under dynamic observation at the State Institution of Science" Research and Practical Centre of Preventive and Clinical Medicine" State Administrative Department (hereinafter SIS) in 2014-2017.

Results: The prognostic model is valid, AUC $=0.97$ (95\% Cl $0.96-0.99)$ showing a significant association of the risk of skin cancer development with the following factors: patient's age, sunburns, using skin sunscreens, exposure to the sun in recent times, exposure to radiological materials, drug administration (antiarrhythmic drugs, antihypertensive medications, hormonal contraceptives, antibiotics), burdened family history (melanoma, squamous cell cancer). Model sensitivity was $95.1 \%$ ( $95 \%$ CI $91.6 \%$ - $97.4 \%$ ), specificity $-88.5 \%$ (95\% Cl 84.6\% - 91.8\%).

Conclusions: The developed and analysed mathematical risk prediction system made it possible to identify 11 factors which are significantly associated with risk of skin cancer development. The prognostic model might be offered for specialists in taking decision at the stage of primary and secondary prevention of skin cancer.
\end{abstract}

KEY WORDS: prognostic model, risk factors, skin cancer, primary and secondary prevention

Wiad Lek 2019, 72, 5 cz. I, 817-822

\section{INTRODUCTION}

Understanding of the most appropriate way to identify people at high risk of skin cancer development can help improve prevention strategy and therapeutic approach [1]. In the international clinical protocols it is recommended to identify risk factors (RF) of skin cancer and to conduct dynamic observation of people at high risk of cancer development [2].

In most countries with predominantly people of European ethnicity, the incidence of non-melanoma skin cancer (NMSC) has increased over the last decade [3]. A recent systematic review of scientific literature has shown that the annual rate of progression of single actinic keratosis (AK) as a predictor of NMSC to an invasive form of squamous cell carcinoma of the skin (cSCC) ranges from $0 \%$ to $0.53 \%$ per year, but this data is incomplete [4]. At the same time, annual regression rates of single AK range from $15 \%$ to $63 \%$, with a relapse rate of $15 \%-53 \%$ [5].

Rational reasoning for screening and follow-up of people at high risk of NMSC is based on the evidence that early diagnosis reduces the incidence of the disease [6], lowers medical costs [7] and decreases anxiety level in patients [8]. Significant role in the development of NMSC according to different authors play the excessive sun expo- sure [9], the use of drugs that increase skin sensitization to UVI [10], the genetic predisposition to cancer $[11,12]$, the influence of chemical carcinogens $[13,14]$ etc.

The detection of individuals with RF of skin cancer development is a part of primary and secondary prevention [15]. However, at present, there are no unified techniques for primary and secondary care physicians that could be used to effectively identify people at high risk of skin cancer development [16].

\section{THE AIM}

The aim of the research is to create a prognostic model for identifying people at increased risk of skin cancer development, which will provide timely dynamic observation of this category of people, as well as early detection of subclinical forms of skin cancer.

\section{MATERIALS AND METHODS}

We used the results of our previous research on identifying risk factors in 244 patients with actinic keratosis (AK), squamous cell carcinoma in situ (SCCis) and cutaneous squamous cell carcinoma (cSCC), who were under dynamic observation at the State Institution of 
Table I. The results of the analysis of one-factor logistic regression models for pathology risk prediction

\begin{tabular}{|c|c|c|c|c|c|}
\hline & Factor & $\begin{array}{c}\text { Coefficient } \\
\text { of the model } \\
\text { equation, } b \pm m\end{array}$ & $\begin{array}{l}\text { Significance } \\
\text { level, p }\end{array}$ & OR $(95 \% \mathrm{Cl})$ & AUC (95\% CI) \\
\hline \multirow{2}{*}{ Sex } & \multirow{2}{*}{$\begin{array}{c}\text { female } \\
\text { male }\end{array}$} & \multicolumn{3}{|c|}{ Reference } & \multirow{2}{*}{$0.56(0.52-0.60)$} \\
\hline & & $0.51 \pm 0.17$ & 0.003 & $1.7(1.2-2.3)$ & \\
\hline \multirow{4}{*}{ Age } & under 65 & & Referenc & & \multirow{4}{*}{$0.76(0.72-0.79)$} \\
\hline & $65-69$ & $0.91 \pm 0.27$ & 0.001 & $2.5(1.5-4.2)$ & \\
\hline & $70-74$ & $0.38 \pm 0.29$ & 0.19 & - & \\
\hline & $>75$ & $2.61 \pm 0.26$ & $<0.001$ & $13.6(8.2-22.8)$ & \\
\hline \multicolumn{2}{|c|}{$\begin{array}{l}\text { 1. How often did you get sunburns of } \\
\text { the skin (especially in childhood or } \\
\text { adolescence)? }\end{array}$} & $0.99 \pm 0.10$ & $<0.001$ & $2.7(2.2-3.3)$ & $0.77(0.73-0.80)$ \\
\hline \multicolumn{2}{|c|}{ 2. Do you use skin sunscreens in the sun? } & $-1.57 \pm 0.16$ & $<0.001$ & $0.21(0.15-0.29)$ & $0.76(0.72-0.79)$ \\
\hline \multicolumn{2}{|c|}{$\begin{array}{l}\text { 3. Have you spent much time in the sun } \\
\text { recently? }\end{array}$} & $-0.95 \pm 0.18$ & $<0.001$ & $0.39(0.27-0.55)$ & $0.61(0.57-0.65)$ \\
\hline \multicolumn{2}{|c|}{$\begin{array}{l}\text { 4. Have you had long-term exposure to } \\
\text { radioactive materials? }\end{array}$} & $1.26 \pm 0.43$ & 0.003 & $3.5(1.5-8.1)$ & $0.53(0.49-0.57)$ \\
\hline \multicolumn{2}{|c|}{$\begin{array}{l}\text { 5. Have you had long-term exposure to } \\
\text { toxic chemicals? }\end{array}$} & $-2.39 \pm 1.04$ & 0.02 & $0.09(0.01-0.70)$ & $0.52(0.48-0.56)$ \\
\hline \multicolumn{2}{|c|}{$\begin{array}{l}\text { 6. How often do you traumatize benign } \\
\text { neoplasms of the skin, such as naevus? }\end{array}$} & $-0.35 \pm 0.10$ & 0.001 & $0.70(0.57-0.86)$ & $0.57(0.53-0.61)$ \\
\hline \multicolumn{6}{|c|}{ 7. What medicines do you often use? } \\
\hline \multicolumn{2}{|c|}{7.1 antiarrhythmic_drugs } & $-1.86 \pm 0.22$ & $<0.001$ & $0.16(0.10-0.24)$ & $0.68(0.64-0.72)$ \\
\hline \multicolumn{2}{|c|}{7.2 antihypertensive_medications } & $-1.06 \pm 0.18$ & $<0.001$ & $0.35(0.25-0.49)$ & $0.63(0.59-0.67)$ \\
\hline \multicolumn{2}{|c|}{ 7. hormonal_contraceptives } & $0.22 \pm 0.30$ & 0.46 & - & - \\
\hline \multicolumn{2}{|c|}{7.4 other_hormonal_agents } & $-0.60 \pm 0.41$ & 0.14 & - & - \\
\hline \multicolumn{2}{|c|}{7.5 antibiotics } & $-1.53 \pm 0.28$ & $<0.001$ & $0.22(0.13-0.37)$ & $0.60(0.56-0.64)$ \\
\hline \multicolumn{2}{|c|}{7.6 cytostatic_agents } & $0.81 \pm 0.52$ & 0.12 & - & - \\
\hline \multicolumn{2}{|c|}{7.7 immune_adjuvants } & $0.63 \pm 0.59$ & 0.29 & - & - \\
\hline \multicolumn{2}{|r|}{7.8 other } & $-0.49 \pm 0.44$ & 0.26 & - & - \\
\hline \multicolumn{6}{|c|}{ 8. Fitzpatrick phototype } \\
\hline \multirow{3}{*}{ photo-type } & 1 & & Referenc & & \multirow{3}{*}{$0.55(0.51-0.59)$} \\
\hline & 2 & $-0.52 \pm 0.22$ & 0.02 & $0.59(0.39-0.90)$ & \\
\hline & 3 & $-0.29 \pm 0.27$ & 0.29 & - & \\
\hline \multicolumn{6}{|c|}{ 9. Have any of your close relatives (father/mother, brother/sister, aunt/uncle) had skin cancer? Namely: } \\
\hline \multicolumn{2}{|c|}{9.1 melanoma $=» Y »$} & $2.12 \pm 0.77$ & 0.006 & $8.3(1.8-37.4)$ & $0.52(0.48-0.56)$ \\
\hline \multicolumn{2}{|c|}{9.2 basalioma $=» Y »$} & $0.87 \pm 0.26$ & 0.001 & $2.4(1.4-3.9)$ & $0.55(0.51-0.59)$ \\
\hline \multicolumn{2}{|c|}{$\begin{array}{l}9.3 \text { squamous_cell__ } \\
\text { skin_cancer=»Y» }\end{array}$} & $1.62 \pm 0.51$ & 0.002 & $5.1(1.9-13.8)$ & $0.53(0.49-0.57)$ \\
\hline
\end{tabular}

Science "Research and Practical Centre of Preventive and Clinical Medicine" State Administrative Department (hereinafter SIS) in 2014-2017. There was also carried out medical and social survey of 323 residents of Kyiv city and Kyiv region with no signs of oncological pathology. To identify RF, the method of building and analyzing the logistic regression models was used. In the course of the analysis, the presence of AK, SCCis, CSCC in patient was considered as a dependent variable Y. As the risk factors, the analysis was carried out for such variables as sex, patient's age and 9 items of the developed questionnaire: the presence of burns in childhood and adolescence, skin phototype, the possible use of skin sunscreens, the possible long-term exposure to radioactive or toxic chemicals, traumatization of benign neoplasms of the skin, the use of drugs that have photosensibilizing effect on the skin and cases of skin cancer among close relatives. Each RF was appraised by points [17]. Statistical processing was 


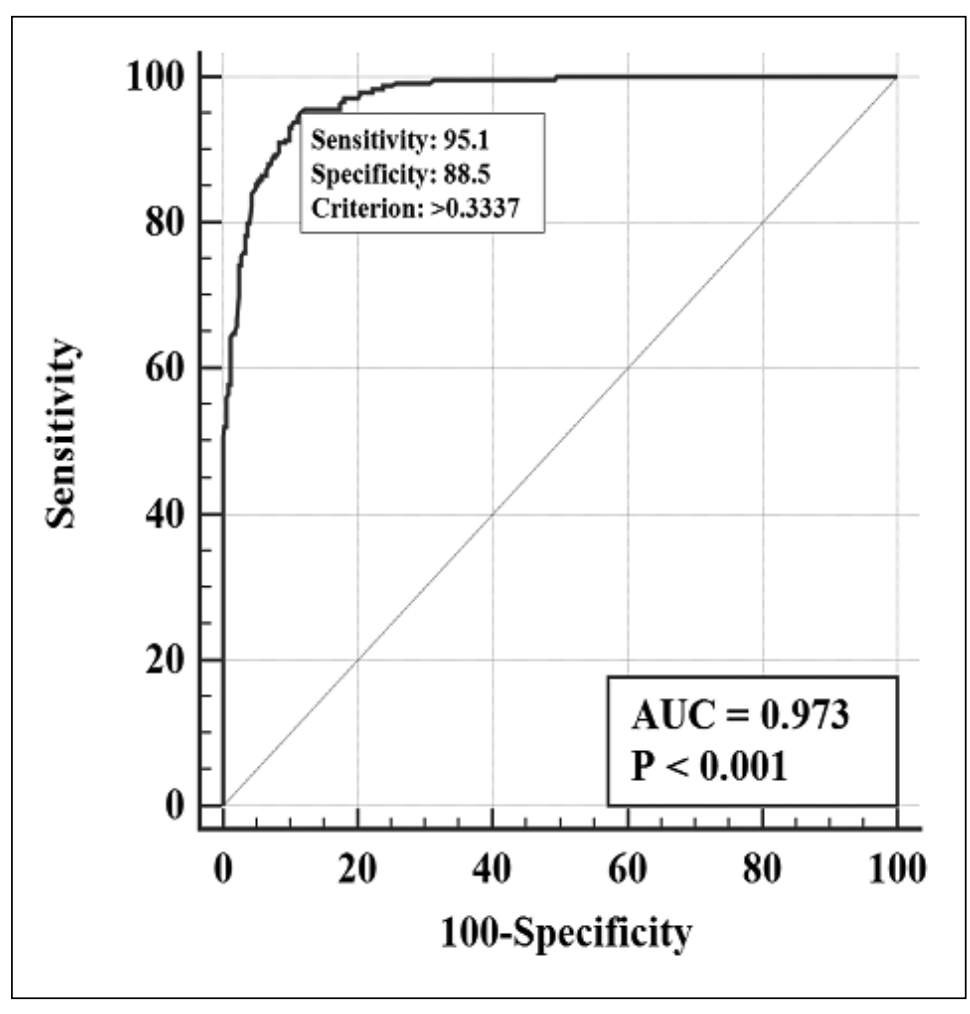

Figure 1. ROC-curve of the 11-factor model for the pathology risk prediction. carried out using MedCalc v.18.11.3 (MedCalc Software Inc., Broekstraat, Belgium, 1993-2019).

\section{RESULTS AND DISCUSSION}

The survey involved 323 residents of Kyiv city and Kyiv region with no signs of oncological pathology of the skin, 157 men and 166 women among them. There was the following age distribution of respondents: $60-64$ years $42.4 \%$ (male $-40.8 \%$, female $-44 \%$ ), $65-69$ years $-24.1 \%$ (male $-20.4 \%$, female $-22.3 \%$ ), $70-74$ years $-24.2 \%$ (male $-22.9 \%$, female $-25.3 \%$ ), 75 years and over $-12 \%$ (male $-15.9 \%$, female $-8.4 \%$ ).

A total of 244 patients with AK, SCCis, CSCC was also surveyed, including 103 patients with AK (62 men, 41 women), 59 patients with SCCis ( 32 men, 27 women), 60 patients with cSCC (38 men, 22 women) and 22 patients with combined course of AK, SCCis, cSCC (17 men, 5 women). There was the following age distribution: 3539 years $-0.8 \%, 40-44$ years $-1.2 \%, 50-54$ years $-0.4 \%$, 55-59 years $-4.1 \%$ (male $-4.02 \%$, female $-4.2 \%$ ), 60 64 years $-8.2 \%$ (male $-6.04 \%$, female $-11.6 \%), 65-69$ years $-18.1 \%$ (male $-18.8 \%$, female $-16.8 \%$ ), $70-74$ years $-11.9 \%$ (male $-10.7 \%$, female $-13.7 \%$ ), 75 years and over $-55.3 \%$ (male $-58.4 \%$, female $-50.5 \%$ ).

Among 323 residents of Kyiv city and Kyiv region with no signs of oncological pathology of the skin, there prevailed the following RF of skin cancer: skin phototype $2-52.4 \%$, excessive sun exposure $-42 \%$ (male $-41.3 \%$, female $-42.5 \%$ ), exposure to radioactive materials $-3 \%$ (male $-4 \%$, female $-1 \%$ ) and toxic chemicals $-4.1 \%$ (male $-4.3 \%$, female $-3.8 \%$ ), the use of drugs with pho- tosensibilizing action $-20.02 \%$ (male $-20.3 \%$, female - $19.7 \%)$, traumatization of benign neoplasms of the skin $-23.5 \%$ (male $-19 \%$, female $-27.8 \%$ ), inheritance of basal cell carcinoma $-8.5 \%$ (male $-8.1 \%$, female $8.9 \%$ ), squamous cell carcinoma $-1.5 \%$ (male $-1.08 \%$, female-1.92\%).

Among 244 respondents with AK, SCCis, cSCC there prevailed the following RF of skin cancer: skin phototype $2-60.9 \%$, excessive sun exposure $-58.6 \%$ (male $-64.4 \%$, female $-49.5 \%$ ), exposure to radioactive materials $-8.2 \%$ (male $-12.1 \%$, female $-2.1 \%$ ), traumatization of benign neoplasms of the skin $-46.7 \%$ (male $-47.0 \%$, female $46.3 \%$ ), the use of drugs with photosensibilizing action - $47.5 \%$ (male $-42.3 \%$, female $-55.8 \%$ ), inheritance of basal cell carcinoma - $18.03 \%$ (male - $18.1 \%$, female $17.9 \%$ ), squamous cell carcinoma $-7.4 \%$ (male $-6.7 \%$, female $-8.4 \%$ ).

The analysis involved the results of the survey of 567 patients, of which 323 patients had no signs of the pathology $(Y=0)$ and 244 were diagnosed with AK, SCC, $\operatorname{SCCI}(\mathrm{Y}=1)$.

At the first stage, one-factor logistic models for the pathology risk prediction were constructed and analysed. Table I presents the results of one-factor regression models.

The analysis showed a weak association (area under ROC-curve AUC $=0.56$ (95\% CI 0.52-0.60)) between risk of pathology and patient's sex; thus among men the risk increases $(\mathrm{p}=0.003)$, OR $=1.7(95 \%$ CI $1.2-2.3)$ compared to women. There was found a moderate association (area under ROC-curve AUC = 0.76 (95\% CI 0.72-0.79)) between risk of pathology and patients' age of 65-69 years 
Table II. The results of the analysis of 11-factor logistic regression model for pathology risk prediction

\begin{tabular}{|c|c|c|c|c|c|}
\hline No. & Factor & $\begin{array}{c}\text { Coefficient } \\
\text { of the model } \\
\text { equation, } b \pm m\end{array}$ & $\begin{array}{l}\text { Significance } \\
\text { level, p }\end{array}$ & OR $(95 \% \mathrm{Cl})$ & AUC $(95 \% \mathrm{Cl})$ \\
\hline \multirow{4}{*}{1} & \multirow{4}{*}{ Age } & \multicolumn{3}{|c|}{ Reference } & \multirow{16}{*}{$0.97(0.96-0.99)$} \\
\hline & & $0.79 \pm 0.48$ & 0.10 & - & \\
\hline & & $-0.29 \pm 0.56$ & 0.60 & - & \\
\hline & & $2.98 \pm 0.53$ & $<0.001$ & $19.7(7.0-56)$ & \\
\hline 2 & $\begin{array}{l}\text { How often did you get sunburns of the skin } \\
\text { (especially in childhood or adolescence)? }\end{array}$ & $1.50 \pm 0.18$ & $<0.001$ & $4.5(3.2-6.4)$ & \\
\hline 3 & Do you use skin sunscreens in the sun? & $-2.39 \pm 0.32$ & $<0.001$ & $0.09(0.05-0.17)$ & \\
\hline 4 & Have you spent much time in the sun recently? & $-0.98 \pm 0.39$ & 0.01 & $0.37(0.17-0.81)$ & \\
\hline 5 & $\begin{array}{l}\text { Have you had long-term exposure to radioactive } \\
\text { materials? }\end{array}$ & $1.56 \pm 0.80$ & 0.05 & $4.7(1.0-22.9)$ & \\
\hline 6 & What medicines do you often use? & & & & \\
\hline 6.1 & antiarrhythmic_drugs & $-2.43 \pm 0.42$ & $<0.001$ & $0.09(0.04-0.20)$ & \\
\hline 6.2 & antihypertensive_medications & $-2.65 \pm 0.42$ & $<0.001$ & $0.07(0.03-0.16)$ & \\
\hline 6.3 & hormonal_contraceptives & $4.41 \pm 0.76$ & $<0.001$ & $82.6(18.5-369)$ & \\
\hline 6.4 & antibiotics & $-1.81 \pm 0.60$ & 0.003 & $0.16(0.05-0.53)$ & \\
\hline 7 & $\begin{array}{l}\text { Have any of your close relatives (father/mother, } \\
\text { brother/sister, aunt/uncle) had skin cancer? } \\
\text { Namely }\end{array}$ & & & & \\
\hline 7.1 & melanoma=»YY» & $1.89 \pm 1.04$ & 0.07 & $6.6(0.9-50.6)$ & \\
\hline 7.2 & squamous_cell_skin_cancer =»Y» & $1.67 \pm 0.98$ & 0.09 & $5.4(0.8-36.2)$ & \\
\hline
\end{tabular}

$(\mathrm{p}=0.001), \mathrm{OR}=2.5(95 \% \mathrm{CI} 1.5-4.2)$ and 75 years and over $(\mathrm{p}=0.001), \mathrm{OR}=13.6$ (95\% CI 8.2-22.8) compared to under 65 years. The analysis also showed a moderate association (area under ROC-curve AUC $=0.77$ (95\% CI $0.73-0.80)$ and $\mathrm{AUC}=0.76(95 \% \mathrm{CI} 0.72-0.79))$ between risk of pathology and sunburns of the skin $(\mathrm{p}=0.001)$, $\mathrm{OR}=2.7$ (95\% CI 2.2-3.3) and non-use of skin sunscreens $(\mathrm{p}=0.001), \mathrm{OR}=0.21$ (95\% CI 0.15-0.29).

Such factors as "exposure to the sun in recent times" and "traumatization of benign neoplasms of the skin" had weak association (AUC $=0.61$ (95\% CI 0.57-0.65) and $\mathrm{AUC}=0.57$ (95\% CI 0.53-0.61) respectively) with risk of pathology $(\mathrm{p}=0.001), \mathrm{OR}=0.39(95 \% \mathrm{CI} 0.27-0.55)$ and $(\mathrm{p}=0.001), \mathrm{OR}=0.70(95 \% \mathrm{CI} 0.57-0.86)$ respectively. The analysis also showed a weak correlation $(\mathrm{AUC}=0.53$ (95\% CI 0.49-0.57) and AUC = 0.52 (95\% CI 0.48-0.56)) between risk of pathology and a long-term exposure to radioactive materials $(\mathrm{p}=0.003), \mathrm{OR}=3.5$ (95\% CI 1.5 $8.1)$ and toxic chemicals $(\mathrm{p}=0.02), \mathrm{OR}=0.09(95 \% \mathrm{CI}$ 0.01-0.70).

A weak relationship between the pathology $(\mathrm{AUC}=$ 0.52 (95\% CI 0.48-0.56), AUC $=0.55$ (95\% CI 0.51-0.59) and $\mathrm{AUC}=0.53(95 \% \mathrm{CI} 0.49-0.57)$ respectively) and hereditary factor of melanoma $(\mathrm{p}=0.006), \mathrm{OR}=8.3(95 \%$ CI 1.8-37.4), basal cell carcinoma $(\mathrm{p}=0.001), \mathrm{OR}=2.4$ (95\% CI 1.4-3.9) and squamous cell carcinoma ( $\mathrm{p}=0.002)$, $\mathrm{OR}=5.1$ (95\% CI 1.9-13.8) was detected.

At the second stage of the analysis, a minimum set of factors which were significantly associated with the risk of pathology was selected. Multi-factor logistic regression models were used for the analysis, the stepwise method (enter variable if $\mathrm{p}<0.1$ and remove variable if $\mathrm{p}>0.2$ ) was used for selection. As a result, 11 factors were selected, namely: patient's age, sunburns, the use of skin sunscreens, exposure to the sun in recent times, exposure to radioactive materials, the use of drugs (antiarrhythmic drugs, antihypertensive medications, hormonal contraceptives, antibiotics), burdened family history (melanoma, squamous cell cancer). Based on the set of signs, the 11-factor logistic regression model for the pathology risk prediction was built. Figure 1 presents ROC-curve of the model.

The prognostic model is valid, AUC $=0.97$ (95\% CI 0.96 - 0.99) showing a significant association of the risk of skin cancer development with the following factors: patient's age, sunburns, using sun-protection preparations, exposure to the sun in recent times, exposure to radioactive materials, drug administration (antiarrhythmic drugs, antihypertensive medications, hormonal contraceptives, antibiotics), burdened family history (melanoma, squamous cell cancer). Table II presents the results of the 11 -factors regression model.

The analysis showed a weak relationship between risk of the pathology with patient's age; thus at the age of 75 and over the risk increases $(\mathrm{p}<0.001), \mathrm{OR}=19.7(95 \%$ CI 7.0 - 56) compared to patients under 65 years (on 
adjustment of other risk factors). There was also found an increase $(\mathrm{p}<0.001)$ of the pathology risk at higher frequency of sunburns $(\mathrm{OR}=4.5$ (95\% CI $3.2-6.4)$ for each frequency rise in the questionnaire (on adjustment of other risk factors), non-use of skin sunscreens ( $\mathrm{OR}=$ 0.09 (95\% CI $0.05-0.17$ ) for each frequency rise in the questionnaire (on adjustment of other risk factors)) and exposure to the sun in recent times $(\mathrm{OR}=0.37$ (95\% CI $0.17-0.81)$ for each frequency rise in the questionnaire (on adjustment of other risk factors)).

On the basis of a strong correlation between 11 selected factors with the risk of skin pathology (AK, SCCis. cSCC) there can be proposed a system for the pathology risk prediction; when choosing the optimal threshold for decision-making, the sensitivity of the model was $95.1 \%$ (95\% CI $91.6 \%-97.4 \%)$, the specificity - 88.5\% (95\% CI $84.6 \%-91.8 \%)$.

For practical use, the 11-factor logistic regression model for pathology risk prediction was implemented in Excel spreadsheet (Risk.xls file).

To perform counts, enter the patient information into appropriate cell of the table and press the ENTER key.

Here are some examples of the 11-factor logistic regression model.

Example 1. A 72-year-old patient with frequent sunburns in history, did not use skin sunscreens, has not been in the sun recently, has not used photosensitizing drugs and is not hereditary tainted. It was found that the risk of skin pathology was high and amounted to 0.951 (risk of pathology development). The patient was diagnosed with actinic keratosis.

Example 2. A 76-year-old patient, sometimes had sunburns and did not use skin sunscreens, has not been in the sun recently, but had a long-term exposure to radioactive materials, did not use photosensitizing drugs and is not hereditary tainted. It was found that the risk of skin pathology was high and amounted to 0.998 (risk of pathology development). The patient was diagnosed with combined pathology of the skin - actinic keratosis and squamous cell skin cancer in-situ.

Example 3. A 64-year-old patient often had sunburns, hardly ever used skin sunscreens, has not been in the sun recently, but had a long-term exposure to radioactive materials, takes antiarrhythmic and antihypertensive drugs and is not hereditary tainted. It was found that there was no risk of skin pathology as it was 0.066 (favourable prognosis). The patient was not diagnosed with the studied skin pathology.

Example 4. A 70-year-old patient sometimes had sunburns, hardly ever used skin sunscreens, has not been in the sun recently, did not have exposure to radioactive materials, takes antiarrhythmic and antihypertensive drugs, has family history of squamous cell skin cancer. It was found that there was no risk of skin pathology as it was 0.059 (favourable prognosis). The patient was not diagnosed with the studied skin pathology.

Example 5. A 56-year-old patient often had sunburns, hardly ever used sun sunscreens, has not been in the sun recently, did not have exposure to radioactive materials, did not use photosensitizing drugs and is not hereditary tainted. It was found that the risk of skin pathology was high and amounted to 0.705 (risk of pathology development). The patient was diagnosed with cutaneous squamous cell carcinoma.

\section{CONCLUSIONS}

The developed and analyzed mathematical risk prediction system made it possible to identify 11 factors which are significantly associated (AUC $=0.9795 \%$ CI $0.96-0.99$ ) with risk of skin cancer development. The prognostic model might be offered for specialists in taking decision at the stage of primary and secondary prevention of skin cancer.

\section{REFERENCES}

1. Mariah M. Johnson, Sancy A Leachman, Lisa G Aspinwall et al. Skin cancer screening: recommendations for data-driven screening guidelines and a review of the US Preventive Services Task Force controversy. Melanoma management.2017; 4(1): 13-37.

2. Perera $E$, Sinclair R. An estimation of the prevalence of nonmelanoma skin cancer in the U.S. F1000Research. 2013; 2:107. PMID: 24358841.

3. Eisemann N, Waldmann A, Geller AC, et al. Non-melanoma skin cancer incidence and impact of skin cancer screening on incidence. J Invest Dermatol. 2014; 134 (1):43-50. PMID: 23877569.

4. Malvehy J. A new vision of actinic keratosis beyond visible clinical lesions. Journal of the European Academy of Dermatology and Venereology. 2015; 29: 1-18.

5. Salasche $S$. Epidemiology of actinic keratoses and squamous cell carcinoma. J Am Acad Dermatol . 2000;42:4-7.

6. Brantsch K.D., Meisner C., Schonfisch B. et al. Analysis of risk factors determining prognosis of cutaneous squamous-cell carcinoma: a prospective study. Lancet Oncol. 2008; 9(8):713-720.

7. Shih ST, Carter R, Sinclair C, Mihalopoulos C, Vos T. Economic evaluation of skin cancer prevention in Australia. Prev Med. 2009; 49:449-453.

8. Guy G.P., Machlin S.R., Ekwueme D.U. et al.. Prevalence and costs of skin cancer treatment in the U.S., 2002-2006 and 2007-2011. Am J Prev Med. 2015, 48:183-187.

9. Zhang M., Qureshi A.A., Geller A.C., et al. Use of tanning beds and incidence of skin cancer. J Clin Oncol. 2012; 30(14):1588-1593. PMID: 22370316.

10. Moore D.E. Drug-induced cutaneous photosensitivity. Drug Saf. 2002, 25:345-372.

11. Jaju P.D., Ransohoff K.J., Tang J.Y. et al. Familial skin cancer syndromes: Increased risk of nonmelanotic skin cancers and extracutaneous tumors. J Am Acad Dermatol. 2016, 74(3):437-51.

12. Eskandarpour M., Hashemi J., Kanter L. High Gene Mutation Rate May Contribute to Hereditary Skin Cancers. J Natl Cancer Inst. 2003, 95:790.

13. Prevention of Skin Cancer. National Cancer Institute 2004. http://www. cancer.gov/.

14. Stapleton J., Turrisi R., Hillhouse J. et al. Comparison of the efficacy of an appearance-focused skin cancer intervention within indoor tanner subgroups identified by latent profile analysis. J Behav Med. 2010, 33:181-190.

15. International Agency for Research on Cancer Working Group on artificial ultraviolet light and skin cancer. The association of use of sunbeds with cutaneous malignant melanoma and other skin cancers: A systematic review. Int J Cancer. 2007; 120 (5):1116- 1122. PMID: 17131335. 
16. Oliveria SA, Heneghan MK, Cushman LF, et al. Skin cancer screening by dermatologists, family practitioners, and internists: barriers and facilitating factors. Arch Dermatol. 2011; 147 (1):39-44. PMID: 21242390.

17. Oshyvalova 0.0 . Study of risk factors for skin cancer. «Wiadomości Lekarskie», 2017; 3(1): 503-507.
Authors' contributions:

According to the order of the Authorship.

\section{Conflict of interest:}

The Authors declare no conflict of interest.

\section{CORRESPONDING AUTHOR}

\section{Olena 0. Oshyvalova}

Department of Dermatology,

Shupyk National Medical Academy of Postgraduate Education

5, Verhnyaya Street, 04012 Kyiv, Ukraine

tel: +380442546435

e-mail: oshivalovaea@gmail.com

Received: 12.03 .2019

Accepted: 24.04 .2019 
PRACA ORYGINALNA

ORIGINAL ARTICLE

\title{
ORAL HEALTH ABNORMALITIES IN CHILDREN BORN WITH MACROSOMIA ESTABLISHED DURING MIXED DENTITION PERIOD
}

\author{
Olga V. Garmash \\ KHARKIV NATIONAL MEDICAL UNIVERSITY, KHARKIV, UKRAINE
}

\begin{abstract}
Introduction: The prevalence of soft tissue and hard tooth tissuediseases in the oral cavity and the morphofunctional disorders of craniofacial complex, require attention ofspecialistsin various branches of medicine. Scientists began to pay attention to metabolic and other violations that have occurred in the fetal development and led to the occurrence of certain changes in the dental status of the child.

The aim of thisresearch is to study the features of the dental health condition in the children of Northeast of Ukraine, who were born with macrosomia during the period of mixed dentition. The study takes into account intrauterine body length growth acceleration, intrauterine obesity or well-balanced acceleration of both the body weight and length gain. Materials and methods: Thirty 6.5-11-year-old children with fetal macrosomia were examined (MainGroup). A Comparison Group was comprised of sixteen children, whose weight-height parameters at birth were normal (fetal normosomia). All children in the Main group were split into four subgroups in accordance with weight-height parameters at birth using the V. I. Grischenko and his co-authors' harmonious coefficient. The evaluation of the hygiene status of the oral cavity, the dental caries intensity evaluation, and the quantitative analysis of minor salivary gland secretion have been performed. The prevalence of dentoalveolar abnormalities was evaluated.

Results: The highest values of caries intensity were recorded in macrosomic-at-birth children born with harmonious (well-balanced) intrauterine development, with intrauterine obesity and increased body length, or with intrauterine obesity and an average body length. Macrosomic children have reduced number of minor salivary glands per unit area in comparison with the normosomic-at-birth children. The saliva secretion of minor salivary glands in macrosomic children is reliably, by $16,5 \%$ on average, reduced. Children born with fetal macrosomia have long narrow faces and high palates more frequently than normosomic-at-birth children. Children born macrosomic have a significantly higher percentage ( $100 \%$ versus $73 \%$ ) of dentoalveolar abnormalitiesin comparison with the normosomic-at-birth children.

Conclusions: The processes causing fetal macrosomia have a great impact on the dental status of children in the period of mixed dentition.
\end{abstract}

KEY WORDS: fetal macrosomia; caries; minor salivary glands; malocclusion

Wiad Lek 2019, 72, 5 cz. I, 823-831

\section{INTRODUCTION}

The prevalence of soft tissue and hard tooth tissuediseases in the oral cavity and the morphofunctional disorders of craniofacial complex, require attention ofspecialistsin various branches of medicine. Changes in the structure of hard and connective tooth tissue and impaired blood supply caused by metabolic disorders have been already investigated. Thepernicious influence of obesity, diabetes mellitus, and metabolic syndrome on the hard tooth tissue and mucous membrane condition in the oral cavity have been described in several papers $[1,2,3]$.

Nevertheless, only a few dentists pay attention to the birth weight of the baby, when parents are consulting the dentist to find out what is causing child's one or the other dental problem. That is, the dentist has information about the current state of health, and the data on the course of the fetal period, as a rule, are lost eventually and are not taken into account in analyzing the causes and characteristics of the current dental status of the child. Over the years, scientists began to pay attention to metabolic and other violations that have occurred in the fetal development and led to the occurrence of certain changes in the dental status of the child $[4,5]$.
One of the variations in intrauterine metabolic disorders is fetal macrosomia, or a large birth weight. The fetal macrosomiameans that the birth weight of a full-term newborn is greater than or equal to $4,000 \mathrm{~g}$ [6]. In recent decades, researchers from different countries have found out high caries intensity in children and adolescents, which were born with fetal macrosomia $[7,8]$.

The investigations we have conducted in previous years have also revealed the presence of a large number of soft tissueabnormalitiesin the oral cavity, the features in the timing of desiduous teeth eruption, hypoplastic changes in minor salivary glands, the high intensity of desiduous teeth caries in pre-school age children which were born macrosomic, as compared tothe children whose weightheight parameters at birth were normal [9].

\section{THE AIM}

The aim of this investigation is to study the features of the dental state condition of the children born macrosomicin the Northeast of Ukraineduring the period of mixed dentition. The study takes into account an intrauterine accelerated increase in the body length; intrauterine obesity, 
or a harmonious acceleration of body weight gain and an increase in body length.

The principal research objectives are to: asses the condition of minor salivary glands in children who were born macrosomic, and compare it with those in children born with normal weight-height parameters; estimate caries indices in macrosomic children and compare with those in children born with normal weight-height parameters; reveal a connection between morphometric parameters of the face and the relative height of the palatein macrosomic children; reveal the prevalence of dentoalveolar abnormalities in macrosomic children, and compare them with the prevalence of those in children born normosomic.

\section{MATERIALS AND METHODS}

The dental examination of children has been carried out at the the University Dental Center (Department of Therapeutic Dentistry of the KhNMU) and at the Polyclinic Department of the Institute of Children and Adolescents Health Care of the Academy of Medical Sciences of Ukraine.Thirty (19 boys and 11 girls) virtually healthy 6.5-11-year-old children with fetal macrosomia were examined, and they comprised the Main Group. A Comparison Group was comprised of 16 apparently healthy children (11 boys and 5 girls), whose weight-height parameters at birth were normal (fetal normosomia), and whose state of dental health was different.

The weight-height parameters at birth of the participants in the study (Table I), namely, the harmoniouscoefficient (Grishchenko at el., 1991 [10]), form the basis for dividing all macrosomic children into four subgroups. The birth somatometric data was retrievedfrom the medical records or the delivery records from maternity hospitals.

Subgroup I consisted of 10 children macrosomic-at-birth (7 boys and 3 girls) with harmonious intrauterine development.

Subgroup II included 7 children macrosomic-at-birth (5 boys and 2 girls) who were born with a long body length and a relatively decreased intrauterine body weight.

Subgroup III consisted of 7 overweight children macrosomic-at-birth ( 5 boys and 2 girls) born with a long body length. These children were classified by V. I. Gryschenko as the children with intrauterine acceleration based on obesity background.

Subgroup IV comprised of the 6 children macrosomic-at-birth ( 3 boys and 3 girls) who were born with average weight parameters in combination with intrauterine obesity.

Each child's parents gave written consentto the participation in the study.

The dental status was evaluated using the document "Child or AdolescentDental Record Sheet " [11]. All partisipants' evaluation of the oral cavity hygienic state, was carried out using the Fedorov-Volodkina 1971-year index. The prevalence of caries was determined as a percentage fraction. The intensity of caries and the significant caries index (SiC Index) [12] was determined in all participants in the study. The rate of release of an unstimulated oral fluid was determined by collecting the fluid into graduated tubes for 10 minutes in the morning. The rate of secretion was measured in $\mathrm{ml} / \mathrm{min}$. Quantitative determination of the secretion of minor salivary glands was carried out according to the method of Yakovleva V.I. [13]. The acidity was measured using the $\mathrm{pH}$ indicator strips over a 4.4-8.0 interval at a 0.2 step. The facial index of Izarfrom [14] was used to measure facial morphology. The shape and size of the dentitions, and the character of occlusal contactsfor molars, incisors, and canines were evaluated in three planes during intra-oral examination andby using plaster diagnostic casts. The anomalies of teeth were evaluated. A quantitative analysis of plaster diagnostic casts was conducted by measuring palatal height in accordance with the recommendations and taking into account the reference points set out in the paper [15].

Since there is a hereditary predisposition to the occurrence of dentoalveolar anomalies, the study of genetic predisposition to dental anomalies from the father, or mother, or close relatives of each child was conducted applying a clinical and anamnestic method.

The evaluation of the mean values of the parameters under study was performed using the MSExcel 2016 program. The difference in the mean of small groups hypothesis was tested by means of nonparametric statistics (according to the Mann-Whitney criterium) using the Statistica 6.0 package. In estimating the number of cases, when observing certain features in the groups and subgroups at the significance level $p$ of 0.05 , the binomial distribution of the random variable [16] was assumed.

\section{RESULTS AND DISCUSSION}

\section{EXTRA-ORAL EXAMINATION}

The children in the Main Group in most cases (26 children or $87 \%$ ) the face was revealed to be disproportionate. In 21 children with macrosomia $(70 \%)$ a decrease in the lower third of the face coupled with a deep mentolabial fold was recorded, and an increase in that was observed in 5 cases (17\%). In the Comparison Group, the decrease in the lower third of the face was detected in 4 children $(25 \%)$, and an increase was observed in 1case (6\%). A convex profile was observed in 21 Main Group children (70\%), and in 4 Comparison Group children (25\%). The explanation for these cases may be the distal occlusion or underdevelopment of the mandible. The concaved profile was observed in 5 Main Group children (17\%) and in 1 Comperison Group child (6\%).

The analysis of the Izar index calculations has shown that the predominant number of children $-21(70.0 \% \mathrm{CI}$ (Confidence Interval): $54.1 \%$ - 82.7\%) in the Main Group had a narrow face, 6children (20.0\%: CI: 9.9\% - 34.7\%) had average faces, and 3 children (10.0\% CI: $3.8 \%$ - 22.1\%) had broad faces. Narrow faces was in 5 (31,3\% ДИ: 15,2\% - 52,4\%) and average faceswas in 11 (68,8\% ДИ: 47,6\% $84,8 \%)$ Comparison Group children. The analysis of the 
Table I. Average children weight, height, and weight-height index at birth in the children with both fetal macrosomia and normosomia

\begin{tabular}{cccccc}
\hline Groups and subgroups & Comparison & Subgroup I & Subgroup II & Subgroup III & Subgroup IV \\
\hline Birth weight $(\mathrm{kg})$ & 3.52 & $4.26^{*}$ & $4.20^{*}$ & $4.41^{*}$ & $4.30^{*}$ \\
\hline Birth length $(\mathrm{cm})$ & 52.5 & $56.3^{*}$ & $58.14^{*}$ & $54.9^{*}$ & 52.5 \\
\hline Weight-height index $\left(\mathrm{kg} / \mathrm{m}^{3}\right)$ & 24.42 & 23.86 & $21.02^{*}$ & $26.73^{*}$ & $29.70^{*}$ \\
\hline
\end{tabular}

* - The difference between macrosomic subgroups and normosomic (comparison) group is significant (within the 0.95 confidence interval).

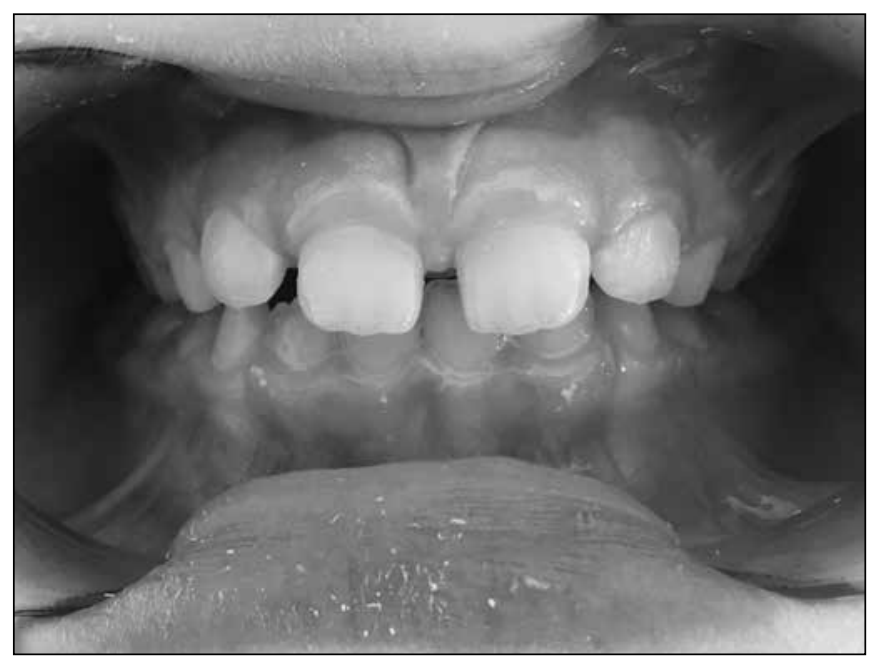

Figure 1. The image of the frontal area of the oral cavity of eight-yearold girl C., born with macrosomia (Subgroup IV); the Class III lip-tie (Horoshilkina F.Ya); Angle Class II malocclusion with deep bite, narrowing and lengthening of the upper dentition, true diastema; mouth breathing, glossoptosis

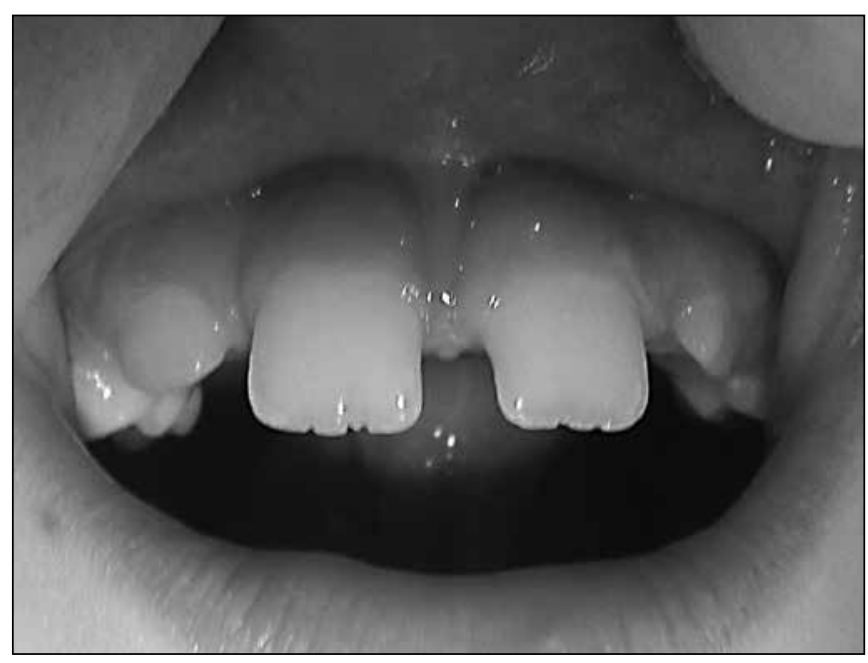

Figure 2. The image of the frontal area of the oral cavity of seven-yearold boy M., born with macrosomia (Subgroup II); the Class III lip-tie (Horoshilkina F.Ya.), true diastema

averaged Isar indices revealed that the children in the Subgroup II, on average, had a significantly narrower face than the children in the Comparison Group ( $p=0.03829)$.

Describing functional disorders, it should be noted that 5 (16.7\% CI: $7.7 \%$ - 30.7\%) of the children born with fetal macrosomia due to ankyloglossia, had problems with the

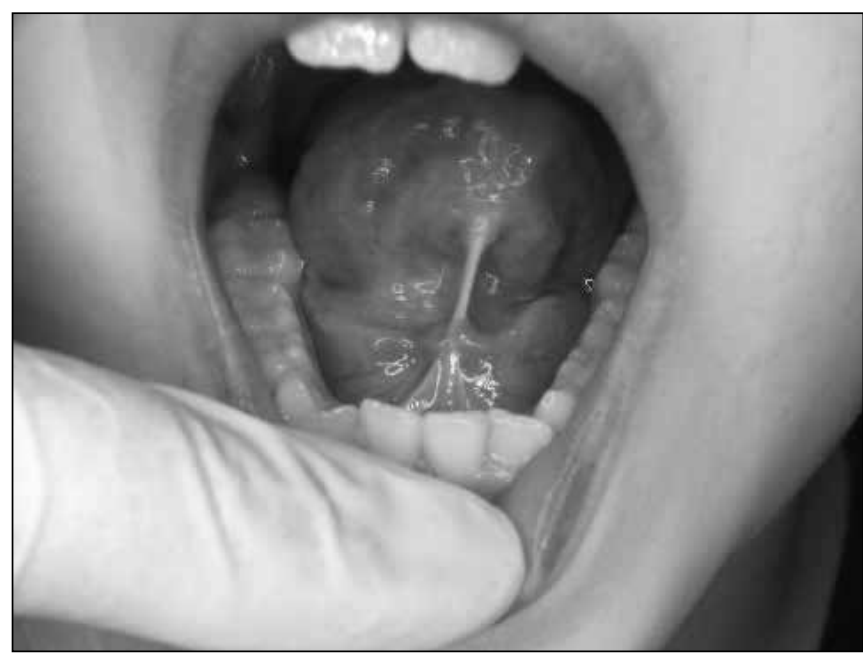

Figure 3. The image of the frontal area of the oral cavity of eight-year-old boy B., born with macrosomia (Subgroup IV); the Class IV of tongue-tie (ankyloglossia). (Horoshilkina F.Ya.); narrowing of the lower dentition with front teeth crowding

pronunciation of sounds. A similar situation was observed in children of younger age who were also born macroscomic [9]. The children in the Comparison Group have not shown any violation in sound pronunciation.

\section{INTRA-ORAL EXAMINATION}

The depth of the oral cavity vestibulum in macrosomic childrenof Subgroup II and of Subgroup IV, in most cases, corresponded to the norm and was comparable to the values for the children of the Comparison Group. However, in childrenof Subgroup I and Subgroup III in this age period, the averaged values of vestibulum'sdepth were significantly lower than in the Comparison Group, $(p=0.02139)$ and $(p=0.00843)$ respectivetly.

Out of the Main Group, anomalous attachment of the upper lip-tie (Fig. 1, 2) had 12children (40.0\% CI: 25.5\% $56.1 \%)$, namely, 4 children in each Subgroup II, III, and IV. Anomalous attachment of the upper lip-tie had also 3 children (18.8\% CI: 7.3\% - 38.3\%) of the Comparison Group. A large percentage of anomalous frenulaof the upper lip is the cause of theupper dentition true diastemas, which were observed in 9 children $(30.0 \% \mathrm{CI}: 17.3 \%-45.9 \%)$ in the Main Group and in 2 children (12.5\% CI: $4.0 \%$ - 30.2\%) in the Comparison Group. Ankyloglossia (Fig. 3) was detected in 12 children (40.3\% CI: $25.5 \%-56.1 \%$ ) in the Main Group and in 3 children (18,8\% CI: 7,3\% - 38,3\%) in 




Figure 4. The images of the oral cavity of eleven-year-old boy R., born with macrosomia (Subgroup II); deciduous and permanent teeth caries; Angle Class II malocclusion with deep bite; upper dental arch shortening with palatal tilting of the maxillary incisor crowns

the Comparison Group. It is noteworthy that four (66.7\% CI: $35.9 \%$ - 88.2\%) out of six children in Subgroup IV had ankyloglossia.

The state of oral hygiene in macrosomic children, in most cases, was comparable to the values for the children of the Comparison Group.

In Main Group children, the prevalence of caries was high (Fig.4) and was equal to $87 \%$ (CI: $73.5 \%$ - 94.4\%) compared to $69 \%$ (CI: $47,6 \%-84,8 \%$ )in the Comparison Group.

The assessment of caries intensity index $(\mathrm{DMF}(\mathrm{T})+$ $\mathrm{df}(\mathrm{t}))$ of the participants in the study is presented in Table II. Table shows that the average values of the Caries Intensity Index were significantly higher for the macrosomic children with intrauterine obesity (Subgroup IV), as compared to the normosomic children. The indicators of caries intensity were also significantly higher than those in Comparison Group in children from Subgroups I and IV in the period of temporary occlusion [9]. Children with intrauterine obesity with acceleration in the background (Subgroup III) andwith harmonious intrauterine development (Subgroup I) had high caries intensity rates, on an average, because the carious process of the first permanent molars takes effect during the period of mixed dentition, although the difference is not reliable in comparison with the normosomic at-birth-children. In the period of the deciduous dentition, the younger children in Subgroup III [9] had indices of caries intensity at a level of that in the Comparison Group.

The averaged rate of unstimulated oral fluid secretion (Table III) in the children of the Main Group were lower than the estimated values in the children of the Comparison Group. This difference is reliable for children from Subgroups III, and IV.

The data on the secretion of minor salivary glands are also presented in Table III. Consequently, children with macrosomia at birth, when they turn the age of 6.5-11, as well as children of the preschool age [9], have a reduced number of minor salivary glands per unit area. The average amount of minor salivary gland secretion is also significantly lower for persons in the Subgroups I, III, and IV. The results presented in Table III are also supported by ourprevious experimental studies on animals, that were born macrosomic $[17,18]$. This data proofs that fetal macrosomia accompanied by morphofunctional changes in the parotid and minor salivary glands. The data we have obtained are important facts for explaining the mechanism of the appearance of high intensity, prevalence of caries and lesions of the oral mucosa among children whose parameters at birth were higher than normal [19].

The value of the $\mathrm{pH}$ indicator (Table III) for all children in the Main Group is on average lower than in the children in the Comparison Group.This difference is reliable for children from Subgroup II.

\section{INTRA-ORAL EXAMINATION AND ANALYSIS OFPLASTER DIAGNOSTIC CASTS}

Results of palatine depth measurement are presented in Table IV. The average indices indicating the height of the palate are the highest in macrosomic children compared with the normosomic ones. This statement is valid for children of the Subgroup III, and according to the data presented in paper [15], the palate in children of this Subgroup is classified as "high".

Thus, children aged 6.5 to 11 years, born with macrosomia, have narrow faces and high palate more frequently than normosomic-at-birth children. These changes are more pronounced in this age period in the Subgroups II and III, which can be taken into account in preventive examinations, planning and providing orthodontic treatment. A combination of a narrow face and a distal occlusion usually characterizes children born with fetal macrosomia.

When evaluating the relation of the upper and lower first permanent molars in the sagittal plane, we found out that 20(66.7\% CI: 50.6\% - 80.1\%) children in the Main Group had Class II malocclusion (Angle's classification), namely: 
Table II. The values of DMF(T) + df(t) and Significant Caries Index (SiC Index)in the children with both fetal macrosomia and normosomia at birth

\begin{tabular}{cccccc}
\hline Groups and Subgroups & Comparison & Subgroup I & Subgroup II & Subgroup III & SubgrouplV \\
\hline $\mathrm{DMF}(\mathrm{T})+\mathrm{df}(\mathrm{t})$ & 2.7 & 5 & 3.0 & 6.0 & $\begin{array}{c}6.8^{*} \\
(\mathrm{p}=0,04347)\end{array}$ \\
\hline $\mathrm{SiC}$ Index & 4,8 & 8,3 & 5,5 & 12,5 & 10 \\
\hline
\end{tabular}

$\operatorname{DMF}(\mathrm{T})$ - decayed missing and filled permanent teeth;

$\mathrm{df}(\mathrm{t})$ - decayed and filled deciduous teeth.

* - The difference between macrosomic subgroups and normosomic (comparison) group is significant (within the 0.95 confidence interval).

Table III. Mathematical expectation of the minor salivary glands secretion rate, unstimulated oral fluid flow rate andthe salivary $\mathrm{pH}$ value in the children with both fetal macrosomia and normosomia at birth

\begin{tabular}{|c|c|c|c|c|c|}
\hline Groups and Subgroups & Comparison & Subgroup I & Subgroup II & Subgroup III & Subgroup IV \\
\hline $\begin{array}{l}\text { The number of minor salivary glands in } \\
\text { the area of } 3.5 \mathrm{~cm}^{2}\end{array}$ & 15.3 & $\begin{array}{c}13.1^{*} \\
(p=0,00020)\end{array}$ & $\begin{array}{c}13.9^{*} \\
(p=0,00260)\end{array}$ & $\begin{array}{c}14^{*} \\
(p=0,02565)\end{array}$ & $\begin{array}{c}13.5^{*} \\
(p=0,01145)\end{array}$ \\
\hline $\begin{array}{l}\text { The amount of secret which is secreted } \\
\text { by one minor salivary gland, } \mathrm{g} / \mathrm{min} \times 10^{-4}\end{array}$ & 1.83 & $\begin{array}{c}1.64^{*} \\
(p=0,04602)\end{array}$ & 1.74 & $\begin{array}{c}1.36^{*} \\
(p=0,00075)\end{array}$ & $\begin{array}{c}1.27^{*} \\
(p=0,00932)\end{array}$ \\
\hline Unstimulated salivary secretion rate $\mathrm{ml} / \mathrm{min}$ & 0.32 & 0.30 & 0.29 & $\begin{array}{c}0.25^{*} \\
(p=0,01161)\end{array}$ & $\begin{array}{c}0.20^{*} \\
(p=0,00050)\end{array}$ \\
\hline Value of the hydrogen index $(\mathrm{Ph})$ & 6.8 & 6.6 & $\begin{array}{c}6.5^{*} \\
(p=0,00294)\end{array}$ & 6.4 & 6.6 \\
\hline
\end{tabular}

* - The difference between macrosomic subgroups and normosomic (comparison) group is significant (within the 0.95 confidence interval).

Table IV. Absolute and relative values of assessment of the depth of the hard palate in the children with both fetal macrosomia and normosomia at birth

\begin{tabular}{|c|c|c|c|c|c|}
\hline Groups and Subgroups & Comparison & Subgroup I & Subgroup II & Subgroup III & Subgroup IV \\
\hline Palatine height (h), $\mathrm{mm}$ & 10.2 & $\begin{array}{c}11.7 \\
(p=0,03246)\end{array}$ & $\begin{array}{c}12.0 \\
(p=0,02384)\end{array}$ & $\begin{array}{c}12.8^{*} \\
(p=0,01274)\end{array}$ & 12.0 \\
\hline Palatine width $(\mathrm{I})_{\iota} \mathrm{mm}$ & 32.6 & 34.3 & 34.3 & 32.1 & 35.75 \\
\hline $\mathrm{h} / \mathrm{l}$ relative units & 0.31 & 0.34 & 0.36 & $\begin{array}{c}0.40^{*} \\
(p=0,00901)\end{array}$ & 0.34 \\
\hline
\end{tabular}

* - The difference between macrosomic subgroups and normosomic (comparison) group is significant (within the 0.95 confidence interval).

5 children (50\%) in the Subgroup I, 4 children (57\%) in the Subgroup II, 6 children (86\%) in the Subgroup III, and 5 children (83\%) in the Subgroup IV. This condition was recorded in 4 children $(25.0 \%$ CI: $11.0 \%-45.6 \%)$ of the Comparison Group. The relation of molars corresponding to Angle Class III malocclusionhad 4 children $(25.0 \% \mathrm{CI}$ : $11.0 \%-45.6 \%)$ of the Main Group: 3 children (30\%) in the Subgroup I and 1child (14\%) in the Subgroup II; and 1 child (7.1\% CI: $1.8 \%$ - 23.2\%) in the Comparison Group.

The Angle class II canine relation was detected in 20 children (66.7\% CI: 50.6\% - 80.1\%) of the Main Group and in 4 children $(25.0 \% \mathrm{CI}: 11.0 \%$ - $45.6 \%)$ of the Comparison Group. The Main Group examination revealed this disorder in 5 children $(50 \%)$ of the Subgroup I, 5 children $(71 \%)$ of the Subgroup II, 6 children (86\%) of the Subgroup III, and 4 children (67\%) of the Subgroup IV. The canine relation corresponding to class III malocclusion was detected in 4 children (13.3\% CI: 5.6\% - 26.5\%) of the Main Group: 3 children (30\%) in the Subgroup I and 1child (14\%) in the Subgroup II. This dental anomaly was detectedin 1 child (6.3\%: CI: $1.6 \%$ - 20.6\%) in the Comparison Group. Clinical cases, when relation of molars corresponds to Class II malocclusion and relation of canines corresponds to Class I, can be explained by medial shift of canines in combination with the lower frontal teeth crowding.

In assessing the relation of incisors in the sagittal plane, we have observed that 8 children(26.7\% CI: $14.7 \%$ - 42.3\%) of the Main Group had a correct incisors relationship, namely: 3 children in the Subgroup I, 2 children in the Subgroup II, 1 child in the Subgroup III, and 2 children in the Subgroup IV. Three children in the Subgroup I and 1 child in the Subgroup IVhad anedge-to-edgecontact. Fifteen children (50.0\% CI: 34.3\% - 65.7\%) of the Main Group were noted to have positive overjet (distance more than $2.5 \mathrm{~mm}$ ), namely: 3 children in the Subgroup I, 3 children in the Subgroup II, 6 children in the Subgroup III and 3 children in the Subgroup IV. The reverse overjet (lower incisor edge occluding anterior to the upper incisors) was recorded in 2 children in the Subgroup II. In the Comparison Group, positive overjet was observed in 4 children $(25.0 \%$ CI: $11.0 \%-45.6 \%)$, thereverse overjet was recorded in 1 child $(6.3 \% \mathrm{CI}: 1.6 \%-20.6 \%)$. The palatal 


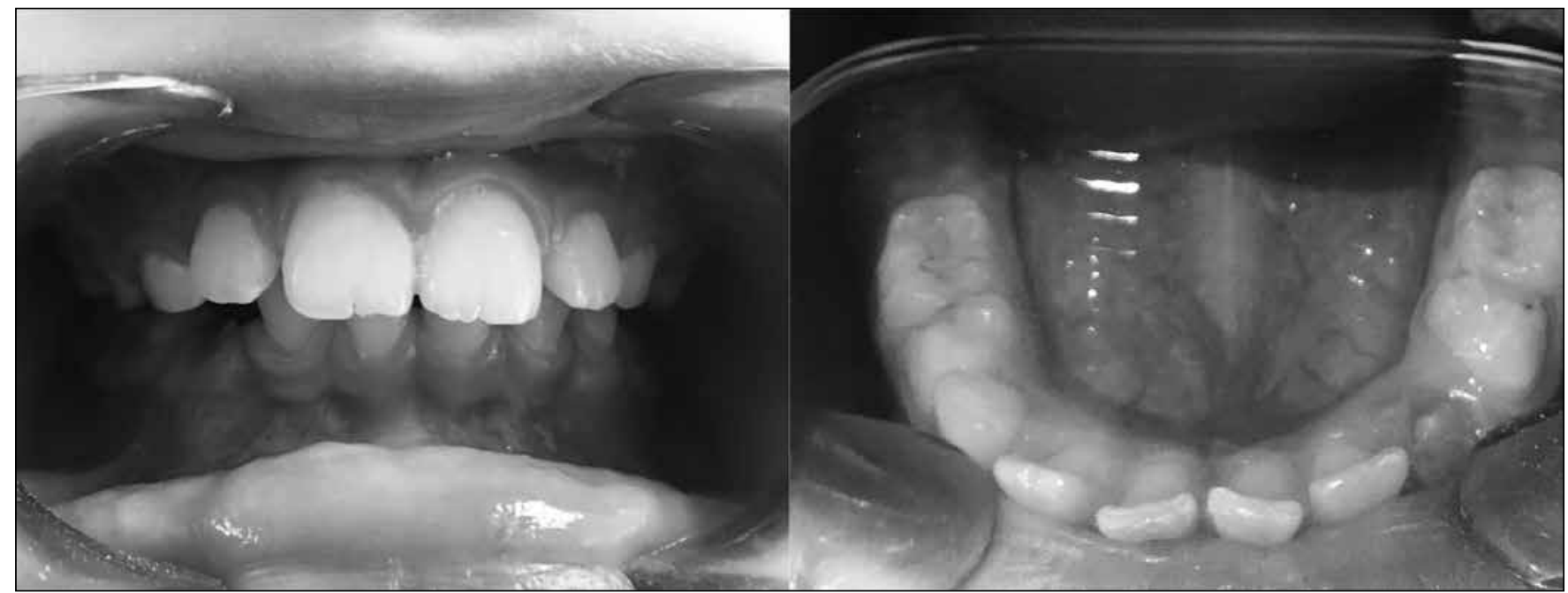

Figure 5. The images of the frontal area of the oral cavity of eight-year-old boy S., born with macrosomia (Subgroup I); Angle Class II malocclusion with deep bite; narrowing and lengthening of the upper and lower dentitions,a tortoanomaly of the tooth 31 (counter-clockwise) and tooth 41 (clockwise), hypoplasia of upper central incisors; shallow vestibulum, chronic catarrhal gingivitis, mouth breathing, glossoptosis

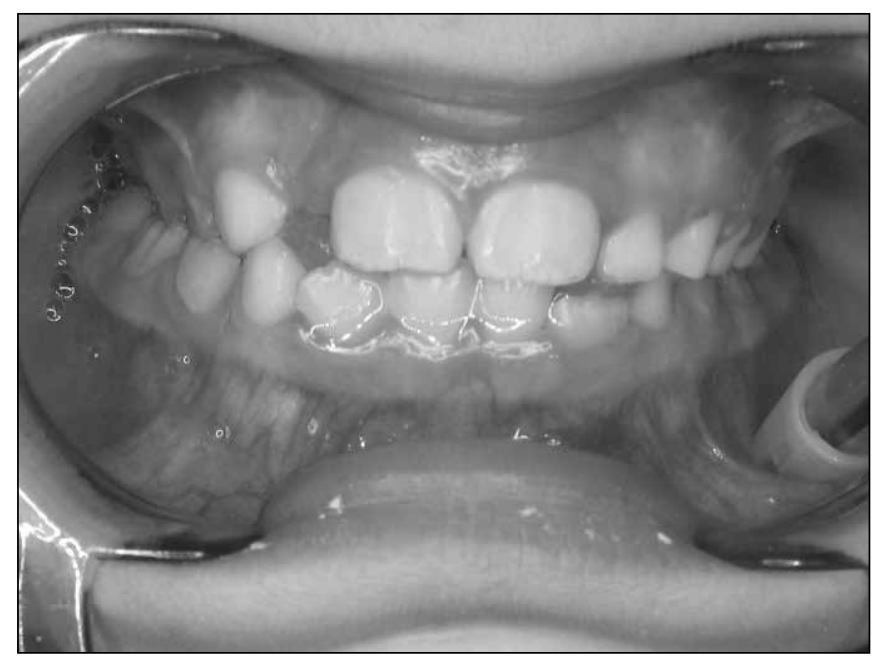

Figure 6. The image of the frontal area of the oral cavity of seven-year-old girl G., born with macrosomia (Subgroup III); Lingual-buccal crossbite with displacement of the lower jaw to the left, narrowing of the upper and lower dentitions, glossoptosis, infantile swallowing

tilting of theincisors'crowns (Fig 4), which was observed in many participants of the study, may occur as a result of the mouth breathing, high palate and highly hypertonic upper lip muscles [20].

When evaluating the occlusion in vertical plane in the molar region, it was noticed there was a tight occlusal contact, (except the teeth that are in the eruptive stage), in most participants of the study. Two children (6.7\% CI: $2.1 \%$ - 17.2\%) of the Main Group (one child in the Subgroups I and III) had a posterior unilateral open bite. This anomaly was not detected in the Comparison Group.

Examining the occlusion in vertical plane in the canine region, wehave observed that upper canine cusps were above the contact points of lower teeth in 16children



Figure 7. The image of the frontal area of the oral cavity of seven-year-old boy V., born with macrosomia (Subgroup III); localized macrodontia

(53.3\% CI: 37.4\% - 68.7\%) of the Main Group: 6children $(60 \%)$ in the Subgroup I, 3children (43\%) in the Subgroup II, 4 children (57\%) in the Subgroup III, and $3(50 \%)$ in the Subgroup IV. Moreover, we noticed that upper canine cusp was above the contact point in 3children (18.8\% CI: $7.3 \%-38.3 \%$ ) of the Comparison Group. This fact can be explained by the delayed eruption of canines in comparison with the standard time of incisors eruption.

Evaluating the occlusion in vertical plane in the incisor region, we noticed that only 8 children $(26.7 \%$ CI: $14.7 \%$ $42.3 \%$ ) out of the Main Group, had upper central incisors covered $1 / 3-1 / 4$ of the anterior surface of the lower central incisors (norm). The norm was observed in 2 children (20\%) of the Subgroup I, 3 children (43\%) of the Subgroup II, 2 children (29\%) of the Subgroup III, and 1 child (17\%) of the Subgroup IV. In the Comparison Group the norm was found in 11 children (68.8\% CI: $47.6 \%-84.8 \%)$. Six children (20.0\% CI: $9.9 \%-34.7 \%)$ of the Main Group 
had an anterior open bite malocclusion (1 to $3 \mathrm{~mm}), 1$ child of the Main Group had no incisors. Fifteen children (50.0\% CI: 34.3\% - 65.7\%) of the Main Group had a deep bite malloclusion (mild, moderate or severe) (Fig. 1, 4, 5). This anomaly was detected in 4children $(25.0 \%$ CI11.0\% - 45.6\%) of the Comparison Group. As a result of a deep bite malocclusion emergence of caries, periodontitis, joints problems, chewing and swallowing difficulties may develope later in life. If the treatment of this abnormalities occurs during the body growth period, the prognosis for a disease will be favorable [20]. Whereas cases of deep bite malocclusion were prevalent in macrosomic children born at the age of 3-6.5 years, we can assume a "tendency" to underdevelopment of the mandible in macrosomic children. This is confirmed by the mandibular anterior teeth crowding (Fig. 3).

Evaluating the occlusion in transverse plane in the molar region, we have observed the posterior cross bite malocclusion in 7 children $(23.3 \%$ CI: $12.3 \%-38.6 \%)$ of the Main Group and only in 1 child (6.3\% CI: $1.6 \%-20.6 \%)$ of the Comparison Group. A partial cross-bite without displacement of the mandible was detected in 3children (30\%) of the Subgroup I, 1 child (14\%) of the Subgroup II, and in 2 children (33\%) of the Subgroup IV. There was 1 child in the Subgroup III (Fig. 6) with a buccal-lingual cross-bite malocclusion with the lower jaw displacement.

The upper and lower canines' relation was found to be the most uniform (stable) dimension in the studied parameters. Evaluating the occlusion in transverse plane in the canine region, we have found normal relation between upper canines and mandibular teeth in 24 children $(80.0 \%$ CI: $65.3 \%-90.1 \%)$ of the Main Group and 15 children (93.8\% CI: 79.4\% - 98.4\%) of the Comparison Group. Onechild (10\%) of the Subgroup I, 4 children (57\%) of the Subgroup II and 1 child (17\%) of the Subgroup IV had palatal positioning of the maxillary canines relative to the mandibular corresponding teeth. The same positioning occurred in 1 child (6\%) of the Comparison Group.

While evaluating the occlusion in transverse plane in the incisor region, we detected the shifted midline in 10 children (33.3\% CI: 19.9\% - 49.4\%) of the Main Group: 3 children (30\%) in the Subgroup I, 4 children (57\%) in the Subgroup III, 3 children (50\%) in the Subgroup IV, and we detected the shifted midline in 3 children $(18.8 \%$ : CI: $7.3 \%-38.3 \%$ ) of the Comparison Group. The high rate of this anomaly in macrosomic children of Subgroups III and IV can be explained by the adaptation of the mandible position to the changed form of the upper dentition, as well as interruption in sequence and timing of permanent teeth eruption.

The analysisof the mandibular dentition (frontal area) state in the sagittal plane revealed that 18 children $(60.0 \%$ CI: $43.9 \%-74.5 \%)$ had the shortening of dental arch, and 5 children (16.7\% CI: $7.7 \%$ - 30.7\%) of the Main Group had an extended dental arch length. The mandibular dentition shortening was found in 4 children $(25.0 \% \mathrm{CI}$ : $11.0 \%-45.6 \%$ ) of the Comparison Group. We analyzed the state of the maxillary dentition (frontal area) in the sagittal plane and revealed the shortening of the dentition in 7 children $(23.3 \%$ CI: $12.3 \%-38.6 \%)$ of the Main Group and in 7 children (43.8\% CI: $24.7 \%$ - 64.6\%) of the Comparison Group. An extended dental arch length was observed in 18children (60.0\% CI: $43.9 \%-74.5 \%)$ of the Main Group and in 2 children (12.5\% CI: 4.0\% - 30.2\%) of the Comparison Group.

Since we observed a large percentage of the mandibular dentition shortening in the sagittal plane in macrosomic children aged 4.5-6.5 years [9], we can suggest several reasons for that. In our opinion, one of the causes of underdevelopment of the frontal area of the mandible, along with ankyloglossia or incorrect myofunctional habits, is a traumatic damage of the lower jaw (for example, injury in the zones of mandible growth during intrauterine compression) during pathological pregnancy or the delivery of a child with a large body weight.

The shortening of mandibular dentition (lateral area) in the sagittal plane was found in 7 children $(23.3 \% \mathrm{CI}: 12.3 \%$ - 38.6\%) of the Main Group and in 3 children (18.8 \% CI: $7.3 \%-38.3 \%$ ) of the Comparison Group. The shortening of the dentition of the upper jaw in the sagittal plane was found in 8 children (26.7\%: CI: $14.7 \%-42.3 \%)$ of the Main Groupand in 3 children (18.8 \% CI: 7.3\% - 38.3\%) of the Comparison Group. An extended dental arch length of mandibular dentition was found in 2 children $(7.1 \% \mathrm{CI}$ : $2.3 \%-18.3 \%)$ of the Main Group and in 1 child $(6.3 \% \mathrm{CI}$ : $1.6 \%-20.6 \%)$ of the Comparison Group. An extended dental arch length of maxillary dentition inwas found in 1 child (3.3\% CI: $0.8 \%$ - 11.6\%) of the Main Group and in the children of the Comparison Groups it was not detected. It should be noted that this parameter was in most cases standard for children aged 4.5-6.5 years. In our opinion, the most probable reason for the dentition shortening during the period of mixed occlusion is a high prevalence of untreated deciduous teeth caries in children of the Main Group [9] with its typical localization on the approximal surfaces of teeth (Fig. 4).

When assessing the state of dentition in the vertical plane, we have found anomalies in 28 children (93.3\%: CI $82.8 \%-97.9 \%)$ of the Main Group and 4 children $(28.6 \%$ of CI: $12,8 \%$ - 50,8\%) of the Comparison Group. Twentytwo children (73.3\% CI: $57.7 \%$ - 85.3\%) of the Main Group had dentoalveolar elongation of the frontal mandibular segment anddentoalveolar elongation of the frontal maxillary segment in 4 cases (13.3\% of CI: $5.6 \%$ - 26.5\%). Dentoalveolar elongation of the frontal maxillary segment was recorded in 2 children (12.5\% CI: $4.0 \%-30.2 \%)$ and dentoalveolar elongation of the frontal mandabular segment was recorded in 1child (6.3\% CI: 1.6\% - 20.6\%) of the Comparison Group. At the same time, 18 children (60.0\% CI: $43.9 \%-74.5 \%)$ of the Main Group and 3 children (18.8\% CI: 7.3\% - 38.3\%) of the Comparison Group had dentoalveolar shortening of the frontal maxillary segment. Taking into consideration that during both temporary [9] and mixed occlusion periods we have observed prevalence of changes in the vertical dimensions of the frontal area dentitions in the Main Group children in correlation to 
Comparison Group children, we came to conclusion that fetal macrosomia associated with of these abnormalities.

The analysis of the mandibular dentition (lateral area) in the transversal plane revealed that 17 children (56.7\%: CI: $40.6 \%$ - 71.7\%) of the Main Group and 4 children (25.0\% CI: $11.0 \%$ - 45.6\%) of the Comparison Group had the mandibular narrowing. Maxillary dentition (or lateral area) in the transversal plane was narrowed in 7 children (23.3\% CI: $12.3 \%-38.6 \%)$ of the Main Group. This abnormality was detected in 1 child $(6.3 \%$ CI:1.6\% - 20.6\%) of the Comparison Group.

The analysis of the frontal area mandibular dentition in the transversal plane showed that 3 children $(10.0 \% \mathrm{CI}$ : $3.8 \%-22.1 \%$ ) of the Main Group had the displacement of the lower dental midline in relation to the tongue frenum. In the Comparison Group, this anomalywas detected in 1 child (6.3\% CI: $1.6 \%$ - 20.6\%). The upper dental midline coincided with the middle palatine suture in all participants of the study.

The developmental disturbances in teeth structure were represented by hypoplastically altered enamel of permanent and deciduous teeth, which were seen in 8 children (26.7\% CI14.7\% - 42.3\%) of the Main Group and 3 children (25\% CI: 9.9\% - 48.4\%) of the Comparison Group.

Among the developmental disturbances in teeth size, there was a predominated relative generalized microdontia, which was observed in 3 children (10.0\% CI: $3.8 \%$ - 22.1\%) of the Main Group. Macrodontia of single tooth was revealed in 1 child (3.3\% CI: $0.8 \% 11.6 \%)$ of the Main Group (Fig. 7). In the Comparison Group one child (6.3\% CI: $1.6 \%-20.6 \%$ ) had had supernumerary permanent tooth (mesiodent) and one child (6.3\% CI: 1.6\% - 20.6\%) had supernumerary deciduous tooth.

There were different levels of pathological conditions among the dentoalveolar abnormalities. They are as follows: occlusion abnormalities, anomalies of the dentition shape and size, and teeth disturbances. The named anomalies do not occur apart from one another. Therefore, the description of the teeth position is not feasible, but the mandibular anterior teeth in 3 children (10.0\% CI: $3.8 \%-22.1 \%)$ of the Main Group were rotated in the longitudinal axis (Fig. 5). This fact deserves attention, because these children did not have ankyloglosia (tongue thrust) and crowded mandibular anterior teeth. The inadvertent abnormality may develop as a result of some local factors, and may also indicate the alormaly of the lower jaw frontal segment.

It is important to notice that in 11 (36,7\% CI: $22,7 \%$ $52,8 \%$ )of the Main Group children, the eruption of lower jaw central incisors occurred prior to thelower first permanent molars eruption. Interruption in sequence and timing of permanent teeth eruption is another sign confirming the underdevelopment of the mandible. There were no abnormalities of this kind found in the Comparison Group.

Along with intrauterine abnormalities [22], the role of hereditary occurrence of dentoalveolar deviations [23] is well known. Analyzing the obtained results, it should be noted that our study gives a comparison of genetic predisposition to dentoalveolar abnormalities occurrence in the Main and Comparison Groups. Consequently, a large number of malocllusions $100 \%$ (CI: $88.4 \%-100 \%$ ) in the Macrosomic Group versus to the the Comparison Group $73 \%$ (CI: $51.9 \%-88.2 \%$ ) is due to some other factors associated with the fetal macrosomia.

We presume that children and adolescents born macrosomic have reduced mineral bone tissue density compared to normosomic-at-birth children. Our assumptions are confirmed by Littnerand his co-authors' research results arguing that bone mineral density can be reduced in macrosimic newborns compared to normosomic ones, explaining this by a decreased intrauterine mobility of very large children [24]. The Schushan-Eisen I. et al. study [25] also confirmed significantly reduced bone mineral density in newborns with fetal macrosomia born from non-diabetic mothers. The authors prove that the bone tissue mineral density is reduced with every $100 \mathrm{~g}$ of the body weight of a newborn child, and the hypothesis of "reduced mobility" is also confirmed in the fetal macrosomia cases.

\section{CONCLUSIONS}

1. Caries intensity indices vary in the macrosomic-at-birth participants of our study in the period of mixed dentition, depending on the weight-height parameters of these children at birth. The high values of these indiceswere recorded in children born with harmonious (well-balanced) intrauterine development, with intrauterine obesity and acceleration or with intrauterine obesity and an average body length.

2. Macrosomic children have, on average, reduced number of minor salivary glands by $1-2$ units in area of $3,5 \mathrm{~cm}^{2}$, in comparison with the normosomic-at-birth children. The saliva secretion of minor salivary glands in macrosomic children is reliably $(\mathrm{p}<0.05)$, by an average of $16,5 \%$, reduced in comparison to the normosomic children.

3. Children agesof 6.5-11 years and born with fetal macrosomia, have long narrow faces and high palate more frequently than normosomic-at-birth children. In the period of mixed dentition, these changes are more pronounced in macrosomic-at-birth children with long body length and a relatively decreased intrauterine body weight, and in overweight children born with a long body length. These features can be taken into account in preventive examinations, planning and conducting of orthodontic treatment.

4. Children born macrosomic have a significantly higher percentage of dentoalveolar abnormalities in the mixed dentition period in comparison with the normosomic-at-birth children (100\% versus $73 \%)$.

Thus, the obtained results proved that the processes causing fetal macrosomia have a great impact on the dental status of children in the period of mixed dentition.

\section{REFERENCES}

1. Hayden C, Bowler J0, Chambers S, Freeman Ret al.Obesity and dental caries in children: a systematic review and meta-analysis.Community Dent Oral Epidemiol. 2013; 41(4):289-308. doi: 10.1111/cdoe.12014. 
2. Osawa H, Sugihara N, Ukiya T et al.Metabolic Syndrome, Lifestyle, and Dental Caries in Japanese School Children.Bull Tokyo Dent Coll. 2015;56(4):233-41. doi: 10.2209/tdcpublication.56.233.

3. Novotna M, PodzimekS, Broukal Zet al.Periodontal Diseases and Dental Caries in Children with Type 1 Diabetes Mellitus Mediators Inflamm. 2015; (51):379626. doi: [10.1155/2015/379626]

4. Drogomiretskaya MS, Ahmad Saleh Khalyaf Salama. Morfolohichni ta morfometrychni doslidzhennia tkanyn zubo-shchelepnoho aparatu u ditei z porushenym perebihom antenatalnoho periodu [The morphological and morphometric study of tissues of dentoalveolar system in children with impaired course of the antenatal period]. Klinichna medytsyna 2016;16 (XXI/1): 96-103. (UA).

5. Garmash OV, Ryabokon EN.The Effect of Fetal Macrosomia on the Neonate and Infant Dental Health International Journal of Clinical Dentistry. 2017; 10 (3): 200-210.

6. Morikawa $M, C$ ho $K$, Yamada Tet al. Fetal macrosomia in Japanese women. J Obstet Gynaecol Res. 2013;39(5):960-5. doi: 10.1111/j.14470756.2012.02059.x.

7. Yokomichi H, Tanaka T, Suzuki Ket al. Macrosomic neonates carry increased risk of dental caries in early childhood: findings from a cohort study, the Okinawa child health study. Japan. PLoS One. 2015; 10(7), doi: 10.1371/journal.pone.0133872.

8. Julihn A, Molund U,Drevsäter Eet al. High birth weight is a risk factor of dental caries increment during adolescence in Sweden. Dent J. 2014; 2(3): 118-33.

9. Garmash OV. Features of the dental state of children with fetal macrosomia in the period of the temporary dentition. Visnyk problem biolohii i medytsyny. 2018; 4 (1/146): 246-253. (UA).

10. Grischenko VI. Krupnyiy plod (kliniko-morfologicheskoe issledovanie) [Large fetus (clinical and morphological study)]. In:VI. Grischenko, AF Yakovtsova. Kiev: Zdorovya;1991, p 183.(Ru).

11. Garmash OV, Ryabokon EN,Bahlyk TV. Karta reiestratsii stomatolohichnoho statusu dytyny abo pidlitka (dodatok do karty rozvytku novonarodzhenoho, istorii rozvytku dytyny abo medychnoi karty statsionarnoho khvoroho)[Child or Adolescent Dental Record Sheet]Cvidotstvo pro reiestratsiiu avtorskoho prava na tvir №73141 vid 25. 07. 17. (UA).

12. Bratthall D. Introducing the Significant Caries Index together with a proposal for a new oral health goal for 12-year-olds, Int Dent I 2000; 50: 378-384.
13. lakovleva VY. Sposob kolychestvennoho opredelenyia sekreta melkykh sliunykh zhelez [Method for quantitative determination of secretion of minor salivary glands] Zdravookhranenye Belorussyy. 1980; 12: 57. (Ru).

14. Obraztsov YuL, Laryonov SN. Propedevtycheskaia ortodontyia: uchebnoe posobye [Propedeutic Orthodontics: Tutorial] SPb.:SpetsLyt, 2007:160. (Ru).

15. Mulazzani MC, Toniolo da Silva AM, Busanello-Stella ARet al. Evaluation of hard palate depth: correlation between quantitative and qualitative method. Rev. CEFAC. 2013 Set-0ut; 15(5):1292-1299.

16. Gerasimov AN. Medical statistics. Moscow: Medical News Agency; 2007: 480.

17. Garmash 0, Gubina-Vakulik G, Vondrášek D.Three dimensional image analysis of minor salivary glands in 180-day rats born with macrosomia Med J (Krag) 2018; 52(1): 7-14.

18. Garmash OV., Gubina-Vakulyk GI. Morphofunctional status of parotid salivary glands in three-month-old rats with experimentally induced fetal macrosomia. Pathologia 2018; 15 (1): 81-87.

19. Yakovtsova AF, Sorokina IV, Aleshchenko IE. Imunnaya sistema ploda cheloveka pri krupnoplodii i ZVRP [Immune system of the human fetus in large and IUGR fetuses]. Kharkov: BSF "Antiqua"; 2004, p 218. (Ru).

20. Bahija B, K Sundeep H, Sham SB,et al. Influence of Mouth Breathing on the Dentofacial Growth of Children: A Cephalometric Study. J Int Oral Health. 2014; 6(6): 50-55.

21. DaokarS, Agrawal G. Deep Bite Its Etiology, Diagnosis and Management: A Review. J Orthod Endod. 2016; 2:4.

22. Joshi N ,Hamdan AM., FakhouriWD. Skeletal Malocclusion: A Developmental DisorderWith a Life-Long Morbidity JClinMedRes. 2014; 6(6): 399-408. doi: 10.14740/jocmr1905w.

23. PatelZ, Ifzah, Sheikh Habibullah. Genetics in orthodontics- a review. EJPMR, 2016;3(7): 539-545.

24. LittnerY, Mandel D, Mimouni FB et al.Decreased bone ultrasound velocity in large-for-gestational-age infants. J Perinatol. 2004;24(1):21-3.

25. Schushan-Eisen I, Cohen M, Leibovitch Let al. Bone Density Among Infants of Gestational Diabetic Mothers and Macrosomic Neonates Maternal and Child Health Journal. 2015; 19 (3): 578-582.

The study is a fragment of the research project "Character, structure and treatment of main dental diseases", state registration No. 0116 U004975.

Authors' contributions:

According to the order of the Authorship.

Conflict of interest:

The Authors declare no conflict of interest.

\section{CORRESPONDING AUTHOR Olga Garmash \\ Apt 51, Heroiv Pratsi St., 4-V \\ 61168 Kharkiv, Ukraine \\ tel: +380666949665 \\ e-mail: o.v.garmash@gmail.com}

Received: 13.03.2019

Accepted: 26.04.2019 


\title{
STUDY OF THE LIFESTYLE OF ECONOMICALLY ACTIVE POPULATION OF THE CHERNIVTSI REGION: THE PREVALENCE OF RISK FACTORS AMONG BUSINESS ENTITIES IN THE MARKET
}

\author{
Lyubov Y. Vlasyk ${ }^{1}$, Natalia 0. Ryngach ${ }^{2}$, Leonid I. Vlasyk ${ }^{3}$, Hanna Y. Stupnytska ${ }^{1}$ \\ 'HIGHER STATE EDUCATIONAL ESTABLISHMENT OF UKRAINE "BUKOVINIAN STATE MEDICAL UNIVERSITY", CHERNIVTSI, UKRAINE \\ 2PTOUKHA INSTITUTE FOR DEMOGRAPHY AND SOCIAL STUDIES OF THE NATIONAL ACADEMY OF SCIENCES OF UKRAINE, KYIV, UKRAINE \\ 'STATE ENTERPRISE"LII.MEDVED'S RESEARCH CENTER OF PREVENTIVETOXICOLOGY, FOOD AND CHEMICAL SAFETY, MINISTRY OF HEALTH OF UKRAINE", KYIV, UKRAINE
}

\begin{abstract}
Introduction: To reduce the burden of non-communicable diseases (NCDs) and premature mortality, it is necessary to influence the risks of their occurrence at all stages of life. Economically active population, which can be more at risk, is required the special attention.

The aim of the study is to investigate the prevalence for risk factors of major NCDs among the economically active population of the Chernivtsi region in the example of business entities in the market.

Materials and methods: The survey of the Chernivtsi business entities ( $n=633$ ) conducted in 2017-2018 on the territory of ME CSC (the Municipal Enterprise City Shopping Complex) "Kalynivskyi market" has been used in the research.

Results: There is the high level of the prevalence of the main risk factors for NCDs (unhealthy diet, lack of physical activity, smoking) among those working in the territory of the market. Only $17 \%$ consume a sufficient amount of fruit and fish. Only $35 \%$ of respondents systematically do physical exercises and special physical exercises. The most common unhealthy diet has been found among young men (25-44 years), in this group, about $40 \%$ are smoking. An acute problem of female smoking (25\%) among market workers has been revealed. It is shown that, in general (taking into account passive smoking), $65 \%$ of respondents suffer from harmful effects of tobacco.

Conclusions: The established features of the lifestyle of workers indicate the need to make maximum efforts to focus on improving medical literacy and the formation of motivation to preserve health.
\end{abstract}

KEY WORDS: economically active population, non-communicable diseases, risk factors

Wiad Lek 2019, 72, 5 cz. I, 832-837

\section{INTRODUCTION}

Over the last decade, the burden of non-communicable diseases (NCDs) is increasing in the world. Every year, 15 million people aged 30-69 die from NCDs (cardiovascular, oncological, chronic respiratory and diabetes mellitus). More than $80 \%$ of these deaths occur in developing countries. One of the goals for achieving the objectives of sustainable development is to reduce the mortality rate from NCDs at the age of 30-69 by one third by 2030. The influence on the risks of NCDs is necessary at all stages of life [1]. The economically active population (15-69 years), which is most at risk, requires special attention. The WHO Global Conference on Issues related to NCD in Montevideo (2017) highlighted the dependence of premature mortality on economic, environmental and social determinants. To counteract a complex set of factors (tobacco use, inadequate physical activity, alcohol abuse, unhealthy eating) and the use of appropriate measures (taking into account gender peculiarities and the level of medical literacy), it is necessary to monitor their prevalence in the state and individual regions [2].

Individual risk factors have been studied regularly for a long time. For example, the Second Global Adult Tobac- co Survey (GATS-2017) showed a significant decrease in the overall and daily prevalence of smoking in Ukraine compared to 2010 [3]. There is a need for a detailed study of the prevalence of all the major factors of the NCDs among the busy economically active population, which spends a significant part of life at work. People who work under stress or instability tend to smoke more, move less and eat inefficiently. The Global Health Action Plan for 2008-2017 considered the need to stimulate health promotion and comprehensive prevention of NCDs through popularization a healthy and regular diet, physical activity, and strengthening mental health and family health [4]. The results of sample household surveys on economic activity through direct inquiries usually have economic and social uses [5]. In the social aspect, the supply of labor and the use of human resources in the production process is evaluated, but the question of health is not included in such questionnaires. As wholesale and retail trade occupy a significant proportion of economic activity (the highest after industry, education, health care, and social assistance), lifestyle research and self-assessment of health workers in the markets are extremely topical. 


\section{THE AIM}

To study the prevalence of risk factors for major NCDs among the economically active population of Chernivtsi region in the example of business entities in the markets.

\section{MATERIALS AND METHODS}

The survey of the Chernivtsi business entities $(n=633)$ conducted in 2017-2018 on the territory of ME CSC (the Municipal Enterprise City Shopping Complex) "Kalynivskyi market" has been used in the research. A specially designed questionnaire has been used, which included questions about eating habits, physical activity, bad habits and self-assessment of health. The research has been carried out personally by the author, which made it possible to ensure a unified approach to the survey, with elements of structured interviewing and observation. The structured survey consisted of three forms of questions that were convenient for filling in a limited time (outside customer service): closed, providing specific answers (gender, age, education, marital status, district of residence); alternatives with the even number of response options and structured with the list of responses provided. The questionnaires provided for an independent filling (6-10 min.). The general aggregate consisted of independent and hired workers in the whole territory of the mentioned markets evenly according to the existing distribution by sectors. 650 questionnaires have been collected, 633 of which have been selected for analysis. The $95 \%$ confidence level has been selected when determining the sample size. Sociological and statistical methods have been used. Before the interview, the necessary information was provided on each case of participation in the study.

\section{RESULTS}

"Kalinovsky market" is a place of work for a significant part of Bukovinians. Of the 633 people surveyed, there were 313 men $(49.45 \%)$, with a mean age of $38.55 \pm 0.20$ and 320 women $(50.55 \%)$, with a mean age of $42.75 \pm 0.20$. The respondents were $488(77.09 \%)$ residents of all neighborhoods of the city, $122(19.27 \%)$ residents of the adjacent districts of the region, and 23 (3.63\%) ones of the neighboring regions. The mean age of the respondents was $40.68 \pm 0.14$ years. The age distribution has been conducted according to the recommended for the economically active population (15-70 years old), taking into account the WHO classification (young (25-44 years old), middle-aged (4559 years old) and elderly (60 and older). In our study, the largest proportion of the respondents - $82.3 \%$ were young and middle-aged people ( 25 to 60 years). It should be noted that there were more than half men of young age (25-44 years), and this age category was $44.06 \%$ among women. About half of all respondents have higher education: men $-54.63 \%$; women $-41.88 \%(\mathrm{p}<0.01)$. According to the marital status, $70.18 \%$ are married, with a higher percentage of single men among the respondents under 25 years and widows among the women, especially at the age of 45-59 years (10.77\%) and 60 years old and older (40.00\%).

The study of the prevalence of the major risk factors for the NCDs allowed identifying the characteristics of nutrition, physical activity, tobacco smoking and alcohol consumption by the respondents. A study of eating habits showed that only $41.21 \%$ of workers monitor their diet, among young people $-34.58 \%$ of men and $52.94 \%$ of women. The most common was 3 meals a day ( $2.31 \pm 0.05$ meals). The sufficient amount of fruit (according to the respondents) is consumed more often by women than men (Fig.1), total $47.55 \%$. The share of fruit consumption is the lowest for men 25-44 years $(35.36 \%)$ and women over 60 years old (43.75\%). Women consume more vegetables than men. There is a group of men $25-44$ years old, in which the index is the lowest $-45.30 \%$, in women of the corresponding group $-57.45 \%$. Men consume more vegetables after 60 years $61.11 \%$, which led to a corresponding contribution to the leadership of vegetables among the products they consume. The respondents do not include a sufficient amount of fish in their diet $-22.9 \%$. The highest index of the consumption of the adequate amount of meat is observed in men up to 25 years old $-67.65 \%$.

Vegetables are in the first place in the popularity ranking of food products among men. We emphasize that potatoes predominate among vegetables, but this vegetable is not included in the majority of international recommendations for useful products/vegetables. Consumption of meat products is in the second place mainly in the group up to 45 years old (maximum up to 25 years old). Consumption of fruit (insufficient consumption at the age of 25-44) is in the third place. Fish products are the next with a large margin (which most respondents motivate as inaccessible for them). Young men up to 45 years old eat fast food, but it is almost ignored at an older age. Fried meals, salt, fat, and sweets are among the restrictions. When detailing the nature of the nutrition, the highest frequency of consumption of fruits, vegetables and fish occur at the age of 40-44 years (24.14\%) and 45-49 years (21.21\%). Among men, the consumption of fruits, fish and vegetables is most closely correlated with the answer in relation to food control (direct strong connection $r=+0.99 ;+0.85 ;+0.78$; $\mathrm{p}<0.05$ ). Women also consume vegetables most often, but, unlike men, evenly in all age groups. Fruit is in the second place, meat products are in the third one with insufficient consumption of those and others after 60 years. Restriction of the fried, fatty, salty and sweet meal for women with age becomes more topical. Fast food is consumed mainly by women up to 25 years old, and it is completely ignored at an older age. For females, control of nutrition correlates with the consumption of fish, meat and fruit (direct strong connection $\mathrm{r}=+0.99 ;+0.98 ;+0.81 ; \mathrm{p}<0.05$ ). Women aged 25-29 and 55-59 manage their nutrition according to these three indices the most (23.3\% and $23.5 \%$ respectively).

426 respondents (67.30\% of the sample) answered the question about the recognition of a sufficient level of their physical activity. $67.61 \%$ of the respondents recognized themselves as active, namely, among 220 men - 155 (70.46\%) and among 206 women - 133 (64.56\%). Women are inferior to men only in jobs with physical workload (Table I). 
Table I. Types of physical activity and leisure $(n=633)$

\begin{tabular}{cccc}
\hline Types of physical activity and leisure & Men (\%) & Women (\%) & Total (\%) \\
\hline Physical exercise during the day & $13.74 \pm 1,95$ & $10.0 \pm 1.68$ & $11.85 \pm 1.29$ \\
\hline Classes 4-5 times a week & $10.22 \pm 1.72$ & $9.38 \pm 1.63$ & $9.80 \pm 1.63$ \\
\hline Classes 2-3 times a week & $9.27 \pm 1.64$ & $8.13 \pm 1.53$ & $8.69 \pm 1.12$ \\
\hline Classes 1-2 times a week & $8.31 \pm 1.56$ & $6.88 \pm 1.42$ & $7.58 \pm 1.05$ \\
\hline Job with physical workload & $39.94 \pm 2.78^{*}$ & $31.25 \pm 2.60^{*}$ & $35.55 \pm 1.90$ \\
\hline Work on the farmland & $29.71 \pm 2.59$ & $35.63 \pm 2.68$ & $32.70 \pm 1.87$ \\
\hline Walking & $39.30 \pm 2.77$ & $44.69 \pm 2.78$ & $42.02 \pm 1.96$ \\
\hline
\end{tabular}

*the difference between the indices is significant

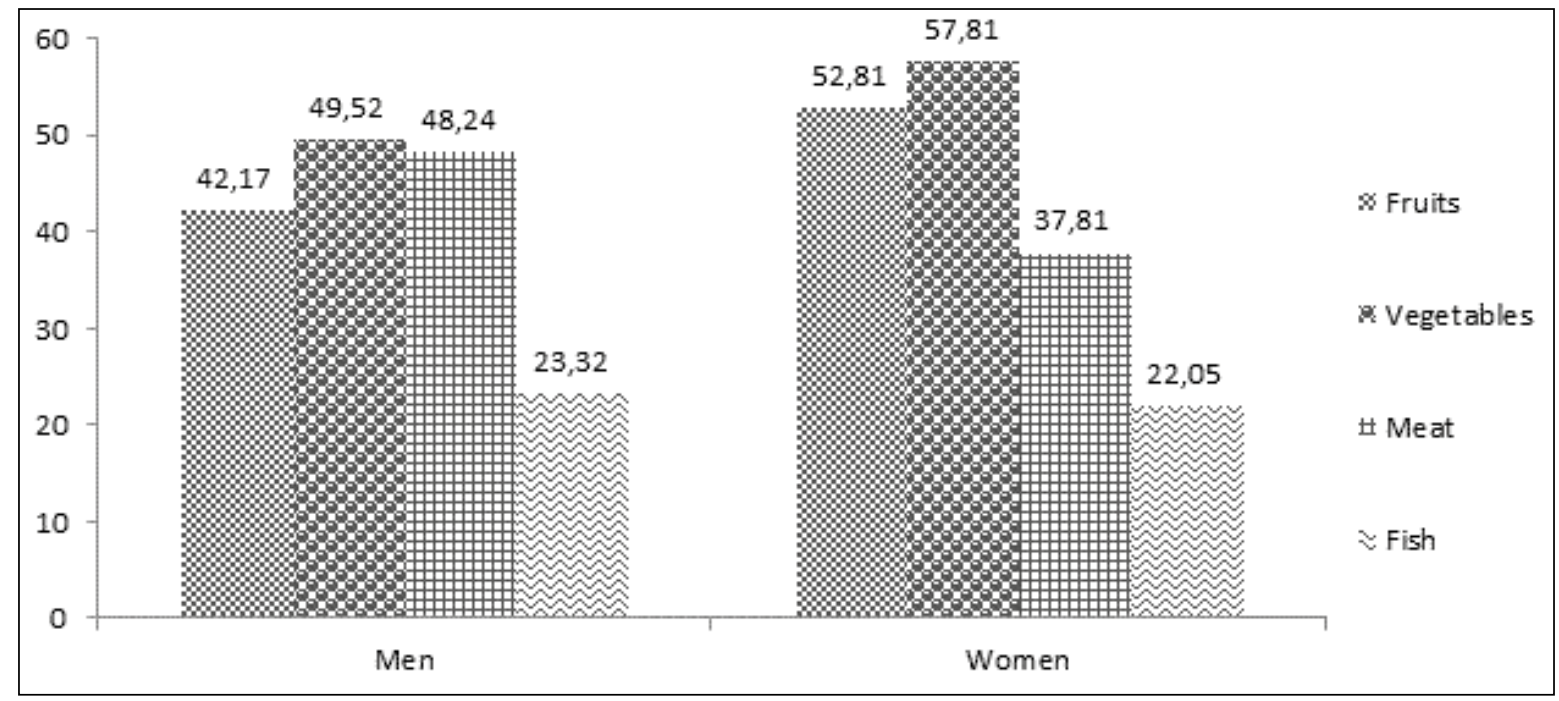

Fig.1. Consumption of the main types of products (\%)

Every 7 th person systematically does physical exercise, - every 5 th $(22.05 \%)$ in the age group $45-59$, and every $2^{\text {nd }}$ $(50.0 \%)$ in the age of 60 and older. Among women, only one out of ten exercises regularly. The respondents in age groups up to 25 years old: $20.59 \%$ of men and $17.86 \%$ of women do special exercises 4-5 times per week; and the other respondents have classes 2-3 times a week and 1-2 times a week equally often, without a significant difference between sex and age. More men than women consider themselves active at work due to the age group of 25-44 years $(44.76 \%)$. Work on the farmland is relevant for 45-59-year-olds: $42.50 \%$ of men; $43.70 \%$ of women (for women 60 and older - 46.88\%). The respondents from older age groups are more likely to walk, in particular, more than half of women $(56.25 \%)$. Weekends (mostly 1 day a week) are spent in front of a computer, surfing the Internet ( $49 \%$ of men, $26 \%$ of women), watching TV (30\%) and housework (37\% men and $67 \%$ women).

Among the respondents 104 men (33.23\%) and 80 women (25.0\%) smoke. Among the rest $(\mathrm{n}=449), 89 \mathrm{men}(42.58 \%)$ and 39 women (16.25\%) used to smoke. The ratio of the number of smokers to those who has given up a bad habit among men is $1.17(104 / 89)$, among women - $2.05(80 / 39)$. The greatest number of smokers is among young people: men $-37.02 \%$ and women $-31.21 \%$. When analyzing the prevalence of tobacco smoking by age, it is necessary to allocate men aged 20 to 30 who smoke the most - $39.5 \%$. Only from the age of 50 , the proportion of male smokers decreases to $19.15 \%$ (Fig.2). Women between 20 and 30 years of age smoke the least (21.8\%), mainly due to childbearing at this age. Later there are two peaks of the indices: aged 30 to 44 years (33.3\%) and from 60 to 64 years $(31.8 \%)$ (Fig.3). Women are not almost inferior to men by number of smoked cigarettes (men 16.39 \pm 0.27 ; women $12.85 \pm 0.30$ ) and smoking experience (men 13.24 \pm 0.24 ; women $15.22 \pm 0.33$ ). Passive smokers are (out of 582 responses - 91.94\% of the sample) $70.79 \%$ of respondents: $69.66 \%$ of men and $71.92 \%$ of women, $55.34 \%$ of them do not smoke.

Alcoholic beverages are consumed by 525 respondents (85.64\%), including $46.96 \%$ men and $33.20 \%$ women, who drink strong drinks; $25.88 \%$ of men and $40.94 \%$ of women drink wine, and $38.98 \%$ men and $15.0 \%$ women drink beer. $10.54 \%$ of men and $4.69 \%$ of women drink alcohol 3-4 times a week and more often; $28.75 \%$ of men and $13.75 \%$ of women drink it 1-2 times a week, the rest - 1-3 times a month and less often.

When analyzing the self-assessment of respondents' health by gender, it should be noted that the vast majority of employees feel good and satisfactorily. Among the rest of the respondents who feel bad or admit that their health has worsened recently, there are a significantly higher percentage of women than men (Table II). 
Table II. Self-assessment of respondents' health by gender (\%)

\begin{tabular}{cccc}
\hline State of health & Men & Women & Total \\
\hline Good & $34.51 \pm 2.70$ & $27.19 \pm 2.49$ & $30.81 \pm 1.84$ \\
\hline Satisfactorily & $55.59 \pm 2.81$ & $49.06 \pm 2.80$ & $52.29 \pm 1.99$ \\
\hline Deteriorates & $8.63 \pm 1.59^{*}$ & $19.38 \pm 2.21^{*}$ & $14.06 \pm 1.38$ \\
\hline Bad & $1.28 \pm 0.64^{*}$ & $4.75 \pm 1.18^{*}$ & $3.00 \pm 0.68$ \\
\hline
\end{tabular}

*the difference between the indices is significant

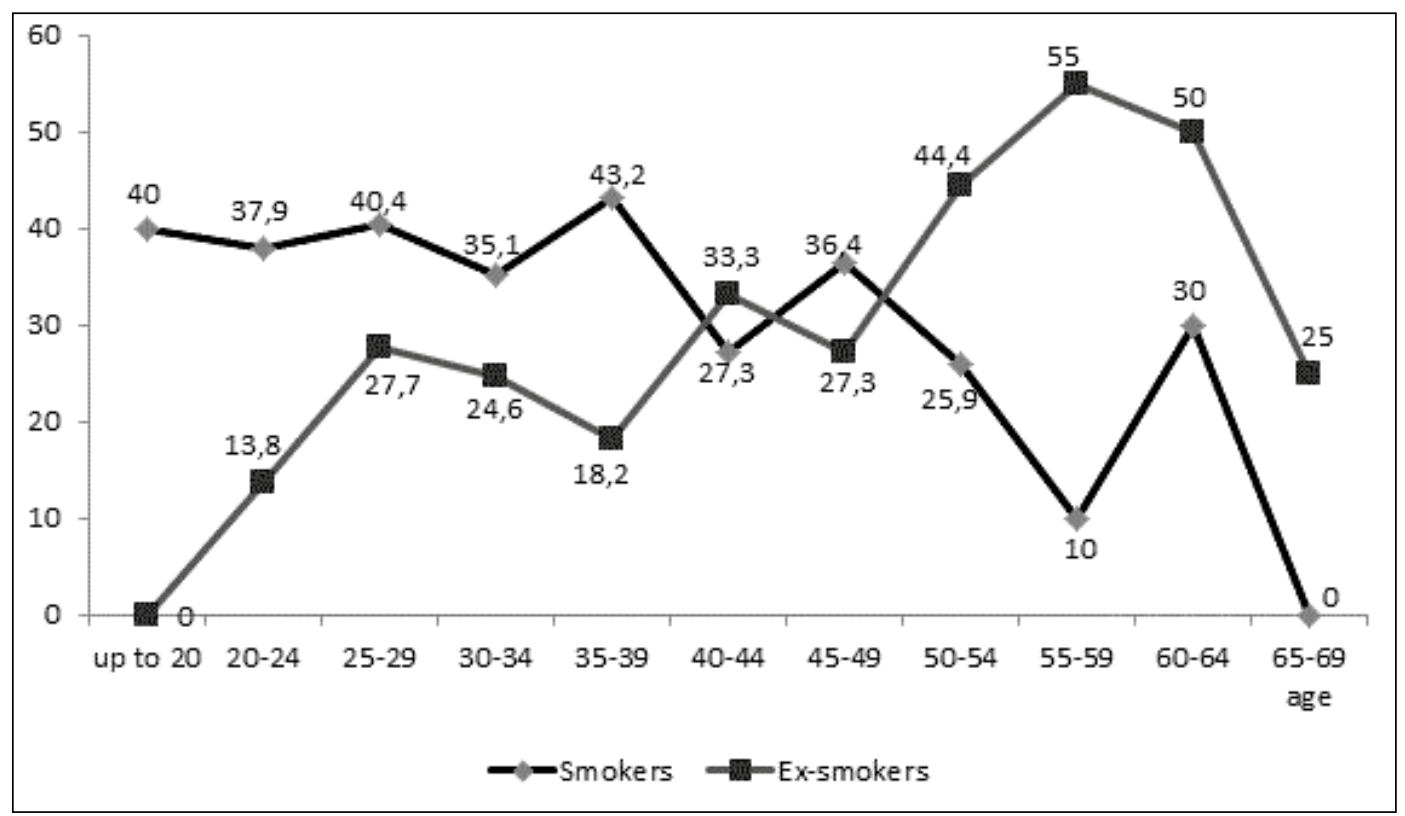

Fig.2. Frequency of smokers and ex-smokers (\%) among men in age intervals



Fig.3. Frequency of smokers and ex-smokers (\%) among women in age intervals

Sources of information on health issues were reported to be the same for men and women. The Internet is leading (60.35\%), followed by television (30.96\%) and health workers $(27.80 \%)$. However, more often men use information from friends (22.36\%).

\section{DISCUSSION}

At the beginning of the activity, "Kalynivsky market" provided work to the residents of Chernivtsi Region, who had lost their jobs through the transformation of the socioeconomic system, the closure of most industrial enter- 
prises and the collapse of the collective farms. "Kalinovsky market" remains a place of work for a significant part of Bukovinians. At first, there were people who differed on age, education, specialty, life experience, but at the moment it is a specific socio-cultural community of workers. It can be argued that their way of life has been formed under the influence of the immediate social environment, as well as the organization of work and conditions created on workplaces. In the market, women generally work on a par with men. The significant proportion of widows $(10 \%$ in middle-age, up to $40 \%$ after 60 years old) found out by us reflects male super mortality in the region in particular and in Ukraine as a whole. It is noteworthy that among the male respondents in all age groups there are significantly more people with higher education. In studying the self-assessment of health, we have found that men are less likely to see deterioration in health or a poor state of health, which may be due to their tendency to inadequately assessment of their own health [6].

Research on eating habits has shown that the most frequent characteristic of nutrition is the consumption of available vegetables. The greatest direct correlation is observed between the control of nutrition and the consumption of fruit, fish, vegetables among men and fish, meat and fruit among women, indicating the need for additional efforts and funds to provide them. Only 54 men (17.25 \pm $2.14 \%)$ and 57 women $(17.81 \pm 2.14 \%)$ confirmed the adequate consumption of fruit and fish at the same time. The choice of a particular product was due to the unwillingness for healthy eating, because of their preferences and opportunities. Thus, with differences in the nutrition of men and women of all ages by the level of consumption of the most important products for the prevention of NCDs, they are equal in the same and extremely low figures.

Regarding physical activity, it should be noted that only $35 \%$ of the respondents are trying to keep their level of physical activity (physical exercise and special physical exercises). Peculiarities of the work in the market, i.e. lifting loads, seasonal work on the farmland, walking, are not characteristic for a sedentary way of working life. Young men (25-44 years), who constitute the biggest part of the age distribution and who have the lowest rates of consumption of fruit, vegetables, fish and the restriction of their consumption of fast, salty, fried and sweet food, are of concern, and more than a third of them are heavy smokers. This circumstance gives grounds for recommending active preventive measures in this age category since young people are exposed to persistent risks for the emergence of dangerous NCDs. The ratio of the number of those who smoke to those who had abandoned testifies to the extremely unfavorable situation with the refusal of the harmful habit among women, and in all age groups. Close communication between the workers supports harmful habits, and the prevalence of passive smoking increases the number of people who suffer from the harmful effects of tobacco smoke twice - 412 people $(65.09 \pm 1.89 \%)$. When studying the consumption of alcohol by the respondents, we did not specify the dose, so as not to reduce their commitment to the survey. Indirectly, the level of abuse could be judged by the amount of advice provided by the doctor regarding the harmfulness of alcohol. 39 (12.46 $\pm 1.87 \%)$ men and $6(1.88 \pm 0.76 \%)$ women reported such advice. The alertness of doctors about alcohol abuse by women is obviously underestimated.

In assessing the sources of health information, the Internet is the leader (60.35\%), health workers provide knowledge to only $27.80 \%$ of the respondents. The availability of reliable sources of information [7] is known to be a prerequisite for the formation of a conscious attitude to disease prevention (health promotion, reduction of risk factors).

\section{CONCLUSIONS}

1. The research has proved the high prevalence of NCD risk factors among those working in the markets (unhealthy diet, lack of physical activity, tobacco smoking). At the same time, the self-assessment of health is rather optimistic - more than $80 \%$ rated it as good or satisfactory.

2. $41 \%$ of the respondents reported that they manage their nutrition. At the same time, only $17 \%$ consume enough fruit and fish. Young men (25-44 years) have the unhealthiest diet.

3. About $70 \%$ of the respondents consider themselves physically active, however, only half of them systematically do physical exercises and special physical exercises, the rest relate physical activity with the peculiarities of daily work.

4. Smoking is a widespread harmful habit, a third of men and a quarter of women smoke. The ratio of smokers and people who have given up it indicates the acute problem of women smoking among market employees. It is shown that $65 \%$ of the respondents are exposed to harmful effects in general (taking into account passive smoking).

5. Almost half of men and one third of women consume strong alcoholic beverages, moreover, women prefer wine and men prefer beer. About $40 \%$ of men and 20\% of women consume alcohol 1-2 to 4-5 times a week.

6. The established peculiarities of the way of life of the workers testify to the need to make maximum efforts to increase the medical literacy and the formation of motivation to preserve health.

\section{REFERENCES}

1. Na puti k Evrope, svobodnoi ot predotvratimykh neinfektsionnykh zabolevanii. [Towards a Europe free from preventable non-communicable diseases.] Diskussionnyi dokument dlia Evropeiskogo soveshchaniia VOZ dlia natsionalnykh rukovoditelei i menedzherov programm po neinfektsyonnym zabolevaniiam v Moskve, Rossiiskaia Federatsyia, 8-9 iiunia $2017 \mathrm{~g}$. [Discussion paper for the WHO European Meeting for National Leaders and Non-communicable Disease Program Managers in Moscow, Russian Federation, 8-9 June 2017] http://www.euro.who. int/_data/assets/pdf_file/0009/340866/Report-1-Ru.pdf(Ru)

2. Highlights from the WHO Global Conference on NCDs: Enhancing policy coherence to prevent and control non-communicable diseases 18-20 October 2017, Montevideo, Uruguay http://www.who.int/conferences/ global-ncd-conference/montevideo-report.pdf?ua $=1$ 
3. Hlobalne opytuvannia doroslykh shchodo vzhyvannia tiutiunu (GlobalAdultTobaccoSurvey - GATS) (ukr. mova). - Kyiv,2017. - 240s.

4. Workers'health: global plan of action SIXTIETHWORLD HEALTH ASSEMBLY WHA60.26 Agenda item 12.1323 May 2007 https://www.who.int/ occupational_health/WHO_health_assembly_en_web.pdf?ua=1

5. Metodolohichni polozhennia shchodo klasyfikatsii ta analizu ekonomichnoi aktyvnosti naselennia. [Methodological provisions for the classification and analysis of economic activity of the population.] Nakaz Derzhavnoho komitetu statystyky Ukrainy za №12 vid 19.01.2011r. [Order of the State statistics Committee of Ukraine №12 from 19.01.2011] https://ukrstat.org/uk/metod_polog/ metod_doc/2011/12/metod.htm(Ua)

6. Dudnyk S. V. Otsinka yakosti nadannia medychnoi dopomohy ta stanu zdorovia cholovikiv pratsezdatnoho viku na prykladi promyslovoho rehionu (za danymy sotsiolohichnoho doslidzhennia). [Assessment of the quality of medical care and health of men of working age on the example of the industrial region (according to sociological research).] Ukraine. Health of nation. 2015;1 (33):67-71 (Ua)
7. Rynhach N.0., Ohai M.lu., Havrylova V.V. Statystychna otsinka vpodoban, kryteriiv vyboru ta stupenia doviry naselennia do dzherel informatsii shchodo zdorovoho sposobu zhyttia, profilaktyky i likuvannia sertsevo-sudynnykh zakhvoriuvan. [Statistical evaluation of preferences, selection criteria and the level of public confidence in the sources of information on healthy lifestyles, prevention and treatment of cardiovascular diseases.] Statistics of Ukraine, 2017;4:70 -78 (Ua)

This work is a fragment of the research work "Study of the processes of socially significant pathology and substantiation of its prevention technologies" 616.1/.9-058-07-084

\section{Authors' contributions:}

According to the order of the Authorship.

\section{Conflict of interest:}

The Authors declare no conflict of interest.

\author{
CORRESPONDING AUTHOR \\ Lyubov Y. Vlasyk \\ Higher State Educational Establishment of Ukraine \\ "Bukovinian State Medical University" \\ 2, Theatralna sq, 58002 Chernivtsi, Ukraine \\ tel: +0380507471015 \\ e-mail:lyubov.vlasyk@gmail.com
}

Received: 15.03 .2019

Accepted: 30.04 .2019 


\title{
OPTIMIZATION OF SURGICAL-ORTHODONTIC TREATMENT TACTICS IN PATIENTS WITH IMPACTED TEETH
}

\author{
Pavlo I. Tkachenko, Maryna I. Dmytrenko, Mykola 0. Cholovskyi \\ UKRAINIAN MEDICAL STOMATOLOGICAL ACADEMY, POLTAVA, UKRAINE
}

\begin{abstract}
Introduction: Impacted teeth is complex anomaly of teeth eruption that requires a balanced approach not only in the differential diagnosis of its forms, but choice of rational methods of treatment.

The aim: Optimization of the tactics of orthodontic-surgical treatment of patients with impacted teeth based on the development and implementation of computed tomographic indices (KT) and photometric indices (FM) of opening of surgical access (OSA) to crowns of impacted teeth

Materials and methods: The results of treatment of 48 patients with delay of permanent teeth eruption have been analyzed. For an objective assessment of treatment results, a group of 24 (aged from 9 to 19 years old ) was formed. All 24 patients had typical clinical situation.

Results: Orthodontic correction of patients envisaged, first of all, the elimination of obstacles in the way of teeth eruption, if necessary to provide space in dental arch and simultaneous treatment of associated bite malocclusions. Surgical exposure of impacted tooth crown was carried out and at the same time a triangular shaped guiding channel was formed, base of channel was at the impacted tooth and its angle finished into the dental arch. Precise dimensions and depth of the channel were preliminary planed on computed tomography slices with $3 \mathrm{D}$ reconstruction.

Mean values of $C T$ width $(7,13 \pm 0,54 \mathrm{~mm})$, and length $(6,42 \pm 0,78 \mathrm{~mm})$ of OSA and CT index $(130,79 \pm 8,19 \%)$ of OSA to impacted teeth crowns were determined.

Conclusion: To improve the quality of diagnosis and optimization of methodological approaches to treatment of patients with teeth impaction, we have proposed CT and FM OSA indices to the crowns of impacted teeth. The developed indices serve as specific reference points for optimization of diagnostic process, for reducing of probability of repeated surgical interventions and choosing the optimal path for instrumental orthodontic treatment of patients with impacted teeth
\end{abstract}

KEY WORDS: impacted teeth, orthodontic treatment, opening of surgical access to the crowns of impacted teeth

Wiad Lek 2019, 72, 5 cz. I, 838-845

\section{INTRODUCTION}

Impacted teeth is anomaly of teeth eruption, when a formed tooth within two years after the period of physiological eruption failed to appear and remains in a jaw [1]. Canines (48\%), central (24\%) and lateral incisors (15\%) are more often impacted, less often premolars and molars (13\%) [2]. Impacted teeth is a complex anomaly of dentition that requires a balanced approach not only in the differential diagnosis of its forms, but choice of rational methods of treatment $[3,4]$.

Main reasons of complete permanent teeth impaction in patients with partial impaction are: early extraction of temporary teeth - $41,28 \%$, delay of temporary teeth in dental arch $-28,44 \%$; discrepancy between teeth size and jaws $-22,02 \%$; anomalies of teeth formation $-16,51 \%$ and supernumerary teeth $-15,6 \%$. Whereas in patients with multiple impaction (more than three teeth), syndromal pathology constitutes $41,67 \%$; the presence of large number of supernumerary teeth $-27,76 \%$, as well as abnormalities of teeth formation $(13,89 \%)$ [2]. The choice of treatment scheme is based on etiologic factor and depends on age of a patient, the depth of tooth location, the presence of space for it in dentition, degree of tooth root formation.
Provision of complex orthodontic treatment in such cases involves combination of surgical, instrumental, protective, and functional (physiotherapeutic) methods $[4,5]$.

A known method of impacted teeth treatment involves staged orthodontic treatment of creating space by instrumental method, surgical opening of access to a crown of impacted tooth, followed by fixing on it of engaging elements (hooks, loops etc.) for traction of impacted tooth to dental arch by means of removable or unremovable constructions [6,7]. An essential drawback of this approach is its long term treatment, an average duration of treatment is $21,6 \pm 8,7$ months $[7,8,9]$.

That is why a search of ways to reduce time of orthodontic appliances in presence of impacted teeth and related orthodontic pathology is a matter of high priority. And optimization of techniques for surgical uncovering of access to crowns of impacted teeth in a complex rehabilitation of such patients is a topical question of modern orthodontics.

\section{THE AIM}

Aim of study is to optimize the surgical-orthodontic treatment of patients with impacted teeth based on the development and introduction of computer tomography 
and photometric indices for the surgical opening of access to crowns of impacted teeth.

\section{MATERIALS AND METHODS}

The results of treatment of 48 patients with delay of permanent teeth eruption have been analyzed. For an objective assessment of our work results, a group of 24 patients was formed. Clinical situation of these patients was typical according to the following criteria: they were born from the first pregnancy; living conditions were the same; they had average family incomes; somatic diseases and genetic pathology were not observed in the patients; satisfactory hygienic condition of oral cavity, there were no gingiva diseases and mucous membrane of oral cavity diseases, presence of no more than three impacted teeth buried in different parts of dental arch. The data showed that there were 12 patients with maxillary canines impaction , 6 patients with maxillary central incisors impaction, 2 patients with impaction of mandibular second molars, 2 patients with mandibular canines impaction and 2 patients with impaction of maxillary premolars. Females $(58,33 \%)(\mathrm{n}=14)$ prevailed in the study, males were $41,67 \%(\mathrm{n}=10)$, the age of patients ranged from 9 to 19 years.

Clinical examination was performed according to the standard technique: history taking, external and internal oral examination, additional methods (photometric examination of face, study of diagnostic jaw models and orthopantomograms, 3D computed tomography). Presence of systemic diseases and teeth impaction of patient's close relatives were finding out while taking patients history data.
Angles of inclination of impacted teeth were marked on the orthopantomogram (OPG) using a modified method of Yu.I. Zhigurta [10]. Tomographic study according to indications made it possible confidently to carry out surgical and orthodontic procedures in complex treatment of patients with impaction of teeth and to achieve positive results. Cone-beam computed tomography (CBCT) allowed to determine accurately the state of crown and roots of impacted and adjacent teeth, to get clear and detailed idea of the position of impacted tooth, what enabled to plan optimal treatment strategy. Clinical and radiological data were carefully analyzed to decide the question of surgical access to impacted tooth, located in the alveolar process.

Surgical exposure of impacted tooth crown was carried out and at the same time a triangular shaped guiding channel was formed, base of channel was at the impacted tooth and its angle finished into the dental arch. Precise dimensions and depth of the channel were preliminary planed on computed tomography sections with 3D reconstruction.

Determination of etiological aspects of dental impaction plays an important role in choosing of an effective treatment method that is specific for each patient. According to etiological criteria, we identified three forms of teeth impaction. The first form of tooth impaction is hereditary one or that is due to the action of unfavorable embryonic factors, the presence of supernumerary teeth, the improper placement of the dental follicle in the jaw. The second form of dental impaction is formed under the influence of common factors, such as endocrine disorders, infectious diseases, general somatic diseases, inflammatory processes and jaw injury. The third form is impaction of teeth is caused by the action of unfavorable local factors - early

Table. I. CT and FM indices of OSA to crowns of impacted teeth.

\begin{tabular}{cccc}
\hline Index & CT & FM & Index of statistic sagnificance, $\mathbf{p}$ \\
\hline OSA Width, $\mathrm{mm}$ & $7,13 \pm 0,54$ & $6,92 \pm 0,58$ & $>0,05$ \\
\hline OSA index, $\%$ & $6,42 \pm 0,78$ & $6,50 \pm 0,74$ & $>0,05$ \\
\hline OSA index, $\%$ & $130,79 \pm 8,19$ & $128,71 \pm 9,98$ & $>0,05$ \\
\hline
\end{tabular}

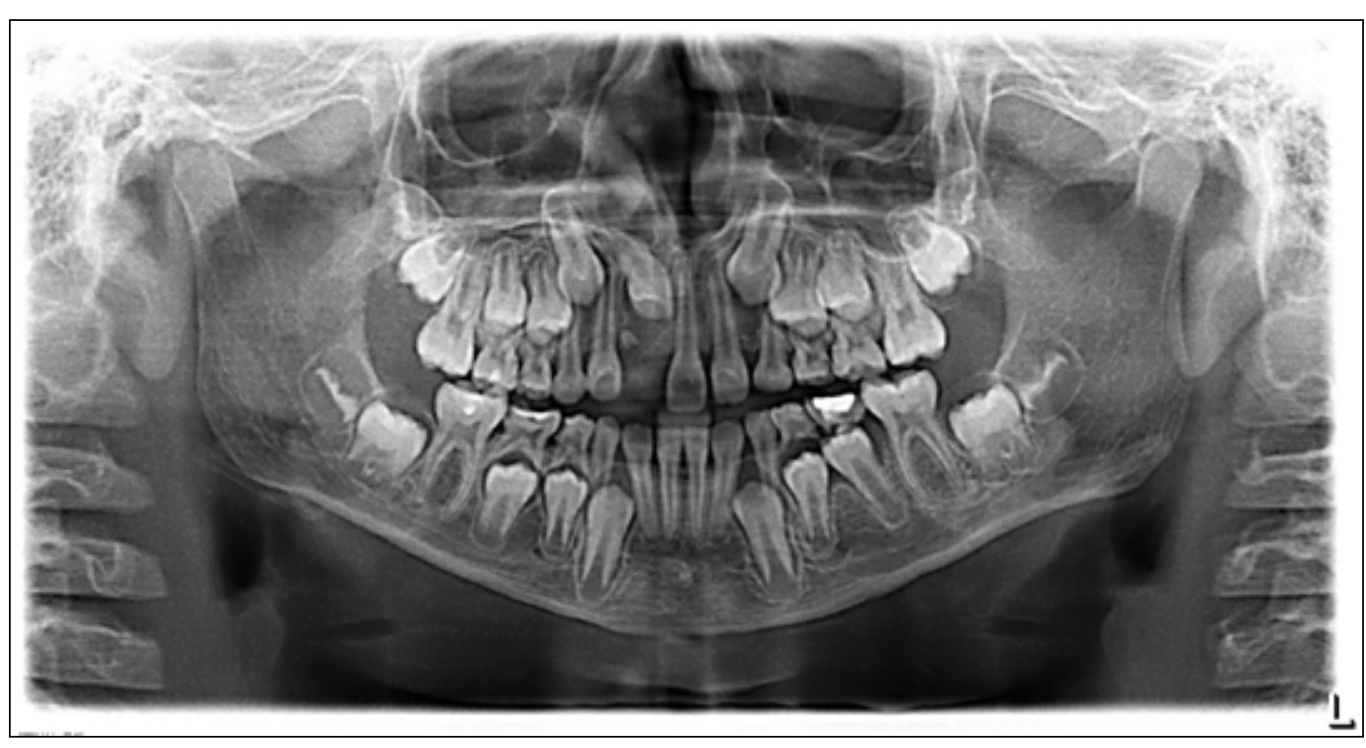

Fig. 1. Patient $X, 9$ years. Orthopantomogram Impacted 11 tooth. 




Fig. 2. Patient X CT, 9 years. Modeling of OSA towards crown of impacted 11 tooth.


Fig. 3. Intraoral Photographs of Patient X. (9 years) oral cavity:

a - after OSA to the crown of impacted 11;

$b, c-$ during orthodontic traction to dentition.

removal of temporary teeth, delay in the dental arch of temporary teeth, underdevelopment of the dentition and jaws as a result of functional insufficiency of muscles of the maxillofacial region

The most likely causes of dental impaction were identified in all patients. Specially designed study protocol (attachment 1.) was filled in for each patient.

All patients underwent surgical orthodontic treatment. First, surgical exposure of the crowns of the impacted teeth was carried out and after the disappearance of the visible postoperative signs, soft tissues edema, morbidity, buttons were fixed on their surface and active orthodontic traction of the impacted tooth using elastic ligament was initiated. Orthodontic treatment was performed using various removable orthodontic appliances in 8 patients, and braces were used in 16 patients. The active period of orthodontic treatment ended with adjustment and correction of occlusal plane, normalization of intermaxillary correlations, achievement of optimal functional occlusion and stabilization of treatment results

Assessment of statistical significance of the results was determined by Wilcoxon T-test. Differences were considered trustworthy at generally accepted in biomedical research error probability $\mathrm{p}<0,05$. 



Fig. 4. Orthopantomogram during orthodontic traction of impacted 11 tooth.
Fig. 5. Orthopantomogram of Patient $\mathrm{E} ., 12$ years. Impacted 23 tooth .

\section{RESULTS AND DISCUSSION}

To improve the quality of diagnostics and optimize treatment methodological approaches, we determined the predicted sizes of surgical window on CT slices and using formula calculated CT index of opening of surgical access (OSA) to crowns of impacted teeth using the formula, which to a certain extent served as a guideline in choosing further treatment tactics.

$\frac{\text { oSA width }}{\text { OSA length }} \times 100 \%=\mathrm{CT}$ index of OSA to crowns

of impacted teeth

At the next stage, intraoral photos of operative access to the crowns of impacted teeth were performed and photometric index of OSA to the crowns of impacted teeth was calculated according to the formula :

$\frac{\text { OSA width }}{\text { OSA length }} \times 100 \%=\mathrm{CT}$ index of OSA to crowns

of impacted teeth
Analyzing data of clinical study, it should be noted that treatment strategy was aimed primarily to ensure process of eruption of impacted teeth. Orthodontic correction of patients envisaged, first of all, the elimination of obstacles in the way of eruption, if necessary to provide space in dental arch and simultaneous treatment of associated bite malocclusions.

Mean values of CT and FM of OSA width and length to impacted teeth crowns were determined with mean squared error of each result $(\mathrm{m})$, values of CT and FM indices of OSA to crowns of impacted teeth and index of statistical significance $(p)$ were determined on the results of study (Tab. I).

It was established that the mean values of $\mathrm{CT}$ and $\mathrm{FM}$ of width and length of OSA for crowns of impacted teeth and the value of CT and FM indices of OSA for crowns were not significantly different $(p>0,05)$. That is, the calculation of CT indices of OSA of crowns of impacted teeth allowed objectively predict the size of surgical window, reducing the risk of unnecessary damage to mucous membrane, what was confirmed by data of FM indexes of OSA. 




Fig. 6. CT of

Patient $\mathrm{E}, 12$ years.

Modelling of $\mathrm{SOA}$

to the crown of

impacted tooth 23

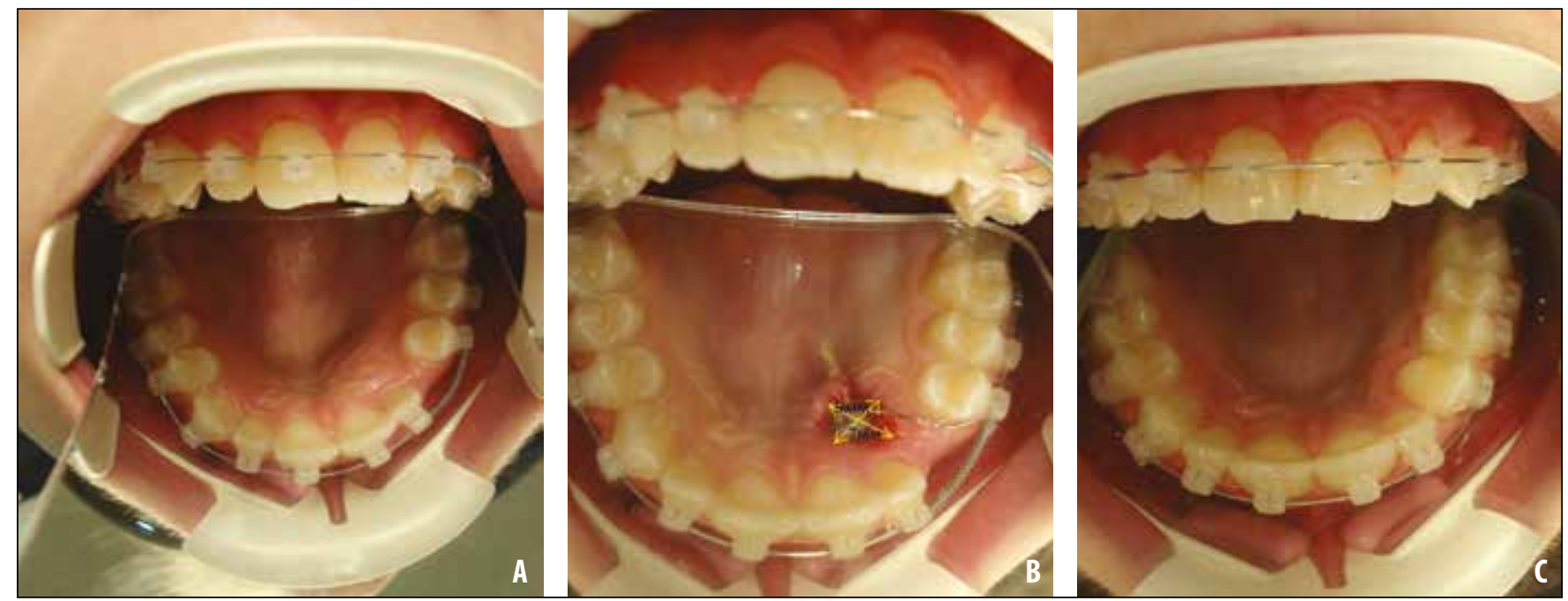

Fig. 7. Case 2. Intraoral photos:

a - the first stage of orthodontic treatment;

b - after surgical procedure (OSA width - 7,00 mm, OSA length - 9,00 mm; FM index of OSA to the crown of impacted 23 tooth - 77,78\%;

c - tooth 23 after traction to dentition.

Case 1. Patient H., 9 - year-old child, complained of aesthetic appearance, as a result of maxillary right central incisor absence. Impacted 11 tooth was diagnosed according to clinical examination and orthopantogram (Fig. 1).

Orthodontic treatment using a removable plate-prosthetic appliance with a screw was initiated. The patient underwent $3 \mathrm{D}$ computed tomography, and OSA dimensions were modeled to the crown of $t$ impacted tooth 11 (OSA width - 8,50 mm, OSA length - 9,40 mm; CT OSA index - 90,43\% (Fig. 2).

After eight months, the patient underwent a surgical exposure of the crown of impacted tooth 11 and guide channel has been formed (Figure 3, a), photometric study was carried out: OSA width $-8,00 \mathrm{~mm}$, OSA length - 12,00 mm; FM index of OSA $-66.67 \%$. Three days after the operation, the button was fixed and orthodontic traction of the impacted tooth 11 was started with elastic ligaments.

To monitor orthodontic treatment orthopantomogram was done after 2 month of treatment (Fig.4).

Term of traction to dental arch of impacted 11 tooth was 3 month.

Case 2. Patient E., 12 years old, complained of an aesthetic appearance due to the absence of the maxillary left canine. After analyzing the orthopantomogram, impacted tooth 23 was diagnosed (Fig.5) 


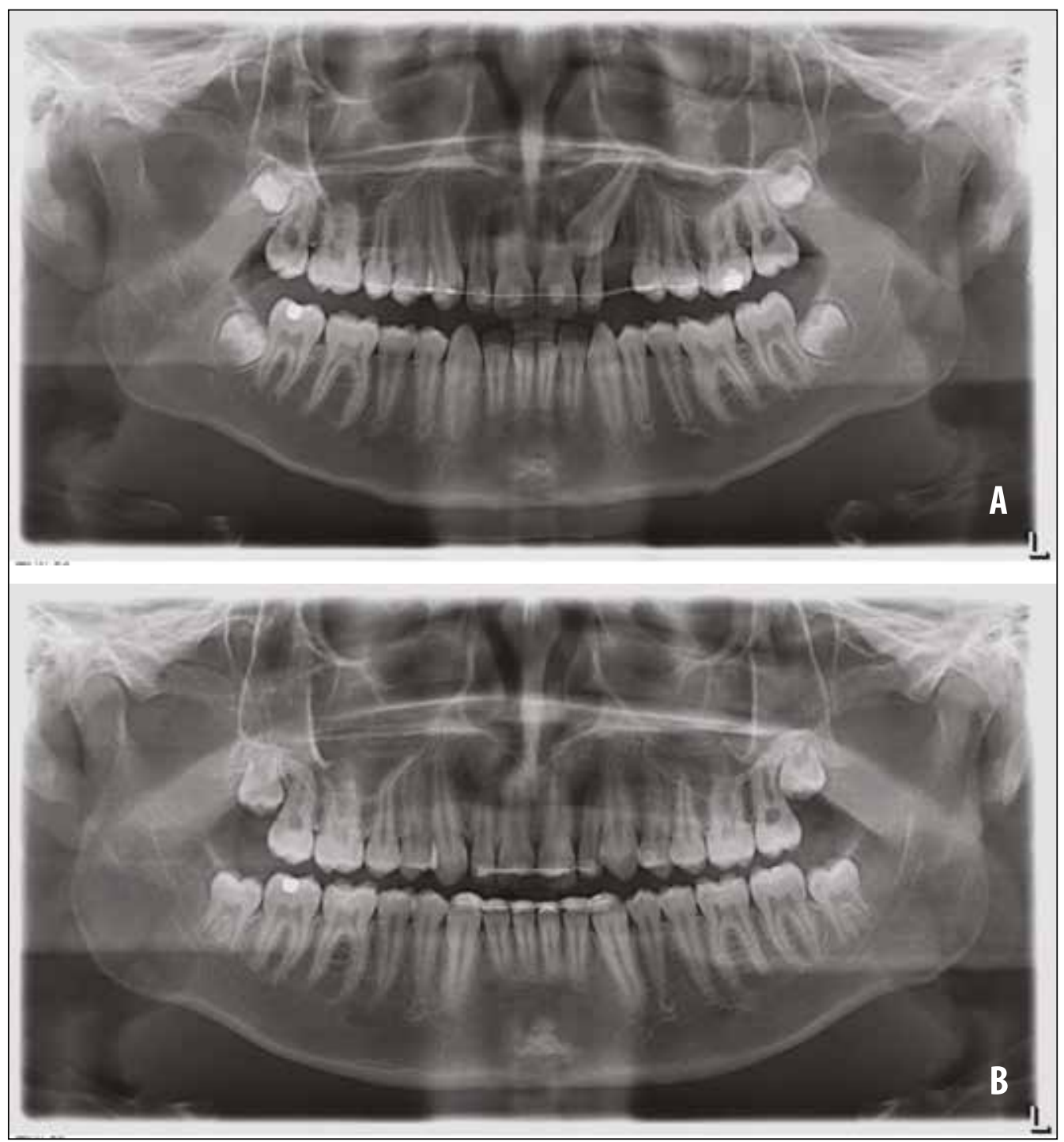

Fig. 8. Case 2.

Orthopantomogram:

$a-$ on the first stage of orthodontic treatment of impacted 23 tooth; $b$ - two years after treatment.

The patient underwent 3D computed tomography and modeled OSA dimensions (width $-8,51 \mathrm{~mm}$, length - 7,86 $\mathrm{mm}$; CT OSA index - 108,27\% (Fig. 6). Active orthodontic treatment was carried out in 2 stages: the first is to create space for tooth 23, to correct shape of dental arch of the upper jaw by braces; the second stage is the surgical exposure of the crown of tooth 23 , formation of surgical opening access to the crown of impacted tooth, fixation of button, traction of tooth 23 into the dental arch, normalization of the intermaxillary ratio.

Term of orthodontic traction of impacted 23 tooth to dental arch was 10 month (Fig.8).

Therefore, planning of optimal path for surgical uncovering of impacted teeth crowns from under mucosa allows to arrange more physiological conditions for eruption.

\section{CONCLUSIONS}

To improve the quality of diagnosis and optimization of methodological approaches to treatment of patients with teeth impaction, we have proposed CT and FM OSA indices to the crowns of impacted teeth. The developed indices serve as specific reference points for optimization of diagnostic process, for reducing of probability of repeated surgical interventions and choosing the optimal path for instrumental orthodontic treatment of patients with impacted teeth.

\section{REFERENCES}

1. Tkachenko P., Bilokon S., Dmytrenko M, Novikov V. Pidvyshhennya rezultatyvnosti likuvannya zubovmishhuyuchyx kist nyzhnoyi shhelepy u ditej v period zminnogo prykusu [Effecacy improvement of mandible detigerous cyst treatment in mixed dentition]. World of Medicine.2012; 1: 96-99.

2. Kulginsky Eu.A. Udoskonalennya dyferencijnoyi diagnostyky ta osoblyvosti likuvannya ditej z riznymy formamy retenciyi zubiv [Improvement of diagnostics and peculiarities of children's treatment with different forms of teeth impaction]. Thesis for candidate of medical sciences degree:"Institute of Dentistry of Academy of Medical Sciences of Ukraine". Odessa; 2010, 20p.

3. Doroshenko S.I., Kulginsky Eu.A. Taktyka likuvannya pacientiv iz retencieyu zubiv [Treatment tactics in patients with impacted teeth]. Ukrainian Dental Almanac. 2006; 1: 6-8.

4. Makeev V.F. Diagnostyka ta likuvannya retenciyi zubiv [Diagnostic and treatment of impacted teeth]. In: Bezvushko E.V., Pylypiv N.V. Lviv; Kvart, 2013, P.126. (Monograph). 
5. Chaushu S.,. Becker T., Becker A. Impacted central incisors: factors affecting prognosis and treatment duration. Am. J. Orthod. Dentofacial. Orthop. 2015; 3(147): 355-362.

6. Becker A., Chaushu S. Surgical Treatment of Impacted Canines: What the Orthodontist Would Like the Surgeon to Know. Oral Maxillofacial Surgery Clinics of North America. 2015; 27(3): 449-58.

7. Becker Adrian Orthodontic Treatment of Impacted Teeth, 3rd Edition. $-2012,446 \mathrm{p}$.

8. Ferrazzano G.F., Cantile T., Roberto L. et al. An impacted central incisor due to supernumerary teeth: a multidisciplinary approach. Eur J Paediatr Dent. 2014; 2(15):187-190.

9. Wang J., Cui N.H., Guo Y.J., et al. Navigation-Guided Extraction of Impacted Supernumerary Teeth: A Case Report. Oral Maxillofac Surg. 2017; 6(75):1136.e1-1136.e5.

10. Zhigurt Yu.L. Plan i prognoz lecheniya pri retentsii zubov [Plan and prognosis of treatment of impacted teeth] : Thesis for candidate of medical sciences degree "Stomatology». Moscow; 1994, 23p.
The study was performed as part of research work of Ukrainian Medical Stomatological Academy in agreement with the Ministry of Health Service of Ukraine "Integrative differentiated substantiation of choice of optimal methods of surgical interventions and content of therapeutic measures in surgical pathology of maxillofacial region", state registration number 0116 U003821.

\section{Authors' contributions:}

According to the order of the Authorship.

\section{Conflict of interest:}

The Authors declare no conflict of interest.

\section{CORRESPONDING AUTHOR Maryna I. Dmytrenko}

Ukrainian Medical Stomatological Academy

Shevchenko 23 str., 36011 Poltava, Ukraine

tel: +380506324055

e-mail:dmitrenk025@ukr.net

Received: 14.03.2019

Accepted: 26.04 .2019 
Attachment 1.

Study Protocol №

Date

Name, Family name

Diagnostic models

Malocclusion: Angle class- ; deep - ; open - ; cross-

\begin{tabular}{|c|c|c|c|c|c|c|}
\hline \multirow{3}{*}{$\begin{array}{c}\text { Group } \\
\text { membership of } \\
\text { impacted tooth }\end{array}$} & & \multicolumn{5}{|c|}{ State of impacted teeth } \\
\hline & \multicolumn{2}{|c|}{$\begin{array}{l}\text { On orthopantomogram Angle of } \\
\text { inclination of longitudinal axis of } \\
\text { impacted tooth } \\
\text { a) from } 15^{\circ} \text { to } 45^{\circ} \text {, } \\
\text { b) from } 46^{\circ} \text { to } 89^{\circ} \\
\text { (nearly horizontal position) and c) } \\
\text { from } 90^{\circ}\end{array}$} & \multirow{2}{*}{$\begin{array}{c}\text { On OPTG } \\
\text { Level of impacted } \\
\text { tooth position } \\
\text { a) high position } \\
\text { - closer to jaw basis, } \\
\text { b)in alveolar process } \\
\text {; c) under mucous } \\
\text { memrane }\end{array}$} & \multicolumn{2}{|c|}{ Modelling of OSA on CT } & \\
\hline & SpP & MP & & OSA width & $\begin{array}{c}\text { OSA } \\
\text { length }\end{array}$ & \\
\hline \multicolumn{2}{|c|}{ Type of impaction } & I- 85-95' & $\begin{array}{c}\text { II }-\mathbf{3 5 - 8 5 ^ { \circ }} \\
\text { vestibular or oral } \\
\text { shift; less then } 2 \\
\mathrm{~mm}\end{array}$ & $\begin{array}{c}\text { III- } 35-\mathbf{8 5}^{\circ} \text {, vestibular } \\
\text { or oral shift; more then } \\
2 \mathrm{~mm}\end{array}$ & $\begin{array}{c}\text { IV - } \\
\text { hotizontal } \\
\text { or oppositly } \\
\text { to tooth } \\
\text { eruption, } \\
\end{array}$ & $\begin{array}{c}\mathrm{V} \text { - due to presence } \\
\text { of supernumerary } \\
\text { tooth } \\
\mathrm{VI}-\text { due to } \\
\text { transposition }\end{array}$ \\
\hline \multirow{2}{*}{\multicolumn{2}{|c|}{ Depth of impaction }} & \multirow{2}{*}{$\begin{array}{c}\text { On CT image } \\
\text { deep }\end{array}$} & superficial & $\mathbf{I}$ & II & \\
\hline & & & III & $\mathrm{VI}$ & & \\
\hline $\begin{array}{c}\text { Stage of root } \\
\text { formation }\end{array}$ & & Unformed & Formed to $1 / 2$ & Completely formed root & \multicolumn{2}{|c|}{ Ankylosis } \\
\hline № & \multicolumn{6}{|c|}{ Causes of impacted teeth } \\
\hline & & \multicolumn{3}{|c|}{ Hereditary } & & \\
\hline & & \multicolumn{3}{|c|}{ Somatic diseases } & & \\
\hline & & \multicolumn{3}{|c|}{ Infectious diseases } & & \\
\hline & & \multicolumn{3}{|c|}{ Avitaminosis. Rickets } & & \\
\hline & & \multicolumn{3}{|c|}{ Supernumerary teeth } & & \\
\hline & & \multicolumn{3}{|c|}{ Maxillofacial trauma } & & \\
\hline & & \multicolumn{3}{|c|}{ Early removal of temporary teeth } & & \\
\hline & & \multicolumn{3}{|c|}{ Delay of temporary teeth in dental arch } & & \\
\hline & & \multicolumn{3}{|c|}{ Surgical procedures on account of odontoma, cyst of maxillofacial region } & & \\
\hline & & \multicolumn{3}{|c|}{ Malformation of tooth bud stage } & & \\
\hline & & \multicolumn{3}{|c|}{ Transposition of tooth germs } & & \\
\hline & & \multicolumn{3}{|c|}{ Inadequate formation of impacted teeth } & & \\
\hline & & \multicolumn{3}{|c|}{ Ankylosis } & & \\
\hline & & \multicolumn{3}{|c|}{ Lack of space in dental arch (trasversal plane) } & & \\
\hline & & \multicolumn{3}{|c|}{ Lack of space in dental arch (sagittal plane) } & & \\
\hline & & \multicolumn{3}{|c|}{ Lack of space in dental arch (vertical plane) } & & \\
\hline & & \multicolumn{3}{|c|}{ Pathologically changed mucous membrane above impacted teeth } & & \\
\hline & & \multicolumn{3}{|c|}{ Bone barrier, deep location of impacted tooth } & & \\
\hline & & & acrodontia (absolute, $r$ & elative) & & \\
\hline & & & One-sided chewin & & & \\
\hline & & & Infantile swallowin & & & \\
\hline & & Anom & ly of frenulum linguae & attachment & & \\
\hline & & & Mouth breathing & & & \\
\hline & & & Fluorosis of teeth & & & \\
\hline
\end{tabular}




\title{
COMPARISON OF METABOLIC PROFILE OF OBESE NON-DIABETIC PATIENTS WITH CORONARY ARTERY DISEASE DEPENDING ON ATORVASTATIN DOSE
}

\author{
Tetiana Maksymets, Maria Sorochka, Olha Bondarenko, Natalia Karpyshyn, Olesia Bochar, Yevhen Sklyarov \\ DANYLO HALYTSKY LVIV NATIONAL MEDICAL UNIVERSITY, LVIV, UKRAINE
}

\begin{abstract}
Introduction: Cardiovascular diseases (CVD) are one of the most important medical-biological and social problems in Ukraine and in the world because coronary artery disease (CAD) is a major cause of death and disability. Overweight and obesity are risk factor of CVD and type 2 diabetes mellitus (T2DM). Although statins have been shown to be beneficial in secondary prevention of CVD in a number of trials, current reports of increased risk of T2DM with statin use raise concerns.

The aim: To compare the metabolic profile and therapeutic targets of non-diabetic obese patients with CAD depending on the dose of atorvastatin.

Materials and methods: The study included 107 patients (82 men and 25 women) with CAD and abdominal obesity. Patients were divided into two groups: those taking $20 \mathrm{mg}$ and $40 \mathrm{mg}$ of atorvastatin daily correspondingly. Glucose, insulin, HbA1c, HOMA-IR, lipids, hs-CRP and anthropometric parameters were measured for each subject.

Results: For patients with CAD and obesity, who had taken atorvastatin in a 40-mg dose, we observed a significant increase in insulin resistance and impaired fasting glucose. Also we found a reliable correlation between the carbohydrate and lipid spectrum. These parameters reflect the mechanism of the formation of metabolic disorders as a result of intensive statin therapy.

Conclusions: Despite of the beneficial reductions in LDL and total cholesterol, atorvastatin treatment on a dose $40 \mathrm{mg}$ resulted in significant increase of fasting glucose, insulin levels and insulin resistance pertaining to those patients.
\end{abstract}

KEY WORDS: insulin resistance, obesity, coronary artery disease, atorvastatin, type 2 diabetes mellitus

Wiad Lek 2019, 72, 5 cz. I, 846-850

\section{INTRODUCTION}

Cardiovascular disease (CVD) is a leading cause of death throughout the world. The greatest part in the structure of mortality takes coronary heart disease and its complications. In the United States, mortality from coronary heart disease is $43.8 \%$ of the overall mortality rate due to cardiovascular disease (AHA,2018) [1].

$\mathrm{CAD}$ is the leading single cause of death, and in Europe there are 862 thousand deaths per year (19\% of all deaths) among men and 877 thousand deaths (20\%) among women each year [2].

Smoking, hypodynamia, unhealthy food and alcohol abuse are the main risk factors that lead to the onset of CVD.As a result, cascading reactions can lead to the arterial hypertension, hyperglycemia with transformation into diabetes mellitus, dyslipidemia and obesity.

According to prospective epidemiological trials, there is a relationship between overweight or obesity, on the one hand, and cardiovascular morbidity, mortality from CVD and overall mortality, on the other. Obesity is closely linked to the main cardiovascular risk factors, such as arterial hypertension, decreased glucose tolerance, type 2 diabetes mellitus and dyslipidemia [3].

The main principle of success in preventing cardiovascular death and death from all causes, high-risk patients primary hospitalization and re-hospitalization associated with atherothrombotic complications, is to achieve and maintain target levels of LDL and cholesterol at that level for as long as possible. In this case, the drugs of choice are statins [4;5].

Statins were introduced to clinical practice over 30 years ago by a Japanese researcher A. Endo and have made the same revolution in the medical possibilities of medical practice, as the introduction of penicillin in the previous century.

The results of such large-scale studies of statins usage (TNT, IDEAL, GRACEA, SPARCL, ASCOT-LLA, JUPITER, PROVE IT-TIMI 22) formed the basis of the concept of "the lower the better". But not always such a concept of using high-dose statins is justifiable for all patients. This is especially true for the treatment of patients with stable forms of coronary heart disease (TNT, IDEAL) [6;7;8;9;10].

\section{THE AIM}

To compare metabolic profile of obese patients with coronary artery disease depending on the dose of atorvastatin and to estimate when the therapeutic target is reached for obese non-diabetic patients with coronary artery disease depending on dose atorvastatin.

\section{MATERIALS AND METHODS}

Clinical trial was conducted with accorandce to the Declaration of Helsinki, The Convention for the Protection of 
Human Rights and Biomedicine, Legislation of Ukraine and agreed by Ethical Committee Danylo Halytsky Lviv National Medical University, protocol №1, 18.01.2016. All patients signed an informed consent before the study.

The study included 107 patients $(82(76,6 \%)$ men, 25 $(23,4 \%)$ women, who underwent treatment in Lviv Hospitals. The average patients age was $60,3(58,8 ; 61,7)$ years.

All patients were divided in two groups depending on the dose of atorvastatin. The cohort groups under examination have received statin therapy: the first group took atorvastatin in a dose $20 \mathrm{mg}$ daily $(\mathrm{n}=56)$, the second group - $40 \mathrm{mg}(\mathrm{n}=51)$.

The criteria for exclusion were the presence of T2D, obesity due to endocrine pathology, severe heart, kidney, liver failure, acute conditions and oncologic diseases.

Physical examination that included measurement of blood pressure pulse, and anthropometric parameters (body mass index, waist circumference, the circumference of the hips and their ratio) was also conducted. Metabolic syndrome diagnosis was confirmed by IDF-2015 criteria. The validated Finnish Diabetes Risk Score (FINDRISC) has traditionally been used as a predictor of type 2 diabetes in our examined groups. Fasting glucose, insulin, $\mathrm{HbAlc}$, HOMA-IR, lipids, hsCRP, ALT, AST, ALP, GGTP, uric acid were measured for all patients. The level of glycated hemoglobin $\left(\mathrm{HbA1}_{\mathrm{C}}\right)$ in the whole blood was determined by turbidimetric assay method, using test system "HemoglobinA1c-direct" BioSystems (Spain). Insulin and hsCRP in serum was determined on chemiluminescent immunoassay analyzer "Immulite 2000" (Siemens, Germany) using a proper reagent (Immulite 2000 Insulin and Immulite 2000 hsCRP, USA).

Insulin resistance index was calculated by the formula:

HOMA-IR=fasting insulin $(\mu \mathrm{IU} / \mathrm{ml})^{\star}$ fasting blood glucose $(\mathrm{mmol} / \mathrm{l}) / 22.5$. Patients with HOMA-IR $>2.77$ was insulin resistance (IR).

Biochemical indices and lipids were performed by generally accepted methods on automatic analyzer "BioSystems" (Spain) using original set of reagents.

We used statistical formulas to calculate values related to statistical concepts or analyses. We cited results in the form of averages with a statistical error. The values with normal distribution are presented as confidence interval (95\%); and the values, where distribution significantly differed from the norm, are presented as interval of $25 \%$ and $75 \%$ percentiles. Comparison of groups was performed by means of Mann - Whitney U-test. Spearman's rho correlation tests were used to report the associations between variables. Categorical data were presented as proportions and analyzed using the Chi-square test. The results were considered statistically reliable at $\mathrm{p}<0.05$.

\section{RESULTS}

In both groups, the highest proportion were patients with a lasting disease, and therefore, they were taking atorvastatin between 1 and 5 years - $37(66.1 \%)$ patients in the $1^{\text {st }}$ and $26(51.0 \%)$ patients in the $2^{\text {nd }}$ group. The duration of the illness was less than 1 year for $6(10.7 \%)$ participants in the 1 st group and 18 (35.3\%) participants in the $2^{\text {nd }}$ group, whereas, more $13(23.2 \%)$ participants in the first and 7 (13.7\%) participants in the second group were sick for more than 5 years. There was no significant difference in the duration of the disease and receiving of atorvastatin.

Patients of both groups were almost identical by gender distribution and age. An abdominal obesity was indicated by WC and WHR for all patients. Glycated hemoglobin was measured for exclusion availability T2DM.

As it is seen from table I, concentration of low-density lipoproteins and total cholesterol was reliably lower in the group of patients, who had taken atorvastatin in a dose 40 $\mathrm{mg}$. But we observed dysglycemic effect of intensive dose of atorvastatin which was appearance of fasting hyperglicemia $(6.20(5.65 ; 7.05) \mathrm{mmol} / \mathrm{l}$ vs $6.01(5.48 ; 6.32) \mathrm{mmol} / \mathrm{l}$, $\mathrm{p}=0.03)$, hyperinsulinemia $(10.80(6.57 ; 20.00) \mu \mathrm{IU} / \mathrm{ml}$ vs $8.41(4.98 ; 12.20) \mu \mathrm{IU} / \mathrm{ml}, \mathrm{p}=0.03)$ and insulin resistance (HOMA-IR $3.28(1.62 ; 5.78)$ vs $2.10(1.38 ; 3.31), \mathrm{p}=0.01)$. Nevertheless, in our clinical trial, we observed that there was no significant difference in ALT, AST, ALP, GGTP, uric acid, HDL and TG among patients receiving atorvastatin. According to FINDRISK, patients taking $40 \mathrm{mg}$ of atorvastatin had a significantly higher risk of developing T2DM (Table I).

In the present study we also evaluated effectiveness of secondary prevention CAD on the way of comparison the proportion of patients who achieved and no achieved therapeutic target levels.In patients taking $40 \mathrm{mg}$ of the drug, the proportion of those who achieved target levels of LDL-C was significantly higher, and there was also a significantly higher rate of blood pressure monitoring in these patients (Table II).

A significant correlation between carbohydrate and lipid profile was observed for patients with CAD and obesity, who had taken $40 \mathrm{mg}$ of atorvastatin. These parameters indicate a mechanism for the formation of metabolic disorders. These associations service as evidence of the effect of a high-dose therapy with atorvastatin on the common pathogenesis of this comorbid pathology, namely atherogenic dyslipidemia, insulin resistance and systemic inflammation of low intensity (Table III).

\section{DISCUSSION}

We have received results that are consistent with the data obtained by other scholars. A meta-analysis conducted by Sattar et al., which included 13 placebo-controlled statin studies (91,148 participants), reported that statin therapy was associated with an increased risk of diabetes mellitus by $9 \%$, with insignificant heterogenity between studies. The study also found that the risk was higher for elderly patients. [11]

A prospective study of the effect of atorvastatin on carbohydrate metabolism has shown that in three groups, with normal fasting glucose, fasting hyperglycemia and glucose intolerance, there was a statistically significant increase in all glycemic parameters regardless of the dose 
Table I. Patients characteristics

\begin{tabular}{|c|c|c|c|}
\hline Baseline Characteristic & $\begin{array}{c}1^{\text {st }} \text { group, } 20 \mathrm{mg} \\
n=56\end{array}$ & $\begin{array}{c}2^{\text {nd }} \text { group, } 40 \mathrm{mg} \\
n=51\end{array}$ & $\mathbf{P}$ \\
\hline Male, $\%$ & $43(76.8 \%)$ & $38(74.5 \%)$ & 0.96 \\
\hline Age, years & $61.8(59.5 ; 64.0)$ & $59.4(56.8 ; 61.9)$ & 0.33 \\
\hline $\mathrm{BMI}, \mathrm{kg} / \mathrm{m}^{2}$ & $28.7(26.6 ; 32.4)$ & $30.8(29.6 ; 31.9)$ & 0.72 \\
\hline $\mathrm{WC}, \mathrm{cm}$ & $104.6(101.5 ; 107.7)$ & $106.7(103.8 ; 109.6)$ & 1.00 \\
\hline $\mathrm{WH}, \mathrm{cm}$ & $98.0(92.7 ; 105.0)$ & $101.0(96.0 ; 104.0)$ & 0.85 \\
\hline WHR & $1.04(1.02 ; 1.06)$ & $1.05(1.03 ; 1.07)$ & 0.89 \\
\hline $\mathrm{SBP}, \mathrm{mm} \mathrm{Hg}$ & $144(138 ; 152)$ & $140(136 ; 144)$ & 0.79 \\
\hline $\mathrm{DBP}, \mathrm{mm} \mathrm{Hg}$ & $82(79 ; 84)$ & $80(77 ; 83)$ & 0.75 \\
\hline $\mathrm{HR}, \mathrm{bpm}$ & $75(73 ; 78)$ & $75(67 ; 78)$ & 0.85 \\
\hline $\mathrm{ALT}, \mathrm{U} / \mathrm{I}$ & $21.75(13.37 ; 33.10)$ & $25.80(20.75 ; 42.70)$ & 0.57 \\
\hline AST, U/I & $25.40(20.15 ; 31.63)$ & $27.60(21.45 ; 32.60)$ & 0.42 \\
\hline $\mathrm{ALP}, \mathrm{U} / \mathrm{I}$ & $83.66(76.57 ; 90.75)$ & $83.10(75.50 ; 90.70)$ & 0.99 \\
\hline GGTP, U/I & $34.10(24.75 ; 47.80)$ & $50.34(43.12 ; 57.56)$ & 0.14 \\
\hline UricAcid, $\mathrm{mmol} / \mathrm{l}$ & $383.87(356.16 ; 411.58)$ & $373.10(311.10 ; 449.50)$ & 0.97 \\
\hline $\mathrm{HDL}, \mathrm{mmol} / \mathrm{l}$ & $1.23(0.96 ; 1.45)$ & $1.15(1.06 ; 1.24)$ & 0.41 \\
\hline $\mathrm{LDL}, \mathrm{mmol} / \mathrm{l}$ & $2.86(2.59 ; 3.13)$ & $2.10(1.63 ; 2.78)$ & 0.02 \\
\hline Cholesterol, mmol/l & $5.10(4.79 ; 5.41)$ & $4.20(3.65 ; 4.86)$ & $<0.01$ \\
\hline Triglycerides, mmol/l & $1.70(1.19 ; 2.49)$ & $1.58(1.04 ; 2.12)$ & 0.43 \\
\hline hsCRP, mg/l & $2,71(1,79 ; 4,27)$ & $2,20(1,04 ; 2,92)$ & 0.18 \\
\hline $\mathrm{HbA} 1, \%$ & $5.08(4.90 ; 5.26)$ & $5.34(5.11 ; 5.57)$ & 0.22 \\
\hline Glucose, $\mathrm{mmol} / \mathrm{l}$ & $6.01(5.48 ; 6.32)$ & $6.20(5.65 ; 7.05)$ & 0.03 \\
\hline Insulin, $\mu \mathrm{IU} / \mathrm{ml}$ & $8.41(4.98 ; 12.20)$ & $10.80(6.57 ; 20.00)$ & 0.03 \\
\hline HOMA-IR & $2.10(1.38 ; 3.31)$ & $3.28(1.62 ; 5.78)$ & 0.01 \\
\hline FINDRISK & $10.95(10.18 ; 11.72)$ & $12.75(11.92 ; 13.58)$ & $<0.01$ \\
\hline
\end{tabular}

Table II. Achieving therapeutic target in obese non-diabetic patients with coronary artery disease depending on dose atorvastatin

\begin{tabular}{cccc} 
& $\begin{array}{c}\mathbf{1}^{\text {st }} \mathbf{9 r o u p , ~ 2 0 ~} \mathbf{~ m g} \\
\mathbf{n = 5 6}\end{array}$ & $\begin{array}{c}\mathbf{2}^{\text {nd }} \mathbf{g r o u p , ~ 4 0 ~} \mathbf{~ m g} \\
\mathbf{n = 5 1}\end{array}$ & $\mathbf{p}$ \\
\hline Target LDL $<1.8 \mathrm{mmol} / \mathrm{l}$ & $8(14.3 \%)$ & $15(29.4 \%)$ & $<0.01$ \\
\hline Fasting glucose $<6.1 \mathrm{mmol} / \mathrm{l}$ & $31(55.4 \%)$ & $21(41.2 \%)$ & 0.43 \\
\hline Target BP $<140 / 90 \mathrm{~mm} \mathrm{Hg}$ & $18(32.1 \%)$ & $28(54.9 \%)$ & $<0.01$ \\
\hline Target HR $<70 \mathrm{bpm}$ & $20(35.7 \%)$ & $22(43.1 \%)$ & 0.22 \\
\hline
\end{tabular}

of atrovastatin. In the normoglycemic group with a low dose of atorvastatin, no significant changes in the glucose tolerance test were observed, however, there was a significant increase in $\mathrm{HbAlc}$ and fasting glycemia, while in high doses, changes in the glucose tolerance test and $\mathrm{HbA1c}$ values were significant after 6 months.In the hyperglycemia group, with both low and high-dose atorvastatin, there were significant changes in all glycemic parameters after 12 months. In the case of impaired glucose tolerance, especially at high doses of atorvastatin, significant changes have been observed after 6 months. [5]

A meta-analysis of the effects of different types and doses of statins was conducted by Eliano Pio Navarese and includes 17 randomized, placebo-controlled studies conducted between 1994 and 2012 involving 113,394 patients. Randomised controlled trials compared the effect of statin to placebo or high-dose statin therapy in comparison with the mean dose. Among various statins, pravastatin $40 \mathrm{mg} /$ day was associated with the lowest risk of T2DM development compared to placebo. And conversely, rosuvastatin $20 \mathrm{mg} /$ day and atorvastatin 40/80 mg were associated with an increased risk of $\mathrm{CD} 2$ development compared to placebo. [6]

Extremely relevant is the study of the effect of statin therapy over 6 years in the METSIM cohort (men with metabolic syndrome. Cederberg and co-authors concluded 
Table III. Correlation relationship between HOMA-IR and biochemical indicators*

\begin{tabular}{|c|c|c|c|}
\hline \multicolumn{2}{|c|}{$\begin{array}{c}1^{\text {st }} \text { group, } 20 \mathrm{mg} \\
\mathrm{n}=56\end{array}$} & \multicolumn{2}{|c|}{$\begin{array}{c}2^{\text {nd }} \text { group, } 40 \mathrm{mg} \\
\mathrm{n}=51\end{array}$} \\
\hline $\begin{array}{l}\text { Relationship between } \\
\text { indicators }\end{array}$ & Correlation coefficient & $\begin{array}{l}\text { Relationship between } \\
\text { indicators }\end{array}$ & Correlation coefficient \\
\hline HOMA-IR- UA & 0.30 & HOMA-IR-ALT & 0.32 \\
\hline \multirow[t]{5}{*}{ HOMA-IR-TG } & 0.37 & HOMA-IR-ALP & 0.38 \\
\hline & & HOMA-IR- GGTP & 0.39 \\
\hline & & HOMA-IR-TG & 0.34 \\
\hline & & HOMA-IR-HbA1c & 0.36 \\
\hline & & HOMA-IR-hsCRP & 0.30 \\
\hline
\end{tabular}

Note: ${ }^{*}-p<0.05$.

that statin treatment increases the risk of T2DM by $46 \%$ for these patients. [7]

Summarizing the results of the above studies, it is important to note that the occurrence of T2DM depends on many factors. On the part of the patient there are age, gender, weight, physical activity, diet, heredity history of diabetes mellitus, smoking, baseline glucose homeostasis, comorbid diseases (polycystic ovary, hyperprolactinemia) and combination with some drugs (diuretics, $\beta$-blockers).

On the part of statin therapy, this is a chemical structure of statin (pitawastatin and pravastatin do not have a negative effect on insulin resistance), duration of use and dose.

Current guidelines recommend assessing the risk of diabetes using the FINDRISK scale for all patients with high cardiovascular risk who need appointment of statins. If the risk is in the range from low to moderate, then no additional assessment of $\mathrm{HbAlc}$ and / or fasting glucose is required. However, patients with high risk of diabetes mellitus should be examined for $\mathrm{HbAlc}$ and/or glucose level in blood plasma before appointing statins and these assessments should be re-evaluated 3 months after treatment start. In addition, patients with a high risk of diabetes development or prediabetes should be recommended to change the lifestyle, which is aimed at reducing the weight or use insulin sensitizers.

Study limitations. The loss of accuracy identification of IR by HOMA-IR in compared with the clamp, but HOMA-IR is a less invasive, inexpensive, and less labor-intensive method to measure IR. Method of determining insulin is not standardized. This may be the reason for the divergence in the measurement. There is controversial cut-off HOMA-IR for different categories of patients.

\section{CONCLUSIONS}

The proatherogenic fractions of the lipids were significantly lower for patients with CAD and obesity, who had taken atorvastatin in a dose $40 \mathrm{mg}$, while insulin, glucose index and NOMA-IR index were significantly higher. This indicates a dysglycemic effect of intensive therapy with atorvastatin. Insulin resistance is a predictor of the occurrence of T2 DM, and that's why in some cohort groups it is important to carefully monitor the state of carbohydrate metabolism during treatment with atorvastatin.

Despite the beneficial reductions in LDL and total cholesterol, atorvastatin treatment on a dose $40 \mathrm{mg}$ resulted in significant increases in fasting glucose and insulin levels consistent with insulin resistance in those patients.

\section{REFERENCES}

1. Benjamin EJ, Virani SS, Callaway CW et al. Heart Disease and Stroke Statistics-2018 Update: A Report From the American Heart Association. Circulation. 2018 Mar 20;137(12):67-492.

2. Wilkins E, Wilson L, Wickramasinghe $K$ et al. European Cardiovascular Disease Statistics 2017. European Heart Network, Brussels. 2017. 188p.

3. International Diabetes Federation. IDF Diabetes Atlas, 8th edn. Brussels, Belgium: International Diabetes Federation, 2017. $147 \mathrm{p}$.

4. Lavie $\mathrm{G}$, Cohen S.Statins for the prevention of cardiovascular disease and diabetes incidence--the benefits versus the risks Harefuah. 2015;154(6):382-6.

5. Parida S, Swain TR, Routray SN et al. Effect of Atorvastatin on Glycaemic Parameters in Normoglycaemic and Prediabetic Subjects: A Prospective, Panel Study. J Clin Diagn Res. 2017;11(2):FC04-FC09.

6. Navarese EP, Buffon A, Andreotti Fet al. Meta-analysis of impact of different types and doses of statins on new-onset diabetes mellitus. Am J Cardiol. 2013;111(8):1123-30.

7. Cederberg H, Stančáková A, Yaluri N et al.Increased risk of diabetes with statin treatment is associated with impaired insulin sensitivity and insulin secretion: a 6 year follow-up study of the METSIM cohort. Diabetologia. 2015;58(5):1109-17.

8. Casula M, Mozzanica F, Scotti L et al. Statin use and risk of new-onset diabetes: A meta-analysis of observational studies. Nutr Metab Cardiovasc Dis. 2017;27(5):396-406.

9. Danchin N, AlmahmeedW, Al-Rasadi Ket al.Achievement of low-density lipoprotein cholesterol goals in 18 countries outside Western Europe: The International ChoLesterol management Practice Study (ICLPS). Eur J Prev Cardiol. 2018;25(10):1087-94.

10. Kohli P, Knowles JW, Sarraju A et al. Metabolic Markers to Predict Incident Diabetes Mellitus in Statin-Treated Patients (from the Treating to New Targets and the Stroke Prevention by Aggressive Reduction in Cholesterol Levels Trials). Am J Cardiol. 2016;118(9):1275-81.

11. Sattar N, Preiss D, Murray HM, et al. Statins and risk of incident diabetes: a collaborative meta-analysis of randomised statin trials. Lancet 2010;375:735-42. 
This article is a fragment of scientific research work of Department of Therapy No.1 and Medical Diagnostics. Faculty of postgraduate education Danylo Halytsky Lviv National Medical University, Lviv. Ukraine: "Features of the respiratory, cardiovascular, digestive system in patients with diabetes mellitus and obesity: features of pathogenesis, clinic, diagnostics".

\section{Authors' contributions:}

According to the order of the Authorship.

\section{Conflict of interest:}

The Authors declare no conflict of interest.

\section{CORRESPONDING AUTHOR}

\section{Tetiana A. Maksymets}

Hrinchenka Str 6/101, Lviv 79037, Ukraine

tel: +380977471613

e-mail: maksymets.@@gmail.com

Received: 18.03 .2019

Accepted: 26.04 .2019 


\title{
MULTIPLEX PCR ASSAY FOR CHLAMYDIA-LIKE BACTERIA DETECTION
}

\author{
Viktoriya K. Zezekalo', Konstantin F. Pochernyaev'², Vasyl M. Voloshchuk², Liudmyla V. Zasukha², \\ Natalia S. Shcherbakova', Serhii M. Kulynych ${ }^{1}$ \\ 'POLTAVA STATE AGRARIAN ACADEMY, POLTAVA, UKRAINE \\ 2INSTITUTE OF PIG BREEDING AND AGROINDUSTRIAL PRODUCTION NAAS, POLTAVA, UKRAINE
}

\begin{abstract}
Introduction: Waddlia chondrophila and Parachlamydia acanthamoebae are well-known and best-studied representatives of Chlamydia-related bacteria carrying a potential zoonotic threat. These bacteria are associated with miscarriage, ectopic pregnancy, diseases of the respiratory system in both humans and animals. Despite the importance of these Chlamydia-like organisms for human medicine along with veterinary medicine, studies on their prevalence in Ukraine were not conducted due to the lack of available tests. The aim of our work was to create relatively cheap and easy method for detection Waddlia chondrophila and Parachlamydia acanthamoebae.

Materials and methods: GenBank database was used to find nucleotide sequences of the 16S rRNA gene of bacteria Chlamydiales' order. Alignment was performed using the MEGA7 software, in order to detect the presence of polymorphic hybridization sites specifically attributed to Waddlia chondrophila and Parachlamydia acanthamoebae. PrimerBLAST software was used to design oligonucleotide primers, to evaluate the critical parameters of the primer, in particular, the melting temperature, difference between melting temperatures for the primer pairs, the GC content, the self-complementarity, etc.

Results and conclusions: The amplification of control DNA of Parachlamydia acanthamoebae and Waddlia chrondophila in single PCR using the corresponding primers and subsequent gel electrophoresis of PCR products determined the size of the amplified DNA fragments 88 b.p. and 123 b.p, respectively; the fragments were in line with the expected sizes. The analytical specificity test was performed by amplifying the control DNA of 15 species of the order Chlamydiales.
\end{abstract}

KEY WORDS: Parachlamydia acanthamoebae, Waddlia chrondophila, multiplex, PCR

Wiad Lek 2019, 72, 5 cz. I, 851-855

\section{INTRODUCTION}

Chlamydiae are gram-negative obligate intracellular bacteria sharing a unique biphasic developmental cycle and replicate exclusively within the interior of living cells in eukaryotic hosts The members of the Chlamydiales order cause diseases of humans, mammals, birds and reptiles. Chlamydiosis in animals can cause asymptomatic infection or may result in pneumonia, abortion, rhinitis, conjunctivitis, arthritis, infertility, enteritis, and more. Humans have their own endemic chlamydial species [1].

Chlamydia trachomatis is human pathogen, the most prominent representative of Chlamydiales order, which is the most common cause of sexually transmitted diseases worldwide [2]. Chlamydia abortus, Chlamydia caviae, Chlamydia felis, Chlamydia psittaci, Chlamydia suis, Chlamydia gallinacea cause zoonotic disease. [3]. Due the development of molecular biology, the number of representatives of the order Clamydiales has increased. In addition to expanding the Chlamydiaceae family, a number of Chlamydia-related bacteria (CRBs) are identified, some of which are associated with animal and human diseases.

The most known and currently the best described representatives of Chlamydia-related bacteria that carry a potential zoonotic threat are Waddlia chondrophila and Parachlamydia acanthamoebae. These bacteria are associated with miscarriage, ectopic pregnancy, diseases of the respiratory system in humans and animals $[4,5]$.
W. chondrophila was first isolated in 1986 from an aborted bovine fetus in the United States [6]. Subsequently, the association between antibodies against Waddlia chondrophila and bovine abortions was confirmed. Moreover, 1 out of 2 calves, which were experimentally infected with $W$. chondrophila, died within 2 weeks [7].

After that, a series of studies performed on humans the connection between the miscarriage and the presence of Waddlia antibodies in humans was observed. The pathogenic role of $W$. chondrophila in humans is confirmed by the strong association between seropositivity of W.chondrophila and human miscarriage. $[4,8,9]$. It was also proven that $W$. chondrophila has a negative effect on human spermatozoa [10], which suggests that $W$. chondrophila plays an important role in reducing the reproductive capacity of animals and humans. In addition, W. chondrophila is found in the respiratory samples of people with bronchiolitis or pneumonia [3].

For the first time, Parachlamydia acanthamoebae was isolated by Rolf Michel and Barbel Hauroder-Philippczyk in Berlin in 1994 during examining nose smears [11]. $P$. acanthamoebae is associated with respiratory diseases and miscarriages in ruminants. [12-14]. In humans, P.acanthamoebae is mainly associated with diseases of the respiratory system, bronchiolitis, pneumonia $[15,16]$, also this bacterium is associated with atherosclerosis [17] 
Parachlamydia acanthamoebae is widespread in nature and due to the symbiosis with Acanthamoeba, it has the ability to withstand a wide range of environmental stresses [18]. Moreover, recent studies of arthropods (mites) have shown the presence of Parachlamydiaceae DNA in mites, which, like birds, bats and mice, are considered to be the so-called "vectors" of chlamydia infection [19-22].

To the foregoing it should be added that Waddlia chondrophila and Parachlamydia acanthamoebae have been detected in drinking water $[23,24]$, which suggests that water can be a source of infection for animals and humans.

Despite the importance of these chlamydia-like organisms for human and veterinary medicine in Ukraine, studies on their prevalence among animals and humans have not been conducted due to the lack of available tests.

\section{THE AIM}

The aim of our work was to create relatively cheap and easy method to detect Waddlia chondrophila and Parachlamydia acanthamoebae, which will be used for widescreen monitoring in current challenging economic situation in Ukraine.

\section{MATERIALS AND METHODS}

GenBank database was used to find nucleotide sequences of the 16S rRNA of the order Chlamydiales. Alignment of 111 nucleotide sequences of 36 bacteria was performed using the MEGA7 software, in order to detect the presence of polymorphic hybridization sites specifically attributed to Waddlia chondrophila and Parachlamydia acanthamoebae. Primer-BLAST software was used to design oligonucleotide primers, to evaluate the critical parameters of the primer, in particular, the melting temperature, difference between melting temperatures for the primer pairs, the GC content, the self-complementarity, etc. The verification of the specificity of polymorphic fragments determined for each type of chlamydia with the nucleotide sequences of microorganisms, both opportunistic and infectious agents, was implemented using the online service Primer-BLAST. [25, 26, 27, 28].

The studies were carried out in the laboratory of animal health and the laboratory of genetics of Institute of Pig Breeding and Agro-Industrial Production, NAAS, which is certified for genetic analysis at the DNA level (Compliance certificate "state of the measurement system" number 02119 from 01/31/2019).

DNA amplification was performed using Thermo Fisher Scientific reagents according to the manufacturer's protocol. Oligonucleotide primers for the identification of Wad- dia chondrophila and Parachlamydia acanthamoebae were synthesized by Metabion international AG, Germany).

The resulting primers were diluted with sterile deionized water. Following reagents were used in PCR tests: $100 \mathrm{ng}$ of DNA template, primer mix, deionized water, $10 \mathrm{x}(\mathrm{N}-$ H)2SO PCR buffer, $25 \mathrm{mmMgCl} 2$, deoxyribonucleoside triphosphate solution ( $2 \mathrm{mmdNTP}$ ) and Taq polymerase (Thermo Fisher Scientific) according to the manufacturer's specifications. PCR amplification was performed in a final volume of $25 \mu \mathrm{L}$.

DNA amplification using PCR was performed on a "Tercyc-2" multichannel thermocycler (DNA technology, Russia). The cycling conditions to amplify consisted of an initial denaturation at $94^{\circ} \mathrm{C}$ for $5 \mathrm{~min}, 30$ cycles of melting at $94^{\circ} \mathrm{C}$ for $1 \mathrm{~min}$, annealing at $63^{\circ} \mathrm{C}$ for $30 \mathrm{~s}$, and elongation at $72^{\circ} \mathrm{C}$ for $1 \mathrm{~min}$ and a final extension at $72^{\circ} \mathrm{C}$ for $5 \mathrm{~min}$.

PCR products were separated using $2 \%$ agarose gel electrophoresis in $1 \times$ TBE buffer for 2 hours at a current of $50 \mathrm{~mA}$ in an electrophoresis chamber (Cleaver Scientific Ltd). Plasmids pUC19 hydrolyzed with Msp I endonuclease (Thermo Fisher Scientific) were used as a molecular weight marker. After the end of the electrophoresis process, the gel was stained with a solution of ethidium bromide $(10 \mathrm{mg} /$ $\mathrm{cm} 3$ ) and results of electrophoresis were captured using gel documentation system (Cleaver Scientific Ltd. UK).

Control DNA samples: Parachlamydia acanthamoebae strains "Berg17" and "Bn9" were kindly provided by Dr. Michel Rolf (Central Military Hospital Koblenz, Germany), DNA of Parachlamydia acanthamoebae, strain Hall obtained from Prof. Gilbert Greub (l'Institut de Microbiologie Médecin chef des laboratoires de microbiologie diagnostique Institut de microbiologie de l'Université de Lausanne, Switzerland), DNA samples of Waddlia chrondophila, Chlamydia avium, Chlamydia pecorum, Chlamydia abortus, Chlamydia psittaci, Chlamydia suis, Chlamydia caviae, Chlamydia trachomatis, Chlamydia abortus, Chlamydia felis, Chlamydia muridarum, Chlamydia pneumoniae, Chlamydia gallinacean, were obtained from Dr. Christiane Schnee (Institut für molekulare Pathogenese, Jena, Germany). Clavochlamydia salmonicola and Piscichlamydia salmonis samples were obtained from Dr. Heike Schmidt-Posthaus, (Center for Fish and Wildlife Health, Bern). Control DNA samples were used to test and verify the analytical specificity of the developed PCR tests.

\section{RESULTS}

Amplification of control DNAs of Parachlamydia acanthamoebae and Waddlia chrondophila with corresponding

Table I. Primers used for detection Waddlia chondrophila and Parachlamydia acanthamoebae

\begin{tabular}{ccc}
\hline Species & Sequence & Product size \\
\hline \multirow{2}{*}{ Waddlia chondrophila } & WADCHOF:GAACGAAGTGTGCTCTTGAGT & 123 b.p \\
\hline Parachlamydia & WADCHOR:CCTCTCTAGCACCATATCCGG & 88 b.p. \\
acanthamoebae & PCHAF:CAAGGTAGCCCTATCGGAAG & PCHAR:CTTGCCCAACCTCGGAAGAT \\
\hline
\end{tabular}






Figure 1. Multiplex PCR amplification with primers for DNA Waddlia chondrophila and Parachlamydia acanthamoebae:

1 - DNA size marker pUc19 / Mspl,

2 - PCR product obtained with primers for DNA amplification Waddlia chondrophila,

3 - PCR product obtained with primers for DNA amplification Parachlamydia acanthamoebae,

4 - PCR product, obtained with primers for multiplex amplification of DNA Waddlia chondrophila \& Parachlamydia acanthamoebae,

5-18 - control of specificity with primers for multiplex amplification (5 - DNA of C. trachomatis, 6 - DNA of C. pecorum, 7 - C. abortus, 8 - DNA of C. caviae, 9 - DNA of C. psittaci, 10 - DNA of C. suis, 11 - DNA of C. felis, 12 - DNA of C. muridarum, 13 - DNA of C. pneumoniae, 14 - DNA of C. gallinacea, 15 - DNA of C. avium, 16 - DNA of Piscichlamydia salmonis, 17 - DNA of Clavochlamydia salmonicola, 18 - negative control).

primers using PCR and the following gel electrophoresis of PCR products determined the size of the amplified DNA fragments as 88 base pairs and 123 base pairs (b.p.) respectively, the fragments corresponded to the expected sizes of the DNA fragments of $16 \mathrm{~S}$ rRNA gene Parachlamydia acanthamoebae and Waddlia chrondophila (Fig. 1.)

At the next stage, the primers for identification of Waddlia chrondophila and Parachlamydia acanthamoebae were mixed and used in multiplex PCR with the DNA of Waddlia chrondophila and Parachlamydia acanthamoebae, after which the electropherogram showed products with fragment sizes of 123 b.p. and 88 b.p. PCR was performed as a duplex to show the different sizes of the amplicon genes of the two organisms and the possibility of using them in a multiplex combination. (Fig. 1) The analytical specificity test was performed by amplifying the control DNA of 15 species of the order Chlamydiales with a primer-mix for the identification of Waddlia chrondophila and Parachlamydia acanthamoebae. The test for analytical specificity showed the absence of PCR products. (Fig. 1)

\section{DISCUSSION}

During the development of PCR test for Waddlia chrondophila and Parachlamydia acanthamoebae detection, conservative $16 \mathrm{~S} r R N A$ genes were selected as target genes for which the corresponding primers were selected. The key step in primers development was to find the most variable regions within each of the $16 \mathrm{~S} r R N A$ gene sequences and use these regions as species-specific.

Waddlia chondrophila and Parachlamydia acanthamoebae are Chlamydia-like bacteria that are associated with diseases of animals and humans. These bacteria are isolated from animals and humans, so they can be considered as a potential zoonotic threat $[4,8-10,12-15]$.

Due to the difficult economic situation In Ukraine deterioration of living conditions and food occurs. Healthcare reform, which, on the one hand, destroyed the Soviet health care system, on the other hand, did not come to an effective completion has led to the unsupervised use of antimicrobials, the lack of proper epidemiological surveillance along with shortness of veterinary and sanitary control over the quality of livestock products. Armed conflict ("hybrid war"), which is being fought in eastern Ukraine and mass impoverishment, generates a high level of migration and population concentration $[29,30,31]$. All of the above are driving factors for the occurrence of infectious diseases in general. Therefore, there is a need for simple, affordable tests that do not need expensive equipment. Higher sensitivity of PCR tests is their main advantage compared to culture technique and other methods which are too time-consuming, difficult to perform and sometimes inaccurate. PCR diagnostics of chlamydial infections available for clinical use is the best and recommended method for detecting chlamydial infections. [32]

The 16S RNA gene was chosen as the molecular target for the differentiation of Waddlia chrondophila and Parachlamydia acanthamoebae, since this conservative gene is the most universal among bacteria on the one hand, and on the other has hypervariable regions, which allows to choose a species-specific region for each species[33].

Waddlia chrondophila and Parachlamydia acanthamoebae primers were designed with the same physical characteristics to ensure simultaneous amplification under the same conditions in single or multiplex PCR. To be able to 
visually assess the amplification product, the primer pairs differ in the length of the amplicons, the gap of the target fragment is $35 \mathrm{bp}$, which meet the resolution requirements for electrophoresis in a $2 \%$ agarose gel. To prevent the appearance of non-specific products, the melting point of the primers was $60^{\circ} \mathrm{C}$, and their length was $20-21$ base pairs. In the process of optimizing PCR tests using temperatures from $55^{\circ} \mathrm{C}$ to $63^{\circ} \mathrm{C}$, the optimum temperature was $60^{\circ} \mathrm{C}$ with standard concentrations of PCR components. Despite the fact that there are foreign-made commercial PCR tests to identify these bacteria, in the current economic situation in Ukraine, the widespread use of these diagnostic kits appeared to be almost impossible, due to the high price, or the need for expensive equipment (for real-time PCR tests) $[34,35]$.

\section{CONCLUSIONS}

An affordable and relatively simple instrumentality to identify Waddlia chondrophila and Parachlamydia acanthamoebae was created, which, after testing on clinical material, can be used for extensive monitoring.

\section{REFERENCES}

1. Everett KD. Chlamydia and Chlamydiales: more than meets the eye. Vet Microbiol. 2000 Jul 31;75(2):109-26.

2. Newman L, Rowley J, Vander Hoorn S, Wijesooriya NS, Unemo M, Low N, et al. Global Estimates of the Prevalence and Incidence of Four Curable Sexually Transmitted Infections in 2012 Based on Systematic Review and Global Reporting. Meng Z, editor. PLOS ONE. 2015 Dec 8;10(12):e0143304. doi: 10.1371/journal.pone.0143304

3. Borel N, Polkinghorne A, Pospischil A. A Review on Chlamydial Diseases in Animals: Still a Challenge for Pathologists? Vet Pathol. 2018;55(3):374-90. doi: 10.1177/0300985817751218

4. Baud D, Goy G, Osterheld M-C, Croxatto A, Borel N, Vial Y, et al. Role of Waddlia chondrophila Placental Infection in Miscarriage. Emerg Infect Dis. 2014 Mar;20(3):460-4. doi: 10.3201/eid2003.131019

5. Hornung S, Thuong BC, Gyger J, Kebbi-Beghdadi C, Vasilevsky S, Greub $\mathrm{G}$, et al. Role of Chlamydia trachomatis and emerging Chlamydia-related bacteria in ectopic pregnancy in Vietnam. Epidemiol Infect. 2015 Sep;143(12):2635-8. doi: 10.1017/S0950268814003616

6. Dilbeck PM, Evermann JF, Crawford TB, Ward AC, Leathers CW, Holland CJ, et al. Isolation of a previously undescribed rickettsia from an aborted bovine fetus. J Clin Microbiol. 1990 Apr;28(4):814-6.

7. Dilbeck-Robertson P, McAllister MM, Bradway D, Evermann JF. Results of a new serologic test suggest an association of Waddlia chondrophila with bovine abortion. J Vet Diagn Invest. 2003 Nov;15(6):568-9. doi: 10.1177/104063870301500609

8. Baud D, Thomas V, Arafa A, Regan L, Greub G. Waddlia chondrophila, a potential agent of human fetal death. Emerging Infect Dis. 2007 Aug;13(8):1239-43. doi: 10.3201/eid1308.070315

9. Baud D, Goy G, Osterheld M-C, Borel N, Vial Y, Pospischil A, et al. Waddlia chondrophila: from bovine abortion to human miscarriage. Clin Infect Dis. 2011 Jun 15;52(12):1469-71. doi: 10.1093/cid/cir205

10. Baud D, Vulliemoz N, Ammerdorffer A, Gyger J, Greub G, Castella V, et al. Waddlia chondrophila, a Chlamydia-related bacterium, has a negative impact on human spermatozoa. Hum Reprod. 201801;33(1):3-10. doi: 10.1093/humrep/dex342
11. Michel R, Hauröder-Philippczyk B, Müller K-D, Weishaar I. Acanthamoeba from human nasal mucosa infected with an obligate intracellular parasite. European Journal of Protistology. 1994 Feb;30(1):104-10. doi: 10.1016/S0932-4739(11)80203-8

12. Borel N, Ruhl S, Casson N, Kaiser C, Pospischil A, Greub G. Parachlamydia spp. and Related Chlamydia-like Organisms and Bovine Abortion. Emerg Infect Dis. 2007 Dec;13(12):1904-7. doi: 10.3201/eid1312.070655

13. Deuchande R, Gidlow J, Caldow G, Baily J, Longbottom D, Wheelhouse $\mathrm{N}$, et al. Parachlamydia involvement in bovine abortions in a beef herd in Scotland. Vet Rec. 2010 May 8;166(19):598-9. doi: 10.1136/vr.c2435

14. Wheelhouse N, Longbottom D. Endemic and emerging chlamydial infections of animals and their zoonotic implications. Transbound Emerg Dis. 2012 Aug;59(4):283-91. doi: 10.1111/j.1865-1682.2011.01274.x

15. Greub G. Parachlamydia acanthamoebae, an emerging agent of pneumonia. Clin Microbiol Infect. 2009 Jan;15(1):18-28. doi: 10.1111/j.1469-0691.2008.02633.x

16. Lamoth F, Aeby S, Schneider A, Jaton-0gay K, Vaudaux B, Greub G. Parachlamydia and rhabdochlamydia in premature neonates. Emerging Infect Dis. 2009 Dec;15(12):2072-5. doi: 10.3201/eid1512.090267

17. Greub G, Hartung 0, Adekambi T, Alimi YS, Raoult D. Chlamydialike Organisms and Atherosclerosis. Emerg Infect Dis. 2006 Apr;12(4):705-6. doi: 10.3201/eid1204.050751

18. Casson N, Medico N, Bille J, Greub G. Parachlamydia acanthamoebae enters and multiplies within pneumocytes and lung fibroblasts. Microbes and Infection. 2006 Apr;8(5):1294-300. doi: 10.1016/j.micinf.2005.12.011

19. Burnard D, Weaver H, Gillett A, Loader J, Flanagan C, Polkinghorne A. Novel Chlamydiales genotypes identified in ticks from Australian wildlife. Parasit Vectors. 2017 26;10(1):46. doi: 10.1186/s13071-017-1994-y

20. Hokynar K, Sormunen JJ, Vesterinen EJ, Partio EK, Lilley T, Timonen V, et al. Chlamydia-Like Organisms (CLOs) in Finnish Ixodes ricinus Ticks and Human Skin. Microorganisms. 2016 Aug 18;4(3). doi: 10.3390/ microorganisms 4030028

21. Pilloux L, Aeby S, Gaümann R, Burri C, Beuret C, Greub G. The high prevalence and diversity of Chlamydiales DNA within Ixodes ricinus ticks suggest a role for ticks as reservoirs and vectors of Chlamydiarelated bacteria. Appl Environ Microbiol. 2015 Dec;81(23):8177-82. doi: 10.1128/AEM.02183-15

22. Croxatto A, Rieille N, KernifT, Bitam I, Aeby S, Péter 0, et al. Presence of Chlamydiales DNA in ticks and fleas suggests that ticks are carriers of Chlamydiae. Ticks Tick Borne Dis. 2014 Jun;5(4):359-65. doi: 10.1016/j. ttbdis.2013.11.009

23. Codony F, Fittipaldi M, López E, Morató J, Agustí G. Well Water as a Possible Source of Waddlia chondrophila Infections. Microbes Environ. 2012 Dec;27(4):529-32. doi: 10.1264/jsme2.ME12048

24. Wheelhouse N, Sait M, Gidlow J, Deuchande R, Borel N, Baily J, et al. Molecular detection of Chlamydia-like organisms in cattle drinking water. Vet Microbiol. 2011 Aug 26;152(1-2):196-9. doi: 10.1016/j. vetmic.2011.03.040

25. Sayers EW, Barrett T, Benson DA, Bolton E, Bryant SH, Canese K, et al. Database resources of the National Center for Biotechnology Information. Nucleic Acids Res. 2012 Jan;40(Database issue):D13-25. doi: 10.1093/nar/gkr1184

26. KumarS, Stecher G, Tamura K. MEGA7: Molecular Evolutionary Genetics Analysis Version 7.0 for Bigger Datasets. Molecular Biology and Evolution. $2016 \mathrm{Jul} ; 33$ (7):1870-4. doi: 10.1093/molbev/msw054

27. Primer designing tool. [accessed 8 Apr 2019] Available from: https://www.ncbi.nlm.nih.gov/tools/primer-blast/index.cgi?LINK_ $\mathrm{LOC}=$ BlastHome 
28. Ye J, Coulouris G, Zaretskaya I, Cutcutache I, Rozen S, Madden TL. PrimerBLAST: a tool to design target-specific primers for polymerase chain reaction. BMC Bioinformatics. 2012 Jun 18;13:134. doi: 10.1186/14712105-13-134

29. dr Artur Jan Kukuła - 0 mnie. [accessed 9 Apr 2019] Available from: https://pracownik.kul.pl/artur.kukula/

30. The Struggle for Ukraine | Chatham House. [accessed 9 Apr 2019] Available from: https://www.chathamhouse.org/publication/strugglefor-ukraine

31. Semigina T. Frustrations or moving forward? Ukrainian social work within the 'hybrid war' context. European Journal of Social Work. 2019 May 4;22(3):446-57. doi: 10.1080/13691457.2017.1366432

32. Blumer S, Greub G, Waldvogel A, Hässig M, Thoma R, Tschuor A, et al. Waddlia, Parachlamydia and Chlamydiaceae in bovine abortion. Vet Microbiol. 2011 Sep 28;152(3-4):385-93. doi: 10.1016/j. vetmic.2011.05.024

33. Chakravorty S, Helb D, Burday M, Connell N, Alland D. A detailed analysis of 165 ribosomal RNA gene segments for the diagnosis of pathogenic bacteria. Journal of Microbiological Methods. 2007 May;69(2):330-9. doi: 10.1016/j.mimet.2007.02.005

34. Bio-T kit ${ }^{\circledR}$ Waddlia chondrophila - Biosellal. [accessed 9 Apr 2019] Available from: http://biosellal.com/famille-bio-t-repro/132-bio-tkit-waddlia-chondrophila.html

35. MICROBExpress Bacterial mRNA Enrichment Kit-Thermo Fisher Scientific. [accessed 9 Apr 2019] Available from: https://www.thermofisher.com/ order/catalog/product/AM1905?SID=srch-srp-AM1905
This research was partially supported by the National academy of agrarian sciences of Ukraine, grant $0119 U 000445$.

Acknowlegments: We express our sincere gratitude to the scientists, who have supported and mentored our studies: Dr. Igor Ksonz, Dr. Michel Rolf, Dr. Gilbert Greub, Dr. Christiane Schnee, Dr. Heike Schmidt-Posthaus, thanks to whom it became possible to carry out our research.

\section{Authors' contributions:}

According to the order of the Authorship.

\section{Conflict of interest:}

The Authors declare no conflict of interest.

\section{CORRESPONDING AUTHOR \\ Viktoriya Zezekalo \\ Poltava State Agrarian Academy \\ Skovorody St, 1/3, 36000 Poltava, Ukraine \\ tel: +380956455626 \\ e-mail:v.zezekalo@gmail.com}

Received: 12.03 .2019

Accepted: 30.04 .2019 
PRACA ORYGINALNA

ORIGINAL ARTICLE

\title{
FALSIFICATION OF MEDICAL PRODUCTS: CRIMINAL LAW MECHANISM COMBATING THREATS TO PUBLIC HEALTH
}

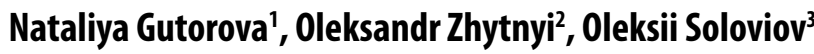 \\ 'POLTAVA LAW INSTITUTE OF YAROSLAV MUDRIY NATIONAL LAW UNIVERSITY, POLTAVA, UKRAINE \\ 2V.N. KARAZIN KHARKIV NATIONAL UNIVERSITY, KHARKIV, UKRAINE \\ ${ }^{3}$ SHUPYK NATIONAL MEDICAL ACADEMY, KYIV, UKRAINE
}

\begin{abstract}
Introduction: Every civilized state has the duty to its citizens to create an effective health care system, a necessary component of which is the use of safe and high-quality medical products. This duty is based both on the standards of international law and national constitutional norms and principles. The spread of falsified medical products poses a global threat to public health, can lead to death or cause significant harm to human health. Given the extreme risk of such acts, there is a need to create and operate an effective criminal law mechanism to combat such acts.

The aim: The purpose of the article is to study the existing criminal law mechanism to combat the falsification of medical products at the international, regional and national levels (Poland and Ukraine as an example), as well as to develop proposals for improving of such a mechanism.

Materials and methods: This study is based on the empirical and analytical data of the WHO, the United Nations Convention against Transnational Organized Crime, the Council of Europe Convention on the counterfeiting of medical products and similar crimes involving threats to public health (The Medicrime Convention), criminal legislation of Ukraine and Poland, General Prosecutor's Office data on the criminal liability of those who committed falsification of medicines. Totally 28 laws and papers, 25 court judgments were analyzed.

Dialectical, comparative, analytic, synthetic and system analyses research methods were used, also for interpretation purposes.

Results: Falsification of medical products worldwide is characterized by high prevalence and is one of the highly profitable activities of transnational organized crime. Therefore, an effective counteraction to these crimes is impossible through isolated actions by one separate State and requires the establishment of a multi-level integrated mechanism to combat this phenomenon. The criminal law mechanism, as a necessary component of abovementioned mechanism, should be established at the international, regional and national levels.

An analysis of the situation in Poland and Ukraine showed that the falsification of medical products is quite common in these countries, but national criminal legislation and practice of its implementation needs improvement.

Conclusions: There is a need to create and implement an effective criminal law mechanism (at international, regional and national levels) to combat the spread of falsified medical products. At the international level, in order to increase the effectiveness of this mechanism, we fully support the EU initiative to amend the United Nations Convention against Transnational Organized Crime, which would establish additional liability for the falsification of medicines. Improving the criminal law mechanism to combat the falsification of medical products at the European regional level requires intensifying of The Medicrime Convention ratification process and full implementation of rules on criminal liability for falsifying medical products into national criminal legislation. At the national level, it is necessary to improve both the criminal legislation and the practice of its implementation, to intensify the activity of law enforcement agencies to combat these crimes, to ensure a fair trial and effective criminal penalties for those who have committed a crime of falsifying medical products.
\end{abstract}

KEY WORDS: falsification of medical products, counterfeit medical products, medicines, medical devices, criminal liability, criminal law mechanism, public health, The Medicrime Convention

Wiad Lek 2019, 72, 5 cz. I, 856-861

\section{INTRODUCTION}

Every civilized state has the duty to its citizens to create an effective health care system, a necessary component of which is the use of safe and high-quality medical products. This duty is based both on international law standards and national constitutional norms and principles. Thus, Article 25 (1) of the Universal Declaration of Human Rights (1948) proclaims the right to a standard of living adequate for the health and well-being, including medical care, and the right to security in the event of sickness [1]. According to Part
1 (11) of the European Social Charter (Revised) (1996) the parties accept as the aim of their policy, to be pursued by all appropriate means both national and international in character, the attainment of conditions in which the following rights and principles may be effectively realised: Everyone has the right to benefit from any measures enabling him to enjoy the highest possible standard of health attainable. Based on Article 11 of this document, European states, with a view to ensuring the effective exercise of the right to protection of health, undertake, either directly or 
in cooperation with public or private organisations, to take appropriate measures designed inter alia: 1 ) to remove as far as possible the causes of ill-health; 2) to provide advisory and educational facilities for the promotion of health and the encouragement of individual responsibility in matters of health;3) to prevent as far as possible epidemic, endemic and other diseases, as well as accidents [2]. The Constitution of the Republic of Poland (Art. 68) states that everyone shall have the right to have his health protected [3], the Constitution of Ukraine (Art. 49) proclaims the right to health protection, medical care and medical insurance [4]. As we can see, the right to health protection refers to the standards of personal and social human rights established at the universal regional and national levels. The duty of the state is to create conditions for the realization of the right to health and its security for every person.

It is unlikely that in the modern world one can find a person who has never ever used medicines. Many people of the world who suffer from chronic and incurable diseases are forced to take medicines daily and in large quantities. A comfortable or at least acceptable standard of living for these people depends on the quality of medicines and other medical products. Sometimes the proper quality of these products is a necessary condition for survival of part of humankind. Although accurate statistics on quantities of poor-quality medical products worldwide doesn't exist for now, however, cases of significant harm to life and health of a large number of people due to their use are not rare.

Among the most serious effects of the use of falsified medicines the following should be mentioned [5]. In 1995, during a meningitis epidemic in Niger, over 50000 people were vaccinated with a counterfeit vaccine, resulting in 2500 deaths. [6]. Quite stunning statistics are presented by J. Chirac saying that every year over 200000 people die because they receive falsified medicines for malaria [7]. Recently, significant publicity has been given to the so-called "heparin case". Over 80 lethal cases in United States have been linked to the use of falsified heparin manufactured in China [8]. Over 125 people died in Pakistan from the use of the falsified generic product isosorbide-5-mononitrate, which contained a toxic quantity of the active substance [9]. The World Health Organization (WHO), given the extreme danger of spreading fake medical products, has determined that combating this negative phenomenon is one of its main activities.

Consequently, the spread of falsified medical products poses a global threat to public health, can lead to death or cause significant harm to human health. Given the extreme risk of such acts, there is a need to create and implement an effective criminal law mechanism to combat such acts.

\section{THE AIM}

The purpose of the article is to study the existing criminal law mechanism to combat the falsification of medical products at the international, regional and national levels (on the example of Poland and Ukraine), as well as to develop proposals for improving of such a mechanism.

\section{MATERIALS AND METHODS}

This study is based on the empirical and analytical data of the WHO, the United Nations Convention against Transnational Organized Crime, the Council of Europe Convention on the counterfeiting of medical products and similar crimes involving threats to public health (The "Medicrime Convention"), criminal legislation of Ukraine and Poland, General Prosecutor's Office data on the criminal liability of those who committed crimes of medicines falsification. Totally 28 laws and papers, 25 court judgments were analyzed.

Dialectical, comparative, analytic, synthetic and system analyses research methods were used, also for interpretation purposes.

\section{RESULTS AND DISCUSSION}

The historical analysis of the formation of an international mechanism to prevent the spread of counterfeit medical products, which was carried out in the monograph "Preventing the spread of falsified medicines at the international and national level" [5], shows that for the first time the question of the need to jointly combat the spread of counterfeit medical products was raised at the international level in 1980s [10, p. 689]. The attention of the international community to the problem of falsified medical products (including medicines) was first drawn by the Conference of Experts on the Rational Use of Drugs held in Nairobi in 1985. The attending experts recommended that the WHO, together with other international governmental and nongovernmental organizations, should study the feasibility of setting up a Accounting Chamber to collect data and to inform governments about the nature and extent of counterfeiting [11].

Two stages of the WHO's activity in this sphere should be highlighted. At the first stage, efforts were mainly focused on strengthening control over the quality of medical products, which was supposed to help prevent falsification. Thus, in 1988 WHO Resolution WHA 41.16 "Rational Use of Drugs" [12, p.19-20] was adopted. This Resolution recommended that the Director-General of the WHO should initiate programmes for the prevention and detection of the export, import and smuggling of falsely labelled, counterfeited or substandard pharmaceutical preparations [13]. In WHO Resolution WHA 52.19 Revised drug strategy (1999) [14], countries were recommended to establish and enforce regulations that ensure quality standards for all pharmaceutical materials and products manufactured in, imported to, exported from, or in transit through their territory. The above-mentioned WHO Resolution, which was welcomed by the $\mathrm{EU}$, gave rise to the adoption of $\mathrm{Di}$ rective 2003/94/EC "The principles and guidelines of good manufacturing practice in respect of medicinal products for human use and investigational medicinal products for human use" [15].

At the second stage, an international mechanism to combat the falsification of medical products has been created and launched. In February 2006 the WHO in order 
to facilitate harmonization of national laws and develop a uniform approach to falsified medicines understanding initiated the International Medical Products Anti-Counterfeiting Taskforce (IMPACT) [16]. In 2011 WHO established a "Member State mechanism", which would be vested with expert functions and assist The International Conference of Drug Regulatory Authorities (ICDRAs). Basic provisions on "Member State mechanism", a new practical activity of the WHO, are set forth in the document of the 65th World Health Assembly [17].

However, it should be noted that criminal law mechanism to combat the falsification of medical products at the international level needs to be improved. Despite the fact that the falsification of medical products and, above all, medicines, poses a serious threat to health of humanity and also belongs to the main activities of international organized crime, this crime cannot be classified as a type of transnational crime in accordance with international law. The problem is that criminal liability for transnational crimes, which include falsification of medical products, cannot be ensured by the efforts of one country. There is a need to solve issues such as extradition of convicts, mutual legal assistance and other aspects of international cooperation in the field of criminal justice. The international legal mechanism that effectively solves these problems is approved by the United Nations Convention against Transnational Organized Crime (Palermo Convention) [18]. Therefore, we fully support the EU initiative to amend the United Nations Convention against Transnational Organized Crime, which would establish additional liability for the falsification of medicines [19, p. 8].

The next level of the criminal law mechanism to combat the falsification of medical products is the level of the $\mathbf{E u}$ ropean region. The main international document at this level is the "Medicrime Convention" which was signed on October 28, 2011 in Moscow the Russian Federation and entered into force on January 1, 2016. This Convention is the first international criminal law instrument to oblige States Parties to criminalise: 1) the intentional manufacturing of counterfeit medical products, active substances, excipients, parts, materials and accessories (Art. 5); 2) committed intentionally, the supplying or the offering to supply, including brokering, the trafficking, including keeping in stock, importing and exporting of counterfeit medical products, active substances, excipients, parts, materials and accessories (Art. 6); 3) the making of false documents or the act of tampering with documents, when committed intentionally (Art. 7); 4) committed intentionally, in so far as such an activity is not covered by Articles 5, 6 and 7: the manufacturing, the keeping in stock for supply, importing, exporting, supplying, offering to supply or placing on the market of medicinal products without authorisation where such authorisation is required under the domestic law of the Party or medical devices without being in compliance with the conformity requirements, where such conformity is required under the domestic law of the Party; the commercial use of original documents outside their intended use within the legal medical product supply chain, as specified by the domestic law of the Party (Art. 8); the intentional aiding or abetting and attempt to commit any of the offences established in accordance with this Convention (Art. 9).[20] As we can see, according to the plan of the developers of this document, criminalization and punishment should cover the whole "chain" of spreading of various types of counterfeit medical products.

As of February 20, 2019, out of 47 Council of Europe Member States, 23 states have signed the "Medicrime Convention", but only 12 of them ratified it. 5 states - non-members of Council of Europe (Benin, Burkina Faso, Guinea, Israel and Morocco) also have signed this Convention and 3 of them (Benin, Burkina Faso and Guinea) ratified it. [21]. It is noteworthy that Ukraine is a state that was one of the first to sign and ratify this Convention. At the same time, Poland has not signed this document yet.

Despite the fact that for Ukraine this Convention entered into force on January 1,2016, it is not yet fully implemented in the national criminal legislation. To date, the falsification of medical devices and medicines for animals has not been criminalized, and no criminal law measures have been established for legal entities. It should be noted that in Ukraine the lack of legislative regulation of medical devices has a negative impact on the quality of medical care [22; 23]. In addition, the commission of an offences by persons abusing the confidence placed in them as professionals, manufacturers or suppliers as well as the offences committed having resort to means of large-scale distribution, such as information systems including the Internet, were not recognized as an aggravating circumstance.

In fact, only $25.5 \%$ (12 from 47) members of The Council of Europe have entered into forces the "Medicrime Convention" for more than 7 years from the time when this treaty was opened for signing. Unfortunately, this situation does not allow using the opportunities provided by the Convention for effective cooperation at the national and international levels between different sectors of government, coordination measures at the national level, preventive measures for the use of public and private sectors and protection of victims and witnesses.[20] The abstention of any country from joining this Convention weakens the effectiveness and speed of international cooperation of national law enforcement and judicial authorities with the relevant services of other states in this area [24]. Thus, the improvement of the criminal law mechanism to combat the falsification of medical products at the European regional level requires intensifying the process of "Medicrime Convention" ratification.

Attention should also be paid to the terminology used in the international documents for definition of falsified medical products. For some time, such products were designated by the term "counterfeit medical products" in WHO documents, later the abbreviation SSFFC (substandard/spurious/ falsely-labelled/falsified/counterfeit) was commonly used in relation to falsified medicines. However, on May 29, 2017, at the 70th World Health Assembly, it was decided to use the unified term "substandard and falsified medical products" $(\mathrm{SF})$ for designation in all future documents [25] 
The basis for legal regulation of preventing the spread of falsified medicines among $E U$ territory is the Directive 2011/62/EU of the European Parliament and of the Council of 8 June 2011 amending Directive 2001/83/EC on the Community code relating to medicinal products for human use, as regards the prevention of the entry into the legal supply chain of falsified medicinal products [26], which entered into force on January 2, 2013. It amends Directive 2001/83/EC on the Community code relating to medicinal products for human use. EU Member States use quite a severe authorization procedure on their territories, i.e. a procedure for admission to the common market of the EU. Key characteristics evaluated during the authorization procedure are the quality, safety and efficacy of a medicine. EU Member States expect to achieve such characteristics by using a number of measures. For example:

- the basis for preventing the spread of falsified medicines must be primarily an efficient control over the origin and quality of an active substance, such as: 1) an obligation of manufacturers to use only an active substance that is manufactured in compliance with GMP requirements and distributed in compliance with GDP; and 2) registration of manufacturers, importers and distributors of an active substance;

- the enhancement of requirements for the labelling of medicines, i.e. the use of a unique identifier ( $2 \mathrm{D}$ code of the format GS1 ECC200). We believe it would be reasonable to expand the use of such labelling firstly into the territory of a subregion or region and subsequently worldwide. However, such a transition is costly;

- the strengthening of administrative measures (registration of trade agents, authorization of all participants in the circulation of medicines to inform competent public authorities of cases of falsified medicines, threats to human life and health);

- the establishment of a single system within the EU that will help inspect all participants of medicines circulation on a regular basis. Such inspection may be carried out both on the territory of the EU and on those of other countries;

- informational methods (informing about officially registered participants in medicines circulation, reporting cases of medicines falsification).

- the maintenance of "white" and "black" lists of medicines. Thus, the "white" list will include prescription medicines that require no additional identification and coding due to a) their low price; b) limited output; c) impossibility to counterfeit due to the physical and chemical properties of a medicinal product, etc. The "black" list will include OTC (over the counter) medicinal products that: a) are expensive; b) are in great demand; c) are from famous brands; and d) of which falsifications have entered the circulation. The "white" and "black" lists are planned to be used at the EU level. Moreover, manufacturers or wholesale distributors of medicines will not be able to influence the process of including medicines in any particular list. [5, p. 63, 64]

Preventive measures of this Directive to combat the falsification of medical products were considered necessary to be combined with measures of a criminal law nature.
Thus, in accordance with Art. 118a (1) "the Member States shall lay down the rules on penalties applicable to infringements of the national provisions adopted pursuant to this Directive and shall take all necessary measures to ensure that those penalties are implemented. The penalties must be effective, proportionate and dissuasive." [26]

Therefore, the next issue that needs to be analyzed to achieve the aim of this study is the functioning of the criminal law mechanism to combat the falsification of medical products at the national level (Ukraine and Poland examples).

Polish legislation criminalizes the falsification of medical products in the Art. $124 \mathrm{~b}$ of The Pharmacy Law [27] and Art. 165 of The Penal Law [28]. According to Art. $124 \mathrm{~b}$ of the Pharmacy Act criminal punishment (fine, restriction of liberty or deprivation of liberty for up to 5 years) is established for a person who makes a falsified medicinal product or a falsified active substance, supplies, sells or provides free of charge, or stores for this purpose a falsified medicinal product or falsified active substance. Art. 165 of The Penal Law states that: whoever causes danger to the life or health of many persons or property of a considerable value by producing or marketing of pharmaceutical preparations which do not conform to binding quality standards shall be subject to the penalty of the deprivation of liberty for a term of between 6 months and 8 years $(\$ 1)$; if the consequence of the act specified in $₫ 1$ is the death of a person, or grievous bodily harm to many persons, the perpetrator shall be subject to the penalty of the deprivation of liberty for a term of between 2 and 12 years $(\$ 3)$. According to the findings of Polish researchers (Iga Kalinowska Maksim), the Art. 124 b of The Pharmaceutical Law is special with respect to the Art. 165 of the Criminal Code of Poland. Such a relationship involves the priority of the latter. [29]

The Criminal Code of Ukraine establishes criminal liability for these offences according to the Art. $321^{1 \text { "Falsification }}$ of medicines or circulation of falsified medicines" and Art. 305 "Smuggling of narcotics, psychotropic substances, their analogues or precursors or falsified medicines" [30], which was adopted in 2011 . This article states that manufacturing, buying, transporting, sending, storing with the purpose to sell, or selling deliberately falsified medicine shall be punishable by deprivation of liberty for a term of three to ten years or deprivation of liberty for life with confiscation of property. According to the Art. 305 smuggling of falsified medicines, that is their movement across the customs border of Ukraine outside the customs control or by concealing from the customs control shall be punishable by deprivation of liberty for a term of five to twelve years with confiscation of property.

Comparison of criminal sanctions imposed in Ukraine and Poland for falsification of medicines and circulation of falsified medicines clearly demonstrate the commitment of the Ukrainian legislator to the severity of punishment as an effective countermeasure. It is evidenced by the presence in the Art. $321^{1}$ (p. 3) of The Criminal Code of Ukraine such a punishment as deprivation of liberty for life. It should be 
noted that so far this is the only example of the establishment in Ukrainian criminal legislation of the most severe type of punishment for committing a crime not related to murder or attempted murder.

However, despite the extraordinary severity of the punishment established by law, in fact, the courts do not apply it. For example, in November 2012 in Lviv region a criminal group was discovered, which was engaged in falsification and sale of falsified medicines for several years. It was detected 597 types of medicines and health-care products at unlicensed warehouses, which had characteristics of being falsified. The criminal group deliberately sold medicines and other medical products that could harm human life and health, a part of legal but expired medicines was re-labelled showing different expiration dates. It should be noted that this group has falsified the most advertised medicines in Ukraine. Falsified medicines entered the circulation mostly through a pharmacy network, in most cases through individual entrepreneurs. Despite the fact that the members of this group agreed to cooperate with the investigators, the source of supply of raw materials for the manufacture of falsified medicines has not been detected. Seven members of the criminal group, among whom four were employees of pharmacies, were convicted on the basis of Art. $321^{1} \mathrm{p}$. 2 of the Criminal Code of Ukraine. Each was sentenced to five years of deprivation of liberty, from which they were released on probation. As you can see, the participants in this criminal group did not suffer any real punishment. [31] Such decisions of the Ukrainian courts unfortunately reflect the established practice of applying punishment for these crimes. This practice requires changes, since the actual impunity of criminals who commit falsification of medicines, testifies to the ineffectiveness of the criminal law mechanism to combat these crimes.

Obviously, the application of criminal liability for falsification of medicines, both in Poland and in Ukraine, is still quite rare. Patryk Słowik referring to the data of the National Prosecutor's Office states that in 2015 there are no indictments under Article $124 \mathrm{~b}$ of the Pharmaceutical Law, in 2016 there were three, in 2017 - six, in the first four months of 2018 - one [32]. In Ukraine, according to the General Prosecutor's Office, in the last five years (the period from 2013 to 2018), 25 criminal cases have been initiated under Art. $321^{1}$ of the Criminal Code [33]. During this period, the courts issued 25 sentences under this article, of which 23 convictions, 2 - acquittals [34]. However, the researchers note that these statistics reflect the effectiveness of law enforcement agencies to combat such crimes, rather than the actual state of crime in this area. $[32,35]$

\section{CONCLUSIONS}

There is a need to create and implement an effective criminal law mechanism to combat the spread of falsified medical products that pose a global threat to public health, can lead to death or cause significant harm to human health. It is necessary that such a mechanism exists at the international, regional and national levels.
In order to increase the effectiveness of the criminal law mechanism at the international level, we fully support the EU initiative to amend the United Nations Convention against Transnational Organized Crime, which would establish additional liability for the falsification of medicines.

Improving the criminal law mechanism to combat the falsification of medical products at the European regional level requires intensifying the process of "Medicrime Convention" ratification and full implementation of rules on criminal liability for falsifying medical products into national criminal legislation.

At the national level it is necessary to improve both the criminal legislation and the practice of its implementation, to intensify the activity of law enforcement agencies to combat these crimes, to ensure a fair trial and effective criminal penalties for those who have committed the falsifying medical products.

\section{REFERENCES}

1. Universal Declaration of Human Rights, United Nations, 1948.

2. European Social Charter (Revised), Council of Europe, 1996

3. Konstytucja Rzeczypospolitej Polskiej: Tekst uchwalony w dniu 2 kwietnia 1997 r. przez Zgromadzenie Narodowe. URL: http://www. sejm.gov.pl/prawo/konst/polski

4. The Constitution of Ukraine: Verhovna Rada of Ukraine, 28.06.1996. URL: http://zakon.rada.gov.ua/laws/show/254 к/96-вp.

5. Demchenko I., Soloviov 0. Poperedzhennia poshyrennia falsyfikovanykh likarskykh zasobiv na mizhnarodnomu ta natsionalnomu rivni [Preventing the spread of falsified medicines at the international and national level]. Kyiv: Novyi druk; 2014.

6. WHO Fact Sheet No.275 revised February 2006 Counterfeit Medicines. URL: http://whqlibdoc.who.int/fact_sheet/2006/FS_275.pdf

7. WCO Address by French President Jacques Chirac at the World Customs Organization Council Session (2010) URL: http://www.wcoomd.org/ / media/WCO/Public/Global/PDF/Media/Newsroom/Speeches/2010/ Discours_Jacques_Chirac_Conseil_2010.ashx?db=web

8. JackA. (2012) Faking it. British Medical Journal. URL: http://www.bmj. com/content/345/bmj.e7836

9. GodleeF.(2012) Time for global action on fake and substandard drugs. British Medical Journal. URL: http://www.bmj.com/content/345/bmj.e7917

10. Burns W. (2006) WHO launches taskforce to fight counterfeit drugs Bulletin of the World Health Organization. 84 (9), 689-690.

11. Spurious/falsely-labelled/falsified/counterfeit (SFFC) medicines. URL: http://www.who.int/medicines/services/counterfeit/en/index.html

12. WHO Division of Drug Management \& Policies (April 1992) Counterfeit Drugs. Report of a WHO/IFPMA Workshop.

13. WHO Department of Essential Drugs and Other Medicines (1999) Guidelines for the development of measures to combat counterfeit drugs

14. WHA Resolution 52.19 dated (May, 24 1999). URL: http://www.who. int/phi/WHA52.19.pdf

15. Commission Directive 2003/94/EC of 8 October 2003 The principles and guidelines of good manufacturing practice in respect of medicinal products for human use and investigational medicinal products for human use, 0J L 262.

16. WHOSecretariat Report A62/14 dated 30 April 2009 Counterfeit medical products. International Medical Products Anti-Counterfeiting Taskforce, URL: http://www.coe.int/t/dghl/standardsetting/medicrime/WHA\%20 A62_14-en.pdf 
17. WHO, WHA65.19 dated 26 May 2012 Substandard/spurious/falselylabelled/falsified/counterfeit medical products, URL: http://apps.who. int/gb/ebwha/pdf_files/WHA65/A65_R19-en.pdf

18. UN General Assembly Resolution A/RES/55/25 Convention against Transnational Organized Crime, URL: http://daccess-dds-ny.un.org/ doc/UNDOC/GEN/N00/560/91/PDF/N0056091.pdf?OpenElement

19. European Parliament: Committee of the Environment, Public Health and Food Safety Session document. A7-0148/2010 dated 7.5.2000 Report on the proposal for a directive of the European Parliament and of the Council amending Directive 2001/83/EC as regards the prevention of the entry into the legal supply chain of medicinal products which are falsified in relation to their identity, history and source. URL: http://www.europarl. europa.eu/sides/getDoc.do?pubRef=-//EP//NONSGML+REPORT+A72010-0148+0+DOC+PDF+V0//EN\&language $=E N$

20. Council of Europe Convention CETS No. 211 on the counterfeiting of medical products and similar crimes involving threats to public health. Moscow, dated 28.10.2011. URL: https://www.coe.int/en/web/ conventions/full-list/-/conventions/treaty/211

21. Chart of signatures and ratifications of Treaty 211 "Council of Europe Convention on the counterfeiting of medical products and similar crimes involving threats to public health": URL: https://www.coe.int/ en/web/conventions/full-list/-/conventions/treaty/211/signatures?p_ auth=VSyRhd7J

22. Vitalii Pashkov, Nataliya Gutorova, Andrii Harkusha Medical device software: defining key terms. Wiad Lek. 2016;6:813-817.

23. Vitalii Pashkov, Nataliia Hutorova, Andrii Harkusha. Vat Rates on Medical Devices: Foreign Experience and Ukrainian Practice. Wiad Lek. 2017;2(II):345-347.

24. Piórkowska M., Macisowicz M. Czy Polska podpisze Konwencję Medicrime? URL: https://pulsmedycyny.pl/czy-polska-podpiszekonwencje-medicrime-893986

25. Definitions of Substandard and Falsified (SF) Medical Products. URL: https://www.who.int/medicines/regulation/ssffc/definitions/en/

26. Directive 2011/62/EU of the European parliament and of the council of 8 June 2011 amending Directive 2001/83/EC on the Community code relating to medicinal products for human use, as regards the prevention of the entry into the legal supply chain of falsified medicinal products. URL: https:/ec.europa.eu/health/sites/health/files/files/eudralex/ vol-1/dir_2011_62/dir_2011_62_en.pdf.

27. Ustawa z dnia 6 września 2001 r. Prawo farmaceutyczne. Ustawa z dnia 6 września 2001 r. URL: http://prawo.sejm.gov.pl/isap.nsf/download. xsp/WDU20011261381/U/D20011381Lj.pdf.
28. Ustawa z dnia 6 czerwca 1997 r. Kodeks karny. URL: http://prawo.sejm. gov.pl/isap.nsf/download.xsp/WDU19970880553/U/D19970553Lj.pdf.

29. Kalinowska Maksim I. Fałszowanie produktow leczniczych - uwagi na tle kodeksu karnego i regulacji pozakodeksowych. Zeszyty Prawnicze. 2017; 17.2: 37-56.

30. The Criminal Code of Ukraine: Verhovna Rada of Ukraine, 05.04.2001. URL: http://zakon.rada.gov.ua/laws/show/2341-14

31. The Verdict of Zaliznychny District Court of Lviv. Unified State Register of Court Decisions. URL: http://reyestr.court.gov.ua/Review/32474082

32. Słowik P. Fałszowanie leków bez żadnej odpowiedzialności. URL: // https://serwisy.gazetaprawna.pl/zdrowie/artykuly/1126524,raportke-na-temat-falszowania-lekow.html.

33. Prosecutor General's Office of Ukraine, URL: https://www.gp.gov.ua/ ua/stst2011.html?dir_id=113281\&libid=100820\&c=edit\&_c=fo\#

34. Unified State Register of Court Decision. URL: http://reyestr.court. gov.ua.

35. Gutorova N. Falsyfikatsiia likarskykh zasobiv - yak v Ukraini suvorist kryminalno-pravovoi normy poiednuietsia z faktychnoiu bezkarnistiu falsyfikatoriv? [Falsification of medicines: how in Ukraine the severity of criminal law coexists with the actual impunity of falsifiers?] Apteka, № 4.URL: https://www.apteka.ua/article/486071?fbclid=IwAR1hkn0ljj_ GHvp4xdep7D0KyV1ihpm7f_yv7HcJ7jhxvPDiMDcDt7LzVTs .

\section{Authors' contributions:}

According to the order of the Authorship.

\section{Conflict of interest:}

The Authors declare no conflict of interest.

\section{CORRESPONDING AUTHOR Nataliya Gutorova}

Poltava Law Institute of Yaroslav the Wise National Law University 6 Monastyrska str., 36000, Poltava, Ukraine e-mail: natalygutorova@gmail.com

Received: 04.03.2019

Accepted: 29.04.2019 


\title{
MENTAL ILLNESS AS A CONSEQUENCE OF CRIMINAL OFFENCE AGAINST THE PERSON
}

\author{
Igor I. Mytrofanov ${ }^{1}$, Igor V. Lysenko ${ }^{1}$, Mykola M. Ryabushko ${ }^{2}$ \\ 'KREMENCHUK MYKHAILO OSTROHRADSKYI NATIONAL UNIVERSITY, KREMENCHUK, UKRAINE \\ ¿UKRAINIAN MEDICAL STOMATOLOGICAL ACADEMY, POLTAVA, UKRAINE
}

\begin{abstract}
Introduction: Among crimes against human health we distinguish serious bodily harms, one of the signs of which is recognized as a mental illness.

The aim: The paper was aimed at the development of the procedure for determining the mental disorder of a victim as a sign of a serious bodily harm, as well as the establishing the possibilities of clarifying the legislative formulation of the above norm of the Criminal Code.

Materials and methods: Over 300 criminal proceedings under the Arts.121, 122 and 125 of the Criminal Code of Ukraine for the period from 2007 to 2018 have been studied. For this purpose, common methods of research have been used, namely, the analysis and synthesis, as well as own observations of the process of consideration of the above criminal proceedings.

Results and conclusions: The findings of the study assisted in identification of gaps in the regulation of the procedure to define mental illness as a characteristic feature of serious bodily harm. The ways of further improvement of the procedure of conducting expert studies of mental illness as a characteristic feature of a serious bodily harm. The rules for determining the psychic (mental) illness that are recognized by us as archaic and that does not correspond to the established procedure of such definition by the comprehensive forensic medical and forensic psychiatric examination involving a forensic medical expert, two or three psychiatrists (narcologists), summarizing in the conclusion of the presence of mental illness in a person, assessed by experts as a characteristic feature of serious bodily harm should be changed.
\end{abstract}

KEY WORDS: mental illness, psychic illness, mental disorders, procedure of determination the degree of mental illness

Wiad Lek 2019, 72, 5 cz. I, 862-867

\section{INTRODUCTION}

In view of the increase in violence and the number of offences against human life and health, the problem of compensation for damage caused by criminal offenses, as well as rehabilitation of victims of violence, is becoming more and more relevant. The consequence of the international community's attention to this problem is the adoption of a number of international legal acts (for example, the European Convention on the Compensation of Victims of Violent Crimes (ETS No. 116), 1984, recommendations of the European Committee on Crime Problems "On the Status of the Victim Crime in the Criminal Law and Process", adopted by the UN Congress on the Prevention of Crime and the Treatment of Offenders (Milan, 1985). In Ukraine, the problem of rehabilitation of victims of violence and redress of wrong, rendered for victims who were exposed to various criminal delinquencies, is no less relevant. We do not have any accessible system of rehabilitation measures, not to mention the indemnification, including for the health rehabilitation and medical treatment.

The presence of almost 300 thousand military personnel, seeking for psychological and, sometimes, psychiatric help, who participated in hostilities in the East of Ukraine, also contributes to this situation. Failure to undergo rehabilitation therapy results in violent acts committed by them, including those related to offence against the life and health of others. Currently, the system of psychological rehabilitation is not completely formed, the integral "vertical" has not been built, in the army many organic assignments are uncompleted by professional psychologists. Eventually, non-professionals are forcedly appointed for the positions of psychologists [1].

\section{THE AIM}

The paper was aimed at the development of the procedure for determining the mental disorder of a victim as a sign of serious bodily harm, punishment for which is provided by the Art.121 of the Criminal Code of Ukraine, as well as the establishing the possibilities of clarifying the legislative formulation of the above norm of the Criminal Code.

\section{MATERIALS AND METHODS}

To determine the range of issues that arise in forensic medical and judicial practice in identifying mental illness as a characteristic feature of serious bodily harm, over 300 criminal proceedings under the Arts.121, 122 and 125 of the Criminal Code of Ukraine for the period from 2007 to 2018 have been studied, in which the forensic medical examination was conducted in order to identify cases for evaluation of victims on mental disorders. For this purpose, 
common methods of research have been used, namely, the analysis and synthesis, as well as own observations of the process of consideration of the above criminal proceedings. In addition, for the purpose of analyzing the perception of victims of crime and their physical condition, individual interviews and survey have been conducted. Respondents of the study were directly victims and their family members in total of 33 people, 18 forensic experts and 11 psychiatrists. The survey was also conducted among judges, investigators and prosecutors (hereinafter - lawyers) in total of 129 people to elucidate their opinion on the need for amendments to legislative acts on the formulation of signs of serious bodily harm.

\section{RESULTS}

The study has showed that criminal-illegal actions of an offender who caused bodily harm to a victim due to various types of influences, namely, mental, physical, chemical, resulting in mental disorders. Optional factors that are significant in the occurrence and "clinical registration" of mental disorders in victims can be the age and individual psychological features of a victim and presence of somatic or mental (including borderline) pathology. Mental disorders that arise in victims due to offences against their health are diverse in the psychopathological structure. The major mental disorders are the acute stress reaction $(\mathrm{F}$ 43.0), post-traumatic stress disorder ( $F$ 43.1), adjustment disorders ( $\mathrm{F}$ 43.2), enduring personality change after catastrophic experience (F 62.4), serious depressive episode with psychotic symptoms (F 32.3), acute and transient psychotic disorder (F 23), psychosexual disorders (F 66). In addition, postcontusional (posttraumatic) syndrome $(\mathrm{F}$ 07.2), organic personality disorders (F 07.0) associated with organic brain damage, various manifestations of dementia, other organic personality and behavioural disorders due to brain disease, damage and dysfunction (F 07.8) are characteristic to victims, who were exposed to craniocerebral trauma due to criminal delinquency.

Consequently, in all criminal proceedings under the Art.121 of the Criminal Code of Ukraine, in which the forensic psychiatric examination was conducted and the presence of mental illness, which is a form of serious bodily harm, was ascertained, it was unclear how the degree of severity was assessed. Thus, the sentence of the Bila Tserkva City Court of Kyiv region is based on the fact that "closed craniocerebral trauma in the form of brain concussion, according to the results of the commission of forensic psychiatric examination of INDIVIDUAL_1, led to the development of mental illness: an organic brain lesion of traumatic genesis in the form of cerebro-asthenic syndrome, convulsive seizures, neurotic-reactive depression, i.e., the indicated disease had a direct causal relationship with the abovementioned events. The findings of the commission forensic psychiatric examination of INDIVIDUAL_1 indicate that closed craniocerebral trauma with subsequent development of mental illness should be regarded as serious bodily harm" [2].
Consequently, both the terminology of the normative legal acts and the procedure for determining the severity of mental illness as a component of bodily harm subject to clarification. In this regard, in the Rules it is necessary to substitute the term "mental illness" to "serious mental disorder" as a sign of serious bodily harm, which will allow the attribution of mental disorders to moderate or minor bodily harm, depending on their degree of severity, which contemporary psychiatry classifies as painful states of the psyche according to the current International Classification of Diseases. The definition of the concepts of "mental disorders" and "serious mental disorder" in the sense of the Law of Ukraine "On Psychiatric Aid" as of 22 February, 2000, No. 1489-III, we cited above. We also find these terms in other normative legal acts, in particular, in the Procedure for conducting forensic psychiatric examination (hereinafter - the Procedure), approved by the Order of the Ministry of Health of Ukraine on 08May, 2018, No. 865.

According to the provisions of the Procedure, mental state of a person at certain legally significant intervals of time is recognized as the subject of forensic psychiatric examination (hereinafter - SPE). The mental state of a person at certain legally significant intervals of time is determined in order to answer the questions posed by the person or body that has involved an expert or by an investigator, judge or court that commissioned the examination [3].

Under the Art.121 of the Criminal Code of Ukraine, during the criminal-legal assessment of bodily harm as a serious one we recognize the use of the term "severe mental disorder" as the most appropriate one. Its detailed medical criteria should be different from the criteria for mental disorders that are incompatible with the sanity, criminal-legal competence or helpless state of a victim or other person. Detailed criteria, specified independently, are to be recorded in the relevant regulatory acts, and, first and foremost, in the Rules. Unfortunately, the Order of the Ministry of Health "On Approval of the Criteria for the Diagnosis and Treatment of Mental and Behavioral Disorders" No. 271 as of 27 October, 2000 has expired on the basis of the Order of the Ministry of Health No.310 as of 08May, 2014, and the new one has not appear to date, creating a certain research environment for the development of precisely detailed criteria for mental disorders that are incompatible with sanity, criminal-legal competence or helpless state of a victim or other person. In addition, the survey of lawyers showed the results (Table I, II,III,IV).

Consequently, more than $50 \%$ of the surveyed lawyers believe that the definition of injury as causing mental illness faced the difficulties in assessing criminal offences under the Art.121 of the Criminal Code of Ukraine as causing mental illness. Almost half of the surveyed indicated the need for legislative changes. Other questions in the questionnaire were related to other five signs of serious bodily harm, which is our subsequent study, findings of which were published in the paper "Irreparable facial defacement" [4], and it will be promulgated in our prospective scientific publications. 
Table I. How many years have you been working as a judge (investigator, prosecutor)?

\begin{tabular}{ccc}
\hline Record of service & judges & investigators, prosecutors \\
\hline 2 years & $3(7,0 \%)$ & $11(13,4 \%)$ \\
\hline 2 to 5 years & $7(16,2 \%)$ & $14(24,7 \%)$ \\
\hline 5 to 10 years & $12(27,9 \%)$ & $42(43,3 \%)$ \\
\hline more than10 years & $21(48,9 \%)$ & $19(18,6 \%)$ \\
\hline total & $43(100 \%)$ & $86(100 \%)$ \\
\hline
\end{tabular}

Table II. Do you consider the formulation of the Article 121 of the Criminal Code of Ukraine as requiring clarification of the cause of mental illness?

\begin{tabular}{ccc} 
& judges & investigators, prosecutors \\
\hline yes & $24(55,8 \%)$ & $49(57 \%)$ \\
\hline no & $19(44,2 \%)$ & $37(43 \%)$ \\
\hline
\end{tabular}

Table III. In your professional activity have you faced the cases involving bodily harm that caused mental illness?

\begin{tabular}{ccc} 
& judges & investigators, prosecutors \\
\hline yes & $18(41,9 \%)$ & $48(55,8 \%)$ \\
\hline no & $25(59,1 \%)$ & $38(44,2 \%)$ \\
\hline
\end{tabular}

Table IV. Then were there any difficulties or not in your professional activity have you faced the cases involving bodily harm that caused mental illness?

\begin{tabular}{ccc} 
& judges & investigators, prosecutors \\
\hline no & $7(28 \%)$ & $18(47,4 \%)$ \\
\hline yes & $18(72 \%)$ & $20(52,6 \%)$ \\
\hline
\end{tabular}

Apparently, the Articles of the Criminal Code of Ukraine, which impose penalties for causing moderate and minor bodily harm (for example, the Articles 122 and 125 of the Criminal Code of Ukraine) do not require fundamental changes and mental disorders cannot be mentioned in them. This is due to the fact that, based on the text from the main article for all these criminal-legal norms of the Special Part of the Criminal Code (the Article 121 of the Criminal Code of Ukraine) it is evident that serious bodily harm are comprised of two types of pathological lesions of a victim's body, namely, somatic and psychic. Thus, similar types of such lesions in the state of deteriorated health of a victim should form the components of moderate and minor bodily harm, since they should differ from serious bodily harm not by the meaningful load of painful disorders, but the degree of their severity. Detailed criteria for all degrees of mental disorders of a victim (serious, moderate, and minor) should be clearly recorded in the normative and legal acts, in particular in the Medical criteria for the diagnosis of mental disorders of various degrees of severity and behavioral disorders.

Surveyed forensic experts and psychiatrists pointed out the lack of such clear rules (medical criteria) for determining the severity of mental disorders, which greatly complicates the examination.

The surveys of victims and their medical records show that in case of any exposure to bodily harm, which are recognized as the serious ones, affects their physical, mental and social well-being, therefore, during forensic medical examination, it is necessary to authorize and conduct a comprehensive legal expertise, involving a forensic medical expert, psychiatrists, psychologists, and, if needed, to establish a causal relationship between serious mental disorder and caused bodily harm, other medical professionals (for example, a roentgenologist) in compliance with the Arts.242 and 243 of the Criminal Procedure Code (CPC) of Ukraine, resulted in the finding on the basis of the Art.101 and 102 of the CPC of Ukraine. Only the comprehensive examination can enable the true expert finding on the presence of serious mental disorder in a victim as a sign of serious bodily harm.

\section{DISCUSSION}

The studies of domestic and foreign researchers and the practice of forensic medical examination show and that the result of a criminal offense against the health of victims is often the emergence in the latter of a variety of mental disorders: from those that easily omit psychological and neurotic reactions to reactive psychotic states and pronounced personality changes. In this case, consideration of the adverse consequences of a criminal delinquency against a victim's mental health has a significant legal value, enabling the judiciary to correctly identify the actions of the accused and establish the degree of their guilt in the presence of findings of properly conducted examinations. 
In addition, the assessment of the severity of the damage to mental health caused by the criminal offence against a victim is a prerequisite for a full-fledged program on protection of the rights and interests of victims. The very sign of "mental illness" in determining the severity of bodily harm remains unclear to date (due to legal uncertainty) and the procedure for its establishment is not well defined.

Issues on mental states and their prophylaxis and treatment are relevant within the provisions of the Mental Health Development Concept in Ukraine for the period up to 2030, which states that assistance to improve mental health and improve the quality of life of people with mental and intellectual disorders will be based on the principles of evidence, respect for human dignity, respect for fundamental human and civil rights, the application of multidisciplinary approach, promotion of living standards for the activities of individuals with mental and intellectual disorders, their inclusion into social communities, the prevention of complications and accessibility [5].

Notably, out of more than 300 criminal proceedings in the cases of bodily harm analyzed during this study, psychiatric examination was authorized for the accused in almost $70 \%$ of the proceedings and only in rare cases it was authorized for victims. In these cases, the subsequent life of victims exposed to various kinds of bodily harm was not monitored; therefore it was difficult to conduct volumetric objective research. However, the survey of victims of the criminal offenses under consideration and studying their medical records has found at least three cases in which the criminal situation on the exposure to various kinds of bodily harm, caused multiple forms of mental disorders. The lack of legislative capacities, as well as any system of their patronage and rehabilitation, were not allowed in the legal field to prove that it was precisely because of the exposure to bodily harm, which forensic experts, within the pre-trial investigation, assessed in two cases as minor, resulted in a short-term health disorder, and in the other case of moderate severity, caused mental disorders.

Issues of legal regulation of punishment for the offence causing bodily harms, improvement of law enforcement practice in this area were considered only fragmentarily in publications of L.O. Andreev, M.K.Aniyanets, M.I. Bazhanov, A.V. Bailov, V.I. Borisov, S.V. Borodin, V.K. Grischuk, L. I. Gurevich, N. O. Gutorova, T. G. Daurova, M. I. Zagorodnikov, T.V. Kondrashov, M. I. Korzhanskyi, Yu.M. Krutov, M. I. Melnyk, V. O. Navrotskyi, I. P. Portnov, B. S. Sidorov, V. V. Stashis, V.V.Shablystyi, M.D. Sharhorodskyi, S.S. Yatsenko and other researchers on criminal legal counteraction to bodily harm. The problems of psychiatric disorders were studied by such physiologists and psychiatrists as Yu.I. Aleksandrov, P.K. Anokhin, I. M. Bachinskyi, V.M. Bekhterev, N.P. Bekhtereva, E. Bleiler, P.O. Butkovskii, K. Vernike, G.L. Voronkov, V. Grinzenger, S. S. Korsakov, O. R. Luria, I. P. Merzheievskyi, I. P. Pavlov, J. A. Polischuk, E.O. Popov, V.P. Protopopov, V.P. Serbskyi, I.M. Sechenov, Ye.M. Sokolov, G.Fechner, Ya.P. Frumkin, E. D. Khomska, T.I. Yudin and others. However, investigations of the problems of imposing punishment for serious bodily harm that caused mental disorders, made jointly by the medical researchers and lawyers have never been conducted, resulting in the terminological confusion that is currently available in the current legislation. At the same time, the research shows that the issues of identifying serious bodily harm that caused mental disorders are complex, that is, are related to both medical and legal aspects.

Part 1 of the Article 121 of the Criminal Code of Ukraine established a punishment for intentional serious bodily harm, i.e., intentional bodily harm, which caused mental illness, liable for imprisonment for a term of five to eight years. In the Criminal Code of Ukraine 2001 no substitution was made for the category "bodily harm" to "damage to health", which is the key one for the investigated group of criminal delinquencies. In the Criminal Code of Ukraine 1960, Part 1 of the Art. 101 provided for punishment for "intentional serious bodily harm, that is, intentional bodily harm, life-threatening at the time of infliction, or causing loss of any organ or loss of its functions, psychic illness or other health disorder, combined with persistent loss of capacity for work not less than one third, or termination of pregnancy or irreparable face defacement, liable for imprisonment for a term of two to eight years" [6]. That is, the legislative body in the current Code provides only the substitution of the words "psychic" illness to "mental" illness, "termination" of pregnancy to "termination" of pregnancy and raising the lower limit of punishment from two to five years.

The positive side of the substitution of the concept of "bodily harm" to inflicting or causing damage to health would be that the latter is wider in content and allows coverage not only violation of anatomical integrity or physiological functions of organs and tissues, but also mental disorders caused by mental trauma, diseases of an infectious or toxic etiology and other painful disorders that can be caused by criminal delinquencies [7]. However, the legislative body, having kept the preliminary term, does not eliminate other shortcomings and defects of this article: "intentional serious bodily harm, that is, intentional bodily harm, life-threatening at the time of infliction, or causing loss of any organ or loss of its functions, psychic illness or other health disorder, combined with persistent loss of capacity for work not less than one third, or termination of pregnancy or irreparable face defacement" [8]. Clarification of this text concludes that the bodily harm results in the consequences defined in the Article 121 of the Criminal Code of Ukraine. However, each of these consequences (the loss of any organ or its functions, mental illness) is by its very nature the concept of "serious bodily harm". In other words, intentional bodily harm is something that causes some kind of damage.

The Rules of Forensic Medical Examination on defining the degree of bodily harm severity, approved by the Order of the Ministry of Health of Ukraine No. 6 as of January 17, 1995 (hereinafter referred to as the Rules) identifies the concept of mental illness with psychic illness, which is understood by these Rules as a mental illness (mental disease). At the same time, the Rules establish that psycho- 
logical diseases cannot be assigned to damage to reactive states (psychoses, neuroses). Damage qualifies as a serious one only when it has caused the development of mental illness, regardless of its duration and degree of curability. The severity degree of a damage that caused the reactive state of the nervous system is determined on the basis of the duration of the health disorder. The diagnosis of mental illness and the causal relationship between injury and developed mental illness are established by a psychiatric examination. The severity degree of the bodily harm is determined by a forensic expert based on the findings of the psychiatric examination [9].

The Law of Ukraine "On Psychiatric Aid" as of 22 February, 2000, No. 1489-III, uses the terms "mental disorders" and "severe mental disorders". The Law interpreted mental disorders as disorders of mental activity, recognized as such in compliance with the International Classification of Diseases, Injuries and Causes of Death (ICD-10) in force in Ukraine; a severe mental disorder is a disorder of mental activity (distraction, disturbance of perception, thinking, will, emotion, intelligence or memory), which deprives a person of the ability to adequately perceive the surrounding reality, his/her mental state and behavior [10].

ICD-10 Version, Chapter "Mental and behavioral disorders" contains the following codes of the diseases: [F00 - F09] "Organic, including symptomatic, mental disorders"; [F10-F19] "Mental and behavioral disorders due to psychoactive substance use"; [F20-F29] "Schizophrenia, schizotypal and delusional disorders"; [F30-F39] "Mood [affective] disorders"; [F40-F49] "Neurotic, stress-related and somatoform disorders"; [F50-F59] "Behavioral syndromes associated with physiological disturbances and physical factors"; [F60-F69] "Disorders of adult personality and behavior"; [F70- F79] "Mental retardation"; [F80-F89] "Disorders of psychological development"; [F90-F98] "Behavioral and emotional disorders with onset usually occurring in childhood and adolescence" ; [F99-F99] "Unspecified mental disorder". ICD-11Version that was released on 18 June, 2018 by the World Health Organization contains more extended list of mental, behavioral or neurotypical disorders.

Such legislative uncertainty leads to the fact that in some cases the courts establish a psychic illness [11], in others it is mental disorder [12], in the third one it is a psychic illness [13], in the fourth one it is a severe mental disorder [14]. At the same time, in the studied sentences, it is not clear how the opinion of the forensic expert on the recognition of the severity of bodily harm that caused mental illness has been established. In this regard, the Malovyskivskiy District Court of the Kirovograd region in its sentence refers in the No. 107 of the Forensic Psychiatric Examination, according to which INDIVIDUAL_6, at the time of the exposure to criminal delinquency, did not suffer from any mental illness. At the time of the examination, which occurred after the forensic examination, INDIVIDUAL_6 revealed the signs of severe mental disorder in the form of dementia due to brain injury. In his mental state at this time, he cannot realize his actions and manage them [15].
Some courts refer to the findings of the forensic examination, preceding the study of forensic psychiatrists, and forensic psychiatric examination, assessing bodily harm as the serious ones, as they caused a mental illness. In this regard, the sentence of the Kherson City Court of Kherson region referred to the forensic examination No.146 as of 07.07.2016, according to which bodily harm were classified as the serious bodily harm according to the life-threatening criterion, due to the presence of intracranial hemorrhage in the volume of $80 \mathrm{ml}$, which was life-threatening for a victim and required life saving surgery and in connection with the penetrating wound of the latter, and the conclusion of the outpatient forensic psychiatric examination No.441/74 as of 16.09.2016, according to which the INDIVIDUAL_3, being exposed to bodily harm, is currently suffering from a severe chronic mental illness in the form of dementia resulted from a traumatic brain injury got on $29 / 04 / 2016$, which has a direct causal relationship with the mentioned mental illness and bodily harm got by the latter on 29.04.2016 from INDIVIDUAL_1, which allowed to conclude that the actions of INDIVIDUAL_1 should be classified in Part 1 of the Art.121 of the Criminal Code of Ukraine, as intentional serious bodily harm, that is, intentional bodily harm that caused mental illness [2].

The records of criminal proceedings contain experts' conclusions, in which it is proposed to establish a direct causal relationship between the caused bodily harm and mental illness; a comprehensive forensic examination (involving psychiatrists, neurosurgeons, neuropathologists, radiologists) should be made [3]. Such a proposal seems logical to us if a forensic medical expert who must evaluate the degree of severity of mental disorder must be included in this list of medical professionals.

\section{CONCLUSIONS}

1 The analyzed rules for determining the psychic (mental) illness that are recognized by us as archaic and that does not correspond to the current established procedure should be changed. The evaluation of the severity degree of bodily harm that caused mental illness should be made by the complex forensic medical and forensic psychiatric examination involving a forensic medical expert, two or three psychiatrists (narcologists), summarizing in the conclusion of the presence of mental illness in a person, assessed by experts as a characteristic feature of serious bodily harm.

2. The procedure for determining the severity degree of bodily harm that caused mental disorders in a victim of a criminal offense should include the following stages:

1) identification of mental disorder in a victim using a differential assessment of structural and dynamic indices, the nature of the stability of such disorder;

2) study of the obligate and additional (optional) factors that are relevant for the process of occurrence and clinical presentation of mental disorders in a victim;

3) identification of mutually contributing factors of mental disorder with the injuries that caused it; 
4) assessment of the severity of bodily harm due to the determined (established) severity of the caused mental disorder.

3. The severity of the bodily harm that caused mental disorder in victims is determined through a consistent assessment of the medical (structural and dynamic characteristics, severity and stability of the mental disorder) and legal elements, involving a) dangers to life; 2) the result in the form of a permanent loss of ability to work of varying degrees (or disadaptation in a minor) or in the duration (short-term) of health disorder of a victim.

4. Part 1 of the Article 121 of the Criminal Code of Ukraine should be stated as follows: "infliction of intentional serious bodily harm, that is, intentional bodily harm, life-threatening at the time of infliction, or causing loss of any organ or loss of its functions, psychic illness or other health disorder, combined with persistent loss of capacity for work not less than one third, or termination of pregnancy or irreparable face defacement is liable for punishment....

\section{REFERENCES}

1. Kokun 0, Agayev N, Pishko I i dr. Osnovy psykholohichnykh znan'pro psykhichni rozlady dlya viys'kovoho psykholoha. Metodychnyy posibnyk [Basics of psychological knowledge of mental disorders for the military psychologist. Methodical manual]. Kyyiv: NDTS HPZSU;2018,310s. (Ua).

2. Tsyro I. Sudebno-psikhiatricheskaya otsenka tyazhesti vreda zdorov'yu pri psikhicheskikh rasstroystvakh u poterpevshikh: avtoref. dis. kand. med. nauk [Forensic psychiatric assessment of the severity of harm to mental health in patients with mental disorders: abstract. dis. candidate of medical science]. Moskva, 2004,25 s. (Ru).

3. Poryadok provedennya sudovo-psykhiatrychnoyi ekspertyzy: zatverdzhenyy nakazom Ministerstva okhorony zdorovya Ukrayiny vid 8 travnya 2018 roku № 865 [The procedure for conducting a forensic psychiatric examination: approved by Order of the Ministry of Health of Ukraine dated May 8, 2018 No. 865]. Ofitsial'nyy vestnik Ukrainy. 2018;53: St.1872. (Ua).

4. Mytrofanov I, Lysenko I, Ryabushko M. Nepopravne znivechene oblychchya: vid medychnoyi do yurydychnoyi otsinky [Indelible facial disfigurement: from medical to legal assessment]. Svit medytsyny ta biolohiyi. 2018;4(66):81-87. (Ua).

5. Pro skhvalennya Kontseptsiyi rozvytku okhorony psykhichnoho zdorovya vUkrayini na period do 2030 roku: Rozporyadzhennya Kabinetu Ministriv Ukrayiny vid 27 hrudnya 2017 r. № 1018-r [On approval of the Concept of development of mental health in Ukraine for the period until 2030: Order of the Cabinet of Ministers of Ukraine of December 27, 2017 № 1018-r]. Ofitsiynyy visnyk Ukrayiny. 2018;16:St.559. (Ua).

6. Kryminal'nyy kodeks Ukrayiny: zatverdzhenyy Zakonom vid 28.12.60 [The Criminal Code of Ukraine: approved Law on 12/28/60]. Vidomosti Verkhovnoyi Rady URSR. 1961;2:St.14. (Ua).

7. Mytrofanov I, Linov V. Zlochyny proty zdorovya lyudyny: navchalnyy posibnyk [Crimes against human health: a textbook]. Kremenchuk: Vydavets «PP Shcherbatykh 0. V.»;2017,328 s. (Ua).
8. Kryminal'nyy kodeks Ukrayiny vid 5.04.2001 [Criminal Code of Ukraine dated 04.04.2001]. Vidomosti Verkhovnoyi Rady Ukrayiny. 2001;2526:St.131. (Ua).

9. Pravyla sudovo-medychnoho vyznachennya stupenya tyazhkosti tilesnykh ushkodzhen. Prikaz MOZ Ukrainy № 6 ot 17 yanvarya 1995 goda [Rules of forensic determination of the severity of bodily harm: Order of the Ministry of Health of Ukraine No. 6 of January 17, 1995]. Dostupno na:http://search.ligazakon.ua/l_doc2.nsf/link1/REG791. html. (Ua).

10. Pro psykhiatrychnu dopomohu:Zakon Ukrayiny vid 22 lyutoho 2000 roku № 1489-III [On Psychiatric Care: Law of Ukraine of February 22, 2000 №. 1489-III]. Vidomosti Verkhovnoyi Rady Ukrayiny. 2000;19:St.143. (Ua).

11. Vyrok Artsyzkoho rayonnoho sudu Odeskoyi oblasti [The sentence Artsyz Raion Court of Odessa region]. Dostupno na: http://www.reyestr.court. gov.ua/Review/61299344. (Ua).

12. Vyrok Bilotserkivskoho miskrayonnoho sudu Kyyivskoyi oblasti [The sentence Belotserkovskogo City District Court of Kiev region]. Dostupno na: http://www.reyestr.court.gov.ua/Review/41480664. (Ua).

13. Vyrok Selydivskoho miskoho sudu Donetskoyi oblasti [The sentence Selidovskogo City Court of Donetsk region.]. Dostupno na: http://www. reyestr.court.gov.ua/Review/63637957. (Ua).

14. Vyrok Malovyskivskoho rayonnoho sudu Kirovohrads'koyi oblasti [The sentence Maloviskovskogo District Court of Kirovograd region]. Dostupno na:http://www.reyestr.court.gov.ua/Review/33339426. (Ua).

15. Vyrok Khersons'koho mis'koho sudu Khersonskoyi oblasti [The sentence of the Kherson City Court of the Kherson region.]. Dostupno na:http:// www.reyestr.court.gov.ua/Review/64220617. (Ua).

The paper is written within the research work entitled: "Clinical and psychopathological study and optimization of medical and rehabilitation-preventive measures in various mental disorders, considering the heliometeofactors and biological rhythms". State registration number: 0115 U000839.

\section{Authors' contributions:}

According to the order of the Authorship.

\section{Conflict of interest:}

The Authors declare no conflict of interest.

\section{CORRESPONDING AUTHOR Mykola Ryabushko}

Ukrainian Medical Stomatological Academy

Shevchenko 23 str., 36011 Poltava, Ukraine

tel: +380667716547

e-mail: ryabushko12@ukr.net

Received: 18.03 .2019

Accepted: 01.05 .2019 
PRACA POGLACDOWA

REVIEW ARTICLE

\title{
TEN INDICATORS WHICH CHARACTERIZE MEDICAL-DEMOGRAPHIC PROCESSES IN ADJACENT REGIONS OF UKRAINE AND POLAND
}

\author{
Jaroslaw L. Grshybowskyj' ${ }^{1}$, Vladyslav A. Smiianov², Ivan M. Myronyuk³ ${ }^{3}$ Oleh V. Lyubinets ${ }^{1}$ \\ 'DANYLO HALYTSKY LVIV NATIONAL MEDICAL UNIVERSITY, LVIV, UKRAINE \\ 2SUMY STATE UNIVERSITY, SUMY, UKRAINE \\ 3UZHHOROD NATIONAL UNIVERSITY, UZHHOROD, UKRAINE
}

\begin{abstract}
Introduction: Medical-demographic processes are one of the main signs of life quality, the level of socio-economic development of society.

The aim of the work is to compare and evaluate the medical-demographic processes in the two neighboring regions of neighboring countries, due to their geographical proximity, the ratio of the size of the territories and the population.

Materials and methods: The study was conducted on the basis of official statistics published by the State Statistics Service of Ukraine and the Main Department of Statistics in Poland, the depth of the research - 2008-2017, the scope of the study - Lviv region of Ukraine and the Podkarpackie region of Poland. The system approach, demographic and medical-statistical methods were used in the work.

Review: In both territories the population aging is going on, illustrated by indicators such as the age structure of the population, the level of demographic load and the average age of the population. Data on population reproduction in both regions is narrowed, indicating a prevalence of mortality over births. The average life expectancy in the Podkarpackie region is higher and has a tendency for further growth. In the Lviv oblast, the average life expectancy is also growing, due to the positive trend towards a decrease in overall mortality, but is offset by a decline in fertility and high infant mortality and mortality rates, especially from circulatory system pathology.

Conclusions: The analysis of our 10 indicators showed the heterogeneity of medical and demographic processes in the two neighboring regions of neighboring countries, despite their geographical proximity, the ratio of the size of the territories and the population.
\end{abstract}

KEY WORDS: medical-demographic processes, population.

Wiad Lek 2019, 72, 5 cz. I, 868-876

\section{INTRODUCTION}

Preserving human health is one of the priorities of social development in each state, because in the system of human values health is of special significance - in case of its loss or substantial deterioration, everything else loses its meaning. The health of citizens has a significant impact on the processes and results of economic, social and cultural development of the country, the demographic situation and the state of national security, is an important social criterion for the levels of development and welfare of society $[1,2]$.

The gross inequalities in health that we see within and between countries present a challenge to the world. The fact that there should be a spread of life expectancy of 48 years among countries and 20 years or more within countries is not inevitable [3]. Complexity defines health. Now, more than ever, in the age of globalization, this is going that way [4].

Eight key themes related to healthy life have been identified: housing; transportation; healthcare; finances; care giving; falls; rural communities; and support systems [5].

In countries of the world, awareness is increasing that medical care alone cannot adequately improve health overall or reduce health disparities without also address- ing where and how people live. A critical mass of relevant knowledge has accumulated, documenting associations, exploring pathways and biological mechanisms, and providing a previously unavailable scientific foundation for appreciating the role of social factors in health $[6,7,8]$.

Studies of inequalities in health between rural and urban settings have produced mixed and sometimes conflicting results, depending on the national setting of the study, the level of geographic detail used to define rural areas and the health indicators studied $[9,10]$. As an example, China has seen the largest human migration in history, and the country's rapid urbanization has important consequences for public health. A provincial analysis of its urbanization trends shows shifting and accelerating rural-to-urban migration across the country and accompanying rapid increases in city size and population. The growing disease burden in urban areas attributable to nutrition and lifestyle choices is a major public health challenge, as are troubling disparities in health-care access, vaccination coverage, and accidents and injuries in China's rural-to-urban migrant population. Urban environmental quality, including air and water pollution, contributes to disease both in urban and in rural areas, and traffic-related accidents pose a major 
public health threat as the country becomes increasingly motorized [11].

According to Movahedi, M. and co-authors, there is still considerable inequality among the rural population and at a provincial level [12]. While rural location plays a major role in determining the nature and level of access to and provision of health services, it does not always translate into health disadvantage [13].

As E. Libanova notes, this also applies to inequalities in the length of life - children from poor families face a higher risk of premature death or illness and are less likely to realize their potential. Usually people with high incomes live longer than the poor; in turn, good health is the foundation of proper economic competitiveness [14]. As noted by Zahnd, Whitney E. and singers - health literacy is lower in rural areas [15].

However, at the moment, the questions remain about how to improve health in an economically efficient and politically acceptable manner. What makes people healthy? Why are the porors less healthy than the rich? Why do some countries have better health than others? [16]. And the main thing is the achievement of political freedom.

\section{THE AIM}

The aim of the work is to compare and evaluate the medical and demographic processes in two neighboring regions of neighboring countries, considering their geographical proximity, the ratio of the size of the territories and the population.

\section{MATERIALS AND METHODS}

The study was conducted on the basis of official statistics published by the State Statistics Service of Ukraine and the Main Department of Statistics (GUS) in Poland, the research depth is 2008-2017, the study volume is Lviv region of Ukraine and the Podkarpackie region of Poland, the data presented are based on gender, age, type of settlement. The system approach, demographic and medical-statistical methods were used in the work.

\section{REVIEW}

Considering the geographical proximity - the joint border, the similarity of the climatic characteristics, the area of the territory and the population of the Lviv region of Ukraine and the Podkarpackie region of Poland (Table I), we have selected 10 indicators for comparing the medical and demographic processes in these regions, which is more likely to give a full characteristic.

1. The population, gender and type of settlement reflect the dynamics of change for the period from 2008 to 2017, considering the number of urban and rural population and their distribution by gender (Table II).

2. The age structure of the population. The dynamics of changes in the age composition of the population of Lviv Oblast and Podkarpackie region for 20082017 was calculated in 3 age groups of population (Table III).

3. Demographic load. While calculating the demographic load index, a generalized quantitative characteristic of the age structure of the population is established, which shows the burden on society by the unproductive population (Table IV).

4. Average age of the population. The dynamics of the change in middle age was calculated considering the place of residence of the population of Lviv region and Podkarpackie region for 2008-2017 (Table V).

5. Fertility and total fertility rate. The fertility rate in Lviv Oblast and Podkarpackie region for 2008 and 2017 is provided both for the whole territory of residence and considering the place of residence of the population (Table VI). The most accurate measurement of the birth rate is total fertility rate, which characterizes the average number of births per woman in a hypothetical generation for all her life, under the conditions of preserving the existing fertility levels at each age, regardless of mortality and age composition changes (Fig. 1).

6. Indicator of population reproduction. The reproduction rate of the female population shows how many middle-aged girls born by one woman throughout their lives would have survived the birth of their mother at their birth, provided that at any age the existing birth rates and deaths were maintained, provided as of January 1 for 2008-2017 and calculated indicator of the dynamics of changes during this period (Fig. 2).

7. Mortality of the population. The total mortality rate in Lviv Oblast and Podkarpackie region for 2008 and 2017 was calculated for the whole territory of residence and considering the place of residence of the population (Table VII).

8. Mortality of infants. One of the basic statistical indicators of demography is data on infant mortality. Indicators provided as of January 1, 2008-2017 in Lviv Oblast and Podkarpackie region (Fig. 3).

Fig. 1,2,3

9. The main cause of death. The main cause of mortality in both regions is the pathology of the circulatory system (Table VIII).

10. The average life expectancy, as a demographic prognostic statistic and target indicator in the UN Human Development Index, indicates the average expected birth-death gap for this generation. We have analyzed the average life expectancy of the population at birth in 2008-2017 in the Lviv region and Podkarpackie region, considering the place of residence (Table IX).

\section{DISCUSSION}

As a result of the survey, despite their geographical features and proximity, the correlation between the size of the territories and the population of the Lviv region of Ukraine and the Podkarpackie region of Poland, a 
Table I. Population data of Lviv region of Ukraine and Podkarpackie region of Poland

\begin{tabular}{cccc}
\hline As of 31.12.2017 & $\begin{array}{c}\text { Lviv } \\
\text { region (1) }\end{array}$ & $\begin{array}{c}\text { Podkarpackie } \\
\text { region (2) }\end{array}$ & Ratio (1/2) \\
\hline Area, $\mathrm{km}^{2}$ & 21833 & 17846 & 1.223 \\
\hline Number of population & 2511238 & 2129138 & 1.179 \\
\hline Population per 1 km ${ }^{2}$ & 115 & 119 & 0.966 \\
\hline Female for 100 male & 111 & 104 & 1.067 \\
\hline Number of women in total population, \% & 52.6 & 51.0 & 1.031 \\
\hline Urban population in total population, $\%$ & 60.5 & 41.2 & 1.468 \\
\hline
\end{tabular}

Table II. Population by sex and type of settlement in Lviv region and Podkarpackie region in 2008 (31.12), 2017 (31.12)

\begin{tabular}{|c|c|c|c|}
\hline Sex, residence & $\begin{array}{c}\text { Year, ratio } \\
(2017 / 2008)\end{array}$ & $\begin{array}{l}\text { Lviv } \\
\text { region }\end{array}$ & $\begin{array}{c}\text { Podkarpackie } \\
\text { region }\end{array}$ \\
\hline & 2008 & 2534559 & 2099495 \\
\hline \multirow[t]{3}{*}{ All, all } & 2017 & 2511238 & 2129138 \\
\hline & Ratio & $99.08 \%$ & $101.41 \%$ \\
\hline & 2008 & 1197351 & 1026117 \\
\hline \multirow[t]{3}{*}{ Male, all } & 2017 & 1190549 & 1042812 \\
\hline & Ratio & $99.43 \%$ & $101.63 \%$ \\
\hline & 2008 & 1337208 & 1073378 \\
\hline \multirow[t]{3}{*}{ Female, all } & 2017 & 1320689 & 1086326 \\
\hline & Ratio & $98.76 \%$ & $101.21 \%$ \\
\hline & 2008 & 1524256 & 859465 \\
\hline \multirow[t]{3}{*}{ All, urban } & 2017 & 1519161 & 876243 \\
\hline & Ratio & $99.40 \%$ & $101.95 \%$ \\
\hline & 2008 & 717011 & 410664 \\
\hline \multirow[t]{3}{*}{ Male, urban } & 2017 & 712780 & 419464 \\
\hline & Ratio & $99.41 \%$ & $102.14 \%$ \\
\hline & 2008 & 807245 & 448801 \\
\hline \multirow[t]{3}{*}{ Female, urban } & 2017 & 806381 & 456779 \\
\hline & Ratio & $99.89 \%$ & $101.78 \%$ \\
\hline & 2008 & 1010303 & 1240030 \\
\hline \multirow[t]{3}{*}{ All, rural } & 2017 & 992077 & 1252895 \\
\hline & Ratio & $98.20 \%$ & $101.04 \%$ \\
\hline & 2008 & 480340 & 615453 \\
\hline \multirow[t]{3}{*}{ Male, rural } & 2017 & 477769 & 623348 \\
\hline & Ratio & $99.46 \%$ & $101.28 \%$ \\
\hline & 2008 & 529963 & 624577 \\
\hline \multirow[t]{2}{*}{ Female, rural } & 2017 & 514308 & 629547 \\
\hline & Ratio & $97.05 \%$ & $100.80 \%$ \\
\hline
\end{tabular}

significant difference was found in the development processes of the regions of the two adjacent states in terms of medical and demographic indicators. Thus, for the period chosen for the calculation period, a positive balance of the population of Podkarpackie region was established
(+ $1.41 \%)$, while in Lviv region it was reduced $(-0.92 \%)$. However, these indicators differed among females: the largest decrease was in the Lviv region (-1.24\%). Against the background of demographic changes for the 10th anniversary, the number of women (-1.24\%), especially in 
Table III. Change in the age composition of the population of Lviv region and Podkarpackie region in 2017 compared to 2008

\begin{tabular}{|c|c|c|c|c|c|c|c|c|}
\hline \multirow{2}{*}{ Kind of settlement } & \multicolumn{4}{|c|}{ Lviv region (persons) } & \multicolumn{4}{|c|}{ Podkarpackie region (persons) } \\
\hline & All & $0-14$ & $15-64$ & 65 and older & All & $0-14$ & $15-64$ & 65 and older \\
\hline \multicolumn{9}{|c|}{ All } \\
\hline All & $-0,92$ & 3,90 & $-2,21$ & 0,05 & 1,41 & $-6,78$ & $-0,80$ & 23,78 \\
\hline Urban & $-0,33$ & 5,91 & $-4,00$ & 13,49 & 1,95 & $-0,40$ & $-4,47$ & 43,09 \\
\hline Rural & $-1,80$ & 1,27 & 0,79 & $-14,56$ & 1,04 & $-10,38$ & 1,90 & 11,66 \\
\hline \multicolumn{9}{|c|}{ Male } \\
\hline All & $-0,57$ & 4,28 & $-1,85$ & 0,40 & 1,63 & $-6,89$ & $-0,19$ & 28,84 \\
\hline Urban & $-0,59$ & 6,22 & $-3,51$ & 10,56 & 2,14 & $-0,24$ & $-3,57$ & 49,05 \\
\hline Rural & $-0,54$ & 1,73 & 0,80 & $-11,99$ & 1,28 & $-10,63$ & 2,17 & 16,17 \\
\hline \multicolumn{9}{|c|}{ Female } \\
\hline All & $-1,24$ & 3,51 & $-2,56$ & $-0,14$ & 1,21 & $-6,67$ & $-1,42$ & 20,61 \\
\hline Urban & $-0,11$ & 5,58 & $-4,45$ & 15,15 & 1,78 & $-0,57$ & $-5,32$ & 39,36 \\
\hline Rural & $-2,95$ & 0,80 & 0,77 & $-15,79$ & 0,80 & $-10,12$ & 1,62 & 8,83 \\
\hline
\end{tabular}

Table IV. Demographic burden of the population of Lviv region and Podkarpackie region for 2017 (31.12.) up to 2008 (31.12.), \%\%

\begin{tabular}{ccc}
\hline Type of settlement & Lviv region & Podkarpackie region \\
\hline All & 104.35 & 107.58 \\
\hline Urban & 113.94 & 125,12 \\
\hline Rural & 92.55 & 97.28 \\
\hline
\end{tabular}

Table V. Average age of the population of Lviv region and Podkarpackie region for 2008 (31.12.) and 2017 (31.12.)

\begin{tabular}{ccccccc}
\hline \multirow{2}{*}{ The region } & \multicolumn{2}{c}{ Average age of population 2008/2017 } & \multicolumn{2}{c}{ Correlation 2017 to 2008 } \\
\cline { 2 - 7 } & All & Urban & Rural & All & Unban & Rural \\
\hline Lviv region & $40.70 / 40.52$ & $40.16 / 40.61$ & $41.52 / 40.38$ & $99.55 \%$ & $101.12 \%$ & $97.24 \%$ \\
\hline Podkarpackie region & $39.83 / 41.49$ & $40.14 / 42.37$ & $39.62 / 40.88$ & $104.17 \%$ & $105.57 \%$ & $103.17 \%$ \\
\hline
\end{tabular}

Table VI. Fertility per 1000 live population on 31.12 the year in Lviv region and Podkarpackie region

\begin{tabular}{ccccccc}
\hline \multirow{2}{*}{ The region } & \multicolumn{3}{c}{ Birth rate in 2008/2017 } & \multicolumn{3}{c}{ Value of 2017 to 2008 } \\
\cline { 2 - 7 } & All & Urban & Rural & All & Urban & Rural \\
\hline Lviv region & $11.30 / 9.90$ & $10.80 / 9.20$ & $12.20 / 10.90$ & $87.61 \%$ & $85.19 \%$ & $89.34 \%$ \\
\hline Podkarpackie region & $10.55 / 10.31$ & $9.93 / 9.74$ & $10.98 / 10.70$ & $97.73 \%$ & $98.09 \%$ & $97.45 \%$ \\
\hline
\end{tabular}

Table VII. Mortality of the existing population at 31.12 the year in Lviv region and Podkarpackie region, \%o

\begin{tabular}{ccccccc}
\hline \multirow{2}{*}{ The region } & \multicolumn{3}{c}{ Mortality in 2008/2017 } & \multicolumn{3}{c}{ Correlation 2017 to 2008 } \\
\cline { 2 - 7 } & All & Urban & Rural & All & Urban & Rural \\
\hline Lviv region & $12.87 / 12.67$ & $10.82 / 11.10$ & $16.04 / 15.20$ & $-1.55 \%$ & $+2.59 \%$ & $-5.24 \%$ \\
\hline Podkarpackie region & $8.85 / 9.08$ & $8.24 / 8.69$ & $9.28 / 9.36$ & $+2.60 \%$ & $+5.46 \%$ & $+0.86 \%$ \\
\hline
\end{tabular}

rural areas $(-2.95 \%)$, was the most pronounced decrease in Lviv oblast. At the same time, in the Podkarpackie region, with the increase in the population, it was the smallest among women $(+1.21 \%)$, including among residents of rural areas $(+0.80 \%)$. Thus, population changes occurred in both regions with opposite development and synchronous changes among residents, both by gender and by place of residence.

Studying the change in the age structure of the population of these regions, the positive dynamics of the 
Table VIII. Mortality of population caused by pathology of the blood circulation system and its share of total mortality, as of 31.12 the year in the Lviv region and Podkarpackie region for 2008-2017

\begin{tabular}{ccccc}
\hline \multirow{2}{*}{ Years old } & \multicolumn{2}{c}{$\begin{array}{c}\text { Mortality per 100 thousand } \\
\text { population }\end{array}$} & $\begin{array}{c}\text { Part of the total } \\
\text { mortality }\end{array}$ \\
\cline { 2 - 5 } & regio & $\begin{array}{c}\text { Podkarpackie } \\
\text { region }\end{array}$ & $\begin{array}{c}\text { Lviv } \\
\text { region }\end{array}$ & $\begin{array}{c}\text { Podkarpackie } \\
\text { region }\end{array}$ \\
\hline 2008 & 888.6 & 422.8 & 64.7 & 48.9 \\
\hline 2009 & 839.5 & 459.5 & 65.2 & 51.9 \\
\hline 2010 & 832.4 & 449.8 & 64.9 & 52.3 \\
\hline 2011 & 785.7 & 430.5 & 64.1 & 50.3 \\
\hline 2012 & 805.8 & 437.5 & 64.6 & 50.6 \\
\hline 2013 & 814.5 & 441.6 & 65.3 & 50.6 \\
\hline 2014 & 824.0 & 398.0 & 64.4 & 46.1 \\
\hline 2015 & 835.6 & 487.3 & 64.5 & 53.4 \\
\hline 2016 & 790.0 & 419.5 & 62.1 & 46.7 \\
\hline 2017 & 790.5 & 391.9 & 62.4 & 43.1 \\
\hline$\% \% 2017$ until 2008 & $-11.04 \%$ & $-7.31 \%$ & - & - \\
\hline
\end{tabular}



Fig. 1. The dynamics of the total fertility rate (for 1 woman) as of 31.12 of the corresponding year in Lviv region and Podkarpackie region for 2008-2017.

population aged $0-14$ in the Lviv region $(+3.90 \%)$ with a more pronounced growth among the inhabitants of urban settlements $(+5.91 \%)$ was found. The more pronounced is the change in the number of people aged 65 and older: urban settlements experienced an increase of $+13.49 \%$, and among residents of rural areas - a decrease of $-14.56 \%$. The same multi-directional dynamics was observed both among male and female population of the region.

In the Podkarpackie region, when estimating the age structure of the population, it was found that the pop- ulation in both age groups: 0-14 years old and 15-65 years, decreased, and same among men and women. At the same time there was a pronounced increase in the number of persons in the senior age group (65 years or more). Overall growth for 10 years is $23.78 \%$. Significantly, it was among the urban population - $+43.09 \%$, among men $+49.05 \%$. In rural areas, this increase was $+11.66 \%$, including among the male population at $+16.17 \%$. Thus, population aging was observed in both regions of the study. However, it was very clear in the Podkarpackie 


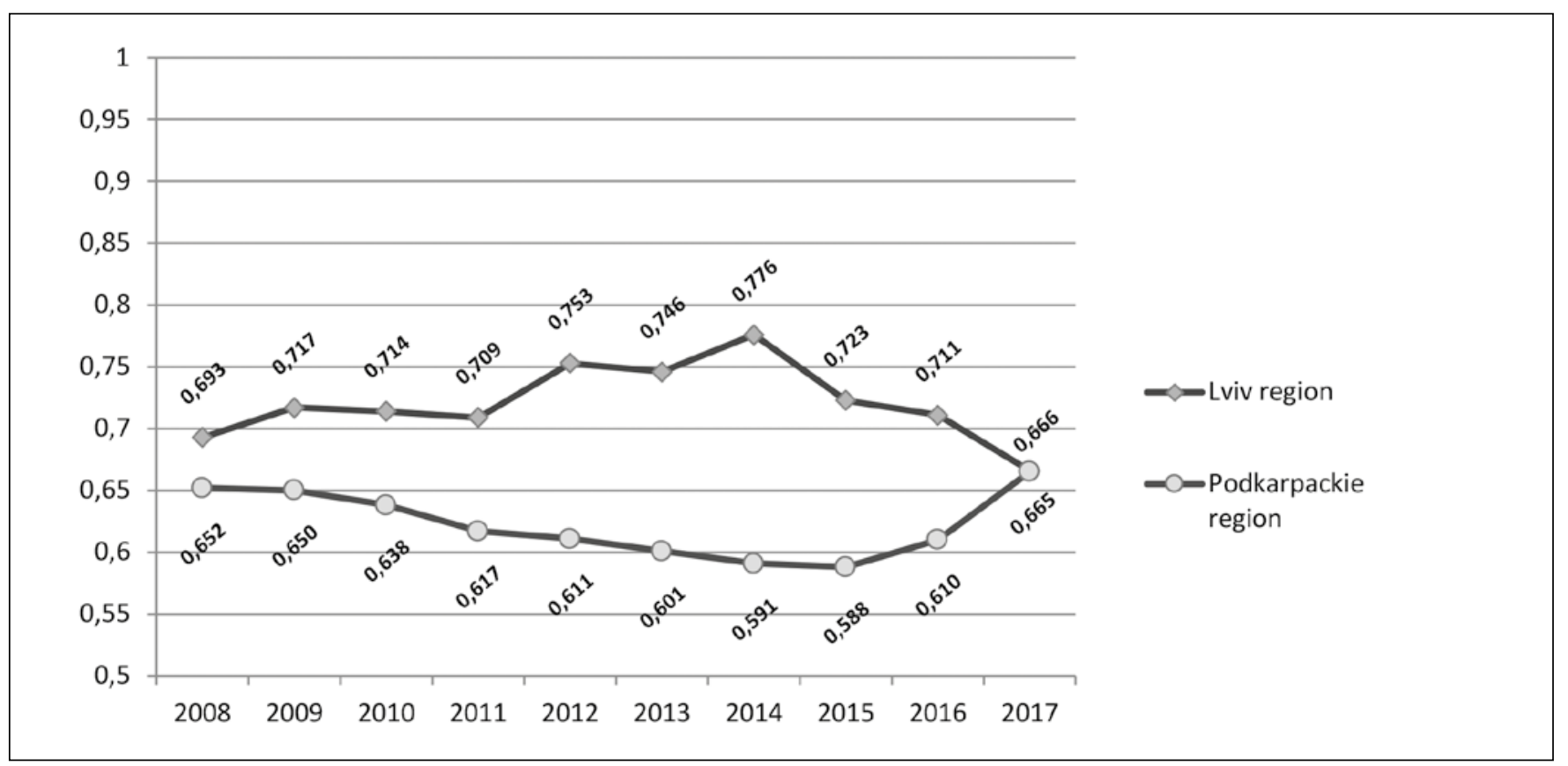

Fig. 2. The dynamics of the reproduction rate of the population (per 1 woman) as of 31.12 of the corresponding year in Lviv region and Podkarpackie region for 2008-2017.



Fig. 3. The dynamics of the infant mortality rate (per 1000 live births) as of 31.12 of the corresponding year in Lviv region and Podkarpackie region for 2008-2017.

region. In the Lviv region, this trend was not so clear due to the small but increasing number of people aged $0-14$ years.

The generalized quantitative characteristic of the age structure of the population of regions was established while calculating the demographic load index. He shows, on the basis of preliminary data, that the burden on society by the unproductive population in both regions has increased, but to a lesser extent in the Lviv region
(+4.35\% vs. $+7.58 \%$ in the Podkarpackie region). The growth of demographic burden among the urban population is considerably higher, correspondingly $+13.94 \%$ and $+25.12 \%$. By contrast, there was a decrease in the countryside. The practical application of this data take place when calculating the expenses necessary for retirement provision, the cost of maintaining children, used in the development of measures for social security and rational use of labor resources. 
Table IX. Average life expectancy at birth as of 31.12 the year in Lviv region and Podkarpackie region, for 2008 and 2017

\begin{tabular}{ccccccc}
\hline \multirow{2}{*}{ Region/years } & \multicolumn{3}{c}{ Men } & \multicolumn{3}{c}{ Women } \\
\cline { 2 - 7 } & All & Urban & Rural & All & Urban & Rural \\
\hline Lviv region 2008/2017 & $65.0 / 68.5$ & $66.2 / 69.5$ & $63.3 / 67.2$ & $76.5 / 78.4$ & $76.7 / 78.9$ & $76.3 / 77.8$ \\
\hline Ratio 2017 to 2008 & $+5.38 \%$ & $+4.98 \%$ & $+6.16 \%$ & $+2.48 \%$ & $+2.87 \%$ & $+1.97 \%$ \\
\hline Podkarpackie region 2008/2017 & $73.1 / 75.6$ & $73.6 / 76.5$ & $72.6 / 74.9$ & $81.3 / 83.1$ & $81.1 / 83.0$ & $81.4 / 83.1$ \\
\hline Ratio 2017 to 2008 & $+3.42 \%$ & $+3.94 \%$ & $+3.17 \%$ & $+2.21 \%$ & $+2.34 \%$ & $+2.09 \%$ \\
\hline
\end{tabular}

Table X. Indicators of evaluation of medical and demographic processes for the period from 2008 (31.12.) to 2017 (31.12.) in Lviv region and Podkarpackie region

\begin{tabular}{|c|c|c|c|}
\hline & Indexes & Lviv region & Podkarpackie region \\
\hline 1 & $\begin{array}{l}\text { Amount and location of the } \\
\text { population }\end{array}$ & $\begin{array}{l}\text { The decline is a greater extent, in the countryside, } \\
\text { and the female population }\end{array}$ & $\begin{array}{l}\text { Insignificant growth in all territories, the } \\
\text { lowest in rural women }\end{array}$ \\
\hline 2 & $\begin{array}{l}\text { The age structure of the } \\
\text { population }\end{array}$ & $\begin{array}{l}\text { The increase in persons aged } 65 \text { and older among } \\
\text { urban settlements and the decrease among rural } \\
\text { inhabitants }\end{array}$ & $\begin{array}{l}\text { The pronounced increase in persons in } \\
\text { the age group of } 65 \text { and older }\end{array}$ \\
\hline 3 & Demographic burden & 401.35: insignificant growth & $\begin{array}{l}\text { 107.58: growth, especially among the } \\
\text { urban population }\end{array}$ \\
\hline 4 & $\begin{array}{l}\text { Average age of the } \\
\text { population }\end{array}$ & $\begin{array}{l}40.52 \text { years: slight growth in urban settlements and } \\
\text { declines in rural areas }\end{array}$ & 41.49 years: growth \\
\hline 5 & $\begin{array}{l}\text { Fertility and total fertility } \\
\text { rate }\end{array}$ & $\begin{array}{l}\text { 9.90\% (1.392): a sharp decline, from 2015, a decline } \\
\text { in the total coefficient }\end{array}$ & $\begin{array}{l}10.34 \% \text { ( } 1.372): \text { decreased, since } 2016 \\
\text { the total factor has started to grow }\end{array}$ \\
\hline 6 & Population Replay Rate & 0.666: narrowed & 0.665: narrowed \\
\hline 7 & Mortality of the population & $12.67 \%$ o: reduced among rural population & $\begin{array}{l}\text { 9.08\%o: increased, a greater extent in } \\
\text { urban settlements }\end{array}$ \\
\hline 8 & Mortality of infants & 9.2 per 1000: high & 3.3 per 1000: decreased \\
\hline 9 & $\begin{array}{l}\text { The main cause of } \\
\text { mortality }\end{array}$ & $\begin{array}{l}\text { Pathology of the circulatory system ( } 790.5 \text { per } 100 \\
\text { thousand), more than } 60 \% \text { of all deaths }\end{array}$ & $\begin{array}{c}\text { Pathology of the circulatory system } \\
\text { (391.9 per } 100 \text { thousand), up to half of all } \\
\text { deaths }\end{array}$ \\
\hline 10 & Average life expectancy & $\begin{array}{l}68.5 \text { for men, } 78.4 \text { for women: growth, with the } \\
\text { prevalence among the male population of the } \\
\text { countryside }\end{array}$ & $\begin{array}{l}75.6 \text { for men, } 83.1 \text { for women: } \\
\text { insignificant growth }\end{array}$ \\
\hline
\end{tabular}

Another indicator that characterizes the age structure of the population is its average age. In the reporting period, the average age of the urban population of the Podkarpackie region was the highest (42.37 years) and for the 10 years since 2008 it has actually grown the most among this population cohort $(+5.57 \%)$. A decrease in the average age was found in a group of residents of the rural area of the Lviv region $(-2.76 \%)$. In this cohort of the inhabitants of the region in 2017, the lowest average age of the population (40,38 years) was found, and in general, the average age of the inhabitants of the Lviv region was lower than in all groups of inhabitants of the Podkarpackie region.

The result of the action of social forces and laws in specific conditions is characterized by such an indicator as birth rate. What are the peculiarities of fertility found in the two adjacent regions? The birth rate in the Lviv region in 2008 exceeded that in the Podkarpackie region, including both urban settlements and rural areas. However, as of 01.01.2018, the birth rate has decreased both in the Lviv region and Podkarpackie region. The decline in fertility was more clear in the Lviv region (by $12.39 \%$, in the Podkarpackie region - by $2.27 \%$ ), which led to a lower level of indicators in general and in urban settlements than in the Podkarpackie region.

The coefficient of total fertility is valuable for performing an interterritorial comparison, allowing to rate the level of fertility in one or another country with one number, the size of which does not depend on the influence of the age structure. We have found that the total fertility rate in 2008-2017 was higher in Lviv region during all the period. However, the dynamics of its change since 2014 in the Lviv region is negative, and in the Podkarpackie region since 2016, the growth of the total fertility rate began to increase, and it became the highest for the entire study period $(2017-1,372)$. 
The assessment of the state of reproduction of the population gives a similar indicator. The calculation of this indicator shows that Lviv region, considering all the fluctuations of its values in 2017, has its lowest level (0.666). At the same time, in Podkarpackie region in 2017 , its value was set to be the highest for 10 years (0.665). Since over the entire period, the reproduction rate of the population on average per woman was lower than 1 , respectively, it established its narrowed character in both regions, indicating an excess of deaths over births.

Considering positive changes in mortality rates of the population of the Lviv region in general and a decrease in the mortality rate among the inhabitants of the countryside, the mortality rate in Lviv region exceeds that in the Podkarpackie region by 1.4 times, according to 2017 year data. In this case, the mortality rate of the infants this year in Lviv region exceeded that in Podkarpackie Voivodeship by 2.79 times.

The main class of diseases that caused the death of the population in both regions was the pathology of the circulatory system. It included $60 \%+$ of all deaths in the Lviv region and from 43 to $54 \%$ (depending on the year) in the Podkarpackie region. The excess in Lviv region was set higher by 1.30 times and the highest was in 2017 (1.45 times).

An important indicator of the characterization of medical-demographic processes and the integral assessment of health state is such an indicator as the average life expectancy. The life expectancy of the female population in both regions is higher than the male life expectancy. However, in Podkarpackie region, both women and men live longer. Comparison over the past 10 years has shown the increase in life expectancy in both regions. It was more clear among the male population of the Lviv region in general $(+5.38 \%)$, as well as among urban residents $(+4.98 \%)$ and in rural areas $(+6.16 \%)$. Extension of the average life expectancy among women in both regions did not exceed $3.0 \%$.

\section{CONCLUSIONS}

A comparative analysis of medical and demographic processes in the two neighboring regions of neighboring countries was conducted, considering their geographical proximity, showed a significant difference in the dynamics of changes in the correlation between the size of the territories and the population (Table X).

In both territories overall population aging takes place, illustrated by indicators such as the age structure of the population, the level of demographic load and the average age of the population. Data on population reproduction in both regions are narrowed, indicating the prevalence of mortality over births. However, the birth rate in Podkarpackie region is higher, and the mortality rate is lower than in Lviv region, including those caused by the main factor - the pathology of the circulatory system. As a result, the average life expectancy in the Podkarpackie region is higher and has a tendency for further growth. At the same time, the average life expectancy in the Lviv region is also increasing, due to the positive trend towards a decrease in the overall mortality rate, but is offset by lower birth rates and high levels of population mortality and infant mortality, especially caused by pathologies of the circulatory system.

Thus, the analysis of the 10 indicators we have selected allows us to assess the medical and demographic situation in society and direct the community's actions to stimulate fertility and reduce mortality and prolong the average life expectancy.

\section{REFERENCES}

1. Baum, Frances. The new public health. No. Ed. 4. Oxford University Press, 2016, $720 \mathrm{p}$.

2. Klos L.E. Technologies for saving health in the social sphere. - Lviv: Lviv Polytechnic, 2015, $248 \mathrm{p}$.

3. Marmot M. Social determinants of health inequalities. The lancet, 2005;365(9464):1099-1104.

4. Solar, 0., Irwin, A. A conceptual framework for action on the social determinants of health. - World Health Organization , 2010, $75 \mathrm{p}$.

5. Bacsu, J. R., Jeffery, B., Johnson, S., et al. Healthy aging in place: Supporting rural seniors' health needs. Online Journal of Rural Nursing and Health Care, 2012;12.2:77-87. doi:10.14574/ojrnhc.v12i2.52.

6. Braveman, P., Egerter, S., \& Williams, D. R. The social determinants of health: coming of age. Annual review of public health, 2011;32:381-398.

7. The impact of socio-economic transformation on population potential in the eastern Poland. Jerzy Banski, Wiktoria Pantylej, Wojciech Janicki et al. - Warszawa, 2014, $155 \mathrm{p}$.

8. Smiyanov, V.A, Tarasenko S.V. Mechanisms of community influence on the development of the health care system at the regional level. In: Local development with participation of the community. Institutional and applied aspects of community-based community-based development management / By co-authors. edit Yu. M. Petrushenko. - Sumy: University Book, 2014; Vol.2:225-233.

9. Riva, Mylene, et al. Unravelling the extent of inequalities in health across urban and rural areas: evidence from a national sample in England. Social science \& medicine, 2009;68.4: 654-663.

10. Agnieszka Beata Ćwirlej-Sozańska, Bernard Sozański, Agnieszka Wiśniowska-Szurlej et al. Quality of life and related factors among older people living in rural areas in south-eastern Poland. Ann Agric Environ Med. 2018;25(3):539-545.

11. Gong, P., Liang, S., Carlton, E. J. et al. Urbanisation and health in China. The Lancet, 2012;379(9818):843-852.

12. Movahedi, M., Hajarizadeh, B., Rahimi, A., et al. Trends and geographical inequalities of the main health indicators for rural Iran. Health policy and planning, 2009;24(3):229-237.

13. Karly B., John S. Humphreys, and Murray GA Wilson. Addressing the health disadvantage of rural populations: how does epidemiological evidence inform rural health policies and research? Australian Journal of Rural Health, 2008;16.2:56-66.

14. Libanova, E.M. Inequality in Ukrainian society: origins and timeliness. Economy of Ukraine, 2014;3:4-19.

15. Zahnd, Whitney E., Steven L. Scaife, and Mark L. Francis. Health literacy skills in rural and urban populations. American journal of health behavior, 2009;33.5:550-557.

16. Abel-Smith B. An introduction to health: policy, planning and financing. - Routledge, 2016, 246 p. 
The work was carried out within the framework of research works:

1. The scientific support of implementation the European policy "HEALTH21 - health for all in the 21st century" in the conditions of optimization the health care system of Ukraine for 2012-2014.

2. Medico-social determinants of health of rural population and life expectancy, 2018-2023 years.

\section{Authors' contributions:}

According to the order of the Authorship.

\section{Conflict of interest:}

The Authors declare no conflict of interest.

\section{CORRESPONDING AUTHOR}

Jaroslaw Grshybowskyj

150/119 Zamartynyvska str., Lviv, 79068, Ukraine tel: +380322759536

e-mail: grshybowskyj@yahoo.de

Received: 24.03 .2019

Accepted: 30.04 .2019 
PRACA POGLĄDOWA

REVIEW ARTICLE

\title{
MEDICAL ERROR AND LIABILITY FOR IT IN SOME POST-SOVIET COUNTRIES (BELARUS, KAZAKHSTAN, MOLDOVA, UKRAINE)
}

\author{
Alesia Gornostay ${ }^{1}$, Alona Ivantsova ${ }^{1}$, Tetiana Mykhailichenko ${ }^{2}$ \\ 'YAROSLAV MUDRYI NATIONAL LAW UNIVERSITY, KHARKIV, UKRAINE \\ 2POLTAVA LAW INSTITUTE OF YAROSLAV MUDRYI NATIONAL LAW UNIVERSITY, POLTAVA, UKRAINE
}

\begin{abstract}
Introduction: Infliction of harm to life and health due to medical errors is common for the whole world and post-Soviet countries, in particular. The problem of these errors is one of the most important in medical law, although there is no unified concept of it. A small number of sentences in cases of criminal negligence of medical professionals indicates a high latency and often unprovability of this crime in a number of post-Soviet countries.

The aim: To disclose the objective and subjective prerequisites of a medical error, reasons for its occurrence, to establish the grounds for criminal liability of medical professionals in case they commit an error and to examine the judicial practice in this regard. Also, to define the concept and types of circumstances exempting criminal liability and their impact on criminal liability issues concerning medical professionals.

Materials and methods: The study is based on the Belarusian, Kazakh, Moldavian and Ukrainian statutory acts as well as international acts, the European Convention for the Protection of Human Rights and Fundamental Freedoms, case law of the European Court of Human Rights (ECHR), national court judgments. Such methods as dialectical, comparative, analytic, synthetic and comprehensive have been used in the paper.

Review: $0 \mathrm{n}$ the basis of the study, it has been established that there is no unified concept of a medical error, medical personnel are fairly brought to criminal liability only if they commit an unjustifiable error in the presence of all the mandatory elements of a crime provided for in the relevant article of the Criminal Code. At the same time, it is extremely difficult to prove existence of such an error. Besides, at the state levels, causes and mechanisms of occurring errors have not been revealed, they are not even discussed, which makes it impossible to outline measures to prevent them or reduce their frequency and degree of danger.

Conclusions: The struggle against medical errors should encompass a number of such activities as standardization of clinical treatment protocols, further education of medical professionals and lawyers in regard to patient safety, thorough investigation of each incident in order to exclude a justifiable error or circumstances exempting criminal liability. Equitable, severe and uncompromising punishments for perpetrators should be an effective means preventing commission of crimes in medicine.
\end{abstract}

KEY WORDS: medical malpractice, medical crime, criminal liability, impunity

Wiad Lek 2019, 72, 5 cz. I, 877-882

\section{INTRODUCTION}

Causing harm to life and health due to medical errors is quite common. Medical errors lead to such negative consequences as deterioration of patient health, loss of time for faster and more effective treatment or death. On the other hand, even when there is no error or there is a justifiable one, quite often patients or their relatives accuse a doctor and/or junior medical personnel of negligence. Therefore, it is very important for both parties, as well as for society, to have a clear, unified mechanism that would help to establish presence or absence of a medical error in actions of a doctor and/or junior medical personnel.

The right to life and health is among the universally recognized, fundamental, inalienable human rights and freedoms that are subject to state protection both internationally ${ }^{1}$ and domestically ${ }^{2}$. At the same time, a number of international conventions have not been signed by the countries considered. In particular, these are: the European Convention on Social and Medical Assistance,

\footnotetext{
${ }^{1}$ At the international level, the right to health is protected by the Universal Declaration of Human Rights, 1948 (Art. 25), the International Covenant on Economic, Social and Cultural Rights, 1966 (Art. 12), the Convention on the Rights of Child, 1989 (Art. 24), the Convention on the Elimination of All Forms of Racial Discrimination, 1965 (Art. 5), the Convention on the Elimination of All Forms of Discrimination Against Women, 1979 (Art. 12 and 14), the Convention on the Rights of Persons with Disabilities, 2007 (Art. 25).

2 The Constitutions of Belarus (Art. 2), Kazakhstan (Art. 1), Moldova (Art. 1) and Ukraine (Art. 3) stipulate that a person, his life and health are recognized as the highest value. They also provide that citizens of the Republic (Art. 45 of the Constitution of Belarus, Art. 29 of the Constitution of Kazakhstan) or each person (Art. 24, 36, 47 of the Constitution of Moldova, Art. 49 of the Constitution of Ukraine) are guaranteed the right to health protection and medical care.
} 
1953, the Agreement on the Exchange of War Cripples between Member Countries of the Council of Europe with a view to Medical Treatment, 1956, the Agreement on the Temporary Importation, free of duty, of Medical, Surgical and Laboratory Equipment for use on free loan in Hospitals and other Medical Institutions for purposes of Diagnosis or Treatment, 1960, the European Agreement on Mutual Assistance in the matter of Special Medical Treatments and Climatic Facilities, 1962, the European Agreement on the Exchanges of Blood-Grouping Reagents, 1962 and others.

Recently, the media has been paid increased attention to occurring medical errors which, in some cases, lead to extremely unfavourable consequences for patients. The number of legal actions on this subject has also significantly increased. However, not a single newspaper article or television program has revealed the causes and mechanisms of the errors that have occurred, but they have not even been discussed, which does not allow for planning measures to prevent them or reduce their frequency and degree of danger. As a rule, both journalists, legislators and individual politicians advocate the increasing administrative and criminal accountability for errors by means of tightening current legislation. Still, the problem under consideration is so specific that it cannot be solved by only prohibitive or punitive measures. In their works, well-known scientists point out other ways to solve it $[1,2]$. This is shown by fairly extensive legislation providing for a different degree of liability for medical errors, but not affecting a reduction of their frequency. The ECHR also arrives at the same conclusions pointing out that legal system should provide victims with an opportunity to receive an appropriate redress using exclusively remedies in the civil courts or in combination with remedies in the criminal courts. Disciplinary measures may also be envisaged $[3,4]$.

\section{THE AIM}

The paper is aimed at identifying types of medical errors, reasons for committing them in post-Soviet countries, studying the legislation according to which medical personnel may or may not be held criminally liable as well as judicial practice on this issue, and also proposing ways to solve the identified problems.

\section{MATERIALS AND METHODS}

The paper is based on the Belarusian, Kazakh, Moldavian and Ukrainian statutory instruments, decisions of the ECHR, scientific articles. Additionally, statistical data, conclusions of experts, judicial practice, doctrinal ideas and views on this issue have been used. In addition, the paper is based on dialectical, comparative, analytic, synthetic and comprehensive research methods.

\section{REVIEW AND DISCUSSION}

Such a branch as medical law regulates the relations developing between the state, a medical institution and a medical professional performing his professional (services) duties at the institution, between medical professionals, as well as the relationship between a patient and a medical professional and/or a medical institution and the state. The problem of medical errors is one of the most important in medical law.

There is no single concept of medical error. At the same time, there is a number of its scientific definitions. In this way, on the website of the World Health Organization (hereinafter, the WHO), it is noted that a medical error is "a medical intervention the intended consequences of which do not occur. They are preventable defects in the health delivery system" [5]. In science, there is a significant number of versions of this concept, from a version of professional error to which a medical professional has the right up to a medical violation, an unlawful deviation from implementation of medical standards [6, 7].

It is equally important to understand that the classification of all medical errors into justifiable (a good faith error) and unjustifiable is of legal importance since the former have no consequences in the form of criminal prosecution, unlike the latter, as there is no sign of culpability. That is, there is an unguilty wrongdoing.

Thus, the occurrence of medical errors has both objective and subjective prerequisites. Objective ones are related to factors that are independent of a medical professional's personality: poor-quality medicines, a breakdown or lack of medical equipment, physiological characteristics of a patient's body, a selected approved (officially recommended) option of medical care which did not result in an expected positive effect in a particular case, etc. Subjective prerequisites include experience or lack thereof, a doctor's professional skills, failure to comply with instructions and standards, personal doctorpatient relationships, that is, the degree of their mutual trust. For instance, in 2002-2016, the Commission on study of lethal consequences of the National Military Medical Clinical Center (Ukraine) has identified 288 defects and their causes in 2,300 patient medical records made at the hospital stage. The causes of medical errors were both objective $(46.8 \%)$ and subjective (53.2\%). At the same time, there were $14.41 \%$ of defects that affected the lethal outcome. Among the objective reasons, there were delays in seeking medical care, objective difficulties in providing assistance (lack of medicines, impossibility of carrying out certain procedures, etc.). Among the subjective reasons, there were as follows: incomplete patient examination, incorrect assessment of clinical data, insufficient professional skills of medical personnel [8, p. 117]. The researchers also attribute to subjective reasons inadequate attention of medical professionals to patients. They believe that social factors contributing to the indifference are as follows: underfunding of medical institutions, lack of decent wages and shortage of qualified personnel, equipment and medicines as well as complexity of work caused by the above factors $[9$, p. 166]. The need for a high level of education has also been indicated $[10$, p. $860 ; 11$, p. 133] with which we absolutely agree. Therefore, it is necessary to introduce separate tutorials and practical courses on patient safety for training both young medical professionals and experienced 
personnel as long as according to the data surgeons leave foreign objects (tampons, instruments) in patient body after a surgical intervention up to 39 times and incorrectly perform surgical interventions up to 20 times every week. It is also known that such "errors" are more often committed by experienced surgeons aged $40-49$ years [ 9, p. 167].

In connection with the above, first of all, it is necessary to establish whether a committed error is justifiable or not. $A$ justifiable error means that with careful and conscientious attitude, a medical professional could not avoid this error due to certain objective and/or subjective reasons. In particular, a surgeon on duty was acquitted by the court because at the time of the examination of a 13-year-old patient after a car accident, he did not find any indications for emergency surgery. Data of analysis and research were without pathological findings, an ultrasound scan showed no damage to internal organs or free fluid. In the morning, the patient was discharged from hospital. In the evening, being impaired, she was re-admitted to hospital and died a month later. The doctor was charged with criminal medical negligence, although the court reasoned that, for objective reasons, he could not immediately determine a diagnosis, namely, a pancreatic contusion within 12 hours after receiving the injury by the patient due to the car accident. According to research in practice, diagnosticating such injuries only on the basis of clinical evidence is rather difficult. A correct diagnosis can be determined only in single observations [13].

So, if a medical error is justifiable, it excludes liability of a medical professional. Having established its absence, it is also necessary to exclude a possibility of presence of circumstances exempting criminal liability, namely, extreme necessity and a risk related act.

Extreme necessity means causing harm to lawful interests in order to eliminate a danger directly threatening a person or a person's or other persons' rights protected by law, as well as public or national interests if this danger could not be eliminated by other means in these settings and if there was no exceeding the limits of extreme necessity herewith. There is legislative consolidation of this circumstance in Art. 36 of the Criminal Code (hereinafter, the CC) of Belarus, Art. 34 of the CC of Kazakhstan, Art. 38 of the CC of Moldova, Art. 39 of the CC of Ukraine which emphasize that an act committed in such a state is not wrongful.

In general, what is meant here is that medical profession, its specific features connected with providing urgent (emergency) medical assistance (anesthesiology, surgery, emergency cardiology etc.) is often related to the concept of extreme necessity since medical professionals' actions are aimed at eliminating a danger to human life. In such cases, to exempt criminal liability of a medical professional for his actions, it is necessary to indicate the criteria for eligibility of the act in regard of extreme necessity in medical activities [14]. A danger has be determined as real if a patient's pathological conditions requiring urgent medical care related to doing harm to his health as an injury or trauma directly threatens his life and health. This applies only to those medical interventions that are urgent since what is meant here is human life, and any delay can lead to death. All other forms of providing medical care, which are not of extreme necessity, cannot be regarded as those excluding criminal liability [14].

A risk related act is an act that does not cause harm to lawful interests if such an act was committed under conditions of justifiable risk to achieve a goal beneficial to society which is not wrongful. This is another reason exempting criminal liability of a medical professional which is enshrined in Art. 39 of the CC of Belarus, Art. 36 of the CC of Kazakhstan, Art. 40 of the CC of Moldova, Art. 42 of the CC of Ukraine. Medical profession is connected with the need for experimentation in certain situations. It is necessary both for the development of medical science and saving a person's life and health [14].

A risk related act in the medical sphere will be legally acceptable under the following conditions. Harm to health is done to achieve a goal beneficial to society. The risk is directed towards the development of medical science or saving a person's life and health. This goal cannot be achieved by conventional means bearing no risk. If the person could be provided with some assistance in an ordinary, traditional way, bearing no risk, then, in this case, the medical professional's acts while causing harm to the person's health would be considered criminal. The medical professional considers the measures he has taken to be sufficient to prevent causing harm to the patient's life and health.

The risk will be justified under all these conditions; this will become a circumstance exempting criminal liability. It should be singled out that for a medical professional, providing for a possibility to use new methods of treatment without any fear of being prosecuted is a big advantage in the criminal law regulating medical activity and, as a result, it is a key factor for the development of medical law and medicine itself [14].

It is also necessary to exclude a casus (fortuitous event) characterized by the absence of culpability of a medical professional. After all, in the provision of medical care, even with the most conscientious attitude of medical professionals to their professional duties, it is sometimes impossible to avoid fortuitous events. In medical practice, fortuitous events are most commonly caused by the fact that a patient has an atypical progression of a disease associated with individual characteristics of his body, an unusual anatomical structure or congenital anomalies, allergic reactions to diagnostic manipulations or medicines [6, p. 83].

Only having excluding a justifiable error, casus and circumstances exempting criminal liability, it is necessary to determine elements of such a crime as non-performance or improper performance of professional duties by a medical professional (Art. 162 of the CC of Belarus, Art. 317 of the CC of Kazakhstan, Art. 213 of the CC of Moldova, Art. 140 of the CC of Ukraine). These are the elements of a crime that constitute grounds for criminal liability for committing an unjustifiable medical error. In this case, there have to be serious consequences for a patient.

Thus, an unjustifiable medical error is an egregious error associated with negligence, carelessness of a medical professional which has resulted in serious consequences. 
It is impossible to establish the entire volume of errors committed worldwide, therefore lawyers, researchers and civil organizations focus their attention on unjustifiable errors. Studies have shown that a lethality risk due to a medical error or medical negligence is dozens and sometimes hundreds of times higher than a risk of dying in a car accident. The experience of medical lawyers and organizations dealing with protection of patient rights, analysis of a significant number of medical records in the course of judicial proceedings has shown that up to 50-70\% of official information documented in medical records is completely or partially false [15]. The WHO notes that "medical errors occur right across the spectrum, and can be attributed to both system and human factors. The most common adverse safety incidents are related to surgical procedures $(27 \%)$, medication errors (18.3\%) and health care-associated infections (12.2\%). Yet, in many places, fear around the reporting of errors is manifested within health care cultures, impeding progress and learning for improvement and error prevention" [16]. The Institute of Medicine (US) points out that about 100,000 people die in hospitals each year as a result of medical errors [7]. Other sources say that in the United States, medical errors are ranked number three among the main causes of death after cardiovascular and oncology diseases [17]. In Belarus, the Department of Complex Examinations of the State Forensic Examination Committee annually examines more than 100 cases of medical errors, mainly related to claims concerning surgeons, obstetriciansgynecologists, anesthesiologists-resuscitators, emergency medical specialists [18, p. 2]. About 6,000 inconsistencies of pathoanatomical and clinical diagnoses are also recorded annually, and there are only 60-65 validated complaints in regard of them. But, in this case, there should be at least 100 times more validated complaints than official statistics fix [19]. In 2017-2018, in Kazakhstan, there were 24 judicial proceedings under Art. 317 of the CC of Kazakhstan, and the charge was brought against 39 persons. 5 acquittals and 34 convictions were issued [20]. In 2018, in Moldova, there were 8 judicial proceedings under Art. 213 of the CC, the charge was brought against 9 persons. No acquittal was issued [21]. Official statistics of medical errors in Ukraine is missing. And only isolated cases become known to the public mainly through the media. At the same time, Ukrainian medical professionals are confident that every second case is launched against them without any grounds [22]. Unlike them, there is a common belief that the probability of bringing a medical professional to justice is extremely small. In 2017-2018, in Ukraine, the courts issued 17 sentences under Art. 140 of the CC, of which 2 are acquittals and 15 are convictions [23].

As a result, bringing medical professionals to criminal liability for unjustifiable errors is possible only under the following conditions: 1) an action (act or omission) was clearly erroneous, contrary to generally accepted rules for the provision of medical care and services; 2 ) a medical professional could and should have understood and predicted that his action was wrong and could cause harm to health (life) of a patient; 3 ) an action caused serious consequences, from harm to health of medium gravity (Part 1 of Art. 317 of the CC of Kazakhstan), serious bodily harm/serious injury to health (Art. 162 of the CC of Belarus, Part 2 of Art. 317 of the CC of Kazakhstan, Art. 213 of the CC of Moldova, Part 1 of Art. 140 of the CC of Ukraine) to introduction of HIV infection (Part 2 of Art. 162 of the CC of Belarus, Part 5 of Art. 317 of the CC of Kazakhstan) or death of a patient (Part 2 of Art. 162 of the CC of Belarus, Part 3 of Art. 317 of the CC of Kazakhstan, Art. 213 of the CC of Moldova, Part 1 of Art. 140 of the CC of Ukraine).

In this case, it is of top priority to establish a medical professional's duties to act in a certain way and a viable possibility of its implementation. The duties are detected by identifying compliance/non-compliance with clinical protocols. A clinical protocol is an instruction for diagnosing and treating a patient. But nowadays in Ukraine, international, national and local clinical protocols are in force at the same time [24]. In practice, their application is complicated by lack of official translation of international protocols, politicization and ideological bias of national ones and primitivism of local ones.

In the meantime, in the case of Lopes De Sousa Fernandes v. Portugal dated 19 December, 2017, the ECHR "has consistently emphasised that, where a Contracting State has made adequate provision for securing high professional standards among health professionals and the protection of the lives of patients, matters such as an error of judgment on the part of a health professional or negligent coordination among health professionals in the treatment of a particular patient are not sufficient of themselves to call a Contracting State to account from the standpoint of its positive obligations under Article 2 of the Convention to protect life" [25]. However, in some countries, for instance, in Ukraine, the majority of criminal proceedings in regard of medical errors do not reach the trial stage due to lack of a clear distinction between criminal and lawful actions of a medical professional. Primarily, it indicates gaps in the legislative techniques and a low level of professional skills of law enforcement officials as they allow erroneous or deliberately incorrect legal treatment of actions committed by medical personnel. All this may indicate the deficiencies in the regulatory framework meant by the ECHR.

Moreover, experts (lawyers) emphasize the extreme complexity of investigating criminal cases against medical professionals which is primarily due to the need to clarify a significant number of specific medical issues. This is especially true for collection and examination of medical records since they contain specific terms and are a source of medical confidentiality (they require a special procedure for accessing them). This is separate difficulty in conducting a forensic medical examination since far too often experts temporize with its conduct, sometimes for several years, abusing their exceptional powers: as evidenced in practice, experts rarely adhere to the established deadline. According to the researchers, the period of pre-trial investigation of such cases is quite long (it takes from 1-2 to 4-7 years from the moment when a crime is committed to delivery 
of a judgment) [26, p. 89]. Among other things, in the case of Yirdem and Others v. Turkey (No. 72781/12), the ECHR has recently noted that incomplete investigation of a patient's death due to a forensic medical examination is in violation of the Convention [27].

In case of inflicted injury, the issue of damages is raised. The ECHR adheres to the position that a prompt examination of cases concerning death in a hospital setting is necessary. In the decision of in the case of Byrzykowski v. Poland dated 26 June 2006, the Court pointed out that "the knowledge of facts and possible errors committed in the course of medical care should be established promptly in order to be disseminated to the medical staff of the institution concerned so as to prevent the repetition of similar errors and thereby contribute to the safety of users of all health services" [28].

Apparently, the criminal legislation of the post-Soviet countries contains a possibility of bringing to account a medical professional who has made an unjustifiable, egregious error. And yet nowadays, in medical law, there are many contradictions and gaps. It is rather difficult to prove the guilt of a doctor, medical personnel or medical institution since it requires special knowledge and professional skills. Unfortunately, laws and statutory acts that should provide a citizen with the right to life and ensure his health are interpreted differently and often, according to the experience, not in favour of patients. It is significant that under Art. 317 of the CC of Kazakhstan, 15 of 34 persons found guilty were exempted from criminal liability due to the expiration of the statute of limitations, 10 persons were amnestied and a suspended sentence was imposed on 5 convicts, which is an example of the ineffectiveness of current legislation and activities conducted by law enforcement agencies and the court. In other words, only 4 medical professionals received a real punishment, 2 of which received a suspension for 5 years and 1 was put on probation [20]. In 2018, in Moldova, under Art. 213 of the CC, the courts heard 8 cases of which 2 were dismissed due to the expiration of the statute of limitations, 2 - in connection with amnesty. 4 convicts were put on probation as there was a conditional sentence. No medical professional received real punishment [21]. In 2017-2018, in Ukraine, under Art. 140 of the CC, courts issued 15 convictions, although 6 convicts were exempted from criminal liability due to the expiration of the statute of limitations, 3 persons were amnestied and 3 persons were put on probation. Only 3 medical professionals received real punishment [23]. In this regard, there is also public opinion on the impunity of medical professionals [29]. We believe that there should be a harsh and uncompromising punishment for an unjustifiable medical error. It should be expressed in real facts of convicting and sentencing persons guilty of committing the errors to real prison terms. Furthermore, criminal punishment should necessarily provide for termination (cessation) of the employment in medicine of convicted persons. In addition, enhancement of the forensic examinations should be the key to the effectiveness of punishment for such errors. Actually, the forensic examination has become a crucial element on which it depends whether there is a conclusion on evidence of elements of a crime committed by a medical professional or not, which is unacceptable since an influence of such an adverse factor as the corporate solidarity of medical professionals on the results of the examination cannot be ignored. In case of an unjustifiable medical error, positive characteristics should not be taken as the basis for making a decision on exemption of criminal liability. In this matter, the severity of a crime committed, reasons for committing an error, a convict's professional skills, his actions aimed at minimizing the harm done to patient health, etc. should be the crucial factors.

\section{CONCLUSIONS}

Thus, it should be noted that the problem of crime and criminal liability of medical professionals is one of the most controversial topics. It should be pointed out that the active criminalization of medical activities, introduction of new elements of a crime related to medicine and tightening sanctions in criminal law are not effective ways to combat medical errors. The issue of struggle against them is rather difficult, therefore we believe that a complex of measures should be taken which are as follows: 1) a clear legal and regulatory framework, uniform harmonized and adjusted clinical treatment protocols; 2) harsh and uncompromising punishments for both immediate subjects of a crime and persons found to conceal the facts within the framework of the vicious system of conspiracy of silence existing among hospital personnel (adherence to the principle of unavoidability of punishment); 3) compensation for damage through civil remedies; 4) solving the problem of forensic medical examination and 5) additional consideration of the education of medical professionals and lawyers in the field of patient safety.

\section{REFERENCES}

1. Tatsiy V., Gutorova N., Pashkov V. Legal aspects of cancer deseases prophylactics of cancer: patients'right context. Wiad Lek, 2017;6:11081111.

2. Golubchykov M., Orlova1 N., Bielikova I. The main directions of reforming the service of medical statistics in Ukraine. Wiad Lek, 2018;2:206-210.

3. Case of Valeriy Fuklev v. Ukraine. Available at: https://hudoc.echr. coe.int/eng\#\{\%22fulltext\%22:[\%22l\%22CASE\%200F\%20VALERIY \%20FUKLEV\%20v.\%20UKRAINE|\%22\%22],\%22documentcollectionid2 $\% 22:[\% 22$ GRANDCHAMBER\%22,\%22CHAMBER\%22],\%22itemid\%22: [\%22001-140009\%22]\}.

4. Case of Vo v. France. Available at: https://hudoc.echr.coe.int/ eng $\#\{\% 22$ fulltext $\% 22:[\% 22$ Vo $\% 20 \mathrm{v} . \% 20$ France $\% 22]$, $\% 22$ documentcollectionid2\%22:[\%22GRANDCHAMBER\%22, \%22CHAMBER\%22],\%22itemid\%22:[\%22001-61887\%22]\}.

5. WHO. Pharmaceuticals Newsletter. 2000, 2, 19 p. Available at: http:// apps.who.int/medicinedocs/en/d/Jwhozip02e/4.html.

6. Cherkies E. Soderzhaniie poniatiia „wraczebnaia oshybka”. Vesnik Akademii MVD Pespubliki Belarus, 2013; 2 (26):81-85. (in Ru)

7. Kohn L., Corrigan J., Donaldson M. To Err is Human: Building a Safer Health System. Washington (DC): National Academies Press (US); 2000. 
8. Asauluk I., Golik L., Denisyuk A., Olkhovskaya E., Siroshtanova I. Analysis of medical mistakes - a factor of increasing professional training of doctors and improving the quality of medical-diagnostic process in the hospital. Patient safety is an urgent problem of the domestic system of health care : Internat. Scientific and Practical Conf. Dnieper, June 6-7, 2017;116-119.

9. Fedorova 0 . The state and ways of improving the safety of patients. Patient safety is an urgent problem of the domestic system of health care: Internat. Scientific and Practical Conf. Dnieper, June 6-7, 2017;165-168.

10. Lester H., Tritter J. Medical error: a discussion of the medical construction of error and suggestions for reforms of medical education to decrease error. Medical Education, 2001;35 (9):855-861. Available at: https:// doi.org/10.1046/J.1365-2923.2001.01003.X.

11. Ghalandarpoorattar S., Kaviani A., Asghari F. Medical error disclosure: the gap between attitude and practice. Postgraduate Medical Journal, 2012, 88 (1037), pp. 130-133. Available at: https://doi.org/10.1136/ POSTGRADMEDJ-2011-130118.

12. Cholan T. Kryminalna widpovidalnist likariv za zloczyny u sferi medycznogo obslugovuvannia. Teoretyczno pravovi zasady formufannia suczasnogo medycznogo prava v Ukraini: zbirnyk tez. Poltava, 2627.10.2012; 192-195. (in Ua)

13. Prigovor Shahtinskogo gorodskogo suda Karagandinskoi oblasti Respubliki Kazakhstan № 3528-17-00-1/172. Available at: http://office. sud.kz/courtActs/site/document.xhtml. (in Ru)

14. Stecenko S.H., Stecenko V.Yu., Seniuta I. Ya. Medyczne pravo Ukrainy, Pidruchnyk. Kyiv, "Pravova Jednist", 2008, p. 507. (in Ua)

15. Ajvazian D. Vrachebnyje oshybki I rol advokata. Available at: https:// www.adv1.ru/med_advokat/. (in Ru)

16. Patient Safety: Making health care safer. Geneva: World Health Organization; 2017.

17. Makary M., Daniel M. Medical error - the third leading cause of death in the US. BMJ, 2016. Available at: https://www.bmj.com/content/353/ bmj.i2139.
18. Belskaia E.V., Kisieliov M.P.,Volchanina E.N. Pravo na strahovanije vrachebnoj oshybki. Medicina. 2004;3:2-3. (in Ru)

19. Sharabchijev Yu.T. Vrachebnyjeoshybki i defekty okazaniia medicynskoi pomoshchi: socyalno-ekonomicheskije aspiekty i poteri obshchestviennogo zdorovia. Mezhdunarodnyje obzory: klinicheskaja praktika i zdorovje. 2013;6 (6):14-31. (in Ru)

20. See: http://sud.gov.kz/rus/content/bank-sudebnyh-aktov.

21. See: http://instante.justice.md/.

22. Franchuk V. V., Trach-Rosolovska S. V., Selskyy P. R., Mykolenko A. Z., Bodnar P. Ya.. Analysis of Final Judgments in Cases of Medical Negligence Occurred in Ukraine. Wiadomości Lekarskie, 2018, № 3, p. 760.

23. See: http://reyestr.court.gov.ua/.

24. Nakaz Ministerstva ohorony zdorovia Ukrainy vid 28.09.2012 r. № 751 "Pro stvorenia ta vprovadzhenia medyko-tehnologichnyh dokumentiv izstandartyzacii medychnoi dopomogy v systemi Ministerstva ochorony zdorovia Ukrainy". Available at: https://zakon.rada.gov.ua/laws/show/ z2001-12. (in Ua)

25. Case of Lopes de Sousa Fernandes v. Portugal, 19.12.2017. Available at: http://hudoc.echr.coe.int/eng?i=001-179556.

26. Lemesh A., Polhovskaja I., Mihajlichenko T. Ugolovnaja otvetstvennost za nienadlezhashcheje ispolnenije professionalnyh obiazannostej medicynskimi ili farmacefticheskimi rabotnikami (st. 140 UK Ukrainy). Legeasiviata, 2017;11/2:88-93. (in Ru)

27. Case of Yirdem and Others v. Turkey, No. 72781/12. Available at: https:// hudoc.echr.coe.int/eng\#\{\%22itemid\%22:[\%22001-185331\%22]\}.

28. Case of Byrzykowski v. Poland, 27.06.2006. Available at: https:// hudoc.echr.coe.int/eng \#\{\%22fulltext\%22:[\%22Byrzykowski\%20 v. $\% 20$ Poland $\% 22$ ], $\% 22$ documentcollectionid $2 \% 22$ : [\%22GRANDCHAMBER\%22,\%22CHAMBER\%22],\%22itemid\%22: [\%22001-76066\%22]\}.

29. Floria V., Ostavchuk D. Ugolovnaia otvetstviennost v sluchaje vrachebnyh prestuplenii iz pokazanii poterpievshyh i ob izbiezhanii vrachami ugolovnogo nakazaniia. REVISTA NAȚIONALĂ DE DREPT, 2012:6:41-45.

\section{Authors' contributions:}

According to the order of the Authorship.

\section{Conflict of interest:}

The Authors declare no conflict of interest.

\section{CORRESPONDING AUTHOR \\ Alesia Gornostay}

Yaroslav Mudryi National Law University

Pushkinskaya str., 77, 61024, Kharkiv, Ukraine

tel: +380957482202

e-mail: gornostayales@gmail.com

Received: 15.01 .2019

Accepted: 29.04 .2019 


\title{
44 Światowy Kongres \\ Międzynarodowego Towarzystwa Hydrologii Medycznej ISMH \\ oraz
}

\author{
XXVII (XXXI) Zjazd Polskiego Towarzystwa \\ Balneologii i Medycyny Fizykalnej
}

\section{“Od badań podstawowych do wyzwań klinicznych"}

\author{
Szanowni Państwo, Drodzy Przyjaciele
}

W imieniu Zarządu Głównego Polskiego Towarzystwa Balneologii i Medycyny Fizykalnej i Uzdrowiska Kopalnia Soli Wieliczka jak również w imieniu Międzynarodowego Towarzystwa Hydrologii Medycznej ISMH z wielka przyjemnością chcielibyśmy Państwa zaprosić do udziału w wyjątkowym wydarzeniu dla Polskiej Balneologii jakim będzie zorganizowany w Wieliczce w dniach 13-16 czerwca 2019 wspólny zjazd ISMH i PTBiMF

Kopalnia Soli Wieliczka oprócz tego, że jest unikalnym zabytkiem wpisanym przez Unesco od 1978 do Światowego Dziedzictwa Kultury jest również zgodnie z decyzję Ministra Zdrowia jedynym na świecie, statutowym podziemnym uzdrowiskiem, w którym od lat leczą się pacjenci z chorobami przewlekłymi, szczególnie z chorobami dróg oddechowych. Miejsce to będzie godną oprawą dla organizacji najważniejszego wydarzenia roku dla światowej balneologii jakim jest coroczny Kongres ISMH. Po raz pierwszy to ogromnej rangi wydarzenie zawita do Polski.

Miejsce Kongresu: Hotel Lenart w Wieliczce oraz Kopalnia Soli Wieliczka

Czas kongresu: 13-16 czerwiec 2019r.

Oficjalny język kongresu: angielski

Główna tematyka zjazdu:

- Nowoczesne leczenie uzdrowiskowe chorób przewlekłych

- Subterranoterapia w leczeniu chorób układu oddechowego

- Postępy w zakresie balneologii, medycyny fizykalnej, bioklimatologii, balneochemii I geologii uzdrowiskowej

- Postępy w badaniach podstawowych w balneologii

- Zagadnienia edukacji zdrowotnej w uzdrowisku.

- Nowoczesne metody zarządzania w uzdrowiskach

Obok bogatego programu naukowego zjazd będzie jak zawsze okazją do wielu spotkań i wydarzeń towarzyskich. Obecność krajowych i międzynarodowych ekspertów pozwoli na zawarcie wielu nowych ważnych znajomości oraz na utrwalenie dotychczasowych relacji.

Pozwoli również na wypromowanie osiągnięć polskiej balneologii na całym świecie.

Jako organizatorzy przewidujemy również bogaty program imprez towarzyszących. Jestem przekonany, że niezapomnianych wrażeń dostarczy Państwu Bal Balneologa, który wyjątkowo zostanie zorganizowany w podziemnej Komorze Warszawa Kopalni Soli Wieliczka. Natomiast Hotel Lenart przygotuje dla Państwa

Grill Party na zakończenie Kongresu. Bliskość Krakowa pozwala na zaplanowanie również w ramach

pobytu na kongresie indywidualnych wizyt w tym najpopularniejszym turystycznie mieście w Polsce.

Wszystkie szczegółowe informacje dotyczące rejestracji, przesyłania streszczeń, opłat zjazdowych oraz programu, naukowego i socjalnego znajdziecie Państwo na stronie internetowej Kongresu udostępnionej na stronie Polskiego Towarzystwa Balneologii i Medycyny Fizykalnej www.balneologia.pl

Do zobaczenia w Wieliczce

Z wyrazami szacunku

Jacek Chojnowski

Prezes PTBiMF 


\title{
EVOLUTIONARY GENETIC APPROACHES TO STUDY THE PROBLEM OF DENTAL CARIES
}

\author{
Nina Perederii, Andrey Zaytsev \\ UKRAINIAN MEDICAL STOMATOLOGICAL ACADEMY, POLTAVA, UKRAINE
}

\begin{abstract}
Introduction: This work has outlined biological aspect in dental caries. Previous research conducted during the XXth century in this direction related to genetic susceptibility of people to tooth caries and gave a positive result. The modern studies on this topic have shown if not impossibility, but the great complexity of genetic factor managing in tooth caries. The aim of the study is to analyze the occurrence of dental caries in an evolutionary aspect and to determine the possibility of using the biological scientific methods for finding the essence of caries phenomenon.

Materials and methods: The material was literary sources with information about caries, which can be used in biological methods of study. The method is the analysis of knowledge from them and their integration with other biological disciplines.

Conclusions: on the basis of the analysis, in which caries was considered for a long period of human evolution, the possibility of managing the carious process, as well as the directions, that would enable a more thorough understanding of the carious phenomenon, were shown.
\end{abstract}

KEY WORDS: dental caries, biology, genetics

Wiad Lek 2019, 72, 5 cz. I, 884-886

\section{INTRODUCTION}

A most problematic place among the modern diseases is occupied by the tooth caries. According to epidemiology reports, almost all living people on our Earth are suffering from dental caries [1], but there are no report of mortality. These circumstances give caries mixed social significance [2]. Therefore, in addition to researchers of this pathology in medicine, many professionals from other fields are working on it as well. For example, archaeologists and anthropologists are engaged in the study of hard tissue biological material (including jaws and teeth) $[3,4]$. Some of the obtained knowledges of modern medicine cannot theoretically justified. And because these phenomena have no clinical significance, they are referred to a sort of curiosities. However, the fact that these "curiosities" change over time in the human population, makes us to take them seriously as well as processes involved in studying $[5,6]$.

Medicine refers to the biological sciences. Biologists noted that «... One of the most important conditions for enhancing the scientific level of the students' knowledge and the effectiveness of the educational process is the didactic integration of knowledge. Relevance of rational directions of integration of Medical Biology with theoretical and clinical disciplines combines with integration processes that occur in Western Europe in recent years « [7].

However, the «biological" knowledge that tooth caries is caused by bacteria or disease manifestation depends on genetics, food consumption and other risk factors is not sufficient to give a good understanding of the pathology and combating dental disease. More over that cariesology itself, having a huge baggage of information being explored, clearly cannot put it into practice: caries treatment is carried out in a way that exists about two thousand years such as replacing lost tooth tissues by restorative material [8].

Allowing for the situation, researchers of caries pathology believe that failure to resolve the problem of tooth caries is at the conceptual level [9]. Therefore, it is more appropriate and relevant is the situation that integration is not only in the didactics as well as in the study of caries phenomenon involving biological scientific methods.

\section{THE AIM}

The aim of the study: to determine the possibility of using biological scientific methods for finding the essence of caries phenomenon.

\section{MATERIALS AND METHODS}

The literary sources are materials for study of the subject. Analysis of these literary sources and integration of knowledge serves as a method of research.

\section{REVIEW AND DISCUSSION}

Cariesology has the knowledges obtained in the study of dental caries by means of twin method. On this issue, a variety of views have been expressed in Russian-speaking literature, the most fully in the work of G. Pakhomova and co-authors. The measure of influence of genetic factors on 


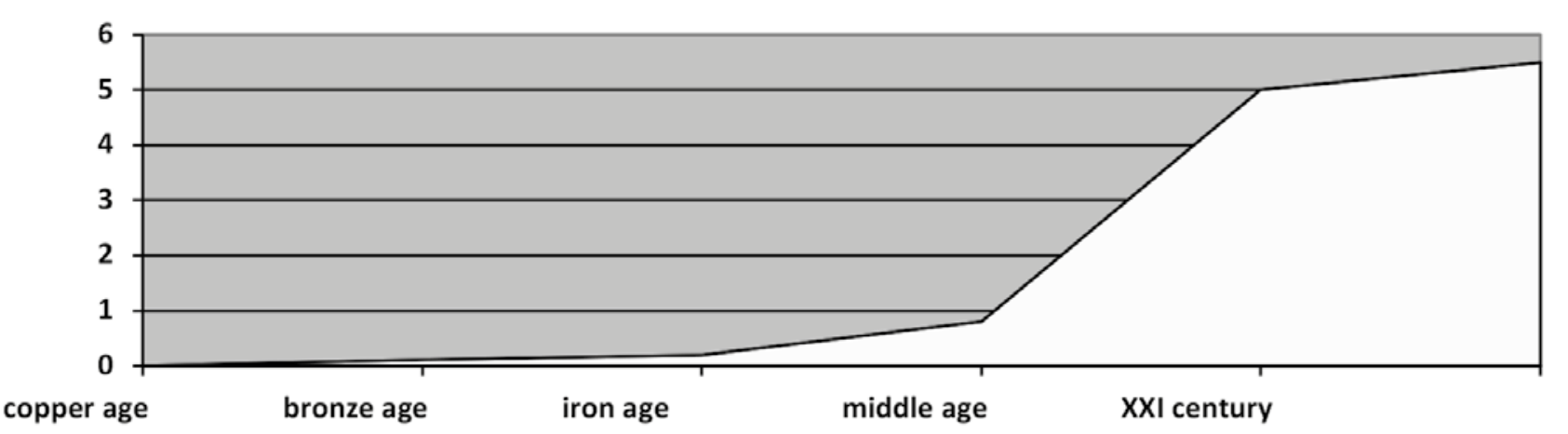

Figure 1. A graph of changes in caries intensity.

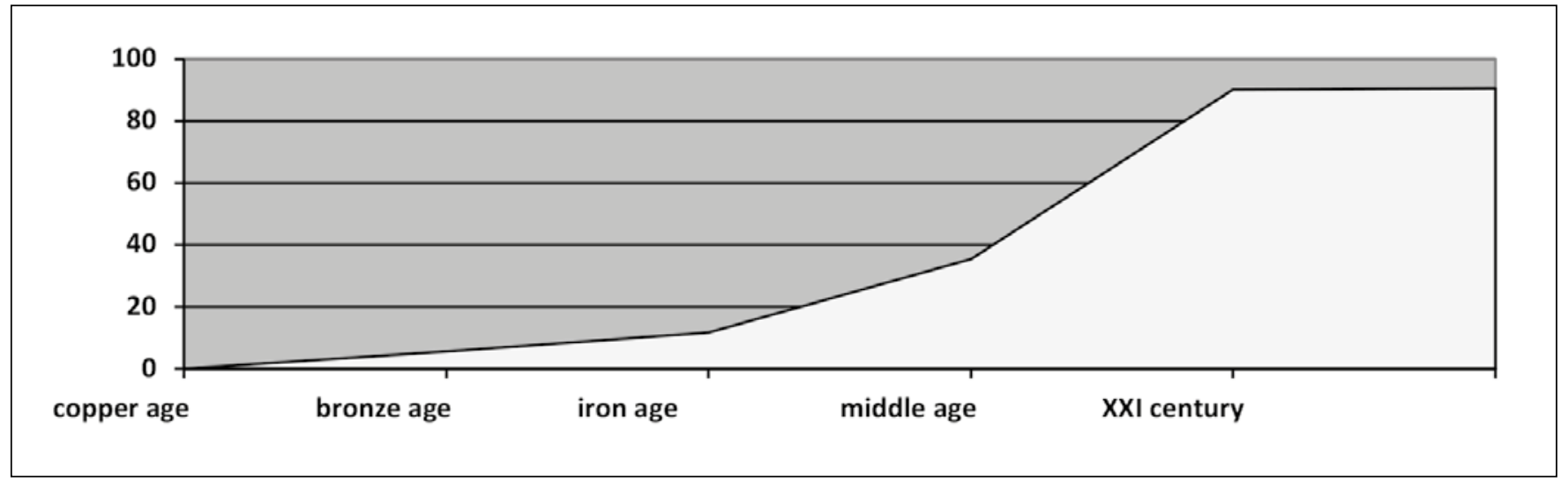

Figure 2. A graph of changes in caries prevalence (\%).

the occurrence of disease is considered to be the ratio of the frequency of its occurrence in pairs of homozygous twins and the same indicator from heterozygous twins. Matching cases of illness (so-called concordance trait) among homozygous twins is $100 \%$ for genetic pathologies, whereas heterozygous concordance virtually zero.

For diseases caused by external (damaging) factors correlation proves otherwise: in all cases equally concordance is low, regardless of twin zygocity. Between these poles of endo- and exogenous diseases are all known nosologic forms. They differ on the basis of genetic determinism, ranging from nonexistent to absolute predestination. Findings regarding tooth caries on the basis of these methodologies are unambiguous: tooth caries is largely genetically predetermined. Significant is the fact that the work of G. Pakhomova was presented as the first message. Further development of the ideas contained in it, and not followed [9].

There is just a limited number of studies of the researches about clinical and pathogenetic mechanisms of development of caries in children with Psychoneurological disorders (PND) presented in medical literature [10]. A study of dental status of children with PND and medico-social data passports allowed E. Denisova in 2011 year to identify the managed and unmanaged risk factors that contribute to the development of caries and periodontal disease. Managed risk factors of development of caries in children with PND author characterised as a high activity of caries microflora, increased rate of formation of tooth plaque, low resistance of tooth enamel against relatively low remineralization ability of saliva.

The most important unmanaged risk of caries and periodontal disease were identified as particular somatic status of a child, socio-economic factors (e.g., low standard of living of families) and genetic factors [11].

In 2012, A. Artemyev was defended thesis for the degree of Candidate of Medical Sciences on the theme «The evolutionary features of development of caries in humans.» There are 499 researches of dental caries in ancient people (from the Copper Age to the Middle Ages) served as background materials. The remains were found as a result of the protective archaeological excavations on the territory of Ukraine. On the basis of the data obtained, the comparative multifactorial mathematical analysis (method of pointed graphs) of pathology were completed using odontological fossil and subfossil materials [12].

According to these studies were drawn graphics. Of particular interest are the following cases: Figure 1 presents the changes in the intensity of caries from Copper Age to predict for future periods. Figure 2 presents the changes in the prevalence of caries from Copper Age to predict for future periods.

The evolution of tooth caries has been evident in the graphs. We see that carious process during its evolution in 
the selected range of human population has made major quantitative and qualitative changes.

One can see in the Figure 1 a surge of intensity of caries process from XVII to XXI century, and then it ascent became slow. The intensity of the caries process shows the reactions of the human body.

Figure 2 is very similar to Figure 1 but there are differences: in the Middle Ages the rise of the incidence of dental caries is not so dramatically, rather than its intensity. But from XXI century the rise in prevalence was also slower than the rise of intensity. The prevalence of caries process shows the reactions of the human population.

Two graphics indicate another interesting thing - to the XVII century caries was a real dental caries. But from XXI century it is another qualitative phenomenon which has already found a title - carious disease.

\section{CONCLUSIONS}

Drawing a conclusion, we would like to highlight the following point:

1. The statement about caries determinism has been well documented.

2. This direction in cariesology is not developed to the full extent.

3. It is likely that this situation is linked with the inability of genetic factors.

4. Changing of the caries process in the evolution of the human population indicates the ability to control, including at the genetic level.

The fact that tooth caries is associated with human genetics, referred to the possibility of research using biological methods. These methods apply to both organismal and population levels. Inaccessibility, but the ability to control tooth caries at these levels are not well known and are under discussion. The development of the given direction will be associated primarily with the measurement of tooth caries. A proven genetic determinism of tooth caries is proved. The ability to manage of caries process is proposed at the genetic level.

\section{REFERENCES}

1. Petrushanko T, Chereda V, Loban G. Yakisniy sklad microbiocenozu porozhnini rota osib molodogo viku z riznoyu intensivnistyu kariesu [Qualitative composition of microbiocenosis of the mouth of persons of young age with different caries intensity]. World of Medicine and Biology. 2013; 1: 57-58.

2. Terapevtichna stomatologiya: Pidruchnik dlya studentov stomatologichnih facultetov vishchih medichnih navchalnih zakladiv IV akreditatsii u dvoh tomah [Therapeutic dentistry: A textbook for students of dental departments of Higher Medical Education Institutions of IV level of accreditation in two volumes / Edited by prof. A.K. Nikolyshin]. Poltava: «Divosvit»; 2005, 392.

3. Buzhilova A. Homo sapiens: istoriya bolezni [Homo sapiens: history of disease]. M.: Languages of Slavic culture; 2005, 320.
4. Ronlin D. Bolezni drevnih lyudey [Diseases of ancient people] Science; 1965, 305.

5. Zaitsev A, Kotelevskaya N, Boichenko 0 et al. Antagonism Dyubua v sovremennih usloviyah [Dubois antagonism in modern conditions] Ukrainian Dental Almanac. 2016; 1 (1);33-36.

6. Okushko 0. K «teoreticheskoy stomatologii» [To «theoretical dentistry»]. New in dentistry. 2003; 4:4-6.

7. Dubinin S., Vacenko A., Ulanovska-Cyba N.Vyrishennya deyakyx problem integraciyi navchannya pry vykladanni medychnoyi biologiyi [Solving some problems of integration in the teaching of medical biology]. Materialy dopovidejVseukrayinskoyi naukovo-praktychnoyi konferenciyi z mizhnarodnoyu uchastyu «Suspilstvo i medycyna: dialog v umovax yevrointegraciyi». 2015: 31- 33.

8. Mamedova L. Karyes zubov y ego oslozhnenyya (ot drevnosty do sovremennosty) [Dental caries and its complications (from antiquity to the present)]. Medycynskaya knyga. 2002:192.

9. OkushkoV.Nasledstvennuj faktor karyesav kachestve эpygenetycheskogo fenomena. [Hereditary caries factor as an epigenetic phenomenon] Innovaciyi v stomatologiyi. 2013; 1: 43-46.

10. Savychuk N., Dzyuba C. Stepanenko L. Ocenka stomatologycheskogo statusa detej s psyxonevrologycheskymy rasstrojstvamy. [Assessment dental status of children with neuropsychiatric disorders]. Sovremennaya stomatologyya. 2011; 4:46-50.

11. Denysova E., Olejnyk E. Opredelenye ryska razvytyya karyesa u detej $s$ syndromom Dauna. [Determining the risk of caries development in children with Down syndrome]. Nauchnue vedomosty BeIGU. 2011;6 (111):69-77.

12. Artemyev A. Evolyutsiyni osoblivosti rozvitku zahvoryuvan na karies zubiv u lyudini: avtoref. dis. na zdobuttya stupenya cand. med. nauk: spets. 14.01.22 «Stomatologiya» [Evolutionary peculiarities of the development of diseases of dental caries in humans: author's abstract for obtaining the degree of candidate of Medical Sciences: specialty 14.01.22 «Stomatology»]. Poltava: 2012, 19.

13. Zajcev A., Perederyj N., Vacenko A. et. al. Yspolzovanye stomatologycheskyx pokazatelej $v$ byologyy [Use of stomatological indexes in biology]. Wiad Lek. 2018; LXXI (5): 1099-1103.

Authors' contributions:

According to the order of the Authorship.

Conflict of interest:

The Authors declare no conflict of interest.

\section{CORRESPONDING AUTHOR Nina Perederii}

Ukrainian Medical Stomatological Academy

Shevchenko 23 str., 36011 Poltava, Ukraine

tel: +380683488826

e-mail:perederii.nina@gmail.com

Received: 12.03 .2019

Accepted: 26.04 .2019 
PRACA POGLĄDOWA

REVIEW ARTICLE

\title{
MODERNIZATION OF STATE ADMINISTRATION SYSTEM IN THE HEALTH CARE SPHERE OF UKRAINE
}

\author{
Serhii V. Knysh', Sergiy M. Gusarov' ${ }^{2}$, Nikolay L. Shelukhin ${ }^{3}$, Ivan F. Kharaberiush', Viktoriia R. Bila ${ }^{4}$ \\ 1 RIVNE INSTITUTE OF THE KIEV UNIVERSITY OF LAW OF THE NATIONAL ACADEMY OF SCIENCES OF UKRAINE, RIVNE, UKRAINE \\ ${ }^{2}$ KHARKIV NATIONAL UNIVERSITY OF INTERNAL AFFAIRS, KHARKIV, UKRAINE \\ ${ }^{3}$ MARIUPOL STATE UNIVERSITY, MARIUPOL, UKRAINE \\ ${ }^{4}$ UNIVERSITY OF THE STATE FISCAL SERVICE OF UKRAINE, IRPIN, UKRAINE
}

\begin{abstract}
Introduction: A new medical reform started in Ukraine from January 1, 2018, new bills were drafted and the current legislation was amended. The legislator began to gradually abandon organizational and legal ways to improve the functioning of medical institutions in order to develop the market of medical services, as well as to ensure the protection of patients' rights. The main issue of health care reform was the improvement of state administration, in particular the creation of new mechanisms for financing medical institutions.

The aim: The objective of the article is to conduct theoretical study of the specific features of state administration in the health care sphere in Ukraine and to substantiate practical recommendations for its improvement taking into account the European integration processes.

Materials and methods: The author of the article has used the methods of analysis and synthesis, as well as a comparative legal method. The analysis of the current legislation and world experience in reforming the medical sector assisted to determine the problematic issues of this publication, as well as to formulate the author's point of view on the ways to improve state administration through the health care system under conditions of medical reform in Ukraine.

Review: The author has studied the directions for the modernization of state administration by the health care system in the context of medical reform in Ukraine.

Conclusions: It has been emphasized that the management reform by its nature does not pay enough attention to ensuring the medical rights of citizens, as evidenced by the legislation's provisions regulating the access to a patient data. Improving public administration of the health care sphere is possible through the involvement of a group of international experts from among the EU Member States to determine the optimal mechanism for transitioning to the system of compulsory state health insurance.
\end{abstract}

KEY WORDS: state administration, health care institution, health protection system, medical reform, organization model of the health protection system

Wiad Lek 2019, 72, 5 cz. I, 887-891

\section{INTRODUCTION}

The relevant issue while implementing medical reform in Ukraine is the improvement of public administration in the health care sphere. Different aspects of this problem were studied in the scientific works of Z.S. Hladun, V. Ye. Kovrihina, B.O. Lohvinenko, O.A. Melnychenko, I.M. Prashycha, V.I. Teremetskyi, V.V. Shevchuk and other scholars. However, the ongoing reform of the health care system in Ukraine requires the introduction of new management methods to increase the level of guaranteeing medical rights of Ukrainian citizens. Problems of legal regulation of medical activity determine the search for ways to improve the system of ensuring and protecting patients' rights and can not be solved without analyzing the legal status of subjects of management activity in the health care sphere in Ukraine, which determines the relevance of this study. In particular, there is still no adequate scientific substantiation of the effectiveness of the National Health Service, its powers and interaction with other subjects of state administration in the health care sector of Ukraine.

\section{THE AIM}

The objective of the article is to study the specific features of state administration in the health care sphere in Ukraine and to substantiate practical recommendations for its improvement taking into account the European integration processes.

\section{MATERIALS AND METHODS}

The author of the article has used methods of analysis and synthesis, as well as a comparative legal method. The analysis of the current legislation and world experience in the medical sector reform assisted to determine the problematic issues of this publication, as well as to formulate the author's point of view on the ways to improve state administration through the health care system under conditions of medical reform in Ukraine.

\section{REVIEW}

Legal provision of managerial relations in the health care sphere is one of the directions of state authorities' activity 
in any country. Therefore, it is important that the medical reform implemented in Ukraine is aimed at improving the institution of public administration in the health care system and modernizing the management tools applied by its subjects.

The majority of scholars in scientific literature understand the executive authorities as the subjects of management activity in the health care sphere. It is explained by the fact that state administration involves the direct administrative influence on the objects of management using administrative and authoritative powers and methods, which are marked by the directive instructions, binding for execution.

Other state authorities (for example, the President of Ukraine, Verkhovna Rada of Ukraine) carry out state regulation, which involves the establishment of certain rules of conduct. At the same time, state regulation of social relations is mainly carried out through the adoption of relevant legislative acts [1, p. 73]. We note that a significant role in the adoption of normative and legal acts belongs to the executive authorities in the health care sphere, namely, the Ministry of Health of Ukraine. Therefore, within the limits of administrative activity, the executive authorities carry out state and legal regulation of their activities, besides the instruments of direct administrative influence on the objects.

This statement has been reflected in the current national health care legislation. For example, the Art. 4 of the Law of Ukraine "On Medical products" is entitled "State Administration in the Field of Creation, Production, Quality Control and Sales of Medical Products" and consists of three parts. Part 1 of the Art. 4 states that Verkhovna Rada of Ukraine defines the state policy and implements the legislative regulation of relations in the field of creation, production, quality control and sale of medical products" [2]. Parts 2 and 3 of the Art. 4 notes that the Cabinet of Ministers of Ukraine and other central executive authorities carry out state administration on the relevant issues.

This indicates to the fact that one of the areas of state administration exercised by the Cabinet of Ministers of Ukraine and other central executive authorities in the health care sphere is the state and legal regulation of the relevant issues [3, p. 65]

The system of public administration of the health care sphere and the need for its reform is revealed in most scientific works through the prism of sources of financing the medical sector.

Considering the classification of management systems by the type of financing, we note that Ukraine in contrast to the EU Member States that successfully implemented the transition from the budget health care system to the system of the state health insurance (Latvia, Lithuania, Estonia, etc.), still does not have the conceptual vision of the system that has to be created instead of the current one.

Today, the main task of the state - is to provide high-quality medical care at all levels and a decent salary to physicians. That is the reason why the Ministry of Health of Ukraine introduces systemic changes in the health care.
First of all, we are talking about the reform in financing within the health care system [4].

According to the Concept of Health Care Financing Reform in Ukraine, approved by the Cabinet of Ministers of Ukraine on November 30, 2016, No. 1013-p, a budget model for health care financing was introduced. This model involves financing of the health care for all categories of people from the general tax revenues to the state budget. At the same time, the bulk of medical institutions are state-owned.

However, back in 2005, researchers in the health care sector paid attention to the need to transform existing state and municipal health care institutions, from budget-financed, into non-commercial business entities operating without budget funding. Researchers in the law sphere grounded the necessity of the existence of medical institutions as subjects of entrepreneurial activity, in terms of their creation as the subjects of private law, focusing on contracts for state orders for medical care [5, p. 227].

One of the first steps towards qualitative changes in the health care system was the adoption of the Law of Ukraine dated from April 6, 2017 "On Amendments to Certain Legislative Acts on the Improvement of Legislation Regarding the Activities of Health Care Institutions", where paragraph 2 of the Final Provisions states that the state and municipal health care institutions - budget institutions can be reorganized into state-owned enterprises or municipal non-profit enterprises. That is, state and municipal health care institutions are granted the right to become autonomous [6]. However, in accordance with clause 2 of the Final and Transitional Provisions of the Law of Ukraine dated from October 19, 2017 "On State Financial Guarantees of Medical Care of the Population", municipal health care institutions, which have not concluded agreements on medical care with the Authorized Agency, may temporarily, during 2018-2019 period according to the decision of the Cabinet of Ministers of Ukraine, fund the provision of primary health care by subventions from the state budget to the relevant local budgets [7]. That is, the state, having foreseen the right of the state and municipal health care institutions to reorganization and obtaining more autonomy, has created the conditions that encourage these institutions to exercise their right.

In order to fulfill the mediator's functions between the state and health care institutions the National Health Service of Ukraine (hereinafter - NHSU) was established in 2017. NHSU is the central executive agency that implements state policy in the field of state financial guarantees of medical care of the population. Activities of the NHSU are directed and coordinated by the Cabinet of Ministers of Ukraine through the Minister of Health.

We note that the budget has more than 15 billion hryvnias in 2019 for the needs of primary health care institutions. This money will be distributed by the NHSU in accordance with the concluded agreements. Money will not be provided without an agreement with the NHSU, because a medical subvention for institutions of primary level in this year is not provided [8]. 


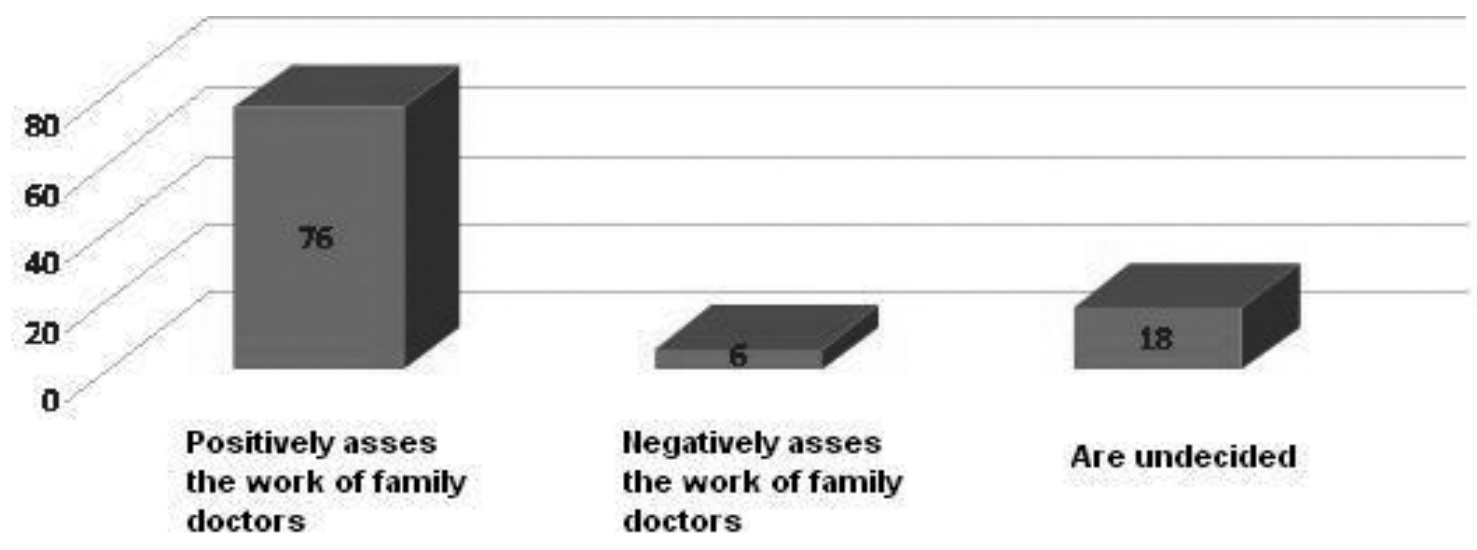

Fig 1. Assessment of Family Doctors' Activities in Ukraine.

Consequently, the state-owned or municipal medical institutions, unlike private ones, have no freedom to choose whether or not to sign an agreement with the NHSU. The latter receives a financial leverage over the provision or non-provision of funds to a health institution. This makes health care institutions to some extent dependent on the policy of the NHSU and deprives the actual autonomy in managerial affairs.

On the other hand, the activity of the NHSU as a manager of funds that a health care institution may receive, should be subordinated and accountable for minimizing corruption risks.

As we know, ineffective control over the reform of medical care at the first level has led to a number of problems, including an artificial increase in the number of affiliated patients to improve the financial support for physicians, the actual lack of the possibility to treat a fixed number of patients (for example, in an acute epidemic period), an imbalance in the wages of average medical staff and physicians, as well as general practitioners at the primary level and specialized specialists of the second and third level [9].

\section{DISCUSION}

The Ministry of Health of Ukraine plans in 2019 to introduce new electronic instruments: electronic recipe, patient card and referral [10]. At first glance, this is a significant positive, but after analyzing the ability of citizens living in rural areas to receive an electronic recipe or an elderly person to fill out an electronic form, one can conclude that it is impossible to take advantage of these innovations to the full extent within the specified timeframes. Free courses for improving computer literacy are held in city libraries for the elderly people in some European countries, in particular in Latvia. Of course, the average domestic pensioner will not be able to effectively implement his own medical rights due to the low level of computer skills and the lack of the access to the Internet in certain areas.

The European Union has effectively implemented the "E-Health" system, which provides electronic document circulation in the health care sphere in many vectors and greatly simplifies the overall management of this area. But the introduction of telecommunication technologies requires significant financial costs and the construction of a secure network between medical institutions to ensure the safety of personal data of patients [4].

According to the survey conducted in 2017, it was determined that $82 \%$ of surveyed Ukrainians supported the view that domestic medicine was not functioning and needed reform.

Such indicators were based on the fact that not all the population was fully informed about the nature of the reforms, and due to technical problems with electronic registries the process became more complicated. Besides, the new legislation has gaps and conflicts that do not allow the most effective resolution of relations that arise in the health protection sphere $[11$, p. 156].

Thus, according to Part 2 of the Art. 11 of the Law of Ukraine "On State Financial Guarantees of Medical Care of the Population" dated from October 19, 2017, No. 2168VIII, the access to patient data contained in the electronic health care system is possible only if there is the consent of a patient (his legal representative) obtained in a written form or in a form that allows to conclude about the obtained consent. The access to information about the patient is possible without the consent: in case there is evidence of a direct threat to the patient's life, in case that the consent of a patient or his legal representatives can not be obtained (until the time when the consent is possible) or by a court decision [7].

Considering the fact that only one of the listed cases is sufficient to obtain the access to information about a patient without his consent, the direct threat to the patient's life is not related to the inability to obtain such a consent. That is, even when the patient is conscious, but his life is under the direct threat, his consent to the access to personal data is not required.

Therefore, there is a need to ensure the patient's right to informed voluntary consent of the latter for medical intervention - consent of the patient or (in clearly defined cases) his legal representative for medical intervention, methods of such intervention, related to it risk and possible alterna- 
tive treatment methods [12, p. 14]. More thoroughly this issue is highlighted in the scientific work of V.I. Teremetskyi and O.Ye. Avramova [13].

The Council of Europe, a member of which is Ukraine since 1995, issued the "Recommendations of the Committee of Ministers to Member States on managing patients' safety and preventing adverse events in the health care sphere" dated from May 24, 2006, which emphasized the importance of: 1) policy formulation in the health care sphere, aimed at improving the quality of medical treatment; 2) the development of well-defined limits for patient's safety, which would contribute to the culture of safety at all levels of health care [14].

In addition, the European Charter of Patients' Rights (2002) has led to the development of the institution of Ombudsman for the Rights of Patients in European States. Since the ratification of the European Social Charter by Ukraine in 2006, the state has undertaken the duty to ensure the effective execution of the right to health care and the right to social and medical assistance [14].

Taking into account the above, it is believed that the aim of improving the state mechanisms for ensuring and protecting the patients' rights is to enshrine the patients' rights with a special Law of Ukraine "On Guarantees of Patients' Rights" and the establishment of the institution of the Medical Ombudsman - the Ombudsman for Patients' Rights.

At the same time, according to the survey results of the sociological group "Rating", $76 \%$ of patients who have chosen family doctors in 2018 are satisfied with them, $18 \%$ hesitate to assessments, and only $6 \%$ expressed dissatisfaction (Fig.1) [15].

At the same time, among the changes that patients received after the reform, they indicated a more responsible attitude of the physician to patients, better conditions for admission (repair, modern equipment), free laboratory tests, etc. [15].

Considering the perspectives for reforming the health care system, it should be noted that in the future - there is the reform of ambulance, the work of specialized and highly specialized medicine and the improvement of state regulation of procurement of medical products [4].

\section{CONCLUSIONS}

Thus, the reform of the health care system in Ukraine is carried out on theoretical and practical levels. Nowadays, the legislator has made important steps towards modernizing state administration in the health care sphere, but the national vector of reform does not take into account advanced European practices in the medical sector. In particular, it is about introduction of compulsory state health insurance.

The authors of the article have found out that the management reform by its nature does not pay due attention to the provision of medical rights of citizens, as evidenced by the provisions of the legislation regulating the access to patient data.
Improvement of public management in the health care sphere is possible due to the involvement of a group of international experts from among the representatives of the EU Member States in order to determine the optimal mechanism for transition to the system of compulsory state health insurance. The authority and the status of the National Health Service of Ukraine should be reviewed, and the main criterion for assessing the effectiveness of the reform should be not the time for a full transition to the health insurance system, but the level of ensuring medical rights of Ukrainian citizens.

\section{REFERENCES}

1. Hladun Z.S. Kontseptualni zasady derzhavno-pravovoho rehuliuvannia vidnosyn u sferi okhorony zdorovia naselennia [Conceptual principles of the state and legal regulation of relations in the health care sphere. Medical law of Ukraine: problems of formation and development]. Medychne pravo Ukrainy: problemy stanovlennia ta rozvytku. Materialy I Vseukrainskoi naukovo-praktychnoi konferentsii 19-20 kvitnia 2007 r., m. Lviv. 2007: 73-79 (In Ukrainian).

2. Pro likarski zasoby [0n Medicinal Products]: zakon Ukrainy vid 04.04.1996 № 123/96-BP. Available from: https://zakon.rada.gov.ua/ laws/show/123/96-\%D0\%B2\%D1\%80 (In Ukrainian).

3. Hanna Sarybaieva. Derzhavno-pravove rehuliuvannia u sferi okhorony zdorovia: postanovka pytannia [State regulation of the health protection: basics of the problem]. Natsionalnyi iuridicheskii zhurnal: teoriia i praktika. 2018; № 2-1 (30):64-67 (In Ukrainian).

4. Serhii Knysh. Udoskonalennia publichnoho upravlinnia sferoiu okhorony zdorovia v Ukraini: analiz reformy ta yevroperspektyvy [Improving public health management in Ukraine: analysis of reforms and European perspectives]. Aktualni problemy pravoznavstva. 2019; № 1 (In Ukrainian).

5. Kovryhina V. Ye. Administratyvno-pravove rehuliuvannia ekstrenoi medychnoi dopomohy [Administrative and legal regulation of the emergency medical treatment]. D.Sc (Ph.D.) dissertation. Kyiv. 2017: 227 (In Ukrainian).

6. Pro vnesennia zmin do deiakykh zakonodavchykh aktiv shchodo udoskonalennia zakonodavstva z pytan diialnosti zakladiv okhorony zdorovia [On amending some legislative acts for improving the legislation on the activit of health care institutions]: zakon Ukrainy vid 06.04.2017 № 2002-VIII. Available from: https://zakon.rada.gov.ua/ laws/show/2002-19 (In Ukrainian).

7. Pro derzhavni finansovi harantii medychnoho obsluhovuvannia naselennia [On State Financial Guarantees of Public Health Care]: zakon Ukrainy vid 19.10.2017 № 2168-VIII. Available from: https://zakon.rada. gov.ua/laws/show/2168-19 (In Ukrainian).

8. Korpusenko B. Pershyi etap medychnoi reformy zavershuietsia. Hroshiydut za patsiientamy v statsionary. UNIAN. Available from: https://hromadske. ua/posts/pershij-etap-medichnoyi-reformi-zavershuyetsya (InUkrainian).

9. Medychna reforma vzhe maie rezultaty, a protiahom 3-5 rokiv ukraintsi vidchuiut novu yakist medychnykh posluh, - Volodymyr Hroisman. Available from: https://www.kmu.gov.ua/ua/news/medichna-reformavzhe-maye-rezultati-protyagom-3-5-rokiv-ukrayinci-vidchuyut-novuyakist-medichnih-poslug-volodimir-grojsman (In Ukrainian).

10. «Skoro my zabudemo pro rozmezhuvannia na derzhavni i pryvatni likarnis: interviu z Pavlom Kovtoniukom. Available from: https://ukr. segodnya.ua/ukraine/-skoro-my-zabudem-o-razgranichenii-nagosudarstvennye-i-chastnye-uchrezhdeniya-intervyu-s-zamestitelemministra-zdravoohraneniya-pavlom-kovtonyukom-ch1-1205395.html (In Ukrainian). 
11. Teremetskii V.I., Muzychuk A.N., Salmanova E.lu., Kaznacheeva D.V., Knysh S.V. Ukreplenie dogovornykh nachal v pravootnosheniiakh mezhdu patsientom i lechebnym zavedeniem pri reformirovanii sistemy zdravookhraneniia v Ukraine [Strengthening of contractual principles within legal relations between a patient and a medical institution while reforming the health care system in Ukraine]. Georgian Medical News. 2018; № 11 (284): 155-159 (In Georgian).

12. Parashchych I.M. Derzhavni mekhanizmy zabezpechennia ta zakhystu prav patsiientiv v Ukraini: stan i tendentsii rozvytku [State mechanisms of ensuring and protecting the rights of patients in Ukraine: state and tendencies for the development]. D.Sc (Ph.D.) dissertation author's abstract. Kyiv. 2009: 23 (In Ukrainian).

13. Vladyslav T., Avramova 0. Informed voluntary consent for medical intervention. Advanced research biobank and pathophysiology. 2018; No 1 (February): 72-78.

14. Diialnist ombudsmena z prav patsiientiv yakzasib rehuliuiuchoho vplyvu derzhavy. Available from: https://www.apteka.ua/article/339724 (In Ukrainian).

15. Medychna reforma: yak zminylasia sfera okhorony zdorovia za rik. Available from: https://24tv.ua/health/medichna_reforma_v_ ukrayini_2018_plyusi_i_minusi_novoyi_medreformi_v_ukrayini_ n1081833 (In Ukrainian).

\section{Authors' contributions:}

According to the order of the Authorship.

\section{Conflict of interest:}

The Authors declare no conflict of interest.

\section{CORRESPONDING AUTHOR} Serhii V. Knysh

Rivne Institute of the Kiev University of Law of the National Academy of Sciences of Ukraine 5, Korolenko str., Rivne, 33028, Ukraine tel: +380503784730

e-mail:s.knush@ukr.net

Received: 08.03.2019

Accepted: 01.05.2019 


\title{
MODERN APPROACHES TO TREATMENT OF PSEUDOMONAS AERUGINOSA VENTILATOR-ASSOCIATED PNEUMONIA (LITERATURE REVIEW)
}

\author{
Olha A. Poda, Tetyana 0. Kryuchko, Inna N. Nesina, Olha Ya. Tkachenko, Nataliia V. Kuzmenko \\ UKRAINIAN MEDICAL STOMATOLOGICAL ACADEMY, POLTAVA, UKRAINE
}

\begin{abstract}
Introduction: Nowadays anti-microbial therapy of ventilator-associated pneumonia caused by is one of the most topical issue as a consequence of widespread multiresistant strains of causative agent and their biological peculiarity of actively formation of resistance to new antibacterial drugs.

The aim is to describe modern approaches to therapy of ventilator-associated pneumonia causative agent of which is presented by Pseudomonas aureginosa .

Materials and methods: An analysis and summing up of results of scientific investigations described in medical publications concerning the issues of therapy of ventilatorassociated pneumonia caused by Pseudomonas aureginosa was done.

Conclusions: Despite the development of modern approaches to anti-microbial therapy of ventilator-associated pneumonia caused by Pseudomonas aeruginosa, which are also concerned with such controversial issues as correct choice of antibacterial drug, its optimal dose, and duration of this therapy, the problem of treatment of hospital-acquired infections of respiratory airways caused by Pseudomonas aeruginosa has been discussable yet and requires the further study.
\end{abstract}

KEY WORDS: ventilator-associated pneumonia, Pseudomonas aeruginosa, treatment

Wiad Lek 2019, 72, 5 cz. I, 892-896

\section{INTRODUCTION}

According to the existing definition of hospital-acquired pneumonia, it is considered to be pneumonia acquired in a medical institution 48 hours after the patient is hospitalized in case of the absence of any infectious disease during the incubation period and at the time of the patient's hospitalization. One of the varieties of hospital-acquired pneumonia is ventilator-associated pneumonia (VAP) - a special form of the disease which stands out, taking into account the severity of its course, the seriousness of the prognosis and the features of the management of reanimation patients. According to the results of the studies, the main pathogenic microorganisms in VAP are gram-negative bacteria (up to 74\%), whose structure is dominated by Pseudomonas aeruginosa, as well as Klebsiella and E. coli. Among gram-positive microorganisms, VAP is most often caused by methicillin-resistant golden Staphylococcus (MRSA) [1,2].

Pseudomonas aeruginosa is a typical species of the genus Pseudomonas, gram-negative aerobic bacterium, widely known associative microorganism of various ecological niches in humans, animals and the environment, which is also widely used as a causative agent of opportunistic infections in medical practice. The presence of multiple molecular mechanisms of pathogenicity, the unique ability to adapt to different environmental conditions, as well as high resistance to various classes of antibac- terial drugs, allows Pseudomonas aeruginosa to persist for a long time inside hospital wards. Hospital-acquired infections caused by Pseudomonas aeruginosa at the present stage are recognized as an urgent and acute problem and occupy one of the leading positions in the structure of hospital-acquired pneumonia in hospitals of various profiles $[2,3,4]$. The frequency of detection of pseudomonas infection in patients with hospital-acquired pneumonia is quite high and according to the results of foreign researchers it ranges from 10 to $35 \%$ [5]. A recent conducted study has shown that mortality from VAP associated with Pseudomonas aeruginosa has increased to $41.9 \%$ in recent years, and as independent predictors of increased mortality researchers consider an increase in patient age and initially inadequate antibiotic therapy in patient management [6].

Antimicrobial therapy of ventilator-associated pneumonia caused by Pseudomonas aeruginosa is today a very topical problem due to the widespread spread of multi-resistant strains and their biological peculiarity to actively form resistance to new antibacterial drugs. At the present stage, a large number of studies is devoted to the problem of ventilator-associated pneumonia therapy. At the same time, recommendations for the management of patients with VAP dynamically change and are regularly supplemented, which is facilitated by the development of innovative medical technologies and the appearance of new antibacterial drugs. 


\section{THE AIM}

The aim of the research is to highlight the main modern therapeutic approaches and the prospects for further directions of treatment of ventilator-associated pneumonia, the causative agent of which is Pseudomonas aeruginosa.

\section{MATERIALS AND METHODS}

A thorough comprehensive analysis and synthesis of the results of conducted scientific researches, covered in fundamental medical publications concerning the treatment of ventilator-associated pneumonia caused by pseudomonas infection, was carried out.

\section{REVIEW AND DISCUSSION}

The latest recommendations for anti-bacterial therapy for ventilator-associated pneumonia (VAP) were developed in 2005 by the American Thoracic Society and the Society of Infectious Diseases of America, which recommend combination therapy of VAP with antipseudomonal cephalosporins (cefepime, ceftazidime) or carbapenems (iepenem, or by perennial venting tubes. $\beta$-lactamase inhibitor (piperacillin-tazobactam) plus antipseudomonal fluoroquinolones (ciprofloxacin or levofloxacin) or aminoglycosides (American Thoracic Society; Infectious Diseases Society of America, 2005). However, since the publication of these recommendations, many conclusions have been made in the field of antibiotic therapy in critically ill patients, including inadequate treatment for reasons of insufficient dosage and non-optimal antibiotic exposure, which, as a result, are associated with increased mortality and worse results $[7,8]$. In addition, the steady growth of multidrug-resistant bacteria strains against hospital-acquired pneumonia makes this approach obsolete.

According to the current general recommendations in the treatment of VAP, it is also necessary to avoid prescription of antibiotics to which the patient has been exposed for the last 30 days, since new episodes of the disease, as a rule, are relapses of a strain with different phenotypic variations, and not a consequence of reinfection. A study conducted in 2013 revealed the main risk factors for the ineffectiveness of VAP therapy, which included the patient's age, the presence of chronic pathologies, the severity of the disease, previous use in the treatment of fluoroquinolones and bacteraemia. Interestingly, neither the definition of antibiotic sensitivity nor the use of combination therapy influenced the frequency of ineffective cases of VAP therapy, while at the same time, treatment with fluoroquinolones significantly reduced it [9]. In our opinion, in order to avoid the irrational use of antibacterial drugs, it is necessary to adhere to an integrated approach, taking into account not only the classical microbiological paradigm, based only on the susceptibility to the drug and the minimum inhibitory concentration, but also having assessed certain risk factors for multidrug resistance.

Undoubtedly, timing is an important condition for successful treatment - effective therapy started timely and at the earliest possible time makes the difference between recovery and lethal outcome, especially in the presence of a patient's shock condition [10]. To date, there are already published data confirming the fact that the delay in effective therapy significantly increases the incidence and mortality rate among patients with VAP [11]. The empirical choice of the prescribed agent is also fundamental, which is based on taking into account the most likely pathogens and their perceived sensitivity to available antimicrobial agents. The results of a recent multicentre research on the study of potentially resistant microorganisms in patients with VAP have shown that late VAP (developing no earlier than the 6th day of hospitalization) is in most cases caused by aerobic gram-negative flora, 70\% of which are Pseudomonas aeruginosa, Acinetobacter baumannii or MRSA [12]. When prescribing a starting antibiotic, we are obliged, first of all, to take into account its activity in relation to the most probable pathogens, the degree of effectiveness and timing of the use of previous antibiotics, the presence of comorbidities in a patient, the duration of hospitalization, and local epidemiology. In particular, the most reasonable approach is the use of a broad-spectrum antibiotic based on local microecology with subsequent re-evaluation of the clinical response and microbiological data after 48-72 hours [13].

Undoubtedly, patients with VAP need a special therapeutic approach, since its pathogens are characterized by multidrug resistance. According to the results of many studies and meta-analyzes, empirical combination therapy of VAP caused by pseudomonas infection with beta-lactams plus aminoglycosides proved to be more effective than monotherapy, making it possible to reduce mortality rates by $50 \%$, mainly due to the corresponding initial therapy $[13,14]$. However, according to some researchers, there is no difference between using one or two effective antibiotics, which serves as a basis for de-escalation to monotherapy as soon as microbiological results are ready [13].

Another important point of the therapy is also the optimization of the choice of antimicrobial drugs in accordance with their pharmacokinetic and pharmacodynamic parameters. It is important to keep in mind that the antibiotic that we choose should reach therapeutic concentrations in the focus of infection, where bacteria interact with an antibacterial agent to obtain bacterial clearance as early as possible [15]. In addition, it should also be noted that the administration of a loading dose and the introduction of beta-lactams in the form of long-term and continuous infusions can increase the degree of exposure to the antibacterial drug, as well as the probability of reaching the target peak concentration, which plays an important role in the treatment of patients with septic shock, severe obesity, and burn lesions. The results of a recent multicentre research on the efficacy of VAP treatment in patients of the intensive care unit showed that about $16 \%$ of all patients did not respond to therapy with standard doses of $\beta$-lactams. While patients receiving antibiotics at a dose of $50 \%$ and $100 \%$ above the minimum inhibitory concentration, had much better clinical outcomes of the disease [16].

In addition to microbiological sensitivity, another equally important issue of antibacterial therapy of VAP, which 
must be considered, is also the degree of pulmonary penetration of active substances. In recent years, methods of inhalation (nebulizer) administration of an antibiotic have been considered, which make it possible to achieve high concentrations in the bronchial tree and promote better alveolar penetration compared with injection administration. Colistin (polymyxin E) is an antibiotic belonging to the group of polymyxins, which has been successfully used for inhalation in patients with cystic fibrosis for a long time. In a small randomized retrospective study, the use of nebulized Colistin (in high doses) in the form of VAP monotherapy was studied. According to the results of the study, its therapeutic effect was not inferior to the combination therapy with injectable $\beta$-lactams in combination with aminoglycosides and quinolones in the treatment of VAP which was caused by susceptible strains of Pseudomonas aeruginosa and A. Baumannii [17]. This approach is of a considerable interest, as it provides a high concentration of antibiotic with minimal absorption at systemic levels, which could be a turning point of therapy in the presence of multidrug-resistant strains, where the available drugs are very toxic. To date, several antibacterial agents (colistin, tobramycin, aztreonam, ceftazidime and amikacin) are available for inhalation use, but should be subject to further study in randomized clinical trials to confirm their safety and the possibility of being adding to standard therapy.

The question of the optimal duration of antibiotic therapy remains controversial today. Until recently, the standard practice was the appointment of a 15-day course of antibiotic therapy for uncomplicated infections. At the present stage, the appointment of a 7-8-day course of antibiotic therapy has become more acceptable if the patient's response to the therapy is satisfactory [18]. Many studies have shown that the 8-day course of antibiotic use in VAP is considered safe. It reduces the likelihood of resistant strains of microorganisms, reduces the cost of treatment, and also avoids unnecessary toxicity $[8,18]$. However, it is also worth noting that with VAP caused by gram-negative bacilli, the use of an 8-day versus a 15-day antibiotic course is associated with an increased risk of recurrence of a pulmonary infection. According to some researchers, longer courses of antibiotics can be recommended for patients with an immunosuppressive state and initial inadequate empirical therapy of VAP caused by strains with extensive drug resistance without clinical resolution of the disease [8].

Today, it is known that cephalosporins are a group of antibacterial drugs with proven efficacy, a broad spectrum of action, and a well-studied pharmacodynamic profile, in addition to a favourable safety profile. These characteristics, undoubtedly, make this antimicrobial class of drugs one of the main ones in the treatment of hospital-acquired infections, including VAP caused by Pseudomonas aeruginosa [19]. In recent years, due to the emergence of hospital-acquired infections caused by $\beta$-lactam resistant gram-negative bacteria, two important strategies have been developed to improve the therapeutic efficacy of antibacterial agents: the development of new $\beta$-lactam drug molecules that can avoid the effects of some of the factors that form the mechanisms of bacteria resistance and addition of new compounds capable of inactivating bacterial $\beta$-lactamases [20]. Ceftobiprole medocaril, which has an increased activity against gram-negative pathogenic microorganisms, should be highlighted among the newest drugs in the latest developments in the field of the cephalosporin range of antibiotics. The activity of Ceftobiprole medocaril against strains of pathogens with multidrug resistance, the so-called ESKAPE pathogens (Enterococcus faecium, Staphylococcus aureus, Klebsiella pneumoniae, Acinetobacter baumanii, Pseudomonas aeruginosa and Enterobacter species) and its resistance to a wide range of $\beta$-lactamases make this drug a promising option for the treatment of hospital-acquired pneumonia [21]. Ceftazidime / avibactam (CAZ-AVI) is a fixed-dose combination of drugs that consists of cephalosporin antibiotic of III generation ceftazidime and a new non-standard $\beta$-lactam inhibitor of $\beta$-lactamase avibactam. The association of avibactam with ceftazidime protects the latter from degradation by $\beta$-lactamases, increasing its activity against various enterobacteria, including Pseudomonas aeruginosa [22]. Ceftolozane is a broad-spectrum cephalosporin antibiotic (similar to III generation cephalosporins). Its main difference is significantly higher activity against Pseudomonas aeruginosa, including ceftazidime resistant strains. According to some studies, ceftolozane exhibits increased affinity for penicillin-binding proteins as compared to other antisealtic $\beta$-lactams. The results of the study demonstrate that the combination of ceftolozane with tazobactam ( $\beta$-lactamase inhibitor) is active against many strains of enterobacteria producing $\beta$-lactamase of extended-spectrum, but is inactive with respect to producers of metallo- $\beta$-lactamase [23].

Plasomicin (ACHN-490, Achaogen), an aminoglycoside of a new generation, which at the present stage is considered as a drug capable of reviving the class of aminoglycosides, is one of the modern drugs used in the treatment of pseudomonas infection. This drug has a fairly wide spectrum of activity, including both gram-negative (Pseudomonas aeruginosa, A. baumanii, K. pneumoniae, E. coli), and gram-positive microorganisms (MRSA). Conducted clinical studies on the assessment of the effectiveness of plasomicin against Pseudomonas aeruginosa revealed its synergistic effect with beta-lactam antibiotics. According to the obtained results, the drug also has no side effects in the form of nephrotoxicity and ototoxicity, which are characteristic of antibiotics of this group [24].

NXL104 (Novexel) is an injectable beta-lactamase inhibitor of a broad-spectrum from a completely new non-beta-lactam structural class, which, in combination with the ceftazopin antibiotic ceftazidime, demonstrated high activity against a wide range of gram-negative bacterial pathogens, including Enterobacteriaceae and Pseudomonas. According to the results of preclinical studies, the spectrum of activity of NXL104 is broader than the modern beta-lactamase inhibitors approved for clinical use (tazobactam, clavulanate and sulbactam). Adding NXL104 to ceftazidime restores susceptibility to gram-negative pathogens and, in case of further successful usage, the NXL104 / ceftazidime combination can be a 
good alternative to carbapenems in the first-line treatment of serious gram-negative infections caused by pathogens with multidrug resistance [24].

Undoubtedly, the attention is also drawn by the drug $P O L 7080$, a new experimental peptidomimetic antibiotic developed specifically to combat Pseudomonas aeruginosa, which, according to published results, has already proved its effectiveness in experiments with mice [25]. At the present stage in Europe, I phase of clinical trials of this drug was successfully completed, which demonstrated clinical safety and tolerability of POL7080. To date, studies are ongoing on the evaluation of $P O L 7080$ therapy of patients with VAP caused by Pseudomonas aeruginosa. One of the main problems with the use of this drug at the present stage is its nephrotoxicity [8].

At the present stage, one of the important directions in the treatment of infection caused by Pseudomonas aeruginosa is the creation of effective vaccines, the action of which will be aimed at blocking the main factors in the development of the infection process. It is worth noting that the development of these vaccines today is rather difficult due to the high variability between different types of Pseudomonas, the complexity of the infection process itself and the interaction of Pseudomonas aeruginosa with the immune system of the affected organism. In many of the studies conducted, the tested vaccines did not provide adequate "coverage" of different strains of Pseudomonas aeruginosa, showed low immunogenicity or had an insufficiently protected safety profile for use in clinical practice $[8,26,27]$. Currently, developments are being continued in this area of therapy.

\section{CONCLUSIONS}

A thorough analysis and synthesis of the results of scientific research on the treatment of VAP caused by pseudomonas infection has shown that despite ongoing research on the discovery and use of new antibacterial drugs, at the present stage Pseudomonas aeruginosa therapy remains an urgent and difficult task of medical practice. The presence of many molecular mechanisms of pathogenicity, as well as high resistance to various classes of antibacterial drugs, allows Pseudomonas aeruginosa to persist for a long time inside hospital wards, taking one of the leading positions in the structure of hospital-acquired pneumonia in hospitals of various profiles. Despite a long and in-depth study of the problems of hospital-acquired respiratory tract infections caused by Pseudomonas aeruginosa by domestic and foreign researchers, many issues of their treatment and prevention are still debatable and require further study.

\section{REFERENCES}

1. Tumbarello M., De Pascale G., Trecarichi E.M. et al. Clinical outcomes of Pseudomonas aeruginosa pneumonia in intensive care unit patients. Intensive Care Med. 2013;39(4):682-92. doi: 10.1007/s00134-0132828-9.

2. Kollef M.H., Chastre J., Fagon J.Y. et al. Global prospective epidemiologic and surveillance study of ventilator-associated pneumonia due to Pseudomonas aeruginosa. Crit Care Med. 2014;42(10):2178-87. doi: 10.1097/CCM.0000000000000510.
3. Sawa T., Ito E., Nguyen V.H. et al. Anti-PcrV antibody strategies against virulent Pseudomonas aeruginosa. Hum Vaccin Immunother. 2014;10(10):2843-52. doi: 10.4161/21645515.2014.971641.

4. Reichert F., Piening B., Geffers C. et al. Pathogen-Specifi c Clustering of Nosocomial Blood Stream Infections in Very Preterm Infants. Pediatrics. 2016;137(4):e20152860.

5. Goel V., Hogade S.A., Karadesai S.G. Ventilator associated pneumonia in a medical intensive care unit: Microbial aetiology, susceptibility patterns of isolated microorganisms and outcome. Indian Journal of Anaesthesia. 2012;56(6):558-562. D0I: 10.4103/0019-5049.104575.

6. MicekS.T., Wunderink R.G., KollefM.H. et al. An international multicenter retrospective study of Pseudomonas aeruginosa nosocomial pneumonia: impact of multidrug resistance. Crit Care. 2015;19:2-19. doi: 10.1186/ s13054-015-0926-5.

7. Blot S., Koulenti Akova M. Does contemporary vancomycin dosing achieve therapeutic targets in a heterogeneous clinical cohort of critically ill patients? Data from the multinational DALI study. Crit Care. 2014;18(3):90-99. doi: 10.1186/cc13874.

8. Sergio Ramírez-Estrada, Bárbara Borgatta, Jordi Rello. Pseudomonas aeruginosa ventilator-associated pneumonia management. Infect Drug Resist. 2016;9:7-18. doi: 10.2147/IDR.S50669.

9. Planquette B., Timsit J.F., Misset B.Y. et al. OUTCOMEREA Study Group Pseudomonas aeruginosa ventilator-associated pneumonia. Predictive factors of treatment failure. Am J Respir Crit Care Med. 2013;188(1):6976. doi: 10.1164/rccm.201210-18970C.

10. Ferrer R., Martin-Loeches I., Phillips G. et al. Empiric antibiotic treatment reduces mortality in severe sepsis and septic shock from the first hour: results from a guideline-based performance improvement program. Crit Care Med. 2014;42(8):1749-55. doi: 10.1097/CCM.0000000000000330.

11. Piskin N., Aydemir H., Oztoprak N. et al. Inadequate treatment of ventilator-associated and hospital-acquired pneumonia: risk factors and impact on outcomes. BMC Infect Dis. 2012; 12:260-268. doi: 10.1186/1471-2334-12-268.

12. Martin-Loeches I., Deja Koulenti M.D., Dimopoulos G. at al. Study Investigators: Potentially resistant microorganisms in intubated patients with hospital-acquired pneumonia: the interaction of ecology, shock and risk factors. Intensive Care Med. 2013;39(4):672-81. doi: 10.1007/ s00134-012-2808-5.

13. Garnacho-Montero J., Corcia-Palomo Y., Amaya-Villar R. How to treatVAP due to MDR pathogens in ICU patients. BMC Infect Dis. 2014;14:130-135. doi: 10.1186/1471-2334-14-135.

14. Garnacho-Montero J., Sa-Borges M., Sole-Violan J. et al. Optimal management therapy for Pseudomonas aeruginosa ventilatorassociated pneumonia: an observational, multicenter study comparing monotherapy with combination antibiotic therapy. Crit Care Med. 2007; 35(8):1888-95. D0I:10.1097/01.CCM.0000275389.31974.22.

15. Vazquez-Grande G., Kumar A. Optimizing antimicrobial therapy of sepsis and septic shock: focus on antibiotic combination therapy. Semin Respir Crit Care Med. 2015; 36(1):154-66. doi: 10.1055/s-0034-1398742.

16. Roberts J.A., Dimopoulos G., Kaukonen K.M. et al. Defining Antibiotic Levels in Intensive care unit patients: Are current beta-lactam antibiotic doses sufficient for critically ill patients? Clin Infect Dis. 2014;58(8):107283. doi: $10.1093 / \mathrm{cid} / \mathrm{ciu} 027$.

17. Arnold H.M., Sawyer A.M., Kollef M.H. Use of adjunctive aerosolized antimicrobial therapy in the treatment of Pseudomonas aeruginosa and Acinetobacter baumannii ventilator-associated pneumonia. Respir Care. 2012;57(8):1226-33. doi: 10.4187/respcare.01556. 
18. Capellier G., Mockly H., Charpentier C. et al. Early-onset ventilatorassociated pneumonia in adults randomized clinical trial: comparison of 8 versus 15 days of antibiotic treatment. PLoS One. 2012;7(8):412-90.

19. Bassetti M., Merelli M., Temperoni C. New antibiotics for bad bugs: where are we? Ann Clin Microbiol Antimicrob. 2013;12:22-36. doi: 10.1186/1476-0711-12-22.

20. Sader H.S., Castanheira M., Flamm R.K. et al. Antimicrobial activity of ceftazidime-avibactam against Gram-negative organisms collected from US medical centers in 2012. Antimicrob Agents Chemother. 2014;58(3):1684-92. doi: 10.1128/AAC.02429-13.

21. Farrell D.J., Flamm R.K., Sader H.S. et al. Ceftobiprole activity against over 60,000 clinical bacterial pathogens isolated in Europe, Turkey, and Israel from 2005 to 2010. Antimicrob Agents Chemother. 2014;58(7): 3882-3888. doi:10.1128/AAC.0246514.

22. Curcio D.Multidrug-resistantGram-negative bacterial infections: areyou ready for the challenge? Curr Clin Pharmacol. 2014;9(1):27-38. PMID: 23489027.
23. Hong M.C., Hsu D.I. Bounthavong M. Ceftolozane/tazobactam: a novel antipseudomonal cephalosporin and $\beta$-lactamase-inhibitor combination. Infect Drug Resist. 2013;6:215-223. doi:10.1007/s40265013-0013-7.

24. Lock R.L., Harry E.J. Cell-division inhibitors: new insights for future antibiotics. Nat Rev Drug Discov. 2008;7(4):324-38. doi: 10.1038/ nrd2510.

25. Srinivas N., Jetter P., Ueberbacher B.J. et al. Peptidomimetic antibiotics target outer-membrane biogenesis in Pseudomonas aeruginosa. Science. 2010;19(32):59-68.

26. Baumann U., Mansouri E., von Specht B.U. Recombinant OprF0 prl as a vaccine against Pseudomonas aeruginosa infections. Vaccine. 2004;22(7):840-7. D0I: 10.1016/j.vaccine.2003.11.029

27. Sharma A., Krause A., Worgall S. Recent developments for Pseudomonas vaccines. Hum Vaccin. 2011;7(10):999-1011. doi: 10.4161/ hv.7.10.16369.

Authors' contributions:

According to the order of the Authorship.

\section{Conflict of interest:}

The Authors declare no conflict of interest.

\section{CORRESPONDING AUTHOR}

Olga A. Poda

Ukrainian Medical Stomatological Academy

23 Shevchenko St., Poltava, Ukraine, 36011

tel: +380667884798

e-mail: olha.poda@gmail.com

Received: 28.03.2019

Accepted: 30.01 .2019 
PRACA POGLĄDOWA

REVIEW ARTICLE

\title{
MEDICAL INSURANCE AS A DIRECTION OF REFORMING THE HEALTH SYSTEM IN UKRAINE
}

\author{
Nadia S. Vasilevskaya' ${ }^{1}$, Olena V. Bailo² \\ 'ODESA NATIONAL MEDICAL UNIVERSITY, ODESA, UKRAINE \\ 2ODESA I.I.MECHNICOV NATIONAL UNIVERSITY, ODESA, UKRAINE
}

\begin{abstract}
Introduction: The right to live, the right to healthcare and medical care insurance, which are affirmed at the constitutional level in Ukraine, are exercised by organizing the healthcare system with the due consideration of all social groups of people. The current state of healthcare funding in Ukraine does not encourage the conditions under which the quality medical care is provided to the population as needed, especially to the socially disadvantaged group of people. The formation of marketing system of management in Ukraine, the declaration of it as a socially-oriented country, results in the necessity to carry out healthcare reforms and to implement new systems of funding. The special emphasis in the process has to be given to the development of the insurance.

The aim: To study, to evaluate and elaborate proposals towards the justification of the changes in the healthcare funding through the reforming the system of medical insurance. Materials and methods: Laws and regulations of Ukraine and related countries are analyzed in the article (by methods of comparison, analysis, synthesis, deductive approach, and scientific abstraction and generalization).

Review: The main forms of healthcare funding (on account of voluntary, compulsory and mixed insurance) were found out. Also, the special features of medical insurance in different countries based on the generalized models were investigated. As a part of the research, the condition of medical (voluntary and compulsory) insurance in Ukraine was analyzed and, as a result, the issues hindering its development were defined.

Conclusions: The model of insurance for implementation in Ukraine had been defined, as well as the condition of reforming system in compulsory insurance such as "taxesbudget-agency" with the stages had also been estimated. The possible consequences of medical reforming in Ukraine and the possible ways to improve the process of insurance in medical area were specified.
\end{abstract}

KEY WORDS: medical insurance, reformation, healthcare

Wiad Lek 2019, 72, 5 cz. I, 897-902

\section{INTRODUCTION}

The modern state of medical care in Ukraine is complicated, both financially and structurally. The main features of medical care are insignificant expenditures on health protection, inadequate and irrational distribution of resources in the system, high frequency of health seeking behavior, the shortage of appropriate medical services at the primary level, as well as the corresponding infrastructure. Medical field in Ukraine requires fundamental reforms, which is the major mission of modern times.

The experience of numerous developed countries witnesses about the successful reformation of the medical field through medical insurance and consolidation it as the platform for funding of the medical care system.

In accordance with the recommendations of the World Health Organization, funding of the healthcare system in a country is to be $6 \%$ of GDP. The expenditures in Ukraine were UAH 57 billiards in 2017. Expenditures for health care did not even reach $2 \%$ instead of recommended $6 \%$ the same year.

In that regard, there is a need in new forms of financial redistribution of medical expenditures. Only in 2018, the political decision to initial reforms (the systems of family doctors) was made. There were changes in emergency system too. Guaranteed package of medical services under medical reform, which refers to the formation of family doctor institution, changes in the system of emergency and immediate care, incorporation of ideas in medical insurance towards the proving the mandatory guaranteed package of medical services at the proper level for each separate individual.

At the same time, despite the fact that medical services will be provided on an insurance basis, the development of obligatory medical insurance as a legal institution is in stagnation. There is no stability in political area, the ambiguity of priorities in funding of medical care, the lack of meaningful and integrated concept from the Ministry of Health regarding the reforming of the field. The formation of a new executive body as a national insurer - the National Healthcare Service and all the previously mentioned factors launched the discussions about the necessity to implement obligatory medical insurance and appropriate legal and regulatory relationship in the area of medical services. 


\section{THE AIM}

The hypothesis has been put forward in the study that the obligatory medical insurance is an important step for the improvement in the system of health care funding and for the improvement of health services. To achieve the set aim, the following questions must be solved: - to study the experience of foreign countries in the area of medical insurance; - to identify the condition of medical insurance in Ukraine; - to find out the directions of reforming the health system.

\section{MATERIALS AND METHODS}

The methods of comparisons (comparing the system of medical insurance in different countries of the world), analysis and synthesis (for defining the concept of medical insurance), deduction and induction (for defining cause-and-effect connection of medical insurance and population's health), scientific abstractions based on generalization (while formulating the conclusions) have been used in the study.

\section{REVIEW AND DISCUSSION}

The lack of the unanimity while formulating the term of "medical insurance" negatively affects the understanding of this legal phenomenon. In accordance with the article 7, subsection 1 of Ukrainian Act on Insurance [1], there are five types of obligatory insurance in medical field: - medical insurance (paragraph 1); - personal insurance of medical and pharmaceutical workers (except those who work in institutions and organizations that are financed by the government) in case of infecting with immunodeficiency virus while performing the duties (paragraph 2); - insurance of life and health of the veterinary service workers (except those who work in institutions and organizations that are funded from the State budget of Ukraine); - insurance or workers (except those who work in institutions and organizations that are funded from the State budget of Ukraine) who are the participant of providing psychiatric help, including those who provide care over the individuals who suffer from mental disorders (paragraph 13); -insurance of medical and other workers of the state, communal health care organizations and the state scientific organizations (except those who work in organizations and institutions, which are funded from the State budget of Ukraine), in case of infectious disease, related to performing their professional duties under conditions of heightened risk of infecting with the contaminators of infectious diseases (paragraph 19).

According to A. B. Kirichenko [2 p.93], the obligatory medical insurance is the "mechanism of health care funding, which is the integral part of the state social insurance, and which provides equal opportunities for medical care among all citizens. M. M. Sadovenko [3 p.139], in his turn, considers such insurance as a constituent part of social insurance, which is based on obligatory participation of the citizens, enterprises or businessmen in funding of health care directly or through medical insurance companies or organizations. According to T. A, Govorushko [4 p.109], medical insurance is an insurance in case of health loss for any reason, including illness or accident. It can be provided both in voluntary, and in obligatory forms.

Types of insurance (state, obligatory, voluntary and their mixed versions) acknowledged at the state level, define the organizational forms of health care. In a separate way, these forms are not used, however in some countries, they take the dominating position. For example, the state medical insurance (voluntary or obligatory) dominates in Denmark, Island, Canada, New Zealand, Norway and Finland, whereas the private medical insurance is dominant in the USA and Israel. In such countries as France and Japan, medical insurance is the part of general system of social insurance. In such countries as Belgium and the Netherlands, Germany and Switzerland, government regulates work of different independent funds.

It is necessary to note that to reform the medical insurance in Ukraine, it is appropriate to look into the experience of foreign countries. Thus, the main form of guarantee that the medical service will be provided properly in the US, is the private insurance (both group and individual). Private insurance covers the significant amount of Americans, whereas the state insurance covers only some categories of the population: elderly people and state employees.

Many Americans, who do not have private insurance, fall under the actions of the state programs of health care: the system of Medicaid is for those people whose income is lower than the federally defined income level (it is necessary to provide the documentary evidence of a low standard of living for this sort of insurance), Medicare is for patients who are over 65, Medicare Part D (includes also access to prescribed medications at reduced rates), SCHIP is insurance for children (from the families which not relate to Medicaid, but not solvent enough for obtaining private insurance), private systems (as a rule, $60 \%$ of Americans receive insurance on account of employers, and only $9 \%$ can afford the given type of insurance by themselves), COBRA is for those individuals who lost the jobs (is given temporarily, considering the reason of work termination), PCIP is for people with high risks (separate type of medical insurance for those individuals with significant chronic diseases). Also, because of the decrease in the number of insured individuals, which in its turn is a result of financial incapability to enter into the Insurance Contract, Americans were included to the program of Health Insurance Marketplace. Such system helps the population to find for them such an insurance company and insurance scheme which suit their needs and financial condition. The great number of expenses on medical service in the US is covered on account of voluntary medical insurance, which is paid by employers and the state. However, the population is responsible for paying the considerable part of expenses for medical services. These payments are generally considered as the mechanisms for regulating cost recovery Americans receive insurance on account of employers, and only $9 \%$ can afford the given type of insurance by themselves), 
COBRA is for those individuals who lost the jobs (is given temporarily, considering the reason of work termination), PCIP is for people with high risks (separate type of medical insurance for those individuals with significant chronic diseases). Also, because of the decrease in the number of insured individuals, which in its turn is a result of financial incapability to enter into the Insurance Contract, Americans were included to the program of Health Insurance Marketplace. Such system helps the population to find for them such an insurance company and insurance scheme which suit their needs and financial condition. The great number of expenses on medical service in the US is covered on account of voluntary medical insurance, which is paid by employers and the state. However, the population is responsible for paying the considerable part of expenses for medical services. These payments are generally considered as the mechanisms for regulating cost recovery [5 p.6-7].

There is a very clearly defined system of the relationship customer-insurance company - doctor in the US. The special attention is given to the list of medicines and the schemes of treatment. In general, it can be said that despite the considerable expenses on medical insurance in the USA, the individuals receive high quality medical services in full, and the presence of medical insurance make them even more advantageous, regarding the prices for each separate type of medical services.

Among the European countries the experience of France seems to be very appealing. There is a system of obligatory medical insurance. Medical insurance in France originated in 1910, at first in a way of mutual funds, and then starting with 1928 those mutual funds were transformed into insurance companies.

Nowadays, each citizen must have a Carte Vitale card to pay for services [6 p.168]. Although it covers only $75 \%$ of expenses, in case of an appointment with a very specialized doctor, it covers only $30 \%$ of the visit cost. $100 \%$ can be covered only in case of accidents at work, and also such privileges are given only to disadvantaged groups of population. Apart from that, private insurance is extremely popular with French, as the most part of French consider state insurance as insufficient. Nonetheless, French system of healthcare works well, as there is the highest average life expectancy in Europe. It is important to note that French system of health care provides even access as to state organizations as to private ones. Except the obligatory state insurance there is a system of voluntary insurance and local funds of social assistance. Owing to the latter, insignificant number of uninsured individuals have access to medical services.

The first insurance company in Germany, which offered medical insurance policy to the customers, appeared in 1848. In German system, the state does not fund the health protection (with the exception of some sectors), although provides the formation of insurance funds by means of employers and employees. The state performs the monitoring function over the whole system of medical insurance, which is decentralized. There are approximately 1200 insurance funds - Krankenkasse, which were formed on a territorial or professional basis. In such a way, the state insurance is the basis of health in Germany [7]. There is an established by the state sum of average annual salary ( 57600 Euros per year) when the citizen has the right to choose whether he needs an insurance or to choose between the private and the state insurance. Due to the fact that the state increases the average salary rate every year, more and more citizens are obliged to pay $7.5-8 \%$ of their annual income. It should be noted that insurance covers the cost of $95 \%$ services provided. As in many countries with the similar system of medical insurance, such insurance does not cover the appointments with the specialized doctors (for example a dentist), but some medical cash registers, in their turn, offer different service packages, relevant to different groups of population

Medical insurance in Russia is rather specific. Medical institutions, in their turn, perform their activities on the account of obligatory insurance contributions from the wages, which the employers are obliged to pay. The territorial programs were also based on the federal system's basis. In such programs there is a list of diseases, diagnostics and treatments which are performed on account of state money. The citizens may receive medical help of emergency outpatient type, in outpatient hospitals or at hospital. The contributions are distributed in the following way in the system of compulsory medical insurance: all businesses and organizations in the territory of Russian Federation allocate money in the amount of 5.1\%from the payroll fund to the funds of obligatory medical insurance each calendar month. In case if an individual is qualified as unemployed, the contributions to the funds are done by the state on his benefit. At a later stage, the accumulated savings of insurance funds are evenly distributed among all the population in all regions of the country. Therefore, the insurer and medical insuring company enter into an agreement, which is the basis of this type of insurance. As a result of concluding a contract, the insurance company commits to organize and fund the insured person with the appropriate medical services in full amount, and who, in his turn, becomes an owner of medical certificate of insurance [6 p.166].

The organization and performing obligatory medical insurance falls into the state powers. In particular, the state articulates the main principles of obligatory medical insurance, adjusts the size of insurance contributions, and establishes special state funds for its accumulation. Obligatory medical insurance in Russian Federation has general nature, in other words, it covers all the population without any exceptions. The main goal of medical insurance is an accumulation and capitalization of insurance contributions, as well as provision of medical services to all the population, funded from the fund of obligatory medical insurance under the established by the state conditions and in guaranteed amount. From this perspective, the field of obligatory medical insurance is to be viewed from two aspects. First of all, obligatory medical insurance is a constituent in the system of social security on equal terms with the social insurance. At the same time, medical 
insurance is a way to supply the systems of health care with extra money, except the assets, which are allowed from the state budget.

Thus, the special features of medical insurance in Russian Federation are: - the insurance proceeds are performed in a form of service; - the monetary aid is not provided, instead of which the services are paid. There is no division while providing medical services.

Medical insurance is in two forms - obligatory and voluntary. Each of these forms has its own features and peculiarities: procedures, organizational and legal principles and financial mechanism of implementation. Relating to the system of healthcare in Russian Federation, obligatory medical insurance has its own advantages, quite attractive to the population, since it enables them to receive medical services in a wide range of diseases for free, and also, insurance certificate is formalized only once.

The world experience of in medical insurance is diverse, although none of the models of health care is impossible to reproduce $100 \%$ without the due regard of national peculiarities. The analysis of the world practice in the area of healthcare funding based on the obligatory medical insurance, enables to feature its main peculiarities: - at first, social medical insurance can represent itself, as the main or additional financing of health care in foreign countries; - secondly, there are several approached to forming the funds of obligatory medical insurance: a) one fund for all the population (such funds are in Korea, Hungary, Turkey, Poland, Luxembourg and Slovenia); b) some centralized funds, maintaining service for the definite regions in the country; c) funds, maintaining service of the population in the same region, but do not compete (such cases occur in Austria, Belgium, France and Japan); d) some funds, either state or private ones that compete (such cases occur in Germany, Netherlands, the Czech Republic and Switzerland); - thirdly, different amount and procedures of making a contribution to such funds of obligatory medical insurance occur: a) single rates of contributions for the population of the country; b) share of a worker's contribution and an employer's contribution separate; c) contributions may be limited (in regions, in different categories of payers); d) additional contributions or deposits not related to the labor compensation are available [8 p.42].

Thus, European countries conduct the provision of the majority of healthcare expenses with the help of obligatory medical insurance. France and Germany provide almost $3 / 4$, Estonia and Romania almost $2 / 3$, Poland and Hungary provide almost $1 / 2$ of all expenses. Sharing the same opinion as A. B. Cherep, who believes that accumulated long-term experience in the area of medical insurance speaks for high efficiency of different models and systems of medical insurance and health insurance $[9$ p.22].

However, medical insurance has not got widespread in Ukraine. In spite the fact that almost 60 insurance companies and an Association "Ukrainian Medical Insurance Agency, which includes 28 insurance companies in Ukraine, representing it in 12 regions and Kiev, function in the country, only 5-6\% of Ukrainians have the certifi- cates of voluntary medical insurance. And what is more, such insurance dominates in corporate area. This is due to the fact that the cost of individual medical insurance is significant; there is such a position that young people are young enough and nothing can happen with them; medical treatment is provided but relies on the word of mouth; the thought prevails that despite medical insurance it is still necessary to pay in the hospital; the trust to insurance companies is absent. All insurance companies offer almost the same programs of voluntary insurance with the same package of services, with the registration in the same hospitals or clinics, with the provision of similar medical services. In view of this, we think that the system of voluntary medical insurance must be complemented with obligatory medical insurance.

It is necessary to note that there is a list of problems, hindering the development in medical insurance area in Ukraine. They are related to out-of-date material base; the shortage of medications; negative rate of demographical development of the country; increase in the morbidity rate; low rate of specialist's training in medical and insurance areas; the lack of eligible remuneration for doctor's work in the form of salaries and bonuses; medical corruption; avoidance of obligations by insurers in the area of paying the treatment of insured individuals; low quality of legislation, regulating medical insurance; different vision of the model by civil servants, insurers and doctors, on the basis of which medical insurance is to be based on, and first of all, its obligatory form; low level of population's awareness in understanding the possibilities of insurance medicine. The reform, having been initiated in Ukraine, must result in the changes of the model of medical insurance. Similar model which is called "taxes-budget-agency" functions in Italy, Canada, Spain, the Nordic countries and Great Britain. The essence of this model reduces to the introduction of medical insurance without any additional contributions and deposits; the introduction of the guaranteed packet of medical assistance which involves defined set of medical services and medications.

Insurance contributions in the country envisaged in the Internal Revenue Code. According to many experts, the introduction of additional obligatory contributions from the salary is inappropriate under crisis economic conditions in the country. For this reason, the model of financing envisages that money for covering the medical expenses will go to the National Health Care Service in Ukraine from the state budget. In this regard, The Law "About the Financial Guarantees of Medical Care for Population" and "About the Access Program to the Quality of Medical Services in the Rural Areas" were enacted and the Conception of Reforming in Financing of the Health Care in Ukraine was approved too.

According to introduction of such a model, three stages are covered: preparatory stage has already finished - it lasted from 2016 till 2017, in 2017 the implementation stage started, its active part was in 2018, when reforming was provided with the first medical assistance (family doctors, pediatricians and physicians). The final stage takes place 
in 2019-2020 - at the level of specialists of outpatient services (cardiologists, otolaryngologists, gastroenterologists and others).

At the same time medical institutions embarked on the course of autonomization and are obliged to be granted the status of institutions and become the main providers of social health care in the nearest 3-5 years. The relationship between them and the central state fund of medical insurance are to be based on the basis of agreements with the service descriptions, which are funded by insurer (there will be stated he necessary volume of expenses and the proper vision of cost prices on the service, which will define the price).These descriptions, in their turn, are forming the insurance plans or packages, which define the status of such insurance package as the State Program of Obligatory Medical Insurance under the conditions of obligatory state medical insurance [10 p.5].

On account of the insurance agency funds (of National Health Care Agency in Ukraine), medical communal companies have the possibility to compete. Such companies, in their turn, gain the possibility to provide the commercial services out of the state program of medical insurance.

Rud V. is sure that obligatory medical insurance is going to ensure additional cash flow to the field and is going to enable the system of health care in Ukraine to become more flexible, dynamic and functional. In the opinion of the scientist, the introduction of mandatory state social medical insurance is going to provide the equal access to medical services by to categories of population. Although the viewpoint of a scientist is that this process must be followed by enhanced monitoring of the state over the functioning the funds of social medical insurance and the condition of the management. Insurance is going to stimulate the quality of the services, rendered to the population, and hold them accountable in accordance to the international standards [11 p.239].

We consider that for further reforming of obligatory medical insurance, the relationship between high medical institutions, postgraduate institutions together with the medical institutions, monitoring the effectiveness and the quality of medical services, must build credibility. Apart from that, the special attention must be paid to the function of interaction with the insurer towards the definition of the factors in the guaranteed volume of medical assistance, established by the state and its quality.

The list of problems related to the experience of foreign medical insurance and introduction of this experience in Ukraine requires the further discussion. Apart from that there is a need for more detailed discussion of the progress in the reforming of medical insurance in Ukraine, the mechanism of incorporating voluntary and obligatory insurance and formation of the complex legal base for functioning of medical insurance.

\section{CONCLUSIONS}

The experience of foreign medical insurance was defined in the course of the study, which justifies the high efficiency of different models combinations and the system of medical insurance. Analyzed state of medical reforming enables to come to a conclusion about the possibility to introduce such a model of funding of medical expenses that will guarantee the protection of the population in Ukraine in case of a disease at the state level, and also will address the corruption while distributing the financial resources and while rendering medical services.

Reforming of the health care in Ukraine must consider some peculiarities, namely:

- The transition from budget funding of health care on specific articles of expenses to funding under long-term stable legal norms, which will taka the due account of peculiarities and focus of medical institutions;

- Incorporation of budget financing of medical institutions with the development of insurance medicine and commercial services provided to the population, and maintaining the service to the companies and organizations on a contract basis;

- Enhancing the institutional autonomy, increasing the initiatives of work communities in addressing the issues of operational activities and social development;

The relationship between the remuneration, social development and material incentive, depending on the final result in the activities of medical institutions, the quality of medical services and efficiency of work;

- Involving different forms of enterprises, including lease relationship, individual work, and the flexible system of remunerations.

\section{REFERENCES}

1. Pro strakhuvannia [On the insurance]: zakon Ukrainy vid 07.03 .1996 No. 85/96-BP. Available from: https://zakon.rada.gov.ua/laws/show/85/96\%D0\%B2\%D1\%80 (In Ukrainian).

2. Kyrychenko A.V. Medychna reforma ta zaprovadzhennia oboviazkovoho medychnoho strakhuvannia [Medical reform and input of obligatory medical insurance] Naukovyi visnyk Natsionalnoho universytetu bioresursiv i pryrodokorystuvannia Ukrainy. 2018; 284: $92-97$ (In Ukrainian).

3. Sadovenko M.M., Chepa A.O. Problemy ta perspektyvy rozvytku meduchnoho strakhuvannia v Ukraini [Problems and prospects of development of medical insurance in Ukraine] Visnyk Odeskoho natsionalnoho universytetu. 2018;. 4: 139-142. (In Ukrainian).

4. Hovorushko T.A. Strakhovi posluhy [Insurance services]. Tsentr navchalnoi literatyru . 2005: 400 (In Ukrainian).

5. Okunev 0.B. Sistema obiazatelnogo meditsinskogo strakhovaniia v svete globalnogo krizisa: riski finansovoi neobespechenosti [System of obligatory medical insurance in the light of global economic crisis: risk of financial material unwell-being]. Strakhovoe delo. 2009; 8 (199): 5-11 (In Russian).

6. Antonova A.E. Osobennosti sistemy meditsinskogo strakhovaniia v Rossii I za rubezhom [Features of system of medical insurance in russia and after border]. Territoriia nauki. 2018; 1: 165-171 (In Russian).

7. Loshakov L.A., Khokhlov A.L., Miroshnikov A.E. etal The evaluation of medical technologies as progressive element of public health system reform in Germany. Zdravookhranenie RF. 2012; 5. https://cyberleninka. ru/article/v/otsenka-meditsinskih-tehnologiy-kak-progressivnyyelement-reformirovaniya-zdravoohraneniya-v-germanii (In Russian). 
8. Stepanova 0.V. Oboviazkove medychne strakhuvannia yak factor finansovoi stiikosti okhorony zdorovia v Ukraini [Obligatory medical insurance as factor of financial firmness of health protection is in Ukraine]. Efektyvna ekonomika. 2015; 11: 40-46 (In Ukrainian).

9. Cherep A.V. Praktychnyi inozemnyi dosvid medychnoho strakhuvannia [ Practical foreign experience of medical insurance] Stalyi rozvytok ekonomiky. 2013; 2: 17-23 (In Ukrainian).

10. Khvysiuk 0.M. Osoblyvosti diialnosti organiv mistsevoho samovriaduvannia ta zakladiv ohorony zdorovia v umovakh modeli meduchnoho strakhuvannia [Features of activity of organs of local self-government and establishments of health protection are in the conditions of model of medical insurance] Problemy bezperervnoi medychnoi osvity ta nauky. 2018; 4: 5-9 (In Ukrainian).

11. Ryd V. Yu., Izhevskyy P.H. Vyklyky chasu ta problemy zaprovadzhennia $\checkmark$ Ukraini [Calls of time and problem of input of medical insurance in Ukraine] Visnuk Khmelnytskoho natsionalnoho universytetu. Ekonomichni nauky. 2017; 5: 237-239 (In Ukrainian).
Scientific work was carried out within the framework of the research theme "Private legal regulation of social relations: traditions, modernity, perspectives".

\section{Authors' contributions:}

According to the order of the Authorship.

\section{Conflict of interest:}

The Authors declare no conflict of interest.

\section{CORRESPONDING AUTHOR \\ Olena V. Bailo}

Odesa I.I.Mechnicov national university

Dvorianskaia street, 2, 65001 0desa, Ukraine

tel: +380972905038

e-mail:m_helen_15@ukr.net

Received: 17.03 .2019

Accepted: 25.05 .2019 
PRACA POGLĄDOWA

REVIEW ARTICLE

\title{
ANALYSIS OF TUBERCULOSIS/HIV CO-INFECTION TRENDS IN UKRAINE IN 2008-2017
}

\author{
Tetiana V. Stepanova', Olga P. Nedospasova², Mykhailo V. Golubchykov' ${ }^{1}$ \\ 1 SHUPYK NATIONAL MEDICAL ACADEMY OF POSTGRADUATE EDUCATION, KYIV, UKRAINE \\ 2SI CENTER FOR HEALTH STATISTICS OF THE MOH OF UKRAINE, KYIV, UKRAINE
}

\begin{abstract}
Introduction: According to WHO estimates for the European Region in 2017, Ukraine had the highest proportion of active tuberculosis cases c0-infected with HIV - 21.6\%, with an average of $12 \%$ in the Region, and the absolute number of tuberculosis/HIV co-infection cases in Ukraine was estimated at the level of 8,000.

The aim: carry out a comprehensive analysis of the epidemical situation regarding tuberculosis/HIV co-infection in Ukraine according to selected epidemiological and clinical characteristics.

Materials and methods: The retrospective epidemiological study was based on the data from national reporting forms "Annual Active TB Report", which was being collected by the Center for Health Statistics of the Ministry of Health of Ukraine for period 2008-2017.

Review: The incidence of newly diagnosed active tuberculosis associated with HIV in Ukraine increased by 89,4\% - from 6,1 per 100,000 population in 2008 to 11,6 per 100,000 population in 2017, against the backdrop of a gradual decrease in the incidence of active tuberculosis by $36.5 \%$ over the same period. The rates of comorbidity TB/HIV increased by 2.8 times from $7.9 \%$ to $20.3 \%$. The highest rates of incidence tuberculosis/HIV co-infection are observed in person aged $25-44$, males, urban residents, and in the southern region of Ukraine.

Conclusions: The revealed tendency to increase the rate of the incidence and comorbidity of tuberculosis/HIV causes necessitates reviewing the organizational approaches to healthcare delivery for tuberculosis/HIV co-infection patients.
\end{abstract}

KEY WORDS: tuberculosis/HIV co-infection, incidence, comorbidity

Wiad Lek 2019, 72, 5 cz. I, 903-907

\section{INTRODUCTION}

Under the concept of WHO, worldwide tuberculosis epidemic is divided into three components: typical tuberculosis (TB), multidrug-resistant tuberculosis (MDR-TB) and tuberculosis/HIV co-infection (TB/HIV co-infection). Each of these components has its epidemiological characteristics and influences the course of the overall TB epidemic. The Global strategy and targets for TB prevention, care and control after 2015 «The END TB Strategy» (adopted at the 67th World Health Assembly in 2014) emphasizes that HIV-associated TB is one of the main reasons may hinder the achievement of the set goals and objectives of the fight against TB in conditions of high prevalence of HIV infection [1]. Despite the fact that, according to WHO estimates [2], Ukraine is not included in the list of high-burden country for TB/HIV co-infection being used by WHO during the period 2016-2020, the epidemic situation with TB associated with HIV infection in Ukraine is challenging. According to WHO estimates for the European Region in 2017, Ukraine had the highest proportion of active tuberculosis cases co-infected with HIV - 21.6\%, with an average of $12 \%$ in the Region, and the absolute number of TB/HIV co-infection cases in Ukraine was estimated at the level of 8,000 [3]. Considering the above, the investigation of national trends in the epidemiological situation, the structure and the regional features of $\mathrm{TB} /$ HIV co-infection incidence becomes especially relevant.

\section{THE AIM}

Therefore, the main objectives of this study were to: carry out a comprehensive analysis of the epidemical situation regarding TB/HIV co-infection in Ukraine for the main epidemiological and clinical characteristics, identify the epidemiological features of the incidence of TB/HIV co-infection compared to incidence of active TB disease without HIV-infection in dynamics based on data from national TB surveillance for 10 years period.

\section{MATERIALS AND METHODS}

The retrospective epidemiological study was based on the data from national reporting forms "Annual Active TB Report", which was being collected by the Center for Health Statistics of the Ministry of Health of Ukraine for period 2008-2017.

In the first stage of our study was analyzed the trend of incidence of newly diagnosed active TB cases under the selected demographic characteristics (age, gender and 
Table I. Incidence of newly diagnosed active tuberculosis with and without HIV (per 100,000 population), comorbidity rate of TB/HIV (\%), demographic characteristics, Ukraine, 2008 and 2017

\begin{tabular}{|c|c|c|c|c|c|c|c|c|}
\hline \multirow{3}{*}{ Characteristics } & \multicolumn{3}{|c|}{2008} & \multicolumn{3}{|c|}{2017} & \multicolumn{2}{|c|}{$\begin{array}{c}\text { Rate of increase/ } \\
\text { decrease 2017/2008 }\end{array}$} \\
\hline & TB/HIV & $\begin{array}{c}\text { Non-HIV } \\
\text { TB }\end{array}$ & $\begin{array}{c}\text { Comorbidity } \\
\text { TB/HIV }\end{array}$ & TB/HIV & $\begin{array}{c}\text { Non-HIV } \\
\text { TB }\end{array}$ & $\begin{array}{c}\text { Comorbidity } \\
\text { TB/HIV }\end{array}$ & TB/HIV & $\begin{array}{l}\text { Non-HIV } \\
\text { TB }\end{array}$ \\
\hline & \multicolumn{2}{|c|}{$\begin{array}{c}\text { Number } \\
\text { (per 100,000) }\end{array}$} & $\%$ & \multicolumn{2}{|c|}{$\begin{array}{c}\text { Number } \\
\text { (per 100,000) }\end{array}$} & $\%$ & \multicolumn{2}{|c|}{$\%$} \\
\hline Overall & $\begin{array}{c}2668 \\
(6,1) \\
\end{array}$ & $\begin{array}{c}31298 \\
(71,6) \\
\end{array}$ & 7,9 & $\begin{array}{l}4458 \\
(11,6) \\
\end{array}$ & $\begin{array}{l}17537 \\
(45,5) \\
\end{array}$ & 20,3 & $+89,4$ & $-36,5$ \\
\hline \multicolumn{9}{|c|}{ Geographical region } \\
\hline Southern & $\begin{array}{c}718 \\
(15,3)\end{array}$ & $\begin{array}{l}3961 \\
(84,6)\end{array}$ & 15,3 & $\begin{array}{l}1363 \\
(29,8) \\
\end{array}$ & $\begin{array}{l}2654 \\
(58,1)\end{array}$ & 33,9 & $+94,6$ & $-31,3$ \\
\hline Northern & $\begin{array}{l}345 \\
(4,3) \\
\end{array}$ & $\begin{array}{l}4917 \\
(61,1) \\
\end{array}$ & 6,6 & $\begin{array}{c}985 \\
(12,3) \\
\end{array}$ & $\begin{array}{l}3389 \\
(42,5) \\
\end{array}$ & 22,5 & $+187,9$ & $-30,5$ \\
\hline Central & $\begin{array}{l}197 \\
(3,6) \\
\end{array}$ & $\begin{array}{l}3650 \\
(66,3) \\
\end{array}$ & 5,1 & $\begin{array}{l}447 \\
(8,7) \\
\end{array}$ & $\begin{array}{l}2213 \\
(42,8)\end{array}$ & 16,8 & $+141,7$ & $-35,4$ \\
\hline East & $\begin{array}{c}1274 \\
(8,6) \\
\end{array}$ & $\begin{array}{c}11864 \\
(80,0) \\
\end{array}$ & 9,7 & $\begin{array}{l}1234 \\
(12,0) \\
\end{array}$ & $\begin{array}{l}4504 \\
(43,8) \\
\end{array}$ & 21,5 & $+39,6$ & $-45,3$ \\
\hline West & $\begin{array}{r}134 \\
(1,3) \\
\end{array}$ & $\begin{array}{l}6906 \\
(64,7) \\
\end{array}$ & 1,9 & $\begin{array}{r}429 \\
(4,1) \\
\end{array}$ & $\begin{array}{l}4777 \\
(45,2) \\
\end{array}$ & 8,2 & $+223,2$ & $-30,2$ \\
\hline \multicolumn{9}{|c|}{ Types of settlements } \\
\hline Urban & $\begin{array}{c}2298 \\
(7,7) \\
\end{array}$ & $\begin{array}{c}20362 \\
(68,3) \\
\end{array}$ & 10,1 & $\begin{array}{l}3370 \\
(13,1) \\
\end{array}$ & $\begin{array}{c}10588 \\
(41,3) \\
\end{array}$ & 24,1 & $+70,5$ & $-39,6$ \\
\hline Rural & $\begin{array}{l}370 \\
(2,7)\end{array}$ & $\begin{array}{c}10936 \\
(78,4)\end{array}$ & 3,3 & $\begin{array}{l}1088 \\
(8,4)\end{array}$ & $\begin{array}{l}6949 \\
(53,7)\end{array}$ & 13,5 & $+216,7$ & $-31,6$ \\
\hline \multicolumn{9}{|l|}{ Gender } \\
\hline Male & $\begin{array}{c}1820 \\
(9,0) \\
\end{array}$ & $\begin{array}{l}22215 \\
(110,1) \\
\end{array}$ & 7,6 & $\begin{array}{l}2843 \\
(15,9) \\
\end{array}$ & $\begin{array}{c}12126 \\
(67,7) \\
\end{array}$ & 19 & $+75,8$ & $-38,6$ \\
\hline Female & $\begin{array}{l}848 \\
(3,6) \\
\end{array}$ & $\begin{array}{l}9083 \\
(38,5) \\
\end{array}$ & 8,5 & $\begin{array}{l}1615 \\
(7,8) \\
\end{array}$ & $\begin{array}{l}5411 \\
(26,2) \\
\end{array}$ & 23 & $+117,3$ & -32 \\
\hline \multicolumn{9}{|l|}{ Age (years) } \\
\hline $0-14$ & $\begin{array}{c}29 \\
(0,5) \\
\end{array}$ & $\begin{array}{l}516 \\
(8,4) \\
\end{array}$ & 5,3 & $\begin{array}{c}44 \\
(0,7) \\
\end{array}$ & $\begin{array}{r}553 \\
(9,1) \\
\end{array}$ & 7,4 & $+53,7$ & 8,6 \\
\hline $15-24$ & $\begin{array}{r}159 \\
(2,4) \\
\end{array}$ & $\begin{array}{l}4028 \\
(60,9) \\
\end{array}$ & 3,8 & $\begin{array}{c}88 \\
(2,2) \\
\end{array}$ & $\begin{array}{l}1361 \\
(34,5) \\
\end{array}$ & 6,1 & $-7,2$ & $-43,4$ \\
\hline $25-44$ & $\begin{array}{l}2172 \\
(17,3)\end{array}$ & $\begin{array}{r}14024 \\
(111,6) \\
\end{array}$ & 13,4 & $\begin{array}{l}3215 \\
(27,1)\end{array}$ & $\begin{array}{l}7878 \\
(66,3) \\
\end{array}$ & 29 & $+56,6$ & $-40,6$ \\
\hline $45-64$ & $\begin{array}{l}308 \\
(2,7)\end{array}$ & $\begin{array}{l}9967 \\
(87,9)\end{array}$ & 3 & $\begin{array}{l}1076 \\
(10,3)\end{array}$ & $\begin{array}{l}5796 \\
(55,2)\end{array}$ & 15,7 & $+277,5$ & $-37,2$ \\
\hline$>65$ & - & $\begin{array}{l}2763 \\
(39,2) \\
\end{array}$ & - & $\begin{array}{c}35 \\
(0,6)\end{array}$ & $\begin{array}{l}1949 \\
(31,6) \\
\end{array}$ & 1,8 & - & $-19,4$ \\
\hline
\end{tabular}

place of residence) for the 2008-2017 period. The analysis was carried out separately for incidence of active TB combining with HIV and incidence of TB without HIV, rate of increase calculated for each indicator. The number of patients who have TB without HIV was determined as the difference between the total number of registered patients and patients who had reported as non-HIV-infected TB patients. The TB/HIV comorbidity rate, was expressed as a percentage, was defined as the prevalence of HIV-infection among patients with the newly diagnosed active TB.
The second phase of the study analyzed the structure of the incidence of active TB by the main clinical forms and the type of TB. For each of these groups, the comorbidity rate of TB/HIV was also determined.

To avoid shifting of the statistical indicators in the dynamics associated with the change in the population of Ukraine after the annexation of the Crimea and Sevastopol city, calculations from 2008 were carried out without these regions data. In the calculation of indicators from 2015, for the Donetsk and Luhansk oblasts, the population of only 
Table II. Structure of the incidence of active tuberculosis with and without HIV, comorbidity rate of TB/HIV (\%), clinical characteristics, Ukraine, 2008 and 2017

\begin{tabular}{|c|c|c|c|c|c|c|}
\hline \multirow{3}{*}{ Characteristics } & \multicolumn{3}{|c|}{2008} & \multicolumn{3}{|c|}{2017} \\
\hline & TB/HIV & $\begin{array}{l}\text { Non-HIV } \\
\text { TB }\end{array}$ & $\begin{array}{l}\text { Comorbidity } \\
\text { TB/HIV }\end{array}$ & TB/HIV & $\begin{array}{l}\text { Non-HIV } \\
\text { TB }\end{array}$ & $\begin{array}{l}\text { Comorbidity } \\
\text { TB/HIV }\end{array}$ \\
\hline & \multicolumn{2}{|c|}{ Number (\%) } & $\%$ & \multicolumn{2}{|c|}{ Number (\%) } & $\%$ \\
\hline \multicolumn{7}{|l|}{ The type of tuberculosis process } \\
\hline $\begin{array}{l}\text { newly diagnosed tuberculosis } \\
\text { - all forms A15-A19 }\end{array}$ & $2668(90,0)$ & $31298(86,1)$ & 7,9 & $4458(79,0)$ & $17537(81,7)$ & 20,3 \\
\hline $\begin{array}{l}\text { relapse tuberculosis } \\
\text { - all forms A15-A19 }\end{array}$ & $298(10,0)$ & $5035(13,9)$ & 5,6 & $1188(21,0)$ & $3938(18,3)$ & 23,2 \\
\hline \multicolumn{7}{|l|}{ Clinical forms of active tuberculosis } \\
\hline $\begin{array}{l}\text { pulmonary tuberculosis } \\
\text { A15.0-3, A16.0-2, A19.-part. }\end{array}$ & $2217(83,1)$ & $28105(89,8)$ & 7,3 & $3601(80,8)$ & $15959(91,0)$ & 18,4 \\
\hline $\begin{array}{c}\text { extrapulmonary tuberculosis } \\
\text { A15.4-9, A16.3-9, A17, A18, A19. } \\
\text {-part. }\end{array}$ & $402(15,1)$ & $3067(9,8)$ & 11,6 & $688(15,4)$ & $1511(8,6)$ & 31,3 \\
\hline $\begin{array}{c}\text { miliary tuberculosis } \\
\text { A19 (except A19.- part.) }\end{array}$ & $49(1,8)$ & $126(0,4)$ & 28,0 & $169(3,8)$ & $67(0,4)$ & 71,6 \\
\hline \multicolumn{7}{|l|}{ Clinical forms relapse tuberculosis } \\
\hline $\begin{array}{c}\text { pulmonary tuberculosis } \\
\text { A15.0-3, A16.0-2, A19.-part. }\end{array}$ & $270(90,6)$ & $4771(94,8)$ & 5,4 & $1022(86,0)$ & $3796(96,4)$ & 21,2 \\
\hline $\begin{array}{l}\text { other forms relapse TB } \\
\text { A15-A18, A19.-part. }\end{array}$ & $28(9,4)$ & $264(5,2)$ & 9,6 & $166(14,0)$ & $142(3,6)$ & 53,9 \\
\hline
\end{tabular}

the controlled territory was taken into account. For the calculation of the incidence rate, information was used on the average annual population (person) and the structure of the population of Ukraine from the data bank "Statistics of the Population of Ukraine", which is published on the website of the State Statistics Service of Ukraine [4], with a population recount for the Donetsk and Luhansk oblasts from 2015 year according to the operational data of the Center of Medical Statistics of the Ministry of Health of Ukraine. The regions of Ukraine were grouped according to the territorial principle (south, north, west, east and center), which corresponds to the distribution presented in the HIV infectious bulletin for 2017 [5].

The statistical analysis of the research materials was performed using the Microsoft Excel 2010 statistical analysis package.

The study was conducted on generalized secondary data using epidemiological and statistical methods, so the conclusion of the ethics commission was not provided.

\section{REVIEW}

During the study period the incidence of newly diagnosed active TB decreased to $26.6 \%$ from 77.7 per 100,000 population (33,966 persons) in 2008 to 57.0 per 100,000 population $(21,995$ persons) in 2017 . These changes occurred due to $36.5 \%$ decrease in the incidence of active TB without HIV-infection. At the same time, the incidence of TB/HIV co-infection has increased by $89.4 \%$. As a result, the comorbidity rate of TB/HIV increased by 2.8 times from $7.9 \%$ to $20.3 \%$.

Table I presents the incidence of TB and of TB/HIV co-infection and comorbidity rate of TB/HIV for 2008 and 2017 for selected demographic characteristics. During the study period, the incidence of co-infection of TB/HIV has increased in all regions. If, in 2008, the regional rate of TB/ HIV co-infection varied from 1.3 per 100,000 population in the western region of Ukraine to 15.3 per 100,000 population in the south, then in 2017 the lower range of the indicator increased to 4.1 per 100,000 population, and the upper range to 29.8 per 100,000 population. Although, for 10 years the highest growth rate of incidence of TB/HIV co-infection were in the western region, in the southern region has had the highest rates of incidence of co-infection and comorbidity TB/HIV.

In addition, a regional redistribution occurred of patients with newly diagnosed TB. In 2008, in the eastern region of Ukraine lived $47.8 \%$ of all registered TB/HIV co-infected patients and $37.9 \%$ of all newly diagnosed TB patients without HIV. But in 2017 the southern region went up in the first place by the number of TB/HIV co-infected patients (30.6\% all registered patients) and the western region has the first place by the number of patients with the newly diagnosed TB without HIV (27.2\% all registered patients).

Rates of TB in combination with HIV and without it have a different focus for the rural and urban population. In 2008 and 2017 the rural population was characterized by higher rates of incidence of active TB without HIV infection than 
for urban population. Among urban residents, conversely, inherent higher incidence of TB/HIV co-infection and TB/HIV comorbidity rates. At the same time, the growth rate of the incidence of TB/HIV in rural areas is 3.1 times higher than the growth rate of incidence in urban areas.

Over 10 years of co-infected TB/HIV gradually increased the proportion of women from $31.8 \%$ in 2008 to $36.2 \%$ in 2017. As a result, the ratio of men and women TB/HIV co-infected in Ukraine decreased from 2.1 to 1.8 , respectively, in 2017 the rates of comorbidity TB/HIV in women with active TB by $21 \%$ over the rate of comorbidity in men.

In 2017 the proportion of adolescents aged 15-24 years among patients co-infected TB/HIV decreased to $2.0 \%$ (from 6\% in 2008) and the proportion of patients aged 45-64 years conversely increased to $24.1 \%$ (from $11 \%$ in 2008). However, the incidence of TB/HIV co-infection and TB/HIV comorbidity rate for 10 years remains the highest in the group of patients aged 25-44 years.

The structure of active TB incidence by type of TB process and the main clinical forms and its changing dynamics presented in Table II. Against the background of a decrease in the total incidence of active TB in 10 years, the proportion of patients with relapse TB increased, as among TB patients without HIV to $18.3 \%$, and among those with TB/ HIV co-infection to $21.0 \%$. And although proportion of extrapulmonary TB patients among co-infected TB/HIV almost unchanged rate of comorbidity TB/HIV in this group increased by 2.7 times among patients with newly diagnosed TB and 6.5 among patients with relapse TB. The highest rate of comorbidity of TB/HIV in 2017 was among the patients with miliary $\mathrm{TB}-71.6 \%$.

\section{DISCUSSION}

The results of our comprehensive research on the epidemic situation of TB in Ukraine showed that during 2008-2017 years, reducing the overall incidence of active TB occurred against a background of growing incidence of co-infection of $\mathrm{TB} / \mathrm{HIV}$, indicating the growing influence of HIV on TB epidemic.

Regional changes in the epidemiology of co-infection of $\mathrm{TB} / \mathrm{HIV}$ on the one hand reflects the impact of military operations in the Donetsk and Luhansk oblasts, causing a redistribution of patients from the eastern regions to the others, and the second side - the deterioration of the epidemiological situation of HIV infection in the western region, where 2017 the proportion of persons aged 15-24 among newly diagnosed with HIV infection was the largest [5]. That is the percentage of HIV-infected young people between the ages of 15-24 new cases of HIV characterizes the spread of new infections. [6]

Epidemic of co-infection of TB/HIV shifted to older age groups 45-64 years repeating trends inherent in the HIV epidemic. Such changes in the age structure of TB/HIV co-infected patients indicate that the "aging" of the HIV epidemic is also confirming the tendency for HIV-infected individuals to be identified at later stages of the disease when TB becomes a major opportunistic infection [5].
The impact of HIV on TB epidemic in Ukraine is also evident higher rate of comorbidity TB/HIV among women and urban residents [7].

Clinical characteristics of TB/HIV co-infection cases in Ukraine, obtained according to the routine monitoring of $\mathrm{TB}$, are consistent with the results of individual studies on TB in HIV-infected people [8-10], which confirms a higher proportion of extrapulmonary TB and relapse TB in TB/ HIV co-infection patients. However, routine epidemiological monitoring does not allow to monitor the number of combined forms of TB (pulmonary and extrapulmonary TB together), which according to individual studies range from $18.7 \%$ to $61.8 \%$ of patients [8-9].

However, there is some limitation of our study that deserves discussion. Since the data is taken from generalized reporting forms, it is not known whether all patients with active TB have a precisely defined HIV status. According to the information of the Public Health Center of the Ministry of Health of Ukraine in 2017, the coverage of HIV testing for TB patients on average in Ukraine was $91.4 \%$. [11].

\section{CONCLUSIONS}

TB/HIV co-infection as a part of the overall TB epidemic has a significant impact on the rate of decline in the overall incidence of TB in Ukraine and slows them down. To accelerate the rate of TB morbidity and achieve the target intermediate indicators of the global «The END TB Strategy» by 2025 (50\% reduction in TB incidence compared to 2015), this means for Ukraine - up to 35.2 per 100,000 population, it is necessary first of all, providing comprehensive access to existing means of assistance and social protection and improving the social-economic development.

Thus, the revealed tendency to increase the rate of $\mathrm{TB} /$ HIV comorbidity necessitates the revision of organizational approaches to helping TB/HIV co-infected patients to increase access to prevention, early detection and proper treatment.

\section{REFERENCES}

1. World Health Organization. The end TB Strategy. Global strategy and targets for tuberculosis prevention, care and control after 2015. Geneva: WH0. 2014. resolution WHA 67.1. URL: https://www.who.int/tb/ strategy/End_TB_Strategy.pdf?ua $=1$

2. World Health Organization, et al. Global tuberculosis report 2018. World Health Organization, 2018. URL: https://apps.who.int/iris/ handle/10665/274453

3. World Health Organization, et al. Tuberculosis surveillance and monitoring in Europe 2019: 2017 data. 2019. URL: http://www.who. int/iris/handle/10665/311349

4. State Statistics Service of Ukraine. Databank of State Statistics Service of Ukraine. URL: http://database.ukrcensus.gov.ua/MULT/Dialog/ statfile_c.asp

5. Kurpita V. et al. VIL-infektsiia v Ukraini. Informatsiinyi biuleten № 49 [HIV infection in Ukraine. News bulletin No 49]. Kyiv: Public Health Center;2018, 121 p.URL:https://phc.org.ua/sites/default/files/uploads/ documents/files/40fc8f955d5286e602e5ce1e8fac0fe2.pdf (UA) 
6. Joint United Nations Programme on HIV/AIDS, et al. Monitoring the declaration of commitment on HIV/AIDS: guidelines on construction of core indicators. UNAIDS, 2003.

7. Horton KC, MacPherson P, Houben RMGJ, White RG, Corbett EL (2016) Sex Differences in Tuberculosis Burden and Notifications in Low- and Middle-Income Countries: A Systematic Review and Meta-analysis. PLoS Med 13(9): e1002119. https://doi.org/10.1371/journal.pmed.1002119.

8. Melnyk V. P., Khursa T. H., Yakymova Ya. 0. et al. Analiz osoblyvostei vyiavlennia, diahnostyky ta perebihu tuberkulozu u khvorykh na koinfektsiiu tuberkuloz/VIL [Analysis of peculiarities of identification, diagnostics and course of tuberculosis in patients with tuberculosis/HIV co-infection]. Zaporozhye medical journal. 2017; Vol. 19, 5(104):604608. D0I: 10.14739/2310-1210. 2017.5.110163 (UA)

9. Nikolaieva 0. D. Osoblyvosti diahnostyky pozalehenevykh form tuberkulozu u VIL-infikovanykh [Peculiarity diagnosis of tuberculosis in HIV-infected]. Tuberculosis, lung diseases, HIV infection. 2018; 2(33):3337. D0I: http://doi.org/10.30978/TB2018-2-33 (UA)
10. Pustovyi Yu. H., Baranova V. V., Roienko H. M., et al. Analiz rozpovsiudzhenosti tuberkulozu u VIL-infikovanykh osib ta efektyvnist yikh likuvannia u Luhanskyi oblasti [Analysis the prevalence of TB infection at the combined TB and HIV infection, and the effectiveness of treatment of these patients]. Ukrainian medical almanac. 2013; Vol. 16, 1:93-95. (UA)

11. Kurpita V. et al. Tuberkuloz v Ukraini. Analitychno-statystychnyi dovidnyk. [Tuberculosis in Ukraine. Analytical and statistical guide]. Kyiv: Public Health Center; 2018, 105 p. URL: http://aph.org.ua/wp-content/ uploads/2018/09/proekt-dovidnika-TB-2018.pdf (UA)

The article is written in the framework of the implementation of the research work of the Department of Medical Statistics of the NMAPE named after P. L. Shupyk "Information and Analytical Support for the Modernization of the Health Care System" No. of the State Registration Number 0113U002210, the term of implementation: 2013-2020.

\section{Authors' contributions:}

According to the order of the Authorship.

Conflict of interest:

The Authors declare no conflict of interest.

\author{
CORRESPONDING AUTHOR \\ Tetiana V. Stepanova \\ Department of Medical Statistics, \\ Shupyk National Medical Academy of Postgraduate Education \\ 9 Dorohozhytska street, 04112, Kyiv, Ukraine \\ tel: +380662279442 \\ e-mail: tetstepanova@gmail.com
}

Received: 28.03.2019

Accepted: 01.05.2019 
PRACA POGLĄDOWA

REVIEW ARTICLE

\title{
PRIMARY AND SECONDARY THROMBOPHILIA: PATHOGENESIS, CLINICAL PRESENTATION, APPROACHES TO THROMBOTIC COMPLICATIONS PREVENTION AND TREATMENT
}

\author{
Olha M. Bereziuk, Julia V. Mazur, Galyna K. Berko, Larysa S. Perebetiuk, Maryna M. Velychkovych, Olena V. Temna, \\ Halyna 0. Movchan \\ NATIONAL PIROGOV MEMORIAL MEDICAL UNIVERSITY, VINNYTSYA, UKRAINE
}

\begin{abstract}
Introduction: Thrombophilia is a predisposition to arterial or venous thrombotic complications as a result of congenital or acquired hemostatic system defects. Thrombophilia increases risk of fatal complications, disability of patients. The assessment of the risk of thrombotic complications makes it possible to prescribe adequate primary or secondary prophylaxis. However, there is no systematic information about estimation risk of thrombosis in various types of thrombophilia and conduction primary and secondary prophylaxis of thrombotic complications, choosing treatment.

The aim: Analysis and arrangement information regarding pathogenesis, clinical features, approaches to diagnosis, risk assessment, primary and secondary prevention and peculiarities of thrombotic complications treatment in patients with thrombophilia.

Materials and methods: There were used methods: content analysis, method of systemic approach. An analysis of the results of clinical trials, the review of articles in the field of hemostasis was conducted.

Conclusions: Patients with deficiency of Pt C, S, antithrombin III deficiency and homozygous factor V Leiden mutation, malignancy, antiphospholipid syndrome, surgical interventions, pregnancy, usage of oral contraceptive pills (OCP s) and hormone replacement therapy (HRT) have the highest risk of thrombotic complications. The type of thrombophilia determinates the choice of anticoagulants, necessity for primary prophylaxis and the duration of secondary prophylaxis.
\end{abstract}

KEY WORDS: hypercoagulation, thrombosis, congenital and acquired thrombophilic condition

Wiad Lek 2019, 72, 5 cz. I, 908-913

\section{INTRODUCTION}

Thrombophilic states are a heterogeneous group of diseases that are characterized by increased blood predisposition to hypercoagulation and high risk of thromboembolic complications. There are congenital (primary) and acquired (secondary) thrombophilia. Blood coagulation is triggered by a tissue factor (TF) that activates the VII coagulation factor, which activates $\mathrm{X}$ and IX coagulation factors. In the center of the coagulation cascade is the synthesis of thrombin under the influence of the prothrombinase complex (factors $\mathrm{Xa}$ and $\mathrm{Va}$ ). Thrombin activates the synthesis of fibrin, functioning of anticoagulation system (Pt $\mathrm{C}, \mathrm{S}$ ) in the presence of thrombomodulin and suppresses the fibrinolytic system (activates the inhibitor of fibrinolysis). Anticoagulants (Pt C, S, antithrombin III) inhibit the activity of V, VIII coagulation factors and thrombin. Violation of this balanced interaction leads to thrombosis or bleeding [1,2].

\section{THE AIM}

The purpose of this work is information analysis and results of clinical trails in thrombophilia, especially, investiagation of pathogenesis peculiarities, clinical picture, prediction of thrombotic complications and systematization of approaches to primary, secondary prophylaxis and treatment of thrombotic complications.

\section{MATERIALS AND METHODS}

There were used methods: content analysis, method of systemic approach. An analysis of the results of clinical trials, the review of articles in the field of hemostasis was conducted.

\section{REVIEW}

\section{PROTEIN C (PT C) DEFICIENCY}

Proteins $\mathrm{C}$ is a vitamin-K-dependent anticoagulant, which is synthesized by hepatocytes. Pt $\mathrm{C}$ inhibits the activity of the blood coagulation factors V and VIII, and also increases fibrinolysis by reducing plasminogen activator inhibitor-I(PAI-I) production by endothelial cells (EC). The pathology is caused by the appearance of an autosomal dominant mutation of the protein $\mathrm{C}$ gene. Acquired deficiency of $\mathrm{Pt} \mathrm{C}$ is possible after surgical intervention, acute thrombosis, in patients with nephrotic syndrome, 
Table I. Relative risk of thrombotic complications for congenital thrombophilia.

\begin{tabular}{cc}
\hline Hypercoaguability state & Relative risk of primary VTE * \\
\hline F V Leiden mutation & $2-10$ \\
\hline Antithrombin III deficiency & $5-40$ \\
\hline Pt C deficiency & $6,5-31$ \\
\hline Pt S deficiency & $2-36$ \\
\hline Prothrombin G 20210A mutation & $2-6$ \\
\hline F V Leiden + prothrombin G 20210A mutation & 20,0 \\
\hline Hyperhomocysteinemia & $2-4$ \\
\hline
\end{tabular}

*Relative risks are compared to persons without thrombophilia

liver failure, disseminated intravascular coagulation (DIC) and after treatment with L-asparaginase. Clinical presentation includes recurrent thrombosis of lower extremities deep veins (DVT), pulmonary embolism (PE), superficial thrombophlebitis, warfarin skin necrosis (in application of large doses of warfarin Pt C synthesis is suppressed faster than thrombin synthesis, therefore coagulant effect develops faster than anticoagulant effect); in homozygous newborns - fulminant purpura (DIC). Prevention and treatment: unfractionated heparin (UFH), low molecular weight heparin (LMWH), vitamin K antagonist (VKA) warfarin (long-term prophylaxis). For the prevention of warfarin-induced necrosis it should be prescribed in low gradually increasing doses $[1,2]$.

\section{PROTEIN S (PT S) DEFICIENCY}

Protein $S$ is a vitamin-K-dependent anticoagulant, which is synthesized by hepatocytes and megacarocytes, is a co-factor of Pt C. Clinical signs: recurrent venous thrombosis, especially DVT and superficial thrombophlebitis, fulminant purpura of newborns. Acquired reduction of $\mathrm{Pt} \mathrm{S}$ production is possible in inflammation, increased content of coagulation factor VIII, autoimmune diseases, HIV and other infections.

\section{FACTOR V LEIDEN MUTATION (FACTOR V RESIS- TANCE TO ACTIVATED PT C).}

The pathology is caused by the appearance of an autosomal dominant mutation. Pt $\mathrm{C}$ inactivates the $\mathrm{V}$ factor of blood coagulation after binding to thrombomodulin, $\mathrm{Pt} S$ and thrombin. There are congenital factor $\mathrm{V}$ resistance to activated $\mathrm{Pt} \mathrm{C}$ and acquired (leukemia, pregnancy, high levels of factor VIII, synthesis of autoantibodies to factor V). Clinical manifestation: DVT, cerebral vein thrombosis, $\mathrm{PE}$, miscarriages in the second trimester of pregnancy, neonatal fulminant purpura in newborns.

\section{PROTHROMBIN G 20210A MUTATION}

Prothrombin G 20210A mutation promotes increasing amount and activity of the prothrombin. Clinically is manifested by arterial and venous thrombosis $[2,3]$.

\section{INCREASED CONCENTRATION OF FACTOR VIII}

Factor VIII synthesis enhancement by endothelial cells is developed in acute inflammation, obesity, hyperestrogenemia, anti-diuretic hormon content increased, usage of OCP, during pregnancy. Clinically is manifested by DVT.

\section{DEFICIENCY OF TROMBOMODULIN}

Thrombomodulin is a membrane protein of EC that activates protein $\mathrm{C}$, coagulation factor $\mathrm{V}$ and platelets. Deficiency of trombomodulin increases risk of myocardial infarction (MI), especially in young patients $[2,4,5]$.

\section{DEFICIENCY OF ANTITHROMBIN III (AT III)}

AT III is synthesized by hepatocytes and endothelial cells. The mechanism of action is based on thrombin inactivation. Clinically manifested by DVT, mesenteric vascular thrombosis and transitory ischemic attakcs (TIA). LMWH is used, because of resistance to UFH is developed. Primary prophylaxis of thrombosis is performed during pregnancy, before and after surgery. Long-life prophylactic use of anticoagulants is recommended for spontaneous and recurrent thrombosis $[1,2,3]$.

\section{HYPERHOMOCYSTEINEMIA}

Congenital pathology is caused by a deficiency of one of the enzymes of homocysteine transformation to methionine (methionine synthase, 5,10-methylenetetrahydrofolate reductase, betaine-methionine methyltransferase) or the enzyme for conversion of methionine to cysteine (cystathionin- $\beta$-syntase). Mechanisms of thrombosis: endothelial dysfunction leads to reducing thrombomodulin expression, inhibition synthesis of nitric oxide, prostacyclin, leads to $\mathrm{PtC}$ and factor $V$ activation and increasing expression of the TF, synthesis of thrombin, adhesion of monocytes to the EC, inhibition tissue plasminogen activator (tPA). Clinical manifestation includes Marfan-like syndrome, lens dislocation, myopia, intellectual deficiency, VTE, early development of atherosclerosis, arterial thrombotic complications (MI, ischemic stroke). The content of homocysteine is $100-500 \mu \mathrm{mol} / \mathrm{L}$. [6,7]. Relative risk of thrombotic complications for congenital thrombophilia

has been shown in table I., for acquired thrombophilia has been shown in table II. 
Table II. Relative risk of thrombotic complications for acquired thrombophilia.

\begin{tabular}{cc}
\hline Hypercoaguability state & RR primary VTE * \\
\hline Lupus anticoagulant & 11 \\
\hline Anticardiolipin antibody & 3,2 \\
\hline Hyperhomocysteinemia & $2-4$ \\
\hline Malignancy (cancer, leukemia, lymphoma) & $4-7$ \\
\hline Fracture, large orthopedic, oncological surgery & $>10$ \\
\hline Nononcological surgery, OCP, HRT, pregnancy, postpartum period & $2-10$ \\
\hline Age, bed rest, smoking, metabolic syndrome & $<2$ \\
\hline
\end{tabular}

$\mathrm{RR}$ - relative risk, * Relative risks are compared to persons without thrombophilia

\section{SECONDARY (ACQUIRED) THROMBOPHILIA}

Malignancy. Pathogenetic mechanisms of hypercoagulation: 1) hyperproduction of TF by activated monocytes, activation of coagulation factor X by sialic acids; 2 ) the synthesis of proinflammatory cytokines (TNF, IL-6) enhance the synthesis of TF, fibrinogen, adhesion molecules, free radicals. Clinical picture of paraneoplastic thrombophilia includes DVT, migratory thrombophlebitis (Trousseau's syndrome), chronic DIC and arterial thrombosis (thrombosis of cerebral artery with development of TIA, ischemic stroke, thrombosis of the arteries of upper and lower extremities). According to NCCN recommendations treatment of VTE is performed with using LMWH (dalteparin $200 \mathrm{U} / \mathrm{kg} \mathrm{OD}$, enoxaparin $1 \mathrm{mg} / \mathrm{kg}$ BID), fondaparinux $(5 \mathrm{mg}$ (<50 kg), 7,5-10 mg (50-100 kg), $10 \mathrm{mg}(>100 \mathrm{~kg})$ OD), UFH; secondary prevention: LMWH, warfarin (2,5-5 $\mathrm{mg} /$ day), direct oral anticoagulants (DOACs) for at least 3 months (NCCN 2013) or 6 months (ASCO 2014). [9,10].

Antiphospholipid syndrome (APS). Antiphospholipid antibodies (APAs) are heterogeneous antibodies that include lupus anticoagulant (LA), anticardiolipin antibodies $(\mathrm{aCL})$, and antibodies against $\beta 2 \mathrm{GPI}$ (a component that inhibits complement activity, suppresses cells apoptosis). $\beta 2 \mathrm{GPI}$ binds to the membrane of ECs, monocytes, platelets, trophoblast cells through receptors: the Toll-like receptor, Annexin A2, GP 1ba, and triggers signaling pathways regulating the cell cycle (proliferation, differentiation, apoptosis of cells), receptor expression, pathophysiological processes (inflammation, lipids peroxidation), activity of anticoagulants (Pt C). Antibodies to $\beta 2 \mathrm{GPI}$ activate expression of adhesion proteins (ICAM, VCAM, e-Selectin), TF on ECs and monocytes; synthesis of thromboxane A2 (TxA2) and expression of GPIIb/IIIa on platelets; reduce activity of anticoagulants ( $\mathrm{PtC}$, Anexin A5), activate the complement, enhance synthesis of proinflammatory mediators, free radicals, stimulate proliferation of ECs (via the signaling pathway PI3K-AKT-mTOR). In the case of pregnancy, APA activates apoptosis and inhibits proliferation, differentiation and maturation of trophoblast and decidual cells, and thus impair placental formation and fetus development. Clinical presentation: thrombosis of arteries and veins of skin, musculoskeletal system and visceral organs; pregnancy and fetus pathology; systemic thrombotic microangiopathy [11].
Usage of OCP, HRT. The synthesis of I, V, VII, VIII, IX, X, XI, XII blood coagulation factors is increased; the production of $\mathrm{Pt} \mathrm{S}$ and AT III is reduced, the activity of the tPA is decreased, and the activity of the plasminogen activator inhibitor-1 (PAI1) and the thrombin-activated fibrinolysis inhibitor (TAFI) is increased. There is a risk of MI, ischemic stroke, thrombosis of the peripheral arteries, DVT and PE $[8,12]$.

Pregnancy. Hypercoagulation is due to increasing the content of I, V, VII, VIII, IX, X, XII blood coagulation factors and decreasing activity of anticoagulants $(\mathrm{Pt} S$ and antithrombin III), inhibition of plasma fibrinolytic activity under the influence of estrogens and progesterones. Hypercoagulation status is maintained 6 weeks after childbirth. The risk of thrombotic complications is high in patients with simultaneous diagnosis of homozygous FV Leiden mutation and the prothrombin G 20210A mutation, AT III deficiency, presence of APS and persistence of APA $[8,12]$.

Acquired hyperhomocysteinemia. It is caused by a deficiency of vitamins B12, B9 and B6, which are cofactors of the enzymes of homocysteine transformation. Homocysteine enhances lipid peroxidation, induces dysfunction and apoptosis of ECs. Hyperhomocysteinemia is associated with increasing synthesis of adhesion molecules by ECs, enhancement synthesis of Tx A2; thrombin, TF, V and VII coagulation factors; reducing synthesis of nitric oxide, prostacyclin, thrombomodulin, $\mathrm{PtC}$ activation, antithrombin activity; activation of PAI-1, and reducing activity of the $\mathrm{PA}$. Hyperhomocysteinemia is divided into mild $(15-30 \mu \mathrm{mol} / \mathrm{L})$, moderate $(30-100 \mu \mathrm{mol} / \mathrm{L})$, severe (more than $100 \mu \mathrm{mol} / \mathrm{L}$ ). In severe hyperhomocysteinemia, recurrent venous and arterial thrombosis (PE, stroke, MI, peripheral arteries occlusion, DVT, superficial phlebitis, rarely - thrombosis of upper limbs veins, mesenteric, portal, cerebral and central retinal veins) are developed. Hyperhomocysteinemia is a risk factor for pathologies associated with pregnant women, pregnancy and fetus: reducing fertility, preeclampsia, fetal nervous tube defects, anencephaly, and fetal development retardation. Prevention of thrombotic complication and pathogenetic treatment includes using vitamins B6, B9 and B12 [6,7].

\section{ACUTE OR CHRONIC INFECTIOUS DISEASES, SEPSIS, AUTOIMMUNE PATHOLOGIES}

The development of the systemic inflammation leads to the releasing of proinflammatory cytokines, including 
TNF, which increases the expression of the TF, molecules of adhesion and VIII coagulation factor synthesis. Systemic inflammation is associated with thrombocytosis, leukocytosis, increasing activity of leukocytes enzymes, provocation of lipid peroxidation, apoptosis of ECs and their dysfunction (inhibition production of nitric oxide and prostaglandins, activation Tx A2 production, reducing activity of anticoagulants). Risk factors of thrombosis include smoking, which provokes the development of endothelial dysfunction; surgical interventions involving TF releasing that activates VII and X blood coagulation factors, as well as immobilization, which results in decreasing venous outflow velocity, and also contributes to the development of hypoxia and endothelial dysfunction [8].

\section{OBESITY}

The accumulation of visceral fat contributes to the development of arterial thrombosis, subcutaneous fat venous thrombosis. The production of reactive oxygen species is increased; activity of the antioxidant system is supressed. Free radicals of oxygen cause chronic inflammation, endothelial dysfunction, activate synthesis of $\mathrm{Tx}$ A2. There is observed increasing synthesis of I, VII and VIII coagulation factors, TF and reducing activity of the fibrinolytic system (enhancement production of PAI-1; TAFI). Insulin resistance inhibits the synthesis of nitric oxide and causes platelet activation, hypercoagulation and vasospasm. Increasing the content of leptin via the Jak2 receptor activates the PI3K/Akt signaling pathway and results in the synthesis of Tx A2 and activation of GPIIb/ IIIa platelet receptors. Lowering and normalizing weight correlates with normalization of hemostasis $[13,14,15]$. The usage of insulin sensitizers (glitazones, biguanides) reduces hypercoagulation, platelet hyperagregability and endothelial dysfunction $[13,14,15]$.

\section{NEPHROTIC SYNDROME AND CHRONIC KIDNEY DISEASES}

Low molecular weight proteins (AT III, Pt C and S, plasminogen) are lost through the glomerular membrane. Loss of fluid in the process of edema development, leads to haemoconcentration. Systemic inflammation, hypercytokinemia, endothelial dysfunction are important factors of hypercoagulation. VTE dominate in clinic presentation. Primary and secondary prevention are not made. Thrombolytics, anticoagulants, antiplatelets, surgical thrombectomy, filter installation in the lower vena cava are used in the treatment of thrombosis. [16].

\section{BLOOD DISORDERS}

The increased risk of thrombotic complications in the case of myeloproliferative neoplasmas (MPN) - polycythemia vera (PV), essential thrombocythemia (ET), - is associated with leukocytosis, thrombocytosis, activation of leukocytes and platelets, high proinflammatory cyto- kines content, that stimulate synthesis of free radicals, cause endothelial dysfunction, enhance the synthesis of TF, Tx A2 and adhesion molecules. Patients with acute leukemia, lymphoma and multiple myeloma (MM) have a high risk of thrombosis also. Pathogenetic pathways of hypercoagulation are the same as in malignancy and MPN. The use of drugs for treatment patient with leukemia and lymphoma (corticosteroid hormones (CS), L-asparaginase, thalidomide, erythropoietin) leads to hypercoagulation state $[17,18,19]$. Patients with haemolytic anemia (HA) and intravascular mechanism of haemolysis, including autoimmune hemolytic anemia with cold antibodies, sickle cell anemia, thrombotic thrombocytopenic purpura (TTP), hemolytic uremic syndrome (HUS), paroxysmal nocturnal haemoglobinuria (PNH) ), less commonly, with intracellular hemolysis (thalassemia) have a high risk of thrombosis. Clot formation is due to the releasing of the heme, that binds nitrogen oxide, increases synthesis of $\mathrm{TF}$, and, in HUS, TTP and NPH, due to complement activation, which triggers coagulation cascade [20]. Clinical picture of thrombotic complication in blood disorder is characterized by development abdominal cavity veins thrombosis, DVT, PE, stroke, myocardial and spleen infarction in MPN; development of cerebral and upper extremities veins thrombosis in the usage of L-asparaginase, DVT in case of CS and thalidomide using, strokes and MI in using erythropoietin. There is a high risk DVT, PE, thrombosis of the microcirculation of kidneys, brain (in HUS, TTP, $\mathrm{NPH})$, lung, liver in HA.

\section{PRIMARY PROPHYLAXIS OF THROMBOTIC COMPLICATIONS}

Primary prophylaxis of thrombotic complications is carried out after evaluation of the risk of thrombotic complications. When detecting congenital thrombophilia, OCP and RHT should be avoided. In the presence of a homozygous $\mathrm{F} \mathrm{V}$ Leiden mutation, a homozygous prothrombin G20210A mutation, AT III or Pt C deficiency and the family history of VTE, primary prenatal and postpartum prophylaxis within 6 weeks is recommended. In Pt S deficiency it is recommended only postpartum prophylaxis within 6 weeks [3].

In acquired thrombophilia, risk of thrombotic complications in patients with MPN, MM, cancer, APS, HA and in case of using chemotherapeutic agents (CT) and corticosteroid hormones should be assessed.

Patients with myeloproliferative neoplasia (PV, ET) should receive antiplatelets. At the beginning of chemotherapy, in high risk of thrombosis (age over 60 years old, cardiovascular disease, mutation JAK2, history of thrombosis) should receive anticoagulants (LMWH). [17, 18,19].

Patients during hemolytic crises with the intravascular mechanism of hemolysis should receive prophylactic therapy using anticoagulants (LMWH). [20].

In patients with $\mathrm{MM}$ presenting with a standard risk to develop VTE or treated with thalidomide as single-agent, antiplatelet therapy with low-dose acetylsalicylic acid (ASA) should be considered. In case of presence of addi- 
tional risk factors or for all patients who receive thalidomide with high-dose dexamethasone or doxorubicin or multi-agent CT, LMWH or full-dose warfarin should be administered. Thromboprophylaxis should be continued for 3-6 months. [21,22].

Primary prophylaxis in case of APS is not prescribed in case of physiological course of pregnancy, absence history of obstetric pathology, absence of APA. But postpartum prophylaxis with UFH or LMWH is conducted within 6 weeks in presence of LA. [11].

\section{SECONDARY PROPHYLAXIS OF THROMBOTIC COMPLICATIONS}

1. Anticoagulation therapy (LMWH, DOAC, VKA). Secondary prophylaxis can last 3-6-12 months or be life-long. [23]. In case of history one thromboembolic event duration of secondary prophylaxis is 3 months; two events - 6 months; three and more events - life-long anticoagulation therapy.

2. The installation of a filter of the lower vena cava is considered if anticoagulant therapy is contraindicated.

3. Risk factors limitation: avoiding the use of OCP in patients with factor $V$ Leiden mutation and women older than 35 years old and who smokes; stopping smoking; body weight correction [4, 23]. Secondary life-long prophylaxis of thromboembolic complication is recommended: 1) after the first episode of VTE in patients with AT III deficiency, homozygous form of factor V Leiden mutation or prothrombin gene 20210A mutation, as well as in the case of a combination of heterozygous forms of these disorders, in some patients with APS. 2) after the first episode of idiopathic thrombosis in thrombophilia another origin than the above in case of PE (especially high risk) and/or proximal thrombosis, if the risk of bleeding is low or moderate; 3 ) after the second episode of VTE or with coexistence of two causes of thrombophilia: a deficiency of Pt C or Pt S, as well as isolated heterozygous form of factor $\mathrm{V}$ Leiden mutation or prothrombin gene 20210A mutation; 4) three and more events of thrombosis. [23]. Secondary prophylaxis of arterial thrombotic complications in patients with blood disorders, cancer, APS, hyperhomocysteinemia, thalidomide using includes antiplatelets, in particular, inhibitors of Tx A2 synthesis - ASA, and thienopyridine-inhibitors of ADP-receptors (clopidogrel, prazugrel), in case of high risk of thrombotic complication is recommended to add anticoagulants (LMWH, AVK, DOAC) $[6,7,17,21]$. Low-dose aspirin (LDA) is recommended in patients with APS with history of arterial thrombotic complications and low titres of aCL, a combination of warfarin or LMWH and LDA is recommended for patients with arterial thrombotic complications history and high titre of aCL [11].

Treatment of arterial and venous thrombotic conditions is carried out in accordance with the protocols for the specific nosologies management. The use of UFH, fondaparinux, LMWH (enoxaparin (cleaxan), dalteparin (fragmin), nad- roparin (fraxiparin), DOAC (rivaroxaban, edoxaban, epixaban, dabigatran, argatroban, lepirudin), and the presence of a thrombophilia may affect the choice of anticoagulants. In AT III deficiency, UFH is ineffective and AT concentrate is recommended. In heparin-induced thrombocytopenia patients are prescribed argatroban or lepirudin. Patients with Pt $\mathrm{C}$ or $\mathrm{S}$ deficiency should be avoid using a high dose saturation of AVK and at the same time use heparin to reduce the risk of skin necrosis (when it has been occur, $\mathrm{Pt} \mathrm{C}$ concentrate is also used) $[1,2,3,4,22]$. APS in a pregnant woman: in presence of obstetric APS, LDA and UFH or LMWH are prescribed [11] In catastrophic APS with systemic thrombotic microangiopathy treatment scheme includes fibrinolytics, anticoagulants (UFH, or LMWH, or DOAC), prostacyclin, CS, immunosuppressants (aminoquinolone, mTOR inhibitors or other immunosuppressants), intravenous immunoglobulin, plasmapheresis. In resistant cases - antibodies against B-lymphocytes (anti CD 20 - rituximab), antibodies against complement - eculizumab [24].

\section{CONCLUSIONS}

1. More than $60 \%$ of patients with spontaneous VTE have congenital thrombophilia.

2. Patients should be screened for congenital thrombophilia in the presence of indication.

3. Among patients with congenital thrombophilia, patients with a Pt C, S, antithrombin III deficiency and F $\mathrm{V}$ Leiden mutation have the highest risk of thrombotic complications.

4. Among the acquired thrombophilia, patients with malignancy, APS, HA, after surgical interventions, during pregnancy, postpartum period, or using of OCP and HRT have the highest risk of thrombotic complications.

5. The type of thrombophilia determinates choice of anticoagulants, the character and duration primary and secondary prophylaxis.

\section{REFERENCES}

1. Megan 0. Nakashima and Heesun J. Rogers. Hypercoagulable states: an algorithmic approach to laboratory testing and update on monitoring of direct oral anticoagulants. Blood Res. 2014; 49(2): 85-94.

2. Robert H. Thomas, MD. Hypercoagulability Syndromes. Arch Intern Med. 2001; 161(20): 2433-2439.

3. Scott M. Stevens, Scott C. Woller, Kenneth A. Bauer, Raj Kasthuri, Mary Cushman, Michael Streiff, Wendy Lim and James D. Douketis. Guidance for the evaluation and treatment of hereditary and acquired thrombophilia. J Thromb Thrombolysis. 2016; 41: 154-164.

4. Morishita E. Diagnosis and treatment of inherited thrombophilia. Rinsho Ketsueki. 2017; 58 (7): 866-874.

5. L Merriman and M. Greaves. Testing for thrombophilia: an evidencebased approach. Postgrad Med J. 2006 Nov; 82(973): 699-704.

6. Ospina-Romero M., Cannegieter SC, den Heijer M., et al. Hyperhomocysteinemia and Risk of First Venous Thrombosis: The Influence of (Unmeasured) Confounding Factors. Am J Epidemiol. 2018; 187:1392. 
7. Jana Hirmerová. Homocysteine and venous thromboembolism — Is there any link? Cor et Vasa. June 2013; Volume 55, Issue 3: e248-e258.

8. Emanuele Previtali, Paolo Bucciarelli, Serena M. Passamonti and Ida Martinelli. Risk factors for venous and arterial thrombosis. Blood Transfus. 2011 Apr; 9(2): 120-138.8.

9. Ryu Ono, Kensuke Fukuda, Masashi Sakayori, Nobuyasu Awano, Keisuke Kondo, Soichiro Ikushima. Trousseau's syndrome: cancer-associated thrombosis. Japanese Journal of Clinical Oncology. 2016;46(3) : 204-208.

10. K.M.J. Brose, MD and A.Y.Y. Lee, MD MSc. Cancer-associated thrombosis: prevention and treatment. Curr Oncol. 2008 Jan; 15(Suppl 1): S58-S67.

11. David Garcia, M.D., and Doruk Erkan, M.D Diagnosis and Management of the Antiphospholipid Syndrome. N Engl J Med. 2018; 378: 2010-2021.

12. Gris, Jean-Christophe; Lissalde-Lavigne, Géraldine Quéré, Isabelle; Dauzat, Michel; Marès, Pierre. Prophylaxis and treatment of thrombophilia in pregnancy. Current Opinion in Hematology: September. 2006; Volume 13, Issue 5: 376-381.

13. Vilahur G, Ben-Aicha S, Badimon L. New insights into the role of adipose tissue in thrombosis. Cardiovascular Research. 2017 Jul;113(9):1046-1054.

14. Andrew L Freeman, Robert C Pendleton, and Matthew T. Rondina Prevention of venous thromboembolism in obesity. Expert Rev Cardiovasc Ther. 2010 Dec; 8(12): 1711-1721.

15. Ilya 0 . Blokhin and Steven R. Lentz. Mechanisms of thrombosis in obesity. Curr Opin Hematol. 2013 Sep; 20(5): 437-444.

16. Hasan F. Al-Azzawi, Onyekachi C. Obi, Javeryah Safi, and Mingchen Song Int. Nephrotic syndrome-induced thromboembolism in adults. J Crit IIIn Inj Sci. 2016 Apr-Jun; 6(2): 85-88.

17. Mallika Sekhar, MBBS, MD. Prevention and Management of Thrombosis in Myeloproliferative Neoplasms . Clinical Advances in Hematology \& Oncology March. 2017; Volume 15, Issue 3: 178-181.

18. Raffaele Landolfi and Leonardo Di Gennaro. Pathophysiology of thrombosis in myeloproliferative neoplasms. Haematologica. 2011 Feb; 96(2): 183-186.

19. Barbui T, Carobbio A, Finazzi G, Vannucchi AM, Barosi G, Antonioli E, et al. Inflammation and thrombosis in essential thrombocythemia and polycythemia vera: different role of C-reactive protein and Pentraxin 3. Haematologica. 2011; 96(2): 315-8.
20. Kenneth I. Ataga. Hypercoagulability and thrombotic complications in hemolytic anemias. Haematologica. 2009 Nov; 94(11): 1481-1484.

21. Antonio Palumbo and Carmela Palladino. Venous and arterial thrombotic risks with thalidomide: evidence and practical guidance. Ther Adv Drug Saf. 2012 0ct; 3(5): 255-266.

22. Gabriela Cesarman-Maus, Esteban Braggio, and Rafael Fonseca. Thrombosis in multiple myeloma (MM). Hematology. 2012 Apr; 17(0 1): S177-S180.

23. Huisman MV, Bounameaux H. Treating patients with venous thromboembolism: initial strategies and long-term secondary prevention. Semin Vasc Med. 2005 Aug; 5(3): 276-84.

24. Deepa R.J.Arachchilage, Mike Laffan. Pathogenesis and management of antiphospholipid syndrome. British Journal haematology. 2017 Jul; 178(2):181-195.

\section{Authors' contributions:}

According to the order of the Authorship.

\section{Conflict of interest:}

The Authors declare no conflict of interest.

\author{
CORRESPONDING AUTHOR \\ Olha M. Bereziuk \\ National Pirogov Memorial Medical University \\ Academic Yushchenko street, 12/52, Vinnytsya, 21018, Ukraine \\ tel: +380966980120 \\ e-mail: olgabereziuk33@gmail.com
}

Received: 19.03 .2019

Accepted: 26.04.2019 
PRACA POGLACDOWA

REVIEW ARTICLE

\title{
ANALYSIS OF INDICATORS OF THE ORTHOPEDIC CAREPROVISION TO THE ADULT POPULATION OF UKRAINE DURING 2012-2017
}

\author{
Serhii M. Hermanchuk' ${ }^{1}$, Volodymyr I. Struk' ${ }^{2}$, Vitaliy I. Bida' ${ }^{\text {, Alexander V. Bida }}{ }^{1}$ \\ 'SHUPYK NATIONAL MEDICAL ACADEMY OF POSTGRADUATE EDUCATION, KYIV, UKRAINE \\ 2PUBLIC MEDICAL ESTABLISHMENT “MUNICIPAL STOMATOLOGICAL POLYCLINIC”, CHERNIVTSI, UKRAINE
}

\begin{abstract}
Introduction: Despite the development of dental science and the introduction of modern methods of treatment of dental diseases into practice that allow solving the most difficult clinical situations, the level of dental morbidity remains high. The decrease in the level of dental health negatively affects the state of general somatic health, causing social maladaptation, which in general is negatively reflected at the level of country's socio-economic development.

The aim of our research is a comparative analysis of the provision of orthopedic care to the adult population of Ukraine on the basis of officially published statistical data of the Ministry of Health of Ukraine.

Materials and methods: For the analysis, the officially published statistical data of the Ministry of Health of Ukraine and the Centre for Medical Statistics of the Ministry of Health of Ukraine have been selected.

Conclusions: A comparative analysis of the provision of orthopaedic dental care to the adult population of Ukraine has shown a change in the quantitative indicators of manufactured orthopaedic constructions both by years and by regions. Coordination of dental care and the introduction of an effective system of monitoring the state of dental health in all parts of the medical and diagnostic process and the necessary forms of statistical reporting will contribute to the creation of an effective system for assessing the quality of dental care.
\end{abstract}

KEY WORDS: dental health, orthopaedic care, statistical data

Wiad Lek 2019, 72, 5 cz. I, 914-917

\section{INTRODUCTION}

One of the most urgent social problems in Ukraine is the public health, including its component - dental health. Despite the development of dental science and the introduction of modern methods of treatment of dental diseases into practice, which allow to solve the most difficult clinical situations, the level of dental morbidity remains high. Of particular concern is the consistently high prevalence of dental diseases in adults, first of all, a significant affection of hard tissues of teeth and periodontal disease, which leads to partial and complete loss of teeth, aesthetic, phonetic, and functional disorders. The decrease in the level of dental health has a negative effect on the state of general somatic health, causing social maladaptation, which in general is negatively reflected at the level of the country's socio-economic development.

The European goals defined by WHO include specific measures to improve the level of dental health, and define clear indicators of the intensity and prevalence of dental diseases. The introduction of WHO recommendations in European countries has proven significant social and medical efficacy in terms of raising and maintaining a high standard of dental health of the population. Most EU countries, which have adopted guidelines recommended by WHO, have already achieved their goals regarding dental health[1].
The results of the analysis of the current state of the dental industry in Ukraine and the prospects for its development indicate the need for reorganization of the dental service in order to increase its accessibility and improve the quality of service delivery [2].

\section{THE AIM}

The main aim of our research is a comparative analysis of the provision of orthopaedic care to the adult population of Ukraine on the basis of officially published statistical data of the Ministry of Health of Ukraine in the context of the implementation of the scientific work of the Department of Orthopedic Dentistry of the Shupyk National Medical Academy of Postgraduate Education on the topic 0117U002587 "Modern methods of rehabilitation of patients with the use of orthopaedic constructions".

\section{MATERIALS AND METHODS}

For the analysis, the officially published statistical data of the Ministry of Health of Ukraine, the Centre for Medical Statistics of the Ministry of Health of Ukraine and the performance indicators of the medical service in 24 regions of Ukraine, and Kyiv, from 2013 to $2017[3,4,5,6,7]$ have been selected. To reduce the 
Table I. Indicators of the Number of Manufactured Units of Single Crowns, Pin Teeth, Inlays, Three-Quarter Crowns, Including Cast Crowns

\begin{tabular}{|c|c|c|c|c|c|c|c|c|c|c|c|}
\hline \multirow[t]{2}{*}{ No. } & \multirow[t]{2}{*}{$\begin{array}{c}\text { Administrative } \\
\text { Region }\end{array}$} & \multicolumn{5}{|c|}{$\begin{array}{l}\text { Manufactured Units of Single Crowns, } \\
\text { Pin Teeth, Inlays, } \\
\text { Three-Quarter Crowns - Overall Number }\end{array}$} & \multicolumn{5}{|c|}{ Including Cast Crowns } \\
\hline & & 2013 & 2014 & 2015 & 2016 & 2017 & 2013 & 2014 & 2015 & 2016 & 2017 \\
\hline 1 & Central & 94708 & 86143 & 87466 & 81529 & 79444 & 12347 & 11354 & 12122 & 11398 & 11717 \\
\hline 2 & Northern & 118233 & 104668 & 102766 & 100483 & 103605 & 35118 & 34099 & 36973 & 34980 & 35675 \\
\hline 3 & Southern & 52519 & 49538 & 51707 & 47558 & 49279 & 14592 & 14449 & 15050 & 15338 & 15925 \\
\hline 4 & Eastern & 77552 & 35780 & 37288 & 35104 & 35665 & 4846 & 2867 & 3732 & 3528 & 3691 \\
\hline \multirow[t]{2}{*}{5} & Western & 91610 & 83737 & 83637 & 77575 & 73108 & 13922 & 15388 & 18197 & 18226 & 18159 \\
\hline & Overall number & 434622 & 359866 & 362864 & 342249 & 341101 & 80825 & 78157 & 86074 & 83470 & 85167 \\
\hline
\end{tabular}

Table II. Indicators of the Number of Manufactured Dental Bridges, Including Cast Bridges

\begin{tabular}{|c|c|c|c|c|c|c|c|c|c|c|c|}
\hline \multirow{2}{*}{ No. } & \multirow[t]{2}{*}{ Administrative Region } & \multicolumn{5}{|c|}{ Dental Bridges - Overall Number } & \multicolumn{5}{|c|}{ Including Cast Dentures } \\
\hline & & 2013 & 2014 & 2015 & 2016 & 2017 & 2013 & 2014 & 2015 & 2016 & 2017 \\
\hline 1 & Central & 63480 & 52444 & 52701 & 51856 & 48942 & 4281 & 3415 & 3087 & 3466 & 3446 \\
\hline 2 & Northern & 62015 & 52957 & 49843 & 46766 & 47450 & 9454 & 8461 & 9159 & 8768 & 8757 \\
\hline 3 & Southern & 28768 & 26031 & 26755 & 24222 & 23983 & 5550 & 5316 & 5831 & 5310 & 5744 \\
\hline 4 & Eastern & 48205 & 21140 & 21330 & 20128 & 19533 & 2027 & 1002 & 1271 & 958 & 1515 \\
\hline \multirow[t]{2}{*}{5} & Western & 53708 & 51361 & 48998 & 36992 & 43353 & 7415 & 8409 & 7796 & 7568 & 8842 \\
\hline & Overall number & 256176 & 203933 & 199627 & 179964 & 183261 & 28727 & 26603 & 27144 & 26070 & 28304 \\
\hline
\end{tabular}

Table III. Indicators of the Number of Manufactured Removable Dentures, Including Bugel Cast Dentures

\begin{tabular}{|c|c|c|c|c|c|c|c|c|c|c|c|}
\hline \multirow{2}{*}{ No. } & \multirow{2}{*}{ Administrative Region } & \multicolumn{5}{|c|}{ Removable Dentures - Overall Number } & \multicolumn{5}{|c|}{ Including Bugel Cast Dentures } \\
\hline & & 2013 & 2014 & 2015 & 2016 & 2017 & 2013 & 2014 & 2015 & 2016 & 2017 \\
\hline 1 & Central & 52688 & 47957 & 45970 & 43710 & 43644 & 768 & 704 & 827 & 643 & 567 \\
\hline 2 & Northern & 53326 & 46754 & 46994 & 44537 & 45720 & 1791 & 1693 & 1774 & 1614 & 1510 \\
\hline 3 & Southern & 32864 & 30298 & 30184 & 28368 & 28915 & 2463 & 2155 & 1997 & 1871 & 1668 \\
\hline 4 & Eastern & 53043 & 24561 & 23960 & 22164 & 23150 & 395 & 216 & 233 & 201 & 205 \\
\hline \multirow[t]{2}{*}{5} & Western & 43686 & 41339 & 39515 & 36876 & 36002 & 647 & 541 & 493 & 435 & 441 \\
\hline & Overall number & 235607 & 190909 & 186623 & 175655 & 177431 & 6064 & 5309 & 5324 & 4764 & 4391 \\
\hline
\end{tabular}

volume of tables, the numerical data was combined according to the administrative division of Ukraine into the Central, Northern, Southern, Eastern and Western regions. The Central region includes: Vinnitsa, Dnipropetrovsk, Kirovohrad, Poltava and Cherkasy region. The Northern region includes: Zhytomyr, Kyiv, Sumy, and Chernihiv region. The Southern region includes: Zaporizhia, Mykolaiv, Odessa, and Kherson regions. The Eastern region includes Volyn, Zakarpattia, Ivano-Frankivsk, Lviv, Rivne, Ternopil, Khmelnytskyi, and Chernivtsi regions.

When conducting a comparative analysis, the dynamics of manufacturing the total number of dentures was studied: single crowns, pin teeth, inlays, three-quarter crowns, including cast, composite dentures, removable dentures, including bugel cast, permanent splints and splintdentures, porcelain fused to metal and porcelain.

\section{REVIEW}

Indicators of the number of manufactured units of single crowns, pin teeth, inlays, three-quarter crowns, including cast crowns, are presented in Table. I.

Analysing the structure of the manufacture of the total number of units of single crowns, pin teeth, inlays, three-quarter crowns, including cast ones in the whole of Ukraine for the period from 2013 to 2017, it should be noted that the smallest number of manufactured units was in 2017 (341101), while compared to 2013 there was a decrease of $21.52 \%$. Analysis of the manufacturing structure by administrative regions showed that the largest number of units was produced in the Northern region in 2013 (118233), and the least in the Eastern region in 2016 $(35,104)$. 
Table IV. Indicators of the Number of Manufactured Permanent Splints and Splint Dentures

\begin{tabular}{ccccccc}
\hline \multirow{2}{*}{ No. } & Administrative Region & \multicolumn{5}{c}{$\begin{array}{c}\text { Permanent Splints } \\
\text { and Splint Dentures - Overall Number }\end{array}$} \\
\cline { 2 - 7 } & & $\mathbf{2 0 1 3}$ & $\mathbf{2 0 1 4}$ & $\mathbf{2 0 1 5}$ & $\mathbf{2 0 1 6}$ & $\mathbf{2 0 1 7}$ \\
\hline 1 & Central & 4349 & 2191 & 2178 & 2767 & 2677 \\
\hline 2 & Northern & 3502 & 3609 & 3069 & 2760 & 2823 \\
\hline 3 & Southern & 327 & 324 & 268 & 227 & 250 \\
\hline 4 & Eastern & 2683 & 542 & 415 & 400 & 380 \\
\hline 5 & Western & 228 & 272 & 401 & 344 & 443 \\
\hline
\end{tabular}

Table V. Indicators of the Number of Manufactured Porcelain Fused to Metal and Porcelain Units

\begin{tabular}{cccccccc}
\hline \multirow{2}{*}{ No. } & Administrative Region & \multicolumn{5}{c}{ Porcelain Fused to Metal and Porcelain Units } \\
\cline { 2 - 7 } & & $\mathbf{2 0 1 3}$ & $\mathbf{2 0 1 4}$ & $\mathbf{2 0 1 5}$ & $\mathbf{2 0 1 6}$ & $\mathbf{2 0 1 7}$ \\
\hline 1 & Central & 9132 & 8054 & 8136 & 8206 & 8708 \\
\hline 2 & Northern & 24101 & 24691 & 26294 & 29733 & 30655 \\
\hline 3 & Southern & 11338 & 12224 & 13265 & 12494 & 14364 \\
\hline 4 & Eastern & 6026 & 4080 & 4303 & 3922 & 4585 \\
\hline 5 & Western & 8512 & 11285 & 12394 & 13890 & 13428 \\
\hline & Overall number & 59109 & 60334 & 64392 & 68245 & 71740 \\
\hline
\end{tabular}

According to the number of solid single crowns, pin teeth, inlays, three-quarter crowns, there is an increase by $5,37 \%$ in 2017 (85167) compared to 2013 (80825). The largest number of manufactured cast dentures was in the northern region $(36,973)$ in 2016 , and the smallest was 2867 in the Eastern region in 2014.

In general, the proportion of manufactured cast constructions of fixed dentures in Ukraine totalled $18.6 \%$ in 2013 and $24.97 \%$ in 2017.

The number of dental bridges made by regions of Ukraine during 2013-2017 is presented in the Table II.

Analysis of the structure of indicators of dental bridges revealed a gradual decrease in the number of manufactured dentures. Dental bridges comprised the smallest number in 2016 (179964). Compared to 2013 (256176), the total number has decreased by $29.75 \%$.

Analysis of administrative regions showed that the largest number of units was produced in the Central region in 2013 (63480), and the least in the Eastern region in 2017 (19533).

According to the number of cast bridges, there was a slight fluctuation in the indicators for the years indicated, but in 2014-2017, according to the total number, there was a percentage increase in the proportion of cast bridges and in 2017 this figure was $15.4 \%$.

Statistical data on the manufacture of removable dentures, including bugel cast ones, is reflected in Table III.

When analysing the indicators of the manufacture of removable dentures, including the bugel cast ones, as well as in the indicators of fixed orthopaedicconstructions, there is a tendency towards a decrease in the total number of manufactured dentures, but there is no sharp failure in 2014. In general, the number of manufactured dentures during 2013-2017 decreased by $24.7 \%$.

Analysing the indicators by administrative regions, it was revealed that the most part of removable dentures was manufactured in the Northern region in 2013 (53326), and the smallest part in the Eastern region in 2016 (22164).

Also, for 2013-2017, there was a significant decrease in the number of bugel cast dentures (6064 in 2013 compared with 4391 in 2017 year). Statistically, the number of manufactured bugel cast dentures decreased by $27.59 \%$.

Indicators of the number of manufactured permanent splints and splint dentures are presented in Table IV.

According to statistics, the total number of permanent splints and splint dentures manufactured in Ukraine decreased almost twice from 2013 (11089) to 2015 (6331) and began to gradually increase until 2017 inclusive. The largest number of permanent splints and splint dentures was manufactured in 2013 in the Central region (4349), and the smallest in 2013 in the Western and in 2016 in the Southern region (228 and 227).

Despite the reduction in the number of manufactured splints and splint dentures in the Central, Northern, Southern and Eastern regions, it is impossible not to isolate the increase in manufactured corresponding orthopaedicconstructions in the Western region almost twice from 2013 to 2017 from 228 to 443 , respectively.

The lowest rates of splints and splint dentures are observed in the Southern region as compared to those of other regions. 
Statistical data on the manufacture of removable dentures, including bugel cast dentures, is shown in Table V.

The analysis of the structure of indicators of porcelain fused to metal and porcelain units showed an increase in the total number from 59,109 in 2013 to 71740 in 2017. The growth rate was $21.4 \%$ over five years.

The largest number of manufactured porcelain fused to metal and porcelain units was in the Northern region $(30,655)$ in 2017, and the smallest was in the Eastern region in 2016 (3922).

In general, in all regions of Ukraine there is a clear tendency towards an increase in the number of modern aesthetic orthopaedicconstructions produced, which indicates an increase in the level of providing orthopaedic care to the population of Ukraine.

\section{CONCLUSIONS}

A comparative analysis of the provision of orthopaedic dental care to the adult population of Ukraine on the basis of officially published statistical data of the Ministry of Health of Ukraine showed a change in the quantitative indicators of manufactured orthopaedicconstructions both by years and by regions with a tendency to reduce the total number of traditional dentures manufactured in the study period up to $24.7 \%$ and an increase in the indicators of porcelain fused to metal and porcelain units (metal-free ceramics) with a growth rate of up to $21.4 \%$ over five years.

Coordination of dental care and the introduction of an effective system of monitoring the state of dental health of the population, improving the mechanism for ensuring the introduction of new therapeutic diagnostic and medical-preventive technologies into all stages of the diagnostic and treatment process in state, municipal and private dental institutions, and the necessary forms of statistical reporting will contribute to the creation of an effective system for assessing the quality of dental care and raising the level of dental health of the population.

\section{REFERENCES}

1. Bida VI, Bida OV, ZabuhaYul. Derzhavne upravlinnia reformuvanniam okhorony zdorov'ia. Rozvytok derzhavnoho rehuliuvannia stomatolohichnoi sluzhby v Ukraini [Public administration of health care reform. Development of state regulation of dental services in Ukraine]. Kyiv: Synopsy; 2011.116 s.

2. Zabuga Ju I, Bida OV, Struk VI. Analiz stanu stomatologichnogo zdorov'ja ta rivnja zubnogo protezuvannja naselennja v Ukrai'ni [Analysisofthestateof dental health and the level of dentures in Ukraine]. Zbirnyk naukovyh prac'spivrobitnykiv NMAP0 imeni P.L. Shupyka. 2013 kviten' 22; 22(1):370-7.

3. VoronenkoJu.V, redaktor. Stomatologichna dopomoga v Ukrai'ni [Dental care in Ukraine]. Kirovograd: "Polium"2014. $84 \mathrm{~s}$.

4. Voronenko Ju V, redaktor. Stomatologichna dopomoga v Ukrai'ni [Dental care in Ukraine]. Kirovograd:"Polium"2015. $85 \mathrm{~s}$.

5. Voronenko Ju V, redaktor. Stomatologichna dopomoga v Ukrai'ni [Dental care in Ukraine]. Kirovograd: "Polium"2016. 84 s.

6. Voronenko JuV, redaktor. Stomatologichna dopomoga v Ukrai'ni [Dental care in Ukraine]. Kirovograd: "Polium"2017.86 s.

7. Voronenko Ju V, Pavlenko OV, Mazur IP, redaktory. Stomatologichna dopomoga v Ukrai'ni: osnovni pokaznyky dijal'nosti za 2008-2018 roky [DentalcareinUkraine: themainindicatorsofactivityfor 2008-2018]. Kropyvknyc'kyj: Polium, 2018. $211 \mathrm{~s}$.

Topic of the research: «Modern methods of rehabilitation patients with dental disease using prosthesis constructions». Beginning 02.2017 Finishing 12.2021.

National Medical Academy named after P.L. Shupik Institute of Dentistry, Health Ministry of Ukraine.

Universal decimal classification 616.314

\section{Authors' contributions:}

According to the order of the Authorship.

\section{Conflict of interest:}

The Authors declare no conflict of interest.

\section{CORRESPONDING AUTHOR \\ Sergii Hermanchuk}

Chekhov street 24, apartment 21, 08200 Irpen, Ukraine

tel: +380506059241

e-mail:shermanchuk@ukr.net

Received: 20.03.2019

Accepted: 02.05.2019 


\title{
INTERDISCIPLINARY APPROACH TO DIAGNOSTICS OF MALOCCLUSIONS (REVIEW)
}

\author{
Lyubov V. Smaglyuk, Hanna V. Voronkova, Anna Y. Karasiunok, Anastasiia V. Liakhovska, Kseniia 0. Solovei \\ UKRAINIAN MEDICAL STOMATOLOGICAL ACADEMY, POLTAVA, UKRAINE
}

\begin{abstract}
Introduction: The main task of modern orthodontics is to create a balanced, morphologically stable occlusion in harmony with facial aesthetics and functional adaptation. The aim of the study is to investigate the relationship between dento-facial anomalies and somatic pathology.

Materials and methods: A literary study was conducted using the Medline database and the Google Scholar database.

Review: The human body is a biological system consisting of interconnected and subordinate elements. Any abnormalities in the operation of this system may lead to functional impairment in a single organ. This is fully applicable to dento-facial anomalies and deformations; their development is closely related to other diseases.

Conclusions: The diagnostics, treatment tactics and prevention of dento-facial anomalies and deformations should be considered in the context of the integrity of the child's unformed organism, the interdependence of the form and functions of its organs and systems.
\end{abstract}

KEY WORDS: diagnostics, dento-facial anomalies, malocclusions

Wiad Lek 2019, 72, 5 cz. I, 918-922

\section{INTRODUCTION}

The main task of modern orthodontics is to create a balanced, morphologically stable occlusion in harmony with facial aesthetics and functional adaptation $[1,2,3]$. During the last decade, there is a clear tendency in the prevalence of dento-facial anomalies, which, according to the data of modern domestic and foreign scientific literature, reaches $80 \%[4,5,6]$, and sometimes exceeds this figure. Thus, according to R. E. Villanuela-Arriaga [7], only $8.2 \%$ of those examined have a physiological bite which makes orthodontic treatment a problem of social importance. Researchers [8] note a constant and statistically significant correlation between the permanent occlusion pathology and the state of somatic health in adolescence. These include diseases of the respiratory, musculoskeletal, endocrine systems, and the psycho-emotional status of the patient. From the data of modern literature, the interconnection between the presence of anomaly of the bite and posture abnormalities due to the dento-facial system as one of the postural sensors that provide harmony and balance of the human body in space [ 9 , $10,11]$. The most important changes in the structural and functional state of the bone tissue are observed during puberty, the course of which affects the further formation and condition of the bone tissue throughout life [12]. Only taking into account the somatic status and the psycho-emotional state of the patient in orthodontic treatment allows choosing the optimal treatment [13]. Therefore, the interdisciplinary approach is one of the most urgent tasks of modern orthodontics and a constant object of searching for new methods of diagnosis and treatment [14].

\section{THE AIM}

The aim of the study is to investigate the relationship between dento-facial anomalies and somatic pathology.

\section{MATERIALS AND METHODS}

A literary study was conducted using the Medline database and the Google Scholar database. Keywords used in the search were: malocclusions, growth and development, orthodontic diagnostic and treatment.

\section{REVIEW AND DISCUSSION}

The human body is a biological system consisting of interconnected and subordinate elements. The peculiarities of their structure and relations are subordinated to their functioning as part of a single integral mechanism. Therefore, any abnormalities in the operation of this system may lead to functional impairment in a single organ. This is fully applicable to dento-facial anomalies and deformations; their development is closely related to other diseases [15]. Genetic, congenital and acquired factors are commonly identified as the main etiological factors in the development of dento-facial anomalies [16]. Most authors note the existence of a direct interconnection between the general somatic pathology and anomalies of the dento-facial system $[16,17,18,19]$. When analysing the literature data, several major groups of diseases that have the greatest impact on the development of the dento-facial system are clearly distinguished: diseases of the ENT organs, the gastrointestinal 
tract, endocrine and musculoskeletal systems. At present, scientists have substantiated the concept of commonality of factors that shape both dental status and state of somatic health $[20,21,22,23,24]$. The morphological basis of the unity of the characteristics of dental and somatic health is the commonality of the embryonic origin of the facial part of the skull, skin, its derivatives, musculoskeletal system, heart valves, and blood vessels $[25,26]$. Thus, based on the analysis of the interconnection between parameters of electrocardiogram and electromyography, the intersystem integration of the functional state of the dento-facial and autonomic nervous systems, as well as the cardiovascular and respiratory systems has been proved [27]. An increase in the frequency of dento-facial anomalies and deformations in 1,6-2,3 times is noted in disorder of the musculoskeletal system [28]. In this category of children, deep incisor occlusion, distal occlusion and neutral occlusion with anomalies of individual teeth predominate. It has been revealed that with the increase in the severity of disorders of the musculoskeletal system (from the posture abnormalities to scoliosis II-IV degree of severity) the prevalence of distal occlusion increases [29]. In children with scoliosis, 72.9-84.3\% of cases are diagnosed with dento-facial anomalies and deformations [30].

According to recent studies, the dento-facial system plays an important role in the postural balance of a person, that is, its condition affects the stability of the human body in space. Decrease in the occlusal vertical dimension occurs in such pathological conditions of the dento-facial system as dentition defects, anomalies of bite, dysfunction of the TMJ, pathological abrasion of teeth. It affects the functioning of not only the dento-facial system, but also the human body as a whole [31, 32,33]. Delaire argued that the position of the upper and lower jaws relative to each other is determined by the ratio of the tone of the posterior group of the neck muscles and the mass of the skull [34]. The position of the jaws has an effect on the spatial orientation of the head, and this in turn affects the position of other structures of the body. When the contact between the occlusal surfaces of the teeth on one or two sides is impaired, the patient's postural status changes, which may lead to pain in the neck or shoulder, changes in the spine, disorders in the body position, and incorrect posture [9]. Some researchers point to the "anterior" position of the head of patients with dysfunction of the temporomandibular joints associated with the shortening of the extensors of the sternocleidomastoid muscles. This confirms the effect of dysfunction of the temporomandibular joints on posture. A high frequency, up to $90 \%$, of dento-facial anomalies in children with allergic pathology has been established [35]. Research showed that in $89,3 \%$ of cases, children with bronchial asthma have dento-facial anomalies. The impairment in the activity of the glands of the internal secretion has a negative impact on the formation of the child's organism in general and on the growth and development of the dento-maxillofacial complex, in particular [36, 37, 38, 39]. Adolescence is one of the critical periods of human life, since it is precisely in adolescence that the neuroendocrine system begins to function, and sex hormones which affect the development of many body systems and the formation of reproductive health are produced. Under the action of steroid hormones, an active development of the musculoskeletal system occurs, which is manifested by the acceleration of total body growth and dento-maxillofacial growth. Insufficient secretion of estrogen leads to impaired bone mineralization and may cause abnormalities in the maxillofacial area [40,41, 42]. Research results show that sex hormones are one of the key factors that determine the growth and development of the mandible. A delay in the sagittal growth of the mandible, disturbance of its architectonics, and disproportional development of the facial part of the skull were observed with changes in the level of sex hormones [43]. In case of hypogonadism there are anomalies of bite, the deformation of the facial skeleton, changes in the structures of the TMJ. Thus, an examination of one hundred and twenty-two patients suffering from $b$-thalassemia, which is accompanied by hypogonadism, revealed a disproportional development of the facial part of the skull [44]. Impaired growth and development of the dento-facial system was detected in case of juvenile rheumatoid arthritis [45]. In juvenile idiopathic arthritis, one third of the patients examined were diagnosed with the skeletal pathology of the Angle I class, as well as impaired functional state of the TMJ [46]. Thyroid hormone, thyroxin, stimulates growth in the sphenoid-occipital synchondrosis, nasal cartilage, and the growth of the upper jaw in the area of bone sutures, thereby determining the size and position of the upper jaw. As a result of a decrease in thyroxin level, there is a delay in craniofacial growth, disproportional development, retroposition of the upper jaw, and decrease in the length of the mandible [47]. According to O.T. Supiieva in children living in foci of iodine deficiency, the frequency of dento-facial anomalies is $39.1 \%$, and the frequency of endemic goiter it is $61.1 \%$ [48]. In case of pituitary insufficiency associated with a decrease in the secretion of all the hormones produced in the anterior lobe of the pituitary gland, disturbances in the dento-facial system were detected [49]. The study by B. Kawala, T. Mathews-Brzozowska et al. [50] showed that in children with growth hormone deficiency, the difference between chronological, dental and bone age is determined. With insufficiency of the growth hormone, due to the proportional delay in craniofacial growth, there is a decrease in all craniometric and gnathometric linear parameters, with the most pronounced changes in the length of the upper jaw, and the length of the anterior part of the skull base $[51,52]$. Hypersecretion leads to gigantism in young people and to acromegaly in adults, which is usually caused by pituitary adenoma. Cephalometric studies with gigantism indicate a large size of the anterior facial height. Growth of the lower jaw occurs gradually and according to research data a cross-bite is often formed. Enlargement of the tongue is noted. An increase in the mandible in case of acromegaly is the result of both appositional growth and hypertrophic changes in the cartilaginous joint. Skeletal anomalies were identified in the experimental study of the role of parathyroid hormones in the maxillofacial development, Accelerated differentiation of chondrocytes and endochondral bone formation in the posterior part of the anterior section of the skull base and in synchondrosis, as well as abnormal bone modelling were observed [53]. Skeletal forms of the Angle Class II anomalies are the dominant pathology in secondary hyperparathyroidism due to chronic renal failure - Sagliker 
syndrome. Under the experimental conditions, it was found that corticosteroid hormones have a significant inhibitory effect on the proliferative activity and differentiation of chondrocytes in the temporomandibular joint, and therefore, adversely affect the normal process of endochondral bone formation in the mandible growth zone. The growth of the inhibitory effect of corticosteroids is partially due to a decrease in the reaction of cartilage cells to insulin-like growth factor-1 (IGF-1) [54]. When studying craniofacial morphology in children with obesity, an increase in the length of the mandible, prognathia of the jaws, and a decrease in the anterior height of the face were recorded [55]. However, the analysis of literature data revealed that it is necessary to specify the prevalence of clinical forms of anomalies and deformations of the dento-facial system in children with endocrine pathology. A. Silvestrini-Biavati et al. prove in their study that the pathological condition in one part of the body affects other areas. Skeletal muscles play a crucial role in the coincidence of various disorders, since they have a continuous anatomical and functional "chain" between the skull, lower jaw, spine, limbs and pelvis [56, 57]. Therefore, when a strong muscle tension occurs in one of the links in this chain, it is immediately transmitted to another part of the body. As a result, the body loses its equilibrium state, generating compensatory mechanisms, for example, muscle tension in other antagonistic parts of the body. Thus, dento-facial anomalies with disturbance of the mandibular position are associated with one of the links in the muscle chain, which leads to an excessive contraction of the masticatory muscles [58]. This tension causes the rest of the body to react, creating postural modifications caused by contractions of other muscles of the chain.

Impaired respiratory function has a direct effect on the formation of the dento-facial area. According to A. Y. Gungora [59], the volume of air passing through the nose and nasopharynx is limited by its shape and diameter. Continuous flow induces a constant stimulus for transversal growth of the upper jaw and proper formation of the palate. Maximum morphological differences were observed between patients with and without respiratory tract problems, showing a potential etiological role in the interaction between the respiratory function and the maxillary growth: shortening and narrowing of the upper jaw, increasing the length and thickness of the soft palate, V-shaped dental arch, high palate and protrusion of incisors.

According to L.V. Polma et al. [60, 61, 62], when planning a treatment, it is mandatory to take into account patients' motivation. A.M. Dybov, H.B. Ospanova emphasize the need to take into account the needs and expectations of the patient [63]. The level of aesthetic component, according to I. Grzywacz [64], reflects the subjective need for dental aesthetics and orthodontic treatment. I.N. Minaieva [65] notes that it is the aesthetic component that is essential for the image of success. $U$. Klages [66] points out that there is an interconnection between physical attractiveness, on the one hand, and social success and high self-esteem, on the other. The author also found that, unlike subjects with higher level of teeth aesthetics, respondents with a low level of aesthetics showed a higher social interest in their own appearance. Thus, taking into account the psycho-emotional state of patients must be necessarily supplemented by clinical diagnostic methods [67].

\section{CONCLUSIONS}

Thus, the interaction of local disorders of the dental-maxillofacial area in children and adolescents with common diseases allows to consider dento-facial anomalies and deformations as a multiorgan, socially significant pathology. Consequently, the diagnostic, treatment tactics and prevention of dento-facial anomalies and deformations should be considered in the context of the integrity of the child's unformed organism, the interdependence of the form and functions of its organs and systems.

\section{REFERENCES}

1. Gerasimov S.N. Ortodonticheskoye lecheniye vzroslykh patsiyentov. Lingval'naya ortodonticheskaya tekhnika [Orthodontic treatment of adult patients]. SPb;: Piter: 2004, 136s. (RU)

2. Kuroyedova V.D. Osnovy tekhniki pryamoy dugi [Fundamentals of a direct arc technique] In: N.V. Kulish. Poltava: Verstka; 2008, 108 s. (RU)

3. Alexander R. G.'Wick' Quintessence Publishing Co Inc.,U.S., 2013, $1740 \mathrm{p}$.

4. Dyen'ha 0.V., Mirchuk B.M., Horokhivs'kyy V.N. etal. Poshyrenist' zuboshchelepnykh anomaliy ta stan porozhnyny rota u ditey $\mathrm{m}$. Dnipropetrovs'ka [Prevalence of tooth-abdominal anomalies and the state of the cavity of mouth in children of Dnipropetrovsk]. Visnyk stomatolohiyi. 2004;2:74-76. (UA)

5. Holovko N.V., Halych L.B., Kulish N.V. [ta in.] Poshyrenist' ZSHCHA v ditey ta pidlitkiv Poltavs'koyi oblasti [Prevalence of malocclusion in children and adolescents of the Poltava region.]. Ukrayins'kyy stomatolohichnyy al'manakh. 2006;5:48-51. (UA)

6. DoroshenkoS.I., Kul'hins'kyyYE.A., IyevlyevaYU.V. [tain.] Rozpovsyudzhenist' zuboshchelepnykh anomaliy ta deformatsiy, a takozh defektiv zubiv ta zubnykh ryadiv sered ditey shkil'noho viku m. Kyyeva [Distribution of toothjaw abnormalities and deformations, as well as defects in teeth and dentition among children of school age in Kyiv].Visnykstomatolohiyi 2009;2:76-81. (UA)

7. Villanueva-Arriaga R.E.,Garsia-LopezS.,Masin-CabreraS. [etal.] Orthodontic treatmentneeds in schoolchildren in south east Mexico city. European Journal of Orthodontics. 1999;21(5): 627.

8. Levenets S.A., Novokhatskaya S. V., Shelud'ko 0. YU. Faktory riska i klinicheskiye osobennosti vtorichnoy oligomenorei u devochek-podrostkov [Riskfactors and clinical features of secondary oligomenorrhea in adolescent girls]. Líkars'ka sprava.Vrachebnoye delo.2015;3-4:128-131. (RU)

9. IvanovV.V., Markov N.M.Vliyaniyezubochelyustnoy sistemy na postural'nyy status patsiyenta [The influence of the dental system on the patient's postural status]. Manual'naya terapiya.2013;3(51):83-89. (RU)

10. Cuccia A.M. Carola C. The measurement of craniocervical posture: a simple method to evaluate head position. Int J Pediatr Otorhinolaryngol. Int J Pediatr Otorhinolaryngol. 2009;Sep 27. doi: 10.1016/j.orl.2009.09.011. Epub 2009 Sep 27. PubMed PMID: 19786307.

11. Fujino S., Takahashi S, T.,Ueno T. Influence of voluntary teeth clenching on the stabilization of postural stance disturbed by electrical stimulation of unilateral lower limb. Gait Posture. 2010;31 (1):122-125.

12. Lazareva Ye.K., LikhachevV.K., NovikovV.M. Rasprostranennost'zabolevaniya visochno-nizhnechelyustnogo sustava na fone endokrinnykh narusheniy [Prevalence of temporomandibular joint disease on the background of endocrine disorders]. Ukr. med. al'manakh. 2014;2:37-39. (RU)

13. Degtyareva I.N., Bulyakov R.T. Problema podgotovki patsiyenta $k$ ortodonticheskomu lecheniyu v trudakh otechestvennykh i zarubezhnykh issledovateley [The problem of preparing a patient for orthodontictreatment in the works of domestic and foreign researchers]. Rossiyskaya meditsinskaya akademiya poslediplomnogo obrazovaniya. M.:2005; 214-216. (RU) 
14. Zholuyev S.Ye., Grin’kova I.YU. Opyt ispol'zovaniya shkaly klinicheskoy stomatologicheskoy dlya ekspress-diagnostiki psikhoemotsional'nogo sostoyaniya patsiyenta [Experience of using the clinical dental scale for express diagnostics of the patient's psycho-emotional state]. Stomatolog. 2000;5:10-12. (RU)

15. Shamov S. M. Vzaimosvyaz' obshchesomaticheskoy patologii i zubochelyustnykh anomaliy u detey i podrostkov Respubliki Dagestan [The relationship between somatic pathology and in children and adolescents in Dagestan]. Kubanskiy nauchnyy meditsinskiy vestnik. 2013;6 (141): 193-195. (RU)

16. Stomatologiya detey i podrostkov: Per. s angl. [Dentistry of children and adolescents: Trans. from English]. M.: Meditsinskoye informatsionnoye agentstvo; 2003:766. (RU)

17. Kim A. A., Karasyunok 0. A. Osobennosti prikusa u lits s zabolevaniyami oporno-dvigatel'nogo apparata [Features of bite in persons with diseases of the musculoskeletal system]. Tezisy dokladov. Minsk:2000:34-35. (RU)

18. Daminov T. O., Yakubov R. K., Mavlyanovl. R.. et al. Rol'obshchikh faktorov v patogeneze razvitiya deformatsiy zubochelyustnoy sistemy [The role of common factors in the pathogenesis of the development of deformations of the dental system]. Stomatologiya. 2002;4: 57-60. (RU)

19. Holovanova I. A., Lyakhova N. A., Sheshukova 0. V. [et al.] Studing the skills attitudes on factors affecting dental health of children. Wiad Lek. 2018; 3(II):640-647.

20. Bida 0.V. Stomatolohichne zdorov'ya ditey molodshoho ta seredn'oho shkil'noho viku i kryteriyi yoho otsinky [Dental health of children of junior and middle school age and criteria for its evaluation]. Ukrayins'kyy stomatolohichnyy al'manakh.2007;1:51-54. (UA)

21. Savychuk N.0., Klityns'ka 0.V. Stomatolohichne zdorov'ya ditey, metodolohichni pidkhody ta kryteriyi yoho otsinky [Dental health of children, methodological approaches and criteria for its assessment]. Sovremennaya stomatolohyya. 2008;1:94-98. (UA)

22. Voronkova A. V., Smaglyuk L. V. Changes in biochemical parameters of oral fluid in patients during the orthodontic treatment with a bracket system under the action of a developed mucosal gel with probiotic Wiad Lek. 2018;3(I):496-500.

23. Voronkova H. V., Smahlyuk L. V. Zminy biokhimichnykh pokaznykiv rotovoyi ridyny u patsiyentiv, yaki znakhodyat'sya na ortodontychnomu likuvanni breket-systemoyu [Changes in biochemical parameters of oral fluid in patients who are on orthodontic treatment with fixed system]. Aktual'ni problemy suchasnoyi medytsyny. 2017;3 (59):199-202. (UA)

24. Trofymenko K. L., A. YE. Karasiunok Kompleksnyy pidkhid do ortodontychnoho likuvannya patsiyentiv v rann'omu zminnomu prykusi [Comprehensive approach to orthodontic treatment of patients in the early mixed dentition]. Aktual'ni problemy suchasnoyi medytsyny Visnyk Ukrayins'koyi medychnoyi stomatolohichnoyi akademiyi. 2016;3 (55):23-26. (UA)

25. Ham A., Cormack D. Histology. Toronto.1983:1-48.

26. Avetikov D.S. Izucheniye biomekhanicheskikh svoystv kozhi sostsevidnoy oblasti pri vypolnenii kosmeticheskoy otoplastiki [Study of the biomechanical properties of the skin of the mastoid area when performing cosmetic otoplasty]. Klíníchna khírurgíya. 2015;8(876): 41-44. (RU)

27. Bugrovetskaya 0.G., Maksimovskaya L.N., Bugrovetskaya Ye.A. Vzaimosvyaz' funktsional'nogo sostoyaniya zubochelyustnoy i vegetativnoy nervnoy systemy [Interrelation of the functional state of the dentition and autonomic nervous systems]. Manual'naya terapiya.2010; №2(38):18-23. (RU)
28. TsimbalistovA.V.,LopushanskayaT.A.,ChervatokA.Ye.Stomatologicheskiy status bol'nykh s zabolevaniyami opornodvigatel'nogo apparata [Dental status of patients with diseases of the musculoskeletal system]. Institut stomatologii. 2005;29: 68-69. (RU)

29. Perova Ye.G. Kharakter zubochelyustnykh anomaliy i deformatsiy u detey s razlichnym sostoyaniyem oporno-dvigatel'nogo apparata [The nature of dental anomalies and deformities in children with different state of the musculoskeletal system]. Institut stomatologii. 2010;46:74-75. (RU)

30. Levenets A.A.,.Perova Ye.G 0 vzaimosvyazi skolioticheskoy bolezni i zubochelyustnykh anomaliy i deformatsiy [0n the relationship of scoliotic disease and dental-maxillary anomalies and deformations]. Stomatologiya. Rezhim dostupa: http://www.mediasphera. ru./ Journals/stomo/dentali/253/3821/(RU)

31. Zozulya I.S., Bredikhin A.V., Bredikhin K.A., at al. Myshechno-fastsial'naya disfunktsiya, puti yeye korrektsii [Musculo-fascial dysfunction, ways of its correction].Mezhdunarodnyynevrologicheskiy zhurnal.2014;4(66):41-50.(RU)

32. Semashko L.V. Stabilometricheskiye issledovaniya vliyaniya original'noy sistemy PFA na funktsiyu ravnovesiya [Stabilometric studies of the influence of the original PFA system on the equilibrium function]. Vestnik vosstanovitel'noy meditsiny. 2009;5:97-100. (RU)

33. SmahlyukL.V., Kulish N.V.,Voronkova H.V.atal. Analizmorfometrychnykh pokaznykiv rozvytku nyzhn'oyi shchelepy u patsiyentiv z perekhresnym prykusom za danymy ortopantomohramy [Analysis of morphometric indices of development of the mandible in patients with cross-occlusion according to orthopantomograms]. Visnyk problem biolohiyi ta medytsyny. 2018;1(146):307-310. (UA)

34. Delaire, J. L'analyse architecturale et structurale cranio-faciale (de profil): principes theoriques. Quelques examples d'emploi en chirurgie maxillo-faciale/ Rev Stomatol Chir Maxillofac.79 (1978):1-33.

35. Admakin 0.I., Geppe N.A., Mamedov A.A. Rezul'taty provedeniya programmy profilaktiki stomatologicheskikh zabolevaniy v gruppakh detey s allergicheskoy patologiyey [The results of the program for the prevention of dental diseases in groups of children with allergic diseases].Voprosy sovremennoy pediatrii. 2006;5:12. (RU)

36. Accurso B., Mercado A., Allen CM. Multiple endocrine neoplasia2Bpresenting with orthodontic relapse. Angle Orthod. 2010;80(3):585590. (RU)

37. Carlos Fabue L., Soriano YJ., Perez MGS Dental management of patients with endocrine disorders. J Clin Exp Dent. 2010;2(4):196-203.

38. Patney A Kocher, Pai K.M., Sholapurkar A.A. Debre Semelaigne syndrome and associated orofacial aspects: report of a case. J. Oral Sci.2011;53:2932.

39. Reichert C,. Deschner J., Jager A. Influence of diabetes mellitus on the development and treatment of malocclusions - a case report with literature review. J Orofac Orthop. 2009;2:60-175.

40. PovoroznyukV., Vovk I., OrlikT. atal. Kostnaya tkan'u devocheki podrostkov. Svyaz's polovym i fizicheskim razvitiyem (chast' 1 ) [Bone tissue in girls and adolescents. Relationship with sexual and physical development]. Pedíatríya, akusherstvo ta gínekologíya. 2000;2 (7):-95. (RU)

41. Smahlyuk L. V., Fetisova A. L., Lyakhovs'ka A. V. Anomaliyi shchelepnolytsevoyi systemy u divchat iz porushennyam reproduktyvnoyi funktsiyi [Anomalies of the maxillofacial system in girls with a violation of reproductive function].Ukrayins'kyy stomatolohichnyy al'manakh.2012;2:56-59. (UA)

42. Soliman A., De Sanctis V, Elalaily R, Advances in pubertal growth and factors influencing it: Can we increase pubertal growth? Indian J. Endocrinol. Metab. 2014;18:53-62. 
43. Fujita T., Ohtani J., Shigekawa M. Influence of sex hormone disturbances on the internal structure of the mandible in newborn mice. Eur J. Orthod. 2006;28(2):190-194.

44. Piras V., Tuveri F., Dessi C. Relation between hypogonadism and malocclusion in beta-thalassemia major patients: analysis of 122 subjects Minerva Stomatol. 2003;52(5):241-246.

45. Mamedov A.A., Admakin 0.I., Zholobova Ye.S. Narusheniye rosta i razvitiya zubochelyustnoy sistemy u detey syuvenil'nym revmatoidnym artritom [Impaired growth and development of the dentition in children with juvenile rheumatoid arthritis].Stomatologiya detskogo vozrasta i profilaktika.2009;4:31-35. (RU)

46. Micky A., Mandall, R., Gray, D. Juvenile idiopathic arthritis (JIA): a screening study to measure class II skeletal pattern, TMJ PDS and use of systemic corticosteroids, J. Orthod.- 2010; 37: 6-15.

47. Persson E.C,. Engstrom C., Thilander B. The effect of thyroxine on craniofacial morphology in the growing rat. Part I: A longitudinal cephalometric analysis. Eur J Orthod. 1989;11;59-66.

48. Supiyeva E.T. Osobennosti profilaktiki stomatologicheskikh zabolevaniy u detey, prozhivayushchikh v ochage yodnogo defitsita [Features of the prevention of dental diseases in children living in the center of iodine deficiency]. Stomatologiya detskogo vozrasta i profilaktika.2002;3-4:88-92. (RU)

49. Scaramucci T., Guglielmi C.A., Fonoff R.D. Oral manifestation associated with multiple pituitary hormone deficiency and ectopic neurohypophysis. Clin. Pediatr. Dent. 2011;35:409-413.

50. Kawala B., MatthewsBrzozowska T., Bieniasz J. Dental and skeletal age in children with growth hormone deficiency treated with growth hormone - preliminary report Endokrynologia, diabetologia ichoroby przemiany materii wieku rozwojowego: organ Polskiego Towarzystwa Endokrynologow Dzieciecych,2007;4:210-212.

51. Singleton D.A., Buschang P.H., Behrents R.G. Craniofacial growth in growth hormone-deficient rats after growth hormone supplementation. Am J. Orthod. Dentofacial Orthop. 2006;130(1):69-82.

52. Erum R. van, Mulier M., Carels C. Craniofacial growth in short children born small for gestational age: effect of growth hormone treatment. J. Dent. Res. 1997;76(9):1579-1586.

53. Differential responses to parathyroid hormonerelated protein (PTHrP) deficiency in the various craniofacial cartilages. Anat Rec. 1999;255(4):452-457.

54. Silbermann M., Weiss A., Raz E. Retardative effects of a corticosteroid hormone upon chondrocyte growth in the mandibular condyle of neonatal mice. J.Craniofac.Genet.Dev. Biol. 1981;1(1):109-122.

55. Ohrn K., Al-Kahlili, BHuggare. J. Craniofacial morphology in obese adolescents. Acta Odontol Scand.2002; 60(4):193-197.

56. Solow B, Sonnesen L: Head posture and malocclusions. Eur J Orthod. 1998;20:685-693.

57. Lippold C, Danesh G, Hoppe G, at al. Trunk inclination, pelvic tilt and pelvic rotation in relation to the craniofacial morphology in adults. Angle Orthod. 2007;77:29-35.

58. Andrade AS, Gaviao MB, Gameiro GH at al. Characteristics of masticatory muscles in children with unilateral posterior crossbite. Braz Oral Res. 2010;24(2):204-210.

59. Gungora AY, Turkkahramanb H. Effects of Airway Problems on Maxillary Growth: A Review European Journal of Dentistry. 2009;3:250-254.

60. Pol'ma L.V., Lomakina V.M., Talalayeva Ye.V. Opredeleniye motivatsii patsiyentov pri planirovanii ortodonticheskogo lecheniya [Definition of patient motivation in planning orthodontic treatment]. Ortodontiya. 2009;1(45):77. (RU)
61. Karasiunok A. Ye., Smahliuk L. V. The role of parents in motivation for orthodontic treatment for children. Wiad lek. 2018;3(I):529-533.

62. Karasyunok A. YE. Rezul'taty zastosuvannya psykholohichnykh metodiv pry ortodontychnomu likuvanni ditey u period zminnoho prykusu. [Results of the application of psychological methods in orthodontic treatment of children in the period of mixedocclusion]. Aktual'ni problemy suchasnoyi medytsyny. 2017;3 (59): 211-215. (UA)

63. Dybov A.M., Ospanova G.B. Vliyaniye potrebnosti patsiyentov v ortodonticheskom lechenii na udovletvorennost'yego rezul'tatami. [The impact of patients' needs in orthodontic treatment on satisfaction with its results]. Ortodontiya. 2009;1(45):62. (RU)

64. Grzywacz I. Znacheniye esteticheskogo komponenta v indekse potrebnosti v ortodonticheskom lechenii pri otsenke sub"yektivnoy potrebnosti v ortodonticheskom lechenii, [The value of the aesthetic component in the index of the need for orthodontic treatment in assessing the subjective need for orthodontic treatment]. Ortodonticheskiy referativnyy zhurnal. 2004;3:6. (RU)

65. Minayeva I.N. Profilaktika zubo-chelyustnykh anomaliy kak faktor povysheniya urovnya stomatologicheskogo zdorov'ya detey [Prevention of tooth-jaw anomalies as a factor in increasing the level of children's dental health]. Ortodonticheskiy referativnyy zhurnal. 2004;3: 74-75. (RU)

66. Klages U., Bruckner A., Zentner A. Dental aesthetics, self-awareness, and oral health-related quality of life in young adults. European Journal of Orthodontics. 2004;26(5):507-514.

67. Vieira-Andrade R.G., de Paiva S.M, Marques L.S. Impact of Malocclusions on Quality of Life from Childhood to Adulthood Issues in Contemporary Orthodontics http://dx.doi.org/10.5772/59485 39-55.

\section{Authors' contributions:}

According to the order of the Authorship.

\section{Conflict of interest:}

The Authors declare no conflict of interest.

\section{CORRESPONDING AUTHOR Anna Karasiunok}

Ukrainian Medical Stomatological Academy

Shevchenko 23 str., 36011 Poltava, Ukraine

tel: +380677544193

e-mail: orthodontic.umsa@gmail.com

Received: 22.03.2019

Accepted: 10.05 .2019 
PRACA POGLA¿DOWA

REVIEW ARTICLE

\title{
EARLY CAROTID ENDARTERECTOMY IN SYMPTOMATIC PATIENTS
}

\author{
Roman I. Trutiak \\ LVIV NATIONAL MEDICAL UNIVERSITY NAMED BY DANYLO HALYTSKYI, LVIV, UKRAINE
}

\begin{abstract}
Introduction: Stroke is a big social problem. The expediency of surgical treatment is justified as the chances for complete reconvalescence of the neurological deficiency increase. The aim: To analyze available sources of scientific information on the terms of surgical treatment of patients with acute neurological deficiency.

Materials and methods: We analyzed 41 English publications in PubMed for 5 years from 2012 to 2017, with the keywords "urgent carotid endarterectomy" and "early carotid endarterectomy".

Conclusions: In the classic course of stroke or TIA, the best treatment results are obtained when the CEA is performed 3-7 days after the marker event. CEA should be performed as soon as possible to restore brain revascularization and prevent the fatal progression of the neurological deficiency after crescendo TIA or stroke-in-evolution, despite the fact that the risk of complications and disability after surgery may be higher than $6 \%$.
\end{abstract}

KEY WORDS: urgent carotid endarterectomy, early carotid endarterectomy

Wiad Lek 2019, 72, 5 cz. I, 923-927

\section{INTRODUCTION}

Stroke is a big social problem [1]. Despite the high risk of complications in the postoperative period among patients with acute ischemic neurological symptoms, the feasibility of surgical treatment is justified as the chances for a reconvalescence of the neurological deficit [2].

The topicality of the determinationfor terms of carotid endarterectomy (CEA) in patients with carotid stenosis after postoperative neurological deficiency with the least risk of developing a re-stroke is uncertain. The risks and timing of the development of repeat neurological deficits in patients with atherosclerotic lesions of the carotid arteries are still controversial. Therefore, today there is no unanimous opinion when CEA is the safest. Depending on the duration of the marker event and the surgical intervention, CEA is divided into urgent, early, delayed and scheduled (or late). Urgent CEA is an operation performed up to 48 hours after the marker event, early CEA - up to 14 days after the transient neurological deficiency, delayed - from 14 to 30 days and scheduled (late) CEA - after 30 days $[3,4,5]$.

A meta-analysis of two studies comparing CEA and the treatment of symptomatic carotid stenoses showed that the short term from the last neurological symptom to surgical revascularization contributes to a better recovery of the patient [6].

However, a clear time interval is not defined and the possible frequency of life-threatening complications in the urgent and early CEA.

\section{THE AIM}

To analyze available sources of scientific information on the terms of surgical treatment of patients with acute neu- rological deficiency and todetermine the safest time for the implementation of CEA with the lowest risk of developing repeated cerebral circulation disorder.

\section{MATERIALS AND METHODS}

It was analyzed 41 English-language publications in Pub Med for 5 years from 2012 to 2017, with the CEAwords "urgent carotid endarterectomy" and "early carotid endarterectomy". Five articles were devoted to the problem of organization of urgent CEA, 5 - discussion letters of the editorial boards of professional editions. Another 5 publications compared the results of different regimens of disaggregation therapy among symptomatic patients after early CEA. In one publication, the authors described a clinical case. In 7 articles, the results of early CEA in symptomatic patients were based on the analysis of less than 100 operations. Among the 12 scientific papers, the clinical sample was from 143 to 989 patients after a neurological deficiency. Six studies have analyzed the complications that have arisen in more than 1000 symptomatic patients after CEA. In most reports patients brain revascularization after developing a stable or regressive neurological deficiency, and in four studies CEA results were compared among patients undergoing crescendo transient ischemic attacks (cTIA) and a stroke-in-evolution.

\section{REVIEW AND DISCUSSION}

The analysis of the sources of scientific reports was based oninformation of the risk of re-stroke after marker event, the influence of the terms of surgical treatment on the risk 
of developing a new neurological deficiency, on the feature of the organization of medical care in different countries, influencing the timing of hospitalization and treatment of patients in specialized clinics, the results of CEA, depending on the type of ischemic lesion of the brain.

In reports E. Johansson et al. (2013) and M. Marnane et al. (2014) the risk of re-development of the neurological deficiency is $5 \%$ during the first 48 hours, and according to M. Mono et al. (2013), the risk of a re-marker event during the first 72 hours is only $4 \%[7,8,9]$.

S. Strömberg (2015) in his study notes that in patients with stenosis $70 \%$ of the ipsilateral internal carotid artery, the risk of recurrent ischemic stroke increases, but only after 3 weeks after the postponed marker event is more than $6 \%[10]$.

According to the results of these publications, the risk of recurrent acute ischemic lesion of the brain with conservative treatment is less than $6 \%$, which calls into question the expediency of urgent surgical treatment of carotid stenosis to prevent the development of a repeated ischemic stroke.

However, the results of D. Bonifatiet. al (2011) are controversial and indicate that the risk of recurrent ischemic stroke or TIA in the first 2 days is higher and is $8 \%$ [11]. Also, the high risk of early recurrent ischemic lesions of the brain was reported by Ois et al. (2009). According to the study, the risk of recurrent ischemic stroke or TIA in the first 3 days is higher than $17 \%$ and increases to $25 \%$ on the 14th day [12].

Themeta-analys of publications from 1950 to 2015 collected data from 2,634 patients. The authors show quite wide limits of the risk of recurrent stroke or TIA: within the first three days - 2.0-17.2\%; during the first week - 0-22,1\%; within 2 weeks - 0-29.6\%. Interestingly, the risk of a repeat marker event, according to this meta-analysis, is reduced to $11.1 \%$ on 30 day [13].

Guided by the information of these studies, which are based on sufficiently large clinical material, urgent and early revascularization of the brain is appropriate.

According to the European management of atherosclerotic carotid and vertebral artery disease in symptomatic patients with stenosis of $50-99 \%$, revascularization is required within 14 days after the onset of the neurological deficiency (class of evidence I, level A), and in case of an increase in the neurological deficit, preference is given to the urgent CEA in the first day (class of evidence IIa, level C). To reduce the risk of postoperative intracranial hemorrhage in patients with ischemic lesions of more than $1 / 3$ of the cerebral hemisphere, with a disturbance in consciousness and severity of neurological disorders greater than 3 points on the modified Rankin score, revascularization should be delayed (class of evidence of class I, level C) [14].

Several publications concerned the organization of urgent CEA. So in a joint work of scientists from London and Ontario (Erin Dyer et al., 2013), attention was drawn to the "circle of hell" that should be addressed to the patient after the development of a neurological deficiency before being hospitalized for surgical treatment. This undoubtedly influenced the fact that urgent CEA were performed only in a small number of patients, since from the onset of the neurological event to the operation, on average, it ranged from 82 to 111 days [15].

That is why in Denmark, according to Saeid Shahidi (2013), no patient was operated in the first two days after the development of an ischemic stroke or TIA, and only $17 \%$ of patients were operated within 2 days of onset of hospitalization. Most (28\%) of brain revascularisations, among patients with acute neurological deficiency, was performed only on tehe 8th-14th day after the postponed marker event [16].

The same author in 2016 repeatedly conducted a study on the timing of the implementation of CEA in symptomatic patients. The results did not differ from the previous 2013 study. So, no patient was operated in the first two days after the development of neurological deficiency. Most patients were operated on the 8th-14th day, and the proportion of such patients increased to $38 \%$. The article states that aggressive drug therapy allows to refrain from performing urgent CEA without increasing the risk of recurrent stroke [17].

Statistic in Sweden is similar, where only 3\% of CEA [5] and in the United Kingdom 3\% follow the first two days after the development of the neurological deficit[1]. Some higher rates of such operations are in Germany - 9\%, but it is also not optimal [18].

Analyzing the causes of deferral of CEA in the University Hospital, Lester, M. Ali et al. (2013) found that the main factors were the development of a marker event during the weekend $(44 \%)$ and a lack of free space in the schedule of operations (24\%) [19].

Several countries have developed special stroke centers that increase patients chances of developing neurological deficits to receive the earliest surgical help for brain revascularization $[2,20,21]$.

In the analysis of the New England (USA) registry from 2003 to 2014, it was found that in this region the number of early CEA in symptomatic patients is gradually increasing. In 2014 , the percentage of early CEA is about $68 \%$, and planned - $32 \%$, respectively. According to the authors, the increase in the proportion of early CEA is a modern trend in carotid artery surgery [2].

The ESVS European management 2017 reports the results of three studies on urgent CEA to prevent recurrent ischemic stroke in symptomatic patients. These are publications from Sweden, Great Britain and Germany [14].

In Sweden, according to investigation in 2012, the frequency of postoperation neurological events among patients with atherosclerosis of carotid arteries, operated in the first two days, was $11.5 \%$. In other patients who were operated later, the incidence of ischemic lesions in the brain was less than 6\% [5]. Studies from the United Kingdom (2016) and Germany (2016) also indicate the highest risk of recurrent neurological deficits among patients operated in the first two days, but did not exceed $6 \%$ and amounted to $3.7 \%$ and $3.0 \%$ respectively $[1,18]$.

Therefore, in studies referring to the authors of the ESVS management, the highest risk of recurrence of stroke was 
in patients who were operated in the first two days after the first ischemic attack, therefore urgent operating CEA are not appropriate. However, there are significant differences in the frequency of this complication after urgent CEA. This is also observed in other publications.

I.M. Loftus with co-authors in 2016, analyzed the results of 33,194 CEA that were included in the UK's national registry and concluded that the highest risk of post-surgical stroke and death was experienced by patients who had experienced CEA in the first two days after the onset of symptoms, which was $3.7 \%$. The frequency of complications in patients who were operated later did not exceed 2.6\% [1].

An article from Göteborg S. Strömberg with co-authors (2015) reported the results of the treatment of 321 patients who had undergone CEA. The incidence of recurrent stroke in patients who were operated during the first 2 days was $20 \%$, and among those who were operated 2 days after the postmarked event - $5 \%$. However, it should be noted that in the first group the number of patients was only 15 patients, in contrast to the second group included 297 patients [10].

In the publications of 2017, Efthymios D. Avgerinos and his collaborators from the United States and A. Nordanstig from Göteborg there were analyzed the results of CEA in 989 and 418 symptomatic patients with atherosclerotic lesions of the carotid arteries. The frequency of an early postoperative stroke in a group of patients who undergo CEA in the first two days after the transmitted neurological deficiency was $7.3-8 \%$. It is statistically significantly higher than in patients who were operated 2-14 days after a neurological deficiency, in which the incidence of ischemic stroke did not exceed $4 \%[2,21]$.

These findings correlate with the results of the analysis of the Paola De Rango conducted in 2015. According to their data, the highest risk of post-surgical stroke or death in patients undergoing CEA in the first 2 days is $8.44 \%$. Among the patients operated later from the moment of neurological deficiency, the given risk decreases. In general, the risk of postoperative ischemia or death among patients who had an early CEA was 3.77\% [22].

In 2013, in Switzerland, Mono M. et al. compared the results of the surgical treatment of 94 patients: 85 of them suffered from CEA, and 9 - stenting. For the duration of the surgical intervention, patients were divided into 3 groups: in the first 3 days, within 3-7 days and from the week to two after the transmitted neurological deficiency. As a result, the incidence of repeat cerebrovascular events was the lowest in patients who operated for 3-7 days and amounted to $2.4 \%$. These rates in groups of operated patients in the first 72 hours and from the 7 th to 14 th day after the marker event were $11.4 \%$ and $7.9 \%$ respectively [9].

Similar conclusions were made by Austrian researchers who analyzed the results of the treatment of 761 patients with symptoms of neurological deficiency. Most often, stroke and death were observed in patients who performed CEA from the 8th-14th days after the transient neurological deficiency, and at least from 3rd-7th day [23].

So, Swiss and Austrian surgeons consider that it is most appropriate to perform surgical interventions in the period from $3 \mathrm{dr}$ to 7 th day after the onset of an ischemic attack, which is an early CEA in the first week.

In Croatian clinics from 2008 to 2014, 69 early CEA were performed in symptomatic patients in the first 14 days after the development of neurological deficits. Postoperative stroke arose at 5.79\% [24]. This indicator is high enough, but below 6\%, and is acceptable in accordance with the European guidelines for the treatment of atherosclerosis of the carotid and vertebral arteries.

James F. Meschia, with a group of contributors from the United States, Canada and England, compared the results of early, delayed, and planned CEA treatments. The work showed the safety of CEA in symptomatic patients, regardless of the duration of the operation after the primary neurological deficiency. Among 597 patients, the risk of postoperative stroke or death after CEA in the first two weeks was $2.6 \%$, from 15 days to 60 days $-2.3 \%$, in 2 months - 2.8\% [25].

In 2017, Barbara Rantner and colleagues conducted a goal analysis of 4 randomized trials. According to his results, the frequency of postoperative stroke is lower after CEA, which was performed by symptomatic patients during the first week after the marker event, than in the operated symptomatic patients after 7 days (1.3\% vs. $3.6 \%$ respectively) [26].

In the publication of Emiliano Chisc with co-authors of 2015, the results of surgical treatment of 322 patients with acute neurological deficiency within 30 days have been analyzed. In $3(10 \%)$ patients who were operated during the first two days, an early postoperative ischemic stroke developed. Among patients in other groups, the incidence of postoperative stroke was the highest in the group of patients who were operated from 15th-30th day after the primary neurological deficiency and amounted to $0.4 \%$ [27].

In favor of early CEA, there is information from Thierry Merlini et al. (2014) that analyzed the results of early CEA in 91 patients operated in two centers in France from 2011 to 2013. Neurological deficiency after the operation developed in only 1 patient in 27 patients with TIA and 1 in 64 patients after acute ischemic stroke. The most frequent complication after such operations, the authors consider postoperative hematomas - 7,7\% [28].

In 2014, the work of Tsivgoulis et al., which analyzed the results of urgent CEA among patients with acute neurological deficiency, developed after carotid stenting (CAS). The sample included 165 patients from 5 centers. In $70 \%$ of patients afterCAS , an ischemic stroke was developed, and in $30 \%$ - TIA, of which $6 \%$ is crescendo TIA. 20 patients were operated in the first 2 days after the development of neurological deficiency, the remaining 145 - in the range of 3 to 14 days. So in the first group the recurrent stroke was diagnosed in 2 patients (10\%), and in the second group - 6 (4.1\%) [29].

Active surgical tactics is recommended by Samuel Bruls et al, who in 2013 published a 5-year experience of urgent CEA in patients with carotid stenosis and brain ischemia at the University of Liege Hospital. Despite a small sam- 
ple (30 patients in total), there was no re-stroke or TIA, $1(3.3 \%)$ died of a primary stroke, and in $5(17 \%)$ - the clinical picture did not improve. The authors specify that when neuroimaging in patients, the diameter of the center of ischemia of the brain did not exceed $1.5 \mathrm{~cm}$ [20].

Authors from Turin, under the guidance of Emanuele Ferrero (2014), emphasize that in order to correctly comparisonof the frequency of complications after CEA, apart from the spread of the focus of brain ischemia, the clinical course of TIA should be taken into account. The researchers analyzed the results of CEA performed for 48 hours in 176 patients with acute neurological deficiency. 55 of them had a classical TIA, 55 - an increasing TIA, 66 - a progressive brain infarction. The percentage of postoperative ischemic stroke and death was the highest in the group with progressive ischemic stroke of the brain and amounted to 7.6\% [30].

Similar findings were made by Rodolfo Pini with co-authors (2017) from the University Hospital in Bologna. Thus, after urgent CEA, a cerebral infarction among the 87 patients with an increasing TIA occurred in 5.5\%, and among 56 patients with classical TIA - only $1.6 \%$. In total, the incidence of cerebral infarction and death was also higher among patients with unstable TIA - $6 \%$ and $2.2 \%$ respectively [31].

Some other results were received by lacopoBarbetta with co-authors from Milan. In a study of 90 post-KE patients with acute cerebral ischemia, which were evenly divided into 2 groups (operated for 48 hours and later), the risk of postoperative re-stroke, regardless of the type and stability of the neurological deficiency, was higher in $6 \%$ in the second group and amounted to $8.8 \%$ [32].

A small study of CEA results from the 3rd to 10th days after a neurological event in 2012 was conducted by GeorgiosTsivgoulis. According to the design of the study, all patients from the onset of neurological deficiency received dual disaggregation therapy - aspirin and clopidogrel. None of the 11 patients experienced severe complications within 30 days after surgery [33].

The 2013 Leicester study (475 patients) has shown that the risk of recurrent stroke and death after $\mathrm{CO}$ in patients with a recent neurological deficiency decreases over time from marker events and does not exceed 3\%. In the first two days, this risk is $2.4 \%$, in 3rd-7th day $-1.8 \%$, 8 th- 14 th and in two weeks - $0.8 \%$ [34].

In the scientific article of the authors from Germany in 2016 under the direction of PavlosTsantilas, the results of surgical treatment of 56,336 patients with neurological deficiency that were conducted within 180 days after the development of the neurological deficiency were highlighted. The patients were divided into four groups: operated in the first two days, from the 3rd-7th day, in the interval from the 8th-14th day and 15th-180th day. Most often, recurrent ischemic deficiency - 3.0\% occurred in patients who were operated in the first two days. Its risk was reduced to $2.3 \%$ in patients who had been exposed to CEA within 15 to 180 days after the marker event [18].

In 2015, Charmoille E. et al. analyzed the results of treatment of patients with acute neurological deficiency that were operated before and after two weeks after the marker event. In total, 149 CEA were performed, 62 of them - within the first 2 weeks after the development of neurological deficits, 87 - after 14 days. The authors did not find a statistically significant difference in the results of treatment depending on the terms of CEA [3].

A group of authors led by SumanAnnambothla from the University of Chicago studied the direct and delayed follow-up of 10 years of treatment of 312 patients depending on the duration of $\mathrm{CO}$ after the development of neurological deficits. Despite the fact that among the analyzed intervals the highest incidence of postoperative ischemic stroke was $6 \%$ in the group operated from 8 to 14 , it was in this group that the lowest frequency of cerebral infarction was 10 years after CEA. In general, according to the results of this study, CEA within the first 30 days, after the development of an ischemic disaster of the brain, is a safe operation [4].

\section{CONCLUSIONS}

So, there is unanimous opinion that when choosing a treatment method and terms for performing a CEA, it is necessary to take into account the prevalence of ischemic focal area of the brain, the severity of the patient's condition and the severity of the course of the disease. Organizational and paramedical factors should not be influenced by the timing of surgical care for patients with ischemic lesions of the brain.In the classic course of ischemic stroke or TIA, the best treatment results are obtained when the CEA is performed from the 3 rd-7th day after the marker event. With crescendo TIA or stroke-in-evolution, despite the fact that the risk of complications and disability after surgical treatment may be higher than 6\%, CEA should be performed as soon as possible to restore brain revascularization and prevent the fatal progression of neurological deficiency.

\section{REFERENCES}

1. Loftus I, Paraskevas K, Johal A, Waton S, Heikkila K, Naylor A et al. Delays to Surgery and Procedural Risks Following Carotid Endarterectomy in the UK National Vascular Registry. Journal of Vascular Surgery. 2016; 52(4):438-443.

2. Avgerinos E, Farber A, Abou Ali A, Rybin D, Doros G, Eslami M. Early carotid endarterectomy performed 2 to 5 days after the onset of neurologic symptoms leads to comparable results to carotid endarterectomy performed at later time points. Journal of Vascular Surgery. 2017;66(6):1719-1726.

3. Charmoille E, Brizzi V, Lepidi S, Sassoust G, Roullet S, Ducasse E et al. Thirty-day Outcome of Delayed Versus Early Management of Symptomatic Carotid Stenosis. Annals of Vascular Surgery. 2015;29(5):977-984.

4. Annambhotla S, Park M, Keldahl M, Morasch M, Rodriguez H, Pearce $W$ et al. Early versus delayed carotid endarterectomy in symptomatic patients. Journal of Vascular Surgery. 2012;56(5):1296-1302.

5. Strömberg S, Gelin J, Österberg T, Bergström G, Karlström L, Österberg K. Very Urgent Carotid Endarterectomy Confers Increased Procedural Risk. Stroke. 2012;43(5):1331-1335.

6. Rothwell P, Eliasziw M, Gutnikov S, Warlow C, Barnett H. Endarterectomy for symptomatic carotid stenosis in relation to clinical subgroups and timing of surgery. The Lancet. 2004;363(9413):915-924. 
7. Johansson E, Arnerlöv C, Wester P. Risk of Recurrent Stroke before Carotid Endarterectomy: The ANSYSCAP Study. International Journal of Stroke. 2012;8(4):220-227.

8. Marnane M, Prendeville S, McDonnell C, Noone I, Barry M, Crowe M et al. Plaque Inflammation and Unstable Morphology Are Associated With Early Stroke Recurrence in Symptomatic Carotid Stenosis. Stroke. 2014;45(3):801-806.

9. Mono M, Steiger I, Findling 0, Jung S, Reinert M, Galimanis A et al. Risk of very early recurrent cerebrovascular events in symptomatic carotid artery stenosis. Journal of Neurosurgery. 2013;:1620-1626.

10. Strömberg S, Nordanstig A, Bentzel T, Österberg K, Bergström G. Risk of Early Recurrent Stroke in Symptomatic Carotid Stenosis. European Journal of Vascular and Endovascular Surgery. 2015;49(2):137-144.

11. Bonifati D, Lorenzi A, Ermani M, Refatti F, Gremes E, Boninsegna Cet al. Carotid stenosis as predictor of stroke after transient ischemic attacks. Journal of the Neurological Sciences. 2011;303(1-2):85-89.

12. Ois A, Cuadrado-Godia E, Rodriguez-Campello A. High Risk of Early Neurologic Recurrence in Symptomatic Carotid Stenosis. Journal of Vascular Surgery. 2009; 40(8):2727-31.

13. Tsantilas P., Kühnl A., Kallmayer M., Knappich C., Schmid S., Kuetchou A et al. Stroke Risk in the Early Period After Carotid Related Symptoms: a Systematic Review. The Journal of Cardiovascular Surgery.2015;56(6):845-852.

14. Naylor A, Ricco J, de Borst G, Debus S, de Haro J, Halliday A et al. Editor's Choice - Management of Atherosclerotic Carotid and Vertebral Artery Disease: 2017 Clinical Practice Guidelines of the European Society for Vascular Surgery (ESVS). European Journal of Vascular and Endovascular Surgery. 2018;55(1):3-81.

15. Dyer E, Lownie S, Ferguson G. Wait Times for Carotid Endarterectomy, London Ontario 2006-2007. The Canadian Journal of Neurological Sciences. 2013;40(03):330-333.

16. ShahidiS, Owen-Falkenberg A, Hjerpsted U, Rai A, Ellemann K. Urgent Best Medical Therapy May Obviate the Need for Urgent Surgery in Patients With Symptomatic Carotid Stenosis. Stroke. 2013;44(8):2220-2225.

17. Shahidi S, Owen-Falkenberg A, Gottschalksen B, Ellemann K. Risk of early recurrent stroke in symptomatic carotid stenosis after best medical therapy and before endarterectomy. International Journal ofStroke. 2015;11(1):41-51.

18. Tsantilas P, Kuehnl A, KönigT, BreitkreuzT, KallmayerM, Knappich Cetal.Short Time Interval Between Neurologic Event and Carotid Surgery Is Not Associated With an Increased Procedural Risk. Stroke. 2016;47(11):2783-2790.

19. Ali M, Stephenson J, Naylor A. Delay Prior to Expedited Carotid Endarterectomy: A Prospective Audit of Practice. European Journal of Vascular and Endovascular Surgery. 2013;46(4):404-410.

20. Bruls S, Desfontaines P, Defraigne J, Sakalihasan N. Urgent Carotid Endarterectomy in Patients with Acute Neurological Symptoms: The Results of a Single Center Prospective Nonrandomized Study. AORTA. 2013:1(2):110-116.

21. Nordanstig A, Rosengren L,Strömberg S, Österberg K, Karlsson L, Bergström $G$ et al. Editor's Choice - Very Urgent Carotid Endarterectomy is Associated with an Increased Procedural Risk:The Carotid Alarm Study. European Journal of Vascular and Endovascular Surgery. 2017;54(3):278-286.

22. De Rango P, Brown M, Chaturvedi S, Howard V, Jovin T, Mazya M et al. Summary of Evidence on Early Carotid Intervention for Recently Symptomatic Stenosis Based on Meta-Analysis of Current Risks. Stroke. 2015;46(12):3423-3436.

23. Rantner B, Schmidauer C, Knoflach M, Fraedrich G. Very Urgent Carotid Endarterectomy Does Not Increase the Procedural Risk. Journal of Vascular Surgery. 2015;49(2):129-136.
24. Ivkošić A, Trajbar T, Budinčević H, Antolić S, Lojo N, Oberhofer D. Early carotid endarterectomy in symptomatic patients - our experience. ActaMedicaCroatica. 2014;8(3):289-293.

25. Meschia J, Hopkins L, Altafullah I, Wechsler L, Stotts G, Gonzales N et al. Time From Symptoms to Carotid Endarterectomy or Stenting and Perioperative Risk. Stroke. 2015;46(12):3540-3542.

26. Rantner B, Kollerits B, Roubin G, Ringleb P, Jansen 0, Howard G. Early Endarterectomy Carries a Lower Procedural Risk Than Early Stenting in Patients With Symptomatic Stenosis of the Internal Carotid Artery. Journal of Vascular Surgery. 2017; 48(6):1580-1587.

27. Chisci E, Pigozzi C, Troisi N, Tramacere L, Zaccara G, Cincotta M et al. "Thirty-Day Neurologic Improvement Associated with Early versus Delayed Carotid Endarterectomy in Symptomatic Patients". Annals of Vascular Surgery. 2015;29(3):435-442.

28. Merlini T, Péret M, Lhommet P, Debiais S, Marc G, Godard S et al. Is Early Surgical Revascularization of Symptomatic Carotid Stenoses Safe? Annals of Vascular Surgery. 2014;28(6):1539-1547.

29. Tsivgoulis G, Krogias C, Georgiadis G, Mikulik R, Safouris A, Meves S et al. Safety of early endarterectomy in patients with symptomatic carotid artery stenosis: an international multicenter study. European Journal of Neurology. 2014;21(10):1251-1276.

30. Ferrero E, Ferri M, Viazzo A, Labate C, Berardi G, Pecchio A et al. A Retrospective Study on Early Carotid Endarterectomy within 48 Hours after Transient Ischemic Attack and Stroke in Evolution.Annals of Vascular Surgery. 2014;28(1):227-238.

31. Pini R, Faggioli G, Gargiulo M, Gallitto E, Cacioppa L, Pilato A et al. SS07. Crescendo and Single TIA: Two Different Scenarios of Urgent Carotid Revascularization. Journal of Vascular Surgery. 2017;65(6):48S.

32. Barbetta I, Carmo M, Mercandalli G, Lattuada P, Mazzaccaro D, Settembrini A et al. Outcomes of urgent carotid endarterectomy for stable and unstable acute neurologic deficits. Journal of Vascular Surgery. 2014;59(2):440-446.

33. Tsivgoulis G, Kerasnoudis A, Krogias C, Vadikolias K, Meves S, Heliopoulos I et al. Clopidogrel Load for Emboli Reduction in Patients With Symptomatic Carotid Stenosis Undergoing Urgent Carotid Endarterectomy. Stroke. 2012;43(7):1957-1960.

34. Sharpe R, Sayers R, London N, Bown M, McCarthy M, Nasim A et al. Procedural Risk Following Carotid Endarterectomy in the Hyperacute Period after Onset of Symptoms. European Journal of Vascular and Endovascular Surgery. 2013;46(5):519-524.

\section{Conflict of interest:}

The Author declare no conflict of interest.

\section{CORRESPONDING AUTHOR \\ Roman I. Trutiak \\ Vyhovskyistr, 57/57, Lviv, 71054, Ukraine \\ tel: +380685018894 \\ e-mail:trutiak_ro@yahoo.com}

Received: 18.03.2019

Accepted: 24.04.2019 
PRACA POGLACDOWA

REVIEW ARTICLE

\title{
METHODS OF TRANSMISSION AND FEATURES OF THE COURSE OF HEPATITIS C VIRUS INFECTION IN CHILDREN: MEDICAL AND SOCIAL ASPECTS
}

\author{
Nataliia 0. lakovenko, Maksim Y. Zak, Mykola O. Klymenko, Svetlana V. Zhuk, Olena K. Nuzhna \\ PETRO MOHYLA BLACK SEA STATE UNIVERSITY, MYKOLAIV, UKRAINE
}

\begin{abstract}
Introduction: Hepatitis C virus (HCV) infection is a major global problem. According to WH0, 150-200 million people globally have hepatitis C infection. Even though HCV infection morbidity rate in children is relatively low in comparison with the adult population, approximately 5 million children in the world have active HCV. There is a number of differences between HCV infection in adults and in children. However, the data pertaining to this issue is controversial.

The aim: Research, analysis and synthesis of information from contemporary literature on transmission of infection and characteristics of the course of HCV infection in children. Materials and methods: Analysis and synthesis of information from contemporary literature on transmission of infection and characteristics of the course of $\mathrm{HCV}$ infection in children were conducted.

Conclusions: Information from literature of the latest years on peculiarities of infection, disease course and complications of HCV infection in children was analyzed and summarized in this article.
\end{abstract}

KEY WORDS: hepatitis C virus infection, children, course of disease, medical and social aspects

Wiad Lek 2019, 72, 5 cz. I, 928-932

\section{INTRODUCTION}

Hepatitis $\mathrm{C}$ virus (HCV) infection is a major global problem. There has been a prominent increase in HCV morbidity rates in recent years, including the instances of chronic forms of disease. According to WHO, there is an estimated 150-200 million people suffering from HCV infection and 350,000 people per year die of complications - advanced liver failure, hepatic cirrhosis and hepatocellular carcinoma [1]. Already, the overall number of patients with hepatites in the world is 14-15 times more than the number of patients with HIV. Viral hepatites are 50-100 times more contagious, than HIV [2]. Even though viral hepatitis C morbidity rate in children is relatively low in comparison with the adult population, approximately 5 million children in the world have active $\mathrm{HCV}$ infection [3]. According to WHO, Ukraine has an average hepatitis C morbidity rate - approximately $3 \%$ of citizens are infected, which amounts to approximately 1170,000 people. However, subsequent to the results of selective risk groups monitoring, $\mathrm{HCV}$ morbidity rates among some of them are significantly higher than the average, reaching $40-60 \%$. In accordance with official statistics in Ukraine in recent years chronic HCV morbidity rates in children vary between 0.25 and 0.3 per 1000 and $1.04-0,55$ per 100000 children under 17 years old [2].

It is worth mentioning that chronization frequency of diseases caused by hepatotrophic viruses in children is different from adults and depends on the child's age when he was infected and reaches its maximum (up to 90\%) during the first year of life, as well as in early childhood, which is caused by physiological aspects of a child's organism and immaturity of the immune system [4].

\section{THE AIM}

Research, analysis and synthesis of information from contemporary literature on transmission of infection and characteristics of disease course of $\mathrm{HCV}$ infection in children.

\section{MATERIALS AND METHODS}

Analysis and synthesis of information from contemporary literature on transmission of infection and characteristics of the course of HCV infection in children were conducted.

\section{REVIEW AND DISCUSSION}

Hepatitis $\mathrm{C}$ virus (HCV) infection is an infectious disease induced by hepatitis $\mathrm{C}$ virus with bloodborne transmission mechanism and predominant injury of liver, as well as other internal organs.

Hepatitis Cvirus is a RNA virus and belongs to Flaviviridae family. Its main distinctive feature is incredibly variable ability to make up the so called "quasispecies", which makes it easy for the virus to avoid immune response, and the antibodies produced by the organism become "witnesses", 
markers of infection and fail to resist HCV reinfection of homologous and other strains.

Today virus genotypes include 11 types, as well as more than 100 of its subtypes and a vast amount of so called quasispecies. Genotypes 1a, 1b, 2a, 2b, 2c and $3 a$ constitute more than $90 \%$ of all virus isolates obtained in North and South America, Europe, Russia, China, Japan, Australia and New Zealand. Genotypes 4, 5a and 6 are found in Central and South Africa and in South-East Asia respectively. In Ukraine genotypes $1 \mathrm{~b}$ (approximately 70\%) and 3a prevail. Genotype does not affect the result of the disease, however it allows for predicting the effectiveness and duration of treatment. Poor response to interferon therapy is more often associated with types 1 and 4; hepatic steatosis is often associated with type 3 .

The main site for HCV replication are liver hepatocytes, and other extrahepatic replication regions are lymphocytes and mononuclear cells of the peripheral blood (they account for about $3.1 \%$ of the viral load).

People's natural susceptibility to the HCV is high. The source of infection are patients with acute or chronic HCV infection and carriers of the virus. The virus appears in the blood 1-3 weeks after infection.

Acute hepatitis $\mathrm{C}$ is an acute $\mathrm{HCV}$ infection in a patient who has not been diagnosed with hepatitis $C$ and hepatitis symptoms 6 months prior. Acute HCV infection is often asymptomatic and does not manifest clinically. Acute $\mathrm{HCV}$ in newborns is defined by detection of HCV RNA in the newborn's blood in the first 1-6 months of life, usually in the context of mother-to-child transmission of HCV. Newborns often have spontaneous regression of HCV. Neonatal HCV infection should be distinguished from perinatal transitory viremia when HCV RNA is detected in peripheral blood in the period of 0-5 days after birth.

In $20-30 \%$ of cases acute HCV infection can result in recovery with complete normalization of alanine aminotransferase (ALT) and the disappearance of HCV RNA for 6 to 12 months, but in the case of chronic hepatitis and progression of liver disease, there is a risk of developing liver cirrhosis and hepatocellular carcinoma. Fulminant forms of $\mathrm{HCV}$ in children are rare. Patients with immunosuppression (HIV infection, onco-hematologic pathology, diabetes mellitus, etc.) have a more severe course and more rapid progression of the disease. Hepatocellular carcinoma (HCC) is rarely found in children, and almost exclusively reported in children with cirrhosis. There are reports stating that children with chronic HCV infection and a history of leukemia may have an increased risk of HCC, but the data are limited [5]. To children with HCV infection and concomitant diseases such as obesity, non-alcoholic fatty liver disease and congenital heart defects with increased pressure in the right heart, and children receiving hepatotoxic drugs doctors should pay more attention and monitor the course of the disease and its progression [6].

The chronic HCV infection is diagnosed in cases where there are signs of active viral infection with detectable HCV RNA for a period of at least 6 months with progressive liver damage.
The spontaneous regression of $\mathrm{HCV}$ infection is diagnosed in case of disappearance of previously detectable HCV RNAs without any treatment, as evidenced by obtaining two consecutive negative tests for the presence of HCV RNA at intervals of at least 6 months.

The most common ways of infecting a child with HCV in developed countries is the vertical transmission of the virus from the RNA-positive HCV mother. The average risk of $\mathrm{HCV}$ transmission from mother to child is $4.7-6.7 \%$ [7]. According to Moskovska I.A. (2007), the genotype and maternal viral load (more than 1 million copies / $\mathrm{ml}$ ) are attributed to the increased risk of perinatal HCV transmission [3]. The presence of a co-infection of the immune deficiency virus (HIV) / HCV virus with the mother increases the chances of mother-to-child transmission by 90\% compared with HCV monoinfection; in such patients, the vertical transmission rate is $20 \%$ [8]. Internal fetal monitoring, prolonged rupture of fetal membranes and fetal hypoxia during delivery may increase the risk of infection.

In other cases, the infection results from contact with contaminated blood products, transplantation of infected organs, and in patients with prolonged dialysis of the kidneys. In addition, HCV infection occurs during using of personal hygiene products (toothbrushes, manicure scissors) with remains of blood infected with hepatitis $\mathrm{C}$ takes place, applying tattoos or piercings, injecting drugs [6].

In developing countries, the horizontal pathway of infection is prevalent - blood transfusion and infusion of blood components. This way of transmission of hepatitis $\mathrm{C}$ virus is widely studied in Egypt. According to the results of Egyptian doctors' research, the highest risk factors for $\mathrm{HCV}$ infection were surgical interventions and blood transfusions. The highest risk factor for $\mathrm{HCV}$ persistence was the treatment of teeth and male sex, especially in those children who had high ALT levels and AST oscillations [9].

Concomitant diseases play a certain role in the infection and subsequent flow of HCV. As demonstrated in foreign research, comorbid conditions were present in $45.9 \%$ of HCV-positive children and included chronic blood diseases such as thalassemia and hemophilia (59\%), insulin-dependent diabetes mellitus (12\%), and other concomitant diseases (29\%). Children with concomitant diseases had a lower body mass index and significantly higher incidence of such symptoms as abdominal pain, jaundice, hepatomegaly and splenomegaly [9].

It is important to note that hepatitis $\mathrm{C}$ is not transmitted through air, uninjured skin, accidental social contact and breastfeeding $[3,10]$. But if the HCV-positive mother's nipples and/or surrounding areola are cracked and bleeding, she should stop nursing temporarily. Once her nipples are no longer cracked or bleeding, she may fully resume breastfeeding.

It was established that there is a possibility of family-owned transmission of HCV infection. According to some authors, the risk of transmission of $\mathrm{HCV}$ does not exceed $2 \%$ in families where 1 person is infected [11], according to other authors - the risk of transmission of HCV from child to child in one family is $31 \%$, from mother to 
child - $23 \%$, from father to child - $12 \%$ [12]. There is no data on the transfer of $\mathrm{HCV}$ infection among children in kindergartens.

The risk of HCV infection during sexual intercourse in a stable sexual relationship is negligible, but this can not be a reason for sexually active adolescents to ignore the rules of safe sex.

There is a number of differences in HCV infection in adults and in children. But the data on this issue is ambiguous. It is believed that children have a higher incidence of spontaneous regression of chronic HCV and slower rate of disease progression compared to adults, a predominantly mild asymptomatic course with a slight increase in transaminases $[5,11]$. Thus, as shown by studies of various authors, in infants infected as a result of vertical transmission the level of spontaneous regression of the disease reaches 25 - 40\%. In most patients, spontaneous regression was observed at the age of up to 24 months $[8,13]$. According to the results of Italian research, spontaneous regression for genotypes $1 \mathrm{a}, 1 \mathrm{~b}, 2,3$ and 4 was observed respectively in $5 \%, 2.5 \%, 7 \%, 32 \%$ and $6 \%$ of asymptomatic HCV patients during the first 3 years of life [14]. According to another European study, among 155 children, the diagnosis of $\mathrm{HCV}$ which was put immediately after birth, spontaneous regression was observed in $17 \%$ of patients up to 2 years of life, $24 \%$ to 3 years and $30 \%$ to 5 years of life [15]. According to another study, only in 6 out of 332 (1.8\%) of $\mathrm{HCV}$ infected children portal hypertension with ascites and varicose veins took place in the course of the disease. In two patients, these symptoms and signs appeared at an early age ( 2 and 5 years), while in 4 older ones - 11-15 years. In another European study, only in $0.5 \%$ (in one child out of 194 infected) the disease went into a stage of decompensation and required liver transplantation at the age of 19 years. All of these children were infected with the HCV genotype 1a [16].

According to other international studies, the risk of progression is higher in infants and early childhood than in adulthood, in almost $85 \%$ of patients infected with $\mathrm{HCV}$ infection in childhood the disease goes into chronic phase, $20-30 \%$ of them develop liver cirrhosis in 20 years [2]. This is confirmed by the results of a study conducted by prof. Uchaikin V.F. in the clinic of RAMS out of 204 children with chronic HCV infection liver tissue fibrosis was detected in $97 \%$ of them in $10-13$ years, and in $10 \%$ of cases liver cirrhosis was formed in the first 5-8 years. Long spontaneous remission was observed only in $8 \%$ of children. In $82 \%$ of patients with chronic HCV infection the course of disease was low-symptomatic but with prolonged activity of the process (increased activity of ALT) and viral replication (detection of HCV RNA in PCR). In more than half of the children, subsequent biopsies of the liver revealed an increase in fibrosis, with the main factor determining the pace of this increase (in the absence of factors causing gapatotoxicity such as alcohol, drugs, concomitant severe diseases and metabolic disorders, drug load, stress and etc.) was the duration of infection, especially with present viral replication [4].

Similar data was obtained by other researchers. Retrospective analysis of 105 anti-HCV positive Egyptian children showed that HCV RNA was detected in more than half of the subjects. Sixty percent of RNA-positive children with HCV have undergone diagnostic liver biopsy, in which chronic hepatitis was detected in $73 \%$ of the subjects, cirrhosis - only one, and seven children (27\%) had a normal histology of the liver [17].

Thus, we can assume that HCV is not always a nonmalignant illness in childhood.

The issue of the course of chronic HCV in children, the timing of the formation of liver cirrhosis, the conditions for progression of the disease and the incidence of liver cancer are still not fully understood.

Generally minimal clinical symptomatology impedes timely diagnosis of HCV infection in children. More than three quarters of children have no symptoms. Minimal nonspecific and short-term symptoms at the onset of the disease are found in approximately $15 \%$ of children (fever, lethargy, anorexia, nausea, vomiting and abdominal pain). These symptoms may be accompanied by dark urine coloration, arthralgia, and yellowness of the skin and sclera.

The rate of progression of chronic HCV infection in children, as well as in adults, is determined by the characteristics of fibrogenesis in the liver. In this regard, it is extremely important to timely diagnose the stages of fibrosis, which largely determines the need for antiviral therapy (AVT). The rates of progression of liver fibrosis are individual and are defined by the factors of the host (iron overload, steatosis, duration of infection, etc.) and the factors of the virus (the genotype of the virus, viral load) [18].

Staging of the disease in children can be accomplished by physical examination and estimation of usual laboratory parameters, including albumin, serum aminotransferase, total bilirubin, international normal ratio (INR) and platelet count every 6-12 months [6]. It should be noted that levels of serum aminotransferases do not always reflect the severity of the disease in children. In one study, almost $33 \%$ of children turned out to have normal levels of aminotransferase, despite severe inflammation and necrosis, as was established after a biopsy [12].

For children with progressing liver disease it is recommended to first visualize the liver to evaluate splenomegaly or venous colaterals using ultrasonography of the liver instead of CT or MRI because of its wide availability and the absence of ionizing radiation [6].

Liver biopsy still remains to be the "golden standard" for assessing the stage of liver fibrosis in both adults and children, however, its implementation is associated with the risk of serious complications and requires the availability of trained specialists. That is why the research of the informativity of non-invasive methods of diagnosing liver fibrosis is actively being conducted. Significance of direct (level of hyaluronic acid (HA), collagen type I and IV, procolagen type III, tissue inhibitor of metalloprotease I and II type, tissue type II and III type in the blood serum) and indirect (Fiber Test (FT), Fiber Meter, Fiber Max, etc.) methods for evaluating liver fibrosis have been studied mainly in adults $[13,19]$. For children such data is insufficient and therefore needs further research.

The index of histological activity (HAI), which was first 
proposed by Knodel (1981), is widely used to determine the stage of the liver disease. The score is set in a gradation from 0 to 18 points. In the study of Italian and Spanish doctors, through the examination of children with hepatitis $\mathrm{C}$ it was found that in most patients the index of histological activity (HAI) was low, with an average of 3.6 (in the range of 0 to 11 ). Normal histology of the liver or minimal changes were detected in 14 of 80 cases, chronic hepatitis with low activity in 48 cases and a highly active form in 17 cases. Those children who were diagnosed with highly active chronic hepatitis were significantly older (12 years) than children with chronic hepatitis with low activity or minimal liver damage (8 years). Only one in 80 children (1.3\%) had cirrhosis of the liver [16]. Fibrosis indicators firmly correlated with the duration of the disease and portal inflammation at the same time. In a later report, according to the results of this study, liver fibrosis was evaluated with a simpler system, the so-called METAVIR scale. According to this scale, histological activity is classified as light (A1), moderate (A2) or pronounced (A3). The study revealed a strong correlation between the stage of fibrosis, the age of children during biopsy and the duration of their infection. Using a linear progression analysis, the average rate of progression of fibrosis was calculated to be $0.227 \pm$ 0.372 units of METAVIR per year with an average of 0.148 , and thus the mean time to cirrhosis was 28 years.

In recent years there have been publications devoted to the role of genetic factors of the host in the course of chronic viral hepatitis. At the present stage, molecular genetic methods have found that changes in the cluster of cytokine genes located on the 19th human chromosome are the main factors that determine the features of antiviral protection of the organism. The greatest significance is polymorphism in the region adjacent to the gene of interleukin (IL) -28V [20]. It was established that the polymorphisms of the IL-28B gene determine the possibility of prognosis of self-mediated elimination of $\mathrm{HCV}$, the effectiveness of antiviral therapy and affect the progression of fibrosis. Carriers of genotypes rs $12979860 \mathrm{C} / \mathrm{C}$ and rs8099917 T/T are associated with spontaneous elimination of hepatitis $C$ virus [21]. There are publications that confirm that the IL-28B genotype is the independent and most reliable predictive factor in the response to AVT in patients with $\mathrm{CHC}$. The association with the frequency of early and sustained virologic response (SVR) with rs12979860 polymorphism also was established [22]. There are only a few literary publications devoted to studying the connection between the polymorphism variant of the IL-28B gene and the progression of fibrosis. The correlation between the polymorphism of the gene IL-28B, the level of gamaglutamyltransferase (GGT), activity and stage of liver fibrosis in patients with HCG has been established. [23].

\section{CONCLUSIONS}

According to the data acquired from literature, not all statements on the development of hepatitis $\mathrm{C}$ in children are explicit and a number of open issues still remain, which requires further study of this problem. Correct diagnostic tactic, timely diagnosis, distinguishing the form and stage of the process and appointment of adequate therapy are the exact factors that positively affect the course of the disease, give opportunity to avoid complications and preserve a patient's chance to live a full life.

\section{REFERENCES}

1. Messina JP, Humphreys I, Flaxman A et al. Global distribution and prevalence of hepatitis C virus genotypes. Hepatology. 2015;61:77-87. DOl: 10.1002/hep.27259

2. Unifikovanij klinichnij protokol pervinnoï, vtorinnoï (specializovanoï), tretinnoï (visokospecializovanoï) medichnoï dopomogi ditjam z virusnim gepatitom C. Nakaz Ministerstva ohoroni zdorov'ja Ukraïni № 729 vid 18.07.2016[Unified clinical protocol on primary, secondary (specialized), tertiary (highly specialized) medical treatment of children with viral hepatitis C. Order of the Ministry of Health of Ukraine No. 729 dated July 18, 2016]. https://zakon.rada.gov.ua/rada/show/v0729282-16 [UA]

3. Gower E, Estes C, Blach S, Razavi-Shearer K et al. Global epidemiology and genotype distribution of the hepatitis ( virus infection. Journal of Hepatology. 2014; 61(1): 45 - 57. D0l: 10.1016/j.jhep.2014.07.027

4. Uchajkin V. F., Nisevich N. I., Cherednichenko T. V. Virusnye gepatity ot A do TTV u detej [Viral hepatites from A to TTV in children]. Novaja volna. 2003: 432. [Ru]

5. Gonzalez-Peralta RP, Langham MR, Andres JM et al. Hepatocellular carcinoma in 2 young adolescents with chronic hepatitis $C$. Journal of Pediatric Gastroenterology and Nutrition. 2009; 48(5): 630 - 635. D0I: 10.1097/MPG.0b013e318170af04

6. American Association for the Study of Liver Diseases: HCV guidance: Recommendations for testing, managing, and treating hepatitis $C$ [Internet]. Accessed on April 23, 2018. - Available at: https://www. hcvguidelines.org/unique-populations/children

7. Pawlowska M, Domagalski K, Pniewska A et al. What's new in hepatitis C virus infections in children? World J Gastroenterol. 2015;21:1078310789. DOI: 10.3748/wjg.v21.i38.10783

8. Polis CB, Shah SN, Johnson KE et al. Impact of maternal HIV coinfection on the vertical transmission of hepatitis ( virus: a meta-analysis. Clin Infect Dis. 2007;44( 8): 1123-1131. D0I: 10.1086/512815

9. Esmat G, Hashem M, El-Raziky M et al. Risk factors for hepatitis ( virus acquisition and predictors of persistence among Egyptian children. Liver Int. 2012; 32(3): 449-456. doi: 10.1111/j.1478-3231.2011.02643.x.

10. World Health Organization. Fact Sheet 2015, № 164 . WHO Guidelines for the Screening, Care and Treatment of Persons with Hepatitis C Infection. Updated April 2016. - Available at: https://www.who.int/hepatitis/ publications/hepatitis-c-guidelines-2016/en/

11. Berezenko V.S. Kliniko-patogenetichni osoblivosti fibrogenezu pechinki pri hronichnih gepatitah u ditej ta shljahi jogo medikamentoznoï korekciï: avtoref. dis. na zdobuttja nauk. stupenja doktora med. nauk: spec. 14.01.10 «Pediatrija» [Clinical and pathogenetic aspects of hepatic fibrogenesis in children's chronic hepatites and ways of its non-surgical correction] K. 2007; 37. [Ua]

12. Casiraghi MAntonietta, De Paschale $M$, Romanò $L$ et al.. Long-term outcome (35 years) of hepatitis ( after acquisition of infection through mini transfusions of blood given at birth. Hepatology (Baltimore, Md.). 2004;39(1):90 - 96. DOI: 10.1002/hep.20030

13. Pirogova I. Ju., Pyshkin S.A. Algoritm differencial'noj diagnostiki hronicheskogo gepatita i cirroza pecheni u bol'nyh s hronicheskoj HCV-i HBV-infekciej [Algorithm for differential diagnosis of chronic hepatitis and liver cirrhosis in patients with chronic HCV-and HBV-infection] Klinicheskie perspektivy gastrojenterologii, gepatologii. 2011; 2: 19-26. [Ru] 
14. Bortolotti F, Resti M, Marcellini M et al. Hepatitis C virus (HCV) genotypes in 373 Italian children with HCV infection: changing distribution and correlation with clinical features and outcome. Gut. 2005; 54 (6): 852-857. D0l: $10.1136 /$ gut.2004.053744

15. European Paediatric Hepatitis C Virus Network. Three broad modalities in the natural history of vertically acquired hepatitis C virus infection. Clin Infect Dis. 2005:41:45-51. D0I: 10.1086/430601

16 Bortolotti F, Verucchi G, Cammà C et al. Long-term course of chronic hepatitis $C$ in children: from viral clearance to end-stage liver disease. Gastroenterology. 2008; 134: 1900-1907. D0I: 10.1053/j. gastro.2008.02.082

17. Raziky MS, Hawary M, Koofy N, et al. Hepatitis C virus infection in Egyptian. JViral Hepat. 2004; 11:471-476. D0I: 10.1007/s00431-0070472-5

18 Valva P, Casciato P, Carrasco J et al. The Role of Serum Biomarkers in Predicting Fibrosis Progression in Pediatric and Adult Hepatitis C Virus Chronic Infection. PLOS One. 2011; 6(8). D0I: 10.1371/journal. pone. 0023218

19. Castera L. Noninvasive methods to assess liver disease in patients with hepatitis B or C. Gastroenterology. 2012;142:1293-1302. D0I: 10.1053/j. gastro.2012.02.017
20. Ge D, Fellay J, Thompson A J et al. Genetic variation in IL28B predicts hepatitis C treatment-induced viral clearance. Nature. 2009;461(7262): 399-401. D0l: 10.1038/nature08309

21. Rauch A, Kutalik Z, Descombes P. et al. Genetic variation in IL28B is associated with chronic hepatitis ( and treatment failure: a genomewide association study. Gastroenterology. 2010;138(4):1338-1347.D0l: 10.1053/j.gastro.2009.12.056

22. Li $W$, Jiang $Y$, Jin $Q$. et al.Expression and gene polymorphisms of interleukin 28B and hepatitis B virus infection in a Chinese Han population. Liver Int. 2011; 31( 8): P. 1118-1126. D0I: 10.1111/j.14783231.2011.02507.x

23. Fabris C., Falleti E, Cussigh $A$ et al. IL-28B rs12979860 C/T allele distribution in patients with liver cirrhosis role in the course of chronic viral hepatitis and the development of HCC. J. Hepatol. 2011;54(4): 716-722. 0I: 10.1016/j.jhep.2010.07.019

\section{Authors' contributions:}

According to the order of the Authorship.

\section{Conflict of interest:}

The Authors declare no conflict of interest.

\section{CORRESPONDING AUTHOR} Nataliia 0. lakovenko

Prospect Myru, bud. 30, kv. 38., 54034 Mykolaiv, Ukraine tel: +380950544782

e-mail:kom75577@gmail.ru

Received: 18.03 .2019

Accepted: 01.05.2019 
PRACA POGLĄDOWA

REVIEW ARTICLE

\title{
INTERNATIONAL EXPERIENCE OF LEGAL REGULATION OF THE PROCEDURE OF TATTOOING SERVICES' PROVISION AND ITS IMPLEMENTATION IN UKRAINE
}

\author{
Alona 0. Milevska', Alexander A. Lyubchik ${ }^{2}$, Alina N. Chorna ${ }^{3}$, Olha M. Khimich ${ }^{4}$, Roman M. Opatskyi ${ }^{5}$ \\ 'UNIVERSITY OF THE STATE FISCAL SERVICE OF UKRAINE, IRPIN, UKRAINE \\ 'LUHANSK STATE UNIVERSITY OF INTERNAL AFFAIRS NAMED AFTER E.O. DIDORENKO, SEVERODONETSK, UKRAINE \\ ${ }^{3}$ KHARKIV NATIONAL UNIVERSITY OF INTERNAL AFFAIRS, KHARKIV, UKRAINE \\ ${ }^{4} U$ NIVERSITY OF MODERN KNOWLEDGE, KYIV, UKRAINE \\ SDNIPROPETROVSK STATE UNIVERSITY OF INTERNAL AFFAIRS, DNIPRO, UKRAINE
}

\begin{abstract}
Introduction: The fashion for tattoos in Ukraine and in the world is becoming massive among young people and middle-aged people. The existence of a great demand and the lack of standards that would establish a procedure for the provision of such services in Ukraine lead to the realization of such activities by persons who are not sufficiently knowledgeable about the safety, contraindications and risks of such activities for the health of a client. The realities of the present time indicate that the unregulated tattoo services can trigger the outbreak and spread of dangerous infectious diseases, and also pose a threat to public health.

The aim: The objective of this article is to comprehensively analyze and study the main tendencies in the legal regulation of the provision of tattoo services in the EU countries and the US. The main task of the paper is to distinguish and generalize the positive experience of legal regulation of the provision of tattooing services, to formulate propositions for their implementation in Ukraine.

Materials and methods: The authors during the research have used theoretical methods (analysis, synthesis, generalization, systematization, etc.) and empirical methods (observation, classification, etc.). The systematization and analysis of national and international legislation in the field of regulation of tattooing services has been carried out. Review: The authors of the article have analyzed the tendencies of legal regulation of the provision of tattooing services in the EU countries and the US. Analysis, systematization and generalization of legal regulation of tattooing in these countries made it possible to find out that the safety of the provision of such services for public health can only be achieved through comprehensive legal regulation that combines sanitary requirements, vocational training and licensing requirements, infection control and control of chemical composition of paints for tattoos.

Conclusions: The necessity of introduction of positive experience in legal regulation of tattooing services in Ukraine has been established. It will protect the population from the spread of dangerous infectious diseases and will promote the health of the youth who massively address for such services.
\end{abstract}

KEY WORDS: tattooing, infectious diseases, medical risk, infection control, sanitary requirements

Wiad Lek 2019, 72, 5 cz. I, 933-937

\section{INTRODUCTION}

Tattooing have been practiced in different cultures for centuries, but today this form of art has undergone significant changes. More and more young people and middle-aged people turn to numerous studios or individual masters to get a picture on the body, trying to express their individuality. According to the analytical report "Safety of Tattoos and Permanent Makeup. The Final Report" of the Joint Research Center of the European Commission, 12\% of Europeans have tattoos as of 2016 [1]. According to open statistics as of $2017-4$ out of 10 adult US residents have tattoos [2]. Unfortunately, the collection of statistical data in Ukraine on this criterion and the registration of persons who have received a tattoo is not carried out. There is also no normative regulation of the procedure for providing tattooing services and requirements for the manufacturers of such services in Ukraine. All this suggests that the state does not perceive a service as the threat to public health, which is globally recognized as potentially harmful to the consumer and the one that can contribute to the spread of dangerous infectious diseases, in particular hepatitis and HIV / AIDS. In particular, outbreaks of hepatitis among people who received a tattoo service were recorded at one time in the United States and Holland.

Considering the fact that Ukraine is the leader in Europe in terms of the number of HIV-positive people (according to estimates at the beginning of 2018, there were 244 $000 \mathrm{HIV}$-positive people in the country, that is, every hundredth of Ukraine's citizens aged 15-49 were infected with HIV [3]), the policy of the state should be aimed at overcoming this situation and minimizing the possible ways of spreading the infection. Therefore, special attention 
in Ukraine should be paid to the problem of providing tattooing services. Besides, the danger to the health of a consumer of tattoo services can be borne and the use of harmful pigment. Thus, the tattoos in Ukraine require an immediate response from the state and the introduction of a positive international experience of legal regulation in this area.

\section{THE AIM}

The objective of this article is to comprehensively analyze and study the main tendencies in legal regulation of the provision of tattooing services in the EU countries and the US. The main task of the paper is to distinguish and generalize the positive experience of legal regulation of the provision of tattooing services, to formulate propositions for their implementation in Ukraine.

\section{MATERIALS AND METHODS}

The authors during the research have used theoretical methods (analysis, synthesis, generalization, systematization, etc.) and empirical methods (observation, classification, etc.). The analysis of international legislation in the field of regulation of tattooing services has been carried out under the following categories: sanitary requirements, training and licensing, infection control, control over chemical composition of pigments. International experience of legal regulation of tattooing services has been systematized and summarized. The application of these methods allowed to properly justify the conclusions drawn and to formulate directions for the improvement of domestic legislation.

\section{REVIEW AND DISCUSSION}

In the early 1980s the outbreak of hepatitis B in Amsterdam was the start of the development of the first guide to hygiene for tattoo producers in the Netherlands. Since then, infection control in the practice of tattoos continues to prove its importance, since we continue to receive reports of outbreaks of infectious diseases associated with tattoos in Europe [4]. The tattoos were generally banned from 1961 through 1996 in the US, due to the outbreak of hepatitis. However, such an approach of the state has only created the "shadow" nature of the masters of tattoos. We believe that it is not appropriate to use the prohibition to apply these legal relationships. It is more effective to develop efficient norms of legal regulation of the provision of tattooing services, which safeguard or minimize the possibility of negative consequences for the health of consumers of such services. Besides, masters of tattooing themselves have a desire to establish requirements for their profession and conduct research on the safety of ink for tattoos. Rick Stevens, one of the representatives of this business in the UK, said that they had to face the influx of cheap Chinese ink of dubious quality. "Systems for checking the quality of these paints just do not exist", - he stressed [5].
The scientific literature includes for medical risks while tattooing:

- bacterial infections, which are manifested as acute infections after tattooing and during tattoo treatment. They can be local or systemic and ultimately progress to sepsis (cases of sepsis from tattoos are fixed in Ukraine [6]);

- traumatic and other local skin phenomena due to the wrong technique of tattooing and amateurism with acute, sub-chronic or chronic consequences;

- chronic infections associated with tattoos, especially viral hepatitis B and C and HIV infections;

- manifestations of carcinogenic, mutagenic and reproductive toxic (CMR) ink ingredients and manifestations of toxic or allergic effects of metals;

- special chronic reactions, which, for example, are related to the lymphatic system and pain syndromes;

- manifestations of interaction with a client's skin diseases, as well as with general diseases and weaknesses of the organism [4, p. 219].

Considering the nature of such risks, the preconditions for their occurrence may be as: the lack of appropriate measures for disinfection and sterilization of tattoo equipment; the lack of knowledge of the tattoo masters about the risks and ways of transmitting infectious diseases during tattooing, methods for preventing allergic reactions and rules for first aid; the lack of state control over tattoo service providers; the use of a pigment to perform a picture containing chemical elements that are hazardous to the health of a client, etc. Taking into account the above-mentioned preconditions for the emergence of medical risks of tattoos, it should be noted that security in the provision of such services can be achieved by defining and consolidating the requirements for the organization of such activities in the law. This is about sanitary requirements, requirements for professional training and licensing, infection control, control over the chemical composition of tattoo paints, etc. We will analyze the international norms defining the ways to overcome the medical risks of using the tattoo according to each of these requirements.

\section{SANITARY REQUIREMENTS}

Most states in the United States have requirements for: the obligation of the authorized health care authority to check tattoo salons (Tennessee - every 90 days); restrictions on the consumption of food and tobacco in the treatment rooms; requirements for disinfection and sterilization of equipment; requirements for the separation of procedural tattoo offices from other premises of the salons; requirements for recycling the waste of tattoo procedure. The Mississippi law provides that all surfaces of the treatment room, including the ceiling, can be washed [7].

Most of the Member States of the European Union have the norms of national legislation that establish sanitary requirements for tattoo salons. In particular, all materials in Belgium according to Arrêté Royal 25/11/2005 réglementant les tatouages et les piercings, must be disinfected or disposable, the sterilization of heat-resistant materials 
should be carried out in an autoclave, tattoo studios and piercings should have the following separate spaces: waiting area, work zones, zone of decontamination / sterilization, waste zone and dirty linen [8].

Sanitary rules in Ukraine are foreseen only for the arrangement of various types of hairdressers and cosmetology offices. However, there are no such rules regarding the arrangement of a tattoo salon or the master's working place. The initiative of the National Association of Masters of Tattoo, Permanent Makeup and Piercing of Ukraine is positive in this aspect. They offer own sanitary rules for the arrangement of offices for the members of the Association on their Internet web-page [9].

\section{REQUIREMENTS FOR PROFESSIONAL TRAINING AND LICENSING}

Almost every American state has requirements for the licensing of tattoo salons. The US law also requires the master of tattooing to undergo anatomy and first aid training. Moreover, the law of the state of Illinois provides that tattoo services by a person who does not have a medical license is the violation of Class A (Ill Rev. Stat. 720, $\$ 5 /$ 12C-35) [10].

The license in the Czech Republic, Romania, Belgium, Italy, Liechtenstein, Malta, Slovenia, Slovakia, Switzerland and the Netherlands is mandatory to open a tattoo studio and provide tattoo services. In particular, a tattoo master in the Czech Republic, according to the Act No. 258/2000 Coll., on the protection of public health - must have the necessary knowledge in the field of public health, verified by the relevant competent authority [11]. Luxembourg requires a hairdresser, cosmetologist or master of manicure diploma to open a salon [12]. In Belgium, the Czech Republic, France, Italy, Liechtenstein, Romania and Sweden, the legislation provides the obligation to take hygiene and health training courses for tattoo masters. The legislation of Austria, Denmark and Latvia also provides the need for special training for those who wish to be engaged in tattooing activities.

The legislation of Ukraine does not contain requirements for special knowledge or qualification of masters on tattoos, and the existence of such specialists in the Classifier of Occupations of Ukraine is not provided at all.

\section{INFECTIOUS DISEASE CONTROL}

The federal law of the United States provides the following measures for the infectious control over tattoo services: the requirement for the use of sterile equipment and disposable needles; requirement for vaccination of the master of hepatitis B; an obligation to inform a client about the risks of the procedure and the particularities of tattoo care; the customer's commitment to complete the medical form [10]. In accordance with the resolutions of the Council of Europe (ResAP (2008) 1) - Belgium, France, Liechtenstein, Norway, Slovenia, Spain, Sweden, Switzerland, the Netherlands, Italy, Malta and Romania have introduced special disposable tattoo containers that provide the sterility of tattoo ink before the use. The laws of these countries also stipulate the requirements for the sterility of equipment and the obligation to use disposable needles. Masters of tattoos in France, Liechtenstein, Malta, Norway, Slovenia, Sweden, Switzerland and the Netherlands should provide clients with extended information on potential health risks, tattoo care features, tattoo removal procedures, indicate the need for the consultation with a physician in case of the occurrence of complications of health. Many countries, such as France, Italy, Norway, Switzerland or the Netherlands, require the written consent of a client or his legal representative, which must be kept for a long time. Norway and the Netherlands, for example, have introduced civic awareness campaigns targeting tattoo clients regarding the potential health risks associated with tattoo procedures. Besides, the website http://www.veiligtatoeerenenpiercen.nl/ contains the list of all Dutch licensed salons and specifies the age limitations of clients, also providing data on the risks of tattoos, care instructions, etc.

The Red Cross in the United States prohibits individuals with tattoos from being blood donors for 12 months from the date of marking, unless the procedure is carried out in a licensed salon using sterile equipment [13]. It is also prohibited in the UK to be a blood donor person for four months after marking a tattoo [14]. The Ministry of Health of Ukraine also sets limits on the ability to be blood donors for people with tattoos or piercings for one year [15].

\section{CONTROL OVER THE CHEMICAL COMPOSITION OF PAINTS FOR TATTOOS}

In the framework of the control over the chemical composition of tattoo paints in the European countries, the Council of Europe adopted the Resolution "On Tattoo and Permanent Makeup" (ResAP (2003) 2) and the Resolution "On Requirements and Criteria for the Safety of Tattoos and Permanent Makeup" (ResAP (2008) 1). The provisions of the Resolution "On Requirements and Criteria for the Safety of Tattoos and Permanent Makeup" establish the list of requirements for the pigments used in the tattoo procedure, in particular regarding their chemical composition, the assessment of their risks and the labeling by the procedure used in the tattooing. The purpose of adopting these resolutions was to introduce established recommendations to the national legislation of the Member States for the protection of public health [16].

The countries that have introduced regulations on the control over the chemical composition of tattoo paints into the national legislation in accordance with ResAP 2003 and 2008 are Austria, Denmark, Belgium, Latvia, Slovenia, France, Netherlands, Germany, Sweden, Norway, Switzerland, Spain. The legislation of the Czech Republic, Finland, Italy, Malta, Romania and Slovakia also has regulatory acts that define the requirements for the safety of tattoo services and provides the supervision over the chemical composition of paints, with reference to the list of hazardous chemicals specified in the Resolution ResAP 
20081 [1]. The National Agency for the Safety of Medicines and Medical Products (ANSM) controls the access of tattoo products to the market in France. The person responsible for producing tattoo products to the market must notify the National Safety Agency of Medicines and Medical Products (ANSM) of all possible serious side effects from the use of these products. Same thing is done by health care employees and tattoo masters who indicate, whether a serious side effect was the result of improper use of the product and a description of the conditions, where the tattoo was performed. Also, consumers can declare to the ANSM the negative impact of tattoo products [17]

The analysis of international tattoo management experience allows us to distinguish the following areas and measures to improve the national legislation. In particular, in the direction of ensuring sanitary requirements: it is necessary to adopt sanitary rules and standards for the equipment of tattoo salons and tattoo master rooms, taking into account the necessary requirements for the disinfection of equipment and tattooing equipment. In the direction of providing vocational training and licensing, it is necessary to legislatively establish the need for licensing the activities of tattoo masters by analogy with the licensing of piercing services, and in the direction of admission to the profession - to oblige the tattoo masters to undergo medical courses for knowing the anatomy, hematopoietic pathogens and the procedure for providing the first aid. In the direction of ensuring the infectious control of tattoo services, it is advisable to establish a requirement for the hepatitis B tattoo masters' vaccination, to oblige to provide a client, before the tattoo, the full information about the risks of tattooing, taking care of it and the need for consultation with a physician in case of complications, and to oblige the masters to keep records of all persons whose condition has deteriorated due to the tattooing and to inform about them the appropriate health care facilities. In the direction of controlling the chemical composition of tattoo paints, it is necessary to develop and adopt the norms of national legislation in accordance with the Resolution of the Council of Europe "On Requirements and Criteria for the Safety of Tattoos and Permanent Make-up" (ResAP (2008) 1). Besides, it is necessary to set at the legislative level, the minimum age for those who want to have a tattoo, since there is a case in Ukraine of rendering a tattoo service for a child of 7 years, which is totally unacceptable in regard to possible health risks [18]

\section{CONCLUSIONS}

The analysis of international experience of legal regulation of tattoo services demonstrates that the legislation of most foreign countries establishes the appropriate requirements for the tattoo procedure, its organization and licensing, infection control, hygienic standards and chemical composition of paints. In regard to comprehensive regulation of tattoo salons activities and providing tattoo services in Ukraine, the authors have offered to establish at the state level clear rules and standards that will ensure the safety of such a service and minimize its negative consequences for public health.

\section{REFERENCES}

1. Paola Piccinini, Sazan Pakalin, Laura Contor, Ivana Bianchi, Chiara Senaldi. Safety of tattoos and permanent make-up. Final report. Publications Office of the European Union [Internet] 2016 [cited 2019 Apr 05]. 110 p. Aviable from : https://ec.europa.eu/jrc/en/publication/ eur-scientific-and-technical-research-reports/safety-tattoos-andpermanent-make-final-report doi: 10.2788/011817.

2. Martin Armstrong. 4 in 10 U.S. Adults Have a Tattoo [Internet]. The Statistics Portal; 2017 [updated 2017 Jun 26; cited 2019 Apr 02]. Aviable from: https://www.statista.com/chart/9980/us-adults-witha-tattoo/.

3. Epidemichna sytuatsiia z VIL-infektsii v Ukraini stanom na 01.10.2018 [Internet]. Tsentr Hromadskoho zdorovia MOZ Ukrainy [updated 2018 0ct. 30; cited 2019 Apr 01]. Aviable from: https://phc.org.ua/kontrolzakhvoryuvan/vilsnid/statistika. (In Ukrainian).

4. Serup J, Kluger N, Bäumler W. Tattooed Skin and Health. Curr. Probl. Dermatol. Basel, Karger, 2015; 48: 218-222.

5. Uchyonyie: Chernila dlya tatuirovok mogut vyizyivat rak [Internet]. Populyarnaya mehanika [updated 2016 Jyl 26; cited 2019 Apr 02]. Aviable from: https://www.popmech.ru/science/249092-uchenyechernila-dlya-tatuirovok-mogut-vyzyvat-rak/.

6. V Kieve paren sdelal tatuirovku i vpal v komu [Internet]. KP v Ukraine [updated 2018 Aug 08; cited 2019 Apr 01]. Aviable from: https:// kp.ua/incidents/615011-v-kyeve-paren-sdelal-tatuyrovku-y-vpalv-komu.

7. Valeria P. Carlson, Everett J. Lehman and Myrna Armstrong. Tattooing Regulations in U.S. States, 2011. Journal of Environmental Health. 2012;75(3):30-37.

8. Arrêté Royal $25 / 11 / 2005$ réglementant les tatouages et les piercings [Internet]. 2006 [cited 2019 Apr 05]. Available from:http://www.etaamb. be/fr/arrete-royal-du-25-novembre-2005_n2005023079.html.

9. Pravyla tatu-saloniv [Internet]. Natsionalna asotsiatsiia maistriv tatu, tatuazhu ta pirsynhu [cited $2019 \mathrm{Apr}$ 01]. Aviable from: https://tattooassociation.com/informatsiya/pravila-tatu-saloniv.

10. Tatooing and body piersing. State Laws, Statutes and Regulations [Internet]. National Conference of State Legislatures ; 2019 [updated 2019 Mar 13; cited 2019 Apr 04]. Aviable from: http://www.ncsl.org/ research/health/tattooing-and-body-piercing.aspx.

11. Act No. 258/2000 on protection of public health [as consolidated to Act No. 471/2005] [Internet]. International Labour Organization [cited 2019 Apr 05]. Available from: http://ilo.org/dyn/natlex/natlex4. detail?p_lang=en\&p_isn=72639\&p_country $=C Z E \& p \_c o u n t=261$.

12. Règlement grand-ducal du 1er décembre 2011 déterminant les modalités de l'instruction administrative prévue à l'article 28 de la loi du 2 septembre 2011 réglementant l'accès aux professions d'artisan, de commerçant, d'industriel ainsi quà certaines professions libérales [Internet]. 2011 [cited 2019 Apr 02]. Available from: http://legilux. public.lu/eli/etat/leg/rgd/2011/12/01/n3/jo.

13. Eligibility Criteria: Alphabetical [Internet]. American Red Cross [cited 2019 Mar 10]. Aviable from: https://www.redcrossblood.org/donateblood/how-to-donate/eligibility-requirements/eligibility-criteriaalphabetical.html.

14. Who can give blood [Internet]. NHS. Blood and Transplant. [cited 2019 Mar 15]. Aviable from: https://www.blood.co.uk/who-can-give-blood/.

15. Khto mozhe buty donorom krovi i yak hotuvatysia do zdachi krovi. [Internet]. Ministerstvo okhorony zdorovia Ukrainy [cited $2019 \mathrm{Mar}$ 12]. Aviable from: http://moz.gov.ua/article/health/hto-mozhe-butidonorom-krovi-i-jak-gotuvatisja-do-zdachi-krovi. 
16. Resolution ResAP(2008)1 on requirements and criteria for the safety of tattoos and permanent make-up (superseding Resolution ResAP(2003)2 on tattoos and permanent make-up). Adopted by the Committee of Ministers on 20 February 2008 at the 1018th meeting of the Ministers' Deputies [Internet]. [cited 2019 Mar 13]. Aviable from: https://rm.coe. int $/ 16805 \mathrm{~d} 3 \mathrm{dc} 4$.

17. LOI n 2014-201 du 24 février 2014 portant diverses dispositions d'adaptation au droit de l'Union européenne dans le domaine de la santé (1) [Internet]. Legifrance [cited 2019 Mar 15]. Aviable from: https: https://www.legifrance.gouv.fr/affichTexte. do?cidTexte $=$ JORFTEXT000028652182\&categorieLien $=$ id.

18. Kolyshnii cholovik nabyv na rutsi 7-richnoho syna tatu: «na zlo druzhyni» [Internet]. Politeka; 2019 [updated 2019 Apr 5; cited 2019 Apr 07]. Aviable from: https://politeka.net/ua/news/society/981977-byvshijmuzh-nabil-na-ruke-7-letnego-syna-tatu-nazlo-zhene/.

\section{Authors' contributions:}

According to the order of the Authorship.

\section{Conflict of interest:}

The Authors declare no conflict of interest.

\section{CORRESPONDING AUTHOR}

\section{Alona 0. Milevska}

University of the State Fiscal Service of Ukraine,

31, Universitetskaya str., Kyiv region, Irpin, 08201, Ukraine e-mail: Milevska-ntsk@ukr.net

Received: 16.03 .2019

Accepted: 24.04 .2019 


\title{
RETROSPECTIVE ANALYSIS OF THE MEDICAL DOCUMENTATION OF PATIENTS WHO APPLIED TO THE AMBULATORY OF GENERAL PRACTICE - FAMILY MEDICINE
}

\author{
Olexander Ye. Kononov, Liliana V. Klymenko, Ganna V. Batsiura, Larysa F. Matiukha, Olha V. Protsiuk, \\ Oleksandr V. Klymenko, Marina A. Trishinska, Oksana I. Pogorila \\ SHUPYK NATIONAL MEDICAL ACADEMY OF POSTGRADUATE EDUCATION, KYIV, UKRAINE
}

\begin{abstract}
Introduction: In today's realities of health care reform in Ukraine family doctors play a leading role.

The aim of our work was to analyze the medical cards of patients who applied for medical care to the family medicine clinic.

Materials and methods: It was analyzed outpatient medical cards of 87 patients who applied to the family medicine clinic in the Khotov village, Kyiv region. The study included people aged 18 to 60 years, which corresponded to the groups of young and middle ages according to the WHO classification.

Review: Our findings indicate the prevalence of functional changes among young people: somatoform dysfunction of the autonomic nervous system - 9 (37,5\%) and the development of organic manifestations at middle-aged patients: arterial hypertension - 32 (62,7\%) and coronary artery disease - 17 (33,3\%).

Conclusions: This study is important for determining the risk groups, early diagnosis and prevention of diseases.
\end{abstract}

KEY WORDS: health care reform, family doctor, risk groups, age groups, early diagnosis, prevention

Wiad Lek 2019, 72, 5 cz. I, 938-941

\section{INTRODUCTION}

The health of a nation is the goal of any state and it shows the degree of development of society and the measure of responsibility that the leadership of the country determines for itself, taking care of the quality of life of its citizens $[1,2]$. The WHO program "Health - 2020" proclaims in an international health declaration that "improving people's health and well-being is the ultimate goal of social and economic development" [3]. In today's realities of health care reform family doctors play a leading role. They become the key figure in the diagnosis and prevention of diseases, as well as the patient's route $[4,5]$. At the prehospital stage, almost $80 \%$ of patients begin and finish treatment $[6,7]$. Therefore, the early diagnostics of diseases is the starting point in the diagnosis, treatment, prevention of possible complications and recovery of the patient. Great importance plays the identification of possible risk groups with various pathologies.

\section{THE AIM}

The aim of our work was to analyze the medical records of patients who applied for medical care to the family medicine clinic.

\section{MATERIALS AND METHODS}

To achieve this aim, we analyzed outpatient medical records of 87 patients who applied to the family medicine clinic in the Khotov village, Kyiv-Svyatoshinsky district, Kyiv region. The study included people aged 18 to 60 years, which corresponded to the groups of young and middle ages according to the WHO classification. Patients with traumatic brain injury, infection as well as persons who had contact with radiation were excluded from the analysis.

\section{REVIEW AND DISCUSSION}

Were analyzed 87 medical outpatient records of patients seeking medical help from a family doctor, $45(51,7 \%)$ young patients (the $\mathrm{I}^{\text {st }}$ Group) and $42(48,3 \%)$ middle-aged patients (the $\mathrm{II}^{\text {nd }}$ Group) according to the WHO classification. Of theme, there were $69(79,3 \%)$ women and 18 $(20,7 \%)$ men. Beside this there were $35(77,8 \%)$ young and $34(81 \%)$ middle-aged women in the young age group and there were $10(22,2 \%)$ and $8(19 \%)$ men respectively. The comparison shows an approximately equal ratio of the number of patients who consulted to the family doctor, both in the age groups and the number of men and women in the groups. These data are shown in Figure 1.

Our studies allowed us to identify the following. In 29 outpatient cards of patients the data for chronic pathology were not identified. Of theme, 25 (55,5\%) were young people (the ${ }^{\text {st }}$ Group), women - $19 \%$, men - $6 \%$. Among middle-aged people (the II ${ }^{\text {nd }}$ Group), there were 4 (9,5\%) patients: women made up $3 \%$ and men - $1 \%$. Among them there were patients with chronic pathology - $20(44,4 \%)$ 



Figure 1. The ratio of appealability for medical care of women and men in both groups.

Figure 2. Presence and absence of chronic pathology in both groups.

Table I. The ratio of the presence and absence of chronic pathology in the outpatient cards in both groups.

\begin{tabular}{|c|c|c|c|c|c|}
\hline \multirow[b]{2}{*}{ Groups } & \multirow[b]{2}{*}{ Number } & \multicolumn{2}{|c|}{ Absolute number } & \multicolumn{2}{|c|}{$\%$} \\
\hline & & $\begin{array}{c}\text { Presence of } \\
\text { chronic pathology }\end{array}$ & $\begin{array}{c}\text { Absence of chronic } \\
\text { pathology }\end{array}$ & $\begin{array}{c}\text { Presence of chronic } \\
\text { pathology }\end{array}$ & $\begin{array}{c}\text { Absence of chronic } \\
\text { pathology }\end{array}$ \\
\hline I & 45 & 20 & 25 & 44,4 & 55,6 \\
\hline II & 42 & 38 & 4 & 90,5 & 9,5 \\
\hline
\end{tabular}

and $38(90,5 \%)$ in the Ist and the IInd Groups respectively. This is shown in Table I and Figure 2.

This observation shows the increase in the identified chronic pathology in the middle age group (the II $^{\text {nd }}$ Group). At the same time, according to medical documentation there is a predominance of a contingent without chronic pathology in young people (the $\mathrm{I}^{\text {st }}$ Group).

When analyzing the identified chronic pathology in age groups, the following is noted. In the first group, 24 diagnoses of chronic pathology were revealed: chronic asthmatic bron- chitis - 1 , chronic cholecystitis - 3 , irritable bowel syndrome - 1 , allergic rhinitis - 1, somatoform dysfunction of the autonomic nervous system of hypertonic type - 3 , somatoform dysfunction of the autonomic nervous system of hypotonic type - 1, somatoform dysfunction of the autonomic nervous system of a mixed type - 3 , somatoform dysfunction of the autonomic nervous system according of the cardiac type - 2 , arterial hypertension of the $\mathrm{I}^{\text {st }}$ stage - 2 , arterial hypertension of the II ${ }^{\text {nd }}$ stage - 1, arterial hypertension of the III ${ }^{\text {rd }}$ stage - 1 , coronary artery disease - 1 , myopia of moderate severity of 


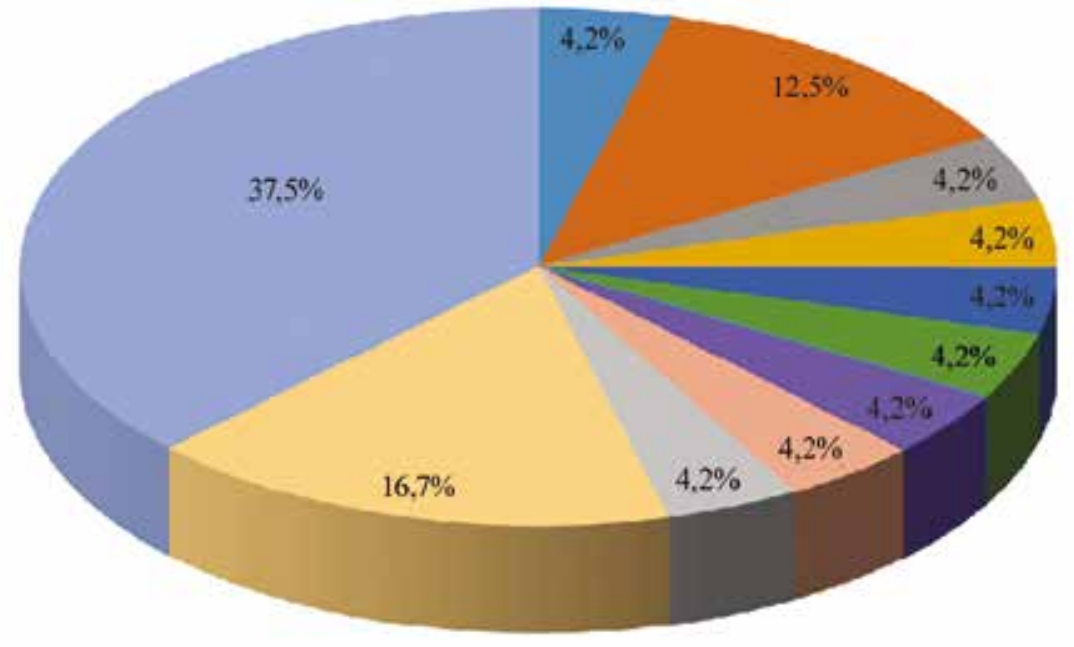

= Chronic asthmatic bronchitis

= Irntable bowcl syndrome

= Chronic otitis

mChronic Ionsillitis

$=$ Coronary artery disease

$=$ Somatoform dysfunction of the autonomic nervous system m Chronic cholecystitis

$=$ Allcrgic rhinitis

=Cluronic pyelonephritis

= Modcrate tyyupia in buth eycs

=Arterial hypertension

Figure 3. Revealed chronic pathology in the $\mathrm{l}^{\mathrm{st}}$ Group of patients.

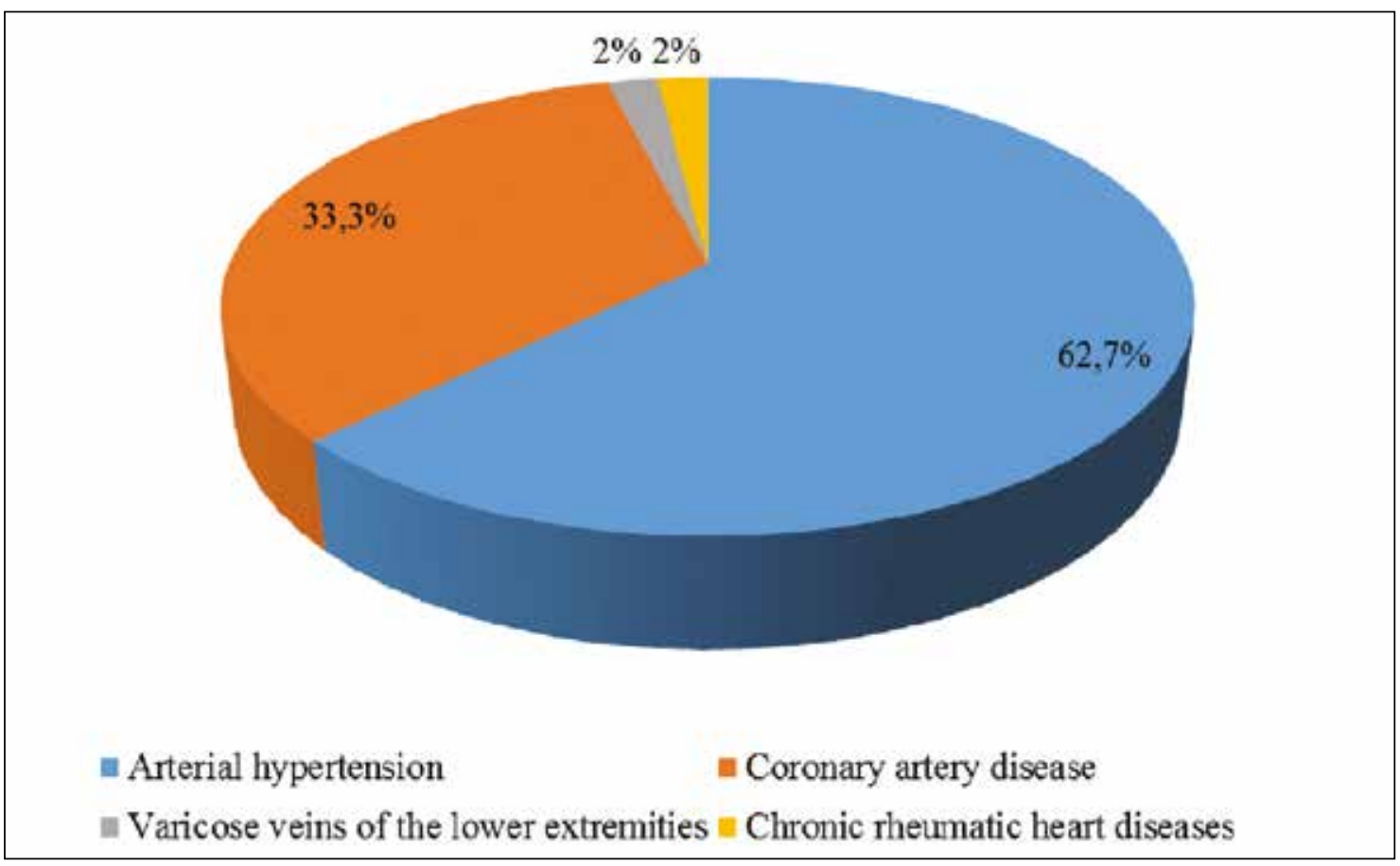

Figure 4. Revealed chronic pathology in the $I^{\text {nd }}$ Group of patients.

both eyes - 1 , chronic otitis - 1, chronic pyelonephritis - 1 , chronic tonsillitis -1 . These data are presented in Figure 3.

Based on this data we can say that somatoform dysfunction of the autonomic nervous system, arterial hyperten- sion and chronic cholecystitis prevailed in this age group. In the $\mathrm{II}^{\text {nd }}$ group in 51 patients were found chronic diseases: varicose veins of the lower extremities - 1, arterial hypertension of the $\mathrm{I}^{\text {st }}$ stage - 11, arterial hypertension of 
the II ${ }^{\text {nd }}$ stage - 15, arterial hypertension of the III $^{\text {rd }}$ stage -6 , coronary artery disease -17 , chronic rheumatic heart disease - 1 .

In the middle aged group, the main diseases were arterial hypertension and coronary artery disease.

Based on the analysis of patient cards, it can be seen that functional changes such as the somatoform dysfunction of the autonomic nervous system predominate among young people - $9(37,5 \%)$. Middle-aged patients suffer from organic changes such as arterial hypertension - $32(62,7 \%)$ and coronary artery disease - $17(33,3 \%)$.

\section{CONCLUSIONS}

1. The study findings show an increasing of frequency of chronic pathology in the middle age group (the $\mathrm{II}^{\text {nd }}$ Group) - 38 (90,5\%) compared with the group of young age (the It Group) - 20 (44,4\%).

2. The analysis of patient cards revealed the prevalence of functional changes among young people: somatoform dysfunction of the autonomic nervous system - $9(37,5 \%)$ and the development of organic manifestations at middle-aged patients: arterial hypertension - $32(62,7 \%)$ and coronary artery disease - 17 (33,3\%).

3. This study is important for determining the risk groups, early diagnosis and prevention of diseases and their complications.

\section{REFERENCES}

1. Alvarez FN, Leys M, Mérida HE et al. Primary health care research in Bolivia: systematic review and analysis. Health Policy Plan. 2016;31(1):114-28. doi: 10.1093/heapol/czv013.

2. Jan CF, Chiu TY, Chen CY et al. A 10-year review of health care reform on Family Practice Integrated Care Project-Taiwan experience. Fam Pract. 2018;35(4):352-357. doi: 10.1093/fampra/cmx111.
3. Jakab Z, Tsouros AD. Health 2020--achieving health and development in today's Europe. Cent Eur J Public Health. 2014;22(2):133-8. doi: 10.21101/cejph.a4045.

4. DiopM,Fiset-LanielJ,ProvostSetal.Doesenrollmentin multidisciplinaryteambased primary care practice improve adherence to guideline-recommended processes of care? Quebec's Family Medicine Groups, 2002-2010. Health Policy. 2017;121(4):378-388. doi: 10.1016/j.healthpol.2017.02.001.

5. Racic M, Pekez-Pavlisko T, Jokovic S. Barriers and facilitators for implementation of family medicine-oriented model of primary care in Bosnia and Herzegovina: A qualitative study. Int J Health Plann Manage. 2018;33(1):e378-e390. doi: 10.1002/hpm.2470.

6. Ouimet M-J, Pineault R, Prud'homme A et al. The impact of primary healthcare reform on equity of utilization of services in the province of Quebec: a 2003-2010 follow-up. Int J Equity Health. 2015; 14: 139. doi: 10.1186/s12939-015-0243-2.

7. Wun YT, Lam TP, Lam KF et al. Introducing family medicine in a pluralistic health care system: how patients and doctors see it. Fam Pract. 2011;28(1):49-55. doi: 10.1093/fampra/cmq064.

\section{Authors' contributions:}

According to the order of the Authorship.

\section{Conflict of interest:}

The Authors declare no conflict of interest.

\section{CORRESPONDING AUTHOR Olexander Ye. Kononov}

Shupyk National Medical Academy of Postgraduate Education 9 Dorohozhytska str., Kyiv, 04112, Ukraine

tel: +380442881034(33)

uadoctorkononov@gmail.com

Received: 23.03 .2019

Accepted: 02.05.2019 


\title{
FAMILIAL HETEROZYGOUS HYPERCHOLESTEROLEMIA: A CASE REPORT
}

\author{
Vyacheslav M. Zhdan, Yevdokiia M. Kitura, Maryna Yu. Babanina, Oksana Ye. Kitura, Maksym V. Tkachenko \\ UKRAINIAN MEDICAL STOMATOLOGICAL ACADEMY, POLTAVA, UKRAINE
}

\begin{abstract}
Introduction: Familial hypercholesterolemia $(\mathrm{FH})$ is an autosomal dominant disorder, caused by the defect of the gene, encoding the structure and function of the receptor for the apoprotein B/E. Patients with FH are predisposed to premature development of atherosclerosis and clinically manifested forms of cardiovascular diseases, in particular coronary heart disease (CHD).

The aim of our article is informing the general practitioners about the diagnosis and management of patients with familial heterozygous hypercholesterolemia. Materials and methods: The data of domestic and foreign literature were analyzed. The case report of familial heterozygous hypercholesterolemia (FHH) was present in this article. Diagnostic criteria, current approaches to the management of patients with hereditary disorders of lipid metabolism are considered.

Conclusions: Familial heterozygous hypercholesterolemia is one of the most common genetic disorders, but this pathology is not well-known to practitioners and is often underdiagnosed. Early diagnosis and aggressive contemporary hypolipidemic therapy is crucial for patients with signs of hereditary lipid disorders.
\end{abstract}

KEY WORDS: familial hypercholesterolemia, diagnosis, statins

Wiad Lek 2019, 72, 5 cz. I, 942-945

\section{INTRODUCTION}

Familial hypercholesterolemia (FH) is an autosomal dominant disorder, caused by the defect of the gene, encoding the structure and function of the receptor for the apoprotein B/E. It is characterized by an extremely high level of low-density lipoproteins (LDL) in blood serum, which leads to the formation of atherosclerotic plaques in the arteries and, consequently, a significantly increased risk of cardiovascular events in young and middle age [1]. Patients with FH are predisposed to premature development of atherosclerosis and clinically manifested forms of cardiovascular disease, in particular coronary heart disease (CHD) $[2,3]$.

\section{THE AIM}

The aim of our article is informing the general practitioners about the diagnosis and management of patients with familial heterozygous hypercholesterolemia.

\section{MATERIALS AND METHODS}

The data of domestic and foreign literature were analyzed. UK Simon Broome Register demonstrates that patients with $\mathrm{FH}$ at the age of 20-39 years old are in 100 -fold increased risk of death from coronary complications and 10-fold increased risk of total mortality. Commonly, homo-and heterozygous $\mathrm{FH}$ are distinguished $[3,4]$.
In patients with heterozygous $\mathrm{FH}$, occurred in general population with the prevalence of one case in 350-500 people, half of the $\mathrm{B} / \mathrm{E}$ receptors are functioning, which leads to approximately 2 -fold elevation in cholesterol $(\mathrm{CH})$ (up to $9-12 \mathrm{mmol} / \mathrm{L}$ ). Despite the fact that FHH is one of the most common genetic disorders, the disease is often underdiagnosed. In most European countries, FH is diagnosed only in $15 \%$ of cases and, generally, after the onset of heart attack at a young age or in the presence of relatives with the history of myocardial infarction [3]. Hypercholesterolemia occurs at birth and is life-long. In most cases, hyperlipidemia (HLD) type IIa (isolated hypercholesterolemia) is detected, but in some patients HLD type IIb can occur (elevated levels of $\mathrm{CH}$ and TG). The pathognomonic sign of the heterozygous form of $\mathrm{FH}$ is xanthomatosis, that is, the deposit of the cholesterol esters in the tendons (achilles tendon, extensor tendons of hands), which leads to their thickening. The lipid arc of the cornea can also be detected. Despite the widespread prevalence of FH and the availability of effective treatment approaches, the disease often remains underdiagnosed, especially in children. Meanwhile, timely diagnosis of FH and prompt therapy could slow down the development of vascular atherosclerosis, postpone coronary intervention in these patients, and save many lives. It has been reported that patients with $\mathrm{FH}$ who start treatment prior to the development of clinical manifestations of coronary heart disease may have normal life expectancy under appropriate lipid monitoring. 


\section{CASE REPORT}

The 60-year-old female patient K. presented with complaints of dyspnea, palpitations, edema of the lower extremities. The history reveled that 3 years ago she first experienced dyspnea, palpitations on exertion, aortic heart defect. It is known that her brother died of myocardial infarction at 45 years of age.

On examination: the state of the moderate severity, upright posture, hypersthenic constitution, body weight $96 \mathrm{~kg}$, height $160 \mathrm{~cm}$, waist circumference $100 \mathrm{~cm}$, body mass index 38.0 $\mathrm{kg} / \mathrm{m}^{2}$, multiple xanthelasma palpebrarum, xanthomas on the chest, lower limbs, tuberous xanthomas on the hands (from the words of the patient, her brother had the similar skin lesions). Lungs: vesicular breathing. BP 140/90 mmHg. The cor- left border of the heart along the anterior axillary furrow, the tones are weakened, above all points, a harsh systolic murmur is heard with max above the aorta, conducting on the vessels of the neck; heart rate 90 beats per minute. The liver protrudes 2,0-3,0 cm from under the margin of the costal arch.

Clinical tests of blood and urine were within normal limits. Biochemical blood test showed total cholesterol (TCH) - $14.53 \mathrm{mmol} / \mathrm{L}, \mathrm{LDL}-8.04 \mathrm{mmol} / \mathrm{L}, \mathrm{HDL}-0.98$ $\mathrm{mmol} / \mathrm{L}$, triglycerides $-2.37 \mathrm{mmol} / \mathrm{L}$.

ECG revealed sinus rhythm, correct, heart rate 95 beats/ min, left ventricular (LV) hypertrophy and left atrium (LA) hypertrophy. Echocardioscopy revealed pronounced fibrosis of the aortic (AV) and mitral valve (MV), calcinosis - +++. EDD LV: 72mm, ESD: 54mm, EDV: 220ml, ESV: 170ml, EF: $34 \%$.

Coronary angiography $(\mathrm{CAG})$ revealed stenosis of the anterior interventricular branch (AIVB) of the left coronary artery (LCA) in the proximal third of $85 \%$, and $60 \%$ in the medial one; stenosis of the proximal third of the circumflex branch (CB) to 50\%, subocclusion of the right coronary artery (RCA) - 99\%.

Chest X-ray revealed pulmonary fields without focal and inofiltrative changes; enlargement of the left heart.

Taking into account the patient's complaints, history, distributed xanthomatosis, hypercholesterolemia, signs of aortic stenosis, calcinosis of the AV and MV, a clinical diagnosis was made: ischemic cardiomyopathy, familial heterozygous hypercholesterolemia. Calcific valvular diseases: calcinosis of the AV and MV. Stage IV degenerative aortic stenosis. Stage II B heart failure (HF) with systolic left ventricular dysfunction. Two surgical operations were performed, namely, aortic valve replacement (AVR), coronary arteries bypass grafting (bypassed AIVA and RCA).

The patient was advised a diet, cholesterol-lowering medications, namely, Rosuvastatin (Evoyd, "Pharmac" 40 $\mathrm{mg} /$ day) under the control of lipidogram 1 time per month (Total Cholesterol level $<4.5 \mathrm{mmol} / \mathrm{L}$ ), sartans (Corsar $\mathrm{H}$ (Valsartan) $160 \mathrm{mg} 1$ time per day), Verospiron $25 \mathrm{mg} /$ day; Syncumar continuously under the control of the INR $(2,5-3,0)$.

One year after the surgery, the condition of the patient was satisfactory, weight $82 \mathrm{~kg}$, continuing therapy, lipid profile: total blood cholesterol - $5.64 \mathrm{mmol} / \mathrm{L}, \mathrm{LDL}-2.04$ $\mathrm{mmol} / \mathrm{L}, \mathrm{HDL}-1.04 \mathrm{mmol} / \mathrm{L}$, triglycerides $-2.44 \mathrm{mmol} / \mathrm{L}$.

\section{DISCUSSION}

Thus, taking into account the family history, the progression of atherosclerosis, coronary heart disease, external manifestations of hyperlipidemia (xanthelasmas, tuberous xanthomas), high levels of total cholesterol and LDL it was established that the patient has a familial heterozygous hypercholesterolemia, which has become the cause for premature development of coronary artery atherosclerosis. The peculiarity of this clinical case is that despite apparent signs of hypercholesterolemia, FH was not diagnosed and, accordingly, hypolipidemic therapy was not provided. This patient is in a high cardiovascular risk group. The finding of the multicenter randomized trials show that issues related to the stratification of the risk of the disease, directly relate to the prognosis of the course of the pathological process, assessment of the potential of the therapy and the rational choice of drugs $[5,6]$.

Apparently, premature development of atherosclerosis is associated with the development of valvular calcification. The findings of the recent studies confirm that valvular calcification is associated with severe damage to the coronary arteries. The sensitivity of calcinosis of the mitral ring and aortic valve as a marker of coronary atherosclerosis is $60.2 \%$ and $52.7 \%$, respectively, that is, in 2 out of 3 patients with mitral ring calcification and in 3 of 4 patients with aortic valve calcification it is probable to detect stenotic atherosclerosis [7].

To date, various criteria (the WHO, Dutch Lipid Clinic Network Criteria) have been proposed for screening and further detailed diagnosis of FH. Almost all of them are based on the assessment of the level of LDL cholesterol, the presence of skin and tendon xanthomas in the patient and his/her relatives, as well as the identification of the type of hyperlipoproteinemia in the family. A genetic examination for $\mathrm{FH}$ is not usually required for diagnosis or clinical evaluation, but may be useful when the diagnosis is uncertain. However, the absence of detected mutations does not exclude the diagnosis of $\mathrm{FH}$, especially when the phenotype of the patient with high probability indicates the presence of $\mathrm{FH}$.

In order to detect the phenotype that is characteristic of the heterozygous form of $\mathrm{FH}$, it is suggested to use the criteria of MedRed and the WHO [8].

Current approaches to the management of patients with hereditary disorders of lipid metabolism include non-medicated (correction of existing risk factors, diet with restriction of consumption of animal fats), drug and extracorporeal therapy (therapeutic LDL-apheresis $[9,10]$. Such patients require the most intense modification of the lifestyle and prescription of appropriate drug therapy, in particular aggressive lipid-lowering therapy with statins, which are the drugs of choice for the treatment of adult patients with $\mathrm{FHH}$ and are characterized by wide spectrum of additional, so-called pleiotropic effects, which are not directly related to the lipid metabolism. It is believed that mainly due to these mechanisms, statins provide normalization of the function of the endothelium, regulate the proliferation of smooth muscle cells, have anti-inflammatory, 
Table I. Diagnostic criteria for the clinical diagnosis of heterozygous familial hypercholesterolemia according to the MedPed and WHO criteria.

\begin{tabular}{|c|c|}
\hline Criteria & Points \\
\hline \multicolumn{2}{|l|}{ Family history } \\
\hline Premature development of cardiovascular diseases * and/or $1^{\text {st }}$ degree relatives with known LDL cholesterol $>95^{\text {th }}$ percentile & 1 \\
\hline $1^{\text {st }}$ degree relatives with tendon xantoma and/or children $<18$ years with LDL cholesterol $>95^{\text {th }}$ percentile & 2 \\
\hline \multicolumn{2}{|l|}{ Clinical history } \\
\hline Premature development of coronary atherosclerosis * & 2 \\
\hline Premature development of cerebral/peripheral vascular disease & 1 \\
\hline \multicolumn{2}{|l|}{ Physical examination } \\
\hline Tendon xanthoma & 6 \\
\hline Corneal arcus in a person $<45$ years & 4 \\
\hline LDL cholesterol >8,5 mmol/L (>330 mg/dL) & 8 \\
\hline $6,5-8,4 \mathrm{mmol} / \mathrm{L}(250-329 \mathrm{mg} / \mathrm{dL})$ & 5 \\
\hline 5,0-6,4 mmol/L (190-249 mg/dL) & 3 \\
\hline 4,0-4,9 mmol/L (155-189 mg/dL) & 1 \\
\hline Definite FHH & $>8$ \\
\hline Probable FHH & $6-8$ \\
\hline Possible FHH & $3-5$ \\
\hline Unlikely FHH & $<3$ \\
\hline
\end{tabular}

*premature development of cardiovascular diseases or coronary atherosclerosis: $<55$ years, men; $<60$ years, women.

antithrombotic, antioxidant effects, influence the apoptosis and stabilize the state of atheromatous plaques $[4,11]$.

Statins are prescribed at a sufficiently high dose, which could provide a decrease in the level of LDL cholesterol by $45-50 \%$. Rosuvastatin is the most powerful hypocholesterolemic drug to date. It is allowed for clinical use in doses of $10 \mathrm{mg}$ to $40 \mathrm{mg}$. The level of LDL cholesterol in administration of Rosuvastatin at recommended doses is reduced by $40-58 \%$, that is, to a much greater extent than with other statins. If necessary, Ezetimib, sequestrants of bile acids, fibrates can be added. At the same time, the risk of the development of serious cardiovascular complications and the overall survival of patients directly depends right at the beginning of statin therapy.

Target LDL cholesterol levels in children are $<3.5 \mathrm{mmol} / \mathrm{L}$, in adults $<2.5 \mathrm{mmol} / \mathrm{L}$; for adults with diagnosed CHD or diabetes, the target level is reduced to $<1.8 \mathrm{mmol} / \mathrm{L}$. In the case of resistant therapy of heterozygous $\mathrm{FH}$ with verified coronary heart disease, extracorporal methods of therapy (plasmapheresis, cascade plasma filtration, heparin precipitation, selective immunosorbtion) are recommended $[8,9]$. All patients with FH need life-long therapy. The use of statins results in $25 \%$ - $40 \%$ reduce of coronary mortality and $26 \%-30 \%$ reduce of the risk of ischemic events.

Lifestyle modification, including dietary restrictions, hypolipidemic therapy, especially the use of statins, can significantly reduce cardiovascular risk in patients with $\mathrm{FHH}$, regardless the age and sex. Apart from effectively selected treatment, an important aspect in the management of patients with FHH remains the high adherence to the provided medical treatment.

\section{CONCLUSIONS}

1. Familial heterozygous hypercholesterolemia is one of the most common genetic disorders, but this pathology is not well-known to practitioners and is often underdiagnosed.

2. Early diagnosis and aggressive contemporary hypolipidemic therapy is crucial for patients with signs of hereditary lipid disorders.

\section{REFERENCES}

1. Soutar AK, Naoumova RP. Mechanisms of disease: genetic causes of familial hypercholesterolemia. Nat Clin Pract Cardiovasc Med. 2007 Apr. 4(4):214-25.

2. Goldberg A.C., Hopkins P.N., Toth P.P., Ballantyne C.M., Rader D.J., Robinson J.G. et al. Familial hypercholesterolemia: screening, diagnosis and management of pediatric and adult patients: clinical guidance from the National Lipid Association Expert Panel on Familial Hypercholesterolemia. J. Clin. Lipidol. 2011;5(3):1-8.

3. Stein EA, Raal FJ. Polygenic familial hypercholesterolaemia: does it matter? Lancet. 2013 Apr 13. 381(9874):1255-7.

4. Ramsey L.B., Johnson S.G., Caudle K.E., Haidar C.E., Voora D., Wilke R.A. et al. The Clinical Pharmacogenetics Implementation Consortium guideline for SLCOIBI and simvas-tatin-induced myopathy: 2014 update. Clin Pharmacol Ther. 2014 0ct; 96 (4):423-428.

5. Zhdan V.M., Kitura Ye.M., Babanina M.Yu., Kitura O.Ye., Volchenko G.V., Tkachenko M.V. ta in. Aktualni pytannia kardiolohii v praktytsi simeinoho likaria [Topical issues of cardiology in the practice of a family doctor]. Druhe vydannia, dopov. i pererob. Poltava; 2017. 248.(UA)

6. Zhdan, V.M. Kitura O.Ye., Kitura Ye.M., Babanina M.Yu., Moroz T.V. Patsiient iz vysokym kardiovaskuliarnym ryzykom (klinichnyi vypadok) [Patient with high cardiovascular risk (clinical case)]. Visnyk problem biolohii i medytsyny. 2010;1:112-115.(UA) 
7. Acarturk E.,Bozkurt A., Cayli M., Demir M. Mitral annular calcification and aoris valve calcification may help in predikting significant coronary artery disease. Angiology. 2003;54(5):561-567.

8. Mitchenko 0.I., Lutai M.I. Dyslipidemii: diahnostyka, profilaktyka ta likuvannia [Dislipidemia: diagnosis, prevention and treatment]. Metodychni rekomendatsii Asotsiatsii kardiolohiv Ukrainy. Kyiv: 2011.(UA)

9. Todurov B.M., Malyishev P.P., Susekov A.V., Konovalov G.A., Zharinov 0.I., Druzhina A.N. Semeynaya dislipidemiya. Ekstrakorporalnyie metodyi lecheniya. Konsensus gruppyi ekspertov [Family dyslipidemia. Extracorporeal methods of treatment. Consensus Group of Experts]. Kardiokhirurhiia ta interventsiina kardiolohiia. 2012;1:67-72.(Ru)

10. Patel R.S., Scopelliti E.M., Savelloni J. Therapeutic Management of Familial Hypercholesterolemia: Current and Emerging Drug Therapies. Pharmacotherapy. 2015;35(12):1189-203.

11. Zhdan V.M., Potiazhenko M.M., Khaimenova H.S., Sokoliuk N.L. Vykorystannia statyniv pry komorbidnii patolohii u praktytsi simeinoho likaria [The use of statins for comorbidity in the practice of a family doctor]. Simeina medytsyna. 2015;3(59):145-147.(UA)
Authors' contributions:

According to the order of the Authorship.

\section{Conflict of interest:}

The Authors declare no conflict of interest.

\section{CORRESPONDING AUTHOR}

Yevdokiia M. Kitura

Ukrainian Medical Stomatological Academy, Shevchenko str., 23, 36011 Poltava, Ukraine tel: +3805075660298

e-mail: e.kitura@mail.ru

Received: 23.03.2019

Accepted: 29.04.2019 


\title{
THE CASE OF FORMATION OF "KISSING» ULCERS OF DUODENAL BULB OF THE PATIENT WITH CHRONIC NONATROPHIC GASTRITIS ON THE BACKGROUND OF THE EATING OF A VEGETABLE SALAD AND PHYSICAL EXERTION
}

\author{
Anatoly A. Avramenko \\ PETRO MOHYLA BLACK SEA NATIONAL UNIVERSITY, MYKOLAIV, UKRAINE
}

\begin{abstract}
Introduction: In certain situations the constituents of food can serve as a catalysator for the formation of such a pathology as peptic ulcer. Not the last role in the formation of ulcerous defects under certain conditions play physical excertion, which is accompanied by sharp rhythmic contraction of the muscles of the anterior abdominal wall.

The aim: To analyze the case of formation of "kissing" ulcers of the duodenal bulb of the 25 -year-old patient.

Materials and methods: The patient took comprehensive examination: step-by-step pH-metry, esophagogastroduodenoscopy, helicobacter infection test (HP) (helicobacter urease test and microscopic examination of stained smears), histological investigations of the gastric stump mucous, HELIC - test.

Case report: It was found that on the eve of the ulcer in the patient's diet during breakfast there was a salad of fresh white cabbage, fresh cucumbers, tomato and radishes and at lunch the patient was subjected to prolonged physical exercise. The level of gastric juice corresponded to the basal normacidity total; endoscopic diagnosis: «Kissing» ulcers duodenal bulb in an active stage. Chronic gastritis type B ». Testing for HP infection revealed a high concentration of the active form of bacteria, the HELIC -test showed a high concentration of ammonia in the stomach cavity.

Conclusions: An abrupt stimulation of secretion by cabbage juice and the presence of urea in vegetables, of which the salad was cooked, led to the formation of a large level of "residual ammonia" in the cavity of the stomach. Physical strain finally formed the mechanism of ulcer formation.
\end{abstract}

KEY WORDS: gastritis, Helicobacter pylori,"residual ammonia"

Wiad Lek 2019, 72, 5 cz. I, 946-949

\section{INTRODUCTION}

Food is an essential attribute of our daily life. However, in certain situations the constituents of food can serve as a catalysator for the formation of such a pathology as peptic ulcer. Not the last role in the formation of ulcerous defects under certain conditions play physical excertion, which is accompanied by sharp rhythmic contraction of the muscles of the anterior abdominal wall [1]. From this point of view, the interesting case of rapid formation of "kissing" ulcers of duodenal bulb after physical exertion, which were preceded by the meal in the form of fresh cabbage salad, fresh cucumbers, tomatoes, and radish.

\section{THE AIM}

To analyze the case of formation of "kissing" ulcers of the duodenal bulb.

\section{MATERIALS AND METHODS}

According to Order № 271 from 13.06.2005 of Ministry of HealthCare of Ukraine [2] a patient took comprehensive examination (№ 6420, 24.03.17), which included stepby-step pH-metry based on V.N. Chernobrovyi methods, esophagogastroduodenoscopy (EGDS) based on general techniques, helicobacter infection test (HP) (helicobacter urease test and microscopic examination of stained smears) and histological investigations of the gastric stump mucous, biopsy material was taken from 4 topographical zones of the stomach (medial third part of antrum and body of the stomach through large and small curvature) [3, $4,5]$. Also, the patient was additionally given a respiratory test (HELIC- test) to determine the level of HP infection according to the latest modification of the method [6].

The study was conducted in accordance with the basic bioethical provisions of the Helsinki Declaration of the World Medical Association on the ethical principles of scientific 549 medical research involving human (19642008) and the order of the Ministry of Health of Ukraine No. 690 dated September 23, 2009, which was confirmed by the findings of the meeting of the Ethical Commission of Petro Mohyla Black Sea National University, Nikolaev

No. 2 dated February 12, 2019.

\section{CASE REPORT}

Patient (man) B., 25 years old, asked 13.03.17 y. for the examination and treatment of a doctor-gastroenterologist 
Table I. Test results of gastric mucosa on HP infection for topographical zones

\begin{tabular}{|c|c|c|c|c|c|c|c|}
\hline \multicolumn{4}{|c|}{ Antrum } & \multicolumn{4}{|c|}{ Fundus of stomach } \\
\hline \multicolumn{2}{|c|}{ Large curvature } & \multicolumn{2}{|c|}{ Small curvature } & \multicolumn{2}{|c|}{ Large curvature } & \multicolumn{2}{|c|}{ Small curvature } \\
\hline 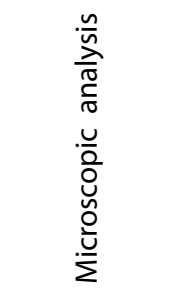 &  & 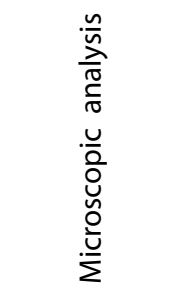 & 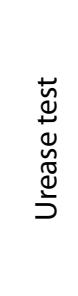 & 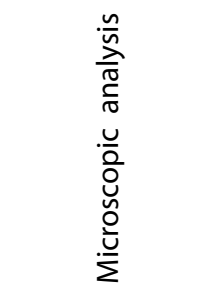 & 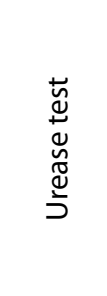 & 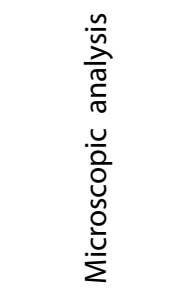 & 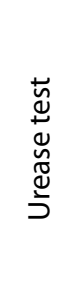 \\
\hline $\begin{array}{l}(+++) \\
\text { Active form, } \\
\text { mitosis }\end{array}$ & $\begin{array}{c}15 \\
\min \end{array}$ & $\begin{array}{l}(+++) \\
\text { Active form, } \\
\text { mitosis }\end{array}$ & $\begin{array}{c}15 \\
\min \end{array}$ & $\begin{array}{c}(+) \\
\text { Active } \\
\text { form, mitosis; } \\
(+++) \\
\text { Cocci form }\end{array}$ & $\begin{array}{c}1 \mathrm{~h} 20 \\
\min \end{array}$ & $\begin{array}{c}(+) \\
\text { Active form, } \\
\text { mitosis; } \\
(+++) \\
\text { Cocci form }\end{array}$ & $2 \mathrm{~h}$ \\
\hline
\end{tabular}

of the clinical department of basic research laboratory on chronic Helicobacter Pylori infection of the Petro Mohyla Black Sea National University about periodic dull and acute pain in epigastria, feeling of heaviness after eating, heartburn after taking sour food. In history, it was found that the first manifestations (epigastric pain) appeared when he was 21 years old against the background of stress. In further aggravations became regular every year and were seasonal (spring/autumn). The current aggravation have appeared in a day after taking the meal for breakfast (fresh cabbage salad, fresh cucumbers, tomatoes, and radish), which was followed by prolonged physical exertion as lifting weights during the lunch time.

The following results were obtained when carrying out investigations:

pH - metry (by V.N. Chernobrovyi method)

Surname. First Name. Patronimic.: B., 25 years

Height: $180 \mathrm{~cm}$; introduced $25 \mathrm{~cm}$
1. 2.791 .68
11. 1.991 .70
2. 2.801 .63
12. 1.991 .73
3. 2.811 .64
13. 1.931 .72
4. 2.841 .78
14. 1.951 .83
5. 2.851 .70
15. $1.95 \quad 1.80$
6. 2.591 .71
16. 1.961 .84
7. 2.491 .70
17. 1.801 .85
8. 2.401 .68
18. 1.811 .80
9. 2.411 .69
19. 1.911 .83
10.2 .401 .69
20. 1.921 .82

$\begin{array}{lll}\text { 5. } & - & - \\ \text { 4. } & - & - \\ \text { 3. } & 10 & 20 \\ \text { 2. } & 10 & - \\ \text { 1. } & - & - \\ \text { 0. } & - & -\end{array}$

Total: $20 \quad 20$

Diagnosis: Basal normacidity total. 24.09.16 y.

The following diagnosis was made when carrying out esophagogastroduodenoscopy: «Kissing» ulcers duodenal bulb in an active stage. Chronic gastritis type $B »$ When testing the gastric mucosa on HP infection for topographical zones were obtained the following results (table I).

While conducting examination of histological research the results have been obtained which confirms the presence of chronic active gastritis in all parts of the patient's stomach. When conducting the HELIK - test no. 7, 25.03.2017 year, the following results were obtained:

a) basic level: $0.5 \mathrm{~mm}$;

b) load level: $6 \mathrm{~mm}$;

c) growth rate: $5.5 \mathrm{~mm}$;

d) conclusion about HP infection-infection (normgrowth up to $3 \mathrm{~mm}$ ): positive (before treatment).

\section{DISCUSSION}

This case can be explained from the position of the new theory of ulcer forming - theory "caustic alkali spit" [1]. Juice of cabbage that exudes while cutting this vegetable, has a distinct stimulating effect on the secretion of the stomach, which leads to increased levels of acidity in the stomach, so it is contradicted for people with gastritis with hyperacidity [7]. Nitrogenous fertilizers may exist in fresh cucumbers, tomatoes and radish, in particular, urea, used to accelerate growth and maturation of vegetables $[8,9]$.

Pylori infection, singling out the enzyme urea, converts urea into ammonia, which while combining with water forms ammonium hydroxide - caustic alkali, necessary bacteria to neutralization of excess hydrochloric acid around it $[1,10,11,12,13,14,15]$. However, some ammonia ("residual" ammonia (RA) does not participate in the process of neutralization of the hydrochloric acid, and fills the stomach. With physical rhythmic stress, according to a new theory, effect of "bellows sound" occurs, when RA concentrates in a tight place - in the pillory channel and bulb of the duodenum, where the humidity is $98 \%$. This leads to local formation on duodenal mucosa ammonium hydroxide at high concentration, causing damages to the mucous membrane, known as peptic ulcer [1]. Graphically, this process can be represented as follows (Figure 1). 




Figure 1. The mechanism of formation of ulcerative lesions of the duodenal bulb in patients with chronic helicobacteriosis:

a) flow direction "residual" ammonia in the gastric cavity;

6) the pyloric sphincter in half-bent state;

B) the place of the maximum concentration of "residual" ammonia (pyloric canal) in the form of sustainable dense flow;

г) the place of ulcerative lesions of the duodenal bulb tissues (any bulb department duodenal ulcer).

\section{CONCLUSIONS}

1. An abrupt stimulation of secretion by cabbage juice and the presence of urea in vegetables, of which the salad was cooked, led to the formation of a large level of "residual ammonia" in the cavity of the stomach.

2. Physical strain finally formed the mechanism of ulcer formation.

\section{REFERENCES}

1. Avramenko AA, Gozhenko Al, Goydyk VS, eds. Yazvennaya bolezn (ocherki klinicheskoy patofiziologii) [Peptic ulcer disease (essays on clinical pathophysiology)]. Odessa : 000 «RA «ART-V», 2008. $304 \mathrm{~s}$. (Ru).

2. Nakaz MOZUkraïni vid 13.06.2005 № 271 «Pro zatverdzhennja protokoliv nadannja medichnoï dopomogi za special'nistju «Gastroenterologija» [On Approval of Protocols for the Provision of Medical Aid in the Specialty «Gastroenterology»].(UA).

3. Avramenko AA. Dostovernost stul-testa pri testirovanii bolnykh khronicheskim khelikobakteriozom pri nalichii aktivnykh i neaktivnykh form khelikobakternoy infektsii na slizistoy obolochke zheludka [Reliability of stool test when testing patients with chronic Helicobacter pylori in the presence of active and inactive forms of Helicobacter pylori infection on the gastric mucosa]. Suchasna gastroyenterologíya. 2014; 3 (77): 22-6. (Ru).

4. Patent 93273 Ukraine, MPK G01N 33/48 (2006.01) Sposíb testuvannya gelíkobakternoyi ínfektsii u khvorikh na khronichniy gelikobakterioz [Method of testing helicobacteric infection in patients with chronic helicobacteriosis] / A0 Avramenko. № u201403956; zayavl. 14.04.2014; opubl. 25.09.2014;18:3. (UA).
5. Kímakovich VY, NikishaevVI, eds. Yendoskopiya travnogo kanalu. Norma, patologiya, suchasni klasifikatsiyi [Endoscopy of the digestive canal. Norm, pathology, modern classifications]. Lviv: Vidavnitstvo Meditsina Svítu, 2008. 208 s., il. 4. (UA).

6. Patent № 128945 Ukraine, MPK G01N 33/497(2006.01), A61B 5/091(2006.01) Sposib testuvannya gelikobakternoyi infekciyi u hvorih na hronichnij gelikobakterioz za dopomogoyu HELIK-testu [A method for testing helicobacter infection in patients with chronic helicobacteriosis using the HELIC -test]/ AO Avramenko, OA Avramenko. - u 201805050; Zayavl. 07.05.2018; 0publ. 10.10.2018; 19:3.

7. Sok belokochannoj kapusty [White Cabbage Juice] [Elektronnyj resurs] // Rezhim dostupa: https://nourriture.ru/stati-po-produktam/1410761/. https://nourriture.ru/stati-po-produktam/1410761/ (Ru)

8. Malahova LP, eds. Produkty bez tajn! Zashiti svoj stol ot ulovok pishevoj industrii [Products without secrets! Protect your table from the tricks of the food industry]. M. : Eksmo, 2012. 271 s.:il. (Ru).

9. Primenenie i harakteristika mocheviny kak udobreniya [Application and characterization of urea as a fertilizer] [Elektronnyj resurs]//Rezhim dostupa: http://goodgrunt.ru/nazvaniya/mochevina-udobrenie.html (Ru).

10. Nazarov VE. Prichiny bezuspeshnosti eradikacionnoj terapii, ne svyazannye $s$ antibiotikorezistentnostyu Helicobacter pylori, i puti in preodoleniya [Causes of failure of eradication therapy, not associated with Helicobacter pylori antibiotic resistance, and ways to overcome them]. Rossijskij medicinskij zhurnal. 2018,3:4-12. (Ru).

11. Nikiforova YaV, Tolstova TN, Cherelyuk NI. Osnovnye polozheniya Soglasitelnoj konferencii po diagnostike i lecheniyu Helicobacter pylori - Maastriht V (2015) [The main provisions of the consensus conference on diagnosis and treatment Helicobacter pylori - Maastricht V (2015)]. Suchasna gastroenterologiya. 2016; 6(92): 119 - 133. (Ru). 
12. Strugatsky D, McNulty RM, Munson K et al. Structure of the proton-gated urea channel from the gastric pathogen Helicobacter pylori. Nature. 2013; 493: 255-258.

13. Buzas GM, Szeles I. Interpretation of the 13C-urea breath test in the choice of second and third-line eradication of Helicobacter pylori infection.J.Gastroenterol. 2008;43(2):108-14.

14. Dzierzanowska-Fangrat K, Dzierzanowska D. Helicobacter pylori: microbiology and interactions with gastrointestinal microflora. J. Physiol Pharmacol. 2006; 57 (3): 5-14.

15. Niv Y, Hazazi R. Helicobacter pylori recurrence in developed and developing countries: meta-analysis of $13 \mathrm{C}$-urea breath test follow-up after eradication. Helicobacter. 2008; 13(1): 56-61.
The work is a fragment of research work «Development of information and communication technologies in the system of medical examinations of seamen", the state registration number 0109 U008375.

\section{Conflict of interest:}

The Author declare no conflict of interest.

\section{CORRESPONDING AUTHOR}

Anatoly A. Avramenko

Petro Mohyla Black Sea National University, Mykolaiv, Ukraine tel: +380976371807

e-mail: aaahelic@gmail.com

Received: 18.03 .2019

Accepted: 02.05.2019 


\title{
INSECT BITES AS THE CAUSE OF INFECTIOUS AND ALLERGIC INFLAMMATORY PROCESSES OF THE MAXILLOFACIAL AREA IN CHILDREN
}

\author{
Pavlo I. Tkachenko, Ivan I. Starchenko, Serhii O. Bilokon, Oleksii K. Prylutskyi, Nataliia M. Lokhmatova, \\ Olha B. Dolenko, Nataliia M. Korotych, Andrii V. Vakhnenko, Andrii M. Gogol, Kateryna Yu. Rezvina \\ UKRAINIAN MEDICAL STOMATOLOGICAL ACADEMY, POLTAVA, UKRAINE
}

\begin{abstract}
Introduction: The part of purulent inflammatory processes (IP) of the maxillofacial area (MFA) as a result of insect bites are increased.

The aim: To attract attention of the medical community to the problem of the complexity of the diagnosis and treatment of these dermatogenic forms of IP MFA. Materials and methods: The work is based on the results of 5 year observations of 42 patients with acute IPMFA arising after insect bites, their comprehensive examination and treatment. Conclusions:1. IP of MFA, arising as a result of insect bites, is a very urgent problem of pediatric surgical dentistry and require an individual approach in the diagnosis and treatment of patients.

2. A large role in preventing the occurrence of these nosological forms is given to medical workers, a sufficient organization level of sanitary and educational work, and the treatment of such cases becomes a common task of doctors of different profiles. However, much depends on the parents, their level of responsibility and competency, ensuring of timely treatment and provision of qualified medical care to children, preventing the development of severe complications.

3. The issues related to the etiopathogenesis of this pathology require profound scientific research.
\end{abstract}

KEY WORDS: children, maxillofacial area, inflammation, insects

Wiad Lek 2019, 72, 5 cz. I, 950-955

\section{INTRODUCTION}

Nowadays, the number of inflammatory processes (IP) in the maxillofacial area (MFA) is steadily increasing in Ukraine. It unfortunately concerns children's surgical practice in full measure $[1,2]$. It is recognized that the general reactivity of the macro organism plays an important role in the occurrence and development of IP, which determines its ability to resist microbial invasion, and the basis of disorders of specific mechanisms of immunological protection is mainly violation of t-cell link of immunity, which happen in the nursing and pubertal periods [3].

Against this background, the presence of secondary immune insufficiency in children and immunosuppressive effects of saprophytic microflora of the oral cavity in conditions of increased antigenic load on the tissues of MFA create prerequisites for the development of IP of different etiology [4].

According to statistical data, $4.11 \%$ of purulent IP MFA are dermatogen of origin, often accompanied by changes in the classical pattern of the disease in the direction of sluggish or aggressive course with the development of severe complications and causing significant difficulties in the rehabilitation of patients [5].

\section{THE AIM}

Constantly monitoring the frequency of occurrence of the IP MFA in children we drew attention to the fact that in recent years among dermatogenic forms the proportion of diseases that develop after insect bites has increased. The lack of sufficient information on this subject in the available literature has prompted us to conduct our own research in order to draw the attention of the medical community to this problem.

\section{MATERIALS AND METHODS}

For an objective assessment of the situation, we analyzed the literature data on the structure of the skin of children and the reaction of soft tissues (ST) to insect bites.

The clinical part of the work is based on the results of 5 year observations of 42 patients with acute IP MFA arising after insect bites, their comprehensive examination and treatment in outpatient and inpatient settings in the clinic of the Department of pediatric surgical dentistry with propedeutics of surgical dentistry of the Ukrainian medical stomatological academy (Poltava).

General clinical and paraclinic methods were used for examination of patients [6].

The work does not contradict the conclusions of the ethical commission.

\section{REVIEW AND DISCUSSION}

According to the literature, in healthy people, even if there is a massive amount of virulent microflora on the skin, IP 


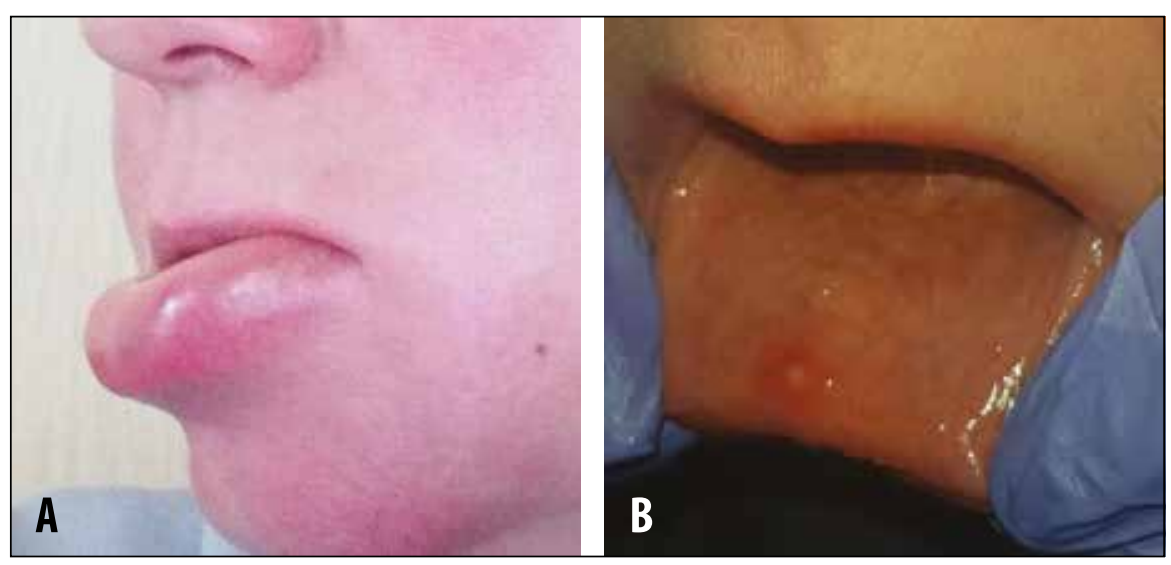

Fig.1. General view of a patient with Quincle edema, which developed as a result of a bee sting (A) and an element of lesion on the mucous membrane of the lower lip at the site of the bite (B)

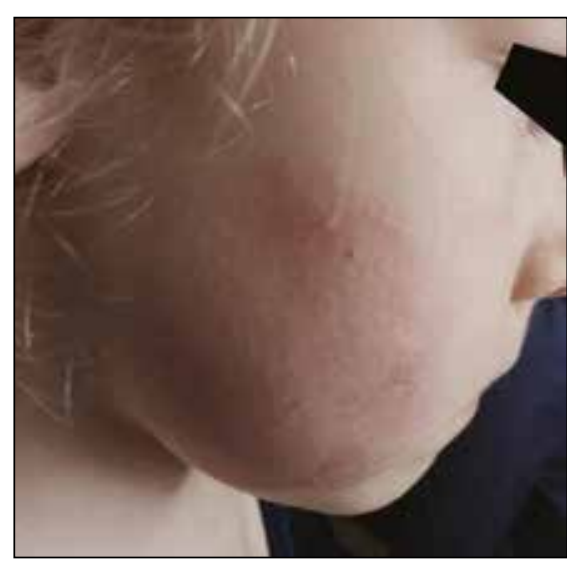

Fig. 2. General view of a child with IP ST right cheek, caused by a mosquito bite


Fig.4. General view of the removed tooth $26(\mathrm{~A}, \mathrm{~B})$ and the view of its pulp chamber $(C)$ after longitudinal cutting

Fig.3. General view of the patient $G ., 5$ years, case history № 8691, at the time of hospitalization

do not occur due to various factors of skin protection which we discussed in previous publications $[7,8]$.

Remembering the factors of human skin protection, we should not forget about the anatomical and physiological features of the children's skin in MFA, which are of great importance in the development of neodontogenic IP in them, creating favorable conditions for the activation of even conditionally pathogenic strains of microorganisms, and the peculiarity of metabolic processes explains the special sensitivity of the skin of children to various toxic effects, including those of biological origin $[9,7,8]$.
So, when insect bites through the skin, the microorganisms easily penetrate with the poison, the aggressive action of which is due to the components depending on the type of insect. The part of almost all insects' poisons can be melitene (actively destroys red blood cells, causes IP, muscle spasm and disturbance of tissue metabolism, reduces blood clotting), apamin (similar to neurotoxins of snakes' and scorpions' poisons considerably excites the elements of the nervous system), hyaluronidase (helps the poison to spread throughout the body), phospholipase A 


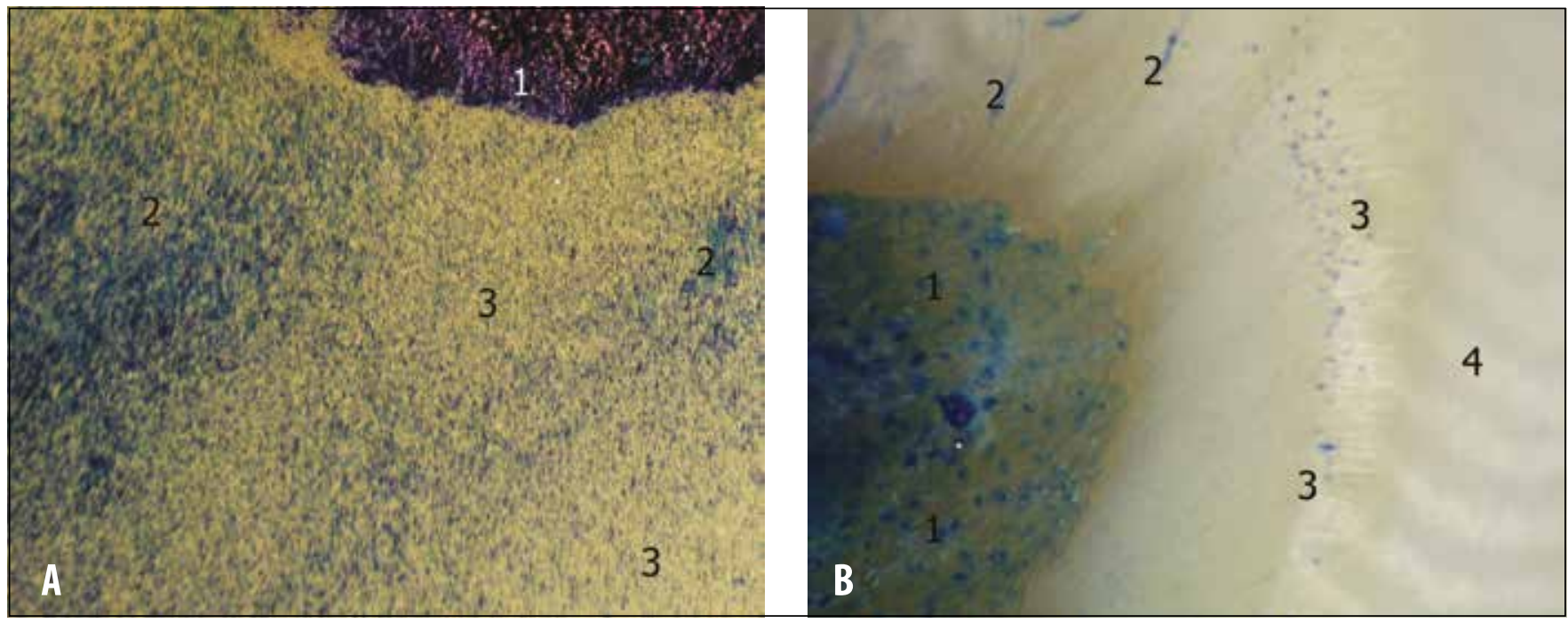

Fig.5. Microscopic picture of the removed tooth. Epoxy grinding, stain with methylene blue. Augmentation: $A-200 x ; B-100 x$. A) 1-necrotizing dentine; 2-areas of hypermineralization with a chaotic arrangement of dentinal tubules; 3-areas of hypomineralization.

B) 1-necrotizing dentine; 2 - pathologically altered dentinal tubules; 3 - unchanged dentin-enamel border, enamel tufts and enamel spindles; 4 - the enamel prisms in unmodified enamel.

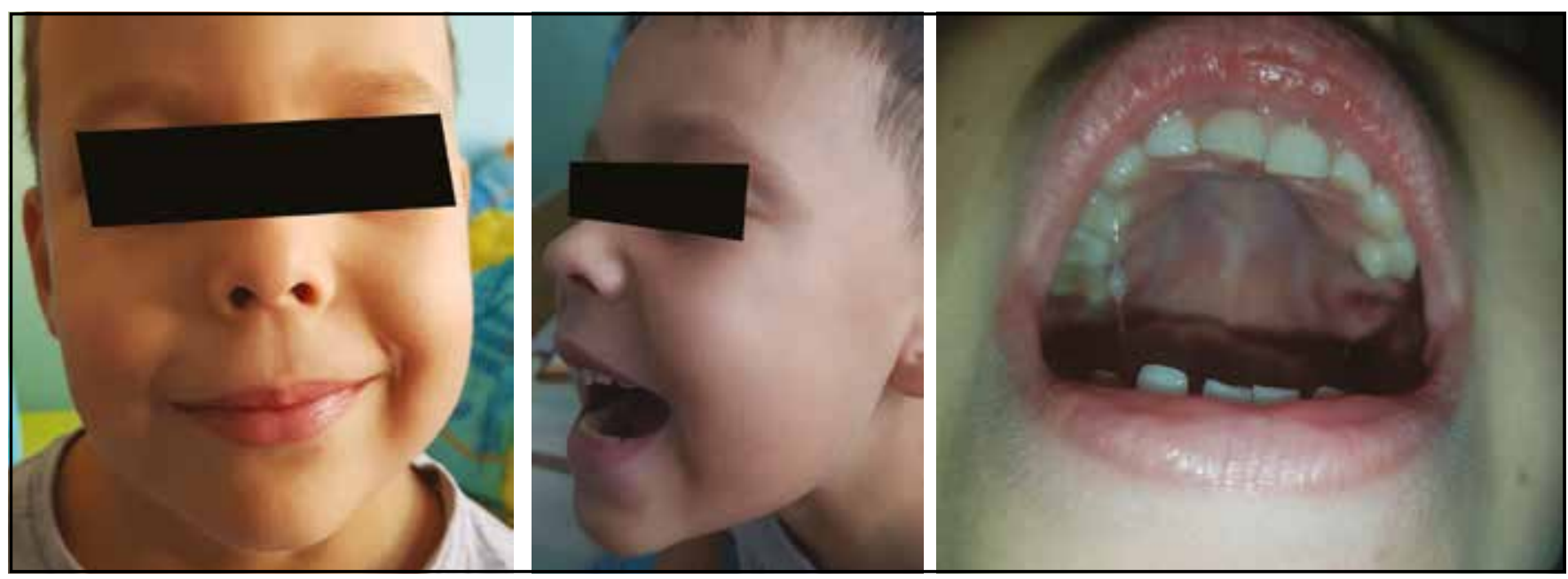

Fig.6. General view of the patient G., 5 years, case history № 8691 , at the time of completion of in-patient treatment.

(strengthens IP and stimulates the hemolysis of red blood cells), histamine (dilates blood vessels, causes inflammatory-allergic process). In addition, a special protein of bee toxin causes mast cells of the affected tissues to release their own histamine. The venom of wasps contains kinin, which promotes vasodilatation and contraction of smooth muscles with provoking IP. The toxins of various types of hornets contain acetylcholine able to reduce heart rate and bronchial muscles, decrease blood pressure, and increase the secretion of bronchial glands $[10,11,12]$.

Remembering that in the early twentieth century $\mathrm{N}$. Arthus and G. P. Sakharov gave the sensitization of the body an important role in the development of infectious and inflammatory diseases [3], we believe that this fully concerns the IP MFA, which arose as a result of insect bites.

In general, the reactions of the child's body on insect bites are quite diverse, differing in nature and severity of symptoms. Thus, we can generically observe urticaria, conjunctivitis, rhinitis, weakness, fever, difficult breathing, decrease of blood pressure, frequent pulse of weak filling, heartache, dizziness etc. In severe cases Quincle edema (Fig.1A) and anaphylactic shock which can threaten life may develop $[13,10]$.

In turn, local reactions also differ in intensity and external signs:-passionate pain, hyperemia, swelling or sealing of the skin with itching and rashes: blisters, nodules, erythematous spots, erosion or other variations that can remain for several days (Fig.1B). In severe cases, hemorrhagic, bullous or necrotic rashes occur. Severe itching at the site of the lesion provokes scratching of the skin, contributing to infection with subsequent complication of IP [13].

According to our observations, the most common complications of insect bites occurred in summer and autumn: 21 (50\%) and $13(31 \%)$ cases respectively, and 8 
observations (19.0\%) were in spring. All patients sought help within 1-2 days from the initial signs of the disease. In the overall structure 40 cases $(95,2 \%)$ were IP MFA, which were complicated in 7 patients $(16,7 \%)$ by abscess and in 2 patients $(4,8 \%)$ by widespread phlegmon of the subcutaneous fatty fiber. 2 (4.8\%) of patients had phlegmon accompanied by inflammation of the bones of the facial skeleton.

In all cases of complications the disease began from the area of inflamed skin with significant collateral edema and infiltration of the surrounding tissues, where subsequently bleeding erosions, rounded or irregularly-shaped, with pink-red bottoms and thick gross straw-yellow "honey» crust were formed. The nidi had a tendency to rapid peripheral growth, could interflow with each other, covering large areas of the skin (Fig. 2). The reactive changes in regional lymph nodes or even their abscessing (3 patients, 7.1 percent) [2] were always observed.

\section{CASE REPORT}

In order to illustrate the received data, we represent a clinical case from our own observations, which demonstrates the difficulties of the course, diagnosis and complex treatment of children with this pathology.

Patient G., age 5, case history No. 8691, a resident of Poltava, hospitalized to the clinic of the chair on the basis of the surgical department of Poltava city children's clinical hospital with a diagnosis of infiltration of the left cheek after an insect bite.

The boy's parents complained of weakness, chills, nausea, deterioration of sleep and appetite, loose stools, fever up to $39^{\circ} \mathrm{C}$, pain and swelling of the ST of the left cheek, which were accompanied by itching.

It was established from anamnesis that a day ago the boy was bitten in the left cheek area by an insect, probably a hornet. Swelling and hyperemia with significant pain and subsequently skin rashes immediately arose in the site of bite. The parents did not consult the doctors employing self-treatment. The child was getting worse, the scratching has led to the violation of the integrity of the skin and the tissues of the cheek have thickened. The boy's condition gradually deteriorated, the infiltration increased significantly and cyanotic areas were formed in some places of the skin.

The parents went to the doctor and the child was immediately hospitalized. At the time of hospitalization: general condition was of moderate severity, body temperature $38.5^{\circ} \mathrm{C}$, skin pale. The pronounced asymmetry of the face due to a significant swelling of the left cheek ST, where the skin is significantly hyperemic and hard, signs of collateral edema and the erosion.in the affected area were determined. The red border of the lips was dry with flaky scales. The mouth opening was limited (Fig. 3). Bad breath. In the oral cavity-there was a small amount of foam, turbid, viscous oral fluid, and the mucous membrane $(\mathrm{MM})$ - without visible pathological changes. Dentition intact. Teeth 65 and 26 were of the II degree of mobility with sensitive percussion, although their crowns were intact, and the gums in their area from the vestibular side were hyperemic.

General blood test: leukocytosis with the increased number of segmented neutrophils and eosinophils, and increased erythrocyte sedimentation rate up to $45 \mathrm{~mm}$ /hour.

A slight proteinuria was determined.

According to the parents, the child did not have any somatic pathology that could affect the occurrence and course of the disease.

According to the results of an objective examination of the patient and taking into account the anamnesis, a clinical diagnosis was established: infiltration of the left half of the face after an insect bite, retrograde acute periodontitis of the teeth. 65 and 26.

The decision to carry out the conservative treatment and dynamic monitoring of the disease was made

The drug therapy was applied according to the classical principles of treatment of acute IP (antibacterial, anti-inflammatory, hyposensitizing, general restorative and infusion therapy) based on calculations per $\mathrm{kg}$ of body weight [6].

The oral cavity and dentition monitoring revealed a significant progression of retrograde periodontitis of the teeth 65 and 26 with the probable death of their pulp. Taking into consideration the fact that the teeth could not be trephined due to insufficient opening of the mouth, on the 3rd day from the beginning of treatment a more mobile tooth 65 was removed under local anesthesia. A small amount of serous-bloody exudate was obtained from the hole.

Despite the complex of therapeutic measures, the general condition of the boy became worse, the body temperature reached $39.5^{\circ} \mathrm{C}$, the inflammatory phenomena progressed. Edema and the degree of ST infiltration of the cheek and zygomatic areas increased with spreading to the lower pole of the temporal area.

The opening of the mouth was limited to $1.0 \mathrm{~cm}$, to which the child reacted with crying, and that indirectly indicated pain.

In the mouth threshold there was a hyperemia of MM and smoothness of the transitional fold from the removed tooth 65 and further behind the hill of the upper jaw. The palpation determined infiltration on a transitional fold from the tooth 65 up to the hill of the upper jaw with extension to the anterior edge of the branch of the mandible.

The presence of other symptoms could not be established in detail because of the lability of the child and his inadequate motor activity, which testified to the existence of other disorders that caused discomfort to the child. The tooth 26 remained movable

According to the clinical symptoms the patient was suspected to have the phlegmon of infratemporal and wing-palatal fossae and the surgical intervention by means of the classical method of intraoral access under intubation anesthesia was carried out. After opening, purulent-bloody exudate was obtained in a significant amount. The cavity of the abscess was sanitized, and a rubber drainage, fixed by the sutures to the MM of the cheek was introduced into 
the wound passage. The tooth 26 was left because of the intact crown with the hope that after fading of the IP, it could remain for further endodontic treatment.

In the future, unfortunately, despite the improvement in the clinical status of the child, in the area of projection of the distal cheek root of the tooth 26 the fistula was formed, tooth mobility increased, which was the reason for its removal. In 3 days after the extraction the fistula was closed, and the hole had an appropriate form for this period of healing.

During the longitudinal cutting of the removed tooth, homogeneous necrotic masses which were easily exfoliated from the solid tissues were determined in all parts of the pulp chamber. In the apical departments the necrotic pulp was in contact with the focus of pathologically altered dentin size $4 \times 3 \mathrm{~mm}$, which had the shape close to ovoid and relatively smooth contours. The nidus occupied nearly the entire thickness of the dentin, almost reaching the dentin-enamel border, and was covered with a layer of visually unchanged enamel from outside (Fig. 4).

In order to study the structure of the above mentioned formation and the state of the surrounding hard tissues, the fragments of the removed tooth were dehydrated and immersed in EPON-812 with the following grinding, polishing and colouring with methylene blue according to our own technique $[14,15]$.

The microscopic examination in reflected light of the samples obtained by the above mentioned method found that the described focus is a necrotic tissue with few cells of inflammatory infiltration, mainly neutrophil leukocytes, surrounded by dentin with the characteristic areas of uneven mineralization, which was manifested by different intensity of colour, uneven thickness and improper course of dentin tubes (Fig. 5 A).

The enamel in the surrounding departments had a typical unchanged structure with clearly visualized enamel prisms, and in the region of the dentin-enamel border had the enamel tufts and spindles (Fig. $5 \mathrm{~B}$ ).

The totality of listed morphological changes allows to consider that the development of retrograde dentine caries with unaltered enamel, the initial mechanism of which is the pathological process in the pulp, takes place in this case.

On the 13th day from the beginning of treatment the general condition of the child was satisfactory. The insignificant final infiltrative changes in the tissues of the left cheek were present, and the holes of the removed teeth 65 and 26 were filled with granulation tissue (Fig. 6).

On the 14th day from the beginning of treatment the child was discharged under the supervision of a dentist surgeon at the place of residence with the provision of recommendations on the volume of rehabilitation measures.

Analyzing the presented clinical case, we can note that the IP, of course, had an infectious-allergic nature. However, interesting is the fact of its distribution with the development of retrograde odontopathology that can be explained by the anatomical and physiological features of MFA tissues in children and the characteristics of their common and local immunity.
It is clear that an important role in preventing the occurrence of such situations is given to medical workers, sufficient organization level of sanitary and educational work, and the treatment of such cases becomes a common task of doctors of different profiles. However, much depends on the parents, their level of responsibility and competency, ensuring of timely treatment and provision of qualified medical care to children, preventing the development of severe complications.

\section{CONCLUSIONS}

1. Inflammatory processes of MFA, arising as a result of insect bites, is a very urgent problem of pediatric surgical dentistry and require an individual approach in the diagnosis and treatment of patients.

2. A large role in preventing the occurrence of these nosological forms is given to medical workers, a sufficient organization level of sanitary and educational work, and the treatment of such cases becomes a common task of doctors of different profiles. However, much depends on the parents, their level of responsibility and competency, ensuring of timely treatment and provision of qualified medical care to children, preventing the development of severe complications.

3. The issues related to the etiopathogenesis of this pathology require profound scientific research.

\section{REFERENCES}

1. Tkachenko P.I. Gurzhij 0.V. Bilokon S.0. Gostri odontogenni procesy shhelepno-lycevoyi dilyanky v ditej (periostyt, osteomiyelit, limfadenit) [Acute odontogenic processes of maxillofacial region in children (periostitis, osteomyelitis, lymphadenitis)]. Lviv. 2006:101 s. (UA)

2. Tkachenko P.I. Starchenko I.I. Bilokon S.0. „i in... Nespecyfichni limfadenity shhelepno-lycevoyi dilyanky u ditej (kliniko-morfologichni aspekty) [Nonspecific lymphadenites of maxillofacial area in children (clinical and morphological aspects)]. Poltava, 2018:120 s. (UA)

3. Tkachenko P.I. Bilokon S.O. Gurzhij 0.V. «i in.». Zapalni procesy shhelepno-lycevoyi dilyanky u ditej [Inflammatory processes of the maxillofacial area in children]. Poltava-Chernivci, 2014:191 s. (UA)

4. Tkachenko P.I. Patogenetychni osoblyvosti zapalnyx procesiv shhelepnolycevoyi dilyanky u ditej ta dyferencijovani pidxody do yix likuvannya [Pathogenetic features of inflammatory processes of maxillofacial region in children and differentiated approaches to their treatment]. Dys. ... d-ra med. nauk. Poltava, 1998:416 s. (UA)

5. Tkachenko P.I. Ishhejkin K.Ye. Bilokon S.0. Dermatogenni gostri zapalni procesy shhelepno-lycevoyi dilyanky u ditej [Dermatogenic acute inflammatory processes of the maxillofacial region in children]. Problemy ekologiyi ta medycyny. 2011; 15, 3-4:152. (UA)

6. Xarkov L.V. Yakovenko L.M. Chexova I.A. Xirurgichna stomatologiya dytyachogo viku [Surgical dentistry of childhood]. K.: Knyga-plyus, 2003:480 s. (UA)

7. Tkachenko P.I. Ishhejkin K.Ye. Bilokon S.0. «i in.». Vugrova xvoroba yak prychyna vynyknennya gostryx zapalnyx procesiv myakyx tkanyn shhelepno-lycevoyi dilyanky u ditej [Acne as the cause of acute inflammatory processes of soft tissues of the maxillofacial region in children]. Svit medycyny ta biologiyi. 2011; 4:144-148. (UA) 
8. Tkachenko P.I. Ishhejkin K.Ye. Bilokon, „i in... Stafilo-streptodermiya yak prychyna vynyknennya flegmon shhelepno-lycevoyi dilyanky u ditej [Staphylo-streptodermia as the cause of phlegmon of the maxillofacial area in children]. Svit medycyny ta biologiyi. 2011; 1:100-104. (UA)

9. Paltsev M.A. Potekaev N.N. Kazantseva I.A. Kliniko-morfologicheskaya diagnostika zabolevaniy koji (atlas) [Clinical and morphological diagnosis of skin diseases (Atlas)]. M.: Meditsina. 2004:432 s. (Ru)

10. Bazon M.L. Silveira L.H. Simioni P.U. LBrochetto-Braga M.R. Current Advances in Immunological Studies on the Vespidae Venom Antigen 5: Therapeutic and Prophylaxis to Hypersensitivity Responses. Toxins. 2018; 10:305.

11. Chai L. Yang X. Liu M. et al. Biopanning of allergens from wasp sting patients. Bioscience Reports. 2018; 38 BSR20181113.https: doi.org /10.1042/BSR20181113.

12. Jakob T. Rafei-Shamsabadi D. Spillner E. et al. Diagnostics in Hymenoptera venomallergy: current concepts and developmentswith special focus onmolecular allergy diagnostics. Allergo J Int. 2017; 26:93105. doi: 10.1007/s40629-017-0014-2.

13. Tkachenko 0.YA. Aktualnyie voprosyi diagnostiki i lecheniya hronicheskoy krapivnitsyi u detey [Topical issues of diagnosis and treatment of chronic urticaria in children]. Pediatriya. Vostochnaya Evropa. 2014; 1(05):58-69. (Ru)

14. Belokon S.A. Vitko YU.N. Tkachenko P.I. "i in... Optimizatsiya issledovaniya strukturnyih elementov biologicheskih tkaney na gistotopograficheskih shlifah [0ptimization of research of structural elements of biological tissues on histotopographic thin sections]. Molodoy uchënyiy. 2014; 15(74):134-137. (Ru)

15. Kostilenko Yu.P. Boiko I.V. Starchenko I.I. et al. A method for making histological preparations equivalent to semithin sections with large examination areas for multipurpose morphological studies. Neurosci Behav Physiol. 2008. Nov; 38(9):897-9. doi: 10.1007/s11055-008-90675. Epub 20080 ct 31.
The paper is written within the research study entitled "Integrative-and-differential substantiation of the choice of optimal methods of surgical interventions and the scope of therapeutic activities in the surgical pathology of the maxillofacial area" (State Registration No. 0116U003821).

\section{Authors' contributions:}

According to the order of the Authorship.

\section{Conflict of interest:}

The Authors declare no conflict of interest.

\author{
CORRESPONDING AUTHOR \\ Serhii 0. Bilokon \\ Ukrainian Medical Stomatological Academy \\ Shevchenko 23 str., 36011 Poltava, Ukraine \\ tel: +380502869041 \\ e-mail:s.o.bilokon@gmail.com
}

Received: 17.03 .2019

Accepted: 29.04.2019 
